Danuta Popinigis

Carillons and Carillon Music in Old Gdańsk

\title{
Volume 13
}

\section{Eastern European Studies}

in Musicology

Edited by Maciej Gołąb 
Danuta Popinigis "Carillons and Carillon Music in old Gidańsk" The history of Gdańsk carillons begins in 1561. It was that year that fourteen automatic bells were installed in the Main Town Hall. Later, a "striking mechanism" appeared in St Catherine's Church, although it was only in 1738 that a magnificent instrument consisting of 35 bells was mounted. The third carillon was built in 1939 in the youth hostel at Biskupia Górka. The play of Gdańsk carillons was interrupted by the Second World War.

The book discusses the history and music of Gdańsk carillons. It contains valuable information on bells, carillon mechanisms, bell founders, carillonists, and bell setters, inviting the reader to study the Protestant repertoire, the unique notation of preserved manuscripts, and the remarkable soundscape of Gdańsk, which for centuries has been marked by the sound of carillons.

Danuta Popinigis is Professor at the Academy of Music in Gdańsk, a musicologist specialized in Gdańsk musical culture, musical manuscripts, carillons, and carillon music. She is an author of two books and numerous articles, co-author of three thematic catalogues of Gdańsk manuscripts and co-author of music editions. 
Carillons and Carillon Music in Old Gdańsk 


\title{
Eastern European Studies in Musicology
}

Edited by Maciej Gołąb

\author{
Editorial board \\ Mikuláš Bek (Brno) \\ Gražina Daunoravičienè (Vilnius) \\ Luba Kyjanovska (Lviv) \\ Mikhail Saponov (Moscow) \\ Adrian Thomas (Cardiff) \\ László Vikárius (Budapest)
}

Volume 13 
Danuta Popinigis

\section{Carillons and Carillon Music in Old Gdańsk}

Translated by Wojciech Bońkowski 


\section{Bibliographic Information published by the Deutsche Nationalbibliothek}

The Deutsche Nationalbibliothek lists this publication in the Deutsche Nationalbibliografie; detailed bibliographic data is available in the internet at http://dnb.d-nb.de.

\section{Library of Congress Cataloging-in-Publication Data}

A CIP catalog record for this book has been applied for at the Library of Congress.

The Publication is funded by Ministry of Science and Higher Education of the Republic of Poland as a part of the National Programme for the Development of the Humanities.

H. national programme

11) FOR THE DEVELOPMENT OF HUMANITIES

This publication reflects the views only of the authors, and the Ministry cannot be held responsible for any use which may be made of the information contained therein.

Translated by Wojciech Bońkowski

Cover Design: @ Olaf Gloeckler, Atelier Platen, Friedberg Printed by CPI books $\mathrm{GmbH}$, Leck

ISSN 2193-8342

ISBN 978-3-631-67603-5 (Print) · E-ISBN 978-3-653-06926-6 (E-PDF) E-ISBN 978-3-631-71104-0 (EPUB) · E-ISBN 978-3-631-71105-7 (MOBI) DOI $10.3726 / \mathrm{b} 15641$

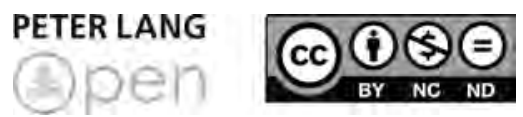

Open Access: This work is licensed under a Creative Commons Attribution Non Commercial No Derivatives 4.0 unported license. To view a copy of this license, visit https://creativecommons.org/licenses/by-nc-nd/4.0/

(C) Danuta Popinigis, 2019

Peter Lang - Berlin · Bern · Bruxelles · New York .

Oxford $\cdot$ Warszawa $\cdot$ Wien

This publication has been peer reviewed. www.peterlang.com 


\section{Contents}

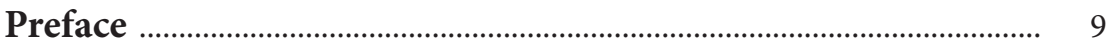

List of abbreviations _........................................................................... 13

Introductory remarks ....................................................................... 15

Part One Automatons and instruments. Bell founders, setters, and carillonists

1 The Main Town Hall automatic carillon, 1561-1945 ................ 35

1 Origin and history ............................................................................. 35

2 Bell founder Jan Moer (Moor) ............................................................ 52

3 Bells and mechanisms ....................................................................... 54

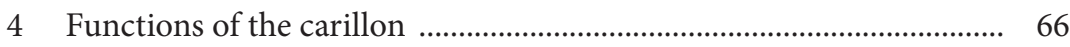

4.1 Time measurement .................................................................... 67

4.2 The signalling of events .................................................................. 69

$5 \quad$ Bell setters: Franciscus de Rivulo and his successors ........................... 89

6 Employment, duties and payment of bell setters .................................. 106

2 The carillons of the church of St Catherine, 1573?-1942 ........ 125

1 Unclear beginnings and granted wishes ............................................... 125

2 The bell founder Jan Nicolaas Derck ................................................... 153

3 Bells and mechanisms ............................................................................ 160

4 Functions of the carillon ...................................................................... 165

4.1 Time measurement ........................................................................ 165

4.2 Signalling of events ...................................................................... 168

4.3 Daily and occasional concertising ................................................. 170 
5 Carillonists: Eltjen Wolthers and his successors .................................... 173

6 Carillon management, carillonist employment and payroll ............... 191

3 Other carillons in Gdańsk ............................................................... 201

1 The automated carillon in Milk Can Gate, 1938-45 ............................. 201

2 The carillon on Bishop Hill, 1939-45 ....................................................... 201

\section{Part Two Musical repertoire}

\section{Overview and description of sources for the Main} Town Hall automated carillon repertoire ...................................... 209

1 Seventeenth-century historical mentions ............................................... 209

2 Manuscripts of works for the Main Town Hall carillon ........................ 212

2.1 The tablatures of Theodor Friedrich Gülich ................................. 216

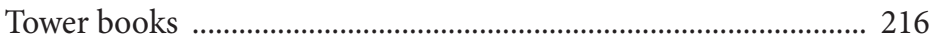

Evangelical-Lutheran songbook .................................................... 229

Evangelical-Reformed songbook .................................................. 246

2.2 The tablature of Paul Friedrich Knaack .......................................... 249

2.3 The notation of Gdańsk carillon tablatures .................................... 253

2.4 The manuscript of Carl Anton Kaschlinsky ................................... 258

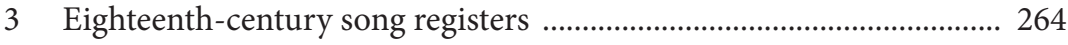

4 Press announcements of 1907-28 ……………................................. 267

5 Evolution of the Main Town Hall automated carillon repertoire ....... 268

\section{The specificity of the musical repertoire for the Main} Town Hall automated carillon ...................................................... 285

1 The settings of Theodor Friedrich Gülich .............................................. 285

1.1 Yearly cycle and holiday songs ....................................................... 285

1.2 Death songs and funeral songs ........................................................ 296 
1.3 Songs for the City Council election, beginning and end of the St Dominic's Fair, and the hymn Te Deum laudamus ............ 300

1.4 Evangelical-Lutheran songs .............................................................. 303

1.5 Evangelical-Reformed songs ........................................................ 304

2 Settings of Theodor Friedrich Gülich copied by Paul Friedrich Knaack .............................................................................................. 308

3 The settings of Carl Anton Kaschlinsky ................................................... 311

3 Overview and description of sources for the carillon repertoire of the church of St Catherine .............................................................. 313

1 Musical manuscripts ................................................................................ 313

1.1 The lost manuscript of Eltjen Wolthers ………………………….. 316

1.2 The manuscript of Johann Ephraim Eggert ................................... 317

1.3 Notation of works in the manuscript of Johann Ephraim Eggert ..... 331

2 Press announcements from 1910-27 ………………………………... 337

3 Evolution of the repertoire of the St Catherine carillon ....................... 337

4 Concert repertoire ................................................................................. 339

4 Structure of the works of Johann Ephraim Eggert ..................... 341

1 Variations for full hours ......................................................................... 342

1.1 Variations based on repetitions of the theme ............................... 346

1.2 Figurative variations ....................................................................... 346

1.3 Nonfigurative variations ................................................................ 349

1.4 Variations with a mixed texture ……………………………….... 349

1.5 Variations with interludes ........................................................... 349

2 Variations for half-hours ................................................................. 362

3 Choral preludes for full hours ............................................................. 366

4 Choral preludes for half-hours .............................................................. 366

5 Choral preludes for quarter-hours ......................................................... 370

6 Monodic chorale settings for full hours .................................................. 371 


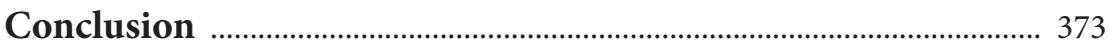

Gdańsk carillons in the city's soundscape .................................................... 373

Appendix: Summary of the repertoire of the automatic carillon of the Main Town Hall and church of St Catherine 379

List of illustrations 391

List of tables 397

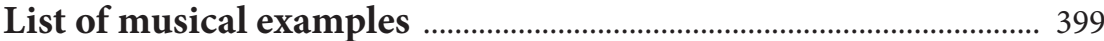

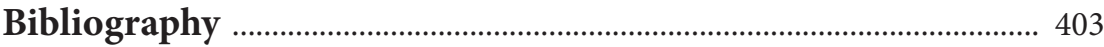

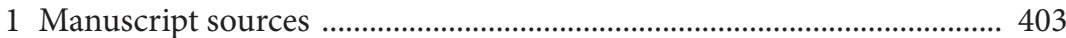

2 Printed sources ........................................................................................... 407

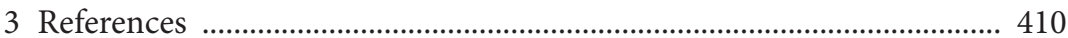

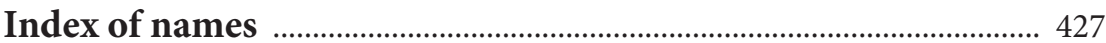


Prayers go to Heaven as heartfelt shots.

Musics rise alongside tall towers,

Harmonies argue in broad choirs.

The town hall clock sings its symphonies

in the clouds, the great cantor of God's glory. ${ }^{1}$

\section{Preface}

This book aims at reconstructing the history of carillons and carillon music in old Gdańsk. The time limit of my enquiry is the year 1945, a pivotal date for the city's history and its culture both material and spiritual. Old Gdańsk, which for centuries gathered traces of its proud identity, was buried under the rubble of demolished houses and churches. During the intense post-war revival, it was not easy to refer to the past or cultivate old customs: post-1945 reality was shaped by Gdańsk's new residents, resettled from Vilnius, Brasław, Grudziądz, Kręćkowo, and God knows where else. At the same time, it was attempted on many fields though not always successfully to return to the old Gdańsk. Its old architectural substance was recreated, and the past was recalled.

An example of this process was the 1970 transfer of bells that formerly belonged to the carillon built in 1939 in the youth hostel at Biskupia Górka (Bishop's Hill) to the tower of the Main Town Hall. These bells replaced the Town Hall's automatic carillon of 1561, destroyed in March 1945 after nearly four centuries of operation. It was decided the carillon would play a song by Feliks Nowowiejski to the poem Rota (The Oath) by Maria Konopnicka, beginning with the telling words: "We shall not abandon the land whence our kin..." Gdańsk residents were so serious about sounds coming from the Town Hall tower as a sign of the city's identity that they insisted Rota should remain in the repertoire even after a new carillon was installed in 2000.

An important initiative of building a carillon in the church of St Catherine was discussed even before 1980, since the historical carillon went missing in 1942 as a result of Nazi policies. Its bells were dismounted and removed from the city; the majority did survive but were never returned to Gdańsk. Instead, they were incorporated into the carillon of St Mary's church in Lübeck. The installation of a new set of bells was proposed by Hans Eggebrecht, born in pre-war

1 Kałaj, 'Klimakteryk heroiczny'. 
Danzig, with contributions by the city authorities and individuals from Poland and Germany. The carillon was cast by the Dutch foundry Royal Ejisbouts in Asten. It was completed in 1989 and consecrated on 1 September, on the fiftieth anniversary of the Second World War. Initially, it functioned as a musical automaton but soon some constructors added a keyboard, thereby restoring the instrument's historical version. Its first concert took place on 28 November 1998. The current carillon of the church of St Catherine includes fifty bells arranged in the scale from $\mathrm{B} b 3$ to $\mathrm{C} 8$.

Since the early 1990s, a new instrument was also considered for the Main Town Hall. The project was fully justified given the faulty timbre and mistuning of the Biskupia Górka bells installed on the local tower, the technical condition of the structure, and its aged mechanism. The build of a new carillon was again commissioned with the royal Dutch foundry in Asten. The new instrument is composed of thirty-seven bells in meantone temperament from G4 to A7. It was first tired out in public on the frosty 31 December 2000.

Gdańsk currently has three concert carillons: apart from those of St Catherine's church and the Main Town Hall, the Gdańsk Mobile Carillon has also been operating since 2009, based on forty-eight bells placed on a truck. This enables the instrument to be transported for concerts to any location. Gdańsk is the only Polish city to possess active concert carillons, which is why it has become a hotspot for this instrument type and an important venue on the worldwide carillon map, attracting musicians from many countries.

This represents the continuation of Gdańsk's century-old tradition. The practice of bell playing has been revived, with both regular and occasional festivals and concerts organised. Enthusiasts have founded the Polish Carillon Society, which became a member of the World Carillon Federation in 2000. In 2008, the first issue of the Association's newsletter, Carillon Review, was published. The www.carillon.pl website is also available. Since 2007, carillon playing is taught at the Stanisław Moniuszko Academy of Music in Gdańsk. Compositions for the three Gdańsk instruments are regularly written. Today, as in past centuries, the carillons are looked after by the city authorities, with direct supervision by the Museum of Gdańsk.

The history of Gdańsk carillons and carillon music proved to be a vast and often fascinating research topic of interest to both cultural historians and musicologists.

This book would not have been possible without the help and benevolence of many individuals. I wish to thank all those who contributed to its writing. I am 
particularly grateful to Prof. Barbara Przybyszewska-Jarmińska of the Institute of Art of the Polish Academy of Sciences, the late Prof. Danuta Szlagowska of the Stanisław Moniuszko Academy of Music in Gdańsk, and Prof. Andrzej Januszajtis for their feedback during the book's gestation. During my archival research, I have benefitted from the useful help and consultation of Jerzy Marian Michalak, who has systematically supplied me with source fragments and helped decipher their content. I also thank my colleague Prof. Dariusz Kaczor: our common work on the facsimile edition of a manuscript by Johann Ephraim Eggert trigger many a scientific discussion from which I have learned a great deal; I have also been able to use the work of Dariusz Kaczor, including transliterations of several important source texts. Dr. Peter Oliver Loew has communicated a number of press clippings about Gdańsk carillons, for which I am grateful. I have also been assisted in my archive and library searches by the staff of the State Archive in Gdańsk and the Polish Academy of Sciences Gdańsk Library; again, my sincere thanks for their hard and patient work. I am also indebted to Jaap Kroon, archivist of the Westrief Archief in Hoorn, and Piet Boon of the same institution, who have referred his materials on the bell founder Jan Nicolaaus Derck. I am grateful for the assistance I received at the Stadsarchief's-Hertogenbosch from Monique Ruzius-Brummans and Lucas van Dijck who helped decipher a contract of Jan Moer. Dr. Frank Deleu, Dr. Carl Van Eyndhoven, Gert Oldenbeuving, Dr. Grzegorz Szychliński, Gdańsk carillonist Dr. Monika Kaźmierczak and the late Dr. Jacques Maassen have provided help in understanding the thorny issues of carillon mechanism. I also thank my colleagues from the Department of Music History, Institute of Music Theory at the Music Academy in Gdańsk for their encouragements. I thank Marta Walkusz and Anna Kasprzycka for their transcription of works for the town carillon, enabling me to analyse them. The book would have received no editorial approval without the tedious work of the late Ewa Jaskulska, for which I am thankful. My thanks also go to Wojciech Bońkowski who undertook the book's translation so that it can find readers beyond Poland. I also thank my friends, family, and children Joanna and Małgorzata, who supported me throughout this work. Finally, I am thankful to my husband Marian for his support and patience.

Danuta Popinigis 



\section{List of abbreviations}

$\begin{array}{ll}\text { ABuch } & \text { Adressbuch } \\ \text { APG } & \text { Archiwum Państwowe w Gdańsku (State Archive in } \\ & \text { Gdańsk) } \\ \text { DaNa } & \text { Danziger Nachrichten und Anzeigen } \\ \text { DDB } & \text { Danziger Dampfboot } \\ \text { DIB } & \text { Danziger Intelligenz-Blatt } \\ \text { DNN } & \text { Danziger Neuste Nachrichten } \\ \text { DTB } & \text { Doop-, trouw- en begraafboeken } \\ \text { DVoPo } & \text { Danziger Vorposten } \\ \text { DZ } & \text { Danziger Zeitung } \\ \text { GA Amsterdam } & \text { Stadsarchief Amsterdam } \\ \text { GAHt } & \text { Stadsarchief's-Hertogenbosch } \\ \text { PAN BG } & \text { Polska Akademia Nauk Biblioteka Gdańska (Polish } \\ & \text { Academy of Sciences Gdańsk Library) } \\ \text { RHCGA } & \text { Regionaal Historisch Centrum Groninger Archieven } \\ \text { RISM } & \text { Répertoire International des Sources Musicales, Serie A/I } \\ \text { SBB } & \text { Staatsbibliothek zu Berlin - Preußischer Kulturbesitz, } \\ & \text { Musikabteilung mit Mendelssohn-Archiv } \\ \text { WA } & \text { Hoorn, Westfries Archief } \\ \text { WDAN } & \text { Wöchentliche Danziger Anzeigen und dienliche Nachrichten }\end{array}$





\section{Introductory remarks}

\section{Terminology}

From the lexicographical entries and remarks in the scholarly literature, it transpires that authors disagree about what carillon actually is. For example, the status of the World Carillon Federation, which unites musicians and lovers of carillon from around the world, as well as sets the technical norms of modern carillon, defines it as "a musical instrument composed of tuned bronze bells which are played from a baton keyboard."2 For a carillon to be considered a musical instrument, it needs to include at least twenty-three bells spanning two chromatic octaves. Sets of between fifteen and twenty-two bells with a keyboard, built before 1940, should be called historical carillons. Sets of fewer bells should not be featured in the World Carillon Federation status at all, nor should automated carillons, which are numerous worldwide.

The definition proposed in 2001 by Luc Rombouts is consistent with that of the World Carillon Federation, though the author explicitly mentions a set of bells played by the carillonneur or carillonist only in the latter half of his text. ${ }^{3}$ Rombouts also remarks that that term of "carillon" is sometimes used for smaller sets of bells called chimes ${ }^{4}$ and that a large group of instruments also possesses a clock-controlled automatic mechanism. ${ }^{5}$ Rombouts thereby observes the existence of a second of type - the automatic carillon. However, in his description employs no such term.

In the latest edition of Die Musik in Geschichte und Gegenwart, the term "carillon" (German: Glockenspiel) is not a separate entry but is rather integrated in the entry on bells: "Glocken und Glockenspiele."' A more thorough discussion of the carillon is included in chapter seven, discussing "ringing" (Läuten), which speaks notably of fixed bells: ${ }^{7}$ automatic ones, where sound generation is triggered

2 World Carillon Federation, accessed 26 August 2018, https://www.carillon.org/eng/ fs_orga.htm.

3 Rombouts, 'Carillon'.

4 "The term is also sometimes applied to smaller, diatonic or automatic chimes." Rombouts, 128.

5 "A large number of instruments also feature an automatic playing mechanism which is controlled by clockwork." Rombouts, 128.

6 Lehr et al., 'Glocken und Glockenspiele'.

7 According to the motion of bells during ringing, bells can be divided into swinging and fixed. 
by striking external hammers, and those sounded by the strike of an internal clapper. Two types of bell sets are distinguished: the carillon (Glockenspiel) and the manual carillon (Handgespieltes Glockenspiel). The former type includes tuned automated bells spanning one or several octaves, while the latter, tuned bells ordered chromatically spanning two octaves or more, played from a baton keyboard. ${ }^{8}$ The author of these remarks is André Lehr, the undisputed authority on campanology and carillon history in the Low Countries, the oldest and still most important region of carillon history development. Nonetheless, I confess that, as in the definition of Luc Rombouts, I miss a direct statement that the name of "carillon" can be applied to both a musical instrument and automaton.

The precise definition of the carillon is not made easier by monographic works on instruments or by those on musical automata. Some of those writings show their authors in difficulty in defining their subject matter. A good example is Curt Sachs. ${ }^{9}$ Although he dedicates some attention to the carillon, he offers no precise definition of it, focusing instead on discussing it history, distribution, and types. Citing the German term "Glockenspiel," Sachs mentions that it refers not to a set of bells but slabs of bronze with or without a keyboard, used in home music making, brass bands, and professional music. ${ }^{10}$ An alternative term is proposed by Stanisław Olędzki, the Polish translator of Sachs' monograph, is "chime" (kurant), also as in "bell chimes" (kuranty dzwonowe). Sachs' commentary, particularly that relevant to Glockenspiel, points to the broad meaning of the term and its evolution in time.

There is no definition of the carillon Mieczysław Drobner's handbook on musical instruments, though the book does mentions chimes (kuranty), understood as mechanisms installed on bells that allow the performance of simple melodies. ${ }^{11}$

In his extensive work on musical automata, Stanisław Prószyński acknowledges the difficulties of the topic by titling one of his chapters "Definition issues."12 This partly justifies the fact he does not offer a precise definition of the terms in question. He once mentions that "carillons, or tower chimes," are composed of several bells, ${ }^{13}$ while elsewhere pointing out that "in Western Europe, tower chimes and watchtowers with carillons, or mechanically controlled sets of bells of varying

8 Lehr et al., 'Glocken und Glockenspiele', cols 1468-79.

9 Sachs, The History of Musical Instruments.

10 Sachs, 379.

11 Drobner, Instrumentoznawstwo i akustyka, 225.

12 Prószyński, Świat mechanizmów grających, 22-32.

13 Prószyński, 27. 
dimensions and pitch, appeared."14 Tellingly, the word "carillon" is italicised, reminding readers of its foreign, that is, non-Polish origin.

In his book Gdańskie zegary, dzwony i karyliony [Gdańsk clocks, bells and carillons], Andrzej Januszajtis precisely defines two types of carillon and unambiguously addresses the Polish terminology. He stresses the difference between automated bell sets from human-operated, keyboard-equipped ones, for which he uses different names: "bell chimes" (kuranty dzwonowe) for the former and "karylion" (Polish adaptation of carillon) for the latter. "Karylion" appears to be the most appropriate version given the character of the Polish language. Andrzej Januszajtis also proposes that both categories be included in the joint category of "bell playing" (gra dzwonów), ${ }^{15}$ a term itself translated from the German "Glockenspiel," which, in my opinion, does not solve the problem.

The above examples confirm my initial opinion that authors essentially disagree on what carillon exactly is. I believe a definition should be given where the definiens part emphasises the two existing types that differ by way of sound generator. My proposal, therefore, is the following definition:

Carillon is a musical instrument or automaton, composed of a set of bells fixed to a permanent structured. In the instrument, sounds are generated by a musician, while in the automaton, by a mechanism.

This definition consciously does not mention the number of bells included in the carillon. This issue is highly problematic, especially when describing historical instruments or automata, so I will abstain from attempting to resolve it. Instead, I shall remind readers that the etymology of "carillon" goes back to the late Latin word "quaternio," meaning a "set of four." 16

Another matter worthy of attention here, before we address the history and music of the old Gdańsk carillon, is the terminology used by Polish scholars of the topic. It has not been regulated to date. Sets of automated bells and those operated from a keyboard are called in Polish literature with one of three terms: "carillon," "karylion," and "kurant" (chime). A musician playing the bells is a "carillonista" (carillonist), "carilloner" (carillonneur), or "karylionista," while "kurancista" denotes someone who sets (programmes) the mechanism in automated carillons. The lack of linguistic norms has been noted by Joanna Zimińska, who in 2003 edited a multiauthor publication on the carillons of

14 Prószyński, 40.

15 Januszajtis, Gdańskie zegary, dzwony i karyliony, 126-27.

16 Władysław Kopaliński, Słownik wyrazów obcych i zwrotów obcojęzycznych (Warszawa: Wiedza Powszechna, 1970), 124. 
Gdańsk. ${ }^{17}$ In that book, the terminology is not made coherent, which Zimińska explains in the conclusion, citing the fact that modern Polish dictionaries do not list a normative definition; she goes on to quote several that include the terms "carillon," "karylion," and "kurant" but also notes the lack therein of "carilloner" or "carillonista," which she qualifies as "neologisms."18

The lack of a unified nomenclature in the Polish scholarly literature can easily be explained. The post-war history of Gdańsk carillons is short, thus despite growing interest in the topic, the number of publications of historical and modern carillons is still limited. Scholars continue to use varying terminology, as binding linguistic norms have not yet emerged and consolidated both in popular and scholarly writing. Referring to the past, name the pre-war Polish literature, is useless in this case, publications from before 1945 are limited to entries in generic lexicons whose natural aim was to address a wide array of meaning for any term. For a broad overview of the topic, it is worth consulting historical dictionaries of the Polish language and generic lexicons, which Joanna Zimińska fails to do. It is particularly relevant in the context of Januszajtis' unambiguous statement that negates the use of the word "carillon" and derived terms.

In the oldest dictionary of the Polish language, published by Samuel Bogumił Linde in the early nineteenth century, there is no mention of "carillon" or "karylion," but the word "kurant" features with several meanings: "a conjunction of melodic tones;" "in painting, a stone to grind paints on a flat stone"; "thick silver coins." ${ }^{19}$ In the Mrongowiusz dictionary, the meaning is extended to include the music of a clock: "die Musik die eine Spieluhr macht." ${ }^{20}$ Maurycy Orgelbrand, ${ }^{21}$ Zygmunt Gloger, ${ }^{22}$ as well as Jan Karłowicz, Adam Kryński and Władysław Niedźwiecki ${ }^{23}$ add further meanings of "kurant," such as: a celebratory song; a public bank; a mortar for grinding seeds or powders; a ditty or tale; and a dance.

17 Zimińska, The Gdańsk Carillons.

18 Zimińska, 79.

19 M. Samuel Bogumił Linde, Stownik języka polskiego (Warszawa: printed by the author, 1808), 1:1187.

20 C[hristoph] C[ölestin] Mrongovius, Dokładny Słownik Polsko-Niemiecki krytycznie wypracowany (Königsberg: Bornträger, 1835), 186.

21 Maurycy Orgelbrand, Stownik jezzyka polskiego (Wilno: printed by the author, 1861), 1:566.

22 Zygmunt Gloger, Encyklopedia staropolska ilustrowana (Warszawa: Wiedza Powszechna, 1958), 3:120.

23 Jan Karłowicz, Adam Kryński, and Władysław Niedźwiedzki, eds., Słownik języka polskiego (Warszawa: Kasa im. Mianowskiego, 1902), 2:638. 
These meanings do not refer to automated playing bells, making it difficult to agree with Andrzej Januszajtis that "bell chimes" (kuranty dzwonowe) should mean an automated carillon, the more so that modern Polish language dictionaries do not link "kurant" with musical bell sets. ${ }^{24}$ I must also add that in no dictionary have I found the word "kurancista," mentioned by Januszajtis with reference to a musician that sets melodies on a chime. ${ }^{25}$

Equally controversial is Januszajtis' proposal to use the word "karylion" to designate sets of bells played from a baton keyboard. The term, which is a Polish adaptation of "carillon," was indeed recorded in dictionaries as early as 1902, but with no reference to a musical instrument. Instead, it was defined as the "chiming of several bells in tune," or "a box that plays when wound up." ${ }^{\text {"26 }}$ Interestingly, a pre-war foreign words dictionary does include "karylion," but the entry crossreferences to "carillon," ${ }^{27}$ while post-war dictionaries very often omit "karylion" altogether, and derived nouns such as "karylionista" or "karylionistka" can be found in no source.

Concerning the term "carillon," one may point to several arguments in favour of its use in the Polish language to designate a musical instrument or automaton composed of a set of bells. First and foremost, the term appears in nineteenthcentury encyclopaedias, notably in that of Samuel Orgelbrand of 1859 and that of Saturnin Sikorski of 1890, as well as several generic dictionaries and lexicons of the interwar period. More important than that very presence is the definition applied to the term in question. The definition listed by Samuel Orgelbrand is fully consistent with the one I propose:

Carillon, a set of bells of varying dimensions placed in a single row, properly tuned and made to sound via a keyboard device or springs (such as cylinders in musical clocks, barrel organs, and so forth, that likely come from this). They were placed on towers of buildings and would customarily made to play tunes on every hour or quarter of an hour. $^{28}$

24 Stownik języka polskiego PWN, accessed 26 August 2018, https://sjp.pwn.pl/szukaj/ kurant.html; Stownik jezyka polskiego, accessed 26 August 2018, https://sjp.pl/kurant.

25 Januszajtis, Gdańskie zegary, dzwony i karyliony, 142.

26 Jan Karłowicz, Adam Kryński, and Władysław Niedźwiedzki, eds., Słownik języka polskiego (Warszawa: Kasa im. Mianowskiego, 1902), 2:286.

27 Stanisław Lam, ed., Encyklopedyczny słownik wyrazów obcych (Warszawa: Trzaska, Evert i Michalski, 1939), 953, 245.

28 Samuel Orgelbrand, Encyklopedyja powszechna (Warszawa: Orgelbrand, 1860), 4:885. 
Carillon, a musical instrument composed of bells appropriately selected and moved through keys or springs. ${ }^{29}$

An equally satisfactory definition is offered by Aleksander Poliński in the encyclopaedia of Saturnin Sikorski:

Carillon (French) bells, a type of musical instrument very widespread in the past, especially in the Netherlands. It was composed of a number of bells of varying size, that played various melodies through a clock device. C. was most often placed on church towers. There were also c. with keyboards. The title of "c." is given by composers to works, especially for the piano, that imitate the sound of bells. ${ }^{30}$

Another argument for using the term "carillon" is the fact that it features (regardless of the definition) in post-war Polish dictionaries and musical encyclopaedias. ${ }^{31}$ A third argument is the ongoing irreversible globalisation. While the Germans are not giving up on "Glockenspiel," the Dutch on "klokkenspel" and "beiaard," and the Lithuanians on "kariljonas," the remainder of the music community has adopted the French term "carillon," pronounced variously depending on the region. In practice, the following two terms are used to denote a musician playing on bells: "carillonneur" and "carillonist," with Polish adaptations of "carilloner" and "carillonista," respectively. I have decided to use the latter consistently in the present book.

Terminological difficulties are haunting not only modern Polish writers on the carillon. Gdańsk citizens faced them as early as 1561 when a fourteen-bell music automaton was installed on the Main Town Hall tower. They did not know what to call it: it was an unknown oddity in Gdańsk. Similar mechanisms were familiar only to travellers who had visited the Low Countries. In the Baltic port, the carillon was identified with the clock, in that before every hourly chime, Protestant melodies would be heard from the tower.

Officials from the City Council, documenting expenses related to the automated carillon, initially also identified it with the clock. ${ }^{32}$ In the oldest extant

29 Samuel Orgelbrand, Encyklopedja powszechna $z$ ilustracjami i mapami (Warszawa: S. Orgelbranda Synowie, 1898), 3:314. This encyclopaedia includes no entry for "karylion."

30 Wielka Encyklopedya Powszechna Ilustrowana (Warszawa: S. Sikorski, 1893), 11:72. There is no entry for "karylion" in this source.

31 Jerzy Habela, Słowniczek muzyczny, 8th ed. (Kraków: Polskie Wydawnictwo Muzyczne, 1972), 33; Stefan Śledziński, ed., Mała encyklopedia muzyki, 3rd ed. (Warszawa: Państwowe Wydawnictwo Naukowe, 1981), 151; Andrzej Chodkowski, Encyklopedia muzyki (Warszawa: Państwowe Wydawnictwo Naukowe, 1995), 139.

32 About the historical terminology of the automated carillon of Gdańsk's Main Town Hall and people who programmed it, see Popinigis, 'Einige terminologische Bemerkungen'. 
cashbook from the accounting year 1576/77, under the name of Michael Colrep, the automaton programmer at the time (or "bell setter" as he was called), his quarterly wage was noted "wegen des Uhrwerks" (against the clockwork), ${ }^{33}$ and on 2 March 1577, "wegen des singenden Uhrwerks" (against the singing clockwork). ${ }^{34}$ In the latter note, the characteristic expression, "singing clockwork," is used for the first time; in later sources, it would be regularly used with reference to the Main Town Hall carillon.

In cashbooks from the late sixteenth century until 1793, we find numerous name variants, referring alternately to the automated carillon of the Main Town Hall. I have notable found the following terms:

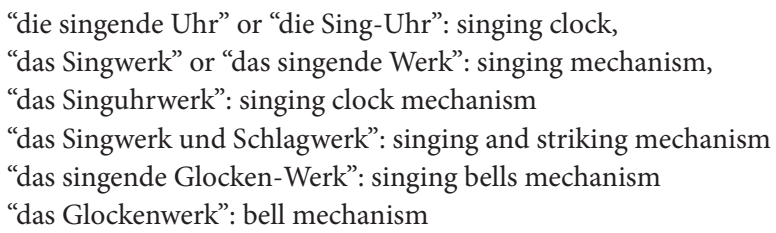

It is noteworthy that in the city's cashbooks, apart from payments to bell setters, a separate chapter was dedicated to expenses related to the repair and conservation of the automaton, titled "das Sing- und Schlaguhrwerk" or "das Singwerk." Only in one archival source have I found a Latin name used for the Town Hall carillon: a letter from bell setter Philipp Schönberg to the City Council of 1572 . In it, the author speaks of "musica automatorum," music of the automata. ${ }^{35}$

The Town Hall carillon is mentioned by seventeenth-century historians, though these failed to contribute anything new to the terminology. Christoph Hartknoch wrote about bells "in dem Singe-Seiger" (in the singing clock); ${ }^{36}$ Reinhold Curicke used expressions "singendes Uhrwerck" and "das Uhrwerck," known from cashbooks; ${ }^{37}$ Stephanus Grau, who referred to Curicke, added "die Sing-Glocken," singing bells. ${ }^{38}$ In his account of the arrival to Gdańsk in 1646 of Marie Louise Gonzaga, the second wife of Polish King Ladislaus IV, Adam Jacob Martini noted the play of the Town Hall bells with the linguistic flourish "das köstliche Cymbel Vhrwerck" (the delicious cymbal of the clock mechanism). ${ }^{39}$

33 APG 300,12/12, pp. 159, 161.

34 APG 300,12/12, p. 162.

35 APG 300,R/Vv, 217, p. 1.

36 Hartknoch, Preussische Kirchen-Historia, 760.

37 Curicke, Der Stadt Danzig, 53, 73.

38 PAN BG Ms 53, fol. 516v.

39 Martini, Kurtze Beschreibung und Entwurff, fol. 43v. 
The term "cymbal" designating the carillon also appears in the account placed under an engraving of the city panorama by Jacobus Hoffman of around 1635. As the note, titled "A Description of the Famous City of Gdańsk," notably reads:

there is a delicious clock on the town hall tower of the Right City, in which at every hour the cymbal plays. ${ }^{40}$

Seventeenth-century poets, such as Daniel Kałaj and Joachim Pastorius, unambiguously identified the Town Hall carillon with a clock. Kałaj, a Cracow-born Calvinist theologist, embedded a verse about the "singing clock" in his panegyric poem on John III Sobieski's victory at Vienna. ${ }^{41}$ Pastorius, the historiographer of King John II Casimir, a Catholic priest and physician, wrote the following poem titled Na Zegar w Gdańsku o każdej godzinie wydzwaniający wielce ujmujące melodie: ${ }^{42}$

In Horologium Gedanense, suavissimas melodias quavis hora decantans

Inclyta dum Gedani suggressus moenia lustrat

Hospes, et attonito pectore spectat opes.

Plurima mirantem turris pulcherrima tandem

Arrigit, aetheros dum canit illa modos.

Ecquis, ait, sacrum modulatour in aëre carmen?

Dissona concordi quis ciet aera sono?

Ne mirere hospes: scandens sub sidere turris

Discit ab Angelica fingere voce melos.
On the Gdańsk Clock, which on every hour chimes very charming melodies

Approaching Gdańsk, the traveller

sees the city's famous walls and dumfounded, watches its riches.

He is struck by the multitude of towers, of which

the most beautiful is dazzling when it sings that melody.

Is someone in the heavens singing a song, he asks?

Deriving a just tone from the dissonances?

Do not wonder, host: the tower that reaches the stars Learns its singing from Angels.

40 Jakrzewska-Śnieżko, Gdańsk w dawnych rycinach, 5-6.

41 See Preface, note 1.

42 Joachim Pastorius, In Horologium Gedanense, trans. Jan Michał Krzemiński, in Krzemiński, 'Emblematyczny wiersz Joachima Pastoriusa', 117-18. 
In the second half of the eighteenth century, the term "Glockenspiel" became widespread, although it appears already in earlier archives. I have found the first instance of its use in a cashbook of the Gdańsk City Council for the year 1729 when Christoph Sievert received on 30 April payment "against the clockwork" (wegen des Glockenspiels) for programming tunes informing about the death and funeral of mayor Salomon Gabriel Schumann. ${ }^{43}$ The name "Glockenspiel," though it became popular in Gdańsk with the project of building a carillon at the church of St Catherine and the animated discussion and correspondence that accompanied it, did not become immediately adopted for the automaton of the Main Town Hall. In cashbooks, earlier terms remained in use. The period of fluid terminology during the second half of the eighteenth century is illustrated by the carillon tablatures for the Town Hall automaton: one in four volumes, dated $1769-1775,{ }^{44}$ and two in single volumes, dated 1775 and early $1776 .{ }^{45}$ Although their titles include the word "Glockenspiel," the texts featured inside the tablatures also include older terms: "die Singuhr" and "das Singe-Werk." ${ }^{46}$ Wuth time, the term "Glockenspiel" came to supplant those earlier names, become standard in the nineteenth century. ${ }^{47}$

A terminological evolution also concerned the person programming the Town Hall automaton. In their motions to the City Councils from the early seventeenth century, their authors signed using one of the two terms:

"Steller des singenden Uhr-Wercks"48 (setter of the singing clock mechanism) or "Regirer des Singenden Uhrwercks" ${ }^{49}$ (manager of the singing clock mechanism).

Cashbooks of the City Council that remained in use until the incorporation ofGdańsk into Prussia contain repeated mentions of the following expressions:

"Singuhrwercksteller": setter of the singing clock mechanism

"Uhrwercksteller": setter of the clock mechanism

"Singuhrsteller": setter of the singing clock

"Regierer des Singendes Uhrwerck": manager of the singing clock mechanism

"Segersteller": clock setter

"Glockensteller": bell setter

43 APG 300,12/142, p. 112.

44 APG 300,R/Pp,q9.

45 APG 300,R/Pp,q10; APG 300,R/Pp,q10a.

46 APG 300,R/Pp,q9, p. 277; APG 300,R/Pp,q10, pp. 18, 22.

47 APG 300,R/LI,96, p. 9; Löschin, Geschichte Danzigs, 1:291; Löschin, Danzig und seine Umgebungen, 49-50; Hoburg, Geschichte und Beschreibung des Rathauses, 10.

48 APG 300,R/Vv,217, p. 15.

49 APG 300,R/Vv,217, pp. 23, 41, 57, 71; APG 300,36/74, p. 19. 
In the eighteenth century, a recurring theme was "Raths-Uhr Glockensteller," Town Hall clock bell setter, which features on the title pages of three Gdańsk tablatures and the official register of persons employed by the City Council..$^{50}$ Consequently, the term can be considered normative at least as long as the eighteenth century is concerned.

In the nineteenth century, programmers of the Town Hall automaton were still called bell setters, though in 1807 Johann Gottlieb Borowski, acknowledging receipt of his wage from the city treasure, signed as "Raths Uhr-Glokenist." ${ }_{1}$ The word "Glockenist" was reserved for musicians playing the instrument at the church of St Catherine and programming the mechanism of the Old Town automaton. In the twentieth century, an alternative appellation was "Glockenspieler."

\section{Existing literature and research premises}

The earliest mentions about the automated carillon of the Main Town Hall are to be found in the above-quoted writings by seventeenth-century historians: Christoph Hartknoch, ${ }^{52}$ Reinhold Curicke, ${ }^{53}$ Stephanus Grau, ${ }^{54}$ as well as in the quoted account of a witness of the 1646 events, Adam Jacob Martini. ${ }^{55}$ In his description of Gdańsk, Curicke also mentions the "striking mechanism" of St Catherine's, installed in 1573-75 and 1634, ${ }^{56}$ which were probably small automated carillons; they are also mentioned in an anonymous chronicle reprinted by Jacob Rhode in $1594 .{ }^{57}$ It is worth adding that in some copies of the Curicke work, there are to be found manuscript remarks by an unknown author from the eighteenth century, including information about a carillon installed at St Catherine's in $1738 .{ }^{58}$

At the beginning of the nineteenth century, a historical topography of Gdańsk was written by Christian Friedrich Wutstrack, in which he makes a brief the construction and play of the Main Town Hall automaton. Wutstrack provides

50 APG 300,R/Pp,q9; APG 300,R/Pp,q10; APG 300,R/Pp,q10a; Das jetztlebende Danzig registers for $1755-1810$.

51 APG 300,12/465, p. 279.

52 Hartknoch, Preussische Kirchen-Historia, 760.

53 Curicke, Der Stadt Danzig, 53, 73.

54 PAN BG Ms 53, fol. 345v, 351r, 516v.

55 Martini, Kurtze Beschreibung und Entwurff, fol. 43v.

56 Curicke, Der Stadt Danzig, 326.

57 Rhode, Chronica oder Handbüchlein Danziger Geschichte, 32.

58 Rhode, 327. 
more information about the carillon of St Catherine's church, narrating the instrument's history from 1738, the cost of construction and rules for its maintenance. He also listed the tuning and weight of the bells, drew their placement, measured the dimensions of the drum, and described the principles of automated and concert playing. ${ }^{59}$

Later writings from the nineteenth century do not provide much information about Gdańsk carillons. Gotthilf Löschin lists some information in his publications about the history of Gdańsk. ${ }^{60}$ In his description of the Main Town Hall, Karl Hoburg mentions the automaton installed on its tower. ${ }^{61}$ Theodor Hirsch published a book on the church of St Mary, discussing the confession complexity of Gdańsk and mentioning the Town Hall carillon as well as the melodies of Psalms to words by Ambrosius Lobwasser played on it. ${ }^{62}$ Also Wilhelm Ferdinand Zernecke mentions both Gdańsk carillons in his guidebook of Gdańsk, published in $1843 .{ }^{63}$ In 1869, Heinrich Döring presented the St Catherine carillon in his Allgemeine Encyklopädie der Wissenschaften und Künste, in the "Glockenspiel" entry. ${ }^{64}$ Another noteworthy source is the manuscripts of Carl Anton Kaschlinsky, a clockmaker and setter of the Town Hall carillon. Of particular interest is his manuscript from 1861, in which he described the bells, mechanism, and technical condition, commented on the way of programming tunes on the drum, listed the repertoire for the entire year, and noted a few melodies. ${ }^{65}$

The interwar period brought several important, detailed accounts exclusively dedicated to the Gdańsk carillons. In 1928, Herbert Pawlowski published an article about the Main Town Hall automaton. ${ }^{66} \mathrm{He}$ described the mechanism, listed the dimensions of the drum, the number and dimensions of the laths, the number and dimensions of holes, to which pins were fixed through slats to programme tunes, and a plan of bell disposition in the tower. Pawlowski also listed the basic facts about the automaton's inception and its repertoire, showing that he was familiar with the carillon tablatures of Theodor Friedrich Gülich, a bell setter from the eighteenth century. He also included a photograph of the

59 APG 300,R/LI,96, pp. 9-10, 145-48.

60 Löschin, Geschichte Danzigs, 1:291, 2:179; Löschin, Danzig und seine Umgebungen, 49-50, 88-90.

61 Hoburg, Geschichte und Beschreibung des Rathauses, 10.

62 Hirsch, Die Ober-Pfarrkirche von St. Marien, 2:237.

63 Zernecke, Cały Gdańsk za dwadzieścia srebrnych groszy, 79.

64 Döring, 'Glockenspiel', 98-99.

65 PAN BG Ms 1093 IV.

66 Pawlowski, 'Das Glockenspiel des Rechtstädtischen Rathause zu Danzig', 477-81. 
mechanism. Post-war scholars who described the Main Town Hall carillon based their analysis mostly on information provided by Pawlowski.

Two years prior, in 1926, another equally important description was made of the carillon of the church of St Catherine. Its author, Bruno Meyer, has access to sources that supplied numerous details. Most importantly, Meyer knew the now lost manuscript of Eltjen Wolthers, first carillonist of St Catherine, which included musical compositions for the Old Town carillon and a manual for programming the mechanism. Meyer also had access to other archive materials, now partly lost. Thanks to that broad base, he presented an extensive historical account of the carillon's construction and the story of the complaint against the faulty bells cast by Jan Nicolaas Derck. He was also able to refer information on Eltjen Wolthers and his son Lucas. Moreover, Meyer described the 1910 carillon, which replaced the 1738 instrument destroyed in a fire. ${ }^{67}$ The Old Town carillon is also mentioned in the writings of Ernst Blech, the archdeacon of St Catherine's, who was deeply involved in the renovation of the church after a fire of 1905, including the construction of a new carillon. One of Blech's articles, published in 1919, is noteworthy for featuring several pieces of information absent from earlier literature. $^{68}$

It is intriguing that no mention is made of Gdańsk carillons by Hermann Rauschning in his invaluable monograph ${ }^{69}$ which to this day serves as a starting point for research on the musical culture of old Gdańsk, even though he did address church tower music and tower pipes. He only makes a single mention about the Town Hall carillon in a footnote relative to Philipp Schönberg. Rauschning researched the motions sent to the City Council and noted without comment that Schönberg was the setter of the "singing mechanism."70

A sort of summary of the pre-war literature on Gdańsk carillons (excluding articles that appeared in the daily press) is offered by the 1935 text of Georg Edel, the last carillonist of St Catherine and setter of the Town Hall bells. In an emotional narrative tinged with nostalgia, but including much sensible information, the author waxes lyrical about the timbre of the two Gdańsk carillons. It is worth noting the appended photograph, showing a unique view from the balcony of the Main Town Hall tower, with several bells in the foreground. ${ }^{71}$

67 Meyer, 'Die Glockenspiele auf St. Katharinen in Danzig', 3-17.

68 Blech, 'Leidensjahre von St. Katharinen in Danzig'.

69 Rauschning, Geschichte der Musik und Musikpflege in Danzig.

70 Rauschning, 30.

71 Edel, 'Aus Danzigs Eigenart', 179-81. 
After the Second World War, studies on the history and music of Gdańsk carillons were developed in the Polish scholarly environment by Andrzej Januszajtis, who was also active in the construction of a new carillon for the church of St Catherine. He authored works that both recalled Gdańsk carillon to the community and largely expanded our knowledge about it. Januszajtis' most important texts include an article from 1988 on the music of Gdańsk bells. ${ }^{72}$ Apart from the first Polish account of eighteenth-century sources with repertoire for both Gdańsk carillons, he also published a transcription of a work by Johann Ephraim Eggert, carillonist of St Catherine's, as well as transcriptions of two Protestant chorale settings in a unique tablature notation by Theodor Friedrich Gülich, setters of the Main Town Hall automaton. Januszajtis also established a crucial piece of information: the dating to 1564 of the death of Franciscus de Rivulo, who had hitherto not been associated with the Town Hall carillon. He was considered the first important author of Flemish polyphony active in Gdańsk, as well as cantor of the St Mary church's chapel, an ensemble also serving the City Council, but was not acknowledged as having come to Gdańsk primarily to programme tunes on the automated carillon's drum at the Main Town Hall.

Andrzej Januszajtis' further research included the publication of a list of the Town Hall carillon's setters ${ }^{73}$ as well as that of the church of St Catherine. ${ }^{74}$ His opus magnum is the second part of his monographic Gdańskie zegary, dzwony $i$ karyliony. ${ }^{75}$

The inauguration in late 2000 of a new instrument in the Main Town Hall kickstarted intense research on the history of the Gdańsk carillon, with a wider circle of scholars involved. ${ }^{76}$ This is also when my interest in the topic initiated, resulting eventually in early publications. ${ }^{77}$ I have notably researched the 1785 manuscript of Johann Ephraim Eggert and the compositions it includes. I have presented my early commentary in $2004,{ }^{78}$ and have returned to that source in 2006 when I edited a facsimile edition. ${ }^{79}$ The latter project involved

72 Januszajtis, 'Muzyka gdańskich dzwonów'.

73 Januszajtis, 'Beiträge zur Musikgeschichte Danzigs', 315-19.

74 Januszajtis, 'Bell-playing in Gdańsk', 53.

75 Januszajtis, Gdańskie zegary, dzwony i karyliony, 117 ff. Other works by Andrzej Januszajtis on the same topic include Januszajtis, 'Mowa i muzyka gdańskich dzwonów'; 'The Bells of Gdańsk'; and 'Die vergessene Kunst des Glockenläutens'.

76 Kaźmierczak, 'What the Gdańsk Carillons Played and Play'.

77 Popinigis, 'W swoim stylu'; Popinigis, 'Carillons and Carillon Music in Old Gdansk'.

78 Popinigis, 'Das Carillon Repertoire'.

79 Eggert, Choral-Lieder zu dem Glocken-Spiel. 
the cooperation of Dariusz Kaczor, whose studies, based not only earlier literature but also hitherto unknown archival sources spanning back to the early nineteenth century, paved the way to a full account of the origin and construction of the St Catherine carillon, the legal status and maintenance of that instrument, duties and remuneration of the carillonists. Based on the research of Jerzy Marian Michalak, Dariusz Kaczor also presented the life and activity of Johann Ephraim Eggert. ${ }^{80} \mathrm{My}$ task in that project was to characterise Eggert's musical compositions and to elucidate the issues of their notation. ${ }^{81}$ Interpreting that notation, I have confirmed the earlier judgment expressed of Georg Köppel that Eggert's works were intended both for the automated and concert carillon. ${ }^{82}$

Meanwhile, independently from the Kaczor-Popinigis research, the manuscript of Johann Ephraim Eggert was studied by Frank Deleu, who presented a paper at the 15th World Carillon Congress that took place in Gdańsk in $2006 .{ }^{83}$ Commenting on the carillon sources from Gdańsk, Deleu stated that it is likely the only city in the world with such a large number of extant eighteenth-century books and works for the instrument. ${ }^{84}$ Yet Eggert's manuscript had been known for a long time: it was mentioned notably by Margarete Schilling ${ }^{85}$ and Stanisław Prószyński. ${ }^{86}$ Georg Köppl published the works of Eggert: 111 transcriptions in $1990^{87}$ and 258 further ones in $2006 .{ }^{88}$ In both publications, he included extensive forewords with a discussion of the manuscript and Eggert's compositional style.

In my research, I have returned twice to the Eggert manuscript, or more specifically, the works included in it. In 2009, I focused on those compositions where Eggert quotes the songs of Carl Philipp Emanuel Bach, ${ }^{89}$ and in 2011, I discussed the formal structure of all works included in the collection Choral-Lieder zu dem Glocken-Spiel der Altstädtschen Ober-Pfarr-Kirche zu St. Catharinen ausgesetzt mit Variationes. ${ }^{90}$

80 Kaczor, 'Wstęp'.

81 Popinigis, 'Wstęp'.

82 Köppl, 'Vorwort', 2-3.

83 Deleu, 'Johann Ephraim Eggert Choral Lieder'.

84 Deleu.

85 Schilling, Glocken und Glockenspiele, 158-61.

86 Prószyński, Świat mechanizmów grających, 353.

87 Eggert, 111 Danziger Choräle.

88 Eggert, 258 Choral-Variationen.

89 Popinigis, 'Bachowskie interludia'.

90 Popinigis, 'Choral-Lieder mit Variationes'. 
Another topic I addressed was the history of the commission, execution, and complaint of the carillon bells cast for St Catherine's in 1737 by Jan Nicolaas Derck. ${ }^{91}$ This research was made possible by the edition by André Lehr of a transliteration of a manuscript by Juriaan Spruijt, one of the experts that assessed the Gdańsk bells. ${ }^{92}$ Kept at the Westfries Archief in Hoorn, that source includes a number of documents directly related to the issue. ${ }^{93}$ It is worthy of note that the Dutch scholarly literature has not overlooked Jan Nicolaas Derck. The bell founder of Hoorn and the St Catherine carillon affair have been presented by André Lehr ${ }^{94}$ and mentioned notably by Luc Rombouts. ${ }^{95}$ Thorough research on the life and activity of Jan Nicolaas Derck was conducted by Piet Boon. ${ }^{96}$

In recent years, our knowledge has also been expanded on the automated carillon of Gdańsk's Main Town Hall. The starting point - as well as an inspiration for my own research ${ }^{97}$ - was the work of Andrzej Januszajtis. Consequently, I have focused on the origin of the Town Hall carillon, ${ }^{98}$ its historical names and those of the automaton's setters. ${ }^{99}$ I have also researched a detailed list of bell setters. ${ }^{100}$ The Main Town Hall carillon is also mentioned by Dutch researchers, as is that of St Catherine's. ${ }^{101}$ A study of Dutch writings on the subject notably revealed the genealogy of the Moer family, including Jan Moer (Moor), the craftsman who cast the Gdańsk Main Town Hall bells. ${ }^{102}$

Of particular relevance to the cognition and assessment of the Town Hall bell music was the establishment of principles of transcription of works from Gdańsk carillon tablatures: four music manuscripts from the second half of the eighteenth and early nineteenth century. Compositions in those sources were notated in a unique system. Its premises were determined in 2000 by Małgorzata

91 Popinigis, 'Gdańska afera carillonowa'.

92 Spruijt, Beschrijving van Klokken.

93 WA Nummer 134E69.

94 Lehr, Van paardebel tot speelklok, 108, 245-46; Lehr, Truyen, and Huybens, The Art of the Carillon in the Low Countries, 188-89.

95 Rombouts, Singing Bronze, 107.

96 Boon, 'De Hoornse Klok- en Geschutgieterij'.

97 Popinigis, 'Die Danziger Glockenspiele'.

98 Popinigis, 'Das singende Uhrwerk'.

99 Popinigis, 'Einige terminologische Bemerkungen'.

100 Popinigis, 'Ustawiacze automatycznego carillonu'.

101 Lehr, Truyen, and Huybens, The Art of the Carillon in the Low Countries, 102-3; Lehr, Van paardebel tot speelklok, 166.

102 Adriaenssen, 'De Bossche klokengietersfamilie Moer'. 
Fiebig-Drzewiecka, Janusz Grabowski, and Grzegorz Szychliński. ${ }^{103}$ I have explained their transcription method in 2012 when discussing the Gdańsk tablatures. ${ }^{104}$

The book Carillons and Carillon Music in Old Gdańsk is based on the existing scholarly literature and my own research - partly published but comprehensively completed in the last few years. A lot of new material was recovered through archival research, allowing to expand the research area and level of detail for issues that were only mentioned in the earlier literature. I have analysed sources unused or only partly used to date. My research has focused on the following archives and libraries:

1. Archiwum Państwowe (State Archive) in Gdańsk

a. carillon tablatures with music for the automated carillon of the Main Town Hall

b. manuscript of Johann Ephraim Eggert

c. cashbooks of the City Council

d. motions by bell setters of the Main Town Hall

e. selected ceremonials

f. mayoral archives

g. documents of the Old Town Council

h. documents of the carillon foundation of St Catherine's

i. archives of the carillon cashbooks

j. documents related to the 1910 carillon construction

k. birth registers of Gdańsk churches

2. Polska Akademia Nauk Biblioteka Gdańska (Polish Academy of Sciences Gdańsk Library)

a. manuscripts of Carl Anton Kaschlinsky

b. Gdańsk press of the eighteenth-twentieth century

c. various manuscripts and prints

d. Lutheran and Calvinist songbooks

3. Stadsarchief Amsterdam

a. bell casting contract of Jan Nicolaas Derck

4. Stadsarchief's-Hertogenbosch

a. bell casting contract of Jan Moer

b. birth registers for the Moer family

103 Fiebig-Drzewiecka, Grabowski, and Szychliński, 'Notacja kołkowa bębna carillonu'. 104 Popinigis, 'Gdańsk Carillon Tablatures'. 
5. Regionaal Historisch Centrum Groninger Archieven:

a. birth registers for the Wolthers family

6. Westfries Archief in Hoorn

a. birth registers of churches in Hoorn and Einkuzen for Jan Nicolaas Derck

b. manuscript of Juriaan Spruijt

The objective of this book is to reconstruct the history and music of the old Gdańsk carillon. This research premise has determined the book's subdivision into two parts. The first discusses the history of the Gdańsk carillon while the second analyses their repertoire. The timeframe of the topic has also determined the research objects. For the automated carillon of the Main Town Hall, it is the period from 1561 to 1945 . For the four successive carillons of the church of St Catherine, the years 1573 (or 1574)-1942. I have also discussed the carillon built in 1939 in the youth hostel on Bishop's Hill (Bischofsberg) as well as the musical automaton in Milk-Can Gate (Milchkannenturm), inaugurated in 1938.

In the first part of the book, I have focused on several aspects: the genesis of the successive automata and instruments, the procedure of bell commissioning and casting, as well as the product itself: bells, mechanisms for manual and automated play, the craftsmen that manufactured them: bell founders and mechanism builders. I then discuss a group of topics related to how the Gdańsk carillon functioned in the urban space. The main purpose of the automata was of course to measure time; they were also signallers of events happening in Gdańsk and other cities of the Polish-Lithuanian Commonwealth, including those private occurrences that were relevant to the social life of the city, such as the deaths and funerals of members of the two councils: that of the Main Town and Old Town. Since St Catherine's carillon was also used for concert playing (both regular and occasional), I have discussed those uses, too. Furthermore, I have listed carillonists and bell setters. From the beginning of the Gdańsk carillons to the year 1945, over thirty musicians of different specialities - mostly organists but even some watchmakers - have worked as carillonists and setters. Where possible, I have sought to list their biographical data and time of employment. Looking at the history of the Town Hall automaton and Old Town instrument through the lives of the carillonists and setters has allowed me to analyse issues related to the management, maintenance, and funding of both Gdańsk carillons.

The book's second part is dedicated to music. I have reconstructed the carillon repertoire based primarily on the extant musical manuscripts from the years 1769-1861, which include 919 compositions: 659 for the Main Town Hall automaton and 260 for the carillon of St Catherine's. I have also used information on books now lost. I have analysed manuscripts that include no musical text 
but that register the musical repertoire of the two carillons. I have analysed those documents that have survived in detail - a task necessary as many contained additional information completing existing historical data on the carillons. I have also commented on the unique system of notation used for the Town Hall automaton as well as the notation of works by Johann Ephraim Eggert for the St Catherine carillon, specifying their structure and stylistic characteristics. Since all those compositions belong to a single category of Protestant song settings, I have endeavoured to discuss them in the context of successive editions of Gdańsk hymnals. The Gdańsk press from the first three decades of the twentieth century proved an invaluable resource for explaining the durability and evolution of the city's carillon repertoire.

In conclusion of these opening remarks, let me list a few editorial principles adopted in this book:

1. First names are listed according to the sources instead of their English adaptations, except for characters known in historiography (kings, and so forth).

2. Institutions, streets, official functions are listed in German, with translations in brackets, or vice versa.

3. Quotes are not edited for orthography and predominantly not translated, as they are discussed in the main text.

4. Chorale titles are uniformed according to RISM spelling.

5. I have presented transcriptions of works from the tablatures of Theodor Friedrich Gülich and Paul Friedrich Knaack, following the method of Małgorzata Fiebig-Drzewiecka, Janusz Grabowski, and Grzegorz Szychliński. ${ }^{105}$

6. In transcriptions of the works of Johann Ephraim Eggert, I have followed the notation of the manuscript but also adhered to modern musical orthography.

105 Fiebig-Drzewiecka, Grabowski, and Szychliński, 'Notacja kołkowa bębna carillonu’. 
Part One Automatons and instruments. Bell founders, setters, and carillonists 



\section{The Main Town Hall automatic carillon, 1561-1945}

\section{Origin and history}

The carillon was invented in the Netherlands, where it developed most intensely over centuries. First mentions of bells being played from a baton keyboard go back to the late fifteenth and early sixteenth century; in 1530, the use of a drum in automatic playing was mentioned. Sets of automatic-playing and keyboard-controlled bells were built in Averbode, Oudenaarde, Mechelen, 'sHertogenbosch, Zierikzee, Zoutleeuw, and Tiel. Some Dutch bell founders began to specialise in the production of carillon bells. More automatons and instruments were gradually constructed and were ordered for the towers of churches and Town Halls of cities beyond the Netherlands. Early sets of musical bells, however, suffered in one decisive aspect: many were out of tune. For a long time, founders were unable to grasp precise pitch and mutual tuning of bells. It was only in the 1640s that a breakthrough was achieved. Born in Levécourt, brothers François (ca. 1609-67) and Pieter (1619-80) Hemony, using the research of carillonist Jacob van Eyck (ca. 1590-1657), developed the rules of casting and tuning bells. The timbre of carillons became satisfactory. The Hemony brothers were extremely active. Carillons cast in their workshop ended up in various cities including Amsterdam, Ghent, Kampen, Antwerp, Groningen, Utrecht, Mainz, Hamburg, Stockholm, and Darmstadt. The activity of these two bell founders consolidated the position of the Netherlands as the leading region of carillon bells production in Europe. ${ }^{106}$

In Gdańsk, the carillon appeared as early as 1561. It was a fourteen-bell automatic chime placed on the Main Town Hall tower. We do not know who inspired the construction of a carillon in a city so distant from the Netherlands and what determined the performance of that project. Circumstances might have included current political events as well as long-term social, cultural, and political processes in the city.

106 The history of carillons in the Netherlands is discussed in many works by André Lehr, including Van paardebel tot speelklok, and Lehr, Truyen, and Huybens, The Art of the Carillon in the Low Countries. See also Rombouts, Singing Bronze, the latest monograph on the history of carillons. 
A single event that triggered the construction of the carillon was the fire of Gdańsk's Main Town Hall, which broke off on 3 October 1556 between 11 a.m. and noon. It was caused by a defective fireplace of the Great Hall of Court. The fire raged for a long time as water was missing in the city because the well was being renovated. Damage was extensive. ${ }^{107}$ After that unfortunate incident, Gdańsk councillors decided to rebuild their Town Hall with a number of new elements, including a carillon, called at that time "singing mechanism" (Singwerk) or "singing clock mechanism" (singende Uhrwerk), a term justified by the link between bells and the Town Hall clock. The mechanism was triggered before every hourly chime to make passers-by look at the tower; before they noticed the high-perched bells, they would see the clock. That is how there emerged the association between sound and vision in the term "singing clock" and similar ones. ${ }^{108}$

The "great reconstruction" of the Town Hall after the 1556 fire sharply reflected some of the social and cultural processes and policies in the city. Councillors wished primarily to emphasise the size and authority of their office. ${ }^{109}$

Scholars have pointed that "the intention of the city's patriciate was to make the Main Town Hall almost a temple, a 'sacred space' for the authorities, seat and symbol of the city's greatest authority, the council, which at time began to style itself the Senate." 110 The Town Hall reconstruction was used to reemphasise the dominant role of the Council, hence the new tower had to be taller than the older one. It stood high above the city and the tower of St Mary's, the city's most important and largest church. The Town Hall reconstruction also provided an opportunity to demonstrate Gdańsk's political links with the Polish-Lithuanian Commonwealth and its allegiance to royal authority, exerted at the time by the last king of the Jagiellonian dynasty: a statue of Sigismund Augustus was placed at the top of the tower.

Discussing the role of town halls as places of culture, Teresa Jakimowicz observed that in urbanised Europe "during the sixteenth century, an imagery, or in other words a set of iconography was worked out that supplied images to express content relevant not only to the city authorities and community."111 Amongst the most important elements, she cites the town hall and its tower as symbolic signs of "sovereignty of the urban commune and its sense of pride,"112

107 Curicke, Der Stadt Danzig, 53; Domagała, Gdańsk. Ratusz Głównego Miasta, 13-14.

108 Popinigis, 'Einige terminologische Bemerkungen'.

109 Zarębska, 'Kontekst urbanistyczny ratusza Głównego Miasta w Gdańsku’, 71-73; Bogucka, 'Funkcje społeczno-polityczne ratusza'.

110 Bogucka, 'Funkcje społeczno-polityczne ratusza', 85.

111 Jakimowicz, 'Ratusz jako miejsce kulturowe', 42.

112 Zlat, 'Ratusz - zamek mieszczan', 20. 


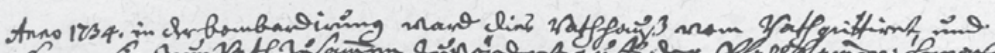

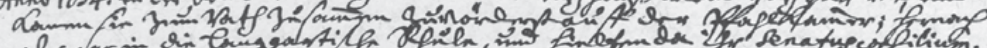

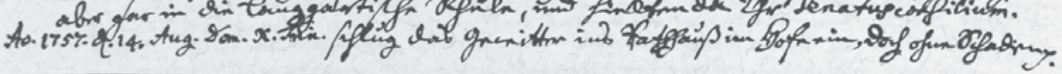

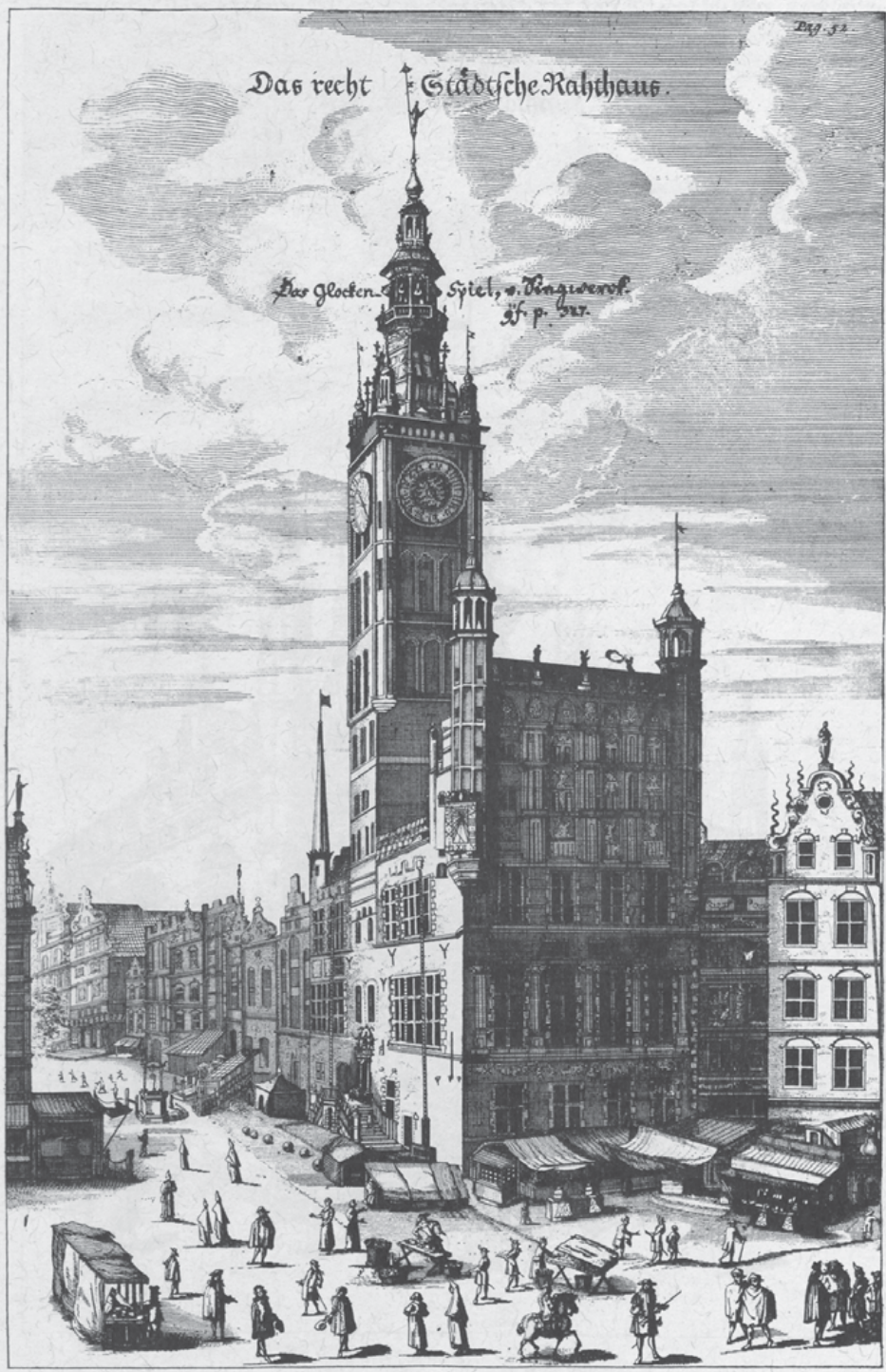

Fig. 1: The Main City Town Hall in Gdańsk. Curicke, Der Stadt Danzig, 52 


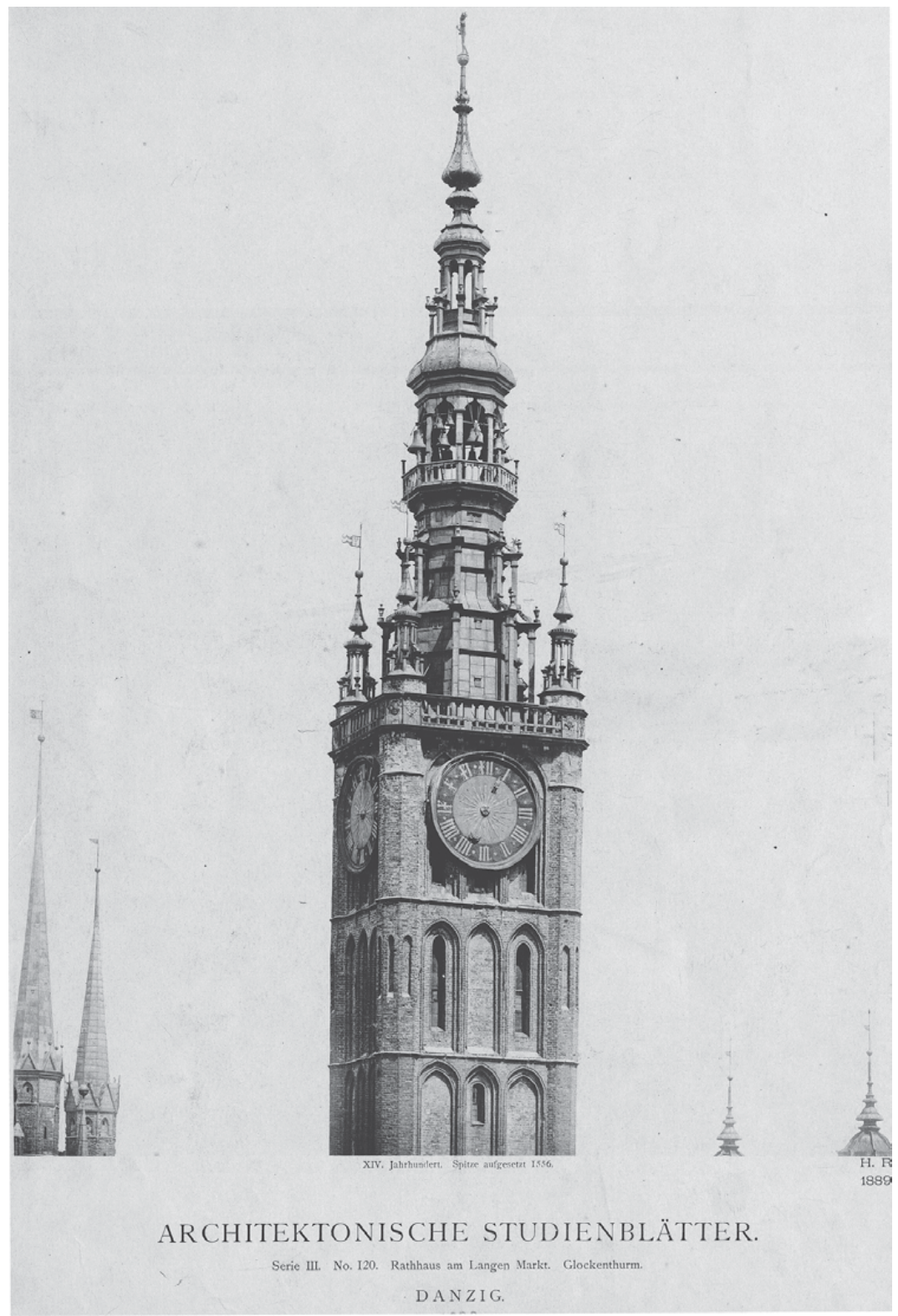

Fig. 2: The Main City Town Hall in Gdańsk. PAN BG AL/IV/23/15 
expressing independence, superiority, and power. $^{113}$ Other characteristic elements of that imagery included a clock and tower bells. Both mechanisms primarily measured time. In the city, scholars note, time was precious not only to the merchant ("merchant's time"114) but also authorities looking to achieve economic prosperity for the benefit and satisfaction of residents. In that sense, clocks and bells were important attributes of power. ${ }^{115}$ Their importance transcended the practical dimension of measuring time. Bells were particularly important in the town hall imagery. In a way, their sounds expressed the "community link between burghers." 116 Ranging from a few to several dozen, playing well-known melodies, bells significantly reinforced that link. In Gdańsk, the repertoire of the Main Town Hall carillon, and later also of the St Catherine carillon, was based on Protestant chants, music that on the religious level united citizens and expressed their faith, recalling the duty of living in unity with God.

Work on the reconstruction and modification of the destroyed Town Hall was enormous in scope. The eastern top was adorned with an open-work attic as well as coats of arms of Poland, Gdańsk, and Royal Prussia. The heightened tower received new clock faces and topped by a Renaissance dome. On the dome spire, a natural-size gilded statue of Sigismund Augustus was placed, a modern, original solution inspired, according to Mieczysław Zlat, by Dutch practice. ${ }^{117}$ The King was portrayed with attributes of royal power: a Roman knight's armour (Renaissance breastplate), proudly standing on a globe, with a standard in hand depicting a ship, symbolising his authority over the Baltic Sea. The statue paid homage to a monarch whose policies toward Gdańsk were often opposed; relations only improved when Sigismund Augustus granted the city some concessions on religious matters in a privilege of $1557 .{ }^{118}$

Many Dutch artisans took part in the reconstruction of the Town Hall and manufacture of its external elements and, later, its interiors. For instance, Dirk Daniels ${ }^{119}$ - who joined other Dutch artists and artisans seeing Gdańsk as an attractive place to work - supervised the reconstruction of both the tower and its dome. Attracted by good pay, they moved to the Baltic city, changing its image

113 Jakimowicz, 'Ratusz jako miejsce kulturowe', 39.

114 Jakimowicz, 41.

115 Bogucka, 'Funkcje społeczno-polityczne ratusza', 85.

116 Zlat, 'Ratusz - zamek mieszczan', 21.

117 Zlat, 22-23.

118 Bogucka, 'Przemiany społeczne i walki społeczno-polityczne', 248.

119 Domagała, Gdańsk. Ratusz Głównego Miasta, 14; Iwanoyko, Sala Czerwona ratusza gdańskiego, 15. 
and adorning its architecture with details and elements typical of their places of origin. Dutch influences changed the character of Gdańsk's art and architecture; they can be found notably in façade top decorations or perrons. Such models derived from the city's economic policy since 1361 when Gdańsk joined the Hanseatic League. ${ }^{120}$ Consequent profits went not only to Gdańsk merchants.

In the Hanseatic League's structure, Gdańsk was an active and important outpost. For centuries, it had competed strongly with Lübeck. With time, it prevailed, strengthening its position as the leading seaport in Eastern Europe. ${ }^{121}$ Around the mid-sixteenth century, it became the most important port on the Baltic Sea, a central hub for maritime trade. The leading merchandise was grain; in the fifteenth century, Gdańsk was nicknamed "Europe’s granary." ${ }^{122}$ Of Gdańsk's many commercial routes, those with the Netherlands were most important, the result of both Gdańsk's own activity and Dutch economic expansion. It is estimated the Dutch Baltic fleet counted between 600 and 800 ships, many times more than Gdańsk's own fleet of several dozen ships. Scholars have calculated that in 1583, $45 \%$ of all ships entering Gdańsk were Dutch. ${ }^{123}$ The most important axis of maritime trade was GdańskAmsterdam ${ }^{124}$ with grain the leading item of that trade. The distance of 850 sea miles between the two cities could be covered, with fair winds, within a week. ${ }^{125}$

Several dozen Dutch companies had permanent agents in Gdańsk. Maria Bogucka writes, "Usually one of the family's sons or younger brothers would be sent from Amsterdam to Gdańsk, where he would obtain a charter or become a local citizen and conduct business for the family firm." 126 Lively trade between the two regions attracted many shipowners, factors, sales representatives, sippers, and simple sailors.

At the same time, however, Gdańsk entrepreneurs also hired representatives in the Netherlands. The Schultze family was active in Amsterdam, Middelburg, and Rotterdam; ${ }^{127}$ Claus Schultze oversaw the business from Gdańsk as a juror of the City Council. ${ }^{128}$ Another well-known trading family was the Schencks. Arndt

120 Nowak, 'Kultura, nauka i sztuka w Gdańsku', 397-402.

121 Mackenney, Sixteenth Century Europe, 85, 88.

122 Dollinger, The German Hansa, $359 \mathrm{ff}$.

123 Bogucka, 'Zmiany w handlu bałtyckim', 449-50.

124 Bogucka, 'Gdańsk - największy port Bałtyku', 482.

125 Davies, God's Playground, 1:200.

126 Bogucka, 'Zmiany w handlu bałtyckim', 454.

127 Bogucka, 453.

128 He was member from 1552 to 1553 ; see Zdrenka, Rats- und Gerichtspatriziat der Rechten Stadt Danzig, 2:28. 
Kleinfeld also traded with the Netherlands, ${ }^{129}$ a member of a well-established Gdańsk family that included Heinrich and then Rheinhold, who held various positions in the City Council for over fifty years from $1533 .{ }^{130}$

Gdańsk patricians and their sons thus familiarised themselves with the living conditions in Dutch cities, including bell music. Youth travel was particularly important as youngsters travelled to the Netherlands to study at universities such as Utrecht, Amsterdam, Leiden, and Groningen. With the spread of the Reformation, such international studies became increasingly popular. Scholars indicate a large number of Gdańsk citizens amongst students: "in Leida alone, throughout the seventeenth century there were over 800 students from Royal Prussia, predominantly from Gdańsk." ${ }^{131}$ This migration was supported by the City Council, which offered scholarship starting with 1540. With time, this bursary fund became the leading position in the city's budget for education, churches, and culture. A bursary of 150 to 200 thalers per year was offered to students for a total duration of one to three years. ${ }^{132}$ City Council scholarship holders included notably Paul Siefert who went to Amsterdam to study organ playing with Jan Pieterszoon Sweelinck for a duration of two years: he was paid 150 marks twice, in 1607 and 1608. Youngsters sponsored by city authorities were supported also after returning to Gdańsk; Paul Siefert had his rent paid as a bursary holder as late as $1611 .{ }^{133}$ Jan Pieterszoon Sweelinck was the organist of Amsterdam's Oude Kerk. Commenting on the social status of musicians in the baroque area, Alina Żórawska-Witkowska states that apart from playing the organ, Sweelinck "also oversaw the city's carillons." 134 Siefert thus had many opportunities to learn the mechanism and repertoire of the Oude Kerk carillon. It is plausible that he later transmitted that musical experience to his pupil Andreas Neunaber, who became employed at the small organ of Gdańsk's St Mary's church ${ }^{135}$ and, more importantly for our topic, inherited from his father Hans Neunaber the position of "Regierer des Singenden Uhrwerks" (manager of the singing clock works) between 1634 and 1663 .

129 Bogucka, 'Zmiany w handlu bałtyckim', 454.

130 Zdrenka, Rats- und Gerichtspatriziat der Rechten Stadt Danzig, 2:18-31, 37-49, 156, 224-25.

131 Kubik and Mokrzecki, Trzy wieki nauki gdańskiej, 11.

132 Nowak, 'Lata rozkwitu kultury, nauki i sztuki', 716.

133 Popinigis, 'Sylwetka Pawła Sieferta w świetle źródeł’, 59.

134 Żórawska-Witkowska, 'Status społeczny muzyka w baroku', 42.

135 Rauschning, Geschichte der Musik und Musikpflege in Danzig, 141, 178, 192, 244, $420,422$. 
It is interesting that the origins of the carillon in Amsterdam's Oude Kerk are related with the same founder that cast the bells for Gdańsk's Main Town Hall: Jan Moer. In 1561, so after having completed the Gdańsk carillon, he was commissioned fourteen bells for the Oude Kerk, which he cast with his son Cornelis. Their work was delayed until 1564 and due to the Oude Kerk tower reconstruction of 1563-65; the bells were eventually installed in the bell tower of the Amsterdam Town Hall. Surprisingly, Jan Moer's work did not satisfy the expectations of councillors, who commissioned a new carillon with bell founders in Mechelen the following year, $1565 .{ }^{136}$

The concept of erecting a carillon in Gdańsk must have occurred to people with relations in the Netherlands. We do not know who that was exactly but the placing of the carillon on the tower of the Main Town Hall, a seat of the City Council, suggests one of their members.

The most relevant amongst potential animators of this project appears to be Johann Brandes. He sat in the Council from 1536 and occupied the highest post, one of four Mayors, between 1548 and $1577 .{ }^{137} \mathrm{He}$ was arguably a music connoisseur, with a special penchant for the most refined and exclusive genres, as evidenced by his collection of beautifully bound prints Netherlandish and French polyphony. After Johann Brandes' death in 1577, ${ }^{138}$ his music collection remained in the family for several decades. In 1610, his daughter Elisabeth Brandes, donated it to the City Council library. ${ }^{139}$ It consisted of prints including masses, motets, transcriptions of psalms after French models, and chansons. From this donation, two items have survived to this day, of which one is particularly interesting as it includes a valuable manuscript addition. ${ }^{140}$ This addition includes fourteen works (chansons and motets) by Orlando di Lasso. ${ }^{141}$ Formerly, scholars considered them autographs of the Netherlandish master, a theory now rejected. ${ }^{142}$ The dates of prints, to which Lasso's works were appended, suggest that the addition

136 Adriaenssen, 'De Bossche klokengietersfamilie Moer', 53, 69.

137 Zdrenka, Rats- und Gerichtspatriziat der Rechten Stadt Danzig, 2:171.

138 Zdrenka, 2:171.

139 Hartmann, 'Musikgeschichtliches aus der ehemaligen Danziger Stadtbibliothek', 394-96.

140 PAN BG Ee $21658^{0}$.

141 PAN BG Ms 4030.

142 Gancarczyk, 'Origin, Repertory, and Context of “Lasso's Autograph from Gdańsk'”, 298-306. 
is posterior to $1560 .{ }^{143}$ That addition is one of the oldest manuscripts with artistic music to survive in Gdańsk. ${ }^{144}$ This shows the interest of the patriciate in refined music. Importantly for our topic, the manuscript was written during the installation of the Town Hall carillon.

The fact that Johann Brandes owned a music collection does not confirm with certainty that he initiated the construction of the carillon. The idea might have been suggested to City Council by any other member, on the mayors serving during the 1556-61 term (Tiedemann Giese, Konstantin Ferber, Johann Proite, and Georg Kleefeld) as well as one of the councillors or jurors, some of which, such as Georg Giese, known from a portrait by Hans Holbein the Younger, were well-travelled and had considerable experience in their family businesses. ${ }^{145}$

The project of installing bells synchronised with a clock mechanism to play pre-programmed melodies each hour in the Town Hall tower must have matured gradually as the reconstruction of the building itself progressed. Eventually, bells were ordered in 1559 in 's-Hertogenbosch in northern Brabant.

The choice is 's-Hertogenbosch was a right one from all points of view. The city had long belonged to the leading centres of bell foundry. Its position was reinforced by good connections to Cologne, Aachen, and Amsterdam, cities that could easily supply the metals needed for bell manufacturing. The clay required for the casting moulds was available near 's-Hertogenbosch itself. ${ }^{146}$ Amsterdam, some ninety kilometres away, made it possible to ship the bells by sea, an important advantage in the case of the Gdańsk commission. It is possible that the choice of bell foundry was facilitated by the Gdańsk diaspora in that city or 'sHertogenbosch citizens who lived in Gdańsk. ${ }^{147}$

In the mid-sixteenth century, bell foundry in 's-Hertogenbosch already has more than two centuries of history. It developed very dynamically in the mid-fifteenth century, with the operation notably of brothers Jan and Willem Hoernken. Later, the city saw the rivalry of two masters (who initially cooperated before competing fiercely): Geert van Wou and Gobel Moer. Ultimately Wou moved to Kempen, leaving his rival free to operate in 's-Hertogenbosch. ${ }^{148}$ It

143 Popinigis et al., Music Collections from Gdańsk 1, 770.

144 The other is four vocal choir books catalogued as PAN BG Ms 4003.

145 Serczyk, 'Hartknoch Krzysztof Jan', 53.

146 Adriaenssen, 'De Bossche klokengietersfamilie Moer', 46.

147 On the contacts between Netherlandish artists and Gdańsk in the latter half of the sixteenth century, see 'Niderlandzcy artyści w Gdańsku'.

148 Adriaenssen, 'De Bossche klokengietersfamilie Moer', 45-46. 
was precisely the Moer foundry, run in the mid-sixteenth century by Gobel's grandson Jan Moer, that was commissioned the bells for Gdańsk. The matter was entrusted to Drik Daniels, a Netherlandish master and city carpenter who designed and oversaw many works on the Main Town Hall reconstruction. ${ }^{149}$ Unfortunately, we know little about the man who left so many traces of his activity in Gdańsk: he also run the construction of the Green Bridge at the end of Long Market, and the "Wasserkunst," i.e., the pump station. ${ }^{150}$ The city carpenter's duty also included the carillon. The construction of the gloriette and tower dome determined the number, size, and disposition of the bells. Dutchborn Dirk Daniels was deemed the right person to negotiate a contract with bell founder Jan Moer.

Daniels did not negotiate on his own. He travelled to 's-Hertogenbosch with other Gdańsk delegates. The contract ${ }^{151}$ signed on 10 January $1559^{152}$ indicates that master Jan Moer, son of Jaspar Moer, engaged to cast bells from good quality materials for master Dirk Daniels and transport them to Amsterdam with a crane at his own expense. ${ }^{153}$ Thus Moer did not opt for a solution practiced as late as the early seventeenth century, namely casting large bells or large numbers thereof at the place of destination; ${ }^{154}$ instead, he preferred to cast them in 'sHertogenbosch. The contract first mentions a bell weighing 6,000 pounds with a tolerance of 200 pounds. The bell was due to be delivered to Amsterdam by the Pentecost holiday; since there is no more precise information, I assume it relates to the year 1559. Further in the contract, Jan Moer engages to cast the carillon ("eenen voerslach"155) consisting of thirteen bells. This part of the commission

149 Iwanoyko, Sala Czerwona ratusza gdańskiego, 14-15; Zarębska, 'Kontekst urbanistyczny ratusza Głównego Miasta w Gdańsku', 73.

150 Zarębska, 'Budowle i urządzenia komunalne Gdańska', 359-60; Zarębska, 'Kontekst urbanistyczny ratusza Głównego Miasta w Gdańsku', 73.

151 City clerks of 's-Hertogenbosch documented all contracts and trade agreements from 1367. For more on this, see Spierings, Het Schepenprotocol van 's-Hertogenbosch 1367$1400,278-83$.

152 GAHt: R 1377, fol. 305.

153 Information relative to this contract is quoted after Adriaenssen, 'De Bossche klokengietersfamilie Moer', 48, with valuable insights from Mr Lucas van Dijck of the Stadsarchief 's-Hertogenbosch, with cordial thanks.

154 Adriaenssen, 49 quotes a commission from 1507, performed by Jaspar and Willem Moer, Jan Moer's father and uncle, respectively. They manufactured the bells for the Onze Lieve Vrouw church in Antwerp on location: they built a furnace at the cemetery near the church and cast the bells there.

155 GAHt: R 1377, fol. 305. 
was due to be delivered on the day of St Jacob, i.e., 20 July 1559. The weight of thirteen carillon bells is also indicated at 6,000 pounds. The contract also determined Jan Moer's payment, linked as per tradition to the bell's weight: 18 florins for every hundred pounds. In total, assuming a weight of 6,000 pounds for the first bell, the fourteen-bell commission amounted to 2160 florins. Half of that sum was guaranteed to the bell founder as an advance on the day of signing the contract, with the balance due after delivery of the bells to Amsterdam. Transport of the bells to Gdańsk was not included in the contract, a matter probably left to Gdańsk merchants.

The contract between Dirk Daniels and Gdańsk delegates on one part and Jan Moer on the other unambiguously indicates that the commission included fourteen bells to be delivered to Amsterdam in May and July 1559. Since both the quantity and date were eventually modified, the matter deserves a commentary.

An inscription on the bells indicates that it was not in 1559 but in 1560 when Moer performed his work: "... ME FECIT ANNO DOMINI MCCCCCLX." Could a renowned master such as Moer not meet a deadline and cast the bells a full year after signing the contract? Or were the latter's terms amended? Perhaps work on the reconstruction of the Gdańsk city hall was delayed and so the carillon commission's deadline was extended. Even if the bells reached Gdańsk in 1559 , they would have had to wait, as their installation had to be synchronised with the inauguration of Gdańsk fifth successive clock, which happened only in $1560 .{ }^{156}$ The largest bell mentioned in the contract, weighing 6,000 pounds, was a clock bell used to chime hours. It was hung before the other bells. The clock mechanism was independent of the carillon but effectively both automatons were synchronised. ${ }^{157}$

The suspension of the first clock bell was noted in 1687 by Gdańsk historian, Reinhold Curicke:

Anno 1560. Die erste Glocke zum Zeyger auf das Rahthau $\beta$ gebracht, ${ }^{158}$

while writing somewhat later, Stephanus Grau even indicated the precise date of the event - 1 May 1560:

Erste Sing-Glocke. Anno 1560. Den 1. May. Die Philippi Jacobi, war die Erste Sing Glocke, zum Uhrwerck auff das Rahthau $\beta$ gebracht. ${ }^{159}$

156 Szychliński, 'Zegar wieżowy Ratusza Głównego Miasta w Gdańsku’, 223.

157 Szychliński, 223.

158 Curicke, Der Stadt Danzig, 51.

159 PAN GD Ms 53, fol. 345v. Nineteenth-century writer Karl Hoburg wrote that the bell was lifted to the belfry on 13 August 1560. I believe it was after this author that other 
Carillon bells and their triggering mechanism were mounted the following year, i.e., 1561, as noted by the two seventeenth-century historians:

Anno 1561. Aber allererst dasselbe nebenst dem Zeyger und singendem Wercke gantz fertig worden. ${ }^{160}$

Work on the mounting of carillon bells, their synchronisation with the automatic play mechanism, and cross-checking the automation must have taken some time, as historians do not indicate the precise date of the carillon's finished construction. We know from later accounts, however, that the latter coincided with another important event relative to the Main Town Hall tower reconstruction: the erection of a gilded statue of Sigismund Augustus. The king's statue was mounted on the spire of the dome on the Tuesday before St Michael's of 1561, i.e., 23 September, at 10 a.m. That is how Rainhold Curicke describes the event:

Eben desselbe Jahr den Dienstag vor Michaëlis umb Segers 10. Ist der vergülte Mann auf die Spitze dess Rahthauses gesetzt. ${ }^{161}$

It was on that occasion that the Town Hall carillon played for the first time. Considering 23 September as the date of inauguration for the Gdańsk carillon also justified the celebration of its 300th anniversary that took place in Gdańsk on 23 September $1861 .{ }^{162}$

The above-mentioned supposition that there must have been additional arrangements between Jan Moer and Dirk Daniels or other Gdańsk City Council representatives is further substantiated by the issue of the actual number of bells. The contract mentions fourteen bells: a clock bell weighing 6,000 pounds and the remaining thirteen also weighing 6,000 pounds in total between them. In reality, Jan Moer cast fifteen bells for Gdańsk: fourteen carillon bells and a clock bell. There can be no doubt the carillon itself consisted of fourteen bells. This is supported by musical manuscripts of the second half of the eighteenth century with settings of Protestant chorale for such a number of bells ${ }^{163}$ as well as a testimony by Carl Anton Kaschlinsky (who set the Town Hall carillon between

scholars quoted this information; see notably Hoburg, Geschichte und Beschreibung des Rathauses, 10; Domagała, Gdańsk. Ratusz Głównego Miasta, 14; Januszajtis, Gdańskie zegary, dzwony i karyliony, 34, 128.

160 Curicke, Der Stadt Danzig, 53.

161 Curicke, 53.

162 PAN BG 1093 IV, p. 7.

163 APG 300,R/Pp,q9; APG 300,R/Pp,q10; APG 300,R/Pp,q10a. 
1847 and 1882) in an 1861 manuscript. Kaschlinsky lists fourteen bells, indicating their height, dimensions, and the weight of some of them. ${ }^{164}$ The fifteenth clock bell, hanging from the central part of the tower's dome, was mentioned by Herbert Pawlowski in 1928:

Zum Schlu $\beta$ verkündet die in der Mitte des Turmhelms hängende $» \mathrm{H} «-G l o c k e ~ d i e$ Tagezeit. ${ }^{165}$

Built in 1561 with bells imported from 's-Hertogenbosch, the Main Town Hall carillon was another example of the ties linking Gdańsk with the Netherlands, based primarily on trade but which also influenced other, noneconomic aspects of social life. The affluent Gdańsk middle class was eager to follow models observed during merchant trips, which were subsequently integrated into the public and private sphere of local life. New elements were added to the cityscape that distinguished Gdańsk from other metropolises in the Polish-Lithuanian Commonwealth, contributing to local pride and identity. The City Council reinforced the city's prestige in various ways, including the installation of a carillon. Noble melodies of Protestant chants coming from the tower of the building where councillors met and worked were a musical reminder of the city's authority. The "singing clock mechanism" became an undisputed decoration of the city, unique in the Commonwealth. When commissioning the carillon, the City Council knew it would be admired. Still, it had the ambition to equal Dutch cities and demonstrate Gdańsk's modernity and openness to Western trends that gathered considerable momentum in the sixteenth and subsequent centuries. In the cities of Frisia and Brabant, carillons were embedded in the city's topography and soundscape as an element of social communication. They measured time, signalled various events, and accompanied official celebrations. Those that could be played on also performed an entertainment function. The situation in Gdańsk was similar, even though the carillon of the Main Town Hall was only a musical automaton rather than an instrument.

Religious songs played by the "singing mechanism" of the Town Hall quickly became a staple of Gdańsk's everyday life and a stable component of the soundscape. It is hard to say whether the carillon continued to be perceived in the following centuries as a special attraction or more an obvious, imperceptible element of the soundscape.

The carillon again came to the fore in mid-September 1861, i.e., before the tricentenary of its inauguration. City authorities decided to emphasise the occasion

164 PAN BG 1093 IV, p. 1.

165 Pawlowski, 'Das Glockenspiel des Rechtstädtischen Rathause zu Danzig', 479-81. 
with public festivities. The anniversary might have been considered an outstanding event if not for the sheer number of other jubilees organised in mid-nineteenth century Gdańsk to strengthen the city's historical identity, as observed by Peter Oliver Loew. Those nineteenth-century jubilees favoured the cultivation of memory and its ritualisation. ${ }^{166}$ The 500th jubilee of the church of St Mary, celebrated in 1843 , was an opportunity to shape two complementary types of identity: liberal bourgeois and Prussian, understood as stately and patriotic. ${ }^{167}$ That cultivation of the past was diligently followed by the local press. "The 60th anniversary of the city's occupation by Prussia in 1853 was celebrated as lavishly as the 40th and 50th anniversary of the 1813 events. Also noteworthy was the 200th anniversary of the Councillor's Cellar (Ratskeller) as well as the 215th of Martin Opitz's death. Besides, the 250th anniversary of the bricklayers' guild was also celebrated. In 1858 , some particularly solemn celebrations were organised for the 300 years of the Gdańsk Gymnasium, which after a stagnant period at the turn of the century, became a universally admired academy." ${ }^{168}$ Thus the 300th anniversary of the Main Town Hall carillon was part of a broader social trend of cultivating Gdańsk's historical culture, re-enacting the past through its solemn remembrance.

The carillon anniversary was discussed at a City Council session on 17 September 1861, a week before the event that took place on 23 September. Yet councillors were not unanimous in agreeing to contribute funds to the celebrations. Councillor Breitenbach voiced his objection that the Town Hall carillon did not occupy a special place amongst Gdańsk's peculiarities; in fact, were the city disposed to celebrate every anniversary, it would need to spend large amounts of money on such events. ${ }^{169}$ Despite those voices of dissent, anniversary celebrations did take place and were widely reported in the media. Two days before the jubilee, a feature story was printed in the Danziger Zeitung, ${ }^{170}$ followed by another in the Danziger Dampfboot on the day of the event:

Heute sind drei Jahrhunderte verflossen, seitdem von dem schlanken Rathausthurm das schöne Glockenspiel ertönt. Wie vielen unserer Vorfahren ist es ein Grabgeläute gewesen! Wie vielen hat es den Lebensmorgen verkündet! Das dreihundertjährige Jubiläum des Glockenspiels auf dem Rathausthurm ist unter allen Umständen ein wichtiges Ereigni $\beta$ für unsere Stadt. ${ }^{171}$

166 Loew, Danzig und seine Vergangenheit, 105.

167 Loew, 89-90.

168 Loew, 105.

169 DZ 1861, no. 1013 (18 September).

170 DZ1861, no. 1016 (21 September).

171 DDB 1861, no. 222 (23 September). 


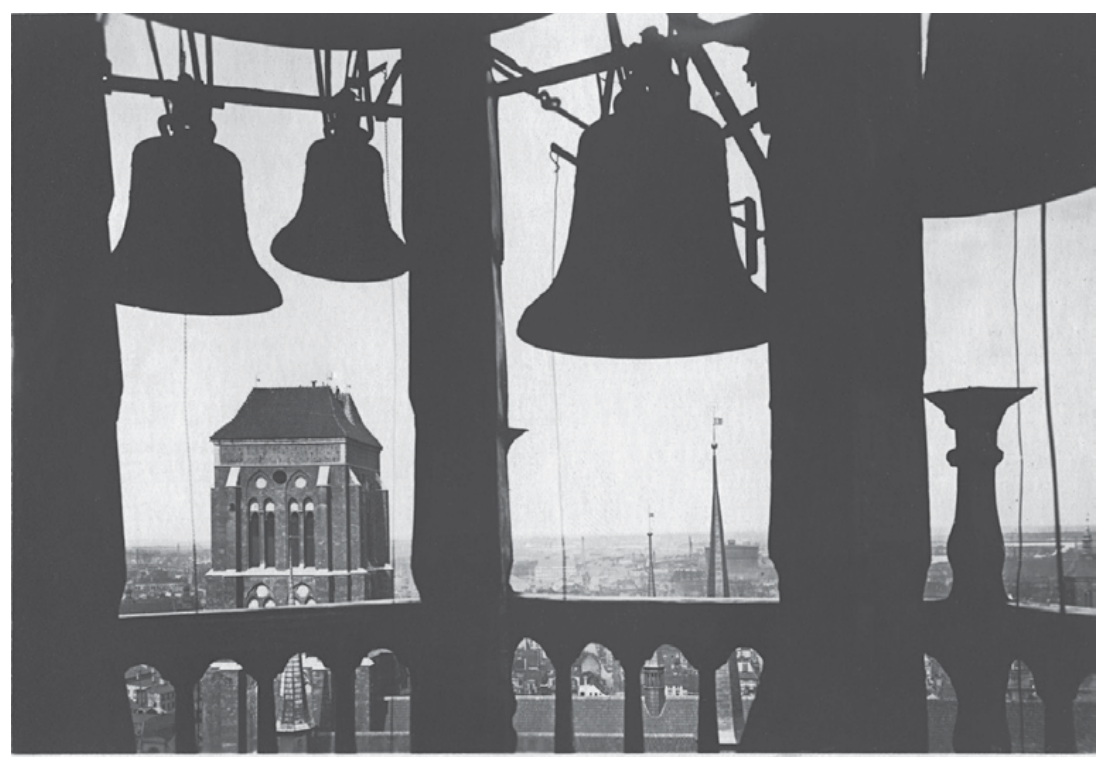

Dansig Blid vom Ratśturm aui Gt. Marien.

Fig. 3: The bells of Jan Moer in the tower of the Main Town Hall. Photo by P. Czarnecki, from the collection of J. W. Wołodźko

The project was to adorn the Town Hall with six flags hung from the tower's-gallery. A consort of ten horn and trombone players played thrice: at six in the morning, noon, and nine in the evening. At the end of the day, probably during the concert, the tower's gallery was illuminated in a memorable way, according to journalists. ${ }^{172}$

Detailed information on the Town Hall carillon was included by bell setter Carl Anton Kaschlinsky in a manuscript dated to the year 1861 (it also discusses the jubilee). ${ }^{173}$ There are notably two remarks on the festivities, written above and underneath the chant Nun lob mein' Seel' den Herren, one of those that Kaschlinsky set on the carillon. Above the score, he wrote:

auch zum 300 jähr[igen] Jubiläum des Glockenspiels dem 23 Sept[em]b[er] [18]61 12 halb $1 \mathrm{u}[\mathrm{nd}] 1 \mathrm{Uhr}$.

172 The impressive illuminations were reported on the following day in the Danziger Dampfboot 1861, no. 223 (24 September).

173 PAN BG Ms 1093 IV. 
And underneath:

zum 300. Jahr[igen] Jubiläum des Glockenspiels dem 23 Sept[em]b[er] [18]61. Morgens 6, halb 7 und 7 Uhr Lobe den Herren, den mächtigen König um 9, halb 10 u[nd] 10 Uhr "Nun danket Alle Gott."174

Those notes suggest that on the anniversary day, Kaschlinsky reprogrammed the automaton on several occasions. At six in the morning, he set the chant Lobet den Herren, which was also played at 6:30 and 7 a.m., after which he proceeded to change the setting to Nun danket alle Gott, which was played at 9, 9:30, and 10. Subsequently he made another change to the solemn Nun lob mein' Seel' den Herren for noon, 12:30, and 1 p.m. The horn and trombone mentioned in the press played during a half-hour intermission in the carillon playing between 6 and 6:30 a.m. (and perhaps also between 6:30 and 7 a.m.), noon, and 9 p.m. The half-hourly carillon playing and reprogramming of its settings during the day belonged to a special festive regime; during the automaton's normal mode, i.e., time measurement, it played every hour.

The timbre of the Gdański Town Hall bells was not perfect. In 1843, Wilhelm Ferdinand Zernecke wrote in a city guide to Gdańsk that the carillon "does not sound ... too melodiously, as it only has bells in full tones."175 Nearly two decades later, in 1867, Józef Ignacy Kraszewski gave a similarly critical account of an instrument playing incomprehensible tunes. ${ }^{176}$ In 1928, a few vitriolic remarks were also penned but Herbert Pawlowski who argued that the bells obscured each other, which made the recognition of each melody difficult. ${ }^{177}$ In defence of the bells, it needs to be said they were manufactured before brothers François and Pieter Hemony discovered the right way of casting and tuning those instruments. Due to their unsatisfactory tone, many sixteenth-century bells were melted and recast or reused for weapons and everyday objects. ${ }^{178}$ The story of the Gdańsk carillon was different: it continued to played for nearly four centuries, with the exception of short periods of repair and conservation of the automaton. The "singing mechanism" only ended its work during the battle for the city in the tragic month of March 1945.

174 PAN BG Ms 1093 IV, p. 7.

175 Zernecke, Cały Gdańsk za dwadzieścia srebrnych groszy, 79.

176 Fabiani-Madeyska, Odwiedziny Gdańska w XIX wieku, 223, 322-23.

177 Pawlowski, 'Das Glockenspiel des Rechtstädtischen Rathause zu Danzig', 481.

178 Lehr, Truyen, and Huybens, The Art of the Carillon in the Low Countries, 104-8, $121 \mathrm{ff}$. 


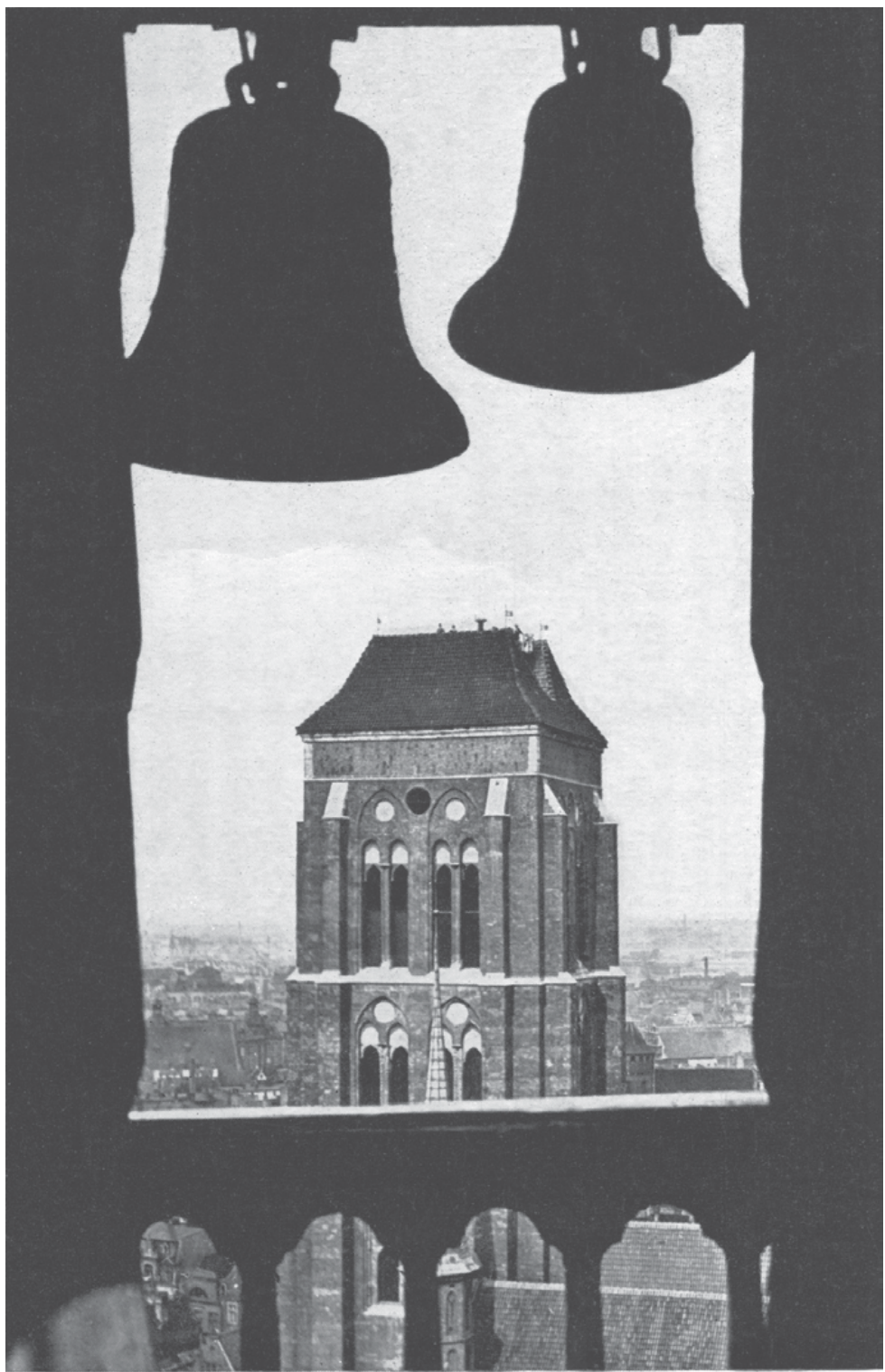

Danzig: Mahnend schaut St. Marien über deutsches Land

Fig. 4: The bells of Jan Moer in the tower of the Main Town Hall. Photo by P. Czarnecki, from the collection of J. W. Wołodźko 


\section{Bell founder Jan Moer (Moor)}

The decision by Gdańsk's Main Town councillors to commission bells with founder Jan Moer testified to their excellent orientation in leading places of bell manufacture. As I mentioned above, the city of 's-Hertogenbosch had long belonged to important bell founding centres, and members of the Moer family were considered masters of the art of the clock and carillon bell casting. Together with the Waghevens and Van den Gheins of Mechelen, the Moers were among the first families to undertake carillon manufacture in the Netherlands. ${ }^{179}$

The Moer family had settled in 's-Hertogenbosch around the mid-fifteenth century but took up bell casting in the second generation; the founder of the line, Jan Moer, originally from Cologne, was not a bell founder. ${ }^{180}$ Judging by his nickname, "die Becker," we can presume he worked as a baker. It was his son, Gobel Moer, residing in 's-Hertogenbosch as early as 1452, who took up bell foundry. His earliest activity on that field consistent of bells for 's-Hertogenbosch and Zutphen cast in the 1460s. In total, around fifty works of Gobel are known today, testifying to intense activity. As I mentioned earlier, Gobel Moer succeeded in ousting his competitor and former partner Geert van Wou from the city, becoming a monopolist on the local market. His bell foundry was located next to the city walls on Aart Berewoutstraat. He transmitted his bell casting expertise to his sons, Willem, Jaspar, and Jan. He continued to work with Willem and Jan until 1492, as indicated on bells by the inscription "cum natu" (with [his] children). Gobel Moer probably died in 1500 , followed likely in 1502 by his son Jan. The business was then run by brothers Willem and Jaspar. Inscriptions on bells quote the name of Willem first, from which we can deduce he was older than Jaspar. The Moer brothers were very active and together cast at least sixty-six bells. Willem's name last appears on their works in 1520 when he likely died. His work but successfully continued by Jaspar who went on to cast at least 43 bells on his own. Jaspar's wife was Sijcken Henricx van der Schaeft, whose brother was an abbot in Averbode. The marriage also brought a professional gain to Jaspar in the form of a number of commissions from his father-in-law between 1503 and 1519. Jaspar and Sijcken Henricx has a son, Jan, who succeeded his father upon the latter's death in 1551 or 1552: it was he who commissioned the carillon for Gdańsk's Main Town Hall.

179 Lehr, Truyen, and Huybens, 68-72, 100-2.

180 I quote the Moer family history after Adriaenssen, 'De Bossche klokengietersfamilie Moer', 45-78; and Lehr, Truyen, and Huybens, The Art of the Carillon in the Low Countries, 68-69, 70, 72, 90, 102. 
Jan Moer, who also used his middle name Jaspers ${ }^{181}$ as well as an alternative spelling of his surname, Moor, ${ }^{182}$ became the most active member of the family. He cast his first three bells working with his father in 1539-41, and proceeded to manufacture 84 more bells on his own and a last one with his son Cornelis Jans in 1565 (a bell for Delft's Nieuwe Kerk). He also produced the largest number of carillon bells. For the church of St John in his native 's-Hertogenbosch, he produced an eighteen-bell carillon between 1551 and 1553. Meanwhile, he also supplied a six-bell chime for St Martin's in Tiel, which he extended by three bells in 1554. He also cast a small chime for Woerden in 1557-58. Soon after his commission for Gdańsk, Jan Moer received another from Amsterdam's Oude Kerk. He worked on this set until 1564 but due to the renovation of the Oude Kerk tower, the bells were eventually installed at the city's town hall. Moer also supplied many other Dutch cities as well as the church of St Catherine in Brunswick with single bells. ${ }^{183}$

The Moer family belonged to affluent middle class. It maintained extensive links to representatives of related crafts, such as brass founders and knifemakers. Jan Moer had two sons. Hansken likely did not survive to adulthood. The second son, Cornelis Jans, was born from the marriage of Jan with Anna Henrick Danielssen. Although he initially cooperated with his father, his later works are unknown. While the number of bells they produced would have indicated that bell foundry was a sufficiently secure profession for the Moers, in 1557 both father and son took up apprenticeships with a gravedigger. That was a stunning change of occupation; perhaps the market for bells experienced a sudden dip and gravedigging appeared a prospective profession to the Moers. It nevertheless is surprising that they did not think it worthwhile to extend their offer to military products, as universally offered by other bell founders and as would have certainly benefitted their business. ${ }^{184}$ In the mid-1560s,

181 This information is quoted from Adriaenssen, 'De Bossche klokengietersfamilie Moer', 56, 66-69, 73 based on his archival research. However, bell inscriptions only quote the first name Jan or Johannes (as on the Gdańsk bells), so in the present book I refer to Moer only by his first name.

182 "Moor" is quoted in inscriptions of the Gdańsk Main City town hall bells and other bells cast by Jan in his last years; see Adriaenssen, 69 and; Walter, Glockenkunde, 310 .

183 Adriaenssen, "De Bossche klokengietersfamilie Moer," 68, indicates that Moer cast the bell for Brunswick's church of St Catherine in 1553, while Walter, Glockenkunde, 310, dates that bell to 1533 .

184 Lehr, Truyen, and Huybens, The Art of the Carillon in the Low Countries, 68. 
Jan Moer's activity slowed down due to illness. He died in 1568 or 1569, after which the family business entered a period of decline. Cornelis Jans Moer, who used the surname De Moor, died in 1573. His son Jan de Moor bought back a part of the bell foundry from his mother but did not work in the profession; he became an altar painter. The Moer (Moor) family became extinct in 1644 with the death of Cornelis de Moor, a Jesuit monk.

Tab. 1: Genealogy of the Moer (Moor) family

Jan Moer "die Becker" of Cologne (active in 's-Hertogenbosch from the mid-1400s)

$\downarrow$

Gobel Moer (active from 1452, died around 1500)

$\downarrow$

Willem Moer - Jaspar Moer + Sijcken Henricx van der Schaeft - Jan Moer

$\downarrow$ Jan Moer (Moor) (died 1568 or 1569) + Anna Henrick Daniellsen

$\downarrow$

Hansken Moer

Cornelis Jans de Moor (Moer)

$\downarrow$

Jan de Moor "altar painter"

$\downarrow$

Cornelis de Moor, Jesuit (died 1644)

\section{Bells and mechanisms}

The carillon installed in Gdańsk's Main Town Hall tower was a musical automaton. It consisted of fourteen bells in a scale from F4 to D6:

F4-G4-A4-B, 4-C5-D5-E,5-E5-F5-G5-A5-Bb5-C6-D6

The nearly four-century operation of the carillon was cut short by the battle of Gdańsk in March 1945 when it was partly damaged. Three bells survived the war as well as, reputedly, the mechanism or rather elements thereof, which however was not timely secured and is now lost. ${ }^{185}$ The surviving bells are currently exhibited at the entrance of the Main Town Hall tower, which is now the seat of the Museum of Gdańsk. Formerly, the Museum only owned two bells of the historical carillon (one was kept for years in the museum warehouse).

185 I thank Dr Grzegorz Szychliński, director of the Gdańsk Science Museum (department of the Museum of Gdańsk), for this information. 


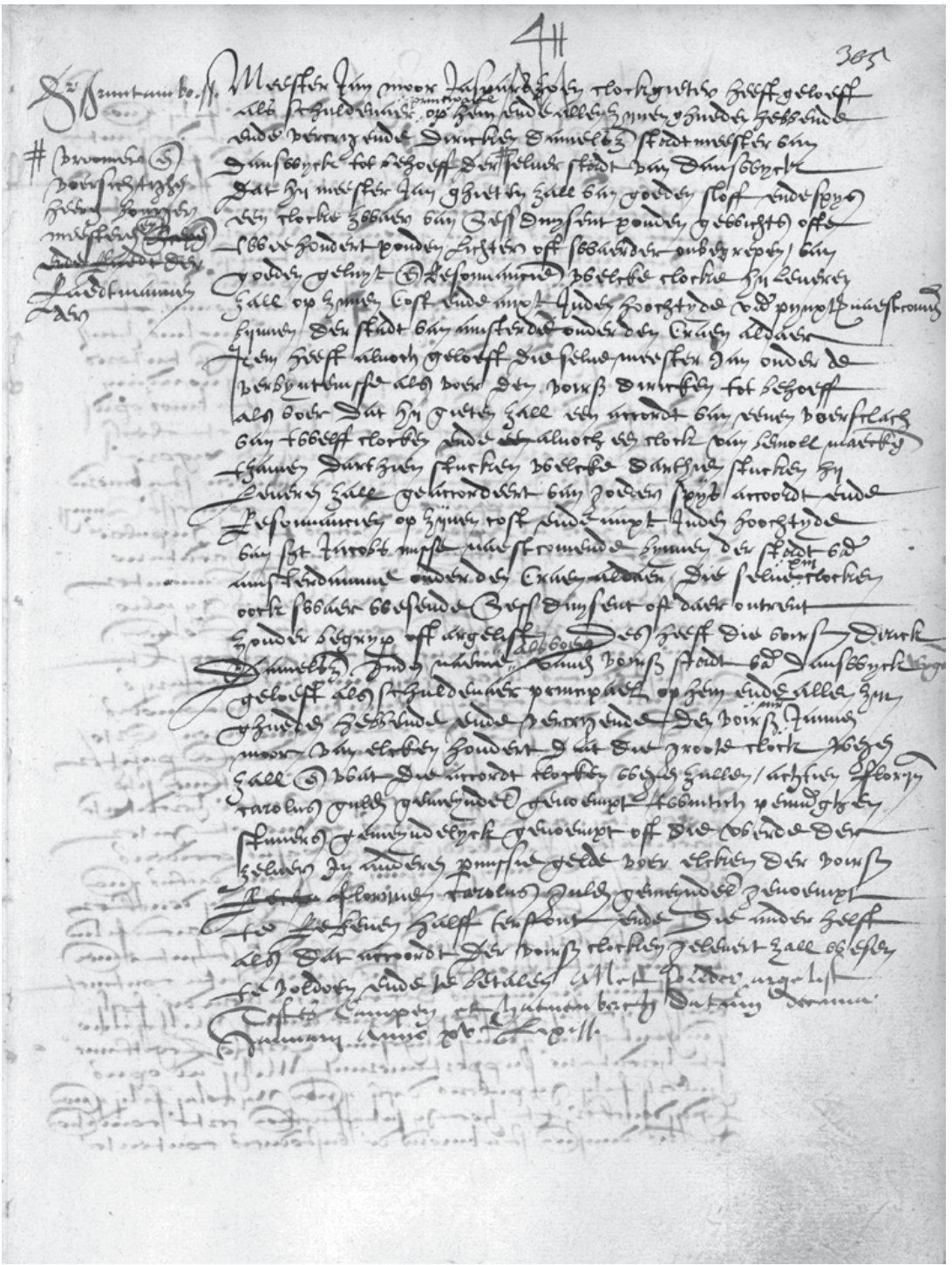

Fig. 5: Contract for the bells of Jan Moer. GAHt, R 1377, fol. 305 


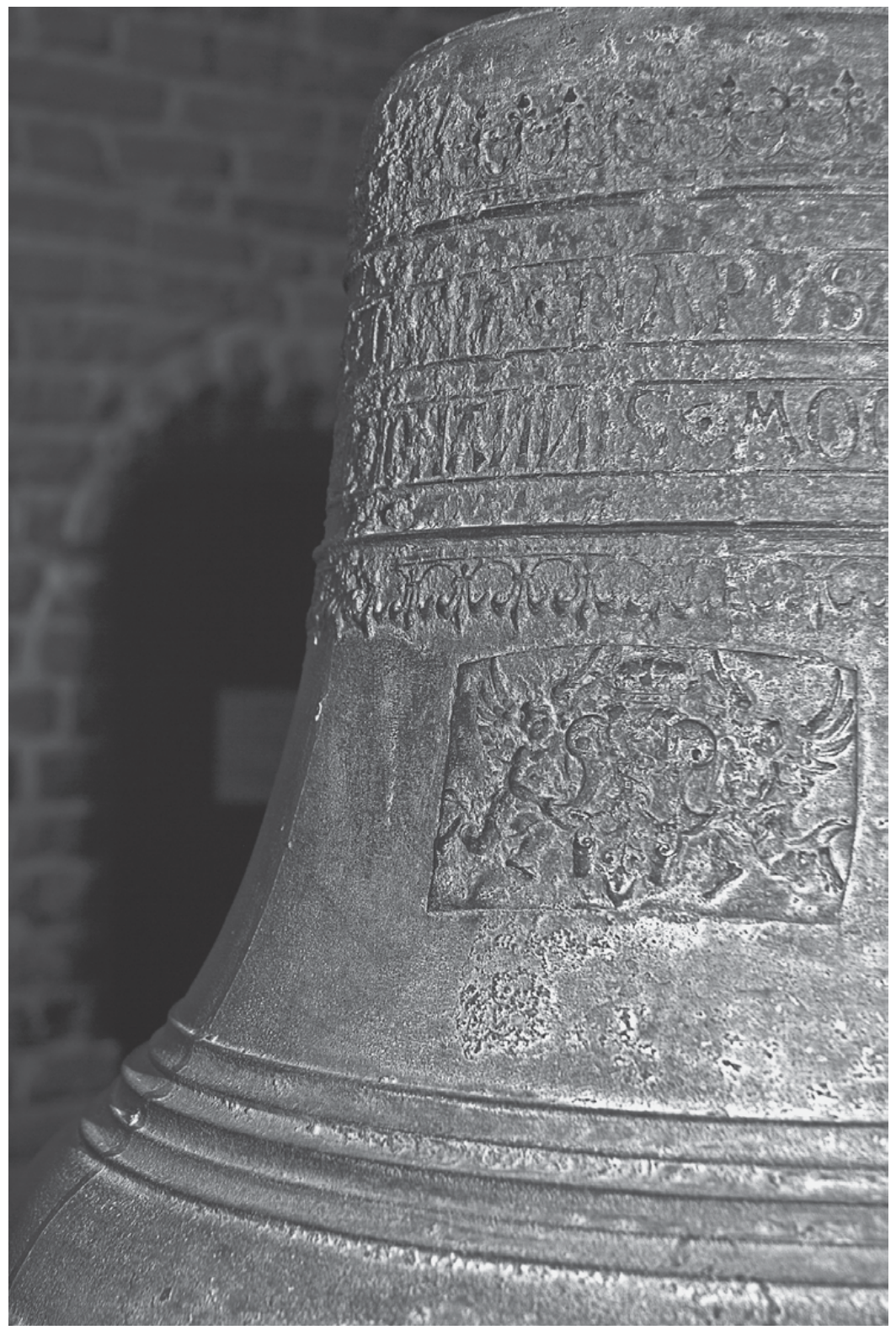

Fig. 6: A bell by Jan Moer. Museum of Gdańsk, photo by M. Popinigis 
After the Second World War, the third surviving bell was moved to the church in Swornegacie before being transferred to the Ethnographic Park in Wdzydze; it was eventually returned to the Gdańsk Town Hall. ${ }^{186}$

The surviving Jan Moer bells were respectively the sixth (D5), eleventh (A5), and fourteenth (D6, the highest) in the series. They have the following parameters: ${ }^{187}$

Tab. 2: Diameter, height, and weight of surviving Jan Moer bells

\begin{tabular}{llll}
\hline Bell & Diameter $[\mathrm{mm}]$ & Height $[\mathrm{mm}]$ & Weight $[\mathrm{kg}]$ \\
\hline D5 & 664 & 530 & $\sim 180$ \\
A5 & 480 & 400 & $\sim 70$ \\
D6 & 373 & 320 & $\sim 32$ \\
\hline
\end{tabular}

In the past, the Jan Moer bells were measured on several occasions, notably by Johann Gottfried Anthony (1697-1765), a bell founder from Leipzig active in Gdańsk and Pomerania in the 1730 s. ${ }^{188}$ He probably made a list of measurement of all bells, perhaps in the context of a planned carillon for the church of St Catherine. His measurements were only approximate, as the bells were not dismounted. Sadly, his estimations did not survive, but his fragmentary notes are quoted by Bruno Meyer ${ }^{189}$ and Herbert Pawlowski. ${ }^{190}$ The latter quoted the weight of the highest and lowest bells and the total weight of all bells: 50 pounds, 10 hundredweights, and 48 hundredweights, respectively. According to that estimate, the total weight of all bells would be $2467.2 \mathrm{~kg} .{ }^{191}$ The highest bell, D6, would weigh the equivalent of $20 \mathrm{~kg}$, which is significantly different from the modern estimate, while the lowest would weigh $514 \mathrm{~kg}$.

Another estimate of the bells' measurements was offered by Carl Anton Kaschlinsky, the city clock serviceman and setter of the Town Hall carillon in the years 1847-82, in his manuscript Beschreibung des Glockenspiels auf dem

186 Januszajtis, Gdańskie zegary, dzwony i karyliony, 129.

187 Private communication from Dr Grzegorz Szychliński.

188 Pawlowski, 'Das Glockenspiel des Rechtstädtischen Rathause zu Danzig', 481; Groth, 'Anthony Jan Gotfryd', 37.

189 Meyer, 'Die Glockenspiele auf St. Katharinen in Danzig', 3.

190 Pawlowski, 'Das Glockenspiel des Rechtstädtischen Rathause zu Danzig', 481.

191 One hundredweight equals $51.4 \mathrm{~kg}$; one pound, $0.4 \mathrm{~kg}$. I quote measurement units after Zernecke, Cały Gdańsk za dwadzieścia srebrnych groszy, 234. 
Rathhausthurme zu Danzig, und Verzeichniss der Melodien, welches dasselbe spielt, dated at $1861 .^{192}$ Kaschlinsky measured the diameter of the bells, estimated the weight of two of them, as well as the weight of ten clappers.

Tab. 3: Diameters of Jan Moer bells after C. A. Kaschlinsky

\begin{tabular}{ll}
\hline Bell $^{193}$ & Diameter $^{194}$ \\
\hline F4 & $3^{\prime} 6^{1 / 2^{\prime \prime}}$ \\
G4 & $3^{\prime} 1 / 8^{\prime \prime}$ \\
A4 & $2^{\prime} 9^{3 / 4^{\prime \prime}}$ \\
Bb4 & $2^{\prime} 7^{1 / 2^{\prime \prime}}$ \\
C5 & $2^{\prime} 4^{1 / 4^{\prime \prime}}$ \\
D5 & $2^{\prime} 13^{\prime \prime}$ \\
Eb5 & $2^{\prime}$ \\
E5 & $1^{\prime} 105 / 8^{\prime \prime}$ \\
F5 & $1^{\prime} 91 / 8^{\prime \prime}$ \\
G5 & $1^{\prime} 63^{\prime \prime}$ \\
A5 & $1^{\prime} 63 / 8^{\prime \prime}$ \\
B,5 & $1^{\prime} 47 / 8^{\prime \prime}$ \\
C6 & $1^{\prime} 33 / 8^{\prime \prime}$ \\
D6 & $1^{\prime} 23 / 8^{\prime \prime}$ \\
\hline
\end{tabular}

Tab. 4: Weight of the lowest Jan Moer bell and the octave higher after C. A. Kaschlinsky

\begin{tabular}{ll}
\hline Bell & Weight \\
\hline F4 & $10=12$ hundredweights ${ }^{195}$ \\
F5 & $1 \frac{1 / 2}{2}$ hundredweight \\
\hline
\end{tabular}

192 PAN GD Ms 1093 IV, p. 1.

193 Kaschlinsky quotes the scale of the carillon as transposed from C2.

194 Kaschlinsky noted on the margin that he quoted data after the "Rheinländisch Maaß". According to Zernecke, Cały Gdańsk za dwadzieścia srebrnych groszy, 234, one foot equalled $0.3 \mathrm{~m}$.

195 "Das C. ist nach ungefährer Annahme $10=12$ Centner, das c. hingegen 1 1⁄2 Centner schwer." See PAN GD Ms 1093 IV, p. 1. 
Tab. 5: Weight of clappers in ten Jan Moer bells after C. A. Kaschlinsky

\begin{tabular}{ll}
\hline Bell & Weight $^{\mathbf{1 9 6}}$ \\
\hline F4 & $28^{1 / 2}$ \\
G4 & $23^{3 / 4}$ \\
C5 & 20 \\
D5 & 18 \\
E,5 & $19^{3 / 4}$ \\
E5 & $17^{1 / 2}$ \\
F5 & 17 \\
G5 & 17 \\
A5 & $16^{1 / 2}$ \\
B 5 & $14^{1 / 2}$ \\
\hline
\end{tabular}

From time immemorial, bells were ornamented. On the waist, most often close to the crown, a decoration band would be engraved with ornaments and inscriptions, using vegetal motifs in the shape of a palm leaf or French lily. Inscriptions were invocations, dedications, or quotations from the Bible. Popular formulas expressed love for God or the passage of time. The name of the bell founder and the date of casting the bell would often be appended, preceded by "me fecit" (I was made by). The inscription's elements were separated by dividers in the shape of rosettes, crosses, lilies, diamonds, or paragraph signs. ${ }^{197}$

The bells of Jan Moer in the Gdańsk carillon also bear ornaments. Alongside the crown, the bell founder placed an inscription within two decoration bands, with added ornamental lilies above and below. The lilies on the bell crown are represented with the calicles up, while the more soberly shaped lilies under the lower decoration band are looking down, a very widespread configuration in bell ornamentation. The inscription in Latin is all upper case:

OMNIA TEMPVS HABET ET SVIS SPATIIS TRANSEVNT VNIVERSA SVB COELO

196 Kaschlinsky did not indicate the unit. I assume he meant pounds.

197 For more on bell inscriptions, see Walter, Glockenkunde, 148-545; Kowalski, Inskrypcje na dzwonach gotyckich $w$ Prusach, 292-95; see also a more popular approach: Zieliński, 'Vivos voco, mortuos plango, fulgura frango', 117-20. 
It is a fragment of the Ecclesiastes (3:1), referring to the passage of time. However, Moer's inscriptions differ somewhat from the biblical text. The Vulgate reads:

Omnia tempus habent, et suis spatiis transeunt universa sub coelo. ${ }^{198}$

This the inscription replaces the correct Latin "habent" with the erroneous "habet." Here is a translation of the Ecclesiastes' motto on the bells of Jan Moer:

For everything there is a season, and a time for every matter under heaven. ${ }^{199}$

There is a time for everything, and a season for every activity under the heavens. ${ }^{200}$

To the inscription, Moer added his first name in Latin, "Johannes," as well as surname, "Moor," in one of the two versions he and his family used; ${ }^{201}$ moreover, he added the Latinised version of the city he operated in, "de Buscoducis" (from 's-Hertogenbosch), the "me fecit" formula, and the year of manufacturing the bell, "1560":

\section{IOHANNES MOOR DE BVSCODVCIS ME FECIT ANNO DNI MCCCCCLX}

Between the bell should and sound bow, various plaques were placed. Very often, they represented Christ's head or figures of patron saints of the churches for which the bells were produced. Plaques also included heraldry signs, states' and cities' coat of arms when they funded the bells instead of churches. ${ }^{202}$

In the middle part of the bells' waist, Jan Moer graved three coats of arms: those of Gdańsk, Royal Prussia, and the Polish-Lithuanian Commonwealth. Each was represented in a typical sixteenth-century version with supporters. The Gdańsk coat of arms' escutcheon is flanked by two lions, that of Poland by two angels, and of Royal Prussia, by two unicorns. That heraldic triad was represented after 1454 on any paintings of Gdańsk and city buildings; one of the most imposing examples is to be found on the frieze of the Upland Gate. ${ }^{203}$

In his rendition of the Royal Prussia and Poland coat of arms, Jan Moer made mistakes. Both in the Commonwealth badge and the Prussian coat of arms, the eagle is turned left instead of right. ${ }^{204}$ That was probably due to Boer's misinformation or a simple oversight by the artisans who designed the emblem.

198 Biblia Sacra Vulgatae Editionis Juxta Exemplaria Ex Typographia Apostolica Vaticana Romae 1592 \& 1593 ... Editio Quinta. Tomus I. Ratisbonae ... 1888.

199 Ecc. 3:1 (New Revised Standard Version).

200 Ecc. 3:1 (New International Version).

201 Adriaenssen, 'De Bossche klokengietersfamilie Moer', 57-69.

202 Kowalski, Inskrypcje na dzwonach gotyckich w Prusach, 293.

203 Januszajtis, Korona herb twój ozdobiono, 38-40, 43-59.

204 I am indebted to Prof. Agnieszka Leszczyńska for pointing the hitherto overlooked error in the Royal Prussia emblem to me. 
Errors were facilitated by the fact commissioners were not present during the manufacturing process and could not confirm the correctness of such signs. In any case, heraldic errors were common at that time. ${ }^{205}$

While there is no doubt as to the manufacturer of the bells, we have no information on the maker of the carillon mechanism: the programming drum, drive and other elements necessary to the correct functioning of the automaton. Jan Moer can be excluded as the potential producer of these parts, as his activity was limited exclusively to bell casting, although we know that other bell founders were also active as gunsmiths and metal workers, including the making of carillon drums. Yet, as argued by Leo F. W. Adriaenssen, bell founders in 's-Hertogenbosch in that period focused exclusively on bell founding. ${ }^{206}$ Moreover, the responsibilities of Jan Moer were precisely indicated in the contract, which makes no mention of the carillon bell. We shall, therefore, look for a maker of the Town Hall carillon automaton amongst local artisans that could handle such a commission.

It appears we can indicate that artisan with a high dose of probability. In 1560, when the first bell - and perhaps all bells - already installed, Franciscus de Rivulo, a music and composer, first setter of the Town Hall bells, who moved to Gdańsk likely from the Netherlands, was already documented as the cantor of the church of St Mary. We can assume he was familiar with the technicalities of the carillon and could have overseen the manufacture of the mechanism.

The making of the drum and other elements could have taken place in one of the clockmaking workshops. We know that in that period, Gdańsk and Elbląg clockmakers did not have their own guild but were united with parent crafts such as locksmithery, gunsmithery, spurmakery, cranemakery, nailsmithery, and pipesmithery. They employed smiths who crafted small items, metal constructions and parts for clocks. ${ }^{207}$ Thus, it is very likely that the production of a metal drum for the carillon and other elements of the automaton was assigned to the same craftsman who was commissioned a new clock to be hung on the Main Town Hall tower. Unfortunately, we do not know his name. Andrzej Januszajtis suggests the Town Hall clock was crafted by the clockmaker of the

205 A similar heraldic error in the Royal Prussia coat of arms can be observed on the Huckster Gate in Gdańsk. The stone plaque on the façade from the Motława side has three sculpted coats of arms: the Polish-Lithuanian Commonwealth in the middle, Royal Prussia to the left, and Gdańsk to the right. The eagle head on the Royal Prussia coat of arms looks left instead of right.

206 Adriaenssen, 'De Bossche klokengietersfamilie Moer', 51.

207 For more on the guild of smiths, there presence therein of clockmakers, and the scope of their work, see Januszajtis, Gdańskie zegary, dzwony i karyliony, 97-104; and Kaczor, 'Gdańskie rzemiosło zegarmistrzowskie od XVI do XVIII wieku', 59. 


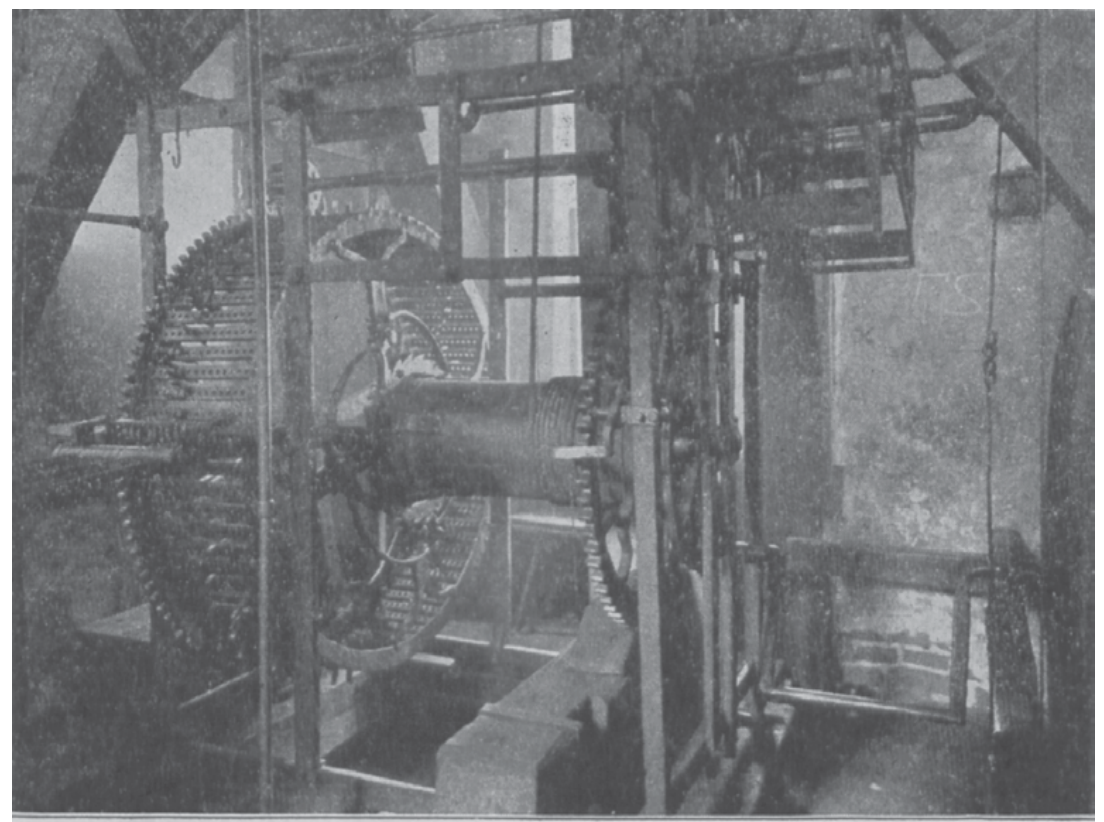

Walze im Danziger Rathausiurm

Phot. Bruno Machtans-D die durch automatische Auslösung das Glockenspiel halbstūndlich und stūndlich in Tătigkeit setzt

Fig. 7: The mechanism of the Main Town Hall automated carillon. PAN BG AL/III/91/8

time, Jorge; ${ }^{208}$ while undocumented, he remains the most plausible candidate for the maker of both works: the Town Hall clock and carillon mechanism.

Our information on the Town Hall carillon mechanism is limited to that written in 1928 by Herbert Pawlowski, who also included a photograph of the automaton. ${ }^{209}$ Its most important element was a metal drum used for programming tunes. It was composed of two rings of a diameter of $1.40 \mathrm{~m}$, connected by 79 slats $34.6 \mathrm{~cm}$ in length. Each slat contained fourteen square holes of $1.1 \times 1.1 \mathrm{~cm}$, on which pins were mounted, used for coding music on the drum. When the drum rotated, the pin would hit a lever linked to a connector, which would pull the bell clapper. After releasing the lever through drum rotation, the

208 Januszajtis, Gdańskie zegary, dzwony i karyliony, 34. Zofia Prószyńska, 'Słownik gdańskich zegarmistrzów i gnomoników’ 155-56, identifies master Jorge with Jorge Scharasch.

209 Pawlowski, 'Das Glockenspiel des Rechtstädtischen Rathause zu Danzig', 479-80. 
clapper hit the bell and a sound was heard. Writing about the Gdańsk carillons in 1935, Georg Edel indicated five types of pins were used:

Eine Spielwalze, die, schmiedeeisern, mit Stiften von 5 verschiedenen Weiten besteckt werden kann, wird mechanisch durch das Uhrwerk ausgelöst.. ${ }^{210}$

Information on the number of pins is extremely valuable, as it confirms that the transcription method of the unique Gdańsk carillon notation, worked out by researchers at the Gdańsk Science Museum, is based on correct premises. ${ }^{211}$ Coding was achieved through one straight and four bended pins of different lengths. The various shapes and lengths of the pins allowed for rendering the rhythm of tunes.

Herbert Pawlowski also listed other elements of the carillon mechanism in his description, including a dead weight, a cogwheel with crank, and three "Windregulatoren" (air brakes). ${ }^{212}$ The dead weight of about 5.6 hundredweight was part of the carillon drive and required daily lifting. Its rope reeled off a wooden drum $76 \mathrm{~cm}$ wide. The carillon mechanism was synchronised with the clock and was triggered before every hour chime. Two tunes were programmed on the drum. ${ }^{213}$ After playing the first tune, the drum stopped and then resumed an hour later to play the second programmed tune. The mechanism worked round the clock, so tunes were heard also at night. Georg Edel reflected in 1935 on the never-ending music from the Town Hall tower:

Eine Spielwalze ... stündlich in Bewegung gesetzt, so da $\beta$ auch zur Nachtzeit in die Träume der friedlich schlafenden Einwohner ein Klang der nimmer schweigenden Turmmusik bringt. ${ }^{214}$

210 Edel, 'Aus Danzigs Eigenart', 179-80.

211 See Fiebig-Drzewiecka, Grabowski, and Szychliński, 'Notacja kołkowa bębna carillonu', 12-25. For more on the Gdańsk carillon notation, see subsequent parts of this book.

212 Pawlowski, 'Das Glockenspiel des Rechtstädtischen Rathause zu Danzig', 480. On the carillon mechanism, see Januszajtis, Gdańskie zegary, dzwony i karyliony, 124-25. For a detailed discussion of carillon construction, mechanism, technicalities, and musical properties, see Lehr, Campanology Textbook, 60-104.

213 Andrzej Januszajtis indicates that full-hour tunes were programmed with the use of 54 slats of the carillon drum, while the half-hour tunes with 25 slats. In the light of the preserved sources, especially musical manuscripts, this information is incorrect. The rule of programming longer tunes for even hours and shorter ones for odd hours was not always followed. See Januszajtis, 'Muzyka gdańskich dzwonów', 11, 14 and later texts by this author on the Main Town Hall carillon; cf. my remarks on tower clock books in the later part of this book.

214 Edel, 'Aus Danzigs Eigenart', 180. 
Operating for nearly four centuries, the Town Hall carillon required repairs and conservation. Looking at the preserved receipts in the city treasury, we observe that at least until 1793, such repairs were frequent. They were occasional rather than regular expenses, varying in value, depending on the scope of the work. Pins ("Stifte", "Noten"), levers ("Clavier"), connectors, ropes, and wheels were replaced. Sums were noted in cashbooks in separate columns, usually headed "An Sing und Schlagwerk" (for the singing and chiming mechanism) or "Singwerk" (singing mechanism) but also "Uhr" (clock), which seems understandable since conservation, repair, and replacement of carillon parts was usually commissioned with city clockmakers. Consequently, it is often difficult to establish whether payment mentioned in the cashbooks related to the clock or the carillon.

Here are a few examples of fees paid to clockmakers, related to the repairs of the Town Hall carillon, quoted after existing literature and cashbooks. Hans Hirsch, city clockmaker who oversaw the clock "not only by day but also by night" 215 in the years 1591-94, was paid one thaler, 62 groschen and three pennies on 2 April 1594 for the production of 130 new pins. ${ }^{216}$ His successor Michael Scharasch was paid several times for his work on the "singing mechanism"217; those payments varied but generally increased over time. As early as 1600, he was paid large sums of money: 45 thalers for repairing the malfunctioning wheels of the "singing mechanism" on 26 June $^{218}$ followed by the hefty sum of 250 thalers on 21 November for manufacturing new wheels supposed to improve the functioning of both the carillon and the clock bell. ${ }^{219}$ Between 4 July 1611 and 25 February 1612, 904 thalers and 12 groschen were spent, mostly on new pins. ${ }^{220}$ Those elements were apparently short-lived and had to be replaced regularly. In 1669, the mechanism was again repaired on several occasions, including new pins and clappers. ${ }^{221} \mathrm{~A}$ comprehensive replacement of pins also took place in 1765, since on 23 February the current city clockmaker, David Zoll, was paid

215 Januszajtis, Gdańskie zegary, dzwony i karyliony, 112.

216 APG 300,12/21, p. 186.

217 Prószyńska, 'Słownik gdańskich zegarmistrzów i gnomoników', 156, indicates that Michael Scharasch was the son of Jorge Scharasch.

218 APG 300,12/28, p. 164.

219 APG 300,12/28, p. 164.

220 APG 300,12/41, p. 122.

221 APG 300,12/109, p. 83. 
574 florins. ${ }^{222}$ A serious renovation of the clock and carillon was also undertaken in 1855; simultaneously with a refurbishment of the tower dome, rotten beams supporting the carillon bells were also replaced. ${ }^{223}$ Spares for the "singing mechanism" were sometimes also supplied by bell setters, who were able to assess the technical condition of the automaton as well as clockmakers. For example, on 26 August 1598, the city treasury paid a small sum for a lock and other elements for the automaton to one Jacobus Tetius. ${ }^{224}$

Bell setters frequently reported to the City Council on defects of the carillon. In an undated letter from spring 1633, Hans Neunaber expressed concern about the mechanism, mentioning that when he took up his position, the carillon was faulty and he brought it to a good condition. ${ }^{225}$ Theodor Friedrich Gülich also mentioned actions aiming at improving the bells' timbre in a dedication letter to the mayor and City Council members, included in a carillon tablature dated to $1775-76.226$

The sound of the city carillon remained controversial also in subsequent centuries. On 24 July 1900, the carillon was the object of a session of the Gdańsk Magistracy. An initiative by one "Dr. J" was discussed, who argued a retuning of the bells was necessary, with the only effective way toward it being to dismount the bells from the tower and having them retuned by bell founders. It was a reasonable but risky idea: the City Magistracy was not willing to take responsibility for it. It was reminded that the mechanism had been active for 340 years; for that alone, care had to be taken in any decision about possible repairs. Comfort was offered by the council's speaker who mentioned there was no tower in Europe with properly tuned bells, citing the example of Salzburg:

Musikalisch rein klingende Glockenspiele findet man auf keinem Thurme, selbst dasjenige zu Salzburg lässt hinsichtlich seiner Reinheit viel zu wünschen übrig. ${ }^{227}$

222 APG 300,12/178, p. 33.1 florin (Polish guilder) was equivalent to 1.5 thaler (mark); see Foltz, Geschichte des Danziger Stadthaushalts, 119; Furtak, Ceny w Gdańsku w latach 1701-1815, 45-47.

223 Januszajtis, Gdańskie zegary, dzwony i karyliony, 129.

224 APG 300,12/26, p. 170.

225 APG 300,36/74, pp. 25-28.

226 APG 300,R/Pp,q10, p. 18. I discuss this letter in more detail in the second part of this book.

227 DZ 1900, no. 342 (25 July). 
We do not know the conclusions reached by members of the Council during that session; they likely took no binding decision, since no radical action was taken to improve the sound of the city hall bells.

Due to planned renovation and unplanned downtimes that happened to the carillon over the several centuries of its operations, bells would occasionally go silent for some time. One such interruption, for example, was announced by the Danziger Zeitung on 7 January 1911: the mechanism was switched off for a few days because of renovation work:

[Rathausuhr] Zweck Aufbesserung der Hämmer muss das Spiel- und Halbstundenschlagwerk der Uhr von Montag, den 9., bis Donnerstag, den 12. Januar $\mathrm{d}\left[\right.$ ieses] J[ahre]s, ausser Betrieb gesetzt warden. ${ }^{228}$

On 29 April 1911, instead of a programme of tunes for the forthcoming week, which that paper had printed since 1907, the following note was published:

Ratsturm-Glockenspiel wegen Reparatur ausgeschaltet. ${ }^{229}$

On that occasion, the bells were switched off for two weeks. In former centuries, when the carillon broke down, bell setters and clockmakers sent appropriate explanations to the Council. Andrzej Januszajtis extensively quotes such archival correspondence from clockmakers Michael Scharasch and Michael Schultz. ${ }^{230}$ Another source can be quoted: clockmaker Michael Schultz filed a complaint in 1633 against the bell setter Hans Neunaber, arguing that imprecisions to the clock mechanism were caused by weather conditions (snow, rain, and storms) as well as Neunaber's naughty children who climbed the tower to tune the bell in lieu of their father; the disorder the caused on those occasions sullied the mechanism and disrupted its operation. ${ }^{231}$

\section{Functions of the carillon}

Gdańsk councillors were practical: they had bells installed in the Main Town Hall tower not only for ornamentation. By introducing a "singing mechanism" in their seat, they believed it would promote a better regulation of public life. Synchronised with the new clock, the carillon was primarily meant to measure time. They that "singing mechanism" signalled full hours was more sophisticated

228 DZ1911, no. 12 (7 January).

229 DZ 1911, no. 199 (29 April).

230 Januszajtis, Gdańskie zegary, dzwony i karyliony, 114.

231 APG 300,R/Vv 217, pp. 63-66. 
and attractive than a mere bell toll; on each hour, the tune of a Protestant chant would be heard, easily recognisable for every Gdańsk citizen, emphasising religious values and principles. The carillon would also communicate current news. It was used for signalling local events as well as those from Cracow, Warsaw, or other cities of the Commonwealth. It was a medium of interpersonal communication $^{232}$ as well as a tool of social discipline for the City Council..$^{233}$

\subsection{Time measurement}

The clock mechanism triggered the largest bell, which chimed full and half-hours. ${ }^{234}$ The carillon played only before full-hour chimes. We can assume that was the case since both mechanisms were built and installed:

Das Glockenspiel ist nur ein simples Werck, welches (vor dem Schlagen der vollen Stunde mit der großen Glocke) einstimmig einen Vers eines Liedes spielt, den der Glockenist, nach der Zeit der Feste, in die Waltze setzt. ${ }^{235}$

The carillon melodies joined other sound signals in the city that marked the passing of time. Within the Main Town, full hours would be announced first by the "singing mechanism," then chimed by the Town Hall tower bell, followed by the pipe player (Turmpfeifer) on the tower of St Mary's who played every thirty minutes. ${ }^{236}$ The carillon, clock, and St Mary's piper worked with no interruption twenty-four hours a day.

Two tunes were programmed on the carillon drum. Even hours were generally signalled with a longer tune while a shorter one was played on odd hours. The earliest testimony of two tunes being programmed is included in the chronicle of Stephanus Grau, a historian who noted that on the night of 23 September 1596,

232 On tools of social communication, see Maliszewski, 'Gdańsk jako ośrodek transferu i komunikacji społecznej’; Kotarski, Gdańsk literacki, 151-58.

233 On social disciplining, see Kizik, Wesele, kilka chrztów i pogrzebów, 13-21.

234 APG 300,R/LI,96, p. 9.

235 Ibid.

236 The belfry piper service (Turmpfeiferdienst) was the oldest musical city service in Gdańsk. Initially, it was performed on just two belfries of the city's churches: St Mary's and St Catherine's. A third belfry, that of St Peter and Paul's, was staffed in the late 1500 s, and a fourth one, St John's, in the eighteenth century. Time signalling was just one of the pipers' tasks, who primarily played the trumpet as well as the shawm; another important duty was warning of enemies and fires. From the mid-sixteenth century, pipers cooperated with City Council musicians and church chapels. For more information on that service, see Rauschning, Geschichte der Musik und Musikpflege in Danzig, 22, 97-100. 
the clock - probably due to a spontaneous fault - wice chimed midnight. Grau goes on to tell how the "Seger-steller" (i.e., clockmaker or rather bell setter, as the term designed someone who programmed the drum) set two tunes for the forthcoming week "on the clock and the singing clock mechanism":

Anno 1596. Den 23. September. Sonnabend bi $\beta$ 24. itto. War Sontag, die Nacht hat der Seeger auffm Rahthaußße zwey mahl zwölfe geschlagen: dieselbe Woche hat der Seegersteller auf dem Seeger und Singenden Uhr-wercke hieselbst zwey Lieder auffgestellet. ${ }^{237}$

The procedure of setting two tunes per week, triggered alternatively in hour sequences to signal the passing of time, remained in use for centuries. A pricelessly valuable documentation of the work of the carillon is a four-volume tablature by Theodor Friedrich Gülich ${ }^{238}$ who worked as Town Hall clock bell setter (Rath-Uhr-Glokensteller) between 1764 and 1776. In that manuscript, the author notably notes the repertoire of the carillon for the entire year and a list of tunes subdivided into even and odd hours for subsequent weeks and liturgical holidays. Three later sources: Paul Friedrich Knaack's manuscript from 1808-12, ${ }^{239}$ Carl Anton Kaschlinsky's from 1861, ${ }^{240}$ and announcements in the Danzinger Zeitung from 1907-28, confirm that the Town Hall carillon continued to work in the same mode.

In his manuscript, Theodor Friedrich Gülich, indicated rules of setting tunes on the carillon drum and exception from them. Tunes were changed every Saturday morning, at different times in spring and autumn. Between Easter and the day of St Michael (29 September), a new pair of tunes was encoded after 7 a.m. so as the seven-hour tune of the following week was played starting with 8 a.m. on that day. Between St Michael's and Easter, the changed occurred two hours later: the carillon announced a new week at $10 \mathrm{a} . \mathrm{m}$. Gülich indicated a few exceptions from those rules. For Christmas Day and Easter Day, tunes were set on the preceding day at 8 p.m. Also for the Feast of the Purification of the Virgin and St Michael's, the tunes were changed the day before at $10 \mathrm{a} . \mathrm{m}$. On four other occasions throughout the day, the drum was reprogrammed in the morning: for Good Friday and Visitation at 7 o'clock, Ascension Day at 6, and St John's at 8.

Die Veränderung derer Lieder auf der Waltze geschiehet jederzeit des Sonnabends, und zwar von Ostern bis Michaelis um $8 \mathrm{Uhr}$, hingegen von Michaelis bis Ostern um $10 \mathrm{Uhr}$ Morgens das erste mahl zu spielen. Doch ist zu mercken, da $\beta$ Weynachten und Ostern

237 PAN BG Ms 53, fol. 516v.

238 APG 300,R/Pp,q9.

239 APG 300,R/Uu,q9.

240 PAN BG Ms 1093 IV. 
die Lieder Heil[igen] Abend um 8 Uhr Abends - Mar[iae] Reinigung und Michael Heil[igen] Abend um 10 Uhr Morgens - Stillen Freytag und Mar[iae] Heimsuch[ung] desselbigen Tages um 7 Uhr des Morgens - Him[m]elfahrt Christi dess[elbigen] Tag: um 6 Uhr des Morgens - und Johan[n]s-Tag imgl[eichen] dess[elbigen] Tages um 8 Uhr des Morgens ihren Anfang nehmen. ${ }^{241}$

The tradition of distinctive signalling of specific holidays continued throughout the first half of the nineteenth century, but when Carl Anton Kaschlinsky noted the programme of tunes for the entire year of 1861, he failed to mention the holidays listed by Gülich. With time, as shown by the announcements published in the Danziger Zeitung between 1907 and 1928, the former practice was abandoned and only Christmas, and Easter were emphasised in the carillon's repertoire.

\subsection{The signalling of events}

Apart from the measurement of time, the Town Hall carillon performed another equally important function: that of information transfer and social communication, signalling events unfolding both in Gdańsk and other places in the Commonwealth. The invention of movable type and widespread practice of printing circumstantial writings significantly encouraged the spread of both local and national news. However, the widespread familiarity with such news, especially amongst the lower classes, was still based mainly on oral communication. Thus, information through the "singing clock," which served the entire city community, continued to be appreciated. Although the carillon was a novelty in Gdańsk, the way in which it was used to pass information on was not new. On the contrary, the use of sound signals is one of the earliest methods of social communication.

Emitted by the "singing mechanism," messages referred to the public sphere when bells informed about events in Gdańsk and other cities of the PolishLithuanian Commonwealth, as well as the private sphere when they announced the death and funerals of members of local authorities and their families. Those two spheres were not directly dichotomous; it is debatable whether the category of "private sphere" was really private. It all depended on the message's addressee. The message was viewed differently by the deceased person's family (private sphere) and by the entire community (public sphere). This was the case not only when bells announced the death of members of Gdańsk's City Council but also that of the King of the Polish-Lithuanian Commonwealth.

The carillon's function of signalling social and political events is well documented. Historical accounts and chronicles testify to the use of Town Hall

241 APG 300,R/Pp,q9, p. 171. 


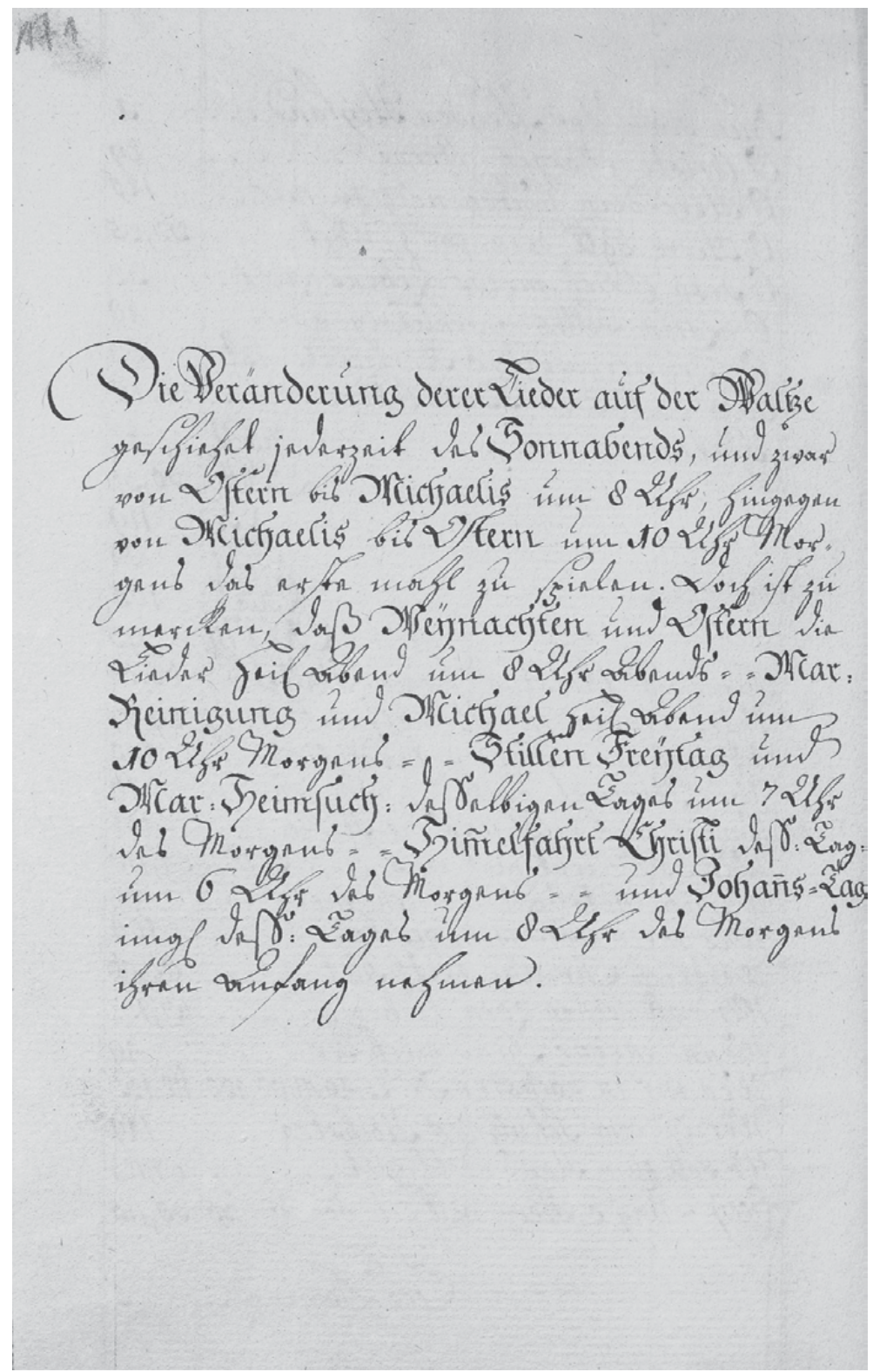

Fig. 8: Instruction for reprogramming tunes on the Main Town Hall automated carillon drum. APG 300,R/Pp,q9, p. 171 
bells for various festivities in the city. Also extant are receipts from the city treasury from 1576 to the end of the eighteenth century that not only disclose the fees of bell setters but also allow to list and classify the circumstances of using bells for purposes other than time measurement. An invaluable source is the already quoted four-volume tablature of Theodor Friedrich Gülich. In the last volume, Gülich included a detailed instruction ("Verordnung") for running festivities with the use of the carillon. Apart from the order of play, he cited the titles of tunes appropriate for various occasions as well as the remuneration of the bell setter for this service. ${ }^{242}$ Gülich's instruction is a set of arbitrary recommendations governed by a long tradition and in tune with the action of the City Council, which aimed at a restrictive control of social life through various laws and regulations. I know of no generic official decree regarding the use of carillon the everyday life of the city, but Gülich's indications are similar in character to the official records issued by the City Council. ${ }^{243}$ Some cases have comments appended, usefully for appreciating the context of their circumstances. Gülich's manuscript summarises the use of the Town Hall carillon when Gdańsk belonged to the Polish-Lithuanian Commonwealth. After the city's incorporation into Prussia (1793), it social and cultural life changed drastically. The carillon's playing in Prussian times is illustrated by the notes of Carl Anton Kaschlinsky, while the later period is documented in the local press.

Public events cyclically signalled by the carillon included elections to the City Council and the St Dominic's Fair. Elections to the City Council were a yearly ritual, taking place on the Tuesday or Thursday in the week of the feast of St Gertrude (17 March), the so-called Kühr-Tag. Only for very important reasons could that date be changed, as happened in 1636 when the day of St Gertrude coincided with the Holy Week; the election was consequently moved a week prior and took place on Thursday 13 March. ${ }^{24}$ The secretary of the French embassy, Charles Ogier, who was in Gdańsk in that time, wrote in his memoirs:

On election day, all orders go to the church [of St Mary], which belonged to the Lutherans. After listening to the sermon and singing their prayers, the senators go in pairs to the Town Hall, where they choose the mayor from themselves ..... ${ }^{245}$

242 APG 300,R/Pp,q9, pp. 277-91.

243 For more on decrees regulating the family life of Gdańsk citizens, see Kizik, Wesele, kilka chrztów i pogrzebów, 13-21; Kizik, 'Gute Policey'.

244 Zdrenka, Rats- und Gerichtspatriziat der Rechten Stadt Danzig, 2:10, 70.

245 Ogier, Dziennik podróży do Polski, 203. 
During the session, the Town Hall guard hand and removed a flag three times, accompanied by a toll on the largest bell of the church of St Mary, the Gratia Dei, cast in 1453 and hung the following year when Gdańsk was returned to Poland. ${ }^{246}$ The carillon would also play. Charles Ogier makes no mention of this in his account; being sensitive to music, ${ }^{247}$ Ogier was even more interested in the City Council structure than in the musical setting of the elections.

The special programme of the Town Hall carillon for election day is cited by Theodor Friedrich Gülich. After 8 a.m. on that day, the two tunes for that week were removed from the drum and replaced by a hymn to the Holy Spirit, Komm heiliger Geist Herre Gott. From 9 a.m., after the mass at St Mary's, until noon when the election took place, the carillon would play that hymn before and after every half-hour chime. After noon, the two tunes selected for the liturgical week were resumed, with the first one played before the 1 p.m. chime:

Am Kühr-Tag wird das Lied gegen 9 Uhr aufgesetzt Kom[m] Heil[iger] Geist H[er] re Gott und singt alle halbe Stunde vor u[nd] nach dem Schlag bis 12 Uhr. Um 1 Uhr darauf die ordinairen Wochen-Lieder. ${ }^{248}$

This eighteenth-century account by Theodor Friedrich Gülich testifies to a long tradition. It is assumed that the "singing mechanism" contributed, together with bell tolls at St Mary's, to the musical setting of elections as early as March 1562. This is confirmed by a motion by Hans Neunaber to the City Council from 1632, in which he mentions the setting of tunes for the elections of city authorities by Gdańsk's first bell setter, Franciscus de Rivulo, and the special setting of the automaton on the occasion of St Dominic's Fair and the New Year. ${ }^{249}$

The musical setting of City Council elections was abandoned in 1793. After administrative reform, when the prerogatives of the Council were taken over by the Magistracy, whose members were approved by the Berlin government, the signalling of that fact lost any sense.

246 Januszajtis, Gdańskie zegary, dzwony i karyliony, 120.

247 Charles Ogier gave several accounts of music at family and social gatherings in which he participated. He also praised the musical ability of the daughter of one of the mayors, Konstancja Czirenberg. See Ogier, Dziennik podróży do Polski, 168, 170, 182, 185, 201, passim.

248 APG 300,R/Pp,q9, p. 286.

249 APG 300,36/74, pp. 19-22. 
Another cyclic event signalled by the Gdańsk carillon alongside church bells was the St Dominic's Fair. Its origins are linked with the arrival to the city of the Dominican Order. In 1260, Dominicans were granted the privilege of dispensing indulgences by Pope Alexander IV. This gave way to the celebration of their patron saint, St Dominic, on 5 August. The Fair quickly became a permanent fixture in the city's life, eagerly awaited by citizens. Johanna Schopenhauer reminisced:

On 5 August, the day marked by the name of St Dominic, with the chime of noon, the sound of bells announced solemnly to foreign merchants the right to start selling their wares. It also meant the start of popular festivities, which lasted four weeks from that moment.

Music and dance, festively dressed people, merry children, riotous passers-by, pickpocketers, and shoplifters: all this moved through the city's streets on both Sundays and weekdays. ${ }^{250}$

The signal for the beginning of the St Dominic's Fair emitted by the Town Hall carillon was the tune of the song Es woll' uns Gott genädig sein. It resounded for the first time before and after the 11 a.m. chime, followed by 11:30 am and noon. Subsequently, the carillon mechanism was reprogrammed so that from 1 p.m. onwards, two tunes would alternate: one before even hours and the other before odd ones. The song Es woll' uns Gott genädig sein remained in use, but since it was programmed in the morning on the entire drum, it had now to be abridged. The introduction (Intonatio) was removed from the drum to make wat for the second tune: Zwei Ding' o Herr bitt' ich von dir.

After five days, when the Fair ended, a thanksgiving song, Lobet den Herren, was programmed. The carillon would play it as Es woll' uns Gott genädig sein for the Fair's opening, repeating it every half-hour before and after the 11,11:30, and 12 p.m. chime. This tune was also programmed in an extended version, composed of an Intonatio and the tune proper. At noon, the introduction would be replaced with the song Nun laßt uns Gott den Herrn.

From these, only Es woll' uns Gott genädig sein would also be played outside the fair period (during the first week after Trinity), while Lobet den Herren and Nun laßt uns Gott den Herrn were excluded from the musical programme. ${ }^{251}$ The fact they were not heard throughout the liturgical year but only on special occasions clearly shows how distinctive the message aired by the Town Hall bells was.

250 Schopenhauer, Gdańskie wspomnienia młodości, 153.

251 Woźniak et al., Music Collections from Gdańsk 3, 61, 72, 76. 
Tab. 6: Programme of Gdańsk Town Hall carillon during St Dominic's Fair (after Gülich’s manual $^{252}$ )

\begin{tabular}{|c|c|c|}
\hline Occasion & Time of play & Remarks \\
\hline \multirow[t]{2}{*}{$\begin{array}{l}5 \text { August (start of } \\
\text { Fair) }\end{array}$} & $\begin{array}{l}11 \text { a.m., } 11: 30 \text { a.m., } \\
12 \text { p.m. }\end{array}$ & $\begin{array}{l}\text { Bey dem Einlauten des Dominiks wird gegen } \\
11 \text { Uhr aufgesetzt das Lied: Es wol uns Gott } \\
\text { genädig seyn etc. und singt selbiges } 3 \text { mahl, } \\
\text { nehmlich um 11, halb } 12 \text { und um } 12 \text { Uhr vor } \\
\text { und nach dem Schlag. }\end{array}$ \\
\hline & 1 p.m. & $\begin{array}{l}\text { Gegen } 1 \text { Uhr wird gesetzt auf die Ungerade } \\
\text { tund[e]: Zwei Ding o Herr bitt ich auf } \\
\mathrm{d}[\mathrm{er}] \text { Geraden Stund[e] verbleibt; Es wol } \\
\text { uns Gott etc. und dieses währet bis zum } \\
\text { Dominic-Auslauten. }\end{array}$ \\
\hline \multirow[t]{2}{*}{$\begin{array}{l}10 \text { August (end of } \\
\text { Fair) }\end{array}$} & $\begin{array}{l}11 \text { a.m., } 11: 30 \text { a.m., } \\
12 \text { p.m. }\end{array}$ & $\begin{array}{l}\text { Bey dem Auslauten des Dominiks wird } \\
\text { gegen } 11 \text { Uhr aufgesetzt das Lied: Lobet den } \\
\text { Herren://: den[n] etc. und singt selbiges wieder } \\
3 \text { mahl, nehml[ich] um 11, halb 12, und um } 12 \\
\text { Uhr vor und nach dem Schlag. }\end{array}$ \\
\hline & 1 p.m. & $\begin{array}{l}\text { Gegen } 1 \text { Uhr wird gesetzt auf die Ungerade } \\
\text { Stund[e] gesetzt Nun last uns Gott den Herrn } \\
\text { auf der Ger[aden] St[unden] verbleibt Lobet } \\
\text { den } \mathrm{H}[\mathrm{er}] \mathrm{r}[\mathrm{e}] \mathrm{n} \text {. Den } 1 \text { sten Son[n]tag nach } \\
\text { dem Dominic geschicht keine Veränderung. }\end{array}$ \\
\hline
\end{tabular}

The City Council was attentive to the "singing mechanism" playing during the St Dominic's Fair. It was so observant as to consider, on 5 August 1767, the structure of the tune settings for the event's opening and ending. Councillors discussed whether the Intonatio should be omitted; in the end, they decided not to interfere with the music and ordered to programme songs with their respective introductions ("die Dominics-Lied[er] mit ihrem Vorspiel verbleiben solten"253). A note about this discussion and decision was made in the decree by Theodor Friedrich Gülich. It is embarrassing to think to what extent city councillors delved into matters related to the carillon. It would seem that the structure of tunes played by the automaton should not bother such high officials, and yet intervention was contemplated into matters so esoteric as the structure of a musical work. 


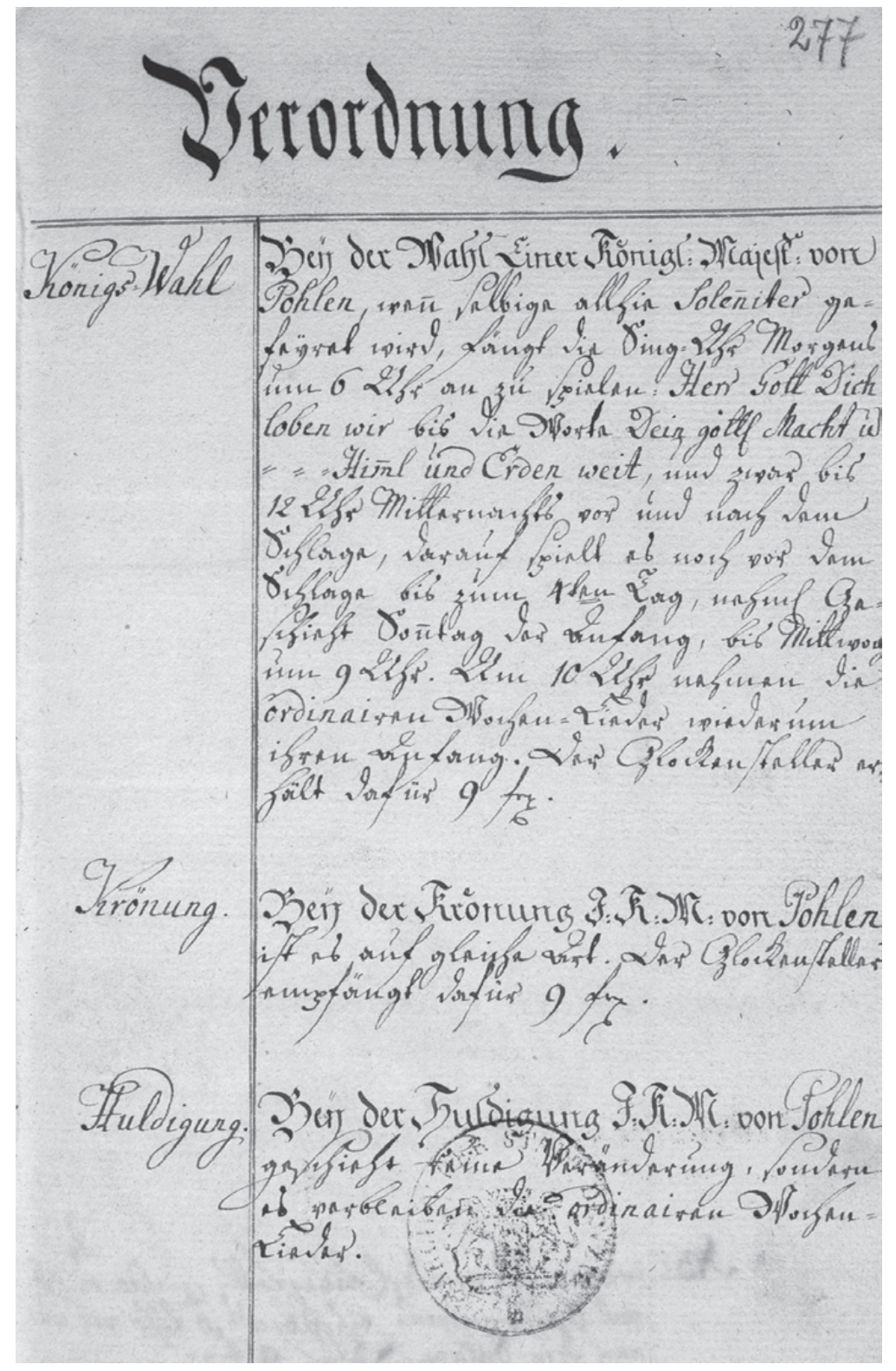

Fig. 9: Instruction for programming occasional tunes on the Main Town Hall automated carillon drum. APG 300,R/Pp,q9, p. 277 


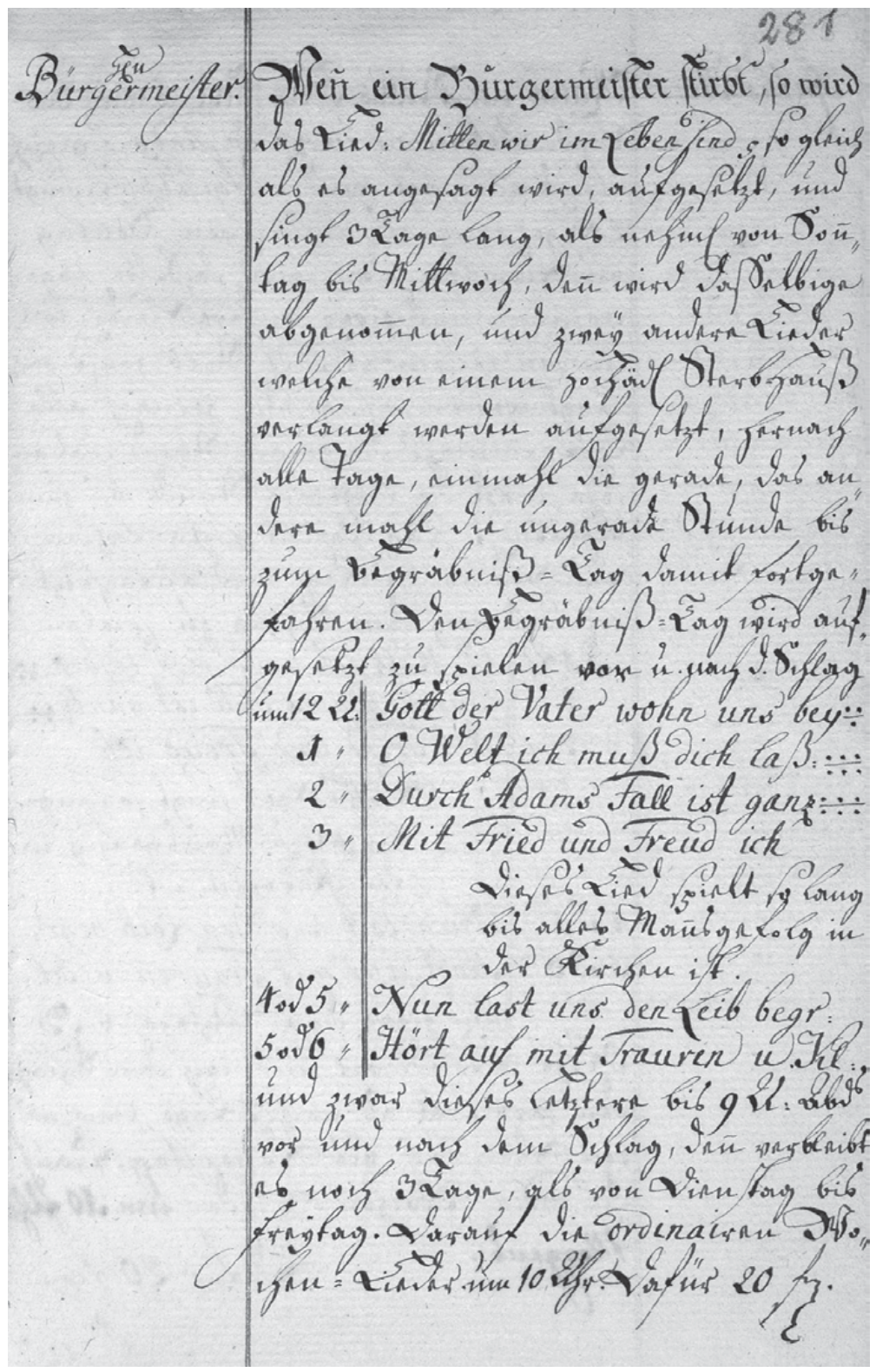

Fig. 10: Instruction for programming occasional tunes on the Main Town Hall automated carillon drum. APG 300,R/Pp,q9, p. 281 


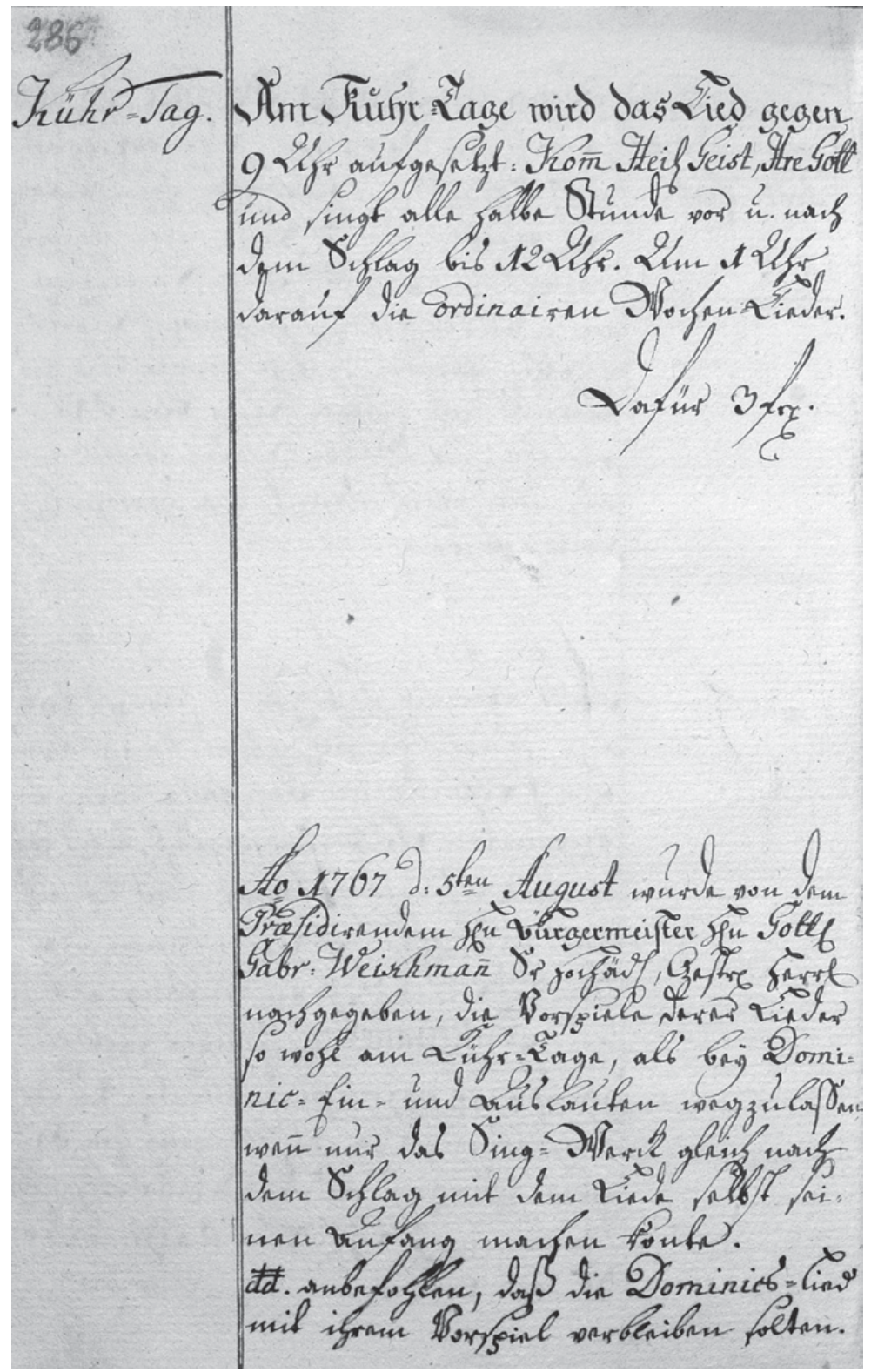

Fig. 11: Instruction for programming occasional tunes on the Main Town Hall automated carillon drum. APG 300,R/Pp,q9, p. 286 


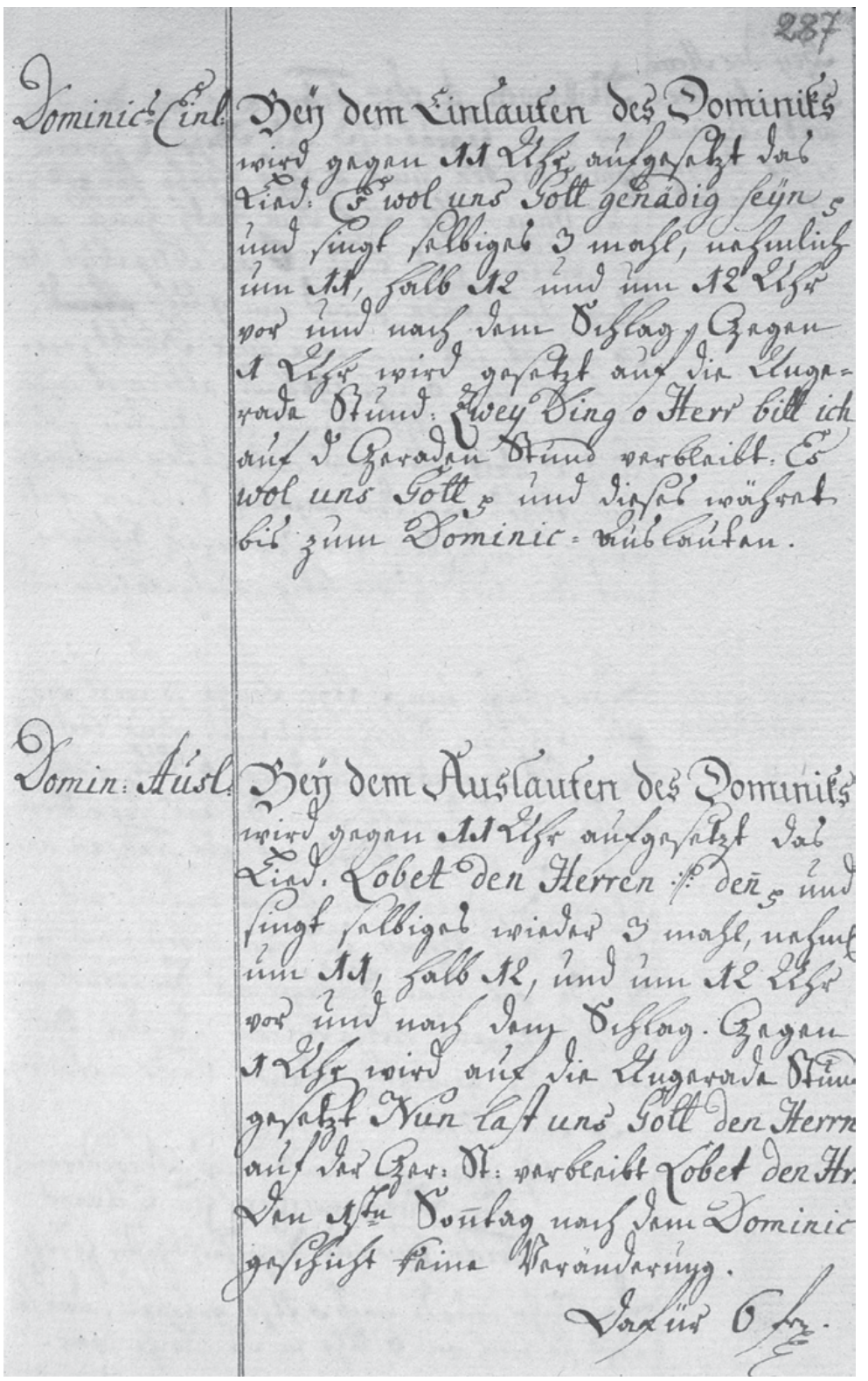

Fig. 12: Instruction for programming occasional tunes on the Main Town Hall automated carillon drum. APG 300,R/Pp,q9, p. 287 
In the nineteenth century, the announcement of the beginning and end of St Dominic's Fair remained unchanged, as indicated by an account left in 1861 by Carl Anton Kaschlinsky. In his manuscript on the Gdańsk carillon, he listed a detailed programme of the automaton. ${ }^{254}$ It transpires that the beginning and ending of the Fair were announced with the same chorales (Es woll' Gott uns genädig sein before and after 11 a.m., 11:30 a.m. and noon, and the thanksgiving Lobet den Herren in the same sequence for the Fair's ending) but Kaschlinsky suggested other tunes for 1 p.m.: Gott ist mein Lied instead of Zwei Ding' o Herr bitt' ich von dir and the chorale Wach auf mein Herz und singe instead of the former Nun laßt uns Gott den Herrn. Given that the permanent tradition consisted of playing the same tunes at the beginning and end of the Fair, the proposal of using different tunes for signalling 1 p.m. is not in my opinion particularly important. It should also be seen in the context of a new yearly programme of tunes presented by Carl Anton Kaschlinsky in the same manuscript.

Did the way of signalling the St Dominic's Fair change in the twentieth century? The history and organisation of that event are frequently addressed in the Danziger Zeitung. In 1907, that paper wrote that

in üblicher Weise wurde heute vormittag der Dominik vom St. Marienturm und durch das Glockenspiel des Ratsturmes "eingeläutet."255

In an article of 5 August 1911, we read the Fair was opened in the traditional way, with the Town Hall carillon and bell tolls at St Mary's. Yet, we do not know if the traditional procedure of tune change was used at the opening of the Fair:

Der Danziger Dominik, der im vergangenen Jahre sein 650 jähriges Jubiläum feiern konnte, wurde heute vormittag in herkömmlicher Weise durch Glockenspiel vom Rathausturm und Glockenläuten der St. Marienkirche eröffnet. ${ }^{256}$

Accounts of the St Dominic's Fair and election to the City Council belonged to the public sphere, of relevance to the entire community of Gdańsk citizens. Many other events, however, were signalled by the Town Hall carillon. The "singing mechanism" was used especially actively through the seventeenth and eighteenth century. On the order of authorities, it repeatedly signalled events that were important for Gdańsk or the entire Polish-Lithuanian Commonwealth. The catalogue of those occasions is vast; in his manual, Theodor Friedrich Gülich listed the following:

1. Election of a King ("Königs-Wahl”)

2. Royal coronation ("Krönung")

254 PAN BG Ms 1093 IV, p. 6.

255 DZ 1907, no. 362 (5 August).

256 DZ 1911, no. 364 (5 August). 
3. Homage ("Huldigung")

4. Wedding ("Beylager")

5. Cure [of the King] ("Genesung”)

6. Royal death (“Tod des Königs")

7. Death of the Queen ("[Tod der] Königin") 257

Events related to the King and royal family were official celebrations in Gdańsk, discussed on special meetings of the Council and performed as agreed by councillors. The way of notification and celebration of the event was agreed. Edmund Kizik, who researched funeral celebrations in Gdańsk after the death of Polish kings, argues that in the seventeenth and eighteenth century, "the protocol of solemn behaviour passed by the City Council of Gdańsk was essentially stable."258 Stable procedures concerned not only the King's death but also other above-cited events. Descriptions of recommended scenarios for specific events were included in special ceremonials. ${ }^{259}$

According to Theodor Friedrich Gülich, the announcement of a new King's election by the Town Hall carillon lasted four days. ${ }^{260}$ It began at 6 a.m. on Sunday, when citizens heard the thanksgiving song Herr Gott dich loben wir aired from the tower. Since the hymn was too long to be encoded on the carillon drum in its entirety, Gülich marked the final verse of the setting. The tune would be played before and after each full hour chime on the clock bell. At midnight, the mechanism was altered as to play the hymn only before each full hour. On Wednesday at 9 a.m., the thanksgiving Herr Gott dich loben wir was played one last time and was followed at $10 \mathrm{a} . \mathrm{m}$. by the succession of tunes scheduled for that liturgical week. According to Theodor Friedrich Gülich, a similar pattern would be employed for royal coronations, while homages did not require changes in the regular set of tunes: "sondern es verbleiben die ordinairen Wochen-Lieder."261

The Town Hall carillon announced the death of a Polish-Lithuanian Commonwealth King's for four weeks. On Sunday at 6 a.m., one of the most popular Lutheran funeral songs was programmed: Mitten wir im Leben sind. It was played until 6 p.m. before and after each full hour chime by the clock bell, followed by a tune before each full hour only. After a week, on the subsequent Sunday at 6 a.m., the former playing pattern was resumed. Gülich does not indicate whether

257 APG 300,R/Pp,q9, pp. 277-80.

258 Kizik, 'Gdańskie uroczystości żałobne po śmierci królów polskich’, 296.

259 APG 300,R/K,4; APG 300,R/K,2.

260 APG 300,R/Pp,q9, p. 277.

261 Ibid. 
Mitten wir im Leben sind was played exclusively for four weeks. He noted, however, the titles of fourteen other funeral songs under remarks on carillon music for the King's death, so it cannot be excluded in subsequent weeks, the bell setter could choose any song from that list. ${ }^{262}$ The ceremonial prescribing the funeral festivities after the death of Sigismund III Vasa (who died on 30 April 1632) does not list titles of songs that were to be programmed on the carillon; it only requires the "singing clock" to play nothing else than funeral songs ("trauer Lieder") for four weeks. ${ }^{263}$ At the same time, however, a ceremonial issued for the festivities after the death of John Casimir (16 December 1672) stated that the "Singwerk" should intone funeral psalms ("Klag Psalmen"), though it cannot be excluded that it was just poetic licence and the carillon drum was actually programmed with Mitten wir im Leben sind, as usually on such occasions. ${ }^{264}$

The successful cure of a King was celebrated with a solemn Herr Gott dich loben wir, programmed for 7 a.m. and played before each full hour until 6 p.m. ${ }^{265}$ The mode described by Gülich is confirmed by a ceremonial issued after Augustus III was healed from an illness in March 1763. ${ }^{266}$

The death of a Queen, listed by Gülich in his manual with no details on how tunes should be programmed on such occasions, was celebrated in Gdańsk with a fourteen-day period of mourning. According to the ceremonial, Town Hall bells played funeral songs ("Todten Lieder"). ${ }^{267}$ The same repertoire was also set after the death of a King's mother and his children.

The Town Hall carillon kept Gdańsk citizens informed not only about sad events from the royal court. While Theodor Friedrich Gülich failed to more specifically discuss the category of "Wedding" and we have no details on the carillon music on such occasions, receipts in the city treasury have a record of the automaton issuing a message of that kind. On 15 March 1670, Jacob Neunachber received 13 thaler and 10 groschen from the treasury for setting the "singing clock" with regard to the wedding of Prince Michał Korybut Wiśniowiecki with Eleonora Maria of Austria, ${ }^{268}$ which took place at Częstochowa’s Jasna Góra monastery on 27 February 1670.

262 APG 300,R/Pp,q9, p. 279.

263 APG 300,R/K,2, p. 313.

264 APG 300,R/K,2, p. 315.

265 APG 300,R/Pp,q9, p. 278.

266 APG 300,R/K,2, p. 543.

267 APG 300,R/K,2, p. 317.

268 APG 300,12/109, p. 144. 
Bells also tolled when royal children were born, especially when on 9 September 1677 Maria Sobieska gave birth in Gdańsk to a son, Alexander. ${ }^{269}$ The bell setter was paid six thaler from the treasury for setting the carillon to announce the news. ${ }^{270}$ Sixteen years later, in June 1693, a special tune announced the engagement of the prince royal, for which setter Gottfried Wernick was paid nine thaler. ${ }^{271}$

To the above-cited festivities within the royal family, we should add an important event of 7 October 1755. On the occasion of Augustus III's birthday, the city chapel master Johann Balthasar Christian Freislich composed an impressive cantata titled Der Herr dein Gott sei gelobet. ${ }^{272}$ An imposing marble statue of the monarch was installed at the Artus Court, and circumstantial panegyrics were published. The King was not present but his birthday was feted for long hours. Both Gdańsk carillons (by that time, the church of St Catherine also had one) were reset several times on that time to play the tunes prescribed by the Council, ${ }^{273}$ and Town Hall bell setter David Krüger became richer of 9 florins. ${ }^{274}$

Other events related to the King, not mentioned in Gülich's manual but nonetheless signalled by the Town Hall carillon, included royal visits to Gdańsk. Many were of a very solemn character. ${ }^{275}$ They were thoroughly prepared and followed ceremonials drafted by the City Council. Each featured carillon music, as substantiated by a large number of sources. Reinhold Curicke wrote that the "singing clock" played during visits by Sigismund III Vasa (1-19 July 1623), ${ }^{276}$ John III Sobieski (1 August 1677-14 February 1678), ${ }^{277}$ and Marie Louise Gonzaga (11 February 1646). ${ }^{278}$ An account of her arrival was earlier given by Adam Jacob Martini, who also noted the use of the carillon in the festivities. ${ }^{279}$ An anonymous author who related the sojourn of John Casimir in Gdańsk in November 1656 also

269 Curicke, Der Stadt Danzig, 364.

270 APG 300,12/116, p. 101.

271 APG 300,12/121, p. 198.

272 PAN BG Ms Joh.19.

273 APG 300,R/K,2, pp. 136-39.

274 APG 300,12/169, p. 111.

275 For more on visits of Polish kings to Gdańsk, see Fabiani-Madeyska, Gdzie rezydowali w Gdańsku królowie polscy?, 116-17; on the stays of John Casimir in Gdańsk and the musical setting of festivities on those occasions, see Szlagowska, 'Gdańscy muzycy w darze królowi Janowi II Kazimierzowi.

276 Curicke, Der Stadt Danzig, 73.

277 Curicke, 363.

278 Curicke, 355.

279 Martini, Kurtze Beschreibung und Entwurff, fol. 43v. 
mentioned the playing by the carillon of laudatory and thanksgiving songs when Gdańsk mayor Nathanael Schmieden handed the King the keys to the city:

das singenden Werck des Rahthausses eine erfreunliche Lob- und Danck-Melodey mit Jedermänniglichem Jubel stündlich intoniert. ${ }^{280}$

During royal visits, the carillon would primarily play the Te Deum laudamus. At the arrival of Marie Louise, it played the laudatory Nun lob mein' Seel' den Herren but other songs were also programmed, as documented in an anonymous account from John Casimir's stay, as well as that of Sigismund III Vasa in July 1623 edited by Reinhold Curicke. ${ }^{281}$

Other events announced by the Town Hall carillon included those related to the Commonwealth's foreign affairs, especially wars. There are again no mentions of these in Theodor Friedrich Gülich's manual, but there are in the ceremonials as well as in receipts for bell setters. The carillon was thus regularly used to magnify the glory of the Polish army. On 1611, a solemn Te Deum laudamus celebrated the victory of Smolensk after a two-year siege; ${ }^{282}$ in 1634 , a triumph over Turkey; ${ }^{283}$ in August 1651, over Kossacks and Tatars; ${ }^{284}$ and in August 1663, the repeal of a Kossack aggression. ${ }^{285}$ In 1710, successes during the Great Northern War were announced, including the taking of Riga ${ }^{286}$ and Tallinn, ${ }^{287}$ followed by the news of the happy return of the King from Grodno to Warsaw in March 1727. ${ }^{288}$ The triumph of King John III Sobieski at the battle of Vienna in 1683, widely commented in Europe, was announced by the Gdańsk carillon over an entire day:

von Morgens an bi $\beta$ auff den späten Abend das spielende Sing-Uhr auff dem Rahthause vorund nach dem Außschlage der Stunden das Te Deum Laudamus den gantzen Tag gespielet. ${ }^{29}$

Another event is worthy of mentioning, as it was eagerly expected in 1660 throughout the Polish-Lithuanian Commonwealth: the signing of the Treaty of

280 Kurtze Relation Des Erfrewliche Einzugs Welchen Ihr Königliche Majestet ... Joannes Casimirus König zu Pohlen ... Aus dem Polnischen Lager In Die Stadt Dantzig gehalten den 15. Novemb. Anno 1656.

281 Curicke, Der Stadt Danzig, 73.

282 APG 300,R/K,2, p. 285.

283 APG 300,12/67, p. 235.

284 APG 300,12/87, p. 182.

285 APG 300,12/100, p. 36.

286 APG 300,12/129, p. 181.

287 APG 300,12/129, p. 181.

288 APG 300,12/140, p. 112.

289 Eigendliche- und gewisse Nachricht Der Von Hr: Kön: Majestät zu Pohlen Wieder Den allgemeinen Erb-Feind der Christenheit Erhaltenen herrlichen Victori, Und Wie es 
Oliva in the Cistercian monastery between 11 p.m. midnight on 3 May. A trumpeter immediately left for Gdańsk with the news, which was announced with bell tolling. The Town Hall carillon also played, though we do not know if immediately at night or on the morning after. ${ }^{290}$ The Treaty was recalled in the following years, with 3 May becoming a thanksgiving day, when bells in all Gdańsk churches were tolling and the Main Town Hall carillon was playing, as documented in cashbooks by fees to the bell setters, for example in $1662^{291}$ and $1710 .^{292}$

The Town Hall carillon announced victories but was also made silent because of wars. A case happened in April 1807 when Gdańsk was sieged by Napoleon's armies. In his history of the blockade written a year later, Friedrich Karl Gottlieb von Duisburg stated that on 23 April at noon, on the order of the Prussian governor, the carillon was switched off:

Am 23sten April hörte auf Befehl des Gouvernements das Glockenspiel um 12 Uhr Mittags auf. ${ }^{293}$

After the Second Partition of Poland (1793), Gdańsk became part of Prussia and again hosted a number of foreign rulers. However, I have found no confirmation whether the carillon celebrated the entry into the city of Napoleon on 1 June 1807 or Frederick William IV of Prussia in early June 1843. On 27 August 1910 in a thoroughly prepared ceremony, the imperial couple of Prussia visited Gdańsk. Special tunes ("Lieder für Kaisertag") were set on both carillons: the Town Hall automaton played the song Großer Gott wir loben Dich on even hours and Lobt Gott ihr Christen allzugleich on odd ones, while the St Catherine carillon played Großer Gott wir loben Dich on full hours and $O$ dass ich tausend Zungen hätte on half-hours. ${ }^{294}$ The visit of Adolf Hitler on 19 September 1939 was also very solemn; his stay was widely reported in the local press, even though there were no mentions of carillon music.

Another category of musical messages transmitted by the Town Hall carillon over many years was the deaths and funerals of members of city authorities and their families. As in other European cities, since the late Middle Ages everyday life was governed by laws and regulations relative to the private

bey dem neulich den 9. und 10. Octobris Anno 1683. blutigen Treffen gegen Gran über abgelauffen. Gedruckt im Jahr Christi An. 1683.

290 APG 300,12/97, p. 36.

291 APG 300,12/99, p. 36.

292 APG 300,12/129, p. 129.

293 Friedrich Karl Gottlieb von Duisburg, Geschichte der Belagerungen und Blokaden Danzig's von der frühesten bis auf gegenwärtige Zeit. Ein historischer Versuch, Danzig 1808, 251.

294 DZ 1910, no. 396 (25 August). 
sphere, supposed to secure social order and shape the behaviour of citizens. In Gdańsk, a number of regulations were issued on family ceremonies between 1564 and $1734^{295}$ Engagements, marriages, baptisms, and funerals followed strict procedures that differed according to social class. During those ceremonies, the number of guests, number and types of wines served, number of plates, bowls, glasses, courses, decorations on guests' clothes, the number of pages on printed wishes, laudations, or funeral threnodies and many other elements were specifically regulated. So was the selection of music: "quiet" instruments could play in a plebeian room while "loud" one in a patrician home; members of musical guilds could play for the former while tower pipers, for the latter. Regulations emphasised the stratification of the local communities, allowing one class what was prohibited to the other. Orders and prohibitions determined the procedures of human behaviour, set the rhythm of urban life, and disciplined the society in the name of stabilising the so-called good order ("Gute Policey"). ${ }^{296}$

Scholars have identified five types of motivations that encouraged various regulations: religious/moral; social/legal; administrative/order enforcement; political; and legal/economic. However, they have also emphasised these elements cannot be unequivocally hierarchised because their importance varied depending on the current circumstances of a given law. Nonetheless, it seems that in Lutheran communities - as prevalent in Gdańsk in the second half of the sixteenth century - the religious and moral aspects were always considered in legislation. The sinful human nature had to be shaped by the lawmakers, as reminded by the Bible, catechism, and the many appearances of populist preachers. The issue of disciplining the modern-era society of Gdańsk has been quite thoroughly researched. ${ }^{297}$ Yet those studies have not looked at the Town Hall carillon, which was also used by regulators as a tool of enforcing their policies. Although decrees issued by the City Council do not include remarks on the "singing mechanism," but there exists the manual of Theodor Friedrich Gülich, where rules of announcing the death and funerals of authority members and their families with the use of bells are specified in great detail. ${ }^{298}$

The instruction in Gülich's manuscript determines how the carillon should play in the case of death of a mayor, councillor, and juror - three groups that composed the Council - as well as wives of mayors and councillors. Bells did not announce the death or funeral of a juror's wife as lowest clerk in the local

295 Kizik, Wesele, kilka chrztów i pogrzebów, 13-21.

296 Kizik, 'Gute Policey', 73-79.

297 Kizik, Wesele, kilka chrztów i pogrzebów, 13-21, 335-37.

298 APG 300,R/Pp,q9, pp. 281-85. 
hierarchy. Thus, announcements were also hierarchised: of course, the most elaborate musical setting was reserved for mayors.

The "singing mechanism" triggered a funeral song as soon as the notice was given of the death of mayor or councillor. In the former case, the bells played the tune Mitten wir im Leben sind for three days, while in the latter case, for two days. Deaths of jurors, mayors' and councillors' wives were announced one day before the funeral at 11 a.m., each time with the song Mitten wir im Leben sind. Hearing that song, citizens knew someone had died but after the first performance, were unsure who the deceased was. They might have been asking themselves as did an interlocutor of local author Nicolaus Volckmar:

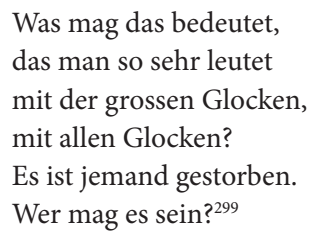

They had to wait for the full hour: if the song was played again and it was six in the morning, it was a sign the King had died. If the carillon played the tune only before the hour, Death had taken one Gdańsk's mayors or councillors. Had the tune been played for the first time before 11 a.m., the deceased was a juror or the wife of a mayor or councillor. ${ }^{300}$

Mitten wir im Leben sind was removed from the carillon drum after a period stated in Gülich's manual (three days after a mayor's death, two after a councillor's, or the following day before $8 \mathrm{a} . \mathrm{m}$. for jurors and wives). Two other funeral songs were then programmed: one for even hours and another for odd ones. Specific song titles were agreed with the funeral house but only for deceased mayors or councillors; there was no choice in the case of jurors or wives, the songs Wenn mein Stündlein vorhanden ist and Herr Jesu Christ wahr'r Mensch und Gott had to be set for 8 a.m.

On the day of the funeral, the carillon had to be reprogrammed several times. Regardless who had died, the songs were not negotiable - the manual's regulation was final. The funeral of a mayor was announced at noon with the song Gott der Vater wohn' uns bei, played before and after each full hour chime. Councillors' funerals were announced an hour later with $O$ Welt ich muß dich lassen, also played

299 Volckmar, Viertzig Dialogi, 288.

300 The hours mentioned in Gülich's manual are relative only to the period of acitivity of that setter. Edmund Kizik has found out that "the funeral timetable set in various cities underwent only minor changes over the centuries, becoming one of the major factors influencing the everyday timetable of a city." See Kizik, Wesele, kilka chrztów i pogrzebów, 222. 
twice, before and after each full hour. An hour later, both mayors and councillors were remembered with Durch Adams Fall ist ganz verderbt, subsequently replaced by Mit Fried' und Freud'. The latter song should remain on the carillon drum for as long as mourners remained in the church. When they left, usually at 4 or 5 p.m. in the afternoon, the tune Nun laßt uns den Leib begraben was set on the carillon, but if they left later, Hört auf mit Trauern und Klagen was programmed for 5 or 6 p.m. As homage to a deceased mayor, the programmed chorale would be left playing before and after each full hour for three days, as opposed to two for councillors. The funerals of jurors and mayors' and councillors' wives followed a different order of play.

In Gülich's manual, there are provisions for carillon music in several other cases: for example, when a councillor's funeral is performed with a hearse ("mit Wagen"), when the death occurred during the St Dominic's Fair, when the mourning period includes a holiday, or when a so-called quiet funeral ("ein still Begräbni $\beta$ "), i.e., more modest one takes place during which the traditional white linen is not hung $^{301}$ and the carillon continues to perform the usual songs for that week. ${ }^{302}$

Apart from the generic but precisely codified rules of using the Town Hall carillon, Gülich cites four other detailed accounts relative to the use of bells with regard to the death of specific individuals. He essentially relates the arrangements decided upon by the Gdańsk City Council on those cases and cites the dates of sessions and name of the mayor who approved the decision.

The first instance was the funeral of juror Michael Gottfried Schmidt. The funeral house (family of the deceased) asked the Council for authorisation to bury the body after eight days, with no funeral sermon, bells, or singing but with the use of several carriages. In this case, the exception, which required authorisation, was not so much the funeral's date, for members of the patriciate could be buried later than burghers or peasants residing in the city, ${ }^{303}$ but rather the relinquishment, likely for economic reasons, of usual attributes of a funeral. The Council agreed, adding that the carillon, financed by the city, would play two songs at agreed times of the day of the funeral. ${ }^{304}$

301 The hanging of white linen on a house of mourning was introduced in Gdańsk by the master of the Teutonic Order, Winrich von Kniprode, in 1351. In the seventeenth century, it was deemed the custom was excessive, and it became prohibited, though patricians kept it until the late eighteenth century. The term "quiet funeral" refers to a savvy ceremony, for example, one where no linen is exhibited or there is no traditional participation by schoolchildren. See Kizik, 190-93, 246.

302 APG 300,R/Pp,q9, p. 284.

303 Funerals were not to be delayed; it was recommended they took plays within a few days of the person's death. See Kizik, Wesele, kilka chrztów i pogrzebów, 189-90.

304 APG 300,R/Pp,q9, p. 289. 
Two other events indicated by Gülich are related, though they happened several weeks apart. On 28 December 1774, after the death of Mayor Carl Groddeck, a Council meeting was called to examine at what time, given the traditional signalling of the New Year, should the performance of funeral songs be interrupted. The usual pattern in such cases (when a holiday happened during a period of mourning) was discarded in favour of interrupting funeral songs with New Year tunes between 8 p.m. on New Year's Eve and 6 p.m. on New Year. ${ }^{305}$ According to Gülich, the solemn funeral of Carl Groddeck was only planned for 24 January 1775. Two days earlier, on 22 January, the councillor Peter Uphagen also died. On the following day, the Council convened to decide what the carillon should play when two deceased were to be buried ("Wenn zwo Leichen zugleich vorhanden"). Eventually, a procedure was worked out and communicated to the bell setter. ${ }^{306}$

A fourth special case described by Gülich is worth mentioning: the funeral of a general called "commander" (it might have been the commander of the fortress in Wisłoujście) planned for 4 February 1773. The ceremony was discussed at a Council meeting on 30 January. The time of mourning, announced by a bell toll from the Town Hall tower, list of tunes, and times of their programming on the carillon drum were decided. ${ }^{307}$ This example shows that communicating death through the sound of bells was not limited to deceased members of the Council and their wives. It can be assumed that every prominent citizen of the city, deemed by the Council to be worthy of such a procedure, has the right to a funeral ceremony with bells.

The manual noted by Theodor Friedrich Gülich, which specifies in detail the rules of using the carillon for announcing the deaths and funerals of members of the City Council, wives of mayors and councillors as well as other prominent citizens, is one of a series of decrees on family ceremonies issued by the Council up to 1793 . The detailed regulation of social life mirrored by these decrees was one of the Council's main duties.

I am unable to precisely date the origin of using the carillon to announce the deaths and funerals of City Council members and their families. Cashbooks record related payments for bell setters only from the 1630s, although a single record dates back to $1619 .{ }^{308}$

The programming of funeral songs on the carillon drum certainly continued through 1793, as there are many records of that practice in cashbooks. But did it survive into Prussian times? A suggestion in that regard was left by Carl Anton

305 APG 300,R/Pp,q9, p. 290.

306 APG 300,R/Pp,q9, p. 291.

307 APG 300,R/Pp,q9, p. 288.

308 APG 300,12/61, p. 279. 
Kaschlinsky who in his manuscript of 1861 noted the titles of songs programmed during funeral of members of the Magistracy and other prominent citizens of Gdańsk ("hohen-Standes-Personen") ${ }^{309}$ : Ich bin ja Herr in deiner Macht, O wie selig seid ihr doch ihr Frommen, Was Gott tut das ist wohlgetan, and Mache dich mein Geist bereit. Thus, the practice of carillon accompaniment for solemn funerals survived political upheavals and remained in use under Prussian rule. It is noteworthy, however, that Kaschlinsky's list does not include Mitten wir im Leben sind, Protestant Europe's most popular funeral song.

\section{Bell setters: Franciscus de Rivulo and his successors}

The first setter of the Main Town Hall's automatic carillon was Franciscus de Rivulo, a musician and composer likely originating in the Netherlands. In earlier research, Rivulo was not linked to the Gdańsk carillon; the composer was discussed in the context of musical practice development in the city, as he introduced Netherlandish sacred and secular polyphony. ${ }^{310}$ Called a "cantor" in a document from the church of St Mary of 4 May 1560, in other sources he is classified as a singer and composer who initiated the activity of the St Mary parish church that was also the City Council chapel. ${ }^{311}$ In 1988, Andrzej Januszajtis wrote that Rivulo died in Gdańsk in 1564 and called him the first setter of the Main Town Hall carillon. ${ }^{312} \mathrm{He}$ established those facts based on a motion by Philipp Schönberg, Rivulo's successor as carillon setter. ${ }^{313}$ This information was introduced into lexicographic literature only in 2004. ${ }^{314}$ The latest research on the composer's life and music was conducted by Agnieszka Leszczyńska ${ }^{315}$ who has considerably extended our knowledge about Rivulo's music and added a few biographical details and suppositions, even though he remains, in Leszczyńska's assessment, "a somewhat mysterious character."

309 PAN BG Ms 1093 IV, p. 6.

310 Rauschning, Geschichte der Musik und Musikpflege in Danzig, 33-34, 36-42.

311 Rauschning, 28.

312 Januszajtis, 'Muzyka gdańskich dzwonów', 11-12.

313 APG 300,R/Vv,217, p. 1: "nach dem Jahr Anno 64. nach dem absterben seligen Francisci de Rivulo, Componisten."

314 Popinigis, 'Rivulo Franziscus de'.

315 Leszczyńska, 'Późnorenesansowe fragmenty mszalne z dawnej biblioteki elbląskiego kościoła Mariackiego’; Leszczyńska, 'Technika parodii w twórczości renesansowych kompozytorów kręgu gdańskiego’; Leszczyńska, 'Tropem Franciscusa de Rivulo’; Leszczyńska, 'Początki niemieckiej polifonii religijnej'; Leszczyńska, 'Franciscus de Rivulo and the Manuscript 4003'; Leszczyńska, 'The Königsberg Manuscript from the Kugelmann Circle'.

316 Leszczyńska, 'Tropem Franciscusa de Rivulo', 61. 
It has proved impossible to substantiate Rivulo's place of birth, though given the task he called to Gdańsk for (setting tunes on a carillon drum), his Dutch origins seem almost certain. Leszczyńska looked for Rivulo's roots in towns that could have given rise to his surname, but to no avail. ${ }^{317}$ There is no trace of him in 'sHertogenbosch, where the bell founder Jan Moer operated who manufactured the carillon for Gdańsk and whence the first setter of the "singing mechanism" might have come. Sadly, the local archive only has birth records from irrelevant periods.

In her research, Agnieszka Leszczyńska also addressed the relation of Rivulo with Königsberg and argued he might have sojourned in that city before coming to Gdańsk. ${ }^{318}$ This hypothesis is based on the chronology of entries in the manuscript appendix to the edition Etliche Teutsche Liedlein Geistlich und Weltlich by Paul Kugelmann, a musician of the Königsberg court. ${ }^{319}$ Among the composition noted in that appendix is a song by Rivulo titled Hier frischen Retick. It is located in the earlier pages of the manuscript than the works of Paul Kugelmann, which are dated at 16 May 1558. Consequently, Leszczyńska supposes that Rivulo might have stayed in Königsberg before that date. ${ }^{320}$ This very probable hypothesis hangs on the question of whether Rivulo stayed at the court of Duke Albrecht of Prussia or returned to the Netherlands. The bells for Gdańsk's Town Hall were commissioned in 's-Hertogenbosch on 10 January 1559 and it likely was only then that the search began for someone to run the automaton. It is impossible to say at this stage whether Franciscus de Rivulo was hired in the Netherlands or in Königsberg, if indeed he stayed there before May 1558 and remained there for the following two years.

However, Leszczyńska has been able to substantiate another contact of Rivulo with Königsberg's court of Duke Albrecht. On 24 April 1561, a "Komponist vhon Dantzke" (Gdańsk) was paid 24 marks and 45 schillings by the ducal treasury. ${ }^{321}$ This must refer to Franciscus de Rivulo, since there was no other composer worthy of the term in Gdańsk in that time. Based on the above-cited manuscript appendix to the Paul Kugelmann edition, Leszczyńska supposes this payment

317 Leszczyńska, 61-62.

318 Leszczyńska, 62-70.

319 Paul Kugelmann, Etlische Teutsche Liedlein Geistlich und Weltlich ... Königsberg [1558], RISM K 2968. A unique copy with a manuscript appendix is held at Torun's Wojewódzka Biblioteka Publiczna Książnica Kopernikańska w Toruniu (Regional Public Library, formerly the Książnica Miejska im. Mikołaja Kopernika, Mikołaj Kopernik City Library) with the catalogue no. Ms. 192680 olim J 40 29-32 [ToruńK 29-32]. For more on that source, see Leszczyńska, 'The Königsberg Manuscript from the Kugelmann Circle, 52-66.

320 Leszczyńska, 'Tropem Franciscusa de Rivulo, 63-64.

321 Leszczyńska, 62. 
was a fee for the four-voice motet Vias tuas Domine, notated in the manuscript after a song by Kugelmann dated 22 July 1560 . By that time, Rivulo was already in Gdańsk, where at the beginning of May he likely oversaw the installation of the clock bell on the Main Town Hall tower and was already working at St Mary's. ${ }^{322}$ Nonetheless, those activities do not exclude a possible trip to Königsberg.

Rivulo's duties as a chapel master in Gdańsk included the sustenance and education of choirboys, for which he was paid 100 thalers, half his yearly salary. ${ }^{323}$ We have no information on his duties related to the Town Hall carillon. I nonetheless assume that Rivulo's primary occupation consisted - as in the case of his successors - of the weekly reprogramming of two Protestant songs on the automaton's drum, which were then played each hour from the tower. Additional duties included the setting of tunes on the day of election to the City Council, at the beginning and end of the St Dominic's Fair, and on occasions indicated by the city authorities. Since no cashbooks have survived from the period of Rivulo's work in Gdańsk, we are unable to confirm whether he got paid for those tasks. We do know, however, that his remuneration included free board, as indicated by Rivulo's successor as the setter, Philipp Schönberg, in a motion addressed to Gdańsk councillors in which he asked for this privilege to be extended to him. ${ }^{324}$

While Franciscus de Rivulo is of interest to us mostly as a setter of the Town Hall carillon, we must mention his own music and the music he presented, alongside his chapel members, at the St Mary parish church and the Artus Court. Rivulo used four choir books that included 143 compositions by a large number of composers, both renowned and anonymous. ${ }^{325}$ These compositions included Latin motets and one mass in Flemish style, German songs, a madrigal, 114 chansons and two Netherlandish songs. Of particular value are the French bicinia and tricinia notated in the early part of the manuscript, a repertoire then unknown in Poland. This part of the manuscript, notated with great care for graphic detail, was ready when Rivulo came to Gdańsk. Works were notated on the subsequent pages during his sojourn in the city, ${ }^{326}$ including seventeen signed with his name or monogram. ${ }^{327}$

322 Cashbooks of the church of St Mary record a payment of four thalers on 4 May 1560 to one "franzisco dem Kantter." This record is now lost but is quoted after Rauschning, Geschichte der Musik und Musikpflege in Danzig, 28.

323 Rauschning, 28.

324 APG 300,R/Vv,217, pp. 1-2.

325 PAN BG Ms 4003.

326 For more on this manuscript, see Leszczyńska, 'Franciscus de Rivulo and the Manuscript 4003'.

327 Popinigis et al., Music Collections from Gdańsk 1, 336-41. On compositions that could be attributed to Rivulo, see Leszczyńska, 'Tropem Franciscusa de Rivulo'. 


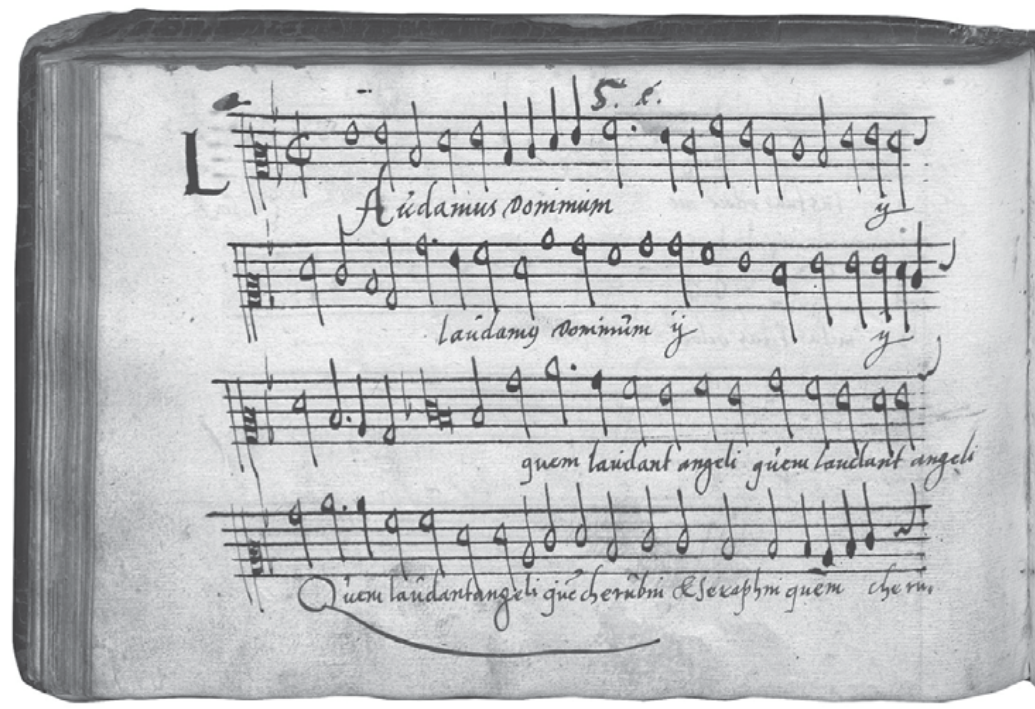

Fig. 13: F. de Rivulo, Laudamus Dominum. PAN BG Ms 4003, Altus book, fol. 75v-76r

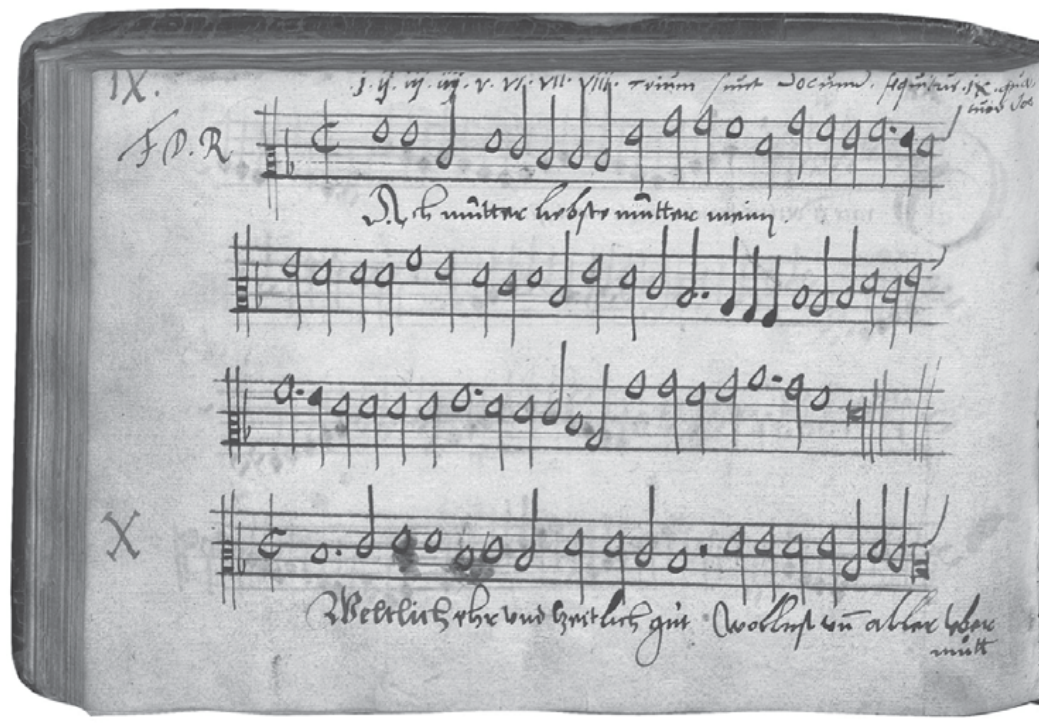

Fig. 14: F. de Rivulo, Ach Mutter liebste Mutter mein.

PAN BG Ms 4003, Altus book, fol. 101v-102r 


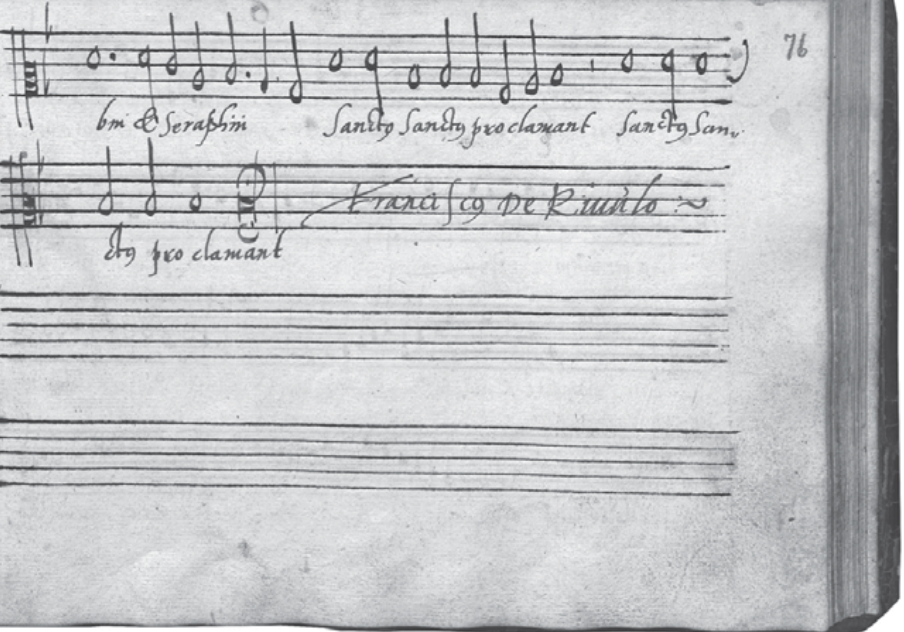

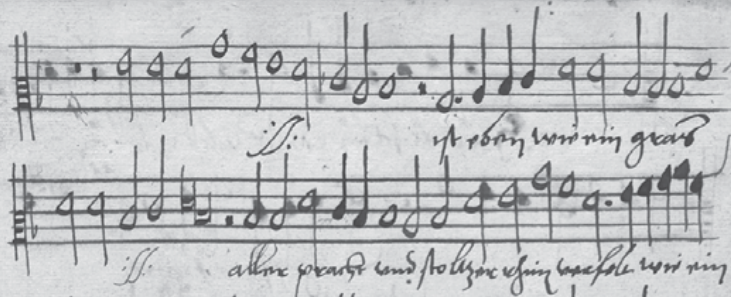

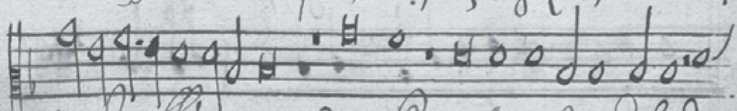

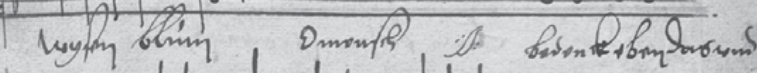
E 
The surviving music by Rivulo includes twenty-seven compositions: ${ }^{328}$ mostly Flemish motets for four, five, and six voices but also for eight voices, based partly on the cori spezzati technique. Rivulo also wrote an untitled six-voice mass that Agnieszka Leszczyńska classifies as based on the parody technique. ${ }^{329}$ An important part of Rivulo's output consists of songs. The sacred Allein Gott in der Höh' sei Ehr' and Weltlich' Ehr' und zeitlich' Gut are the first examples of polyphonic settings of Protestant chorale composed in Gdańsk, while Hier frischen Retick, Ach Mutter liebste Mutter mein, and Auf von der Banck machts nicht lang, composed primarily for guests of the Artus Court, belong to the earliest examples of secular polyphony in the city. The appreciation for Rivulo's compositional skills is shown by the fact that several of his works were included in the four volumes of the anthology Thesaurus musicus, published in $1564 .{ }^{330}$

Franciscus de Rivulo turned to be the most significant musician and the only eminent composer in the group the carillon setters in Gdańsk. In later years, the automaton was also serviced by musicians, mostly organists as well as city chapel members and a member of the music guild. But none played a role as important as Rivulo, though some contributed significantly to Gdańsk's musical life. In the last decades of the seventeenth century, a clockmaker was appointed for the first time as carillon setter, followed by three more representatives of that craft in the subsequent centuries. Because of their duties, clockmakers were familiar with the "singing mechanism" and could easily programme tunes on the carillon drum.

Amongst setters, no fewer than thirteen were organists: Michael Colrep, Jacobus Tetius, Franz Tetius, Andreas Neunaber, Jacob Neunachber, Christian Biehn, Theodor Friedrich Gülich, Rudolph Liebegott Liebendey, Carl Simon Eggert and Julius Johann Krieschen, Paul William Krieschen, Gustav Krieschen, and Georg Edel.

Tab. 7: Town Hall carillon setters who were also organists in Gdańsk churches ${ }^{331}$

\begin{tabular}{lll}
\hline Name $^{332}$ & Church & $\begin{array}{l}\text { Time of service } \\
\text { at church }\end{array}$ \\
\hline Michael Colrep (Kolrep, Kalrep) & St Catherine & $?-1578$ \\
Jacobus Tetius & St Barbara & $?-1586$ \\
& St John (large organ) & $1586-1602$
\end{tabular}

328 Leszczyńska, 'Tropem Franciscusa de Rivulo'.

329 Leszczyńska, 'Technika parodii w twórczości renesansowych kompozytorów kręgu gdańskiego', 47.

330 RISM $1564^{1}$, RISM $1564^{3}$, RISM $1564^{4}$, RISM $1564^{5}$.

331 Employment data, unless indicated otherwise, is quoted after Rauschning, Geschichte der Musik und Musikpflege in Danzig.

332 Alternative name spellings only quoted in dubious cases. 


\begin{tabular}{|c|c|c|}
\hline Franz Tetius & Holy Trinity & $1607-10$ \\
\hline & St John (large organ) & $1610-12$ \\
\hline Andreas Neunaber & St Mary (choir organ) & $1635-37$ \\
\hline & St Catherine & $1640-63$ \\
\hline Jacob Neunachber (Neunaber) ${ }^{333}$ & ??? & ??? \\
\hline Christian Biehn (Bihn, Bühn) $)^{334}$ & St Catherine $e^{335}$ & after $1682 ?$ \\
\hline Theodor Friedrich Gülich & Holy Spirit ${ }^{336}$ & $?-1776$ \\
\hline Rudolph Liebegott Liebendey & St James ${ }^{337}$ & $?-1779$ \\
\hline Carl Simon Eggert & St Mary (second organist) ${ }^{338}$ & $?-1831$ \\
\hline Julius Johann Krieschen & St Catherine (small organ) ${ }^{339}$ & $1861-95$ \\
\hline Paul William Krieschen & St Barbara ${ }^{340}$ & $1883-1923$ \\
\hline Gustav Krieschen & St Salvator ${ }^{341}$ & 1924-? \\
\hline Georg Edel & St Salvator ${ }^{342}$ & $1920-24 ?$ \\
\hline & St Barbara ${ }^{343}$ & $1924-$ \\
\hline
\end{tabular}

The most well-known of these was the son of Hans Neunaber, Andreas (160363), ${ }^{344}$ initially a pupil of Mathias Läder, the organist at the church of St Peter and Paul in Gdańsk, later residing at the royal court in Warsaw and studying with Paul Siefert and Tarquinio Merula. ${ }^{345}$ But the key figure for us is not Andreas

333 I believe Jacob Neunachber is identical to Jacob Neunaber. Hermann Rauschning cites Jacob Neunaber among organists who in 1652 signed a motion (now lost) to the City Council but sadly does not indicate in which church he played; see Rauschning, Geschichte der Musik und Musikpflege in Danzig, 213.

334 In cashbooks, the surname is cited as "Christian Bihn" and Christan Bühn"; see APG $300,12 / 123$ and APG 300,12/131.

335 APG 300,43/110, fol. 103r-v.

336 PAN BG Ms 145, 2 May 1776.

337 PAN BG Ms 146, 22 October 1779.

338 DIB 1831, no. 159 (12 July), 1617.

339 J[erzy] M[arian] M[ichlak], Krieschen Julius Johann, accessed 27 August 2018, http:// www.encyklopediagdanska.pl/index.php?title=KRIESCHEN_JULIUS_JOHANN.

340 J[erzy] M[arian] M[ichlak], Krieschen Paul, William, accessed 27 August 2018, http:// www.encyklopediagdanska.pl/index.php?title=KRIESCHEN_PAUL_WILLIAM.

341 ABuch 1924, III, p. 30.

342 ABuch 1920, III, p. 48.

343 ABuch 1924, III, p. 29; see also Loew, 'Lexikon Danziger Komponisten', 246.

344 Buried on 11 July 1663; see APG 354/349, p. 37; APG 354/351, p. 20.

345 See Seiffert, 'Paul Siefert (1586-1666)'; Rauschning, Geschichte der Musik und Musikpflege in Danzig, 141, 178, 192, 244; Przybyszewska-Jarmińska, Muzyczne dwory polskich Wazów, 198. 
Neunaber but Theodor Friedrich Gülich, author of three carillon tablatures that have survived to this day in the collection of the State Archive in Gdańsk. ${ }^{346}$ Only limited biographical data could be established for Gülich:

1. Years of life: $1733-76$

2. Day of death: $2 \mathrm{May}^{347}$

3. Period of work as Town Hall carillon setter: $1764-76^{348}$

4. Church he worked as organist: Holy Spirit. ${ }^{349}$

Theodor Friedrich Gülich might have been the son of Christian Gülich and brother of Johann Christian Gülich, both cantor at the church of St Catherine, but in the current state of knowledge, this is just a supposition. ${ }^{350}$

The carillon tablatures edited by Theodor Friedrich Gülich include the settings of 532 Protestant songs as well as invaluable information about the functioning of the Town Hall carillon and the circumstances in which it was used. For editing the first tablature in four volumes, Gülich was paid 214 florins on 1 April 1769. ${ }^{351}$

Since Julius Johann Krieschen, Paul William Krieschen, Gustav Krieschen, and Georg Edel were also carillonists at St Catherine's, I will discuss them in more detail in the chapter on musicians servicing the other Gdańsk carillon.

Another group of musicians who programmed tunes on the Town Hall carillon included city chapel members: Philipp Schönberg, Bartel Biehn, and Johann Gottlieb Borowski.

Philipp Schönberg, who succeeded Franciscus de Rivulo as the first setter, was a singer in the city chapel. ${ }^{352}$ For some time, Michael Colrep, a notary and the organist at St Catherine's, was in charge of the "singing mechanism" as his replacement. ${ }^{353}$ After Colrep's death, however, the Council hired Schönberg again, as indicated by his letter to the City Council where he asked for a rise, referring to the thirty years of his service for the city. ${ }^{354}$

346 APG 300,R/Pp,q9; APG 300,R/Pp,q10; APG 300,R/Pp,q10a.

347 PAN BG Ms 145, 2 May 1776.

348 Das jetztlebende Danzig, 1764-75.

349 PAN BG Ms 145, 2 May 1776.

350 Rauschning, Geschichte der Musik und Musikpflege in Danzig, 347, 421.

351 APG 300,12/181, p. 118.

352 Rauschning, Geschichte der Musik und Musikpflege in Danzig, 30, 32, 107.

353 Documented in cashbooks between 20 June 1576 and 2 March 1577; see APG $300,12 / 12$, pp. 159-62.

354 APG 300,36/74, pp. 1-3. 


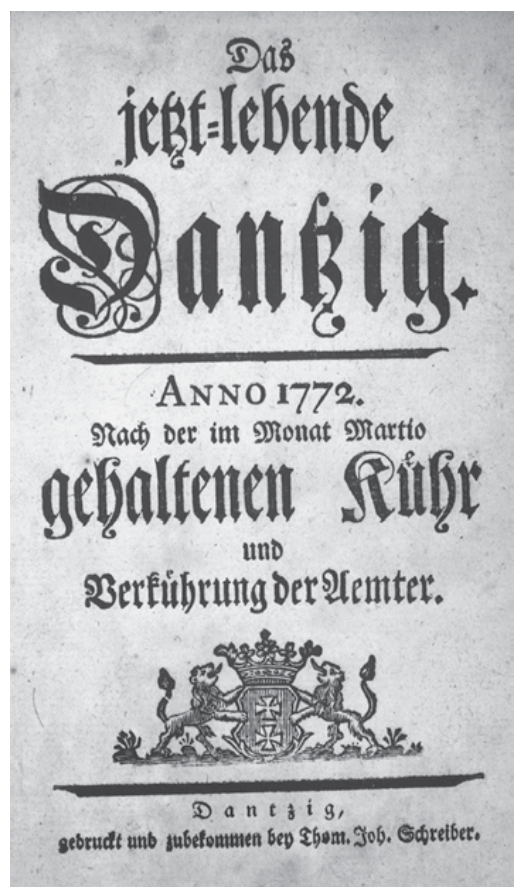

Fig. 15: Das jetzlebende Danzig, 1772, title page

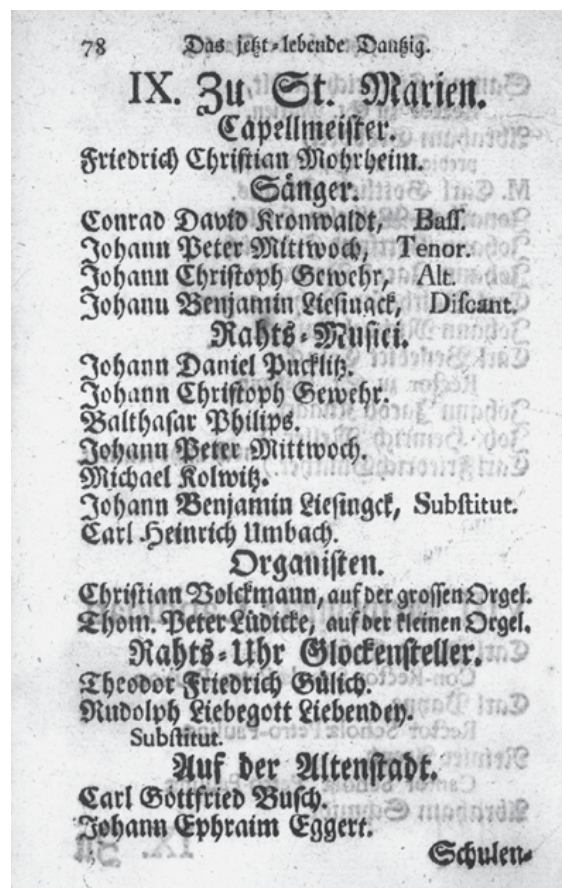

Fig. 16: Das jetzlebende Danzig, 1772, register of musicians, 78

Apart from Schönberg, city chapel singers also included Bartel (Barthell, Bartolomaus) Biehn (Byhahn, Bichan, Bian), who was also a lutist. ${ }^{355}$ For some time, Biehn replaced the sick chapel master Johannes Wanning, as documented by a note in the death register of St Mary's, where the name of Biehn has a note added: "lautenista und vice Capelmeist[er]."356

The third chapel member, Johann Gottlieb Borowski, ${ }^{357}$ was also a singer. $\mathrm{He}$ was born in 1760 and died on 30 March $1813 .{ }^{358} \mathrm{I}$ assume he was the object of Johann Gottfried Hingelberg's irony in 1785:

Borowski. Spielt so leidlich mit, könnte sich mehr Mühe geben, da er noch so jung ist, allein er behandelt seine Kunst zu handwerksmäßig. ${ }^{359}$

355 APG 300,R/Vv,217, pp. 25-28, 33-34; APG 354/351, p. 21.

356 Bartel Biehn was buried on 15 June 1609; see APG 354/351, p. 21.

357 Das jetztlebende Danzig, 1784-89, 1791-92, 1809-10.

358 DIB 1813, Nr 27 (3 April), 250.

359 Hingelberg, Über Danziger Musik und Musiker, 26. 


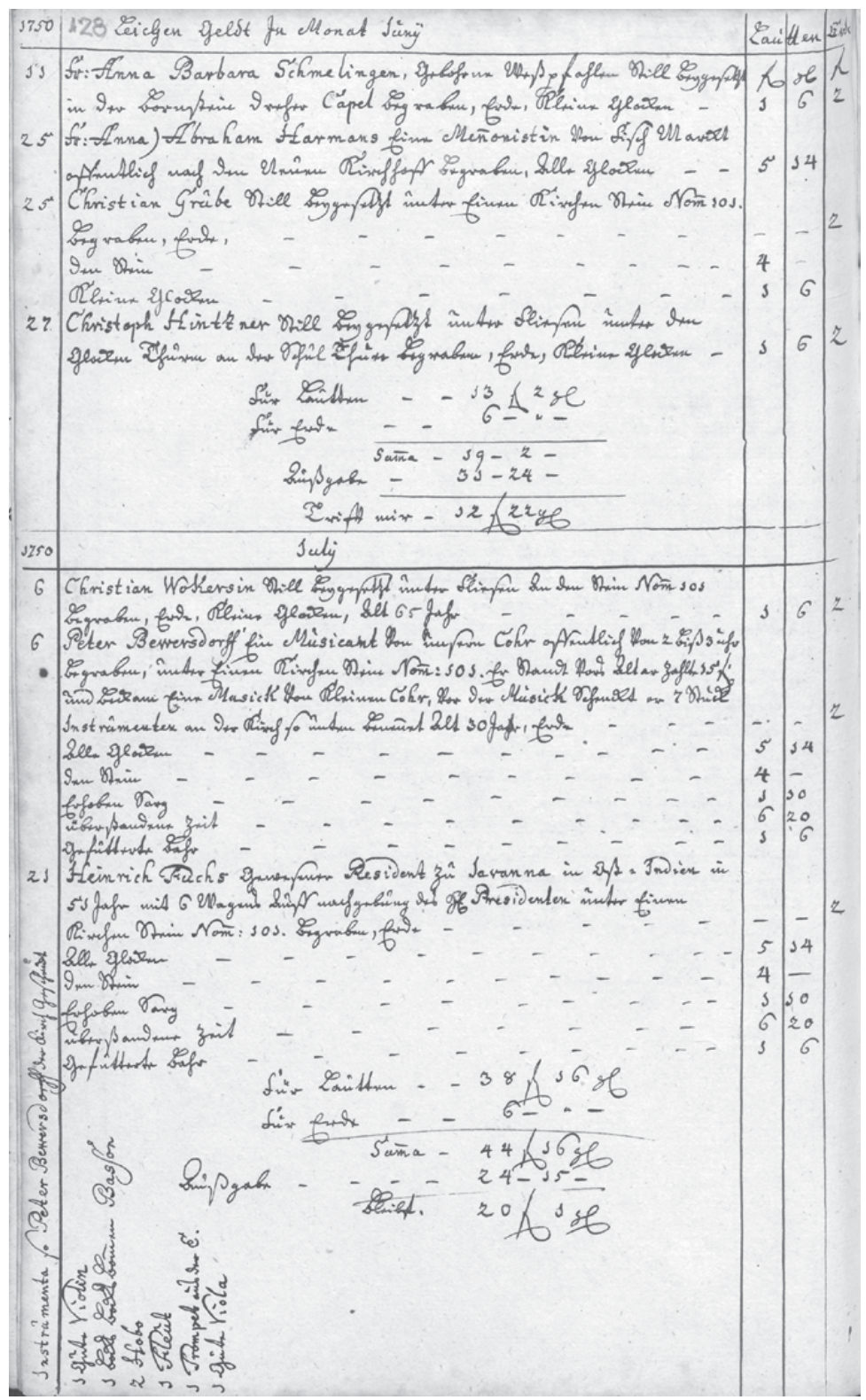

Fig. 17: Entry informing of the death of P. Bewersdorff and the instruments he bequeathed to the church of St John. APG 352/22, p. 128 
The setter of the "singing mechanism" included one guild musician: Hans Neunaber, who died in 1634 at the age of $68 .{ }^{360}$ In the guild's structure, he achieved the highest honour, ${ }^{361}$ yet even in combination with his income as a bell setter, he did not earn enough to sustain a numerous family (he was a father to at least nine children, including Andreas Neunaber ${ }^{362}$ ). Consequently, he took another post as a cellar master ("Kellermeister") at the Artus Court. ${ }^{363}$ Several motions to the City Council by Hans Neunaber survived, which together with correspondence from clockmakers, in which he is mentioned, supply many details about the life and work conditions of bell setters in the early 1600s.

Peter Bewersdorff (1720-1750) undoubtedly performed a music profession, too. ${ }^{364} \mathrm{He}$ might have played many instruments, as before his death, he donated no fewer than seven to the church of St John as payment for his funeral music: a violin, bass pommer (like a bombarde, still popular in Gdańsk), two oboes, a flute, trumpet in E, and viola. The prematurely deceased Bewersdorff was buried between 2 and 3 p.m. on 6 July 1750. ${ }^{365}$

There were four clockmakers amongst Town Hall carillon setters: Johann Eichstedt, Paul Friedrich Knaack, Carl Anton Kaschlinsky, Gustav Krieschen. Johann Eichstedt, employed as the setter for no more than two years until $1680,{ }^{366}$ was considered a particularly gifted clockmaker and ran a prospering workshop in the city. Between 1671 and 1677, he serviced the tower clock at St John's, where he installed the first pendulum of any Gdańsk tower clock, a feat believed to confirm his excellent skills and artistry. ${ }^{367}$

The following clockmaker to tune the "singing mechanism" was Paul Friedrich Knaack, who for thirty years serviced the "dam clock" at the church of St Mary. ${ }^{368}$ During his activity as a setter, he produced a carillon tablature with settings of Protestant songs for the different week of the liturgical year. ${ }^{369}$ However, Knaack

360 APG 354,351, p. 100.

361 Rauschning, Geschichte der Musik und Musikpflege in Danzig, 94, 112, 355.

362 APG 300,R/Vv,217, pp. 37-40.

363 APG 300,R/Vv,217, pp. 55-57.

364 APG 352/22, p. 128.

365 Ibid.

366 See APG 300,12/116, p. 181; APG 300,12/338, p. 27; APG 300,12/118, p. 106.

367 Januszajtis, Gdańskie zegary, dzwony i karyliony, 57; Prószyńska, 'Słownik gdańskich zegarmistrzów i gnomoników', 137.

368 The clock hung at the northern top of the transept above the Dam Gate. See Januszajtis, Gdańskie zegary, dzwony i karyliony, 27-29; Prószyńska, 'Słownik gdańskich zegarmistrzów i gnomoników', 148.

369 APG 300,R/Uu,q9. 
was not the author of arrangements included in that collection; he merely copied them with nearly no changes from the manuscripts of Theodor Friedrich Gülich.

An interesting character was Carl Anton Kaschlinsky (1822-82), pupil and for some time apprentice of Paul Friedrich Knaack, who became sole carillon setter in 1847. ${ }^{370}$ Apparently, however, he did not consider this task to equal his profession as a clockmaker: in an address book of the 1880s, he is cited solely as "Uhrmacher" (clockmaker), ${ }^{371}$ and he signed a note on one page of the carillon tablature of Paul Friedrich Knaack as "Raths-Uhrmacher" (Town Hall clockmaker). ${ }^{372}$ In 1855, he was also active repairing lamps and other "physical instruments."

It is hard to decide which of Kaschlinsky's many activities had the priority: he served as a setter for 35 years, the longest of any setter in Gdańsk, but he also edited several manuscripts on various topics, leaving scholars with valuable sources on the history of Gdańsk. Those writings include:

1. A manuscript of 1861, in which Kaschlinsky describes the Main Town Hall carillon, offers a register of song titles for subsequent weeks of the liturgical calendar (very different from the pattern that had been used for nearly a century), and a mention of the 300th jubilee of the Town Hall carillon, including the celebrations that took place on 23 September 1861. It thereby registers the date of the official inauguration of the carillon in the sixteenth century. ${ }^{374}$

2. An organ choir book including settings of 184 Protestant songs by various authors, derived from the then valid Gdańsk, published in $1841 .{ }^{375}$ It is worth emphasising that Kaschlinsky included many settings by composers operating in Gdańsk: Benjamin Gotthold Siewert, Friedrich August Klügling, and Theodor Friedrich Kniewel, thus consolidating the local chorale tradition.

3. A manuscript with biographical entries of varying length for several hundred citizens of Gdańsk, including many musicians: Carl Friedrich Bartholdi, Crato Bütner, Carl Friedrich Eggert, Georg Friedrich Eggert, Johann Ephraim Eggert, Kaspar Förster Sr and Kaspar Förster Jr, Johann Balthasar Christian

370 See the title page of PAN BG Ms 1093 IV. For more biographical information on Carl Anton Kaschlinsky and his links to the Gdańsk music community, see Michalak, 'Organista i dyrygent chórów Julius Wilhelm Frühling.

371 ABuch 1880, p. 73.

372 APG 300,R/Uu,q9, p. 1.

373 DIB 1855, Nr 289 (10 December), p. 3072.

374 PAN BG Ms 1093 IV.

375 SBB Ms. Danzig 4254. This manuscript is discussed in Heinemann, 'Siewert, Kniewel, Klügling'; Popinigis et al., Music Collections from Gdańsk 1, 223-25. 
Freislich, Maximilian Dietrich Freislich, Friedrich Genée, and Andreas Hakenberger. ${ }^{376}$

4. A genealogy of Gdańsk families, including notes on several hundred prominent citizens, including patricians, scholars, professors, and members of the City Council. ${ }^{377}$ Those names included three Försters: Kaspar Sr, Kaspar Jr, and Georg. ${ }^{378}$ Kaschlinsky also cited the name of Old Town councillor Andreas Stendel indicating that he bequeathed 18,000 florins for the construction of the carillon at the church of St Catherine; he also cited Daniel Böttcher as the builder of the mechanism. ${ }^{379}$

5. A manuscript in two volumes, a kind of memoir, in which he narrated some events from the recent and more distant history of Gdańsk. ${ }^{380}$ This included the carillon of the Main Town Hall and the statue of Sigismund Augustus, placed on the top of the tower on 23 September 1561. Kaschlinsky ends his remarks quoting the inscription from the Town Hall bells, which he calligraphically reproduced in all details of the font and ornaments: ${ }^{381}$

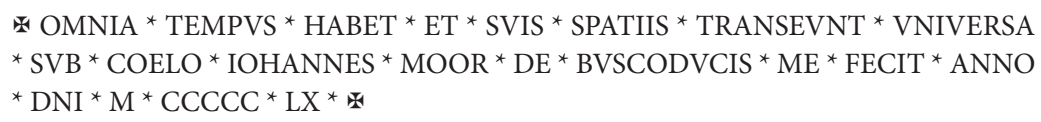

The existing documents do not allow a more detailed discussion of all Town Hall carillon setters. Cashbooks repeatedly add the note "Seegersteller" (clockmaker) to the name of Gottfried Wernick but it is hard to say whether this referred to his main profession or was an alternative term for his bell setting. ${ }^{382}$ We do not know the primary occupation of Christoph Sievert, Johann (Andreas) Gottlieb Schröder ${ }^{383}$ and David Krüger. An entry survived in the mayor's acts about hiring David Krüger for

376 PAN BG Ms 5751: Danziger Familien, see Dzienis, Katalog rękopisów Biblioteki Gdańskiej Polskiej Akademii Nauk, 143-52.

377 PAN BG Ms 806: Genealogien einiger Danziger Patricier-Familien, mit Anmerkungen von C. A. Kaschlinsky.

378 PAN BG Ms 806, p. 76.

379 PAN BG Ms 806, p. 60.

380 PAN BG Ms 1089 II; PAN BG Ms 5750. See Szafran, Katalog Rękopisów Biblioteki Gdańskiej Polskiej Akademii Nauk, 17; Dzienis, Katalog rękopisów Biblioteki Gdańskiej Polskiej Akademii Nauk, 142.

381 PAN BG Ms 1089 II, pp. 68-69.

382 The name of Gottfried Wernick is missing from the dictionary of Gdańsk clockmakers; see Prószyńska, 'Słownik gdańskich zegarmistrzów i gnomoników'.

383 APG 300,1/140, pp. 248-49. Johann Gottlieb Schröder, who is quoted in that document, is also listed in cashbooks as Andreas Gottlieb Schröder; see APG 300,12/149 ff. 
68.

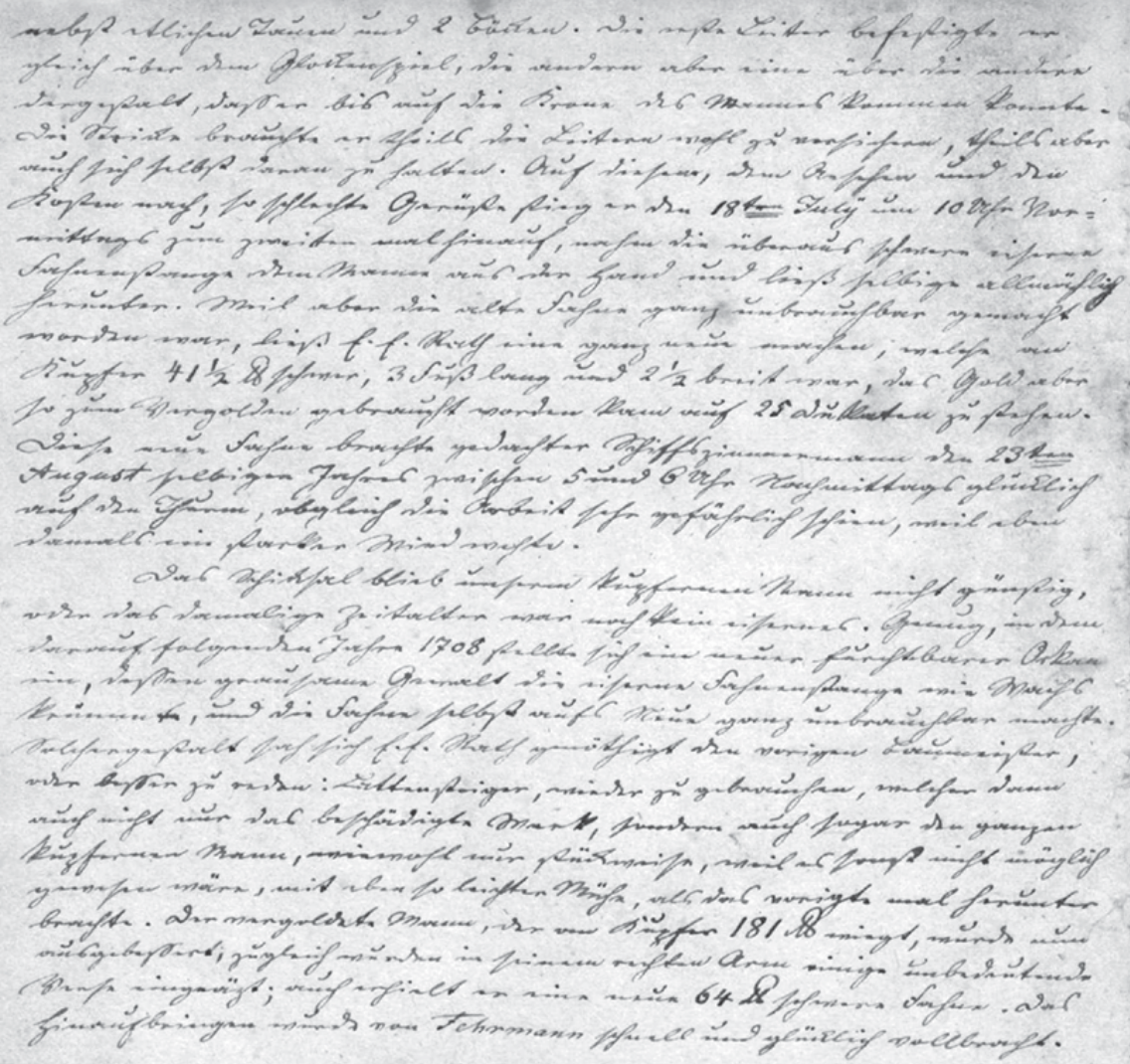

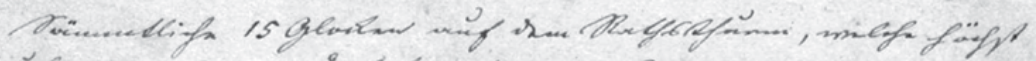

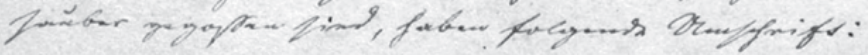 \\ *OMNIA*TEMPVS *HABET*ET*SVIS*SPATIIS* TRANSEVNT*VNIVER $*$ SVB*COELO * IOHANNES* MOOR*DE*BVSCODVCIS*ME*FECIT*ANNO *}

Fig. 18: Notes by C. A. Kaschlinsky. PAN BG Ms 1089 II, pp. 68-69 


\section{$\mathrm{DNI} * \mathrm{M} * \operatorname{ccccc} * \mathrm{~L} X * \frac{*}{\%}$}

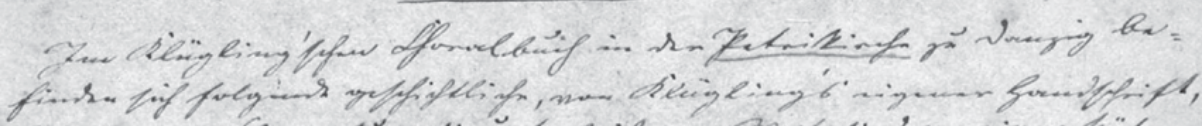

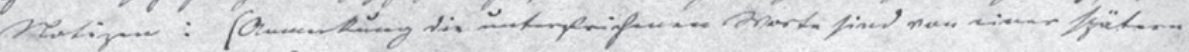

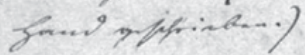

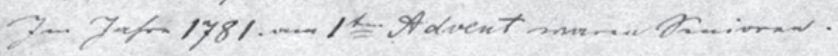

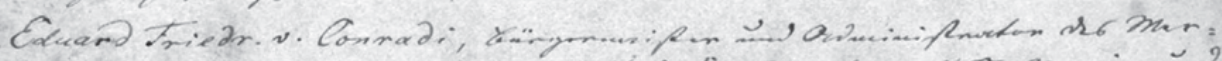

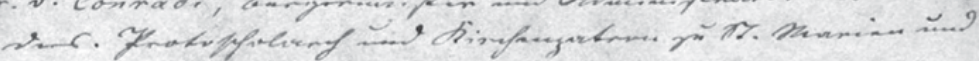

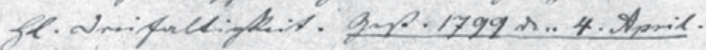

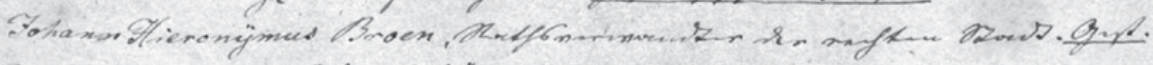

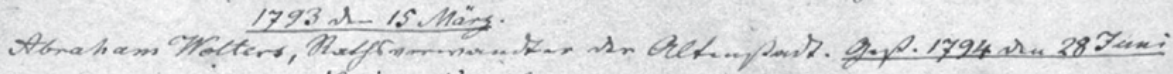

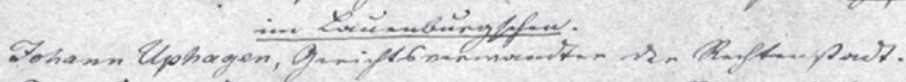

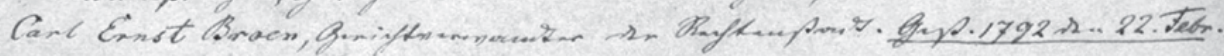

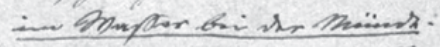

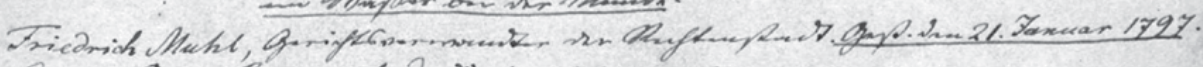

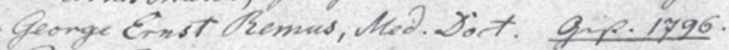

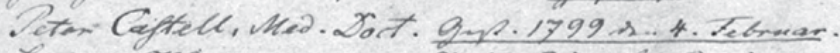

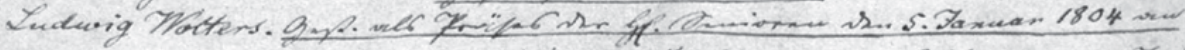

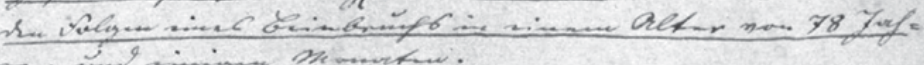

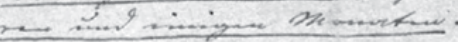

Barpatar an dinfa.

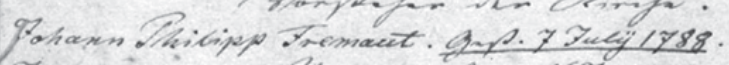

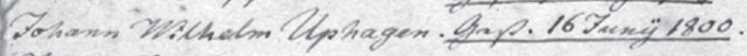

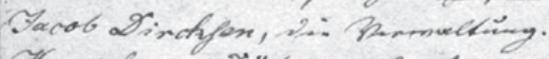

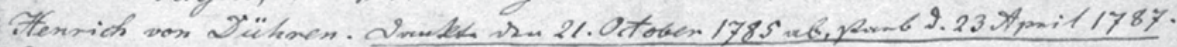

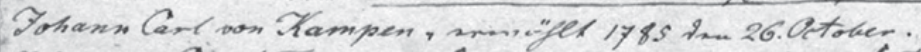

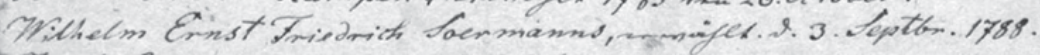

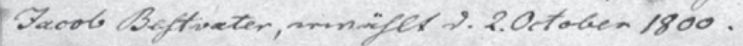




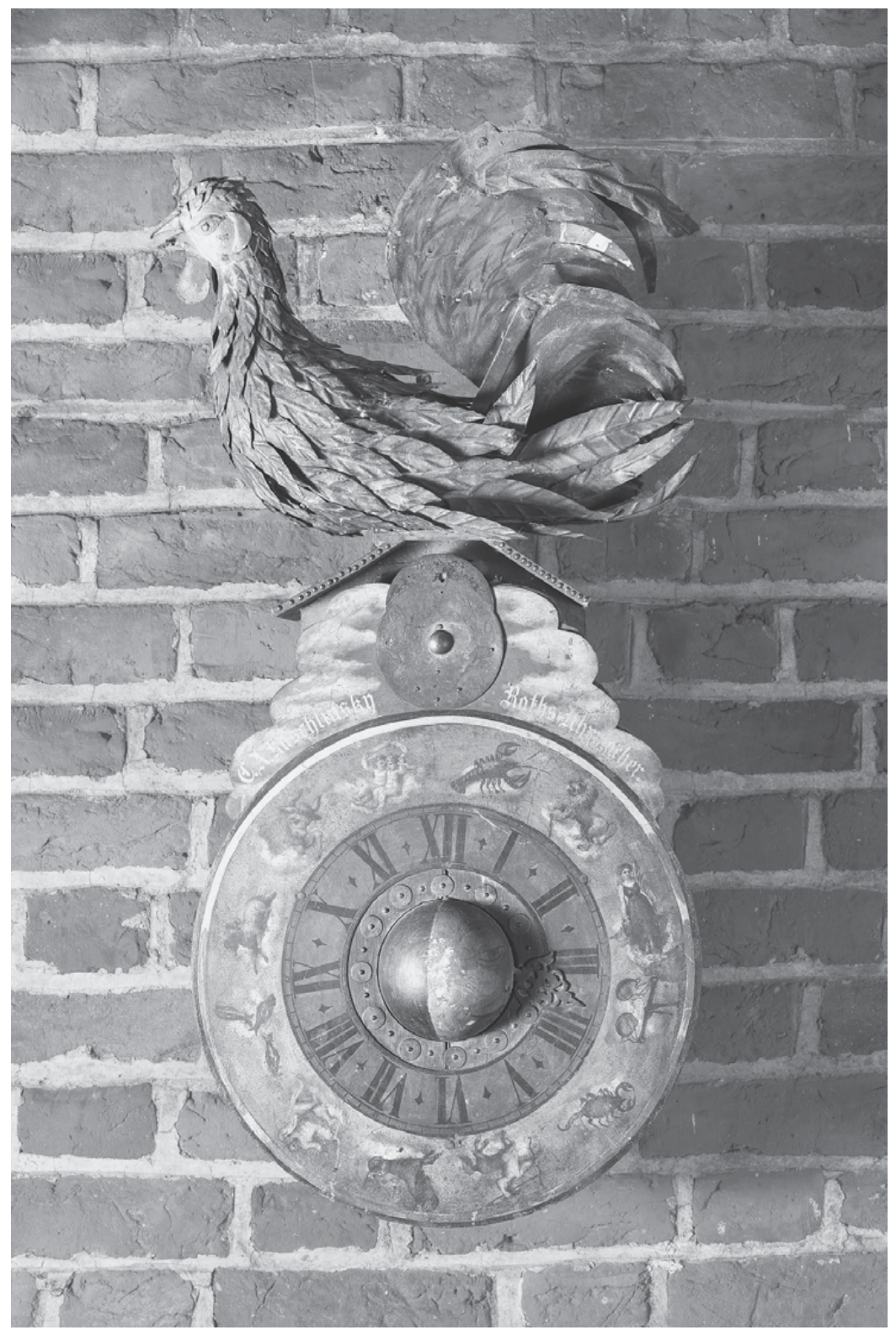

Fig. 19: Advertisement of C. A. Kaschlinsky. Gdańsk Science Museum, desposit of the National Museum in Gdańsk, photo by M. Popinigis 
the position of bell setter, ${ }^{384}$ but that otherwise important document does not clarify whether his work at the tower was his sole source of income. I am also unable when Carl Simon Eggert was hired as clock setter and bell setter ("Rathsuhrglockensteller") and was what his relationship with clockmaker Paul Friedrich Knaack, as the two worked together for some time. ${ }^{385}$ In several cases, it is impossible to specify the period of employment. There are also no direct sources to confirm whether Gustav Krieschen, who took over the post of carillonist at St Catherine's from his father Paul William Krieschen, was also in charge of the Town Hall bells.

The table below lists the carillon setters of the Main Town Hall, reflecting the current state of research:

Tab. 8: List of carillon setters at the Main Town Hall in Gdańsk

\begin{tabular}{ll}
\hline Name & Time of service \\
\hline Franciscus de Rivulo & $1561-64$ \\
Philipp Schönberg & $1564-76 ?$ \\
Michael Colrep (Kolrep, Kalrep) & $1576-77$ \\
Philipp Schönberg & $1577-86 ?$ \\
Jacobus Tetius & $1587 ?-1602$ \\
Bartel (Barthell, Bartolomaus) Biehn (Byhahn, Bichan, Bian) & $1603-9$ \\
Franz Tetius & $1609-12$ \\
Hans Neunaber & $1612-34$ \\
Andreas Neunaber & $1634-63$ \\
Jacob Neunachber (Neunaber) & $1663-78$ \\
Johann Eichstedt & $1678 ?-80$ \\
Gottfried Wernick & $1680-93 ?$ \\
Christian Biehn (Bihn, Bühn) & $1699 ?-1715 ?$ \\
Christoph Sievert & $1719 ?-36$ \\
Johann (Andreas) Gottlieb Schröder & $1736-46$ \\
Peter Bewersdorff & $1746-50$ \\
David Krüger & $1750-63 ?$ \\
Theodor Friedrich Gülich & $1764-76$ \\
Rudolph Liebegott Liebendey & $1776-79$ \\
\hline
\end{tabular}

(continued on next page)

384 APG 300,1/144, p. 46.

385 The notice that Carl Simon Eggert was Town Hall clock bell setter ("Rathsuhrglockensteller") was quoted in the press announcement of his death; see DIB 1831, no. 159 (12 July), 1617. Eggert died on 9 July 1831 at the age of 36, leaving his wife and two children; see APG 1461/136, no. 91.

386 Rudolph Liebegott Liebendey was the deputy ("Substitut") of Theodor Friedrich Gülich in the years 1770-76. 
Tab. 8: Continued

\begin{tabular}{ll}
\hline Name & Time of service \\
\hline Johann Gottlieb Borowski & $1780-1813$ \\
Paul Friedrich Knaack & $1808 ?-47$ \\
Carl Simon Eggert & $?-1831$ \\
Carl Anton Kaschlinsky & $1847-82$ \\
Julius Johann Krieschen & $1882-92$ \\
Paul William Krieschen & $1893-1920$ \\
Gustav Krieschen? & $1920 ?-23 ?$ \\
Georg Edel & $1923 ?-45$ \\
\hline
\end{tabular}

\section{Employment, duties and payment of bell setters}

Town Hall bell setters were employed by the City Council. The earliest confirmation of that fact is a note on the motion of 24 January 1603 in which Bartel Biehn applied for the post of "singing clock mechanism manager" ("Regierer des Singenden Uhrwercks"). ${ }^{387}$ There are further confirmations in the next century in books with mayors' decisions. For example, on 10 June 1746, a note was given about the employment of Peter Bewersdorff to replace the deceased Johann (Andreas) Gottlieb Schröder, ${ }^{388}$ and on 3 July 1750, about the hiring of David Krüger. ${ }^{389}$

The position was for life. Applying candidates informed the Council of the former setter's death, as did Schröder and Krüger in the above-cited documents; they declared to perform their duties diligently for the rest of their lives - as written by Bartel Biehn ${ }^{390}$ - and argued about their musical abilities and their practice in using the carillon. Franz Tetius mentioned he was the organist at the gymnasium church (of the Holy Trinity) and had been trained as a setter by his father Jacobus Tetius, whom he had replaced for two years when the latter was sick. ${ }^{391}$ Earlier apprenticeship with Jacobus Tetius and his son Franz, who died in 1612, was also quoted in his application by Hans Neunaber. ${ }^{392}$ In turn, Hans Neunaber's son Andreas referred to his apprenticeship with his father. ${ }^{393}$

387 APG 300,R/Vv,217, pp. 25-26, 28.

388 APG $300,1 / 140$, pp. 248-49.

389 APG 300,1/144, p. 46.

390 APG 300,R/Vv,217, pp. 25-26, 28.

391 APG 300,R/Vv,217, pp. 29-32.

392 APG 300,R/Vv,217, pp. 37-38, 40.

393 APG 300,R/Vv,217, pp. 67-70. 
Employment, duties and payment of bell setters

107

248

Ge

ctctum d g. Sunii $1746 \%$

Lomumon fole.

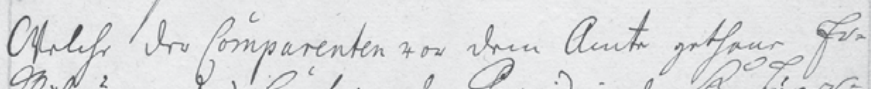

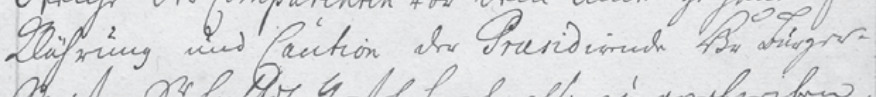

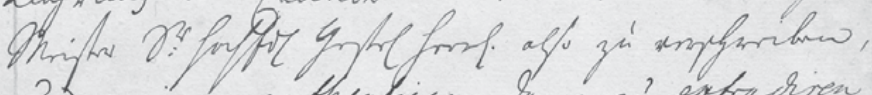

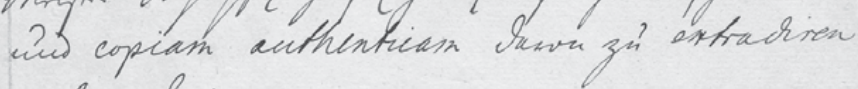
unafgry bru:

Actum d: 10. Fuxic 1746\%

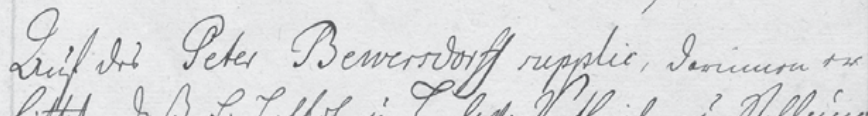

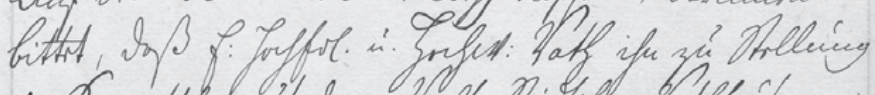

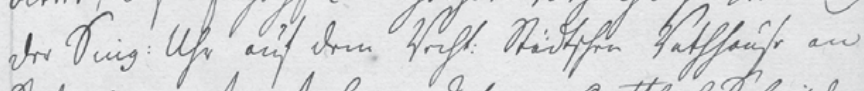

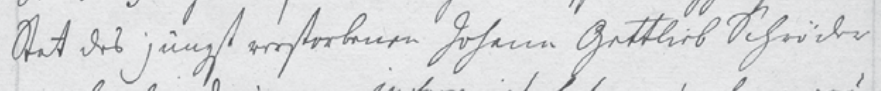

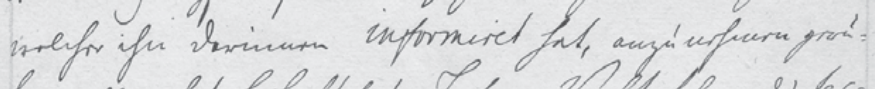

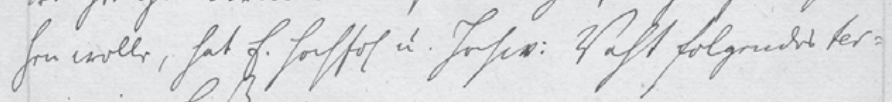
miniven lo 3 m.

Lect in fenat 2:10. Suncii 1746\%

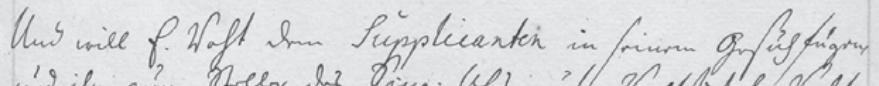

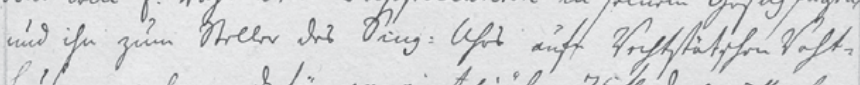

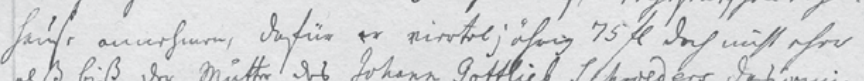

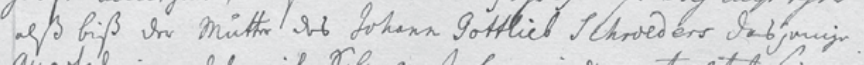

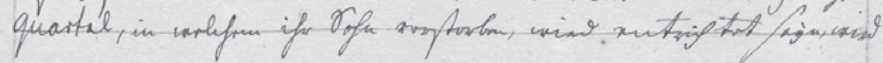

Fig. 20: Employment of P. Bewersdorff as bell setter. APG 300,1/140, p. 248 


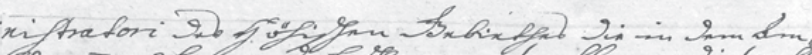

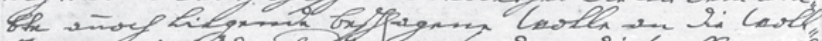

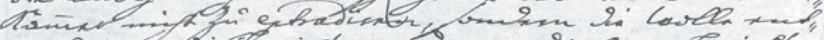

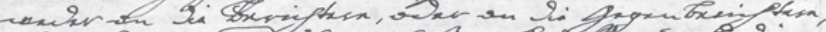

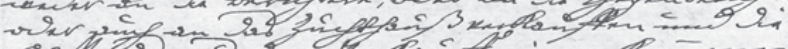

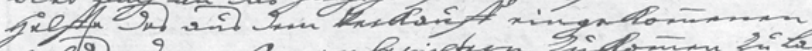

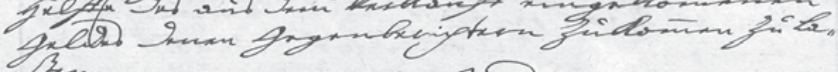

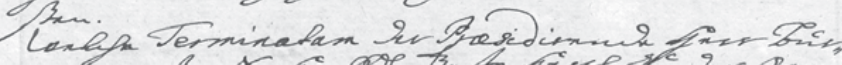

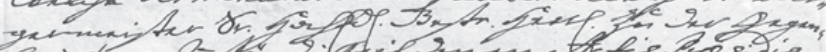

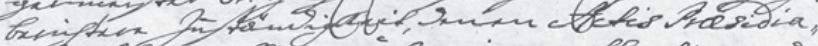
libus zir ingrofiru, ang covian aothexkicam is

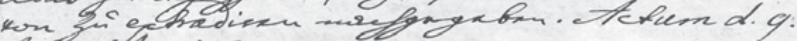
uli. to 1750

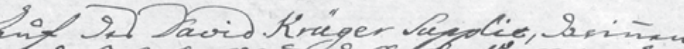

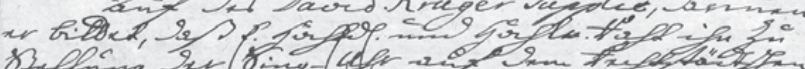

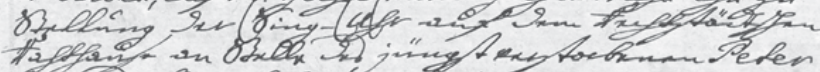

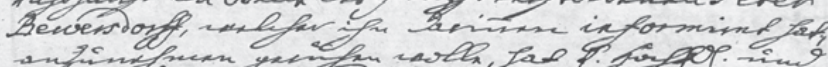

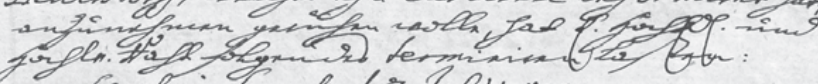
- Leefici Lenal. d. 3. Mehi 1750. Un 9 vill p the g.

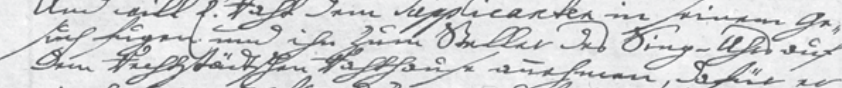

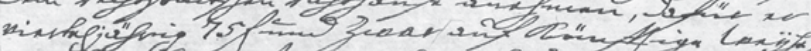

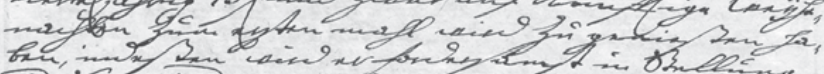

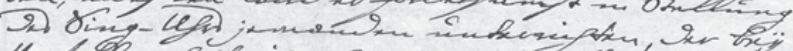

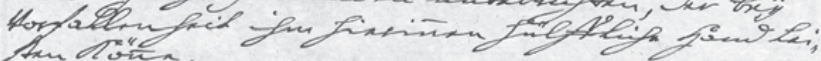
Am divin.

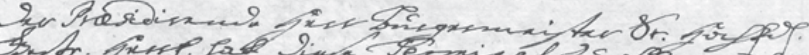

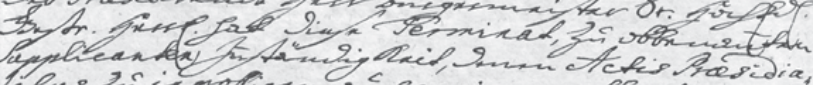

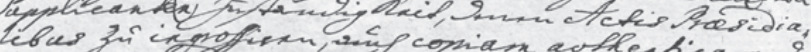

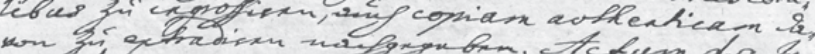
Lir Ita 1750. Theren d.g. Ke,

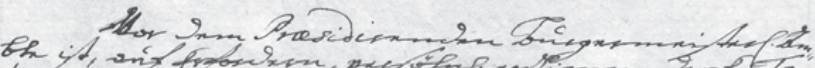

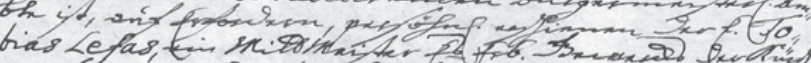

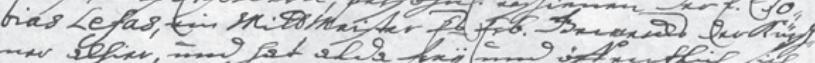

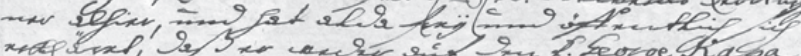

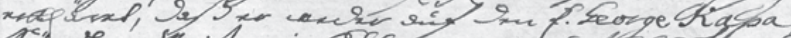

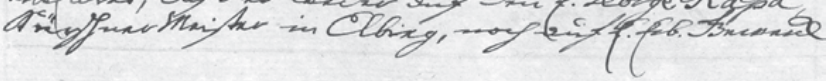

Fig. 21: Employment of D. Krüger as bell setter. APG 300,1/144, p. 46 
From the above remarks, it could transpire that a son would inherit the setter position from his father. This was far from obvious, however, and required additional effort. Hans Neunaber, though encouraged by councillors to nominate his son as his successor, asked for extra confirmation from one of the mayors, Valentin von Bodeck. ${ }^{394}$ When applying for the job, Andreas Neunaber cited the earlier promise given to his father, which the Council respected. ${ }^{395}$ On the other hand, things evolved differently after the death of Jacobus Tetius. His son Franz, despite excellent training, was judged too young by the Council to take the post for which he applied; he only obtained it in 1609, after the death of Bartel Biehn. ${ }^{396}$

Franz Tetius was not the only person to apply twice for the post of a setter. It was also the case of guild musician Hans Neunaber, which reapplied after the death of Franz Tetius. This time, the application was accepted by the Council who hired Neunaber on 22 February $1612 .{ }^{397}$ Neunaber likely did not expect to service the "singing mechanism" for the following twenty-two years until his death in $1634 .{ }^{398}$

The Franz Tetius case shows another solution of employing as bell setter: before he was hired, the Council offered him one-week probation on 3 July 1609, only taking him on a permanent post a month later. ${ }^{399}$

The Council only employed and paid one setter; remunerating a possible apprentice or deputy was not a responsibility of the Council. Asking for a pay rise, Bartel Biehn wrote that due to his elderly age, he occasionally needed to hire help. ${ }^{400}$ Jacobus Tetius and Hans Neunaber were helped by their sons who also replaced their fathers when need occurred. In 1629, Hans Neunaber complained about a lack of stamina and having to hire a replacement, which cost him each time 26 groschen; ${ }^{401}$ we do not know if he paid that money to his son or another person. In 1633, he asked the Council to hire Andreas Neunaber as his official aide, reminding that he had nominated him as his successor on the encouragement of councillors. The Council preliminarily agreed; Andreas would become setter provided he dutifully performs his tasks; at the same time, no additional payment was offered to Hans, who remained the only beneficiary until his

394 APG 300,36/74, pp. 25-28.

395 APG 300,R/Vv,217, pp. 67-70.

396 APG 300,R/Vv,217, pp. 29-32.

397 APG 300,R/Vv,217, pp. 37-38, 40.

398 Buried on 27 February 1634, see APG 354,351, p. 100.

399 APG 300,R/Vv,217, pp. 29-32.

400 APG 300,R/Vv,217, pp. 33-34.

401 APG 300,R/Vv,217, pp. 55-57. 
death. ${ }^{402}$ The matter of employing an aide and remunerating him was thus to the setter. That situation changed in the eighteenth century, possibly due to the construction of a carillon at the church of St Catherine and the ensuing practice of employing two carillonists there. In the decisions of the City Council from the mid-eighteenth century, the matter of apprentices was unambiguously clarified: both Peter Bewersdorff and David Krüger were obliged to hire a person that would replace them when needed. Remuneration was not mentioned, meaning that the apprentice was paid by the setter. ${ }^{403}$ Between 1770 and 1776 , the title of an official apprentice ("Substitut") was used by Rudolph Liebegott Liebendey ${ }^{404}$ who helped the ageing Theodor Friedrich Gülich. Later, Liebendey briefly became an independent setter but on 22 October 1779, as indicated by the chronicle, he secretly left the city ("heimlich von der Stadt entwichen"): ${ }^{405}$ it is not clear whether he fleeing for debtors or for some other motive.

Setters were paid quarterly, though the three-month periods were not regularly respected. The first documented confirmation of a setter's salary consists of four notes in a cashbook from the accounting year 1576-77. They refer to a payment of 23 thalers and two and a half groschen to Michael Colrep (Kolrep, Kalrep). ${ }^{406} 25$ thalers were paid on 4 December 1594 to Jacobus Tetius for the Christmas quarter. ${ }^{407}$ The rise was likely negotiated by Philipp Schönberg; in any case, he motioned for one to the Council, referring to the word given to him by councillor Joachim Elert in 1577, when he was hired again as the setter. ${ }^{408}$ Did he benefit from the rise or was the latter only offered to his successor Jacobus Tetius, we do not know.

The quarterly salary of 25 thalers remained in use for many years. Hans Neunaber received that pay for the last time on 17 September $1614 .{ }^{409}$ His next payment on 17 December of that year rose to 30 thalers ${ }^{410}$ before reaching 37 thalers and 10 groschen in subsequent years. Hans Neunaber asked for another rise in 1629. In a letter to the Council, he complained the monthly pay of a sergeant ("Schersanten") in the current war was higher than his salary, while

402 APG 300,36/74, p. 28.

403 APG 300,1/140, pp. 248-49; APG 300,1/144, p. 46.

404 Das jetztlebende Danzig, 1770-76.

405 PAN BG Ms 146, 22 October 1779.

406 APG 300,12/12, pp. 159-62.

407 APG 300,12/21, p. 123.

408 APG 300,36/74, pp. 1-3.

409 APG 300,12/45, p. 175.

410 APG 300,12/45, p. 205. 
musicians in the St Mary chapel earned 100 or even 200 florins per years, considerably more than he did. ${ }^{411}$ While the Council disregarded the request (see the reply of 29 July 1629), ${ }^{412}$ cashbooks show that Neunaber's request was eventually granted: for the "Pfingstquartall" (Pentecost quarter), he was paid 37 thalers and 10 groschen on 22 May 1630, ${ }^{413}$ but for the "Michaelisquartall" (St Michael's quarter) on 18 September, this rose to 50 thalers. ${ }^{414}$

In subsequent decades, the quarterly salary must have risen, as on 30 March 1680, Johann Eichstedt ("Joh[ann] Eichstedt dem Uhrmacher u[nd] Glockensteller") was paid 50 florins, that is, 75 thalers. ${ }^{415}$ In that note, the quarterly wages of other musicians paid by the Council were also mentioned: the chapel master Balthasar Erben earned as much as Eichstedt, while Michael Vorsing, organist of the chapel of St Anne, earned half that amount. ${ }^{416}$

Such high salaries for the setter, equal to those of the city chapel master, meant the Council considered the post as fairly prestigious. It requires further comparative analysis of the two salaries to confirm whether that had always been the case. From a rough overview of the cashbooks with notes of quarterly wages (incomplete, because the various elements of the pay were not always registered) indicates unequivocally that the chapel master and bell setter were the highestearning musicians in Gdańsk.

In the mid-eighteenth century, we note a further rise in pay of the bell setters. Peter Bewersdorff and then David Krüger were paid 75 florins per quarter. ${ }^{417}$

We know nearly nothing about the salaries of bell setters in the nineteenth and twentieth century. I am only familiar with the receipts of Johann Gottlieb Borowski from the second quarter of 1807. It was a difficult period for Gdańsk: the war and the ensuing financial contributions had impoverished the city's residents. Borowski received his quarterly salary in two instalments: on 21 May he signed a receipt for 18 thaler, 67 groschen and 9 pennies, while on 1 June, for 6 thalers, 22 groschen and 9 pennies. ${ }^{418}$

After a setter's death, his family received his last salary. This rule seems to have been respected for centuries. Thus, the widow of Jacobus Tetius was paid

411 APG 300,R/Vv, 217, pp. 55-57.

412 Ibid.

413 APG 300,12/61, p. 37.

414 APG 300,12/61, p. 123.

415 APG 300,12/338, p. 27.

416 Ibid.

417 APG 300,1/140, pp. 248-49; APG 300,1/144, p. 46.

418 APG 300,12/465, pp. 279, 287. 


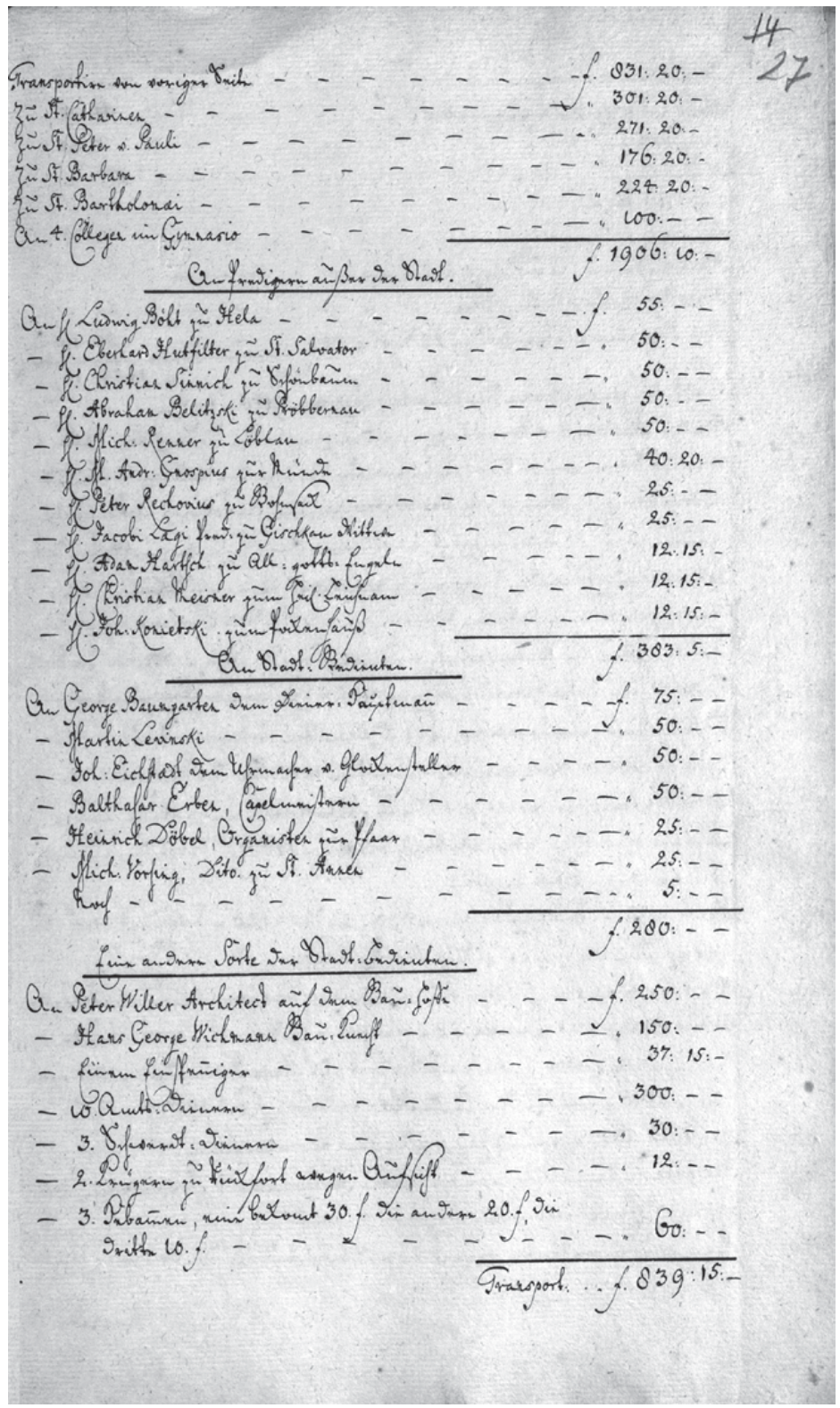

Fig. 22: Quarterly salary of J. Eichstedt. APG 300,12/338, p. 27 


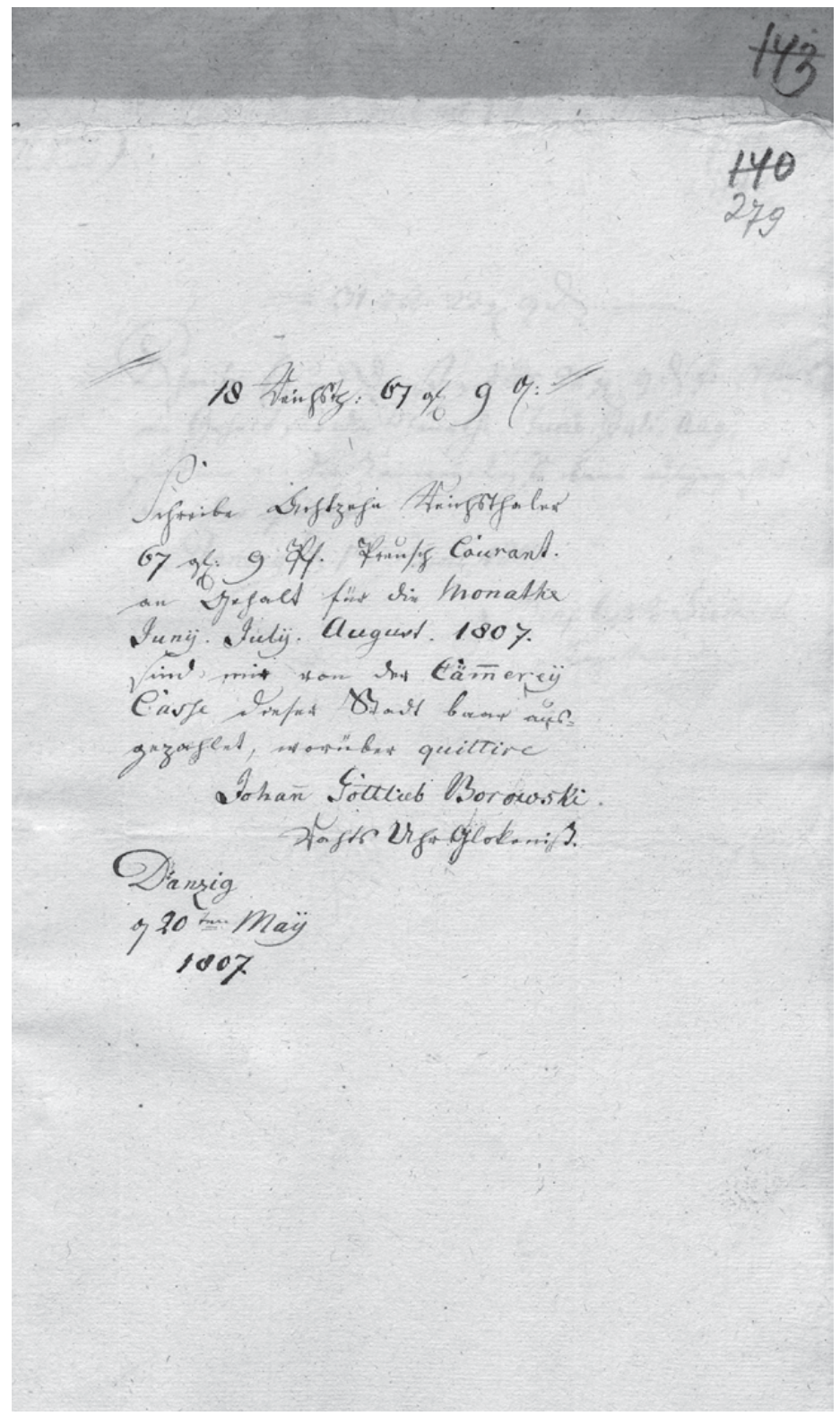

Fig. 23: Quarterly salary of J. G. Borowski, PG 300,12/465, p. 279 
the quarterly salary of her late husband on 30 January $1603,{ }^{419}$ while Peter Bewersdorff received his first salary only three months after being employed after it was ordered that payment for the current quarter be given to the mother of late Johann (Andreas) Gottlieb Schröder. ${ }^{420}$

Apart from their regular quarterly salary, bell setters received other regular and occasional payments from the Council. Only the first setter and his successor had right to free board; the right to an official apartment was transferred from the late Franciscus de Rivulo in 1564 to Philipp Schönberg by mayor Johann Proite, but in 1572 the apartment became an issue. Schönberg was asked to leave it and moved to another venue indicated by the mayor at the time, Georg Kleefeld, but after some time he had to free that place as well. ${ }^{421}$ Schönberg's motion remained without an answer and we do not know how his request was settled. His difficulties suggest he was the last setter to enjoy that benefit. In any case, there is no mention of free board in later sources discussing the salary of setters.

Setters were paid a small amount once per year for buying candles ("Lichtgeld"). This is documented by a receipt for 8 florins issued by Johann Gottlieb Borowski on 14 November $1789 .{ }^{422}$

As we know, apart from a weekly programming of the bells, it was the duty of setters to programme the automaton on special occasions. From the beginning of the carillon's operation, they set special tunes on the day of election to the City Council ("wegen Kühre") as well as for the beginning and end of the St Dominic's Fair. Initially, work on those days as well as New Year was paid on top of the setter's regular quarterly salary. However, those occasional payments were abandoned at some point, as indicated in a motion of 1612 sent by Hans Neunaber and clockmaker Michael Scharasch. We do not know the exact timing of that change; the two musicians only mentioned it happened during the term of Hans Schwarzwald ${ }^{423}$ who worked at the City Council in 1579 (when he became a juror; he served as councillor from 1585 until his death in 1608): ${ }^{424}$

wie es von alters here gebreuchlich geweßen, das der Segersteller, nebenst dem Regierer des Singenden Wercks aufs Neuge Jahr, Chüre undt Dommenick von EER eine Verehrung bekommen, aber durch seligen Herrn Hans Schwarzwald abgeschafet worden. ${ }^{425}$

\footnotetext{
419 APG 300,12/31, p. 110.

420 APG 300,1/140, pp. 248-49.

421 APG 300,R/Vv,217, pp. 1-2.

422 APG 300,12/199, p. 11.

423 APG 300,36/74, pp. 19-22.

424 Zdrenka, Rats- und Gerichtspatriziat der Rechten Stadt Danzig, 2:304-5.

425 APG 300,R/Vv,217, p. 41.
} 


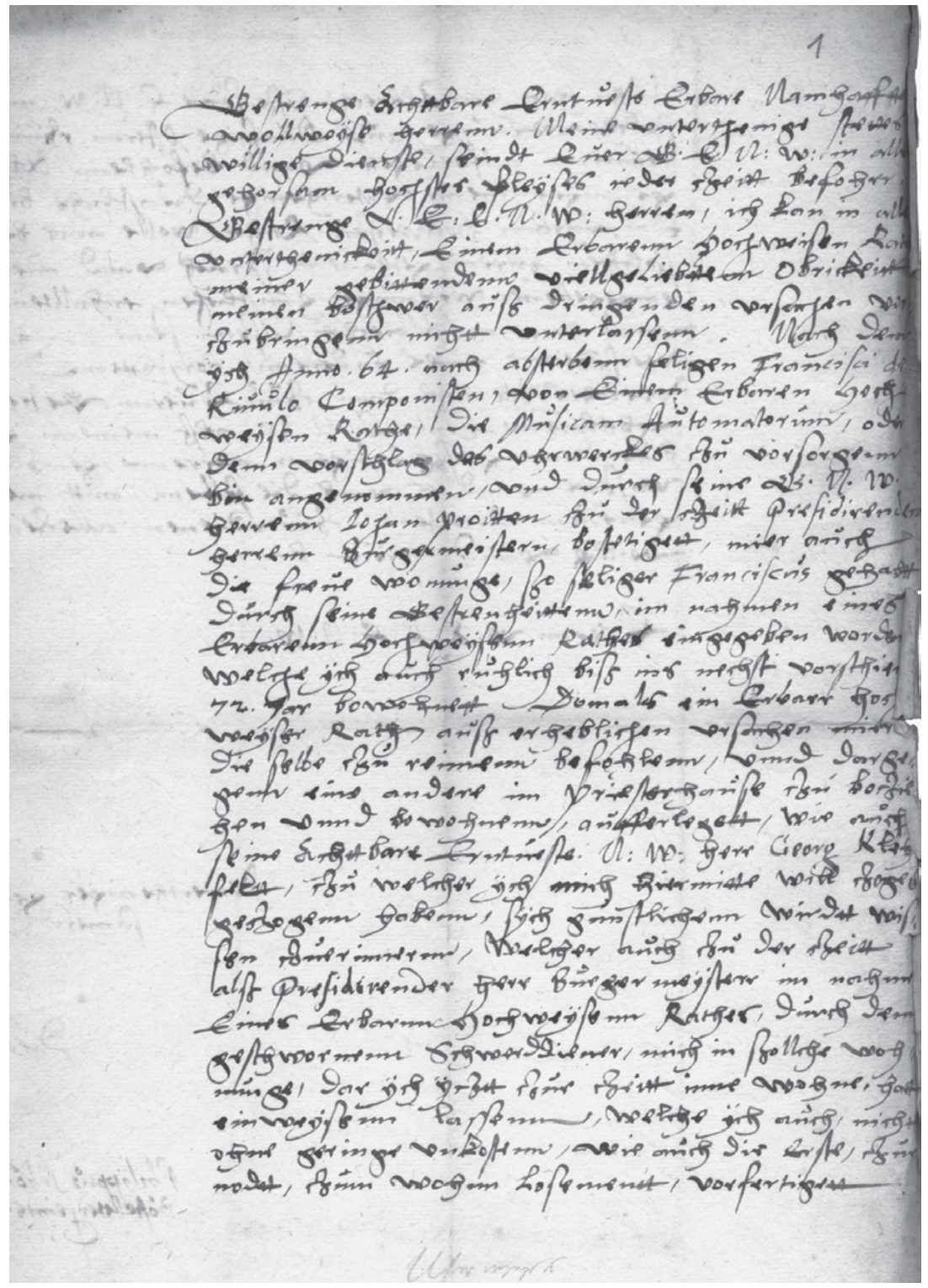

Fig. 24: Motion of Ph. Schönberg. APG 300,R/Vv,217, p. 1 


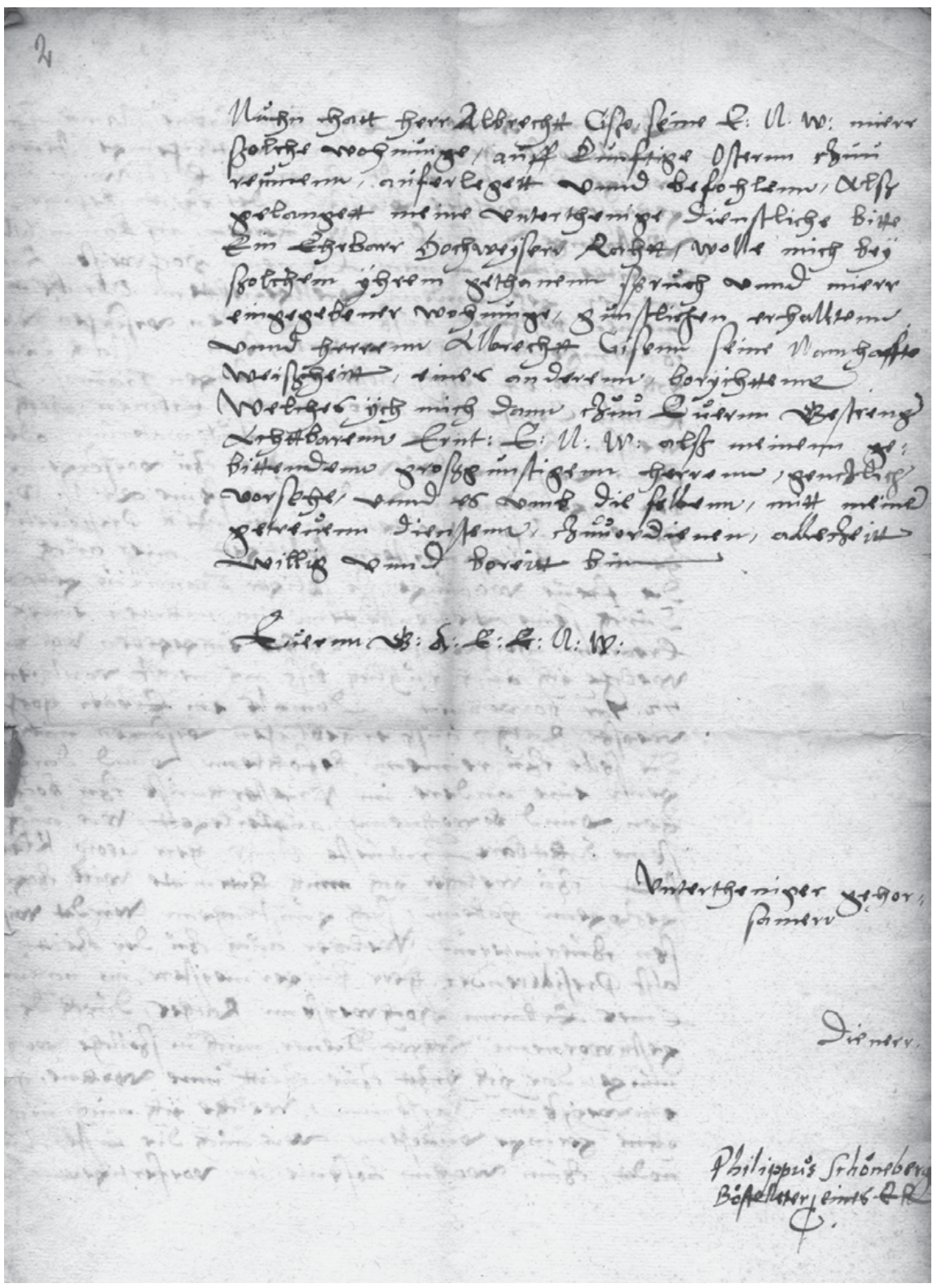

Fig. 25: Motion of Ph. Schönberg. APG 300,R/Vv,217, p. 2 
In 1612, the Council rejected that request, stating that the two musicians were paid sufficient salaries. ${ }^{426}$ After the 1630 election, an exception was made for Hans Neunaber: instead of the traditional bottle of wine mentioned in a note to the cashbook of 19 March, he was paid four thalers. ${ }^{427}$ That sum is also documented in another cashbook. ${ }^{428}$ The clockmaker, however, was not paid, even though his participation in setting the carillon was necessary as he saw to the synchronisation of the clock and the carillon automaton. Hence in 1632, the new clockmaker Michael Schultz together with Hans Neunaber sent another motion to the Council regarding the aborted payments; it was again rejected. ${ }^{429}$ Payments continued to be made only to Neunaber and only in later years, were offered to the clockmaker as well. In 1661, each received 4 thalers and 10 groschen. ${ }^{430}$

It took equally long to convince the Council to resume extra payments for signalling the beginning and end of the St Dominic's Fair. I only found confirmation of such a payment in a cashbook of 1645: 12 August money was paid to Andreas Neunaber, Michael Schultz, and a bell-ringer at St Mary's. ${ }^{431}$ An added note saying "as usual" suggests they had been paid such extras before. Later entries indicate that bell setter Jacob Neunachber was paid 9 thalers and the clockmaker, 4 thalers 10 groschen. ${ }^{432}$

Fees for signalling the election day and the St Dominic's Fair remained stable for decades and amounted respectively to 3 florins for programming the song Komm heiliger Geist Herre Gott and 6 florins for the fair songs; the same fees were documented by Theodor Friedrich Gülich. ${ }^{433}$

Occasionally, bell setters received additional payments for signalling social and political events in Gdańsk and other cities of the Polish-Lithuanian Commonwealth. The standard fees for various occasions are quoted by Theodor Friedrich Gülich, while cashbooks document actual amounts paid to setters.

426 APG 300,R/Vv,217, pp. 41-42.

427 APG 300,12/59, p. 166.

428 APG 300,12/60, p. 113.

429 APG 300,36/74, pp. 19, 22.

430 APG 300,12/97, p. 37.

431 APG 300,12/81, p. 199.

432 For example, APG 300,12/112, p. 33.

433 APG 300,R/Pp,q9, pp. 286, 287. 
Tab. 9: Comparison of hypothetical fees as quoted by Gülich with actual payments documented in cashbooks

\begin{tabular}{|c|c|c|}
\hline Occasion & $\begin{array}{l}\text { Fee according to } \\
\text { Gülich's manual }^{434}\end{array}$ & Fee according to cashbooks \\
\hline $\begin{array}{l}\text { Royal } \\
\text { election }\end{array}$ & 9 florins & $\begin{array}{l}\text { Hans Neunaber with trumpeters and pipers from the } \\
\text { Artus Court were paid a total of } 46 \text { thalers and } 10 \\
\text { groschen on } 15 \text { December } 1632 \text { for their playing on the } \\
\text { occasion of Ladislaus IV's election }^{435}\end{array}$ \\
\hline $\begin{array}{l}\text { Royal } \\
\text { coronation }\end{array}$ & 9 florins & $\begin{array}{l}\text { Hans Neunaber and Michael Schultz were paid } 18 \\
\text { thalers on } 18 \text { February } 1633 \text { for programming the } \\
\text { "singing mechanism" on the occasion of Ladislaus IV's } \\
\text { coronation }{ }^{436}\end{array}$ \\
\hline $\begin{array}{l}\text { Cure of } \\
\text { the King }\end{array}$ & 9 florins & No data \\
\hline $\begin{array}{l}\text { Death of } \\
\text { the King }\end{array}$ & $\begin{array}{l}50 \text { florins for } \\
\text { programming } \\
\text { tunes over } 4 \text { weeks }\end{array}$ & $\begin{array}{l}\text { Andreas Neunaber was paid } 75 \text { thalers on } 30 \text { June } 1648 \\
\text { for programming tunes after the death of Ladislaus IV } \\
(\text { died } 20 \text { May } 1648)^{437}\end{array}$ \\
\hline $\begin{array}{l}\text { Death of } \\
\text { the Queen }\end{array}$ & no fee mentioned & $\begin{array}{l}\text { Christoph Sievert was paid } 20 \text { florins on } 11 \text { October } 1727 \\
\text { for programming funeral songs after the death of } \\
\text { Christiane Eberhardine, wife of Augustus II. }{ }^{438}\end{array}$ \\
\hline
\end{tabular}

Until the end of the eighteenth century, there was also a fixed fee for signalling war triumphs: in the seventeenth century, it amounted to 9 thalers, followed by 6 florins in the next century. This was the amount paid for example in August 1651 for announcing the victory of Kossacks and Tatars; ${ }^{439}$ in May 1660 for setting a thanksgiving song after the signing in Oliva of a "perpetual peace"; 440 in December 1660 again for a "Dank Lieder" after a victory "über die Moscowiter;" in August 1663 for announcing the stopping of a Kossack aggression; ${ }^{442}$ in 1710

\footnotetext{
434 APG 300,R/Pp,q9, pp. 277-80.

435 APG 300,12/64, p. 206.

436 APG 300,12/64, p. 207.

437 APG 300,12/84, p. 185.

438 APG 300,12/141, p. 111.

439 APG 300,12/87, p. 182.

440 APG 300,12/97, p. 36.

441 APG $300,12 / 97$, p. 37.

442 APG 300,12/100, p. 36.
} 


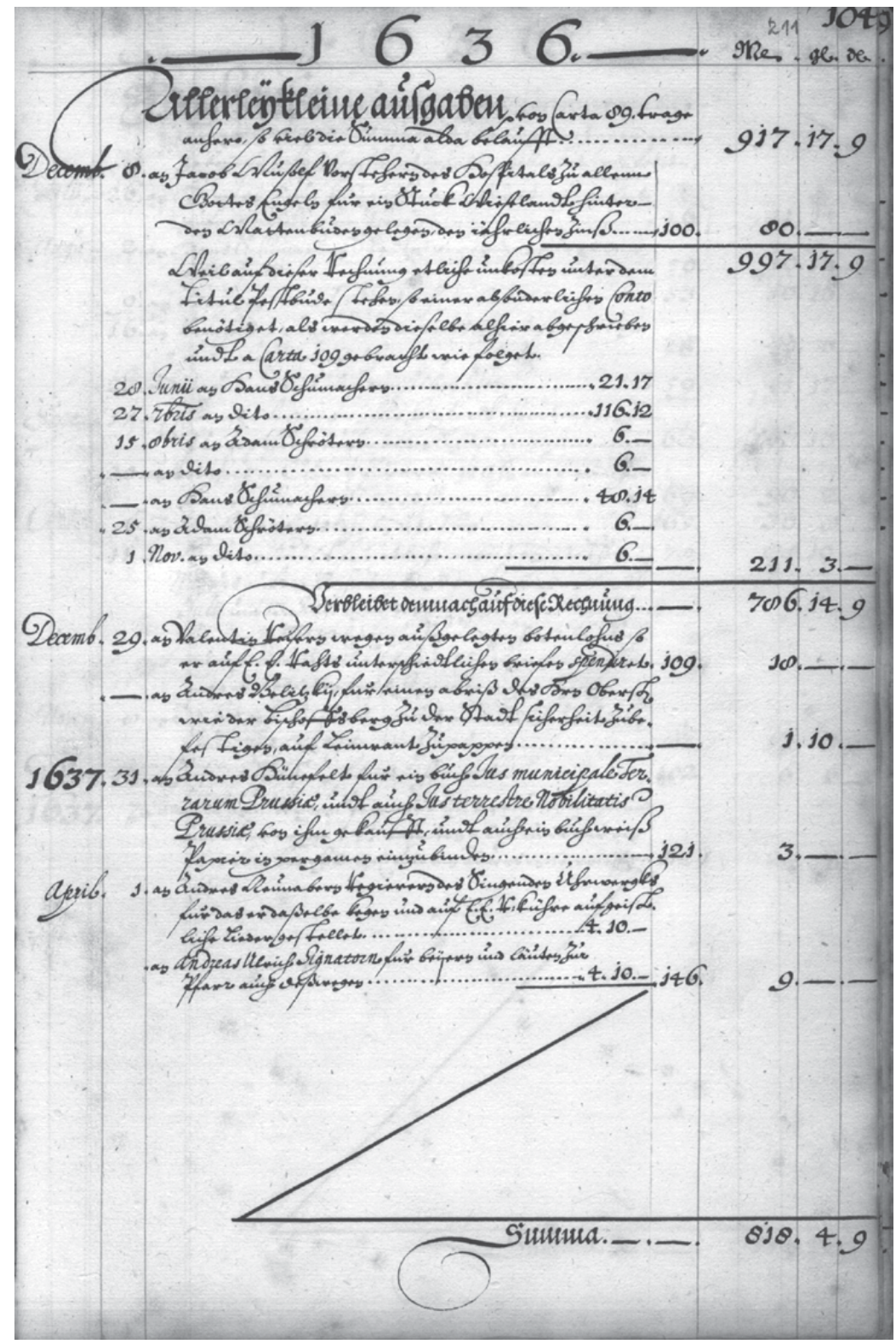

Fig. 26: Salary for A. Neunaber for occasional programming of the carillon. APG $300,12 / 69$, p. 211 


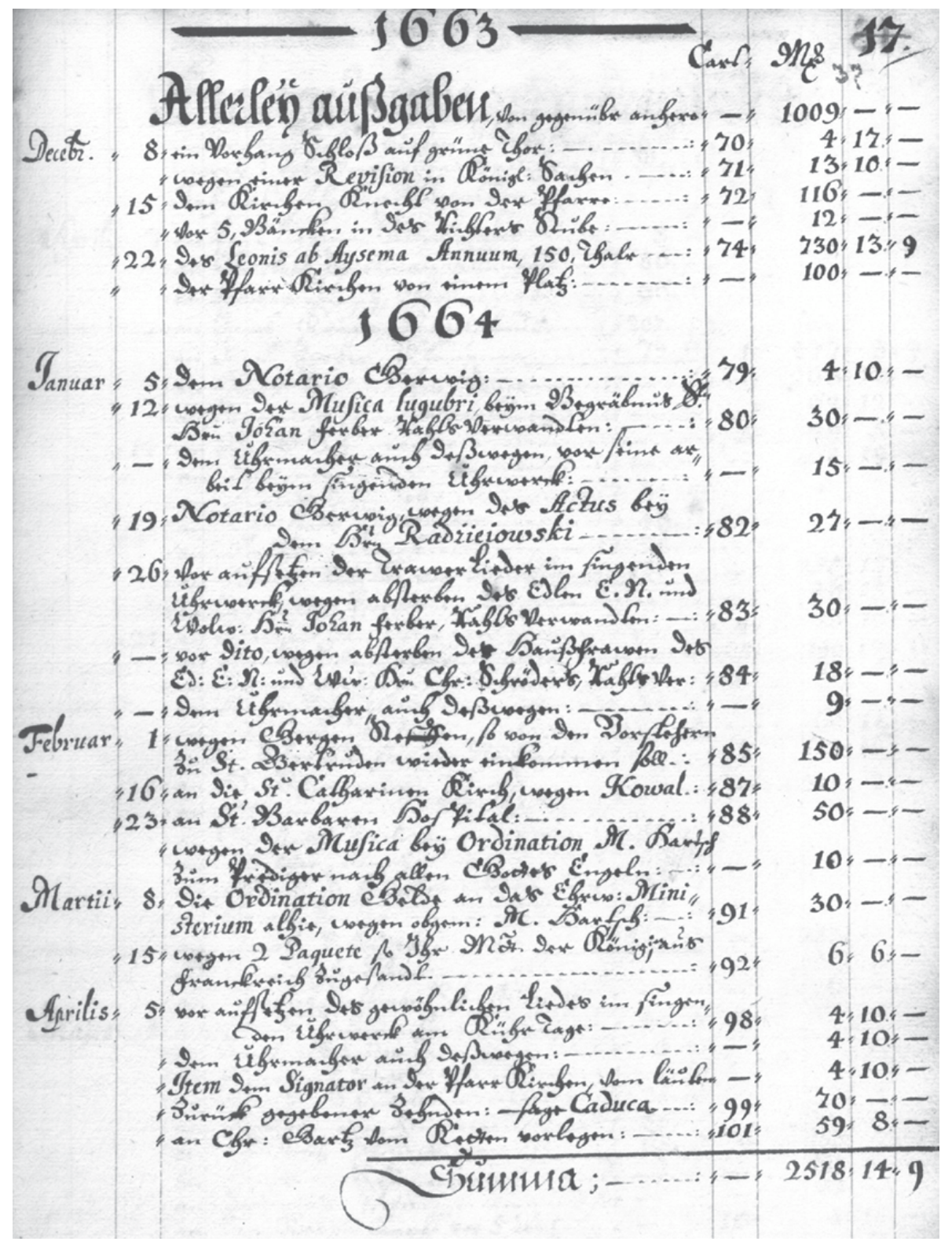

Fig. 27: Salary for J. Neunachber for occasional programming of the carillon. APG $300,12 / 100$, p. 37 


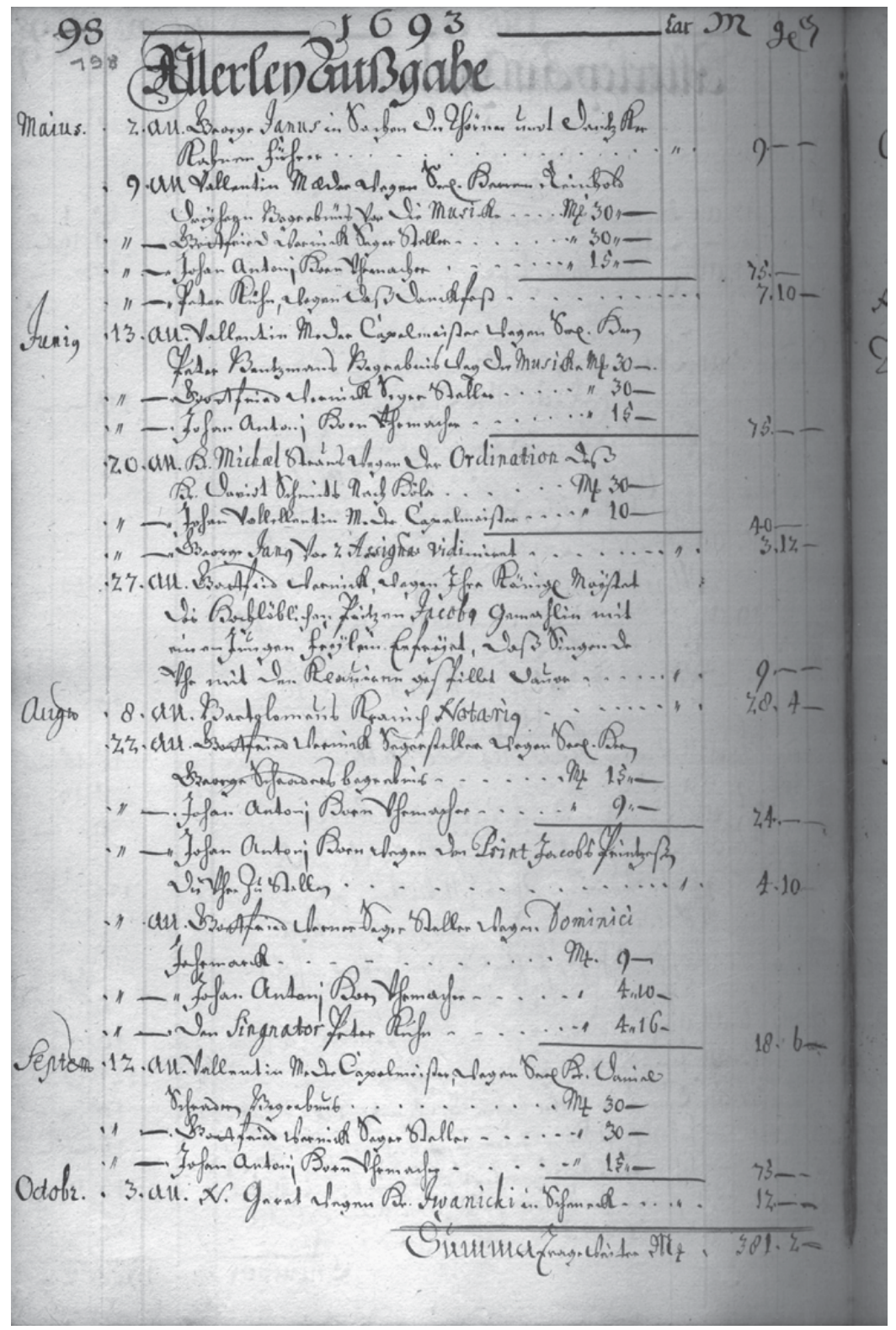

Fig. 28: Salary for G. Wernick for occasional programming of the carillon. APG $300,12 / 121$, p. 198 
for programming a Te Deum laudamus after victories in the Great Northern War, the falls of Riga ${ }^{433}$ and Tallinn; ${ }^{444}$ and in March 1727 for notifying of Augustus II's happy return from Grodno to Warsaw. ${ }^{45}$

Setters could hope for extra income during visits to Gdańsk by the King and his court. After a brief sojourn by Ladislaus IV in the spring of 1634, Hans Neunaber was paid a modest 4 thalers and 10 groschen on 31 March. ${ }^{446}$ But his son Andreas Neunaber, who had to reset the carillon several times after Ladislaus' visit two years later, earned no less than 45 thalers on 18 March $1636 .{ }^{447}$ Setters were also paid for programming tunes on the occasion of royal weddings (as shown, for example, on 15 March 1670 when Jacob Neunachber was paid 13 thalers and 10 groschen for announcing the wedding of Eleonora Maria of Austria and Michał Korybut Wiśniowiecki ${ }^{448}$ ) or other previously discussed events in the royal family.

The most significant additions to the bell setters' salaries were payments for announcing the death of members of the City Council as well as wives of mayors and councillors and accompanying their funerals. The earliest note I found in cashbooks is dated 13 May 1631: Hans Neunaber and chapel master Kaspar Förster Sr were paid 15 florins each (for a total of 45 thalers). Justifying that expense, the scribe recalled a relevant decision of the Council of 28 January 1619. It can, therefore, be assumed that the practice of using the "singing mechanism" for announcing the death of City Council members and their funerals predates that decision:

Verehruung/dem Capellmeister Casparo Forstern und Hans Newnabern der das singende Glockenwerk stellet, verehret iedem fl 15,- poln., weil bey der Leichbegangnüs seligen Herrn Arnholdi von Holten, vor und nach der Predigt aufm Chorr figural gesungen, undt der Glockensteller auch das singende Werck, da die Leiche von Hause bis in die Kirche getragen, gespielet, wie auch alle stunden fast 3 tage vorher mit trawer liedern sich hat hören laßen, usw. Weil E[ines] E[dlen] Rath solches geschloßen Anno 1619. am 28. Januarii. T[itulierten] Michaële Borck Secr[etär]. welchs auch hinfuro bey allen Leichbegängnüßen der Hrn Burgermeisterr und andern allen des Rahts dero gestalt observiret, und sollen der Capelmeister sambt dem Uhrsteller verehret warden. ${ }^{449}$

For the following decades up to the incorporation of Gdańsk into Prussia, the city's cashbooks contain a considerable number of notes documenting

443 APG 300,12/129, p. 181.

444 APG 300,12/129, p. 181.

445 APG 300,12/140, p. 112.

446 APG 300,12/67, p. 235.

447 APG 300,12/67, p. 252.

448 APG 200,12/109, p. 144.

449 APG 300,12/61, p. 279. 
payments for subsequent bell setters and clockmakers for announcing the death of City Council members and members of their families (mostly mayors, councillors and their wives) and their funerals, as well as for chapel masters for performing funeral music (but only after the deaths of mayors and councillors).

Initially, the bell setter and chapel master were paid 221/2 thalers (15 florins) for a mayor or councillor funeral, but from the late 1630s, the fee rose to 30 thalers (20 florins) and remained stable through the following century. Initially, the bell setter likely shared his fee with the clockmaker, but from the 1660s the latter was paid half the fee of a bell setter's (whose fee remained unchanged).

Setters and clockmakers, as opposed to chapel masters, were also paid for announcing the deaths of mayors' and councillors' wives and their funerals. The fee for these celebrations, however, was lower than for mayors and councillors themselves: initially, a bell setter was paid 18 thalers and a clockmaker, 9. At the end of the seventeenth century and throughout the eighteenth, the setter's fee was lowered to 15 thalers (10 florins). That was also the fee quoted by Theodor Friedrich Gülich who noted that a similar fee was paid after the death of a juror and for his funeral. ${ }^{450}$

Announcements of the death and funeral of prominent citizens together with other occasional payments significantly increased the bell setters' budget. The joint amount of extra payments could sometimes equal a quarterly salary. Between 8 May and 31 July 1660, Andreas Neunaber earned no less than 69 thalers: twice 30 thalers for programming tunes after the deaths of City Council members and 9 thalers for announcing the Treaty of Oliva. ${ }^{451}$

Nonetheless, the financial condition of bell setters remained difficult, though it varied in different periods. Jacobus Tetius' request in 1600 for a weekly allowance from the city stables (Stadthof) of fodder for his little horse sounds dramatic. Tetius had received the horse from a citizen whose son he taught, but could not afford to buy fodder for it because of high prices. He needed the horse, however, because he was elderly and ill of red skin, stones, and gout, making it difficult to walk on the city's cobblestones and thus performing his duty ("mein Ampt vnd Dienst zu Thurme auffm Rahthause"). ${ }^{452}$ Tetius' only gain was a one-off payment

450 APG 300,R/Pp,q9, p. 284.

451 APG 300,12/97, p. 36.

452 APG 300,R/Vv,217, pp. 21-23. 
for his horse's fodder. ${ }^{453}$ Reapplying for the post of setter in 1612, Hans Neunaber wrote he needed work to sustain his numerous offspring. ${ }^{454}$

Some setters looked for other sources of income. Some took up jobs unrelated to music. Michael Colrep had three positions: organist at the church of St Catherine, bell setter, and city notary. It is worth noting the City Council valued Colrep higher as a musician than a notary: his bell setter salary was 23 thalers and $2^{1 / 2}$ groschen, while his notary one was only 20 thalers. ${ }^{455}$ Setters also served as cellar masters at the Artus Court. It was the case of Hans Neunaber, though that job did not improve his financial standing, since he complained to the City Council in 1629 that he received no remuneration after three years of work, and asked for mediation at the Artus Court. ${ }^{456}$ Also Bartel Biehn applied to become cellar master, asking the City Council for the post vacated by the late Carl Lindus; he emphasised that occupation would not interfere with his duties at the tower. ${ }^{457}$

Due to a lack of sufficiently detailed sources, it is only partly possible to define and compare salaries for regular duties of bell setters. The archives I examined indicate nonetheless that rules of payment essentially remained unchanged until the end of the eighteenth century. Bell setters received quarterly salaries that gradually increased over time, as well as occasional extra fees that were reasonably stable. They also received small amounts of money for the purchase of candles, while it is unlikely they benefitted in the seventeenth and eighteenth century from free board as enjoyed by the first bell setter in Gdańsk, Franciscus de Rivulo and (for some time) his successor Philipp Schönberg. Sadly, there is no conclusive data about the salaries of Town Hall bell setters in the nineteenth and twentieth century, as we only have two receipts signed in 1807 by Johann Gottlieb Borowski.

The question remains open whether setters were obliged to present a yearly plan of tunes for the forthcoming year to the City Council. We do not know whether they made their own transcriptions of songs or used their predecessor's notes. The only trace of payment for editing a collection of songs for programming on the carillon drum is a note relative to the four-volume tablature by Theodor Friedrich Gülich, indicating that on 1 April 1769 he was paid 2214 florins for that work. . $^{458}$

453 APG 300,R/Vv,217, p. 24.

454 APG 300,R/Vv,217, pp. 37-38.

455 APG 300,12/12, pp. 159-62.

456 APG 300,12/12, pp. 55-57.

457 APG 300,R/Vv,217, pp. 33-34.

458 APG 300,12/181, p. 118. 


\section{The carillons of the church of St Catherine, 1573?-1942}

\section{Unclear beginnings and granted wishes}

The history of the first carillon of the church of St Catherine goes back to the 1570s, but its origins remain unclear. An anonymous chronicle, reprinted in 1594 by Jacob Rhode, stated that a "striking mechanism" ("das schlagende Werck") was installed in the church's tower. Work on that mechanism was started on the day of St Martin in 1574 and finished on Easter 1575. 459 The same information is then repeated by Reinhold Curicke, although the latter moved the beginning a year prior:

das schlagende Werck aufm Kirch Thurm Anno 1573. auf Martini zu machen angefangen und Anno 1575. auf Ostern gäntzlich verfertiget worden. ${ }^{460}$

We assumed that the "striking mechanism" was an automated carillon with a limited number of bells, used not so much for playing melodies and more for announcing, in coordination with the clock, the passing of time. Sadly, we have no detailed information about it.

We can address that "striking mechanism," just as the reasons of installing an automated carillon on the Main Town Hall, in no more than probably terms, based on the mentality of the city authorities. To understand the motives of constructing a carillon for the Old Town church tower, we need to recall the administrative divisions of the city in the second half of the fifteenth century, going back to the return of Gdańsk to Poland after a period of Teutonic rule.

The privileges issued by King Casimir IV Jagiellon (the Elbląg privilege of 16 June 1454 and especially the Gdańsk greater privilege of 15 May 1457) modified the existing territorial divisions within the city, revoking their autonomy. The major administrative unit became the Right Town (Rechtstadt), today known as the Main Town. Other city units, hitherto autonomous, became subjugated to the Right Town. A degree of autonomy was only left to the Old Town. ${ }^{461}$ A token of autonomy was the existence of the Old Town Council, which performed administrative, treasury, chancellery, and judicial functions within its area. Yet

459 Rhode, Chronica oder Handbüchlein Danziger Geschichte, 32.

460 Curicke, Der Stadt Danzig, 326.

461 Samsonowicz, 'Gdańsk w okresie wojny trzynastoletniej', 73-76. 
the Main Town (Right Town) Council became now considered as that of the city itself. In the years 1458-1792, it included four mayors and fourteen councillors, as well as five members of the Old Town Council, though they possessed a single vote only. ${ }^{462}$

The Old Town councillors, despite their limited power, had their own seat. Their town hall was located in the centre of the Old Town, next to the Great Mill and close to the parish church of St Catherine, Gdańsk's oldest church. The idea of installing a carillon in that church occurred to Old Town councillors probably from the wish to imitate their Main Town colleagues. But for technical reasons, the Old Town Hall was not suitable for a "striking mechanism." For this reason, the carillon was installed in the tower of St Catherine's. ${ }^{463}$

In 1643, the church tower was renovated and received an early Baroque dome. It was then that a new "striking mechanism" was installed, too, as noted by Reinhold Curicke:

Nachmals vor wenig Jahren als nemlich Anno 1634 hatt man den alten Thurm abgenommen und einen zierlicheren mit Kupfer gedecket nebst einem neuen schlagendem Werck dahin gesetzet. ${ }^{464}$

We do not know how long that second "striking mechanism" remained in use, but it appears to be unsatisfactory, as in 1712, the idea was put forward of building a new carillon. The initiative came from the administrator of the church of St Catherine (Vorsteher der Katharinengemeinde) but many years passed before the project came to fruition. ${ }^{465}$

According to a document now lost, quoted by Bruno Meyer, the church administrators wanted "zu mehrer bequemer Einrichtung der Stunden ein gewisses Klockenspiel auf dem Turm daselbst einzurichten.”466 They

462 Węsierska-Biernatowa, Czaplicka, and Sławoszewska, Archiwum miasta Gdańska, 11; Zdrenka, 'Rada Miejska', 858-59.

463 Jadwiga Habela quotes an unconfirmed notice of the existence of a carillon in the small tower of the Old Town hall that would have been moved to St Catherine's due to the construction of a new town hall; see 'Ratusz Staromiejski w Gdańsku', 136.

464 Curicke, Der Stadt Danzig, 326.

465 The history of the third carillon of St Catherine's is well researched. It was first described by Wutstrack, see APG 300,R/LI,96, p. 145; see also Löschin, Geschichte Danzigs, 179; Löschin, Danzig und seine Umgebungen, 88-90; Döring, 'Glockenspiel', 98-99; Blech, 'Das alte und das erneute Glockenspiel', 16; Meyer, 'Die Glockenspiele auf St. Katharinen in Danzig', 4-5; Januszajtis, Gdańskie zegary, dzwony i karyliony, 131-33; Kaczor, 'Wstęp', 19-21; Popinigis, 'Gdańska afera carillonowa'.

466 Meyer, 'Die Glockenspiele auf St. Katharinen in Danzig', 4. 


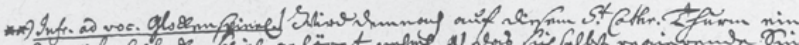

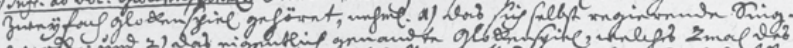

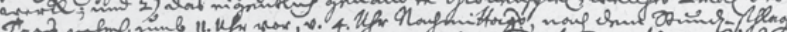

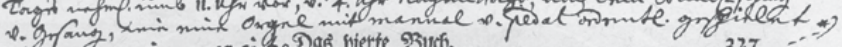

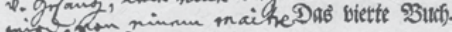
ons Anteriam,

inf fis ex-

TOANNES

Pre FRE WDENBER GIVS

1200. * Anno Chrifti M. D. XC.

Apre. pensip̀ Breffa in Silefia honeftè natus

Amorgat. Ibidemque

Qua prima literarum Rudimenta Fideliter formatus.

$327=-20$ foling enoft uberioris eruditionis caufa. folif. inf im In Academiis Nobilifimis Argentoratenfi, Parifienfi, Senenfi. Avera. Deggi Laudabiliter commoratus. timnabul.p Germanie, Gallie, Italia. m. 94.

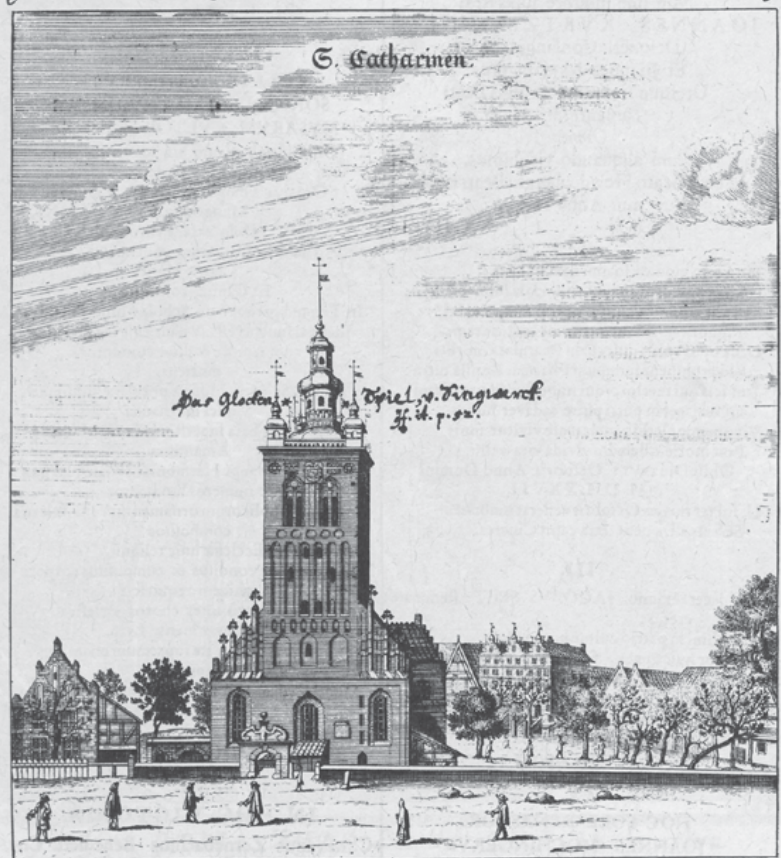

Cultifimas partes.

Prudenter contemplatus. Omnibus honeftis literatis \& Muficis

Ubique valde charus habitus Ut nemini innotuerit.
Ipfe honeftate literis ac mufices fcientia. Longe ornatiffimus. Anno Chrifti crs roxxv. die xxy. Novembr. Etatis fur XLVr.

Gedani pie \& placide denatus.

Hic in fpem Refurrectionis conditus eft.

-7) Quin \& ftatim \& conftanter amaretur. Hicin pem Refurrectionis conditus eft.

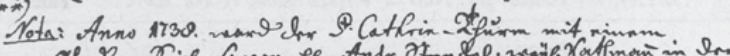

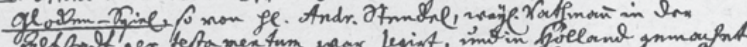

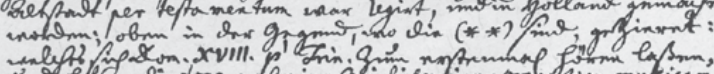

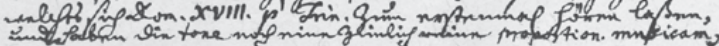

Fig. 29: Church of St Catherine. Curicke, Der Stadt Danzig, 327 


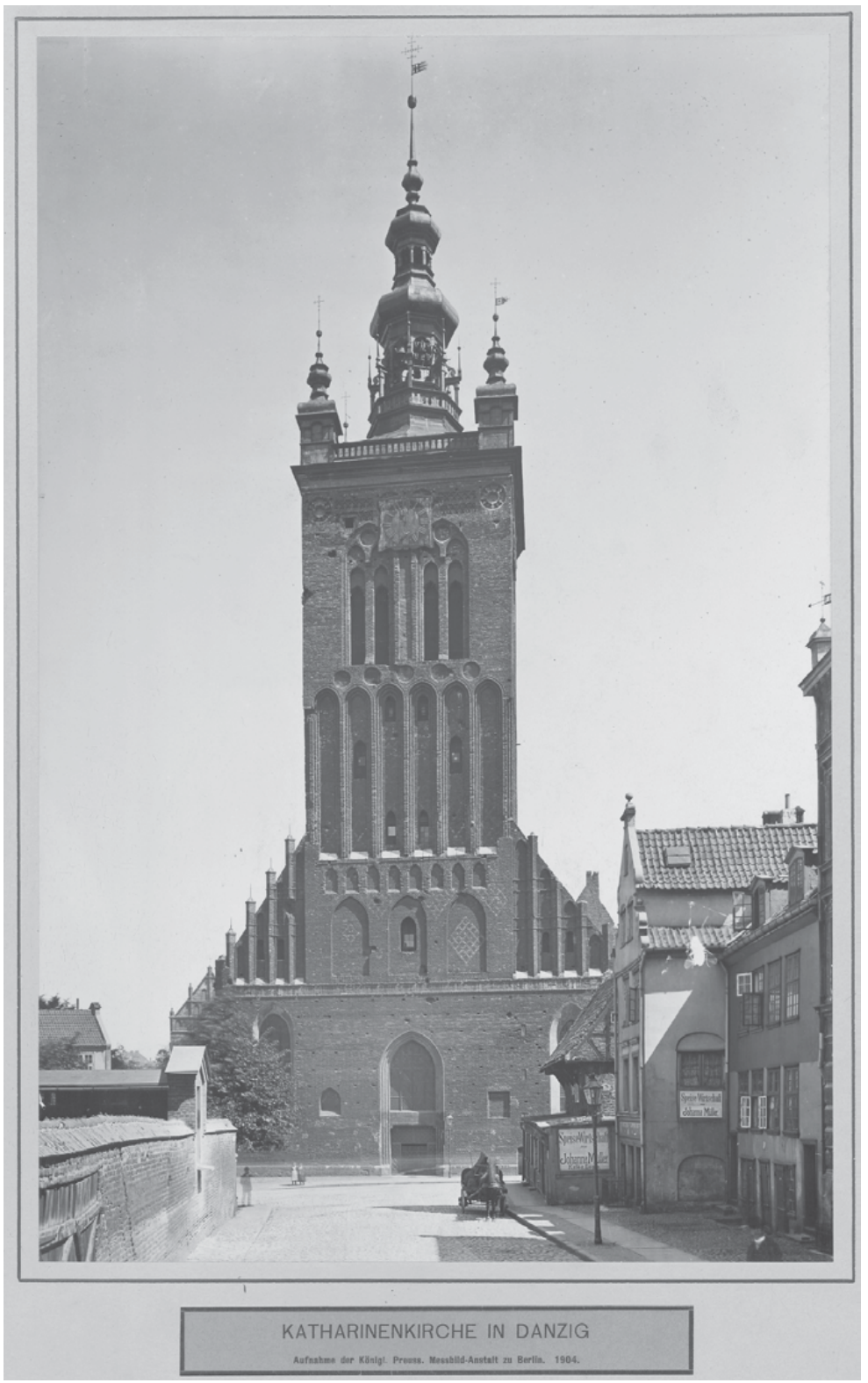

Fig. 30: Church of St Catherine. PAN BG Al./IV/3/6 
approached the Old Town Council asking for permission and funding. Permission was granted, but a financial contribution was tied to the Council raising around 9-10,000 florins on its own. This attempt failed and the project was delayed by over a decade. Yet the idea of installing a carillon was so deeply ingrained with Old Town residents that it was finally realised. A new impulse was given by Councillor Andreas Stendel, who in his will of 12 April 1728 bequeathed a part of his estate for the cause: a whopping 18,000 florins. The donation came under two conditions: the money would be made available only after the death of his widow or if she remarried. Seven months after writing his will, Andreas Stendel died on 13 November $1728,{ }^{467}$ and a few years later, on 19 November 1736, his widow Dorothea Constantia, née Fischer, married Johann Ernst Ferber (1692-1757). ${ }^{468}$ Accordingly to Andres Stendel's will, his money was transferred to the Old Town treasury, enabling work on the carillon to start as early as November $1736 .{ }^{469}$

Old Town councillors and administrators of the church of St Catherine expected the money they had been bequeathed to be insufficient for the construction of the carillon. Hence, they came up with the idea of two lotteries ${ }^{470}$ the income from which would add to the carillon's budget. Organised in 1739, the lottery brought a vast profit. After deducting the costs of organisation, the carillon budget was increased by no less than 12,000 florins, two-thirds of Andreas Stendel's bequeath. The total sum of 30,000 florins proved sufficient for the construction of the carillon. Dariusz Kaczor has computed that the total investment, which was concluded in 1754, reached 29,658 florins and 23 groschen. The money was spent primarily on casting the bells, sea transport, installation on the church's tower, manufacture of the keyboard and mechanism for automated play, the remuneration of the first carillonist and steward of the tower clock, as well as necessary supplementary work. ${ }^{471}$

467 Zdrenka, Rats- und Gerichtspatriziat der Rechten Stadt Danzig, 2:189.

468 Zdrenka, 2:189.

469 Meyer, 'Die Glockenspiele auf St. Katharinen in Danzig', 5.

470 Lotteries were organised in Gdańsk from the second half of the sixteenth century. Maria Bogucka mentions an event from 1577 when "an enterprising art dealer from Lüneburg offered to residents of Gdańsk to draw prizes such as a painting or engraving." See Bogucka, 'Kultura materialna i obyczajowość, 672.

471 Kaczor, 'Wstęp', 19. 
The construction of the carillon was overseen on behalf of the Old Town Council by councillor Johann Gottlieb Becker. ${ }^{472}$ Although he negotiated the commission, he did not commission them personally, relying instead on Amsterdam merchant and shipowner Christian Sprengel, ${ }^{473}$ who hired metal merchant Johannes Smit. ${ }^{47}$ The latter approached Jan Nicolaas Derck (1688-1764), a bell founder from Hoorn, and commissioned him with the Gdańsk assignment. Smit had formerly cooperated with Derck, supplying him with material to cast the bells for Copenhagen's Royal Residence. ${ }^{475} \mathrm{He}$ again was due to contribute to the commission by providing the bell founder with enough supplies. ${ }^{476}$

The contract for the Gdańsk bells, composed of eight points, was signed in Amsterdam on 11 April 1737. ${ }^{477}$ The contract's parties included merchant Johannes Smit and bell founder Jan Nicolaas Derck. Derck agreed to cast forty bells tuned from $\mathrm{C} 4$ to F7. The weight of the smallest bell was fixed at the six pounds, and that of the largest at sixteen hundred pounds, with the total weight of all bells at approximately eight thousand pounds. The contract noted that the bells' clappers should weigh between four and five hundred pounds in total. ${ }^{478}$ The bells were due to be delivered within ten months. The contract's second, third, and fourth point discuss the bells' properties. Jan Nicolaas Derck declared to cast them in tune. They were supposed to sound loud, clear, and in tune. Should the tone of one bell prove inadequate, Derck agreed to cast it again. Such provisions were standard in contracts for carillon bells, as it was a great art to cast them in tune. This was universally acknowledged and so earlier contracts included a point about recasting a bell if it sounded out of tune and had other defects. ${ }^{479}$ In point six of our contract, the parties agreed to select

472 Johann Gottlieb Becker (1684-1747) sat on the Old Town Council from 1715, and was its chairman in 1733, 1737, 1741, and 1746. See Zdrenka, Rats- und Gerichtspatriziat der Rechten Stadt Danzig, 2:196-212, 287, 461. The Old Town Council was composed of five councillors, a judge, and twelve jurors. The chairman was elected from among the councillors.

473 The names of Johann Gottlieb Becker and Christian Sprengel are listed by Bruno Meyer based on documents now lost ('Die Glockenspiele auf St. Katharinen in Danzig', 5) but are also quoted in the Juriaan Spruijt manuscript; see Spruijt, Beschrijving van Klokken, 77.

474 Spruijt, Beschrijving van Klokken, 76-77, commentary by André Lehr, 80.

475 Commentary by André Lehr in Spruijt, 74.

476 Commentary by André Lehr in Spruijt, 80.

477 GA Amsterdam, Notariële Archieven, no. 9939, akte nr. 139 [pp. 1-8].

478 Lehr comments it was "unusually much." See Spruijt, Beschrijving van Klokken, 80.

479 Adriaenssen, 'De Bossche klokengietersfamilie Moer', 49. 


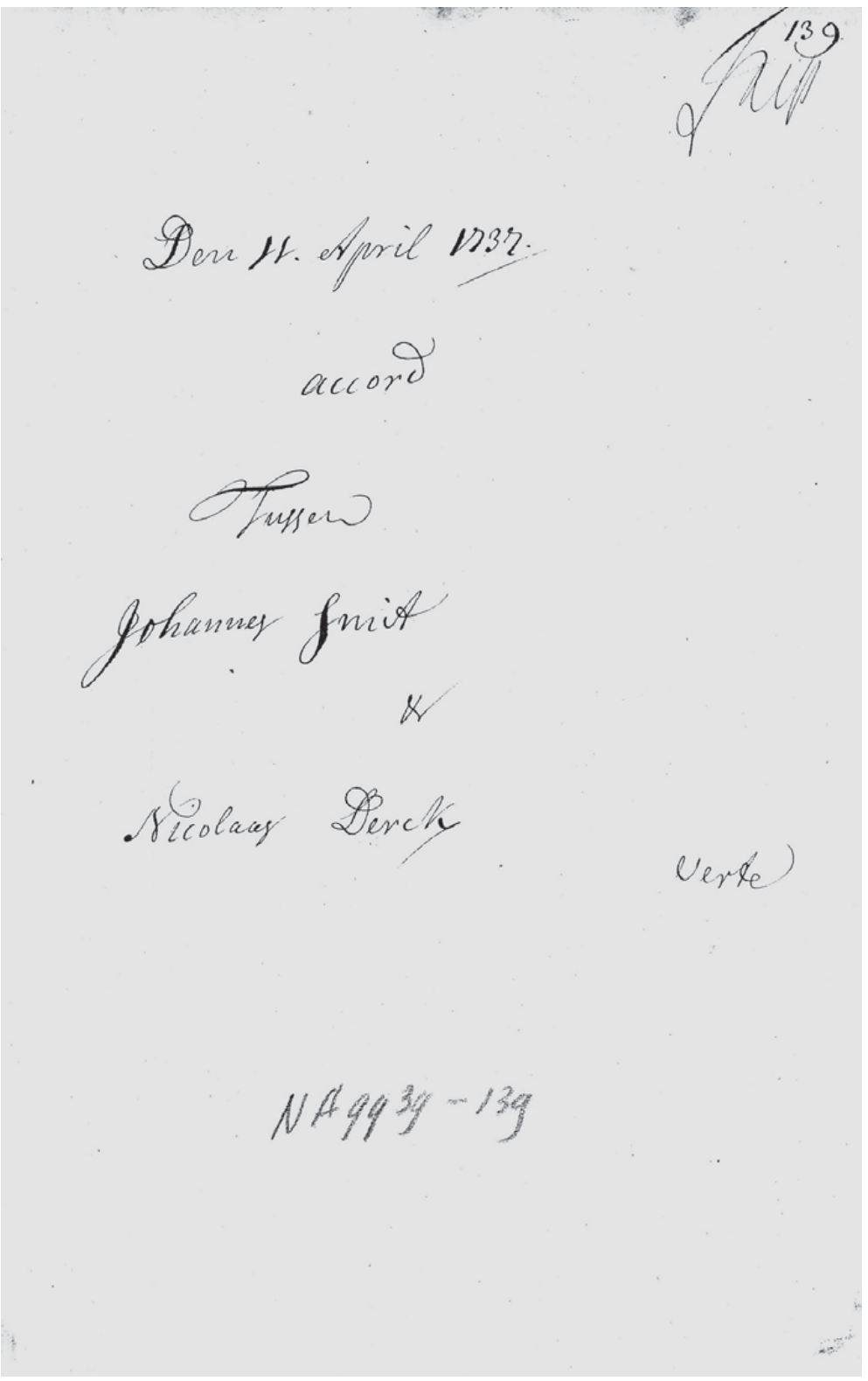

Fig. 31: Contract for the bells of J. N. Derck, GA Amsterdam, Notariële Archieven, no. 9939 , akte nr. 139, [p. 1] 


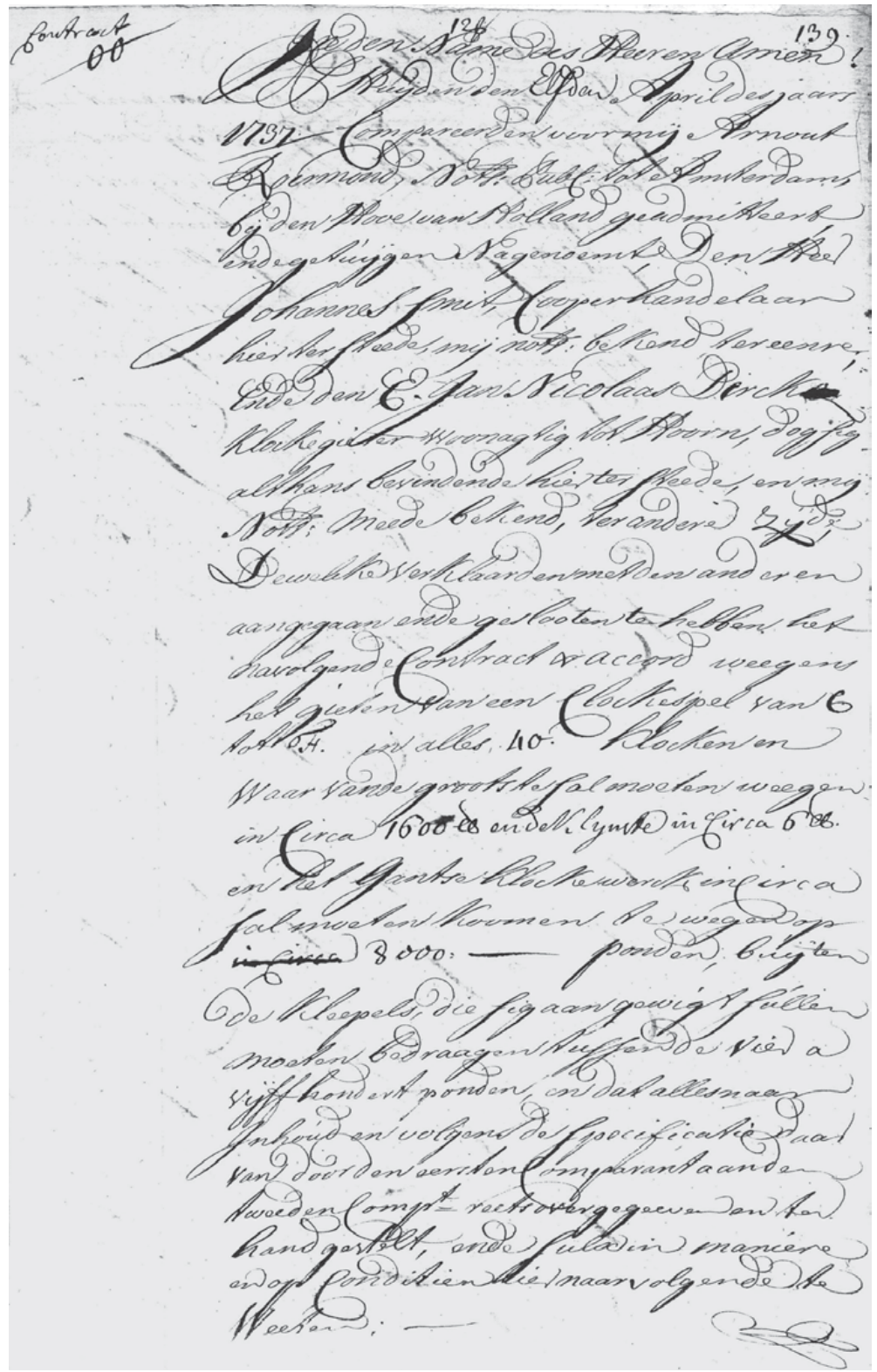

Fig. 32: Contract for the bells of J. N. Derck, GA Amsterdam, Notariële Archieven, no. 9939 , akte nr. 139, [p. 2] 
two experts to assess the bells and the cost of certification would be borne by Derck. Transport, on the other hand, was Johannes Smit's responsibility, though the parties agreed to share the transport cost. Finally, the bell founder's remuneration was decided: Johannes Smit would pay Derck six groschen per pound of bell weight and the same amount per pound of clapper weight. In point eight, an inscription on the bells was agreed to include the names of bell founder cast Jan Nicolaas Derck and Johannes Smit, alongside the customary "me fecit" mention. ${ }^{480}$ This differed from usual arrangements, where only the bell founder was cited on the bells. We do not know, however, if Derck respected that additional agreement (entered on the margin of the contract's page), as his bells perished in a fire in 1905, and extant writings do not mention the inscription.

As agreed in the contract, Derck's work was assessed by two experts he selected: Juriaan Spruijt, carillonist and organist in Hoorn, and Gerhardus Havingha, organist from Alkmaar. ${ }^{481}$ The review was favourable. The bells, which eventually were thirty-five, and not forty as agreed in the contract, were shipped by sea to Gdańsk; the skipper was one Marten Kohl. ${ }^{482}$ They arrived in the city on 21 May $1738 .{ }^{483}$

Meanwhile, in Gdańsk, a keyboard was commissioned from well-known organ builder Andreas Hildebrandt, ${ }^{484}$ since the carillon of St Catherine's was to serve as a musical instrument and not an automaton, as the carillon of the Main Town Hall. A musician was hired to play it: Eltjen Wolthers, carillonist from Groningen. We do not know when he arrived in Gdańsk but was busy with the instrument as early as September $1738 .{ }^{485}$

Many writings state that music on the new carillon was inaugurated on St Andrew's day, 30 November 1738, in honour of Andreas Stendel, the benefactor whose bequeath permitted the construction of the instrument to be started. It is rarely mentioned, however, that the bells sounded on the eighteenth

480 GA Amsterdam, Notariële Archieven, no. 9939, akte nr. 139, [p. 7].

481 Spruijt, Beschrijving van Klokken, 76-77, commentary by André Lehr, 80.

482 Ibid.

483 Meyer, 'Die Glockenspiele auf St. Katharinen in Danzig', 6.

484 Meyer, 6; Kaczor, 'Wstęp', 20; Janca, 'Hildebrandt, Andreas'.

485 Bruno Meyer indicated that Eltjen Wolthers travelled from Groningen to Amsterdam twice, in April and June 1738, with relation to the Gdańsk bells. See Meyer, 'Die Glockenspiele auf St. Katharinen in Danzig', 6. 
Sunday after Trinity, i.e., as early as September, as stated in a handwritten note in the monograph of Reinhold Curicke:

Nota: Anno 1738. ward der S. Cathrin-Thurm mit einem Glocken-Spiel, so von H[errn] Andr[eas] Stendel, weyl[and] Rathman[n] in der Altstadt per testamentum war legirt, und in Holland gemachet worden; oben in der Gegend, wo die ... sind, gezieret; welches sich Dom[inica] XVIII. p[ost] Trin[itatis] zum erstenmal hören laßen, und haben die tone noch $[\mathrm{k}]$ eine ziemlich reine proportion musicam etc. ${ }^{486}$

This information becomes important when reconstructing the chronology of events in the autumn of 1738. Most likely the September demonstration of the carillon was merely a rehearsal before the official inauguration scheduled for 30 November. But it became evident that the bells cast by Jan Nicolaas Derck were out of tune. Eltjen Wolthers was undoubtedly at the keyboard, as it was him who signalled the disastrous sound of the bells. On 24 September 1738, he wrote an outspoken letter to one of the bells' reviewers, the Alkmaar organist Gerhardus Havingha, ${ }^{487}$ expressed his indignation at the positive assessment of the bells that he deemed far removed from any harmony. He ironised that Havingha was so drunk with wine or received so much gold to cover his ears with it - only thus could he have judged the bells' false tones to be in tune. In any case, Wolthers warned Havingha of the Gdańsk councillors. ${ }^{488}$

When it became evident the Gdańsk carillon was out of tune, the news went big. The second expert, Juriaan Spruijt, became so concerned with his premature favourable opinion that he copied a number of documents related to the Gdańsk carillon and included them in his manuscript titled Beschrijving van Klokken en Klokken-Spelen door Juriaan Spruijt klokkenist en organist Stad Hoorn in WestFriesland, ${ }^{489}$ allowing us to trace the subsequent history of the bells cast by Jan Nicolaas Derck for Gdańsk's St Catherine. The manuscript, which is a professional carillonist's notebook, was likely edited in the years 1755-65. Its entries include information on campanology, carillons (predominantly from the Netherlands), bell casting, weaponry, a list of Dutch bell founders starting from Rudolphus de Montigni, active in 1393, and copies of bell contracts. The name of Jan Nicolaas Derck appears many times in the manuscript, which is understandable given the fact that Derck and Spruijt were active in Hoorn in the same period. Spruijt

486 Curicke, Der Stadt Danzig, 327.

487 Spruijt, Beschrijving van Klokken, 76.

488 Spruijt, 76. A fragment of the letter of Eltjen Wolthers is quoted in a Polish translation by Andrzej Januszajtis, who does not list a source; see; Januszajtis, Gdańskie zegary, dzwony i karyliony, 132.

489 WA Nummer 134E69, see Spruijt, Beschrijving van Klokken. 


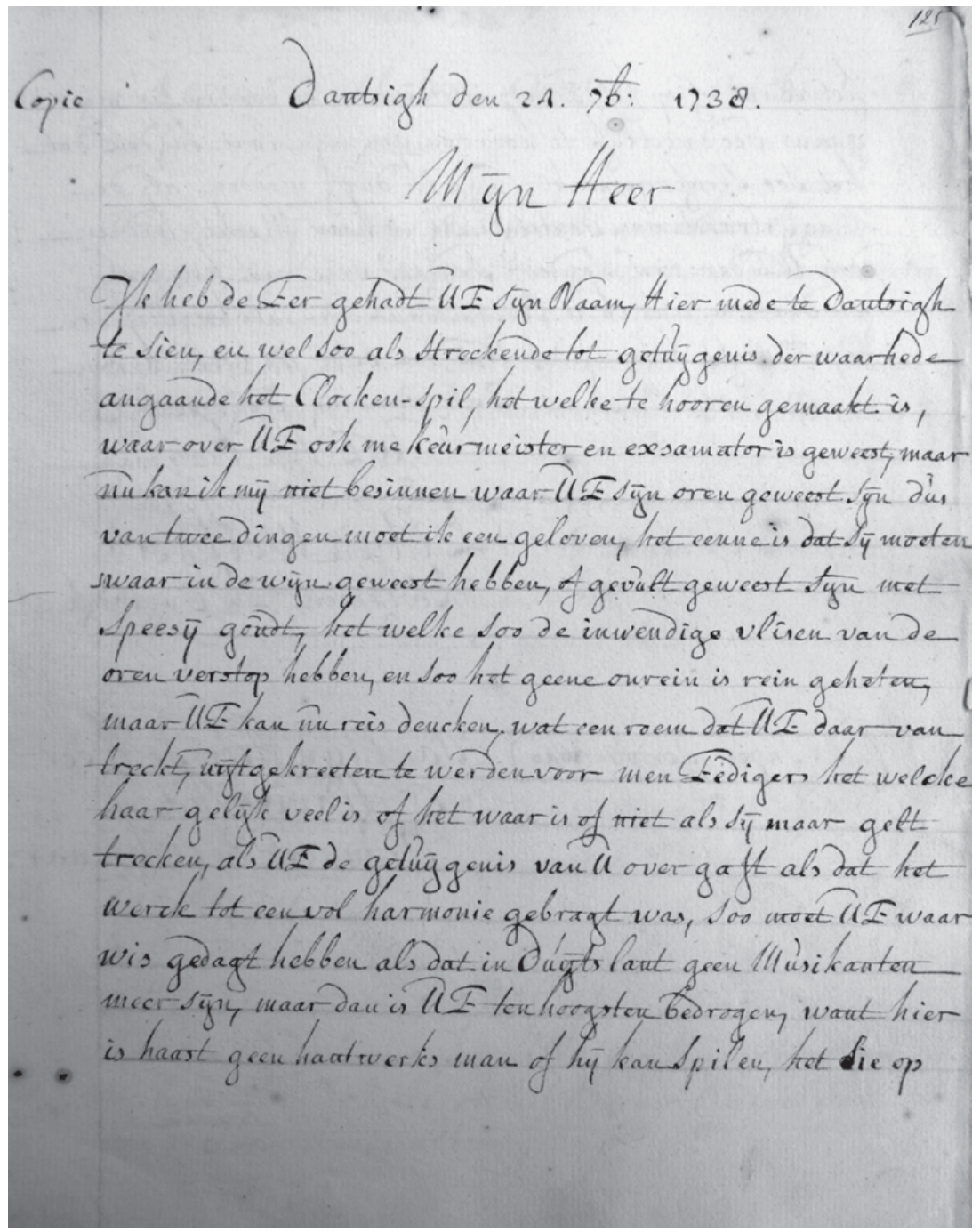

Fig. 33: Letter of E. Wolthers to G. Havingha. Spruijt, Beschrijving van Klokken, 125 


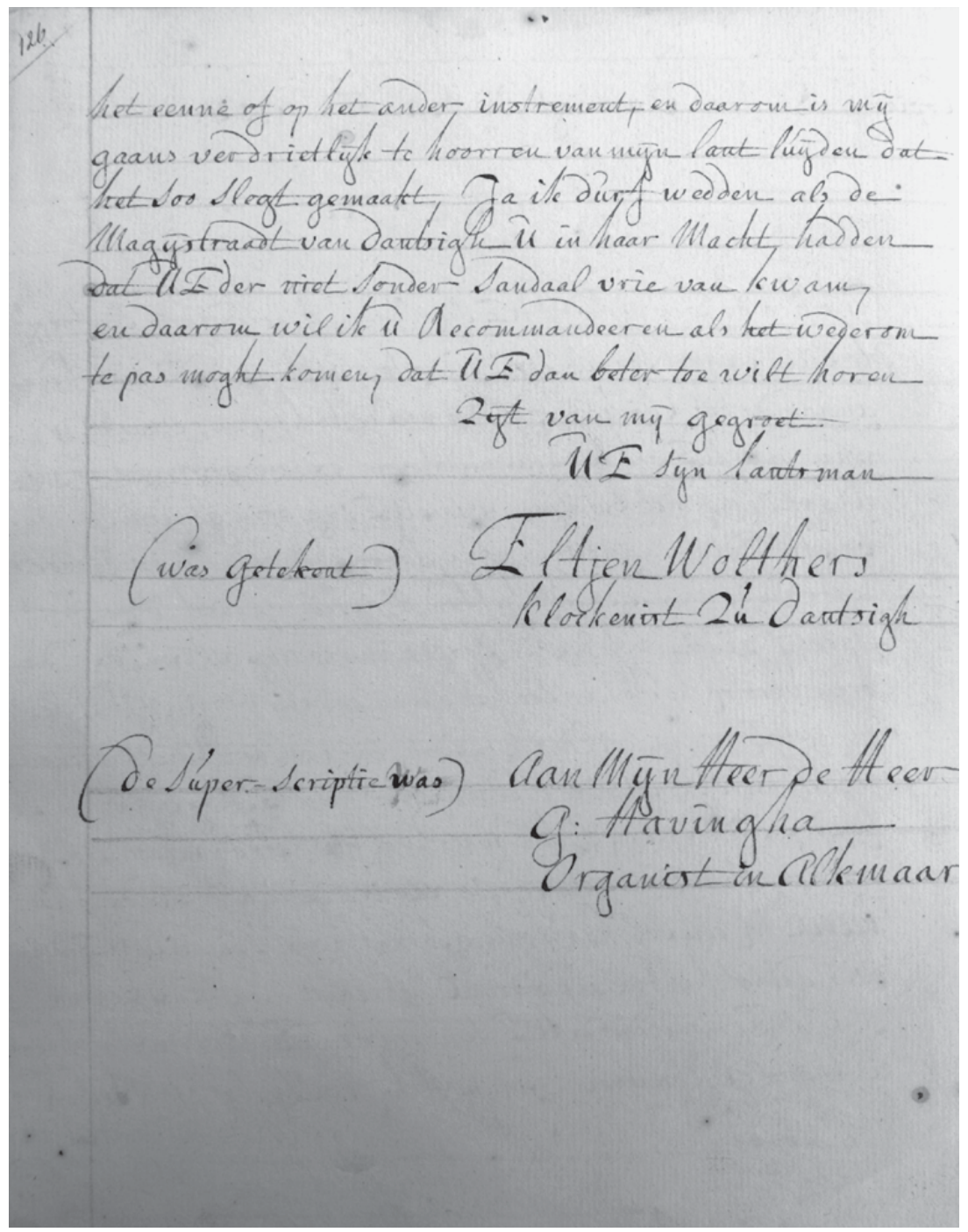

Fig. 34: Letter of E. Wolthers to G. Havingha. Spruijt, Beschrijving van Klokken, 126 
notably quotes technical data about the bells cast by Derck, lists that founder's bells' locations, and gives a copy of the contract for a carillon commissioned with Derck for St Peter and Paul's church in Saint Petersburg. The following fragments from the manuscript are relevant to the Gdańsk bells affair: ${ }^{490}$

1. A note on the weight of bells cast by Derck for Gdańsk in 1737

2. A copy of the letter of Eltjen Wolthers to Gerhardus Havingha, organist from Alkmaar, of 24 September 1738

3. A copy of the assessment of Derck's bells, made by Gdańsk musicians, of 3 October 1738

4. A copy of the letter of Christian Sprengel, intermediary for the bells' commission, to Gerhardus Havingha of 10 December 1738

5. A copy of the notary act with the specification of the Derck bells of 3 October 1738, handed over to notary Raphael Waga and witnesses in Gdańsk

6. A copy of the Hoorn court report confirming the correct execution of the complaint against defective bells of 16 September 1739

After critiques of the carillon's sound, on the motion of Johann Gottlieb Becker, the councillor that oversaw the commission on behalf of the Old Town Council, a commission was summoned to assess the work of Jan Nicolaas Derck. The commission included seven people: Johann Balthasar Christian Freislich (16871764), chapel master and composer, Gdańsk's senior musician; Ephraim Biehn, organist of the parish church of St Mary; ${ }^{491}$ Daniel Magnus Gronau (1700-47), organist of the church of St John and composer; ${ }^{492}$ Christian Petratz, organist of the church of St Catherine; ${ }^{493}$ Johann Carl Braunitz, City Council musician; ${ }^{494}$ Andreas Hildebrandt, organ builder; and Eltjen Wolthers, carillonist of St Catherine's. The commission established that the bells had been cast from poor quality metal, have a false sound and are out of tune. It stated which bells were tuned too high and which too low. Some, including the lowest, were deemed entirely useless. In a documented edited on 3 October 1738, the names of the experts who issued the original assessment are mentioned; both were accused

490 Spruijt, 76-80.

491 Rauschning, Geschichte der Musik und Musikpflege in Danzig, 316, 317, 349, 420.

492 Rauschning, 321, 345, 420, 421, 422; Popinigis et al., Music Collections from Gdańsk $1,158-201,749-50$.

493 There is no notice about him in the literature.

494 Rauschning, Geschichte der Musik und Musikpflege in Danzig, 316, 355, 387. 
of ignorance and recklessness, as well as abjuring their nobility and knowledge through their false statement on the bells' quality. ${ }^{495}$

Despite this damning report by Gdańsk musicians, the decision to file a complaint was not immediate. Before it was made, the carillon was inaugurated on 30 November 1738. Many burghers were dissatisfied with the sound of the bells. Bruno Meyer quotes the opinion of Salomon Jantzen (Janzen), ${ }^{496}$ the city clerk who surveyed the expenditure related to the carillon's manufacture. According to Jantzen, some Gdańsk burghers likened the sound of the carillon bells to cowbells:

... da einige wenige zwar dasselbe lobten, andere aber verachteten und seinen Schall teils einem Kühehorn (Küheflöte), teils anderen lächerlichen Dingen verglichen. ${ }^{497}$

Christian Sprengel, the intermediary who acted in Amsterdam on behalf of councillor Johann Gottlieb Becker, must have been notified about the issue, as he wrote on 10 December 1738 to Gerhardus Havingha. He referred the events to him and expressed surprise at the positive assessment issued by Havingha. $\mathrm{He}$ wondered how two leading music experts failed to notice the defects in the bells' tuning and attached the declaration of Gdańsk experts. ${ }^{498}$

Meanwhile, the decision was taken in Gdańsk to file a complaint. Eighteen bells were sent back to the Netherlands. The transport and complaints were overseen from Hoorn by Eltjen Wolthers. According to the contract, Jan Nicolaas Derck had to retune the defective bells or cast them anew. ${ }^{499}$

Derck met his obligations, and a confirmation of the work he did appears in a document signed on 16 September 1739. It is a sort of final protocol, edited in the Hoorn city court. The document states that Jan Nicolaas Derck cast thirteen bells anew and lowered the tuning of five other ones. Wolthers, who was present in court, expressed satisfaction at the work done by Derck. On the request of the bell founder, the document was also signed by two witnesses (Mighiel de Wit and Hendrik Leseman), the notary Jacob van Beek, as well as Eltjen Wolthers. ${ }^{500}$

495 Also Andrzej Januszajtis knew this document; see Januszajtis, Gdańskie zegary, dzwony i karyliony, 132.

496 Salomon Jantzen (1723-1780) was a town secretary in 1755 and a town clerk in 1774; Bertling, Katalog der Danziger Stadtbibliothek, 1:654.

497 Meyer, 'Die Glockenspiele auf St. Katharinen in Danzig', 6.

498 Spruijt, Beschrijving van Klokken, 78.

499 Spruijt, 79.

500 Spruijt, 79. 
Copia

Ljacn 16: Septenbar 123g. Comparcardevor thy Gaceb van Becle Openbaar Notaris, 6y Jonttore van Hollawt Geaduittert, binuende. Fart Hoom Acriderende,

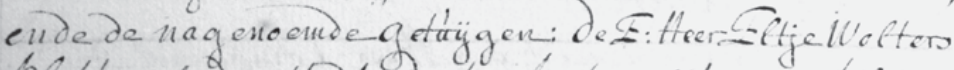

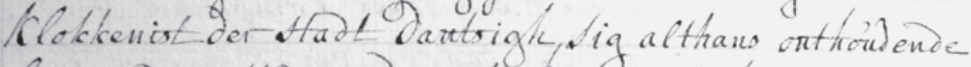
bimnendere. tadt: Dewelketer verscelee vau

Jan Aicolain. Derle, III: Tolokleegieter alhier, Verklaarden hoe waar an Warragtigh ig, dat de Horg -0: Agtt: Naart der. Hadt Dartsigh hem fter Comparant. heeft afgesonden na de. Hadt Acorn mat agtien/slocken

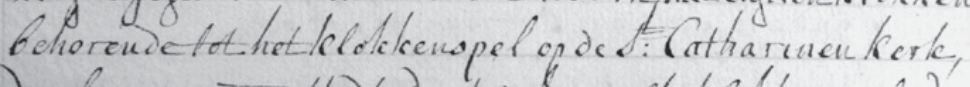
Der boven geme that dantsighy welk klokkeuspel door

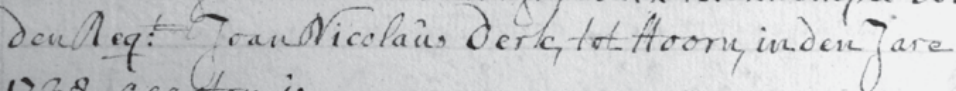
1).8. gegoten is.

dat de epgem: Hoog Ec: Agtb: had Dt dermargem: Hadt

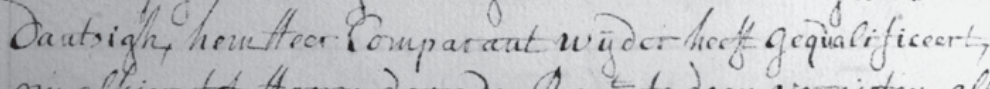
onalfier tet Hoorn doorden Aeq te docu vergieteryalk de kfoklen welke te laag in. Foon warem endickeken welkete hoog infoon warcu te doenveriagen, alles, wa de Püpen dic den Comparant daar toc vandaretsioh heft

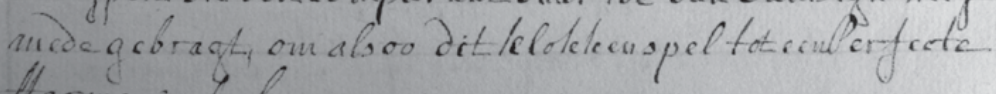
Harmonic Fe brengen:

Fig. 35: Acceptance report of bells refurbished by J. N. Derck. Spruijt, Beschrijving van Klokken, 139 


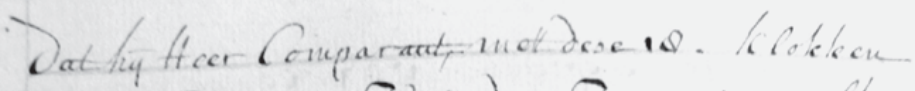

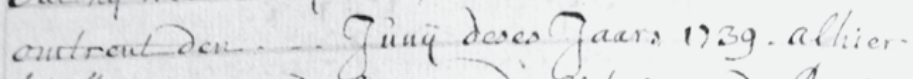

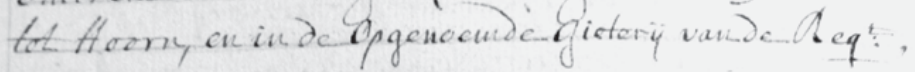
is Gearivert:

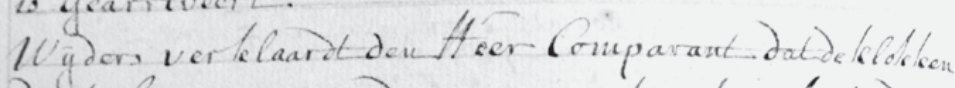

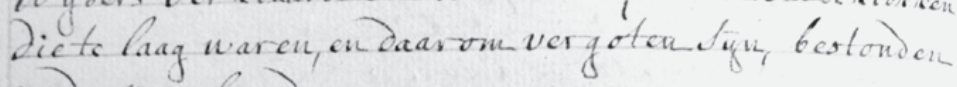
inderiavoloude:

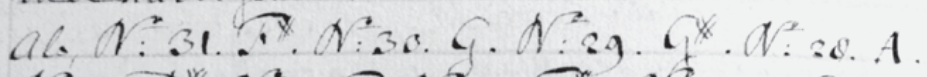

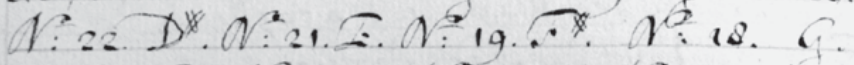

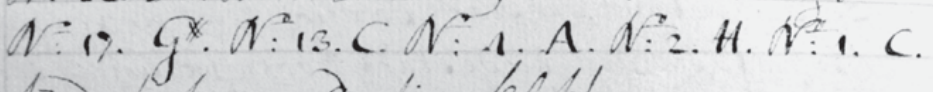

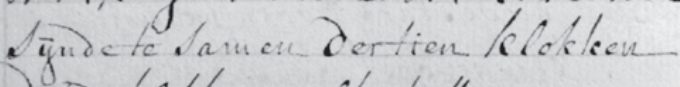

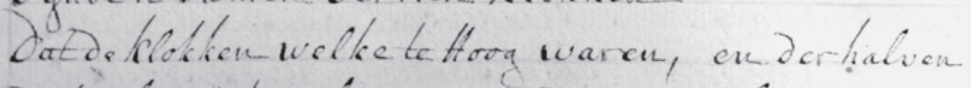

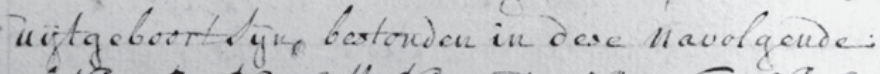

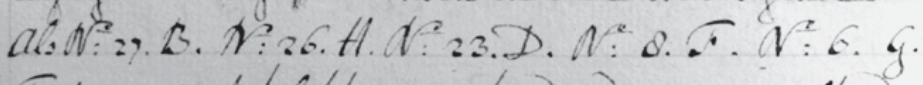

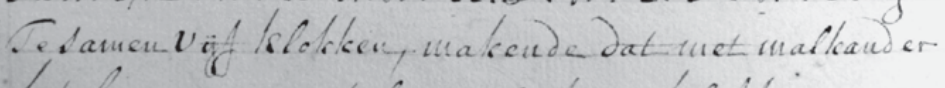

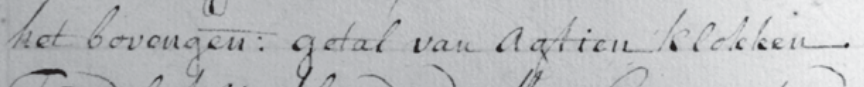

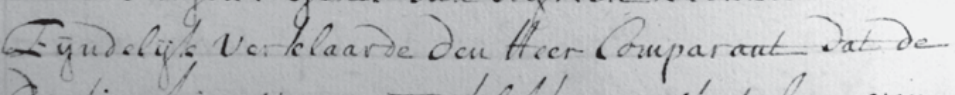

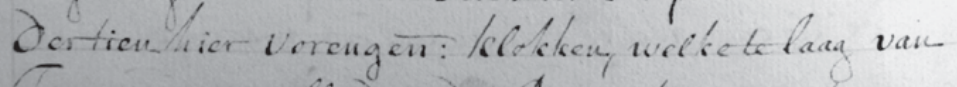

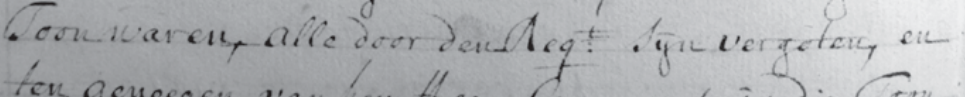

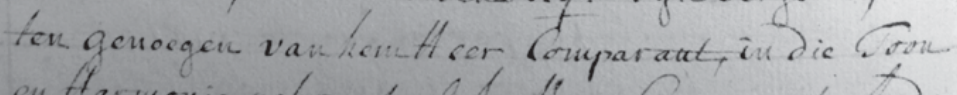

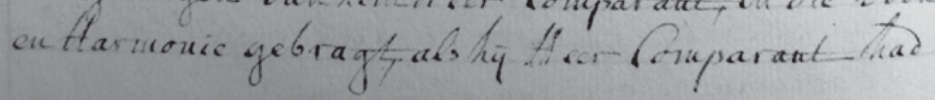

Fig. 36: Acceptance report of bells refurbished by J. N. Derck. Spruijt, Beschrijving van Klokken, 140 
Unclear beginnings and granted wishes

141

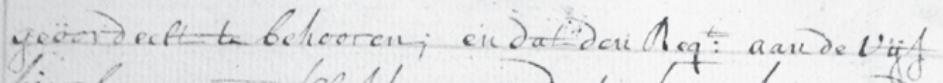

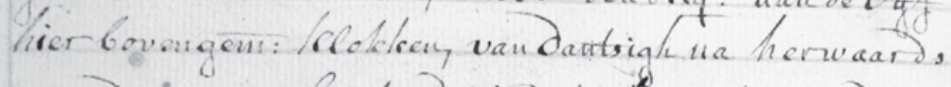

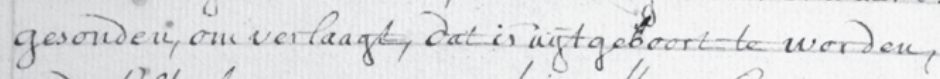

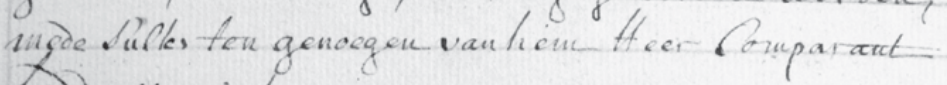
hiade verrigt

Waas rude endigowde, gaf vor rodenen van Weteriekrap: yn ingon ondervinding on behandeling,

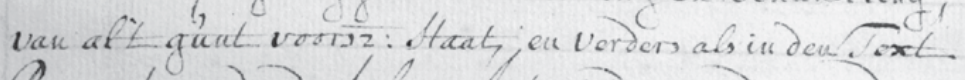
Prasenterende dorhaiven ret qedeposcerde, nader

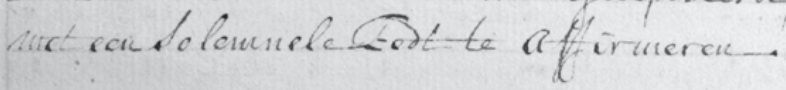

Gedaan inflomm Present Mighiel de Wir en fendrik feseman als versogte Gofungen.

Now getelcert Eltion 10 oftery klotecuit lliguid do ltit.

A Endris leseman

Mig Prasert 7 : ve Beek, Dot:

$(\log e-1$ (10u) $)$ Llyigegeven voor sopic Aütrientyily in Aoond deu 20. September-1939.

by $211 \overline{4}$.

:v: Bopk Nola

Fig. 37: Acceptance report of bells refurbished by J. N. Derck. Spruijt, Beschrijving van Klokken, 141 
Recast and properly tuned, the bells were returned to Gdańsk in the autumn of 1739. Bruno Meyer states that they were installed in the Old Town church tower on 2 December that year. ${ }^{501}$ This time, there were no objections to their sound.

The carillon of St Catherine's, just as the "singing mechanism" of the Main Town Hall, became a permanent part of the Old Town soundscape and citizens' lives. It has always been the centre of attention. The most evident sign was the money paid both regularly and occasionally for the instrument's maintenance. In the nineteenth and twentieth century, anniversaries of the instrument's construction were celebrated. In 1838, a solemn academy was organised at St Catherine's, with a speech given by pastor Borkowski. ${ }^{502}$ In 1888 , the 150th anniversary of the carillon was an even bigger event. The ceremony's scenario was debated on 28 November at a meeting of the St Catherine's Parish Council. It was decided that on 30 November, the day the carillon officially sounded 150 years prior, all bells would chime for fifteen minutes at five o'clock in the afternoon, followed by an hour-long concert, during which the carillonist would play thanksgiving songs. ${ }^{503}$ On the day of the ceremony, the morning edition of the Danziger Zeitung published a celebratory article by Otto Krieschen. ${ }^{504}$ In 1938, the Gdańsk press celebrated the 200th anniversary of the carillon. ${ }^{505}$

The history of the third carillon of St Catherine's also included tragic moments. Ernst Blech recalls an accident from 1803 when the rope holding the ballast of the "singing clock" ("Singuhr") broke; the clump weight of twelve hundredweights fell on the pavement, destroying a funeral plate. Blech also mentions the carillon suffered during the French siege in $1807 .{ }^{506}$ We also know that during the city's bombardment that started on 23 April 1807, both carillons of Gdańsk went silent, having been switched off the day before on the order of the city commander, General Friedrich Adolf von Kalckreuth. ${ }^{507}$

The most tragic event took place on Monday 3 July 1905. A powerful storm moved over the city and several lightning hit the church tower. A fire broke out. The sounds of the Herz und Herz vereint zusammen and Ringe recht wenn Gottes Gnade songs were heard. Soon, the bells were silenced. They were destroyed

501 Meyer, 'Die Glockenspiele auf St. Katharinen in Danzig', 6.

502 DZ 1888 no. 17408 (30 November).

503 DZ 1888 no. 17407 (29 November).

504 DZ 1888 no. 17408 (30 November).

505 DNN 1938 no. 280 (30 November).

506 Blech, 'Das alte und das erneute Glockenspiel', 18.

507 DZ 1888 no. 17408 (30 November). 
alongside the carillon mechanism, clock, and the church's other bells. The tragedy was a shock to Gdańsk residents, with despaired reports in the press.

The decision to reconstruct the tower and build a new carillon - the fourth one in the history of St Catherine's - was taken immediately. ${ }^{508}$ Gdańsk burghers were convinced of its success, though they acknowledged the time necessary. A year after the tragedy, the press wrote:

Glücklicherweise ist sein Wiedererstehen in der früheren Gestalt gesichert, wenn es dazu auch noch einiger Jahre bedürfen wird - und auch das oft bewunderte Glockenspiel wird hoffentlich nach Jahren wieder den Danzigern erklingen. ${ }^{509}$

The crucial issue was securing the necessary funds. Local press debated the state of the city's finances, the plans of reconstruction of the new tower, the new carillon, and ways to raise funds, followed by the state of renovation work. On 4 November 1905, the Danziger Zeitung wrote:

Nach den aufgestellten Plänen und Kostenanschlägen werden zur Wiederherstellung des Turmes und Glockenspieles 290000 Mk. erforderlich sein. Die Brandentschädigung der Versicherungsgesellschaften für die zerstörten Turmteile betragen 115000 Mk., so da $\beta$ noch 175000 Mark aufzubringen sein werden. Davon stehen der Gemeinde bis jetzt aus Sammlungen für das Glockenspiel und aus ihren laufenden Mitteln zirka $15000 \mathrm{Mk}$ zur Verfügung und vom Parochialverbande Danzig ist ihr ein Darlehn von $60000 \mathrm{Mk}$. in Aussicht gestellt. Wegen des Restes von zirka $100000 \mathrm{Mk}$. wird die Gemeinde auf Beihilfen des Staates, der Stadt und Provinz angewiesen sein. ${ }^{.10}$

Organisers received substantial assistance. Money flew notably from the imperialroyal treasury and the Gdańsk city treasury ${ }^{511}$ Citizens made substantial donations. They must have been very generous, as noted by the press a few years later:

Wie jedem Danziger seine Glocken lieb geworden, zeigte sich auch bei der Opferfreudigkeit für die Wiederherstellung des Glockenspieles von St. Katharinen, das jener verhängnisvolle Blitzstrahl am 3. Juli 1905 vernichtete. $^{512}$

The destroyed carillon was remembered in poetry (including a poem by Hedwig Andersen, Du fuhrest daher in Wetter und Sturm ${ }^{513}$ ) and concerts that

508 The reconstruction process of the tower, clock, and carillon of St Catherine's is made possible by documents kept at the State Archive in Gdańsk; see notably those filed under catalogue no. APG 353/149 and ff.

509 DZ 1906 no. 305 (3 July).

510 DZ 1905 no. 520 (4 November).

511 APG 353/150, p. 57; Meyer, 'Die Glockenspiele auf St. Katharinen in Danzig', 11.

512 DZ 1914 no. 95 (26 February).

513 APG 353/149, inside cover. 


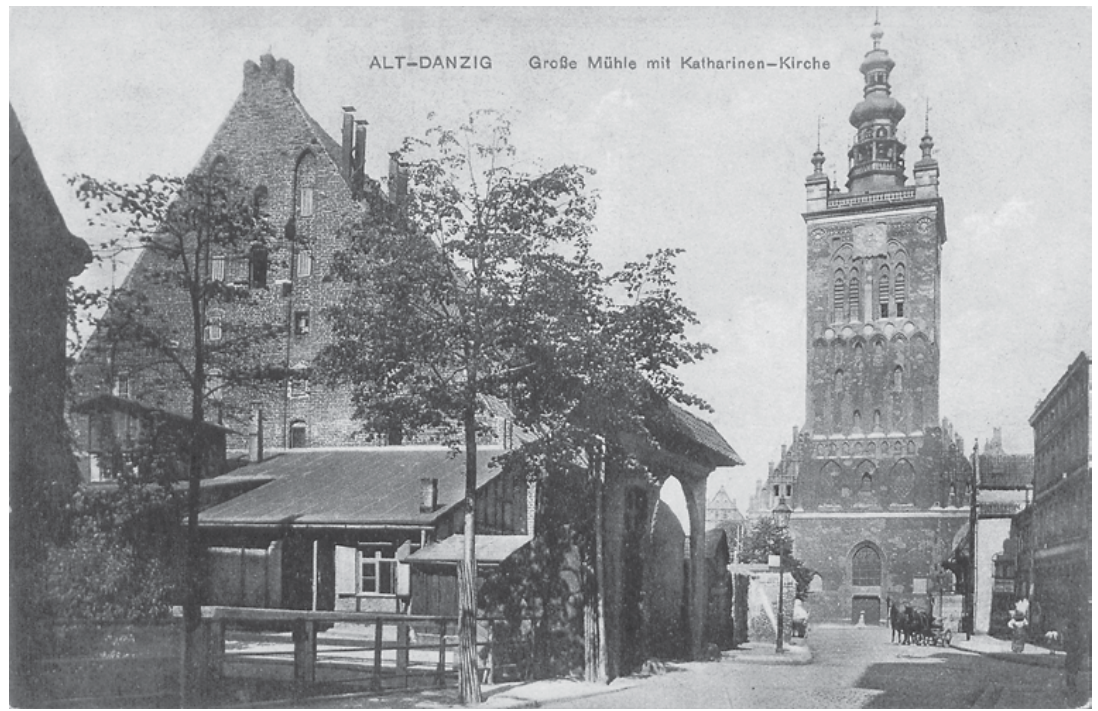

Fig. 38: Church of St Catherine in Gdańsk. PAN BG P/1

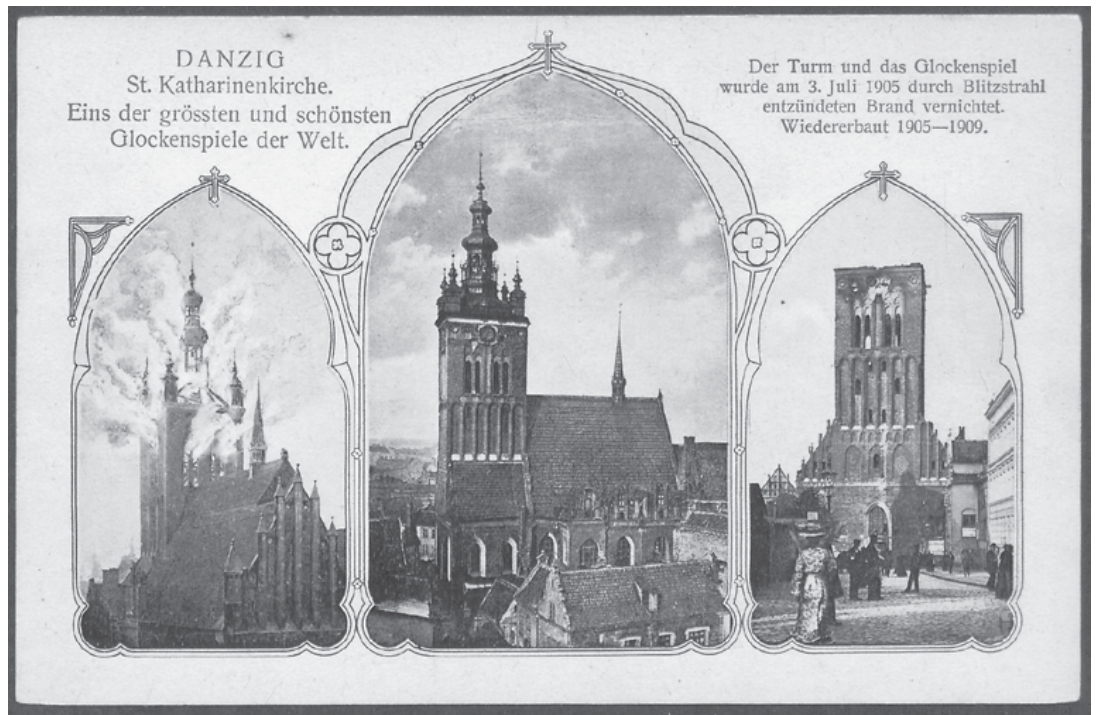

Fig. 39: Church of St Catherine in Gdańsk. PAN BG P/1 
expressed nostalgia for the sound of the beloved Old Town bells. One of such concerts took place on 14 December 1905 in the House of St Joseph ("im großen Saale des St. Josephshauses, Töpfergasse 7") and was titled "Musikalischtheatralische Aufführung zum Besten des Glockenspiels von St. Katharinen.” It was organised and directed by singing and piano teacher Gertrude Funk. Performers included her pupils, a women's and children's choir, as well as two violinists (Seltenreich and Sonnenburg), a violist (Sausse), a cellist (Fischer), and "other gentlemen." A typical programme was presented, included a medley of movements from various works, from Advent songs to the gypsy dance from the opera Die Kinder der Pussta op. 13 by the now-forgotten composer Mary Clement. ${ }^{514}$

It also happened that some canny citizens tried to make money on the tragedy mourned by others. In autumn 1905, the following classified was published in the Danziger Zeitung:

Vom St. Katharinenkirchen-Glockenspiel sind aus den schmiedeeisernen Teilen mit Glockenmetall verschmolzen kleine und größere Gegenstände, gekennzeichnet mit Stempel "Zum Andenken an den Brand der St. Kath.-Kirche", Kohlenmarkt Nr. 11 bei Herrn Neumann schon von 0,50 Mk. an zu haben. Gebr[üder] Heyking, Danziger Gitterfabrik und Treppenbau, Schuitensteg. ${ }^{515}$

Thus, objects crafted from remainders of the destroyed carillons were offered with a celebratory stamp. It is hard to gauge how many buyers the offer found in Gdańsk and what the profits were. The announcement does not make it clear whether the income was destined for the carillon reconstruction fund or diverted into the announcers' pocket.

Work on the reconstruction of the carillon was meticulously prepared, starting with a detailed account of damage caused by the fire. ${ }^{516}$ On the instruction of the St Catherine's Parish Council archdeacon Ernst Blech, municipal construction councillor Karl Fehlhaber, and merchant George Gronau travelled in the autumn of 1905 to Germany, Denmark, and Sweden in order to familiarise themselves with the carillons in use there and local bell casting workshops. Later, Ernst Blech also went to Belgium to study carillon building and playing. ${ }^{517}$ Offers poured in to Gdańsk from companies interested in

514 DZ 1905 no. 579 (10 December); Silke Wenzel, 'Mary Clement', Musik und Gender im Internet (MUGI), accessed 28 August 2018, http://mugi.hfmt-hamburg.de/old/A_ lexartikel/lexartikel.php?id=clem 1861 .

515 DZ 1905 no. 434 (15 September).

516 APG 353/153, pp. 71-78.

517 Meyer, 'Die Glockenspiele auf St. Katharinen in Danzig', 3. 
fulfilling the commission, including from Stettin (C. Voss \& Sohn) and Lübeck (M. \& O. Ohlsson). Eventually, the bell casting workshop of Franz Schilling from Apolda in Thuringia was selected.

The company had flourished for several decades following its foundation in 1826 by Carl Friedrich Urlich. During the first half-century of operation, it cast 1,260 bells, primarily for churches in Thuringia. In 1878, Urlich sold the workshop to Franz Schilling (1830-1926), who significantly increased production. Until 1902, the workshop under his direction produced 2798 bells. In 1880 Schilling, purveyor of the Saxon court (Grossherzoglich Sächsischer Hofglockengiessermeister), founded a bell casting atelier in Olsztyn; ${ }^{518}$ that was perhaps the reason why his offer was later accepted in Gdańsk.

It was decided that the Old Town bell collection would be modelled on the Bruges carillon. Thus in 1906 Franz Schilling travelled to Belgium to examine that instrument. ${ }^{519}$

Negotiations with the bell founder on the commission's conditions, scope, and costs were protruded. Only in 1908 was the contract ready, with the main copy bearing the date 6 May. The contract was signed between Franz Schilling and the St Catherine's Parish Council (Gemeindekirchenrat von St. Katharinen zu Danzig) ${ }^{520}$ It included the delivery by Franz Schilling of:

1. Forty-two bells, including five chime bells ("Läutenglocken") and thirtyseven carillon bells ("Glockenspielglocken")

2. A keyboard ("Spieltisch") for manual play

3. The carillon mechanism ("Glockenspielwerk")

4. A tower clock ("Turmuhr")

It was agreed that the chime bells, tuned in F, A flat, B flat, C, and E flat, would weigh $23,100 \mathrm{~kg}$ in total, while the thirty-seven carillon bells, $17,326 \mathrm{~kg}$. The price of chime bells was 2 marks and 20 pfennigs per kg, while that of carillon bells, 2 marks and 35 pfennigs. The value of each position in the contract was thus as follows:

1. Five chime bells: 50,820 marks

2. Remainingconstructionelementsforchimebellsplusinstallation:15,300 marks

3. Thirty-seven carillon bells: 40,716 marks and 10 pfennigs

518 Walter, Glockenkunde, 866, 892.

519 APG 353/154, p. 105.

520 APG 353/154, pp. 85-92. Contracts were long-term, and their terms varied only slightly during negotiations. 
4. Carillon mechanism: 15,600 marks

5. Keyboard: 1050 marks

6. Clock: 3485 marks

7. Other elements (clappers, hammers, metal construction parts): 3525 marks

8. Installation: 1000 marks

The entire commission was estimated at 131,496 marks 10 pfennigs. Franz Schilling agreed to cast the bells from quality materials in tune to a clean, powerful sound. The commission was to be received in Apolda by emissaries of the church of St Catherine, after weighing the bells and assessing the timbre. The bell founder issued a ten-year warranty. The entire commission was to be delivered on 1 July $1909 .^{521}$

The quoted document suggests Franz Schilling was the main executer of the commission. In reality, he only cast the bells and produced the clappers and hammers. The remaining tasks were subcommissioned to the renowned workshop of Ed. Korfhage \& Söhne, located in Buer near Osnabrück, following a referral from archdeacon Ernst Blech. ${ }^{522}$ Founded in 1810, the workshop specialised in the production of tower, factory, railway, electric, and suspended clocks, as well as sound signalling devices. ${ }^{523}$ The company was contacted as early as September 1905, ${ }^{524}$ with Eduard Korfhage soon preparing to undertake the commission. A cost assessment and task description sent to Gdańsk is dated on 28 February $1906 .{ }^{525}$ Actual work started after the contract was officially signed between the St Catherine's Parish Council and Franz Schilling.

Cooperation between the two main contractors required coordination. Unfortunately, as transpires from the extant correspondence, the latter left much to be desired. The commission was not ready on time, and delays occurred mainly with Ed. Korfhage \& Söhne. Its owner sent a series of explanations to Gdańsk, indicating that the contractual deadline was impossible to meet. This proved inefficient in reducing tensions between contractors. ${ }^{526}$

521 APG 353/154, pp. 85-92.

522 According to Ernst Blech, the company had already produced a modern carillon mechanism in Lehe; see 'Das alte und das erneute Glockenspiel', 19.

523 Ed. Korfhage Söhne, accessed 27 August 2018, http://www.korfhage-turmuhren.de.

524 APG 353/153, pp. 115-17.

525 APG 353/154, pp. 389-98.

526 APG 353/154, pp. 437 ff. 
Nonetheless, work progressed. The bells were received on 13 August 1909 in Apolda by a commission of three emissaries from Gdańsk: government building councillor Albrecht Ehrhardt, municipal building councillor Karl Fehlhaber, and merchant Georg Gronau. Musical trials proved satisfactory, with an expert opinion provided by Prof. Wilhelm Freudenberg of Berlin. ${ }^{527}$ The bells were transported to Gdańsk by dispatch train, likely in the last week of August 1909 (before 2 September). ${ }^{528}$ The final installation of the carillon occurred at the end of 1909 and the beginning of 1910. Winter hindered work on the installation, putting further strain on the relations between contractors and commissioners. The press reported that a first trial of the carillon, executed in secret ("an dem schon lange geheimnisvoll gearbeitet wird"), took place in the afternoon of 13 April. The chorale Befiehl du deine Wege resounded over the city's rooftops. The sound was deemed at first undecided, but then fuller, with soft, harmonically pure chords. ${ }^{529}$ The concert was also covered by the Danziger Zeitung of 14 April, which stressed that the instrument was not fully ready to play. ${ }^{530}$

The new bells were consecrated on Sunday, 1 May $1910 .{ }^{531}$ Erna MüllerLandeck was inspired to the following celebratory poem:

\footnotetext{
Und heute - ein jubelerfüllter Tag,

Im Frühlingskleide rings Heide und Hag,

Im Schmuck prangst du, Sankt Katharinen;

Der neuen Glocken herrlicher Klang

Geht segnend die Straßen und Fluren entlang,

Allzeit ihm, dem Höchsten, zu dienen. ${ }^{532}$
}

The instrument was officially handed over to the parish of St Catherine on 24 August 1910. At seven in the evening, the notes of the thanksgiving hymn Herr Gott-dich loben wir were heard, and half an hour later, the song $O$ dass ich tausend Zungen hätte. ${ }^{533}$ Bells for automatic play were programmed for the first

527 APG 353,/154, pp. 527-29.

528 APG 353/154, pp. 285, 289.

529 APG 353/164, loose press clippings.

530 DZ 1910 no. 172 (14 April).

531 The ceremony is described in DZ 1910 no. 202 (2 May).

532 Erna Müller-Landeck, Zur Glockenweihe in St. Katharinen (fourth verse), see APG 353/164, press clippings.

533 Blech, 'Das alte und das erneute Glockenspiel', 19; Meyer, 'Die Glockenspiele auf St. Katharinen in Danzig', 11. 
time on the occasion of the imperial couple's visit to Gdańsk on 27 August 1910, as notified by the Danzinger Zeitung of Thursday 25 August. ${ }^{534}$

According to the income and expenditure report for the period between 3 July 1905 and 30 March 1911, the fourth historical carillon of St Catherine's cost a total of 60,958 marks and 57 pfennigs. The lion's share, 50,562 marks and 17 pfennigs, was paid to Franz Schilling for delivering the carillon and accessories ("für Lieferung des Glockenspiels mit Zubehör"), with the balance paid notably to the installer and carpenter for manufacturing thirtyseven keys. The report also mentions Eduard Korfhage, who received a small payment (182 marks 10 pfennigs) for maintenance work; according to the contract, the bulk of his remuneration was paid by Franz Schilling as the main contractor. ${ }^{535}$

The new carillon of St Catherine's, like that of 1738, was surrounded by Gdańsk burghers with financial support and genuine respect. The esteem transpires from works of poetry ${ }^{536}$ and journalism. ${ }^{537}$ The Old Town bells were considered a permanent element of Gdańsk's cultural heritage, deeply ingrained as they were in the pre-war social consciousness. The prestige of the carillon was evidenced by the fact that after the establishment in September 1926 of a local radio station, transmissions from 11:00 a.m. matinées played on the instrument by Georg Edel were aired from December. Advertised on the Danziger Zeitung from 25 December, the programmes were aired thrice weekly: on Mondays, Wednesday, and Fridays (with the exception of holidays ${ }^{538}$ ). Given the esteem for the Old Town carillon, the order of Hermann Göring of 15 March 1940, requesting all European church and town hall bells to be scrapped for weapon production, ${ }^{539}$ surely did not go down well. The Gdańsk Old Town carillon was allowed to play until 1942 when the bells were dismounted and move near Hamburg to a venue later called the "bell cemetery." Luckily, most of the Gdańsk bells survived the war. From the

534 DZ 1910 no. 396 (25 August).

535 APG 353/150, pp. 616-17. The total cost of the carillon of 60,958 marks and 57 pfennigs is also quoted by Blech, 'Das alte und das erneute Glockenspiel', 20.

536 For example, the poem of Ernst Blech-Trebnitz, In Danzig alten Gassen, DNN 1927, no. 94 (23 April).

537 Meyer, 'Die Glockenspiele auf St. Katharinen in Danzig', 12-15; Edel, 'Aus Danzigs Eigenart', 180-81; Siegler, 'Im alten Danzig', 13-15; Roome, 'Die Glöckner der Katharinen Kirche in Danzig', 28-29.

538 DZ 1926 no. 357 (25 December).

539 Rombouts, Singing Bronze, 251 ff. 
original set of thirty-seven, twenty-eight were extant: the series from C\#4 through G\#5 as well as A\#5, B5, C\#6, D6, E6, F\#6, G6, and G\#6. These bells were incorporated in the carillon of the church of St Mary in Lübeck, playing for the first time there on 10 April 1954 at six in the afternoon. ${ }^{540}$ The current St Mary's carillon is composed of thirty-six bells and continues to operate; thus, every half-hour, one can hear the sound of the former St Catherine's carillon bells.

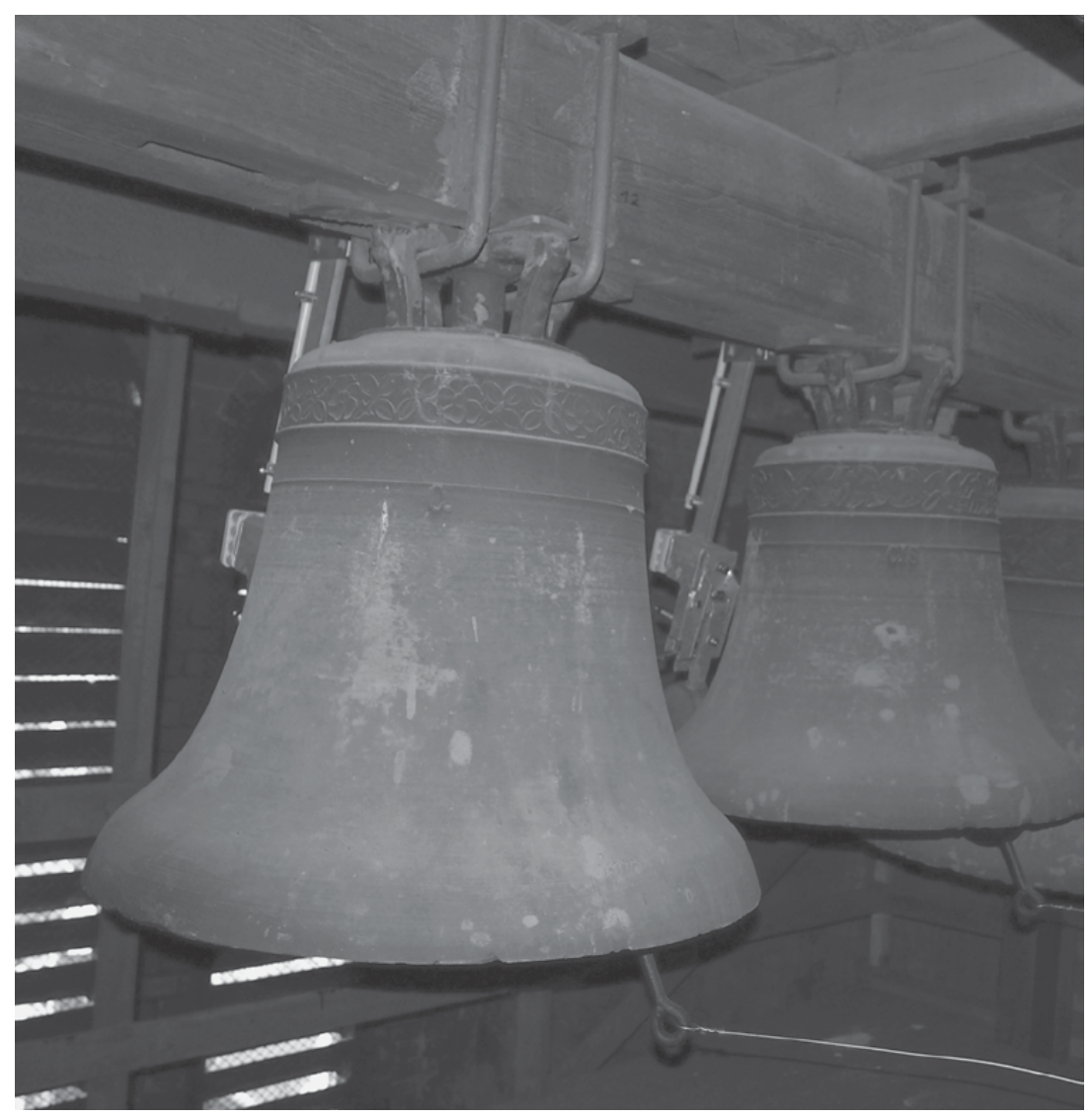

Fig. 40: Church of St Mary in Lübeck: the carillon bells of Gdańsk' St Catherine. Photo by D. Popinigis

540 'Das neue Glockenspiel', St. Marien Jahrbuch 1955/56 des St.-Marien-Bauvereins 1955, 136; 'Über die weitere Vervollständigung des Glockenspiels', St. Marien Jahrbuch 1961 des St.-Marien-Bauvereins 1960, 82. 


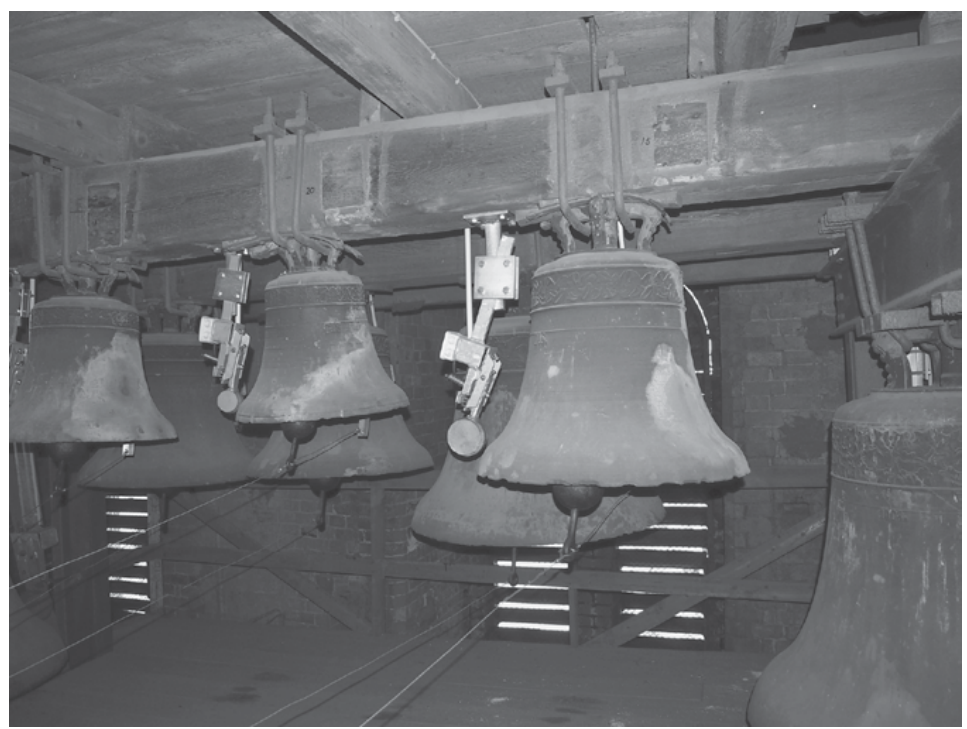

Fig. 41: Church of St Mary in Lübeck: the carillon bells of Gdańsk' St Catherine. Photo by D. Popinigis

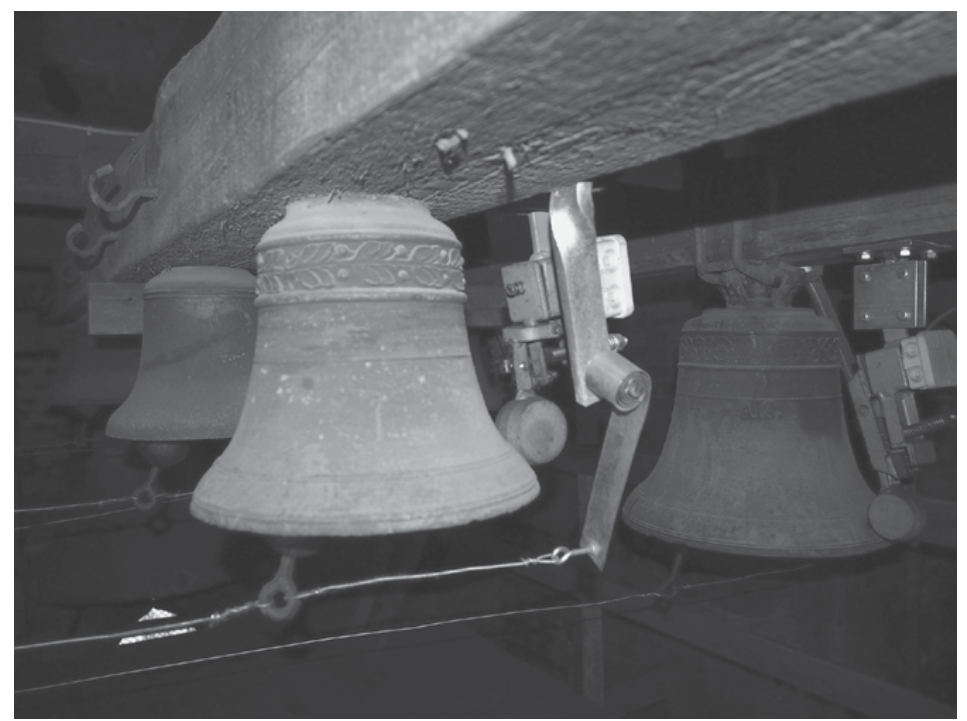

Fig. 42: Church of St Mary in Lübeck: the carillon bells of Gdańsk' St Catherine. Photo by D. Popinigis 


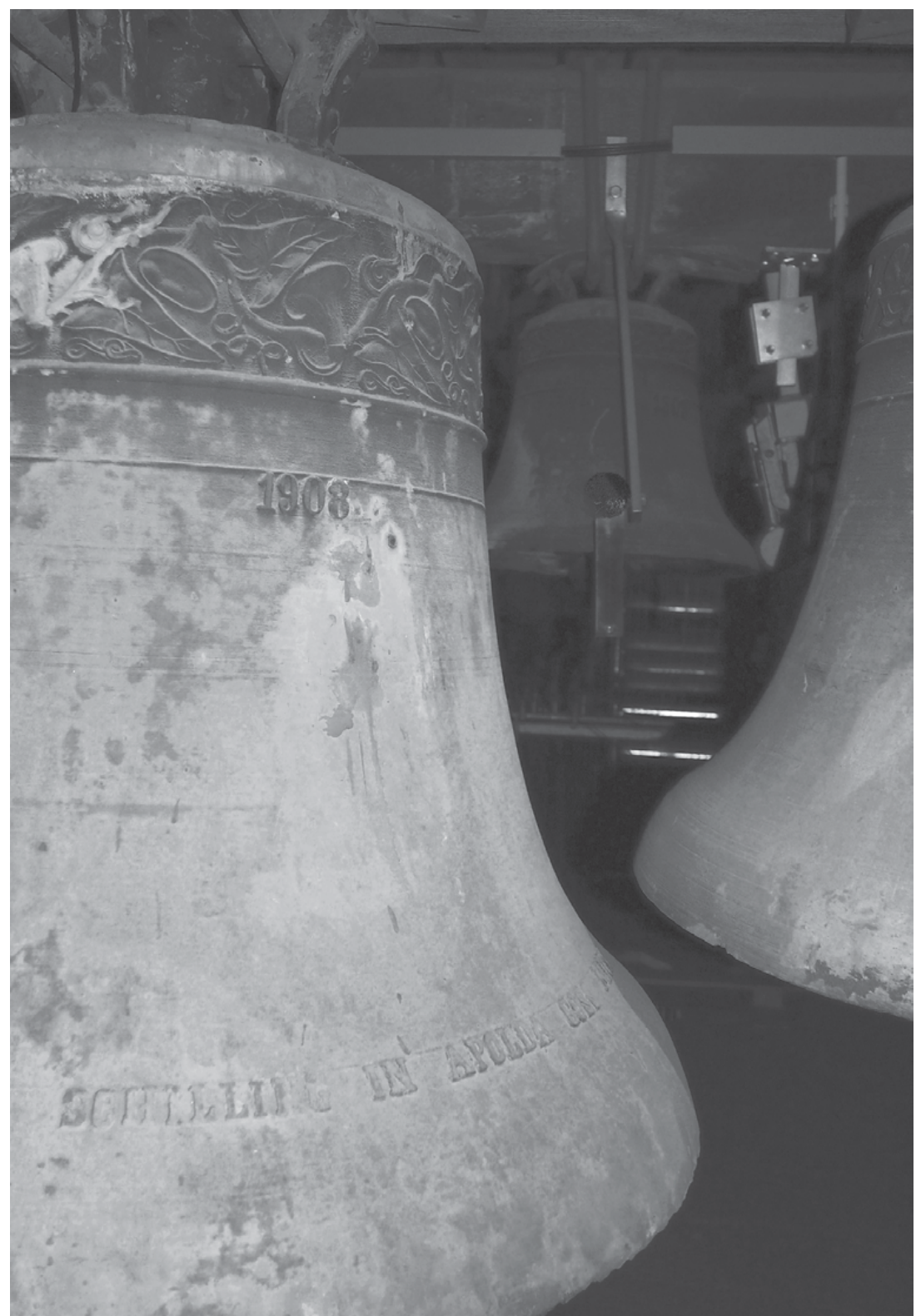

Fig. 43: Church of St Mary in Lübeck: the carillon bells of Gdańsk' St Catherine. Photo by D. Popinigis 


\section{The bell founder Jan Nicolaas Derck}

Pre-war German and post-war Polish literature includes little information about the bell founder who manufactured the bells for the 1738 carillon. Mentions included his residence in Hoorn and the complaint about his flawed commission. In the last decades, the life and activity of Jan Nicolaas Derck were researched by Dutch archivists and campanologists. ${ }^{51}$ We now know much more about Derck; a research into sources kept at Hoorn's Westfried Archief helped me complete details about the bell founder's family and determine the correct spelling of his first name and surname.

The documents I consulted include the following variants of his name: Johan Nicolaus, Johan Nicolaas, Jan Nicolaus, Jan Nicolaas, Jan Nicolaes, as well as Joan Nicolaas, Niclaas, and Jan Niclaas. The choice of the first of these, Johan Nicolais, as the recommended spelling, would be substantiated by his likely descent from Germany; it was likely the spelling under which he is recorded in 1688 in the baptism register of the church in Schleusingen, his birthplace. Yet he spent the majority of his adult life in Frisia, and documents most often quote his name in the Dutch version, "Jan Nicolaas." For this reason, I have adopted this version in the present book.

His surname appears in the sources under five forms: "Dirck," "Dirk," "Derk," "Derks," and "Derck." As the former two can only be found in the earliest documentation, they can be considered secondary. The three latter ones are used in later sources, with "Derck" the most frequent one; I suggest using it as standard.

The fact of Derck's faulty casting of the bells for Gdańsk's church of St Catherine could suggest he lacked professional experience, yet precisely the opposite was true. Derck was the son of a German bell founder (also named Johann Nicolaus), so he obviously taught the profession by his father. Jan Nicolaas Derck junior was born in 1688 in Schleusingen, a town on the river Schleuse in Thuringia. ${ }^{52}$ At

541 Boon, 'De Hoornse Klok- en Geschutgieterij'; Lehr, Van paardebel tot speelklok, 24547; and the commentary of André Lehr in Spruijt, Beschrijving van Klokken, 10.

542 I am paraphrasing Boon, 'De Hoornse Klok- en Geschutgieterij', including unpublished material obtained from that author, and comments by André Lehr in Spruijt, Beschrijving van Klokken, 10-11. 
the age of twenty-four, in late 1712, he came from Mannheim to Enkhuizen in Western Frisia. He took up a job in a workshop casting bells and cannons, run by Jan Crans. The following year, on 20 October 1713, he married Hester Alida Wehart at the church in Enkhuizen. ${ }^{543}$ The couple had seven children, three born in Enkhuizen - Jacob and two boys named Johannes (both died in infancy) - and four in Hoorn, where the family relocated in 1718: Johannes, two boys named Jacob (both died in infancy), and Margerieta.

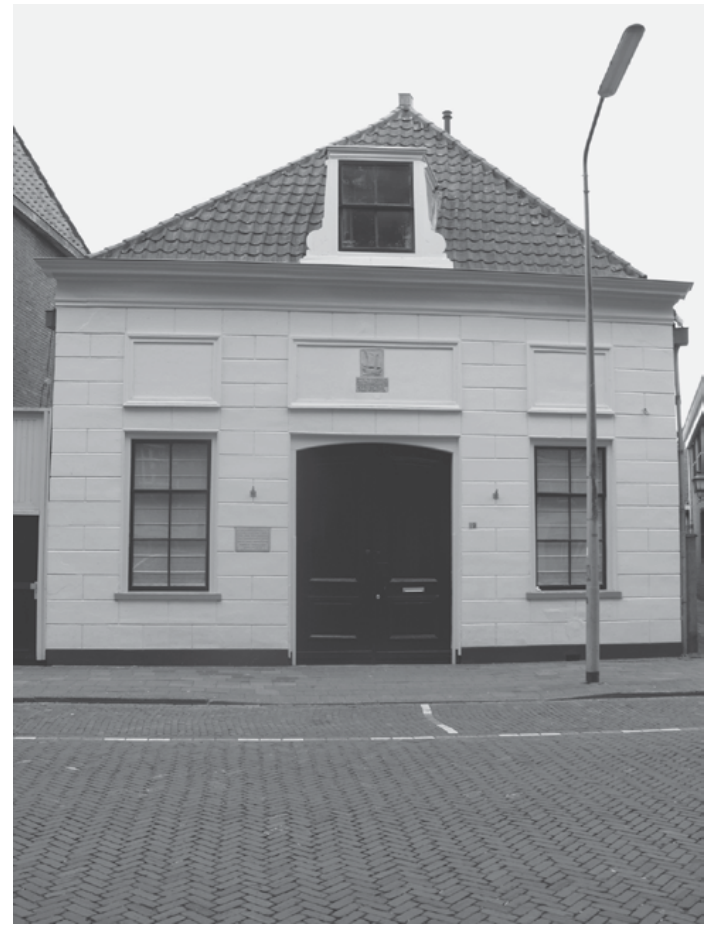

Fig. 44: Hoorn, house of J. N. Derck. Photo by D. Popinigis

We do not know what Jan Nicolaas Derck did in the first years of his stay in Hoorn, but he certainly entertained the idea of his own bell casting workshop from the beginning. He finally opened it four years later, obtaining a licence from the municipality to run a manufactory of cannons and bells on 9 November 1722 .

543 WA DTB, Enkhuizen 98/1, 20 October 1713. 


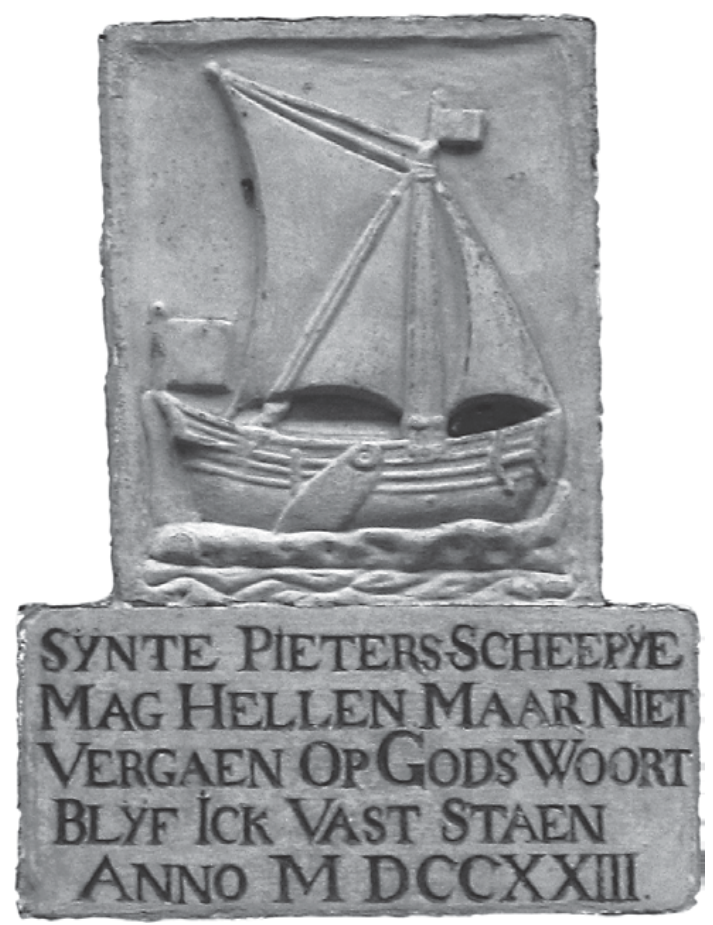

Fig. 45: Hoorn, house of J. N. Derck, detail. Photo by D. Popinigis

The company had its seat at the former location of St Clara's monastery church, also known as the Peat Church ("Turfkerk"), demolished in 1716 and located near the town's North Church ("Noordekerk"). Derck bought a house standing on the lot for 100 guilders. The building still stands, now numbered Veemarkt 19. Over the official entrance, a rectangular plate was erected with the image of a ship, the year 1723 and an inscription recommending the house to divine providence and the infallible Church, symbolically represented through the Barque of St Peter:

SYNTE PIETERS SCHEEPYE MAG HELLEN MAAR NIET

VERGAEN OP GODS WOORT

BLYF ICK VAST STAEN

ANNO MDCCXXIII 


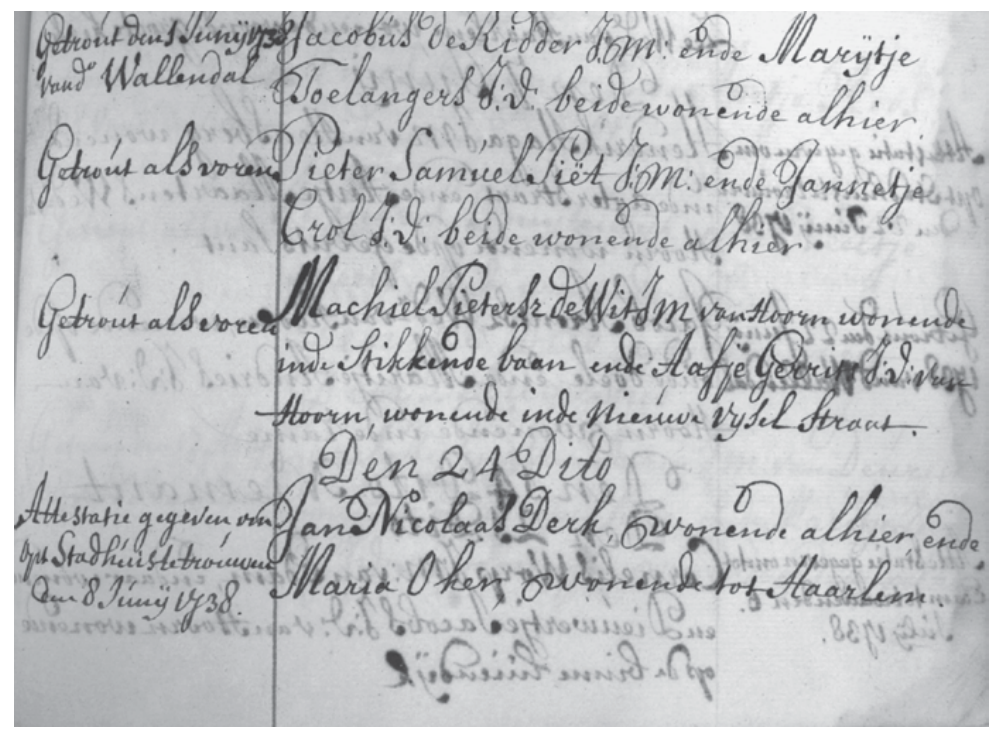

Fig. 46: Entry with information about the marriage of J. N. Derck and Maria Oker. WA DTB, Hoorn 68, fol. 229

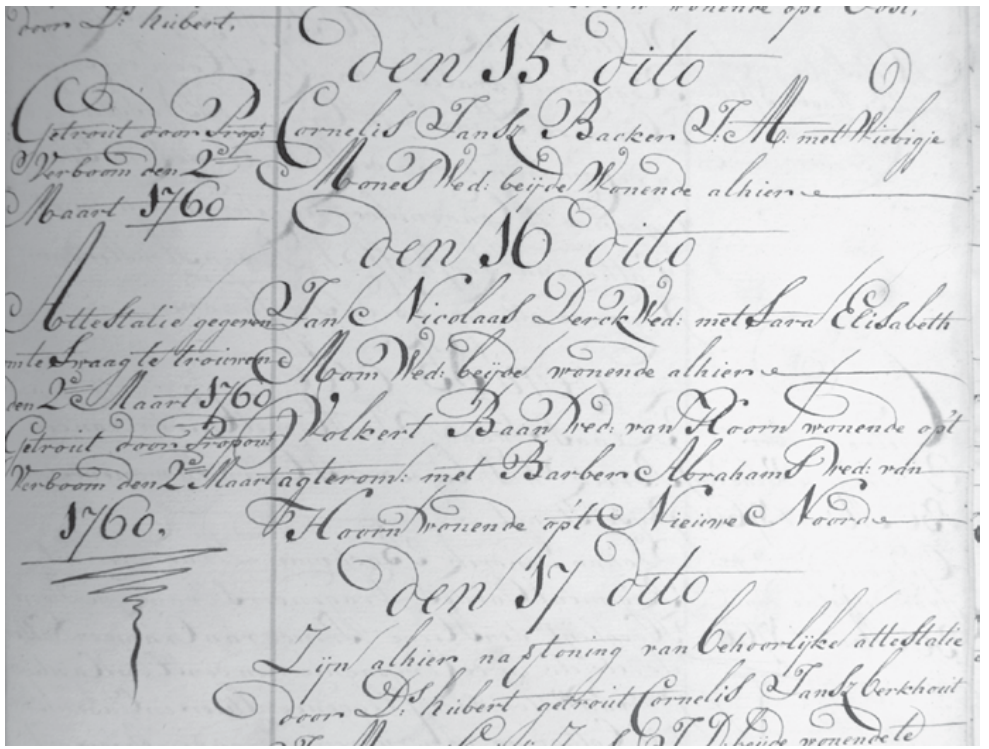

Fig. 47: Entry with information about the marriage of J. N. Derck and Sara Elisabeth Mom. WA DTB, Hoorn 69, fol. 107 


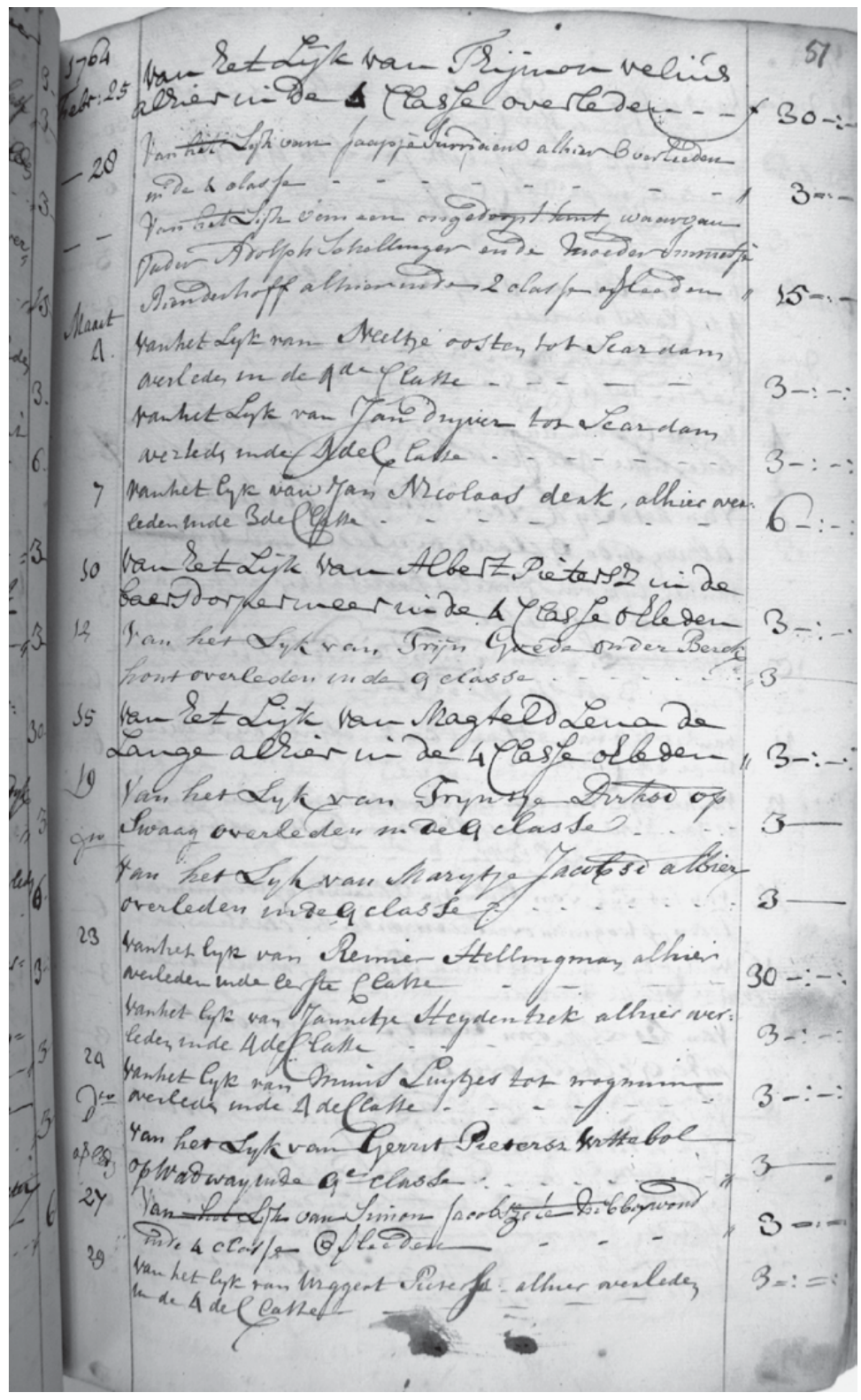

Fig. 48: Entry with information about the death of J. N. Derck. WA DTB, Hoorn 109, fol. 51 
After the death of Hester Alida, Jan Nicolaas Derck married Maria Oker on 8 June $1738 .{ }^{544}$ The couple had two children: Maria Magdalena and Melchior Nicolas. At the end of his life, on 2 March 1760, Derck married his third wife, ${ }^{545}$ Sara Elisabeth Mom, in Zwaag, her birthplace. Soon, their son Jacobus was born, followed by daughter Catharina.

Jan Nicolaas Derck then moved shortly to Haarlem. In 1761, he sold his bell casting workshop to his eldest son Johannes. The latter, however, seems not to have lacked business acumen, since a year later Derck senior resumed ownership and returned to Hoorn. He did not, however, develop the production, dying at the age of 76 in March 1764.

Tab. 10: Genealogy of the Derck family

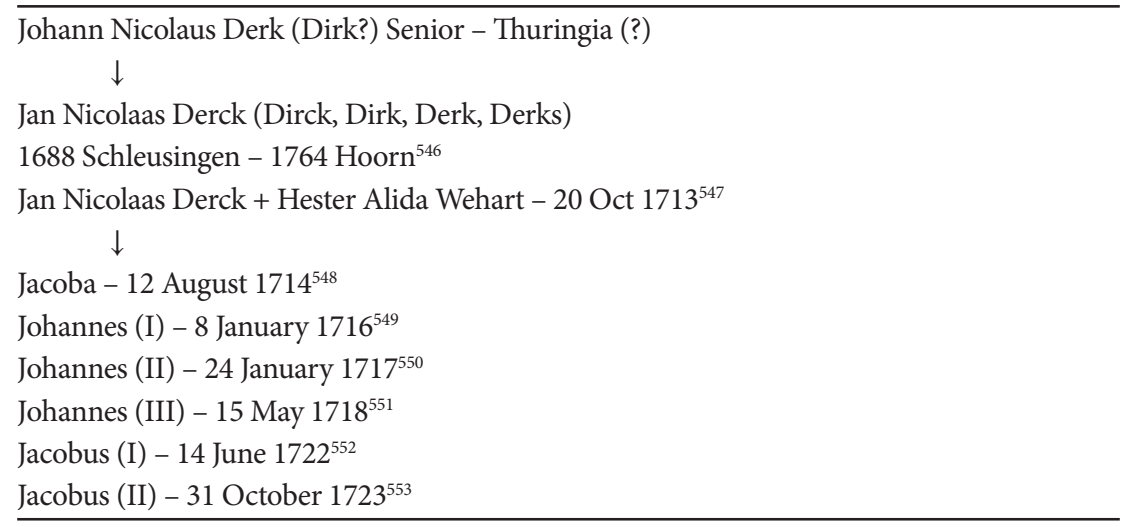

544 WA DTB, Hoorn 68, fol. 229, 8 June 1738.

545 WA DTB, Hoorn 69, fol. 107, 2 March 1760.

546 WA DTB, Hoorn 109, fol. 51, 7 March 1764 (date of entry informing about Derck's death).

547 WA DTB, Enkhuizen 98/1, 20 October 1713 (date of marriage).

548 WA DTB, Enkhuizen 38/2, 12 August 1714 (date of baptism).

549 WA DTB, Enkhuizen 38/2, 8 January 1716 (date of baptism).

550 WA DTB, Enkhuizen 38/2, 24 January 1717 (date of baptism).

551 WA DTB, Hoorn 49/4, 15 May 1718 (date of baptism).

552 WA DTB, Hoorn 49/4, 14 June 1722 (date of baptism).

553 WA DTB, Hoorn 49/4, 31 October 1723 (date of baptism). 
Tab. 10: Continued

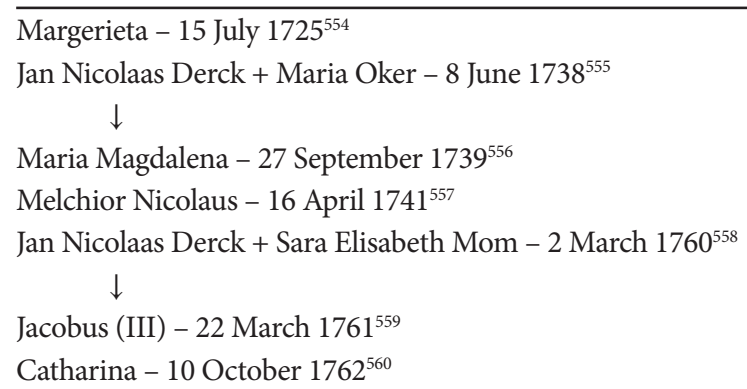

After Jan Nicolaas' death, his workshop remained in the family for a certain time. In 1767, his widow sold it to her grandson, also named Jan Nicolaas. ${ }^{561} \mathrm{He}$ ran the business until 1776 when he sold it to bell founder Jan Frederik Bagge. After three years, the workshop was taken over by Leonardus Haverkamp. In 1807, production was discontinued and the workshop sold to P. J. Meurling, who converted it into a warehouse. In 1862, a charity purchased the allotment from Meurling and began storing peat there. Since 1923, the municipal carpenter's shop has been located in the building on Veemarkt, managed by the council of Hoorn.

The nearly four decades of Jan Nicolaas Derck's work included many different activities: as many bell founders, he took up other occupations, too. In a classified published on 22 March 1728 in the "Oprechte Haarlemsche Courant," he made it known he was available to manufacture bells and "complete carillons," pharmacy mortars, pans, skillets, cranes, and other objects "adapted to needs," as well as cannons. ${ }^{562}$ For economic reasons, weaponry was particularly important, affording the bell cast an exemption from tax. Two cannons cast by Jan Nicolaas Derck are known today: one from 1747, now kept at the Songkhla National

554 WA DTB, Hoorn 50/1, 15 July 1725 (date of baptism).

555 WA DTB, Hoorn 68, fol. 229, 8 June 1738 (date of marriage).

556 WA DTB, Hoorn 50/1, 27 September 1739 (date of baptism).

557 WA DTB, Hoorn 50/2, 16 April 1741 (date of baptism).

558 WA DTB, Hoorn 69, fol. 107, 2 March 1760 (date of marriage).

559 WA DTB, Hoorn 50/3, 22 March 1761 (date of baptism).

560 Date of baptism quoted after the materials of Piet Boon.

561 Based on the archives of Piet Boon, I understand it was Joan Nicolaas Derck, son of Johannes Derck III, baptised on 19 August 1743.

562 André Lehr in Spruijt, Beschrijving van Klokken, 10. 
Museum in Thailand, and another from 1763, kept at the Westfris Museum in Hoorn. Other objects from Derck's workshop include a 1748 baptistery element (a copper baptising arch) for the Reformed Church in Zwaag.

Derck's main area of activity, however, remained bell casting. It has now been established how many bells he cast. André Lehr estimates that Derck merely cast one bell per year, a small production for that period. ${ }^{563}$ Several bells were ordered for towers in Hoorn, including the old town hall and the bell tower on the Kerkplein square, while others ended up in churches in Ursem, Obdam, Alkmaar, Bergen, and the town hall in Edam.

Derck's most important commissions came from Copenhagen, Gdańsk, and Saint Petersburg, and were not individual bells but carillon bell sets. Here, Derck had no previous experience, as neither his father nor Jan Crans, with whom he was an apprentice in his youth, did undertake such production. Derck would also have been in difficulty to learn that craft in adulthood, as carillon bell casting was a difficult art undergoing a severe crisis in the Netherlands at that time. Nonetheless, Derck decided against turning down those offers. For the royal palace in Copenhagen, he manufactured a carillon composed of fortyone bells. For his next commission, the carillon of Gdańsk's St Catherine, he could already produce referrals from Copenhagen, and his failure in producing good quality bells did not discourage him, since in 1758 he took the challenge of casting thirty-eight carillon bells and a drum for automated play for the tower of St Peter and Paul's church, located within the Peter and Paul Fortress in Saint Petersburg.

\section{Bells and mechanisms}

We know nothing about the 1573 and 1634 carillons of St Catherine's, called by Reinhold Curicke "striking mechanisms." They were possibly manufactured by some local craftsman, perhaps the bell casting workshop of the Benning family, at that time the most renowned in Gdańsk and the entire region. ${ }^{564}$ It is impossible to indicate which Gdańsk clockmaker or blacksmith could have been commissioned with manufacturing the remaining elements of the "striking mechanisms."

The situation is different with the bells and mechanism of the carillon installed at St Catherine's in 1738. Although that instrument was destroyed in a fire in 1905, its description is made possible by historical mentions, depictions, and commentaries. We can find the basic parameters of the bells and mechanism in

563 Ibid.

564 Januszajtis, Gdańskie zegary, dzwony i karyliony, 151-62. 
the contract of Jan Nicolaas Derck of 11 April 1737; $;^{565}$ the notebook of bell quality expert Juriaan Spruijt; ${ }^{566}$ the manuscript of carillonist Johann Ephraim Eggert of 1784; ${ }^{567}$ the monograph of historian Christian Friedrich Wutstrack from the early nineteenth century; ${ }^{568}$ and the testimony of organist and carillonist Paul William Krieschen of $1905 .{ }^{569} \mathrm{New}$ details on the carillon mechanism were also added in 1926 by Bruno Meyer. ${ }^{570}$

Jan Nicolaas Derck cast thirty-five bells for the carillon of St Catherine's. These spanned three octaves, in a chromatic series from C4 through C7, with the omission of two pitches in the lowest octave: $\mathrm{C} \# 4$ and $\mathrm{D} \# 4$. Thanks to the notebook of Juriann Spruijt, we know the bells' weight:

Tab. 11: Summary of 1738 Gdańsk carillon bell weights, after the notebook of Spruijt (in pounds $)^{571}$

\begin{tabular}{|c|c|c|c|c|c|c|c|c|}
\hline No. & Pitch & Weight & No. & Pitch & Weight & No. & Pitch & Weight \\
\hline \multirow[t]{2}{*}{1} & $\mathrm{C}$ & 1627 & 11 & $\mathrm{C}$ & $2073 / 8$ & 23 & $\mathrm{C}$ & $35^{1 / 4}$ \\
\hline & & & 12 & C\# & $1641 / 4$ & 24 & $\mathrm{C \#}$ & $297 / 8$ \\
\hline \multirow[t]{2}{*}{2} & $\mathrm{D}$ & 1180 & 13 & $\mathrm{D}$ & $1481 / 4$ & 25 & $\mathrm{D}$ & $27^{1 / 2}$ \\
\hline & & & 14 & $\mathrm{D} \#$ & 125 & 26 & $\mathrm{D} \#$ & $22^{1 / 2}$ \\
\hline 3 & $\mathrm{E}$ & 830 & 15 & $\mathrm{E}$ & $106^{3 / 4}$ & 27 & $\mathrm{E}$ & $201 / 8$ \\
\hline 4 & $\mathrm{~F}$ & 675 & 16 & $\mathrm{~F}$ & 92 & 28 & $\mathrm{~F}$ & $185 / 8$ \\
\hline 5 & $\mathrm{~F} \#$ & 603 & 17 & $\mathrm{~F} \#$ & $86^{3} / 4$ & 29 & $\mathrm{~F} \#$ & $171 / 4$ \\
\hline 6 & G & 480 & 18 & G & 74 & 30 & G & $16^{1 / 2}$ \\
\hline 7 & G\# & $3891 / 2$ & 19 & G\# & 60 & 31 & G\# & $15 \%$ \\
\hline 8 & A & 327 & 20 & A & $561 / 2$ & 32 & A & 14 \\
\hline 9 & $\mathrm{~B}_{b}$ & 304 & 21 & $\mathrm{~B}_{b}$ & 45 & 33 & $\mathrm{~B}_{b}$ & $12^{1 / 4}$ \\
\hline \multirow[t]{2}{*}{10} & $\mathrm{H}$ & 255 & 22 & $\mathrm{H}$ & $391 / 2$ & 34 & $\mathrm{H}$ & $93 / 4$ \\
\hline & & & & & & 35 & C & $81 / 4$ \\
\hline
\end{tabular}

Total weight of bells in pounds: 8123 3/8

565 GA Amsterdam, Notariële Archieven, no. 9939, akte nr. 139.

566 Spruijt, Beschrijving van Klokken, 76.

567 APG 300,R/Pp,45, p. vii.

568 APG 300,R/LI,96, pp. 146-47.

569 See notably APG 353/149, pp. 167-74.

570 Meyer, 'Die Glockenspiele auf St. Katharinen in Danzig'.

571 Spruijt, Beschrijving van Klokken, 76. 
The summary indicates that the total weight of bells cast by Derck topped 8123 3/8 pounds. Additionally, Derck manufactured 60 iron hammers weighing 475 pounds in total and thirty-five clappers, weighing 523 pounds in total. ${ }^{572}$ The estimated weight of all bells and the largest bell is also noted on the coloured illustration, featured in the manuscript of Johann Ephraim Eggert, which presents the location of bells in the St Catherine tower:

Die Glocken wiegen 9000. tt. davon No: 1 da $\beta$ Große C alleine 1700. tt. wiegt. ${ }^{573}$

This source lists (in a small table placed in the lower right corner of page vii of the manuscript) the dimensions of each bell: height and diameters, given in ells and inches (see Fig. 88).

The bells were hung in the tower in eight groups of three, five, or six. The lowest bell, C4, was placed centrally. Each bell had a clapper and one or two hammers: ten had one and twenty-five, two.

The illustration in Eggert's manuscript shows clearly that the bells were ornamented on the top part of the waist, just underneath of the shoulder. They were placed on three decorations bands, which unfortunately Eggert rendered in such a way that they are not readable. The outer decorations bands feature vegetal patterns, while the middle one, a blurred text. According to the last point of the contract between Jan Nicolaas Derck and Johannes Smit, the former was supposed to press both surnames on the bells. Usually, inscriptions on bells included the names of the dedicatees: saint patrons, bell founders, or benefactors. It cannot be excluded, however, that Derck honoured the contract and places both his own name and that of merchant Johannes Smit.

The Old Town carillon featured a manual keyboard and a pedalboard. The former encompassed the instrument's full range, with thirty-five keys, while the latter included the lower register only, limited to eighteen keys. They keys were made of oak wood. ${ }^{574}$

Concertising on bells proved an insufficient use of the carillon, with the Old Town councillors soon deciding to commission a mechanism for automated play. The task

572 Spruijt, 76.

573 APG 300,R/Pp,45, p. vii.

574 The number of keys in the keyboard and pedalboard is quoted by Paul Krieschen in his description of the carillon after the 1905 fire; see APG 353/149, pp. 167-74. 
was given to well-known Gdańsk clockmaker Daniel Böttcher. ${ }^{575}$ A contract was signed on 19 November $1740,{ }^{576}$ and the following year the mechanism was ready.

In 1926, Bruno Meyer wrote that the drum manufactured by Böttcher was wooden ("eine hölzerne Waltze" ${ }^{\text {"577) }}$ ). This seems controversial, though in early stages of carillon development, wooden drums were occasionally used. ${ }^{578}$ Christian Friedrich Wutstrack, who described the Old Town carillon at the beginning of the nineteenth century, mentioned wooden slats fixed to the drum. ${ }^{579} \mathrm{~A}$ similar account is offered in 1888 by Otto Krieschen. ${ }^{580}$ Externally, therefore, the drum looked as if made of wood, but the wheels, to which the slats were fixed, also wooden? I believe Meyer's remark should be disregarded and we should assume clockmaker Daniel Böttcher made the drum's construction from metal, with only slats made of wood.

The drum diameter was $2.06 \mathrm{~m}$ and the length, $1.4 \mathrm{~m}$. The construction included three rings, linked by 120 oak slats ("eichenen Latten"). A single slat was composed of two equal parts two inches long and $5 / 8$ inches thick. ${ }^{581}$ The extremities of the slats were screwed to outer rings and linked to the middle one to create a single unit. Each slat part featured thirty holes (thus sixty in total), the number matching that of hammers fixed to bells. In the holes, pins were placed used for programming tunes on the drum. Every fifth slat was numbered, making it easier to programme music. Tunes for full hours was programmed on seventy-five slats, while those for half-hours on thirty-five. The remaining ten slats were used to programme short tunes for the quarter-hours, and occasionally for short signals every half-quarter.

The drum manufactured by Daniel Böttcher remained in use for over a century. It was changed in 1862 , as stated by Bruno Meyer. A new drum was prepared by Sinkenbring, a locksmith, as told Meyer by the sexton, named Schmidt. ${ }^{582}$ Sometime later, engineers from the Klawitter ship works and employees of the

575 Daniel Böttcher was active as a clockmaker in the years 1734-73, see Januszajtis, Gdańskie zegary, dzwony i karyliony, 55; Kaczor, 'Gdańskie rzemiosło zegarmistrzowskie od XVI do XVIII wieku', Appendix 2, 67; see also the entry in Prószyńska, 'Słownik gdańskich zegarmistrzów i gnomoników', 134.

576 APG 300,R/LI,96, p. 146. The contract has not survived.

577 Meyer, 'Die Glockenspiele auf St. Katharinen in Danzig', 6-7, 10. Drums were mostly made of metal. See Lehr et al., 'Glocken und Glockenspiele', col. 1469.

578 Rombouts, Singing Bronze, 123.

579 APG 300,R/LI,96, p. 146.

580 DZ 1888 no. 17408 (30 November).

581 APG 300,R/LI,96, p. 146.

582 Meyer, 'Die Glockenspiele auf St. Katharinen in Danzig', 10. 
Heyking brothers' company concluded renovation work on the carillon. ${ }^{583}$ Paul Krieschen also mentions the replacement of parts of the mechanism in 1893 when describing the fire destruction of 1905. Krieschen also lists dimensions of the drum that are slightly higher than Böttcher's: $2.5 \mathrm{~m}$ in diameter and $1.75 \mathrm{~m}$ in length. That drum had 120 iron slats fixed to it, composed of two parts, as the earlier wooden slats. Each part featured thirty holes for fixing pins. ${ }^{584}$

That metal drum was lost in the tragic fire of 3 July 1905. The only remains were three fire-bent slats measuring $124 \times 5 \times 1 \mathrm{~cm}$, which were kept in the church archive at the time of Krieschen's writing. ${ }^{585}$

The fourth Gdańsk Old Town carillon, built in 1910, was supposed to be a copy of the earlier version, but in fact differed from it significantly. First, it was composed of thirty-seven bells instead of thirty-five. Second, the bells had a different profile, modelled on those of Joris Dumery (1701-65) and his carillon in Bruges. Third, the total weight was several times that of the 1738 carillon. In the contract, Franz Schilling declared he would cast bells weighing a total of $17,326 \mathrm{~kg}$. In reality, they weighed less: $16,760 \mathrm{~kg}$, but the new carillon still belonged to the world's heaviest. The weight of the lowest bell was $2855 \mathrm{~kg} .{ }^{586}$

The scale of the new carillon spanned three octaves, from C4 through C7. Two bells added to the 1738 set completed the lowest octave with the missing notes C\#4 and D\#4, giving a full chromatic series. The mechanism was also connected to two church (chime) bells: $\mathrm{A}_{b}$ and $\mathrm{B}_{b} .^{587}$

Franz Schilling adorned the bells with a vegetal and flowery ornament, placed on the decoration band along the bell's shoulder. On the waist, he pressed a letter stating the pitch and the date "1908." On the A4 bell, he left the following inscription: "Franz Schilling in Apolda goss mich."

The bells were equipped with clappers and a larger number of hammers compared to the 1738 carillon. Twenty bells received two hammers each (forty in total), while the seventeen highest bells, three hammers each (fifty-one in total). In total, the carillon bells were equipped with ninety-one hammers. Two each were further added to the chime bells, linked to the carillon mechanism. ${ }^{588}$

583 Blech, 'Das alte und das erneute Glockenspiel', 18.

584 APG 353/149, pp. 167-74.

585 Meyer, 'Die Glockenspiele auf St. Katharinen in Danzig', 10.

586 Januszajtis, Gdańskie zegary, dzwony i karyliony, 133.

587 Januszajtis, 134.

588 Januszajtis, 134. 
The metal drum of the fourth St Catherine's carillon was larger than the preceding one. Although narrower in diameter with just $2.2 \mathrm{~m}$, its length was increased to $2.2 \mathrm{~m}$. On the drum's outer ring, 180 series of holes were made, ninety-five in each series: ninety-one for carillon bells and four for chime bells. In total, the new drum had 17,100 holes, into which pins were inserted to programme music and sound signals. In front of the drum, a metal rail was mounted showing the scale of the carillon to facilitate music programming. ${ }^{589}$

The keyboard possessed a full-scale manual as well as a pedalboard for the lowest bells. ${ }^{590}$ It was placed in a small room, protecting the carillonist from the powerful sound of the bells and the noise of the carillon mechanism..$^{591}$

\section{Functions of the carillon}

\subsection{Time measurement}

Time measurement by the carillon of the church of St Catherine became possible in 1741 when it was equipped with a mechanism for automated play. For over two centuries, the automaton was set to various frequencies: every halfhour, every quarter, or every seven and a half minutes, contrarily to the "singing clock" of the Main Town Hall, which for its entire existence (from 1561 to 1945) was always triggered with the same frequency, before the clock chimed the full hour. The Old Town carillon was programmed by the carillonist. $\mathrm{He}$ was assisted by a "clock winder" ("Uhraufwinder"), ${ }^{592}$ whose tasks included the unscrewing and screwing of pins that served to programme tunes on the drum, maintenance work on the instrument, and winding the clock's weights twice a day. The mechanism operated round the clock, with music resounding also in the night.

In the first decades after it was installed, the automaton was triggered every quarter of an hour, as indicated by the manuscript (now lost) of Eltjen Wolthers. ${ }^{593}$ Later, the frequency was increased to every seven and a half minutes. This happened at the end of the life of councillor Johann Anthon von

589 Meyer, 'Die Glockenspiele auf St. Katharinen in Danzig', 12-15.

590 Meyer, 16, writes that the pedalboard included twenty pedals, while Edel, 'Aus Danzigs Eigenart', 181, lists sixteen.

591 Meyer, 'Die Glockenspiele auf St. Katharinen in Danzig', 16.

592 Dariusz Kaczor uses the term "clock supervisor" instead of "clock winder." See Kaczor, 'Wstęp', 22, 24.

593 Meyer, 'Die Glockenspiele auf St. Katharinen in Danzig', 7-8. 
Waesberghe (Waesberge, Wassberge; d. 1776), who suffered from arthritis and was bed-ridden; he requested that the bells sound in seven and a half-minute sequences. ${ }^{594}$ This frequency is confirmed by the accounts of Christian Friedrich Wutstrack from the early nineteenth century and Wilhelm Ferdinand Zernecke from 1843:

Das Glockenspiel intonirt alle halbe Viertel- und ganze Viertel-Stunden, spielt alle halbe Stunden volstimmig die ganze Melodie, und alle ganze Stunden mit einem Präludio zweimal die Melodie eines geistlichen Liedes und zwar das zweite Mal mit Variationen. ${ }^{595}$

It plays a chorale verse not only before every full and half-hour but also every quarter and half-quarter so that those beautiful, pure sounds become too many. ${ }^{596}$

I am unable to determine precisely how long the half-quarter frequency was maintained. A return to a quarter frequency likely coincided with the installation of a new metal drum, which according to Bruno Meyer, took place in $1862 .{ }^{597}$ Quarter-hour frequencies are also mentioned in 1905 by Paul William Krieschen ${ }^{598}$ and 1888 by Otto Krieschen:

Vor dem Schlage der vollen Stunde wird ein längerer Choral, vor dem Schlage der halben Stunde ein kürzerer von dem Uhrwerke gespielt; außerdem erklingt in der Viertel- res[pective] Dreiviertelstunde dei erste Strophe des Chorals, welcher in der darauf folgenden halben resp[ective] ganzen Stunde gespielt wird. ${ }^{599}$

The automaton of the last pre-war carillon was only triggered twice every sixty minutes: before the half-hour and full hour chime. It was the duty of Georg Edel to programme a longer two-voice chorale for full hours and shorter, one-voice tunes (ending with a chord) for half-hours. ${ }^{600}$

The programme on the drum of the Old Town carillon was changed once per week, on Saturdays, as was the case with the Main Town Hall automaton. This procedure is mentioned by Johann Ephraim Eggert in his 1803 account of his

594 Löschin, Geschichte Danzigs, 2:179. Johann Anthon von Waesberghe died on 24 February 1776; see Zdrenka, Rats- und Gerichtspatriziat der Rechten Stadt Danzig, 2:315.

595 APG 300,R/LI,96, p. 146.

596 Zernecke, Cały Gdańsk za dwadzieścia srebrnych groszy, 79.

597 Meyer, 'Die Glockenspiele auf St. Katharinen in Danzig', 10.

598 APG 353/149, pp. 167-74.

599 DZ 1888 no. 17408 (30 November).

600 APG 353/231, pp. 217-19. 
own duties, edited on the request of the School and Church College, ${ }^{601}$ and at about the same time by Christian Friedrich Wutstrack:

In die Walze wird die Melodie eines Liedes durch die Glockenisten abwechselnd jeden Sonnabend mit eisernen Stiften, welche Noten heißen, für jede Woche, nach den Jahresund Festzeiten gesetzt. ${ }^{602}$

The procedure of reprogramming tunes every Saturday between eight and eleven in the morning is also mentioned in the contract of Friedrich Wilhelm Pfahl of 1840. That document also indicates that tunes for Easter should be programmed on Good Friday afternoon or evening so that they are ready to play on Holy Saturday from eight o'clock. ${ }^{603}$ Thus similarly to the Main Town Hall automaton, its Old Town counterpart signalled liturgical calendar holidays in a special way. However, I have no more detailed data on those. Only in a later period, announcements in the Danziger Zeitung confirm this festive procedure, but only with reference to Christmas.

Who decided the tunes that appeared on programmes throughout the year? Gottfried Lengnich, describing the laws and institutions of Gdańsk, stated:

Der wortführende Herr ... giebt die wöchentlichen Lieder zum Glockenspiel ${ }^{604}$

meaning that from the Second Partition of Poland in 1793, the programming of tunes to be performed by the automaton was the duty of the Council Spokesman (Wortführender Herr). ${ }^{605}$ In practice, this likely meant merely the acceptance of a programme edited by the carillonist. But did the Magistracy approve programmes also in the nineteenth century? We do not know. The contract of the last carillonist Georg Edel indicates that he would have consulted the automaton programme with the pastor of the Old Town church. ${ }^{606}$

601 APG 353/231, p. 3, quoted after Kaczor, 'Wstęp', 22.

602 APG 300,R/LI,96, p. 146.

603 APG 353/231, pp. 59-64.

604 Gottfried Lengnich, Ius publicum civitatis Gedanensis oder der Stadt Danzig Verfassung und Rechte, 1769. Nach der Orginalhandschrift des Danziger Stadtarchivs, ed. Otto Günther, Quellen und Darstellungen zur Geschichte Westpreussens 1 (Danzig: Theodor Bertling, 1900), 214.

605 Dariusz Kaczor replaces the term "Wortführender Herr" with "chairman of the Old Town Council.” See Kaczor, 'Wstęp', 20; cfr. Zdrenka, 'Rada Miejska', 858-59. 606 APG 353/231, pp. 217-19. 


\subsection{Signalling of events}

From the carillon tradition, starting with the "singing mechanism" of the Main Town Hall, the following customs were borrowed: playing during elections for the Old Town Council, on the opening and closing day of the St Dominic's Fair, and during the funerals of prominent citizens of the Old Town.

Nonetheless, the carillon played for the first time during elections for the Old Town Council in 1786. This information transpires from the resolution of 7 April 1785 of the Old Town Council, ${ }^{607}$ which requested the carillonist to play the chorale Komm heiliger Geist Herre Gott on the election day, starting before the clock chimed nine oclock in the morning and repeating after the hour. The chorale should then be intoned in the same away every half-hour until midday. Thus, the Komm heiliger Geist Herre Gott was played in the Old Town according to the pattern used during elections in the Main Town. In 1793, the custom was discontinued after the Second Partition of Poland.

The tradition of carillon playing for the opening and closing of the St Dominic's Fair was somewhat different and continued in the following centuries. Several documents confirm this tradition: a work contract of Friedrich Wilhelm Pfahl of 1840; receipts for payment to carillonists from the eighteenth and nineteenth centuries; the contract of Paul William Krieschen of 1895; and his account of the destroyed carillon of $1905 .{ }^{608}$

On the occasion of the St Dominic's Fair, the city's prime commercial event, the St Catherine carillon played in a less schematic way than the Main Town Hall instrument. On the opening and closing day of the Fair, the carillonist was expected to concertise at eleven oclock for an hour. The contract of Friedrich Wilhelm Pfahl stated that he should programme two songs for the given week of the liturgical calendar, with the remaining repertoire left to his discretion. ${ }^{609}$

The Old Town carillon was also played during funeral ceremonies of citizens of the Old Town. However, its use on those occasions is less well documented than that of the Main Town Hall automaton. Dariusz Kaczor theorises that the carillon funeral music began as early as 1741, based on the record of a donation by councillor Gottfried König, who on 12 June that year offered 1000 florins for the maintenance of the carillon in exchange for playing funeral tunes during the funeral of his sister. ${ }^{610}$

607 APG 300,41/10, p. 307, quoted after Kaczor, 'Wstęp', 22.

608 APG 353/231, pp. 59-64, 93-94, APG 353/149, pp. 167-74.

609 APG 353/231, pp. 59-64.

610 Kaczor, 'Wstęp', 22. 
The programming of funeral tunes on the automaton's drum and their playing by carillonists on the keyboard was mentioned on 19 September 1803 by Johann Ephraim Eggert in a statement made for the School and Church College. Eggert stresses that musicians played and programmed tunes alternately, meaning that there were two carillonists employed at St Catherine's in that time, and funeral service was assured by the carillonist on duty in any given week: ${ }^{611}$

Nur noch bei Sterbefällen, bey welchen Todtenliedern zu spielen nachgegeben worden, wird auf dem Clavis solches von uns abwechselnd bewürket und zwar die Walze dazu eingerichtet oder die Lieder gesetzet. ${ }^{612}$

We do not know precisely whose death was announced by the Old Town carillon. In analogy to the Main Town Hall carillon practice, we can infer that it was used primarily for deceased members of the Old Town Council and their family members. Perhaps, though, the practice was extended to anyone who was able to pay for the service, as suggested by the statement of Johann Ephraim Eggert, who mentioned that carillonists received payment from the deceased person's family; this practice differed from that of the Main Town Hall, where carillonists were paid from the city treasury. Since carillon use during funerals is also mentioned in 1905 by Paul William Krieschen, ${ }^{613}$ we can assume the practice survived until the destruction of the church and carillon in the tragic fire.

Another confirmation of the contribution of the St Catherine carillon to the funerals of Old Town councillors is to be found in the manuscript of Johann Ephraim Eggert of 1784, which includes settings of many funeral songs. These vary in length, with the longer settings for programming on full hours, and shorter ones for half-hours, as well as being adapted to manual play.

I have only two pieces of information about the carillon being used on the occasion of other social or political events in Gdańsk and beyond. The first is a mention by Ernst Blech that after the unsuccessful assassination attempt on King Stanislaus Augustus Poniatowski, on 10 November 1771 the carillon played a thanksgiving Herr Gott dich loben wir. ${ }^{614}$ The other is an announcement in the Danziger Zeitung of 25 August 1910 of two songs programmed on the automaton (Großer Gott wir loben Dich and O dass ich tausend Zungen hätte) on the occasion of the planned visit, two days later, of Emperor Wilhelm II and his wife. ${ }^{615}$

611 I address the rules of hiring carillonists at St Catherine's later in this book, including management and maintenance as well as funding.

612 APG 353/231, p. 4.

613 APG 353/149, pp. 167-74.

614 Blech, 'Leidensjahre von St. Katharinen in Danzig', 165.

615 DZ 1910 no. 396 (25 August). 


\subsection{Daily and occasional concertising}

Apart from signalling social events such as elections to the Old Town Council, the beginning and end of the St Dominic's Fair, deaths and funerals of Old Towns citizens, carillonists of the church of St Catherine also had another duty: concert play.

Eltjen Wolthers, who was officially hired in November 1738, played two halfhour concerts a day: at eleven in the morning and four in the afternoon (in the winter, at three). This information is given by Bruno Meyer based on documents now lost: the account of town clerk Salomon Jantzen of around 1740 and the letter of Eltjen Wolthers to councillor Gottfried König of $1750 .{ }^{616}$

In later times, likely after the departure of Wolthers, carillonists played once per day. In the period running from the day of St Michael's (29 September) to Easter, they played from eleven to half-past twelve in the morning, and from Easter to St Michael's as follows: Monday through Saturday as above, Sundays and holidays in the afternoon, usually from five to half six. These playing times are quoted in 1803 by Johann Ephraim Eggert in his account for the School and Church College. ${ }^{617}$ Yet just a few years later, the rules were changed. Christian Friedrich Wutstrack stated that concert play only took part on Sundays and holidays, from eleven to half twelve, and in the period between Easter to St Michael's, from five to half six in the afternoon. ${ }^{618}$ Dropping everyday concert play was likely the result of political events, wars, the entry of Napoleon's army into Gdańsk, political changes, difficult living conditions, and finally the redundancy after the death of Johann Ephraim Eggert ${ }^{619}$ of the second carillonist position. Only one musician became employed from that point: Carl Friedrich Eggert, the former second carillonist.

Daily concertising was reinstated briefly after the hiring of Friedrich Wilhelm Pfahl, when two carillonists were employed again. In Pfahl's contract of 1840, a provision was made that carillonists should play thirty-minute concerts throughout the year at eleven in the morning and additionally, from Palm Sunday through harvest feast ("Erntedankfest") on each Sunday and holiday also at five in the afternoon. ${ }^{620}$ Concert play had a limited scope: the contract stated

616 Meyer, 'Die Glockenspiele auf St. Katharinen in Danzig', 9-10.

617 APG 353/231, pp. 3-4.

618 The chronicle of Christian Friedrich Wutstrack was written in 1807; see APG 300,R/ LI,96, p. 147.

619 We do not know the death date of Johann Ephraim Eggert. The last certain date of his life is 19 September 1803, when he made a statement for the School and Church College.

620 The "Erntedankfest" (harvest feast) was celebrated on the first Sunday after St Michael's (29 September). 
that the morning sessions should include a short prelude ("Vorspiel") followed by two songs consistent with the liturgical calendar, while afternoon concerts should include two chorales. ${ }^{621}$

This pattern of concertising was described in 1888 by Otto Krieschen, though he does not set a precise time limit for the summer period ("im Sommer"). ${ }^{62}$ In later years, the frequency of concertising was reduced. Characterising the carillon destroyed in the 1905 fire, Paul William Krieschen mentions that it was played for thirty minutes before noon every day with the exceptions of Saturdays, Sundays, and holidays. ${ }^{623}$ This limitation of concert play was allowed probably when Paul William Krieschen remained with no official helper after he became main carillonist at the death of his father Julius Johann Krieschen (on 2 February $1895^{624}$ ) - and he had a lot of duties, being also the main bell setter of the Main Town Hall. ${ }^{625}$

Georg Edel's employment contract of 18 September 1924 includes the duty of concertising each day before noon. ${ }^{626}$ But in 1926 Bruno Meyer noted that the carillon concerts at St Catherine's took place every day with the exception of Saturdays and Sundays. ${ }^{67}$

Apart from these patterns of concert play, carillonists were obliged to several permanent performances throughout the year, on the eves of the first Sunday of Advent, Christmas, and the New Year, at eight, nine, and ten in the evening. This provision can be found in the contracts of both Friedrich Wilhelm Pfahl ${ }^{628}$ and Georg Edel, the last Old Town carillonist. ${ }^{629}$

Carillon play on the eve of the first Sunday of Advent followed a characteristic pattern, consistent with the Gdańsk tradition of signalling the end of the liturgical year. On that evening, chorales were played by trumpeters, trombonists, and hornists from the towers of several of the city's churches: St Mary, St John, St Catherine, and in 1926, also the Holy Trinity church. The concert started at seven or eight in the evening. As the chorales were played on one of the towers, the carillon of St Catherine's answered. During the following hours, Advent songs were played from subsequent towers, followed each time by a setting on

621 APG 353/231, p. 60.

622 DZ 1888 no. 17408 (30 November).

623 APG 353/149, pp. 167-74.

624 APG 1609/509 no. 278.

625 DZ 1907 no. 24 (15 January).

626 APG 353/231, pp. 217-19.

627 Meyer, 'Die Glockenspiele auf St. Katharinen in Danzig', 17.

628 APG 353/231, pp. 59-64.

629 APG 353/231, pp. 217-19. 
the Old Town carillon. This unique music-making tradition was described by the Danziger Zeitung in announcements running yearly from 1910. In 1929, the programme was as follows:

Adventsklänge aus den Türmen. Wieder ist die schöne Adventszeit herangenaht, in der wir von den Glockenspielen unserer Stadt die herrlichen Adventslieder "Wie soll ich dich empfangen" und "Gott sei Dank durch alle Welt" klingen hören. Heute abend nun - um 7 Uhr, von Katharinen, um 8 Uhr von St. Marien und 9 Uhr von St. Johann werden wir außer den bereits gennanten Liedern noch den herrlichen Adventschoral "Wachet auf, ruft uns die Stimme", geblasen von einem Posaunnenchor, hören. In der Zwischenzeit bringt der Rats- und Katharinenglockenist Edel, dessen kunstfertiges Spiel wir ja täglich um $11 \mathrm{Uhr}$ vormittags vernehmen, auf St. Katharinen außer den geblasenen Adventschorälen noch mehrere Adventslieder zu Gehör.

Auch von St. Trinitatis erschallen seit einigen Jahren Posaunenchöre an diesem Tage herab und bringen Advents- und Weihnachtsstimmung in die Herzen der lauschenden Menschen. Möchte doch dieser alte Danziger Brauch sich auch auf die andern Gemeinden Danzigs erstrecken. ${ }^{630}$

From the 1870s, carillonists also played a concert on 2 December, following the wish of master baker Carl Wilhelm Körner, ${ }^{631}$ who donated a sum of money for the maintenance of the carillon, ${ }^{632}$ in exchange asking for music to celebrate his death anniversary. ${ }^{633}$ The "memorial concert" started at noon and lasted for an hour. The tradition continued until the carillon was dismantled in 1942; in any case, the obligation to perform music on that day is included in the contract of Georg Edel. ${ }^{634}$

In late October 1938, a cycle of music concerts, meetings, and lectures was organised in Gdańsk under the title "Die ostdeutsche Kirchenmusiktagung," concluded on 30 October with a performance of Bach's St John Passion at the church of St Mary. The announcement and later press reviews indicate this was an event of some stature. The official welcome address took place at the Old Town Hall on 26 October at eight in the evening, and an hour earlier, "tower music" and "carillon music" was heard from the St Catherine tower. A celebration article was written for Danziger Neueste Nachrichten by Konrad Krieschen,

630 DZ 1929 no. 332 (30 November).

631 Likely for the first time in 1879; see APG 353/232, p. 915; APG 353/240, pp. 6, 12, 20.

632 APG 353/232, p. 907.

633 DZ 1888 no. 17408 (30 November).

634 APG 353/231, pp. 83-84, 217-19. 
organist of St Mary. ${ }^{635}$ The following day the press wrote about Georg Edel's improvisations and performance of his own chorale-based composition (Thema mit Variationen) and Handel's sonata:

Organist Georg Edel improvisierte über mehrere Choräle und erwies in einer gehaltvollen eigenen, "Thema mit Varationen« betitelten Kompositionen seine innige Vertrautheit mit dem von ihm seit Jahren betreuten Glockenspiel. Auch trug er mit virtuoser Beherrschung eine Weltfreudigkeit atmende Glockensonate von Georg Friedrich Händel vor. ${ }^{636}$

\section{Carillonists: Eltjen Wolthers and his successors}

A list of carillonists of the church of St Catherine was first compiled by Andrzej Januszajtis in 2000. ${ }^{637}$ Research since that time allowed to complete and amend that list, though satisfactory answers to some biographical queries have still not been found. Between 1738 and 1942, the following carillonists were active at the church of St Catherine:

Tab. 12: Carillonists of the church of St Catherine

First (or only) carillonist

\begin{tabular}{|c|c|c|c|}
\hline \multirow{2}{*}{\multicolumn{2}{|c|}{ Years of work }} & \\
\hline Name & & Name & Years of work \\
\hline Eltjen Wolthers & $1738-48 ?$ & & \\
\hline Daniel Rothländer & $1754 ?-66$ & Carl Gottfried Busch & $1754 ?-66$ \\
\hline Carl Gottfried Busch & $1766-98$ & Johann Ephraim Eggert & $1766-98$ \\
\hline Johann Ephraim Eggert & $1798-1803 ?$ & Carl Friedrich Eggert & $1794-1803 ?$ \\
\hline Carl Friedrich Eggert & $1803 ?-43$ & Friedrich Wilhelm Pfahl & $1836-43$ \\
\hline \multirow[t]{2}{*}{ Friedrich Wilhelm Pfahl } & $1843-81$ & Carl Friedrich Müller & $1843-66$ \\
\hline & & Julius Johann Krieschen & $1866-81$ \\
\hline Julius Johann Krieschen & 1881-95 & Paul William Krieschen & 1882-95 \\
\hline Paul William Krieschen & $1895-1905$ & Walter Krieschen & $1895-1905$ \\
\hline \multicolumn{4}{|c|}{ 1905-1910 Construction of a new carillon } \\
\hline Paul William Krieschen & $1910-20$ & Gustav Krieschen & $1912-20$ \\
\hline Gustav Krieschen & $1920-24$ & Georg Edel & $1923-25$ \\
\hline Georg Edel & $1925-42$ & & \\
\hline
\end{tabular}

635 DNN 1938 no. 251 (26 October).

636 DNN 1938 no. 252 (27 October).

637 Januszajtis, Gdańskie zegary, dzwony i karyliony, 150. 
For most of the Old Town carillon's activity, two musicians were simultaneously employed for its programming and concert playing. The double occupancy was decided after the first carillonist, Eltjen Wolthers, left Gdańsk in 1748. ${ }^{638}$ Two successors were referred by Wolthers himself: Daniel Rothländer and Carl Gottfried Busch, ${ }^{639}$ and as Old Town councillors could not agree on the better candidate, they decided to hire both. ${ }^{640}$ That solution had undoubted advantages, securing the operativity of the carillon in the case of an illness or absence of one of the musicians. Dariusz Kaczor dates the first archival mention of two musicians being hired at 4 April $1754 .{ }^{641}$

The practice of dual employment survived until the death of Johann Ephraim Eggert after 1803. At that point, no new carillonist was hired, with Eggert's duties taken over by his nephew Carl Friedrich, the hitherto second carillonist. I believe the relinquishment of dual employment resulted from changes in the carillon's management, a decrease in living standards of Gdańsk burghers, and a stagnation in cultural developments after the city was removed from the PolishLithuanian Commonwealth in 1793.

With time, again under the influence of administrative changes after Gdańsk was reincorporated into Prussia, the practice of hiring two carillonists was resumed. Surviving sources suggest this happened no earlier than the 1830s. In 1836, Friederich Wilhelm Pfahl was employed to assist the ageing Carl Friedrich Eggert ${ }^{642}$ but only in 1840 was he officially recognised as the second carillonist. ${ }^{63}$ Double employment was practiced in subsequent decades, formally until 1895, the death of Julius Johann Krieschen. Paul William Krieschen, taking over the position from his father, agreed to hire a helper at his own expense. Simultaneously he asked for his former salary as second carillonist to be paid to his mother, the widow of Julius Johann Krieschen. ${ }^{644}$ Authorities obliged; consequently, two carillonists continued to work at St Catherine's, but only one was formally remunerated. Paul William Krieschen was helped successively by his

638 Based on APG 300,41/7, p. 335, Dariusz Kaczor states that the last quarterly payment was made to Wolthers on 18 November 1748; see Kaczor, 'Wstęp', 23.

639 Meyer, 'Die Glockenspiele auf St. Katharinen in Danzig', 10.

640 APG 353/231, pp. 6-7.

641 APG 300,41/7, p. 478, quoted after Kaczor, 'Wstęp', 23.

642 APG 353/231, pp. 43-46.

643 APG 353/231, pp. 59-64.

644 Julius Johann Krieschen died on 2 February 1895; see APG 1609/509, Nr. 278. Formally, Paul William Krieschen was hired as first carillonist on 1 July 1895; see APG 353/231, pp. 79, 83, 85-87, 93-94. 
two sons: first Walter Krieschen, likely until the church's fire and destruction of the carillon in $1905,{ }^{645}$ and then from 1912 by Gustav Krieschen. ${ }^{646}$ Gustav was formally employed only after Paul William Krieschen retired in 1920. Initially, Gustav Krieschen had no helper. He had difficulty fulfilling his obligation, as the Foth company, where he was employed as a watchmaker, did not agree for him to play the carillon every day at the customary time of eleven oclock. ${ }^{647} \mathrm{In}$ 1924, Gustav Krieschen gave up his position at St Catherine's. A year prior, in 1923, Georg Edel started working at the Old Town carillon, ${ }^{648}$ becoming officially employed on 1 January 1925 . He had no problem fulfilling his duties and worked alone until 1942 when the bells were dismantled.

All carillonists at St Catherine's were musicians, apart from Walter Krieschen. They played the organ but also had other occupations: tower piper, music teacher, army musician, choirmaster. We know that three were composers. Eltjen Wolthers and Johann Ephraim Eggert focused on works for the carillon and authored collections of Protestant chorale settings. Georg Edel wrote, apart from works for the carillon, a cantata, songs, organ, and chamber works. Some carillonists also worked outside the world of music, as watchmakers, goldsmiths, workers, and mechanicians. They made a living selling musical instruments, sheet music, organising lotteries, concerts, and even running a textiles shop.

Tab. 13: Occupations and activities of St Catherine's carillonists

\begin{tabular}{|c|c|}
\hline Carillonist $^{649}$ & Occupation/activity \\
\hline Eltjen Wolthers & composer, chorale arranger for the carillon \\
\hline Daniel Rothländer ${ }^{650}$ & organist at the St Bartholomew church \\
\hline $\begin{array}{l}\text { Carl Gottfried } \\
\text { Busch }^{651}\end{array}$ & organist at the St Catherine church \\
\hline $\begin{array}{l}\text { Johann Ephraim } \\
\text { Eggert }\end{array}$ & $\begin{array}{l}\text { composer, tower piper, organist at the Corpus Christi church, lottery } \\
\text { organiser, musical instrument and scores merchant }\end{array}$ \\
\hline
\end{tabular}

(continued on next page)

645 APG 353/231, p. 139.

646 APG 353/231, pp. 191-93.

647 APG 353/231, p. 215.

648 Quoted after a 1935 article by Edel himself; Edel, 'Aus Danzigs Eigenart', 180.

649 A note lacking at the name indicates that the carillonist in question is discussed in detail later in this subchapter.

650 Rauschning, Geschichte der Musik und Musikpflege in Danzig, 318, 323, 348, 422.

651 Rauschning, Geschichte der Musik und Musikpflege in Danzig, 381, 422. 
Tab. 13: Continued

\begin{tabular}{|c|c|}
\hline Carillonist $^{649}$ & Occupation/activity \\
\hline $\begin{array}{l}\text { Carl Friedrich } \\
\text { Eggert }\end{array}$ & organist at the St James church and Charity House, textiles store owner \\
\hline $\begin{array}{l}\text { Friedrich Wilhelm } \\
\text { Pfahl }\end{array}$ & organist at the Mennonites church \\
\hline $\begin{array}{l}\text { Carl Friedrich } \\
\text { Müller }\end{array}$ & $\begin{array}{l}\text { army musician, instrument builder ("Instrumentenmacher"), music } \\
\text { teacher, organist }\end{array}$ \\
\hline $\begin{array}{l}\text { Julius Johann } \\
\text { Krieschen }{ }^{63}\end{array}$ & organist at the church of St Catherine, goldsmith \\
\hline $\begin{array}{l}\text { Paul William } \\
\text { Krieschen }\end{array}$ & $\begin{array}{l}\text { rifle factory worker, watchmaker, organist at the St Barbara church, } \\
\text { singing teacher, choirmaster }\end{array}$ \\
\hline Walter Krieschen ${ }^{64}$ & mechanical engineer, technician \\
\hline Gustav Krieschen ${ }^{65}$ & organist at the St Salvator church, watchmaker \\
\hline Georg Edel & $\begin{array}{l}\text { organist at the St Salvator and St Barbara churches, choirmaster, } \\
\text { music teacher, composer }\end{array}$ \\
\hline
\end{tabular}

The first carillonist of the church of St Catherine was Eltjen Wolthers. Since in the source documents and scholarly literature, his name and surname appear in slightly different spellings, let us first discuss which is the correct one: Eltjen, Elthien or Eltje; Wolthers czy Wolters? In the present book, I have used the spelling "Eltjen Wolthers" as the one accepted in the Groningen Archive $^{656}$; this is also the spelling used in the manuscript of Juriaan Spruijt, in the copy of Wolthers' letter to Alkmaar organist Gerhardus Havingha of 24 September $1738 .{ }^{657}$

Eltjen Wolthers belonged to a family of carillonists, active in Groningen in the eighteenth century. Between 1705 and 1759, four musicians of that name played the carillon in the Martinitoren.

652 APG 353/231, p. 73; ABuch 1854, p. 116; DIB 1855 no. 232 (4 October), 2448.

653 Michalak, 'Organista i dyrygent chórów Julius Wilhelm Frühling', 210-11.

654 ABuch 1902, I, p. 219; ABuch 1925, I, p. 207.

655 ABuch 1922, I, p. 226; ABuch 1924, I, p. 219; ABuch 1925, I, p. 207.

656 RHCGA, accessed 27 August 2018, http://allegroningers.nl/zoeken-op-naam/ persons?ss=\%7B $\% 22 \mathrm{q} \% 22: \% 22$ Eltjen $\% 20$ Wolthers $\% 22 \% 7 \mathrm{D}$.

657 Spruijt, Beschrijving van Klokken, 76. 
Tab. 14: Carillonists of the Martinitoren in Groningen in the years 1705-59

Lucas Wolthers 1705-29

Wolther Wolthers 1729-34

Goosen (Gosen) Wolthers 1734-50

Eltjen (Elthien) Wolthers $1750-59^{658}$

We know of Lucas Wolthers that on 10 October 1719 he married Aaltjen Grobbema, a resident of Groningen and widow of Rudolph Wiardi. ${ }^{660}$ The couple had four children: ${ }^{69}$ son Goosen (baptised 28 April 1720) and three daughters, Johanna (baptised 28 August 1721), Namijna (baptised 21 May 1724), and Luckreesija (baptised 14 June 1729). Lucas Wolthers probably died in 1729. He was followed as carillonist at Martinitoren by Wolther Wolthers, likely his relative, and three years later Lucas' son Goosen Wolthers, then aged fourteen. In 1750, the position was taken over by Eltjen Wolthers, who had returned to his native Groningen after relinquishing his job in Gdańsk. It is difficult to establish the family relationship between Eltjen and the other Wolthers carillonists of the Martinitoren.

A few years before coming to Gdańsk, Eltjen Wolthers married Reintjen Doedens in Groningen. They had a son named Lucas, baptised on 6 October 1733 at the Martinitoren. ${ }^{661}$ There is no information of other offspring.

Officially, Wolthers' employment in Gdańsk commenced in early November 1738. The decision was taken by the Old Town Council. ${ }^{62}$ We know, however, that Wolthers arrived in the city several months before, at an unspecified date. It is possible that he accompanied the bells when they reached the city's port in May 1738. He was certainly present in the city in September when the carillon was installed at the St Catherine tower. As we remember, Wolthers was the first to question the

658 Martini carillon, accessed 27 August 2018, http://www.martinicarillon.nl/beiaardier_ toen.html.

659 RHCGA Collectie DTB Inventarisnummer 175, fol. 281v.

660 RHCGA Collectie DTB Inventarisnummer 149.

661 RHCGA Collectie DTB Inventarisnummer 150.

662 Based on APG 300,41/7, p. 38, Dariusz Kaczor states: “This information is given by an undated entry in the city book (liber memorandorum) of the Old Town, written between the entries for 6 and 13 November 1738. However, the book does not quote the content of the resolution, merely including a reference to an attachment, now lost." "This information comes from an undated entry (liber memorandorum) in the Old Town book in between entries for 6 and 13 November 1738. The book entry, however, does not record and actual content of the decree and instead refers to ab appendix that not longer exists.” See Kaczor, 'Wstęp', 37. 
quality of bells delivered by Jan Nicolaas Derck; on 24 September he wrote an indignant letter to Gerhardus Havingha, one of the two experts (the other being Juriaan Spruijt) who issued a positive assessment of the instrument. Wolthers also belonged to the group that on 3 October 1738 signed an opinion on Derck's work; in June that year, he travelled to Hoorn with eighteen bells and delivered them to be repaired. When Derck recast thirteen and retuned five, Wolthers received the work, officially accepted it on 16 September 1739, and returned with the bells to Gdańsk. He worked as Old Town carillonist at least until 1748: the last observed mention of his quarterly payment of 150 florins is recorded on 14 November that year. ${ }^{663}$ Wolthers left a collection of 171 chorale settings for the carillon, with remarks on setting tunes on the automaton's drum. Sadly, the manuscript, though mentioned by Bruno Meyer, appears not to have survived. ${ }^{664}$

Bruno Meyer also discussed the now lost correspondence of Eltjen Wolthers and his son Lucas, sent from Groningen to Gdańsk's Old Town councillor Gottfried König. In a letter from 1750, Eltjen thanks König for his referrals and a present for his son. He acknowledges the good that he experienced in Gdańsk. He takes the opportunity to recommend conservation works on the bells' hammers and renovation of the windows behind the keyboard bench. He also mentions that in the Netherlands, he tried to find a solid successor for his Gdańsk position, but the task proved daunting as the local carillonists, learning of the duties at Gdańsk's St Catherine's, preferred to stay at home: they led a more comfortable, less busy life in the Low Countries. For example, in Harlem the carillonist gave three concerts a week, while in Gdańsk he was supposed to play twice a day; in the former city, the drum was reprogrammed once every three months as opposed to once per week in Gdańsk. Carillonist in the Netherlands earned significant money playing during weddings and funerals; apparently, this remained rare in Gdańsk. ${ }^{665}$

Despite his criticism for the work conditions as a carillonist at St Catherine's in Gdańsk, Eltjen Wolthers must have felt uneasy in his hometown, as in 1751, he contemplated returning to Gdańsk. His correspondence with Gottfried König indicates that he offered his services to the city, asking for a high salary and a promise that his son Lucas would be offered his succession. Although he was not hired again, he did keep contacts with Gdańsk and Gottfried König. Bruno Meyer states that Eltjen Wolthers' son Lucas visited the city in 1755 and was received with honours. He applied for the position of carillonist, as we know, with no success. ${ }^{666}$

663 APG 300,41/7, p. 335, quoted after Kaczor, 'Wstęp', 23.

664 Meyer, 'Die Glockenspiele auf St. Katharinen in Danzig', 7-9.

665 Meyer, 'Die Glockenspiele auf St. Katharinen in Danzig', 9-10.

666 Meyer, 'Die Glockenspiele auf St. Katharinen in Danzig', 10. 
Johann Ephraim Eggert was a very important character for Gdańsk musical culture, even beyond the carillon. He is remembered not only as the author of Protestant chorale settings for the carillon, ${ }^{667}$ but also of a manuscript that catalogued the specifications of organs in Gdańsk and surrounding towns. ${ }^{668}$ Researchers had known and commented on both Egeert's manuscripts for a long time, but failed to research his biography. It was Dariusz Kaczor who vitally contributed to this area of scholarship, publishing a full account of Eggert's life in 2006, based on existing research and his own studies. In recent years, this knowledge has been further extended with new details. ${ }^{669}$

Johann Ephraim Eggert was born in Gdańsk on 1 November 1728. He was baptised on Sunday 7 November at the church of Corpus Christi. His parents were Daniel and Dorothea Eggert. ${ }^{670}$ Johann Ephraim had three brothers and three sisters. The family lived for many years at 1 , Neugarten Street. ${ }^{671}$

Tab. 15: Siblings of J. E. Eggert

\begin{tabular}{ll}
\hline Name & Baptism at the Corpus Christi church \\
\hline Johann Benjamin & 21 November $1723^{672}$ \\
Dorothea Elisabeth & 10 February $1726^{673}$ \\
Johann Abraham & 22 April $1731^{674}$ \\
Elisabeth & 11 February $1733^{675}$ \\
Johann Daniel & 2 October $1735^{676}$ \\
Regina Florentina & 14 April $1737^{677}$ \\
\hline
\end{tabular}

We do not know the occupation of Daniel Eggert senior, but apparently the musical interest ran deep in the family: both Johann Ephraim and his younger brother Johann Daniel were musicians. In adulthood, Johann Daniel worked as

667 Eggert, Choral-Lieder zu dem Glocken-Spiel.

668 PAN GD Ms 926: [Eggert Johann Ephraim], Orgeln in Danzig.

669 I discuss Johann Ephraim Eggert mostly based on the research of Dariusz Kaczor without quoting the sources referenced by this author, unless required by the remarks I add. See Kaczor, 'Wstęp', 39-40.

670 APG 353/231, p. 3; APG 349/208, p. 342.

671 Numbering in the source: APG 349/208, p. 342.

672 APG 349/208, p. 239.

673 APG 349/208, p. 291.

674 APG 349/208, p. 391.

675 APG 349/208, p. 424.

676 APG 349/208, p. 458.

677 APG 349/208, p. 478. 
organist at the church of All Angels and then at St Bartholomew's; he also traded in harpsichords and pianos. ${ }^{678}$ Later, the musical profession was also taken up by Johann Daniel's sons: Georg Friedrich (1765-1813) played the organ at the churches of the Holy Trinity and St Mary, was a sheet music and instruments merchant, as well as a piano teacher and tuner ${ }^{679}$; Simon Daniel Wilhelm (17681825) was organist at the Holy Trinity and St Mary and a piano trader ${ }^{680}$; elder Carl Friedrich, likely taught by his uncle Johann Ephraim, eventually became the carillonist of St Catherine's.

The first documented mention of Johann Ephraim Eggert's professional activity dates back to 15 May 1755 in the Old Town documents. Eggert initially worked at St Catherine's initially as a trumpeter, or "tower pieper" ("Thurm-Pfeiffer"), since Carl Henrich Dircksen was sworn in as his replacement on that day. ${ }^{681}$

The next confirmed information comes from 1766 and refers to his works as Old Town carillonist. After the death of Daniel Rothländer, the vacant position of first carillonist was taken by Carl Gottfried Busch, while that of the second carillonist went to Johann Ephraim Eggert. Both appointments were made on 25 July 1766. Following the custom, Eggert was notified of his duties and salary orally. ${ }^{682}$

Eggert worked as the second carillonist for thirty-two years. In 1798, after Carl Gottfried Busch died on 2 November, ${ }^{683}$ Eggert became the first carillonist.

Apart from his carillonist duties, Johann Ephraim Eggert was also active as organist at the church of Corpus Christi. Unfortunately, I have been unable to establish the dates of his employment there. One cannot exclude that he took up the position as early as 1755 when he terminated work as a tower piper ("TurmPfeifer") at St Catherine's. In his statement of 1803 for the School and Church

678 APG 348/586, pp. 538, 552, 574, 592, 640; WDAN 1774 no. 42 (22 October), p. 597; WDAN 1779 no. 30 (31 July), p. 385; WDAN 1781 no. 37 (15 September), p. 459; DaNa 1803 no. 63 (6 August), p. 800 (notes by Jerzy M. Michalak); Rauschning, Geschichte der Musik und Musikpflege in Danzig, 422.

679 APG 348/586, p. 574; DaNa 1799 no. 17 (27 February), pp. 146-47; DaNa 1799 no. 44 (1 June), p. 410; DaNa 1799 no. 62 (3 August), p. 624; DaNa 1805 no. 86 (26 October), p. 1495; DaNa 1805 no. 87 (30 October), p. 1513; DaNa 1807 no. 5 (17 January), p. 55 (notes by Jerzy M. Michalak).

680 APG 353/51, p. 422; APG 300,1/186, fol. 86rv; DaNa 1799 no. 46 (8 June), p. 436; DaNa 1799 no. 62 (3 August), p. 624; DaNa 1799 no. 63 (7 August), p. 642 (notes by Jerzy M. Michalak).

681 APG 300,41/7, p. 519.

682 APG 353/231, p. 3.

683 APG 353/231, p. 6. 


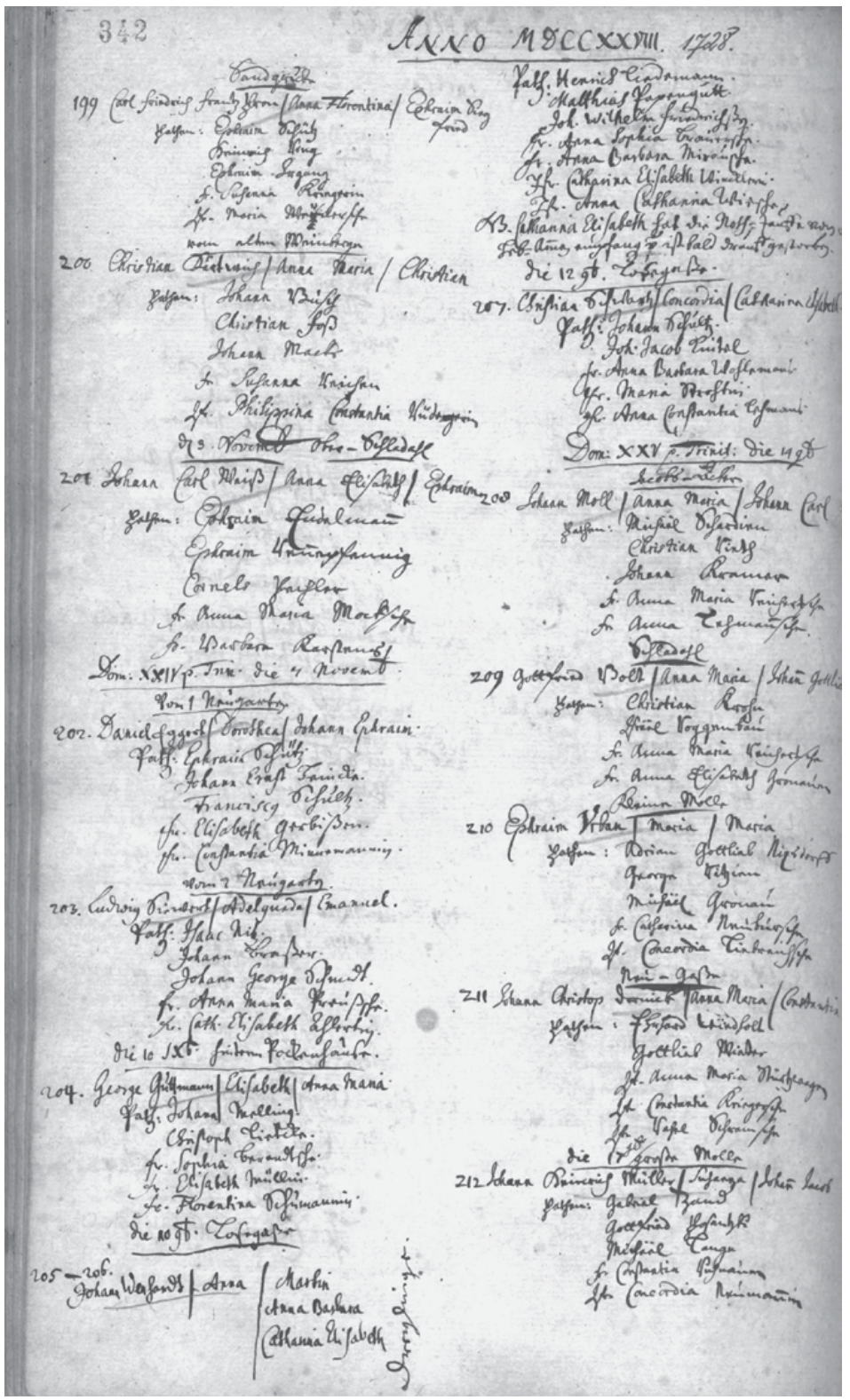

Fig. 49: Entry with information about the baptism of J. E. Eggert. APG 349/208, p. 342 


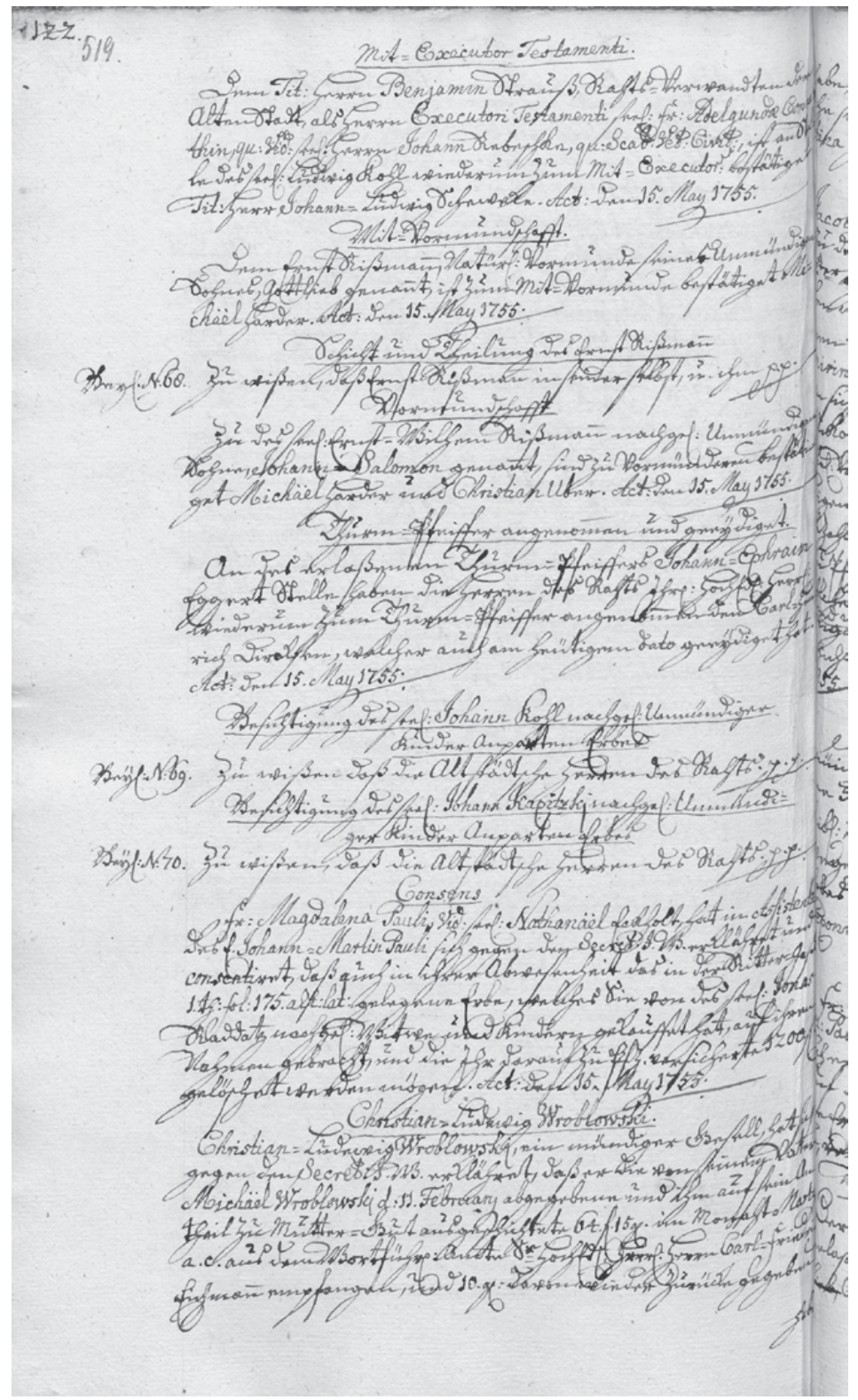

Fig. 50: Entry with information about the employment of C. H. Dircksen as trumpeter at the church of St Catherine, replacing J. E. Eggert. APG 300,41/7, p. 519 


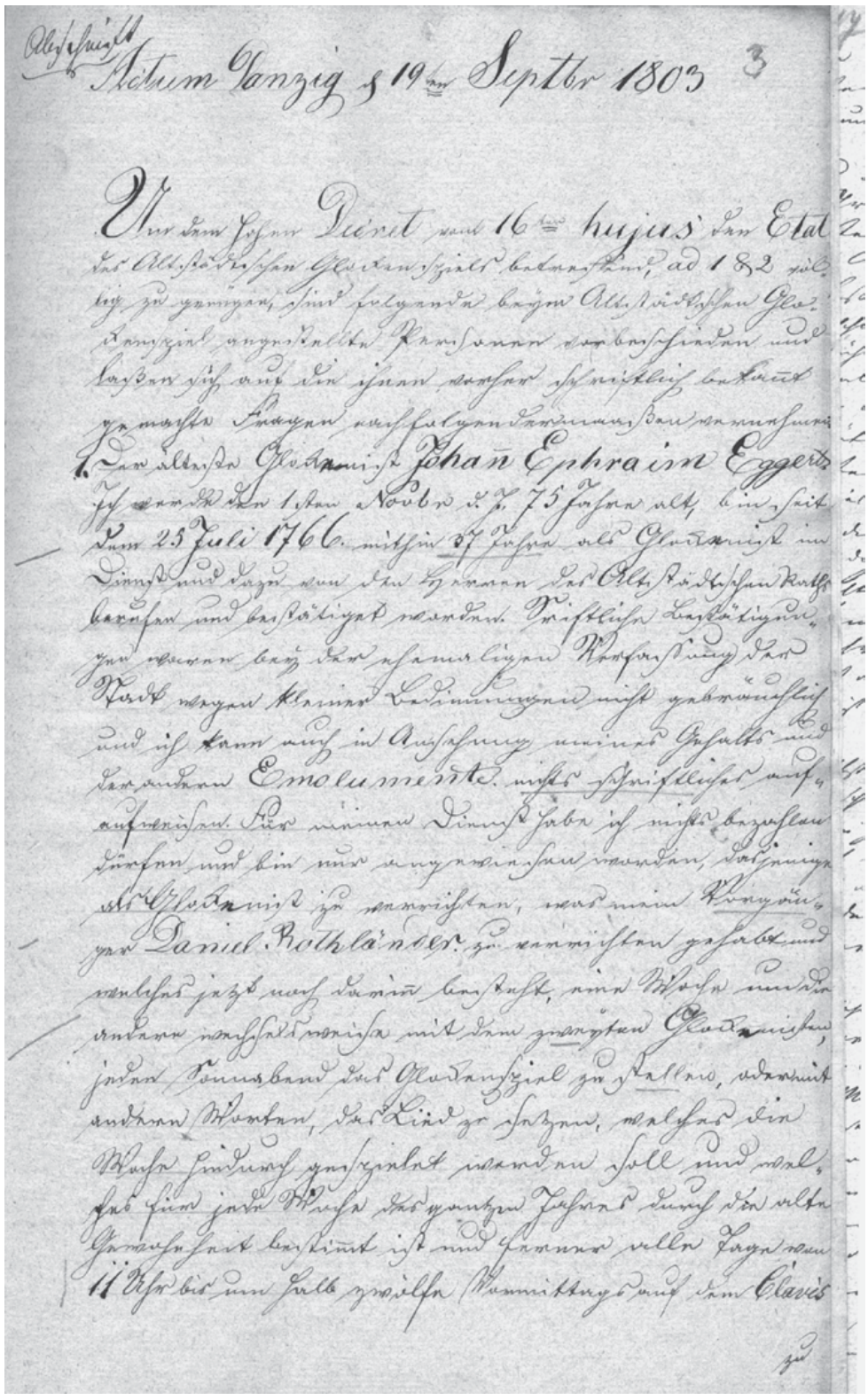

Fig. 51: Testimony of J. E. Eggert. APG 353/231, p. 3 
College, he mentioned he had worked at the church of Corpus Christi for some time, but with no further details. ${ }^{684}$ The confirmation of his work as organist there only comes with press announcements from 19 and 26 February $1780^{685}$ and with a manuscript with carillon compositions of $1784 .{ }^{686}$

Eggert is also mentioned as organist by Johann Gottfried Hingelberg in his brochure on Gdańsk musicians, published in 1785. Assessing his capability, Hingelberg wrote:

Eggert. Organist zu heil[igen] Leichnam. Macht auf seiner schönen neuen Orgel manches hockus pockus, und haselirt ohne alle Verbindung herum. Daß er Genie hat, wird ihm niemand absprechen, nur fehlt ihm mehr gesetztes und ernsthaftes in seinem Vortrage. ${ }^{687}$

This critical opinion is full of irony if not downright sarcastic. Should we, however, believe Hingelberg, who was ironic of many other, often very distinguished Gdańsk musicians? That author expressed general disappointment with the modern musical life of the city and could hardly summon a good word for anyone.

Through my archival research, I have established a few new facts from Johann Ephraim Eggert's private life. We know that at the age of seventy, in 1798, he intended to marry with one Eleonora, daughter of Philip Kaless. It is not clear whether the marriage actually took place, nor whether Eggert had married before. In 1770, at the age of forty-two, he was a bachelor, living on 3, Kirchen Steig (currently Katarzynki Street) "with an unspecified man named Wilhelm Bleche and maid Anna Rosina Czikorska." ${ }^{688}$

In the mid-1770s, looking for additional income, Eggert organised lotteries. This is indicated by announcements in the local press of 30 December 1775 and 20 January $1776 .{ }^{689}$ In the 1780 s and 1790s, he also traded in sheet music and musical instruments. He advertised subscriptions of the piano works of Georg Benda "für geübte und ungeübte Spieler," ${ }^{190}$ sold and purchased clavichords and harpsichords ("bandfreyes Clavier," "sehr schöne Flügel mit doppelt Clavier"), ${ }^{691}$ produced notably by the eminent Gdańsk keyboard maker Johann Werner Woge. ${ }^{692}$

684 APG 353/231, p. 5.

685 WDAN 1780 no. 7 (19 February), p. 72; WDAN 1780 no. 8 (26 February), p. 83.

686 Eggert, Choral-Lieder zu dem Glocken-Spiel.

687 Hingelberg, Über Danziger Musik und Musiker, 20.

688 Kaczor, 'Wstęp', 25.

689 WDAN 1775 no. 52 (30 December), p. 779; WDAN 1776 no. 3, (20 January), p. 31.

680 WDAN 1780 no. 7 (19 February), p. 72; WDAN 1780 no. 8 (26 February), p. 83.

691 DaNa 1796 no. 24 (23 March), p. 209; DaNa 1796 no. 29 (9 April), p. 255; DaNa 1796 no. 30 (13 April), p. 262; DaNa 1796 no. 32 (20 April), p. 281.

692 For more on Johann Werner Woge, see Vogel, 'Johann Werner Woge', 541-53. 
The last documented date from Eggert's life is 19 September 1803, when he issued a statement for the School and Church College concerning the duties of carillonists at the church of St Catherine. We do not know the date of Eggert's death.

An account of his life and professional activity would be incomplete without mention of his two manuscripts: the Choral-Lieder zu dem Glocken-Spiel der Altstädtschen Ober-Pfarr-Kirche zu St. Catharinen ausgesetzt mit Variationes, ${ }^{693}$ which I will analyse in detail in the second part of this book, and Orgeln in Danzig. ${ }^{69}$

The latter, despite its modest dimensions (twenty folios in $20 \mathrm{x} 16 \mathrm{~cm}$ format), is an invaluable source for learning about the organ in old Gdańsk. Most of the instruments discussed by Eggert do not exist anymore. He lists the specifications of thirty-two organs, including some in churched beyond the city of Gdańsk. He also gives details about organ construction, the names of organ makers and other people working in their construction, as well as the names of organists of the various churches. His remarks are useful not only for researching the material culture of old Gdańsk, but also the musical life of the city. ${ }^{695}$

Eggert did not sign the manuscript's title page. His name was recorded in another hand under the title: "Zusammengetragen von Organisten Johann Ephraim Eggert circa 1802." The same person also made several remarks on the manuscript's margins, ${ }^{696}$ dated 1813,1817 , and 1828 , which also confirms that the manuscript was edited later, consistently with the title page note.

Eggert's manuscript is bound jointly with an anonymous print, published in Wrocław in 1757, which includes the specifications of organs in seventy towns in the German empire and comments on organs from Italy, France, and the Netherlands. ${ }^{697}$

Examining the manuscript, we see than Eggert followed that print closely. The information is organised in a similar way: name of the church in which the organ is to be found, general number of the instrument's voices, specification of registers divided by manuals, often with the number of bellows, as well as names of organ-builders and organists. Moreover, the print and manuscript

693 APG 300,R/Pp,45.

694 PAN BG Ms 926.

695 The Eggert manuscript was used by Jan Janca and Werner Renkewitz in their monograph of organ building in Eastern and Western Prussia, see Renkewitz and Janca, Geschichte der Orgelbaukunst.

696 PAN BG Ms 926, fol. 2r, 2v, 7r, 17r.

697 Sammlung einiger Nachrichten von berühmten Orgel-Wercken in Teutschland mit vieler Mühe aufgesetzt von einem Liebhaber der Musik, Breßlau, verlegts Carl Gottfried Meyer, 1757. 
have an identical format: the folios of the manuscript were designed and cut to the dimensions of the print and bound together with it. It can thus be presumed that Johann Ephraim Eggert was the first owner of the printed edition and later decided to write down the specifications of the various organs in Gdańsk as a sort of appendix to the publication; aiming at a coherent whole, he did not include his name on the manuscript's title page.

After Eggert's death, it was decided to relinquish the employment of the second carillonist, with all duties now on another member of the Eggert family: Carl Friedrich, the son of Johann Daniel, Johann Ephraim's brother. ${ }^{698}$ Carl Friedrich was born on 8 May $1766 .{ }^{699}$ In 1794 , he became a helper to Old Town carillonists and trained in the profession. In 1798, after Carl Gottfried Busch's death, he became the second carillonist. ${ }^{700} \mathrm{He}$ must already have been fairly proficient at his tasks and able to combine them with other jobs, as he did not give up his post as organist at St James', a position he had held since at least $1797,{ }^{701}$ though he did leave his post at the church of St Bartholomew, where had been musical director since 5 October $1788 .^{702}$ In 1815 , the church of St James was seriously damaged after a gunpowder tower exploded, and was desacralised. ${ }^{703}$ An organist was therefore not necessary anymore, and Carl Friedrich Eggert was left with no additional income. The 1817 directory indicates that he soon opened a textiles shop. ${ }^{704}$ It must have been a temporary occupation, as he later returned to a more secure job, playing the organ at the Charity House (Spendhaus) in $1828 .{ }^{705}$

In the mid-1830s, the subsequent generation of the Eggert family began applying for the post of carillonist. Two sons of Carl Friedrich, Friedrich Theodor and August Eduard, considered taking up the position at St Catherine's. ${ }^{706}$ After

698 See PAN BG Ms 149 (5 October 1788).

699 APG 353/231, p. 5.

700 APG 353/231, p. 6.

701 ABuch 1797, p. 32.

702 PAN BG Ms 149 (5 October 1788).

703 Szarszewski, Szpital i kościół św. Jakuba, 89.

704 ABuch 1817, p. 149. In the same directory, Carl Friedrich Eggert is called a "RathausUhr-Glockenist" (carillonist of the town hall clock), I believe by mistake, though it could suggest that he was also employed as bell setter at the Main Town Hall automaton.

705 APG 353/231, pp. 29-34. On the Spendhaus organ see Renkewitz and Janca, Geschichte der Orgelbaukunst, 1:276-77.

706 APG 1461/147, pp. 7-8. 


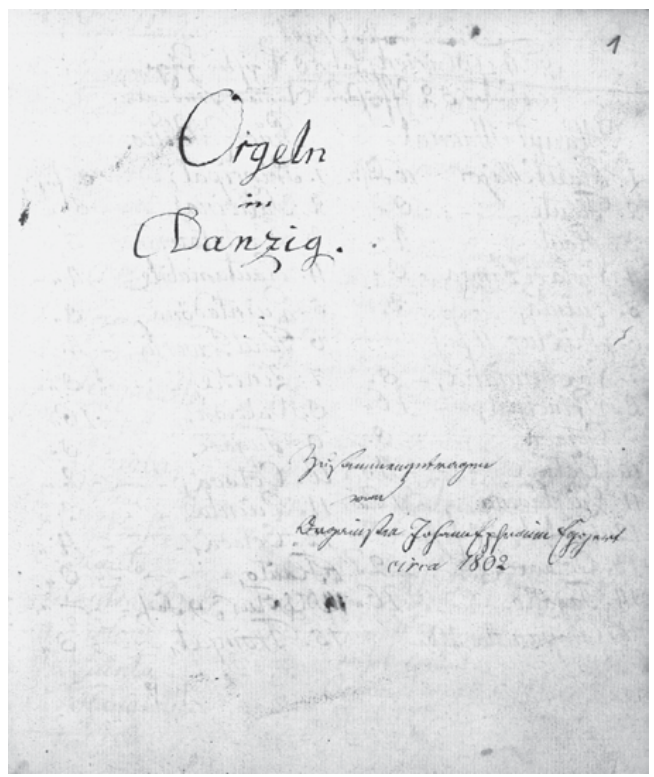

Fig. 52: J. E. Eggert, Orgeln in Danzig. PAN BG Ms 926, title page

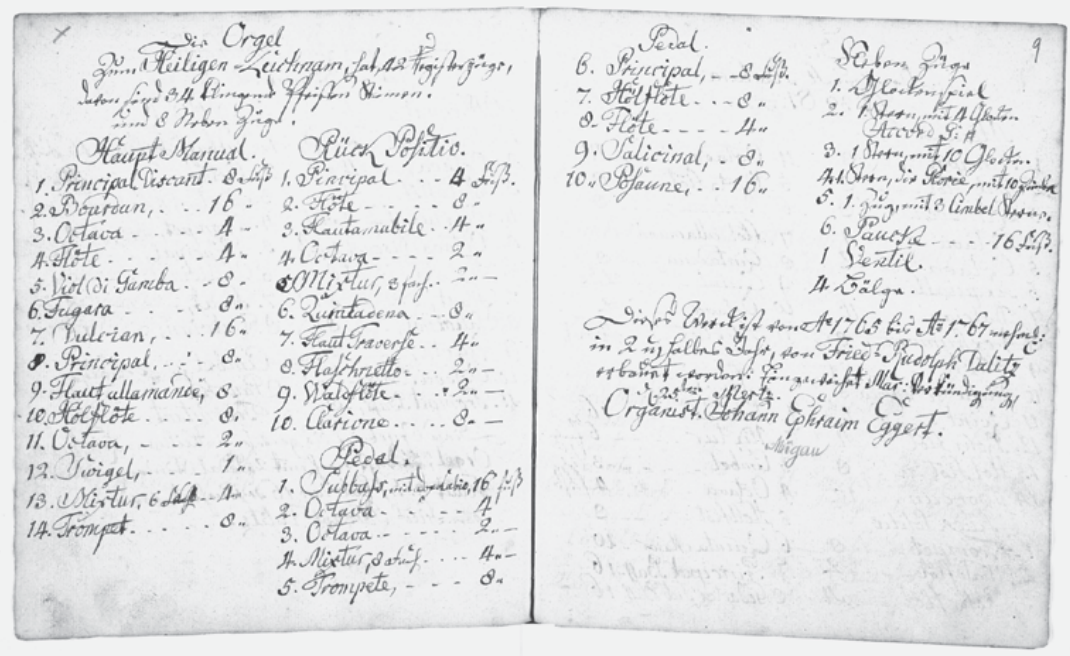

Fig. 53: J. E. Eggert, Orgeln in Danzig. PAN BG Ms 926, fol. 8v-9r 
Friedrich Theodor unsuccessfully applied to the church administrators in $1834,{ }^{707}$ the following year Carl Friederich Eggert wrote a letter on behalf of his other son, asking that August Eduard be hired as his helper and become carillonist after his death. He clarified his son was apprenticed and was already helping him set the carillon. The church administrators replied they would petition the Old Town Council to hire August Eduard as the second carillonist. ${ }^{708}$ Thus the idea of double employment was revived, after a period of only one carillonist being employed since the death of Joahnn Ephraim Eggert. Yet the ageing Carl Friedrich Eggert was later assigned not his son, by Friedrich Wilhelm Pfahl, organist of the Mennonite church, as his helper. ${ }^{709}$ Pfahl accepted a lower salary, which undoubtedly convinced the administrators. Pfahl was hired for a threemonth trial period from 1 May 1836. Carl Friedrich Eggert was tasked to teach the new carillonist and remain on friendly terms with the new apprentice. ${ }^{710}$ After a positive assessment of his trial period, Friedrich Wilhelm Pfahl was offered permanent employment. Although he is tagged "2er Glockenist" in the 1839 directory, ${ }^{711}$ a formal contract was only signed in $1840^{712}$ - hence it is only from that time that we can speak about the official reinstatement of the second carillonist position at St Catherine's.

Soon, another practice from the eighteenth century was revived, too: the second carillonist taking over from the first after the latter's death. Hence, when Carl Friedrich Eggert died on 27 April 1843, ${ }^{713}$ he was succeeded as first carillonist by Friedrich Wilhelm Pfahl, ${ }^{714}$ whereas the latter's post was offered to army musician Carl Friedrich Müller, who had already been apprenticed to Pfahl..$^{715}$

From 1866 to late 1924, carillonists at St Catherine's were members of the Krieschen family: Julius Johann, Paul William, Walther, and Gustav. The family

\footnotetext{
707 APG 353/231, p. 39.

708 APG 353/231, p. 41.

709 DNN 1929 no. 148 (27 June).

700 APG 353/231, pp. 43-46.

711 ABuch 1839, p. 56.

712 APG 353/231, pp. 59-64.

713 At the time of his death, Carl Friedrich Eggert was a widower. He died at midnight and was buried on 1 May at the church of Corpus Christi. He left two sons: August Eduard, a shop clerck (comptuaris) and the mentally deficient ("blödsinnig") Friedrich Teodor; see APG 1461/147, p. 7-8.
}

714 APG 353/231, pp. 75, 77.

715 APG 353/231, p. 73. 
originated from Grudziądz and settled in Gdańsk in the mid-nineteenth century, where it remained active through the 1950s. ${ }^{716}$ The Krieschens held many positions, significantly contributing to the city's musical life.$^{717}$ At some point, they held a virtual monopoly on Gdańsk carillons, as two members, Julius Johann and Paul William (and perhaps also Gustav), were also setters of the Main Town Hall carillon. At St Catherine's, three successive generations of Krieschen were carillonists: the already mentioned Julius Johann, ${ }^{718}$ whose third wife was the daughter of carillonist Friedrich Wilhelm Pfahl, Emma Wilhelmine ${ }^{719}$; then Julius Johann's son Paul William; and finally, his sons, Walther and Gustav Krieschen. ${ }^{720}$

The most active of them was Paul William Krieschen, born in Grudziądz on 8 May $1853 .{ }^{721}$ In his youth, he trained as a watchmaker and started work in that profession before eventually dedicating to music. From 1882, he played the organ at the church of St Barbara, where he also led the choir, organised charity concerts for the benefit of poor parishioners, and taught music. Simultaneously, from 17 January 1883, he worked as an assistant of his father Julius Johann as the second carillonist at St Catherine's. ${ }^{722}$ After his father's death, from 1 July 1895 he agreed to perform the duties of the first carillonist. ${ }^{723}$ This activity lasted until 1920, when due to old age and ailing health, he gave up the position in favour of his son Gustav, who had been his helper since 1912. ${ }^{724}$

In 1893, the Gdańsk City Council charged Paul William Krieschen with servicing the Main Town Hall carillon. ${ }^{725}$ It is possible that it was on Krieschen's initiative that from 6 July 1907, information on the Main Town carillon's

716 Michalak, 'Krieschen Anna Maria Hertha', 539.

717 Michalak, 539; see also Michalak, 'Organista i dyrygent chórów Julius Wilhelm Frühling', 210-11, 213-14, 217-18, 221, 223-24, 231, 261.

718 Meyer, 'Die Glockenspiele auf St. Katharinen in Danzig', 17; DNN 1929 no. 148 (27 June).

719 They married on 24 October 1878 , see APG 1609/77 no. 650.

720 APG 353/231, pp. 85-87, 93-94, 139, 202-3.

721 Michalak, 'Organista i dyrygent chórów Julius Wilhelm Frühling', 211.

722 DZ 1907 no. 24 (15 January). The employment of a new carillonist was necessary after Friedrich Wilhelm Pfahl died the preceding autumn, on 11 September 1881; see APG 1609/159, Nr. 2188.

723 APG 353/231, pp. 79, 83.

724 APG 353/231, pp. 139, 191-93, 197, 199.

725 DZ 1907 no. 24 (15 January). 
programme was printed weekly in the Danziger Zeitung, extended from 1910 to the automated carillon of St Catherine's. In any case, Krieschen was responsible for supplying the weekly programme to the newspaper. ${ }^{726}$

Paul William Krieschen was a distinguished Gdańsk musician. On 17 January 1907, after twenty-five years of employment, he was offered a jubilee honouring his achievements, an occasion respectfully mentioned by the local press. ${ }^{727} \mathrm{He}$ died after a long illness on 27 June $1923 .{ }^{728}$

The last carillonist of the church of St Catherine was Georg Edel, the shortsighted organist of the St Salvator church in Gdańsk-Siedlce. In 1935, he declared having worked at the Old Town carillon since 1923 and having set tunes on the Main Town Hall carillon as well. ${ }^{729}$ Initially, the former occupation was informal, since a contract for the position was only signed on 18 September 1924 with a note stating employment would commence on 1 January $1925 .{ }^{730}$ In 1924, Gustav Krieschen resigned from the position and Georg Edel worked there alone until 1942 when the bells were dismantled by the Nazis.

Soon after commencing employment at St Catherine's, Edel was given the position of organist at the church of St Barbara, ${ }^{731}$ where he also led the choir. Under his direction, the choir gave many performances, primarily at charity concerts. Edel's major achievements included a performance of Heinrich Schütz St John Passion on 13 April $1938^{732}$ and his contribution to the opening concert of the above-mentioned cycle "Die ostdeutsche Kirchenmusiktagung" in late October 1938.

Georg Edel was also active as a composer. He wrote chamber music (e.g. the Streichquartettsatz), organ (chorale preludes), vocal (Arien mit obligaten Instrumenten), vocal-instrumental (Ecksteinkantate), and, of course, carillon music (Thema mit Variationen, Improvisationen über Choräle). ${ }^{733}$ In autumn 1943, a jubilee of 25 years of activity in Gdańsk was organised in honour of Edel. The rich programme of that concert was almost exclusively composed of his own works, with reviewers praising both the music and performers. Edel

726 DZ 1907 no. 311 (6 July).

727 DZ 1907 no. 24 (15 January).

728 DNN 1923 no. 148 (28 June).

729 Edel, 180.

730 APG 353/231, pp. 217-19.

731 Edel was replaced at the church of the Redeemer in Siedlce by Gustav Krieschen; see ABuch 1924, III, pp. 29-30.

732 DNN 1938 no. 85 (12 April); DNN 1938 no. 88 (14 April).

733 Loew, 'Lexikon Danziger Komponisten', 246. 
himself conducted the Ecksteinkantate, ${ }^{734}$ but one important element was definitely missing: the sound of the Old Town carillon, played by Edel for nearly twenty years.

\section{Carillon management, carillonist employment and payroll}

Although the carillon was installed at the church of St Catherine, it was managed until 1793 by Gdańsk's Old Town Council. The Council Spokesman (Wortführender Herr) approved programmes for automated playing, ${ }^{735}$ and the Council hired carillonists and oversaw the instrument's finances. ${ }^{736}$ This practice was unequivocally confirmed by Johann Ephraim Eggert in his statement for the School and Church College. Eggert stated that carillonists were not formally employed by St Catherine's church administrators (Vorsteher der Katharinengemeinde) and referred exclusively to the Old Town Council, who was also the carillon's owner. ${ }^{737}$

After the incorporation of Gdańsk into Prussia and the reorganisation of the city's administration, management of the Old Town carillon was handed over in 1802 to the School and Church College (Kirchen- und Schulkollegium), which was a dependency of the Old Town Council. ${ }^{738}$ Carillonists referred directly to that organ. ${ }^{739}$ During the First Free City, after the liquidation in 1807 of the School and Church College, supervision over the carillon was handed over to one of the four mayors. The task fell to Karl Renner. ${ }^{70}$ Under Prussian rule, after the city's administration was constituted and consolidated, authority over the carillon belonged to the Chairman of the Magistracy, i.e., the lord mayor. The first to perform that function was Joachim Heinrich von Weickhmann. ${ }^{741}$ In 1826, the Church College (Kirchencollegium), composed of four church elders (Kirchenvätern) and the pastor, petitioned for taking over supervision of the instrument. Permission was granted on 12 September 1826. Yet this did not mean that the College became independent from the Magistracy.

734 DVoPo 1943 no. 281 (12 October); DNN 1943 no. 238 (11 October).

735 Lengnich, Ius publicum civitatis Gedanensis, 214.

736 I refer carillon finances and the remuneration of carillonists until 1803 primarily after Kaczor, 'Wstęp', 20-24.

737 APG 353/231, p. 3.

738 Blech, 'Das alte und das erneute Glockenspiel', 16. The School and Church College was founded in 1799 after the dissolution of the Schooling College (Collegium Scholarchale). See Cyrson, 'Ustrój Gdańska w latach 1793-1807', 118.

739 APG 353/231, pp. 4-5.

740 Blech, 'Das alte und das erneute Glockenspiel', 16; Gliński, 'Gdańszczanie epoki napoleońskiej', 136-37.

741 Włodarczyk, 'Miejsce Gdańska w państwie pruskim’, 41. 
In later years, following a reorganisation of church institutions confirmed by the decree of 10 September 1873 (Kirchengemeinde- und Synodalordnung), the duties and rights of the Church College were transferred to the Church Council and Representation (Kirchenrat und Vertretung). On its behalf, church affairs, including the carillon, were managed by the pastor in cooperation with the St Catherine Parish Council (Gemeindekirchenrat von St. Katharinen zu Danzig). ${ }^{742}$

The Old Town carillon was not financed from the city treasury (Old Town or Magistracy) or the St Catherine church's treasury. Money for the instrument's construction and, later, maintenance, including conservation work, repairs, and carillonists' salaries, were gathered in the so-called carillon fund (Glockenspiel-Cassa, Casse des Glockenspiels). ${ }^{743}$ Income into the fund came from several sources. Often, these were bequeaths by Old Town burghers. The two most well-known donations came from councillor Andreas Stendel and master baker Carl Wilhelm Körner.

In the years $1738-43$, the custom was established for each newly elected Council Spokesman to donate 150 florins for the carillon. Anyone applying to take the post of sexton or bell ringer had to donate 500 florins. Soon after the carillon's construction in 1747 , it was decided that the following interest should be paid to the carillon fund: on house mortgages; on mortgages of meat stalls; on city bonds. This system proved fairly effective, as in the second half of the eighteenth century there were occasions where yearly balances showed a surplus. ${ }^{744}$ In 1802, when supervision of the carillon was taken over by the School and Church College, an audit confirmed the carillon fund had 15,400 florins. Soon, thanks to a successful house sale, it was increased to 24,000 florins. ${ }^{745}$ Income and expenses continued to be documented through the twentieth century. ${ }^{746}$

The fund paid the carillonists' salaries, composed of several parts. The base was a quarterly wage, on top which a so-called Dominiks-Geschenck (St Dominic's premium) and "Weihnachts-Geschenk" (Christmas premium) were added, as well as a small sum for lighting ("Lichtgeld"). Carillonists were also entitled to rent an apartment, paid by the fund.

742 Blech, 'Das alte und das erneute Glockenspiel', 16-17.

743 Dariusz Kaczor calls the carillon fund a sort of public foundation; see Kaczor, 'Wstęp', 21.

744 The relatively sound state of carillon finances did not always match that of the church of St Catherine. Especially in later years, the church was often much indebted. On its financial difficulties and remedies to them, see Blech, 'Leidensjahre von St. Katharinen in Danzig', 161-92.

745 Blech, 'Das alte und das erneute Glockenspiel', 16.

746 See for example APG 353/240. 
I have not found receipts for carillon playing during elections to the Old Town Council, which perhaps indicates that task was not paid separately, as was the case for setters of the Main Town Hall automaton, but rather was included in the basic quarterly wage. From the 1880s, carillonists at St Catherine's were also remunerated for playing on 2 December, when an hour-long concert commemorated the death anniversary of master baker Carl Wilhelm Körner.

The various elements of carillonists' pay were mentioned in their contracts only from the 1840s (starting with Friedrich Wilhelm Pfahl); earlier agreements were probably oral. In any case, Johann Ephraim Eggert worked according to an oral agreement, as he testified in his 1803 statement for the School and Church College.

Apartment rental compensation was an important component of carillonists' pay. Dariusz Kaczor supposes that only the first carillonist was entitled to it. ${ }^{77}$ However, a more recent analysis of existing directories and receipts confirms that lodgings were offered and rents were reimbursed to both carillonists at St Catherine's. Carl Gottfried Busch received a six-month lump sum of 15 florins against his rent on 19 May 1791: "den halb-Jährigen Oster-Zins, von der Glockenisten Wohnung f15," Eggert also received two lump sums of 15 florins per year when he was the second carillonist, as indicated by receipts for the years 1773, 1774, 1777, and 1778: "laut befinden d[en] Herren des Raths 1[aut] Z[ins]." "749 Carl Gottfried Busch loved on 342, Kleine Mühle Gasse (today Podmłyńska Street), ${ }^{750}$ while

747 Kaczor, 'Wstęp', 22. In his erroneous theory, Kaczor quotes a remark by Ernst Blech, who related the apartment information to his own time, when a second carillonist was not employed anymore. Authors misquoting house numbers have added to the confusion about carillonists' living quarters is introduced by; we need to remember that house numbering in Gdańsk was reformed in the mid-nineteenth century. See Blech, 'Das alte und das erneute Glockenspiel,' 18, and Verzeichni $\beta$ der Grundstücke in der Stadt, und zwar innerhalb der Rachtstadt, Altstadt, Vorstadt, Niederstadt und Außenwerke, zusammengestellt nach den neuen und alten Servisi Nummern. Hinzugefügt sind die Hypothekenbuchs-Nummern und Namen der Besitzer nach den Kämmerei-Heberegistern (Danzig, 1854), 71, 72, as well as [Daniel] Buhse, Plan von Danzig. Nach trigonometr. Aufnahme im Auftrage d. Magistrates in d. Jahren 1866 bis 1869 gefertigt (Danzig, [1869]).

748 APG 300,41/74, p. 64.

749 APG 300,41/71, pp. 57, 59; APG 300,41/73, pp. 3, 5.

750 ABuch 1796, p. 31; ABuch 1797, p. 30 - no. 7 according to Verzeichniß der Grundstücke in der Stadt, 72; Buhse, Section 7. 


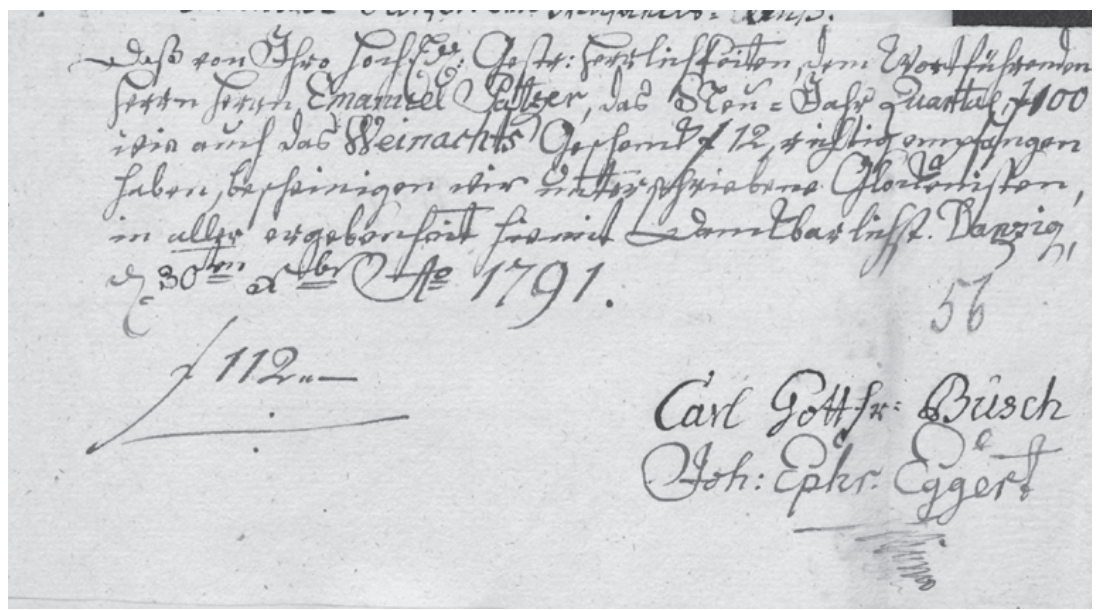

Fig. 54: Quarterly salary of C. G. Busch and J. E. Eggert. APG 300,41/74, p. 56

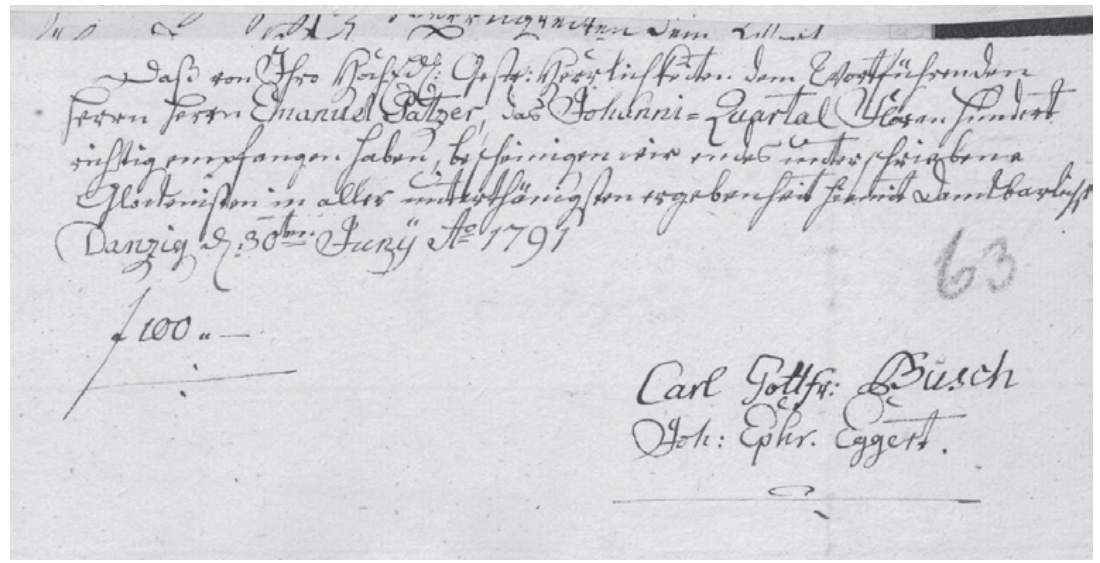

Fig. 55: Quarterly salary of C. G. Busch and J. E. Eggert. APG 300,41/74, p. 63

Johann Ephraim Eggert resided at 349, An der großen Mühle 349 (today $\mathrm{Na}$ Piaskach). ${ }^{751}$ Both lodgings belonged to the church of St Catherine. ${ }^{752}$ Later, the An der großen Mühle apartment was occupied by Friedrich

751 ABuch 1796, p. 31; ABuch 1797, p. 30 - no. 4 according to Verzeichni $\beta$ der Grundstücke in der Stadt, 71; Buhse, Section 7.

752 See Verzeichni $\beta$ der Grundstücke in der Stadt, 71, 72. 
Wilhelm Pfahl, ${ }^{753}$ as written in his 1840 contract, followed by Paul William Krieschen. ${ }^{754}$

The use of a church-owned apartment, however, was not compulsory. This is shown by the example of Johann Ephraim Eggert's nephew, Carl Friedrich, who, as the second carillonist, resided first at 1454, Hökergasse (today Straganiarska Street $)^{755}$ and then for several years at 1974, Glockenthor (today inexisting) ${ }^{756}$ and received a financial premium against his rent ("Mietsvergüthung"). ${ }^{757}$

It is difficult to estimate the payments received by musicians for playing at funerals. In his statement for the School and Church College, Johann Ephraim Eggert said he was paid 32 florins by the deceased persons' families, of which he would give half to the second carillonist. ${ }^{758}$ Such payments were made from the carillon fund only when the deceased would be directly linked with the church of St Catherine. In 1841, Friedrich Wilhelm Pfahl received two thalers for programming a tune after the death of archdeacon Schmidt. ${ }^{79}$

Old Town carillonists earned much more than organists of St Catherine's, a fact emphasised by Dariusz Kaczor. In 1784 Carl Gottfried Busch, when he was the church's organist, earned a total 181 florins and 8 groschen (premiums included), and the following year, 194 florins and 13 groschen, while his basic income as the first carillonist (without the extras for playing at funerals, which are difficult to estimate, his rent allowance and lighting premium) during the same period reached 256 florins (200 florins of salary, 50 florins of the "St Dominic's premium" and 6 florins of Christmas premium). ${ }^{760}$ The comparison shows the high rank enjoyed by Old Town carillonists as compared to organists.

The best-remunerated carillonist in the history of the Old Town carillon was its first: Eltjen Wolthers earned 600 florins per year. The earliest recorded payment made to Wolthers is dated 14 May $1739 .{ }^{761}$ After Wolthers left and two carillonists were hired to replace him, the conditions of employment changed: the

753 APG 353/231, pp. 59-64.

754 APG 353/231, pp. 93-94.

755 ABuch 1797, p. 32; ABuch 1800, p. 28.

756 ABuch 1817, p. 88; ABuch 1839, p. 56; see Zernecke, Cały Gdańsk za dwadzieścia srebrnych groszy, 235.

757 APG 353/231, p. 11.

758 APG 353/231, p. 4.

759 APG 353/238, p. 272.

760 APG 353/238, pp. 22-23.

761 APG 353/238, p. 23 
two musicians shared duties and consequently received the same salary, but a much lower one than Wolthers': 200 florins per year. ${ }^{762}$

After the incorporation of Gdańsk into Prussia, the material conditions of carillonists deteriorated. Because of the city's financial situation, they lost income, although as a professional group, they were no exception: material degradation involved all residents of the city. ${ }^{763}$

In 1825, the salary of Carl Friedrich Eggert, composed of the same elements as formerly (a quarterly basic salary, premiums for St Dominic's and Christmas, a rent allowance, a lighting premium), amounted to just over 138 thalers.

Tab. 16: Remuneration summary of C. F. Eggert for the year $1825^{764}$

\begin{tabular}{ll}
\hline Payment & Thaler/silver groschen/pfennigs \\
\hline Salary paid on Easter ("Osternquartall") & 25 \\
Rent ("Mietsvergüthung") & $3 / 22 / 6$ \\
Salary paid on St John's & 25 \\
Premium for St Dominic's Fair ("zum Dominick") & 25 \\
Salary paid on St Michael's & 25 \\
Rent ("Mietsvergüthung") & $3 / 22 / 6$ \\
For lighting ("Lichtgeld") & $3 / 7 / 6$ \\
Salary paid for Christmas & 25 \\
Christmas premium & 3 \\
Total & $138 / 22 / 6$ \\
\hline
\end{tabular}

Carl Friedrich Eggert repeatedly applied for a raise. The correspondence about this has survived for the years 1827 and 1828. Eggert justified his request, indicating the many duties he had, working alone. At the same time, however, St Catherine's church administrators rebuked him for being unreliable and lying in his statements. The result was a defeat for Eggert: he got no raise, and additionally, his employers decided to hire a second carillonist. Consequently, Eggert's income was further diminished. His salary was cut, including all customary premiums for St Dominic's, Christmas, and lighting, with only the rent allowance left unchanged. ${ }^{765}$ Hired for a three-month trial, Friedrich Wilhelm

762 APG 353/238, p. 22.

763 Kizik, 'Finanse Gdańska w latach napoleońskich', 55-64; Kaczor, 'Podstawy prawne polityki fiskalnej, 67-83.

764 APG 353/231, p. 11.

765 APG 353/237, pp. 281, 283. 
Pfahl agreed to work for 20 thalers per year: the provision is written into his agreement, although that was prepared only in 1840. Significantly in the context of the raise request of Carl Friedrich Eggert is another provision in Pfahl's contract, which prohibits him from making similar requests. ${ }^{766}$

After the death of Carl Friedrich Eggert in 1843 and the employment as the second carillonist of Carl Friedrich Müller, the musicians' remuneration structure was amended. Both now received the same yearly salary of 50 thalers. ${ }^{767}$ Allowances for lighting and rent remained unchanged, as did the Christmas premium, ${ }^{768}$ but the only the first carillonist was now entitled to the St Dominic's premium of 25 thalers. ${ }^{769}$

In the mid-1870s, musicians were paid in marks. The yearly salary of each of the two carillonists was 150 marks, with allowance for lighting and a Christmas premium (each of 9 marks and 38 pfennigs) and a St Dominic's premium of 75 marks for the first carillonist. ${ }^{770}$ After the death of Friedrich Wilhelm Pfahl, the salary of the first carillonist Julius Johann Krieschen was increased to 180 marks per year, ${ }^{771}$ and Paul William Krieschen, hired as the second carillonist, was offered 160 marks per year. ${ }^{772}$

In summer 1895, Paul William Krieschen signed a contract for the position of the first carillonist on the same conditions. His salary amounted to 274 marks, including 180 of basic yearly pay, 75 marks of St Dominic's premium, 10 marks of Christmas premium and 10 marks of lighting allowance. As mentioned before, Krieschen also received lodgings at 4, An der großen Mühle Street. A new element of his remuneration was a 9-mark premium for an hour-long commemoration concert for master baker Körner (2 December). ${ }^{773}$ A second carillonist was not officially employed; according to Krieschen's concert, the salary related to the position, 160 marks, was paid to the widow of Julius Johann Krieschen. ${ }^{774}$

For nearly two centuries of existence of the Gdańsk Old Town carillon, conditions of employment of its players remained relatively stable, notwithstanding changes in currency and the fall of salaries due to crisis times for the entire city of Gdańsk.

\footnotetext{
766 APG 353/231, pp. 59-64.

767 APG 353/237, pp. 745, 749, 841.

768 APG 353/237, pp. 747, 751, 845.

769 APG 353/237, p. 841.

770 APG 353/328, p. 885.

771 APG 353/239, pp. 579, 581, 583, 585.

772 APG 353/239, pp. 591, 593, 595, 597.

773 APG 353/231, pp. 83-84, 93-94.

774 APG 353/240, p. 196.
} 


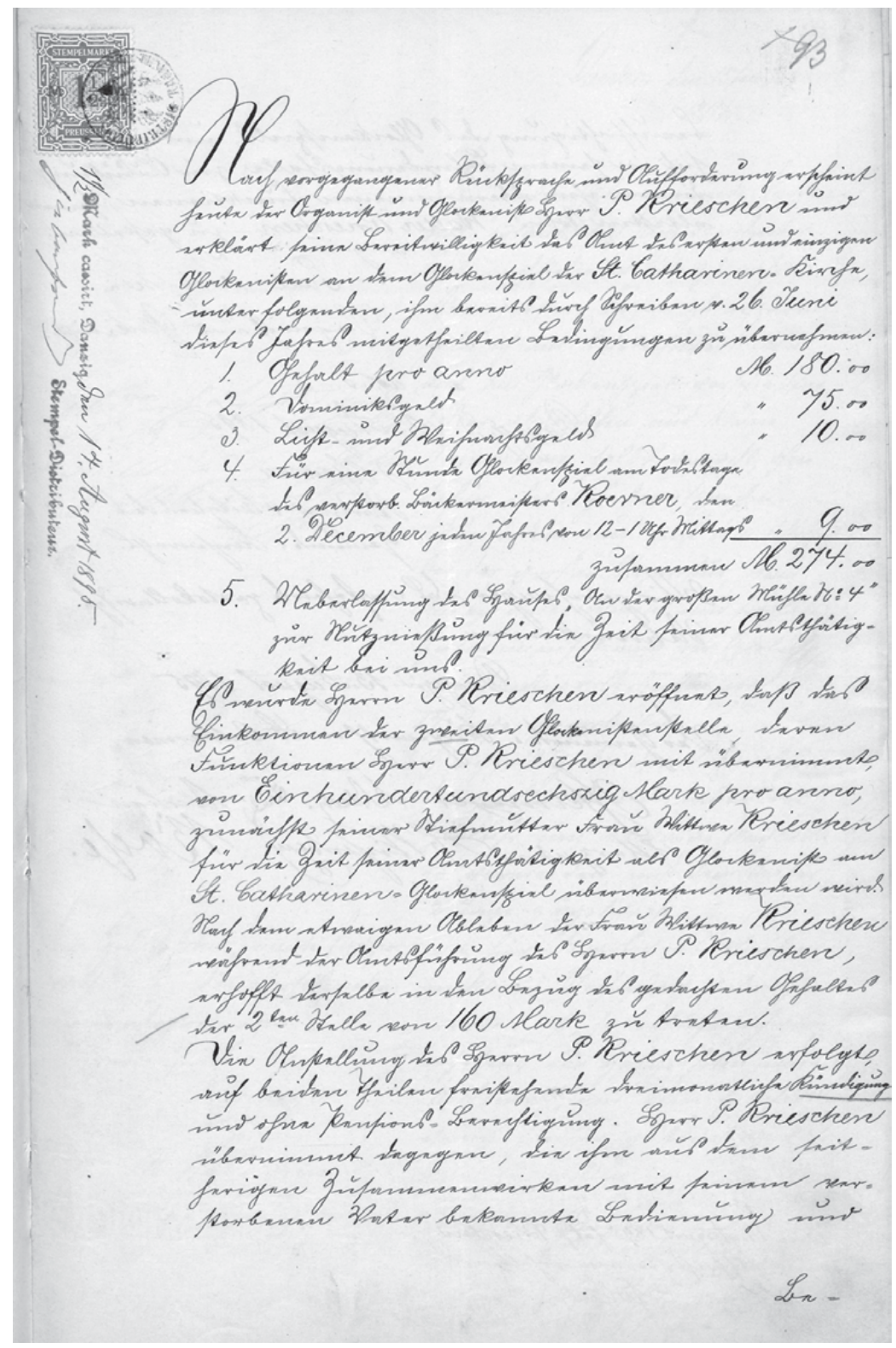

Fig. 56: Contract with P. W. Krieschen. APG 351/231, p. 93 


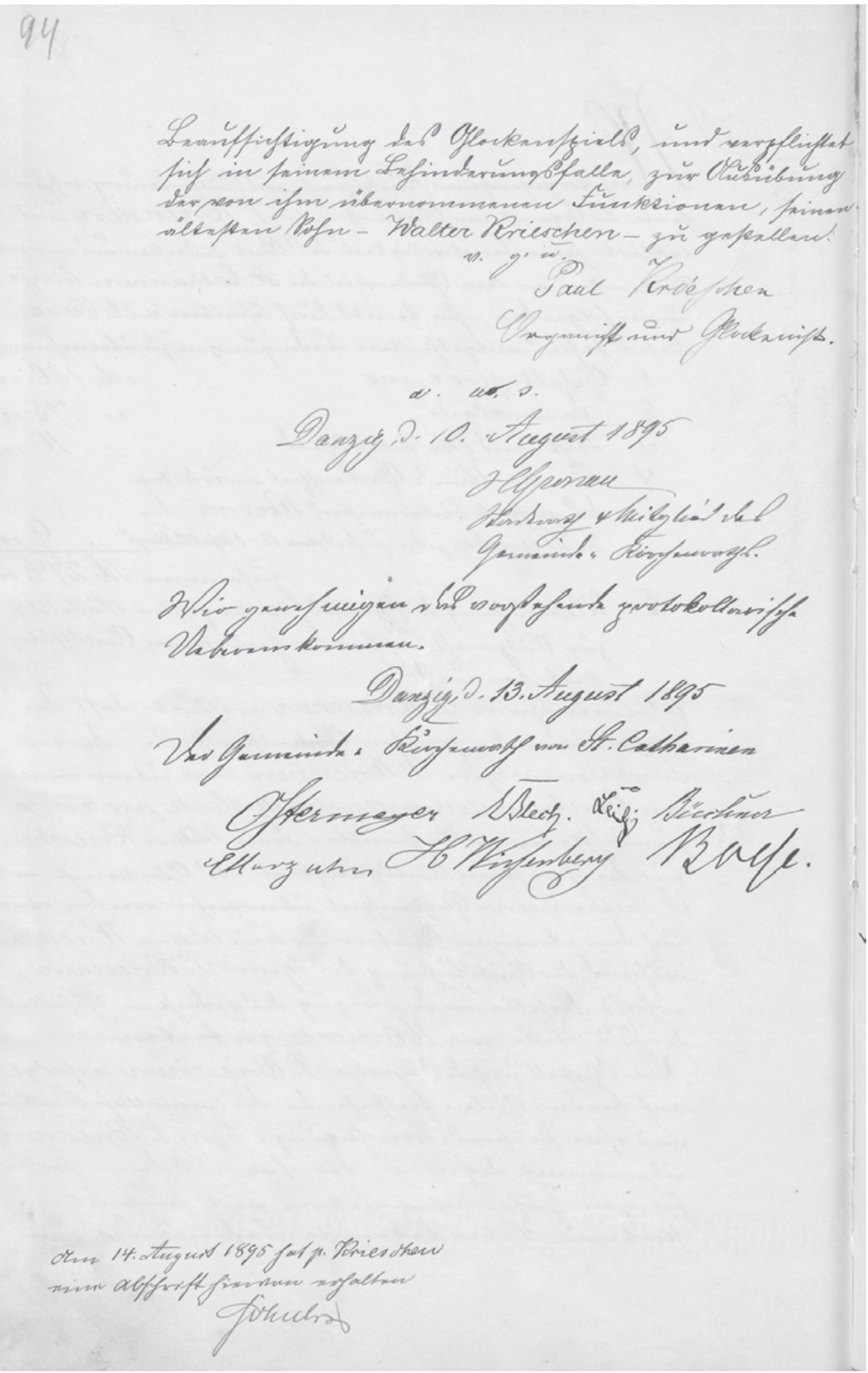

Fig. 57: Contract with P. W. Krieschen. APG 351/231, p. 94 



\section{Chapter 3 Other carillons in Gdańsk}

\section{The automated carillon in Milk Can Gate, 1938-45}

On 1 April 1938, a note was published in the Danziger Neueste Nachrichten paper, announcing a new carillon installed in the Milk Can Gate (German: Milchkannenturm, Polish: Stągwie Mleczne) of the Lower City: "Das Glockenspiel auf dem Milchkannenturm." ${ }^{775}$ The article went on describing the difficulties in elevating the largest bell (no. 26) under the tower's roof and announced a planned night-time trial of the carillon. The article indicates that although it possessed a programming drum ("Spielwaltze"), the Milk Can Gate carillon was similar to that of St Catherine, if smaller. Indeed, its hammers struck not the bells themselves, but large metal pipes, similar to those used by Richard Wagner in Parsifal. We do not know with what frequency the mechanism was triggered, nor the carillon's repertoire. We can only presume that in the automaton played patriotic soldiers' tune or other national songs: one such song was heard during the 1 April trial: Steh ich in finstrer Mitternacht, a soldiers' song by Friedrich Silcher to words by Wilhelm Hauff, composed in $1824 .{ }^{776}$ The building itself was classified and had hosted a youth hostel (Jugendherberge) since $1931 .{ }^{777}$

The Milk-Can Tower was severely damaged in the battle of Gdańsk in March 1945. No trace was left of the carillon-like sounding musical automaton.

\section{The carillon on Bishop Hill, 1939-45}

Before the Second World War, construction commenced of another carillon in Gdańsk. It was part of a development project on Bishop Hill of the Paul Beneke Youth Hostel (Paul-Beneke-Jugendherberge); the cornerstone was walled on 26 July 1938 by Gauleiter Albert Forster. The new project was supposed to embody the steadfast spirit of its German users, just as its patron, Gdańsk's most famous privateer, who won many naval battles, routed the English fleet, and conquered the triptych of Hans Memling The Last Judgment, remained a symbol of heroism

775 DNN 1938 no. 77 (1 April).

776 Volksliederarchiv, accessed 27 August 2018, https://www.volksliederarchiv.de/ steh-ich-in-finstrer-mitternacht/.

777 ABuch 1939, p. 15. 
to the city's citizens. Paul Beneke was the perfect model for a national hero and had long featured in historical fiction novels and patriotic poetry. ${ }^{778}$ The interior of the youth hostel was adorned with a fresco consistent with National Socialist aesthetics, representing Beneke inciting his comrades to combat. ${ }^{779}$ In the designers' project, the youth hostel would shape and reinforce the national spirit of German youth. Hence probably the idea of placing a carillon on the building's tower. Tunes played by the automaton would educate the building's residents. Despite efforts to finish construction promptly, merely the topping out ceremony took place on the first day of spring 1939. The outbreak of war somewhat slowed progress, but the youth hostel was eventually opened in early $1940 .^{780}$

The carillon was commissioned to the Gdańsk Shipworks, which had considerable experience in casting stones. Yet although it had produced no fewer than 700 bells to that date, it had never cast a set of carillon bells. Twenty-two bells were planned for that commission. ${ }^{781}$ An electromagnetic-controlled mechanism was commissioned from the Eduard Korfhage company. ${ }^{782}$

The carillon was played both as an automaton and manual instrument. The keyboard was planned in a special room. The instrument's range was scheduled over two and a half octaves, from C4 through G6. In total, the carillon would weigh $2300 \mathrm{~kg}$, with the smallest bell at $272 \mathrm{~mm}$ in diameter and $13 \mathrm{~kg}$ in weight.

In September 1939, the carillon was still not ready. Around mid-September, those bells that were already made were exhibited at the Gdańsk Shipworks. The two largest bells were still missing. The presentation was run by engineer Berger, responsible for the instrument's construction. He assured guests the bells sounded fine, with the reservation that one would need to be recast because out of tune. To present the bells' sound, he struck them and played familiar tunes. Journalists present at the exhibition were raptured. The two remaining bells were quickly cast and the carillon installed within six weeks; soon after, the press reported on a trial concert. ${ }^{783}$ The official inauguration took place on 26 July $1940 .{ }^{784}$

778 Loew, Danzig und seine Vergangenheit, 201-2.

779 Loew, 243.

780 Anna Perz, 21 marca 1939 r. na Biskupiej Górce, accessed 27 August 2018, http:// ibedeker.pl/obiekty/21-marca-1939-na-biskupiej-gorce/\#axzz2QpbzSaKg.

781 DNN 1939 no. 215 (14 September).

782 DVoPo 1940 no. 204 (27 July).

783 DNN 1939 no. 281 (30 November).

784 DVoPo 1940 no. 204 (27 July). 


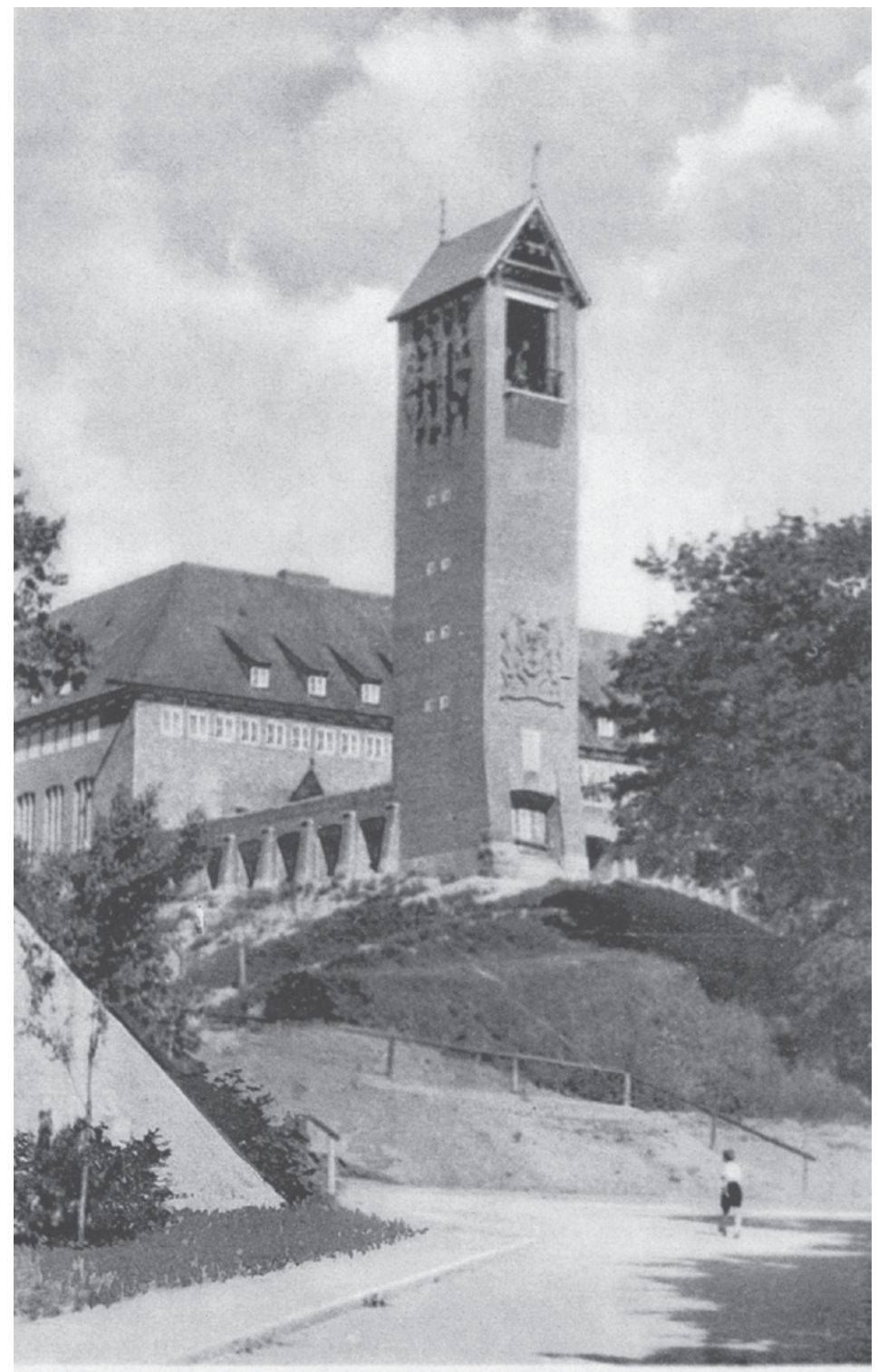

\section{Danaig. "Baul Benecke" Jugend- Herberge.}

Fig. 58: Youth hostel on Bishop Hill. Photo from the collection of K. Grynder 


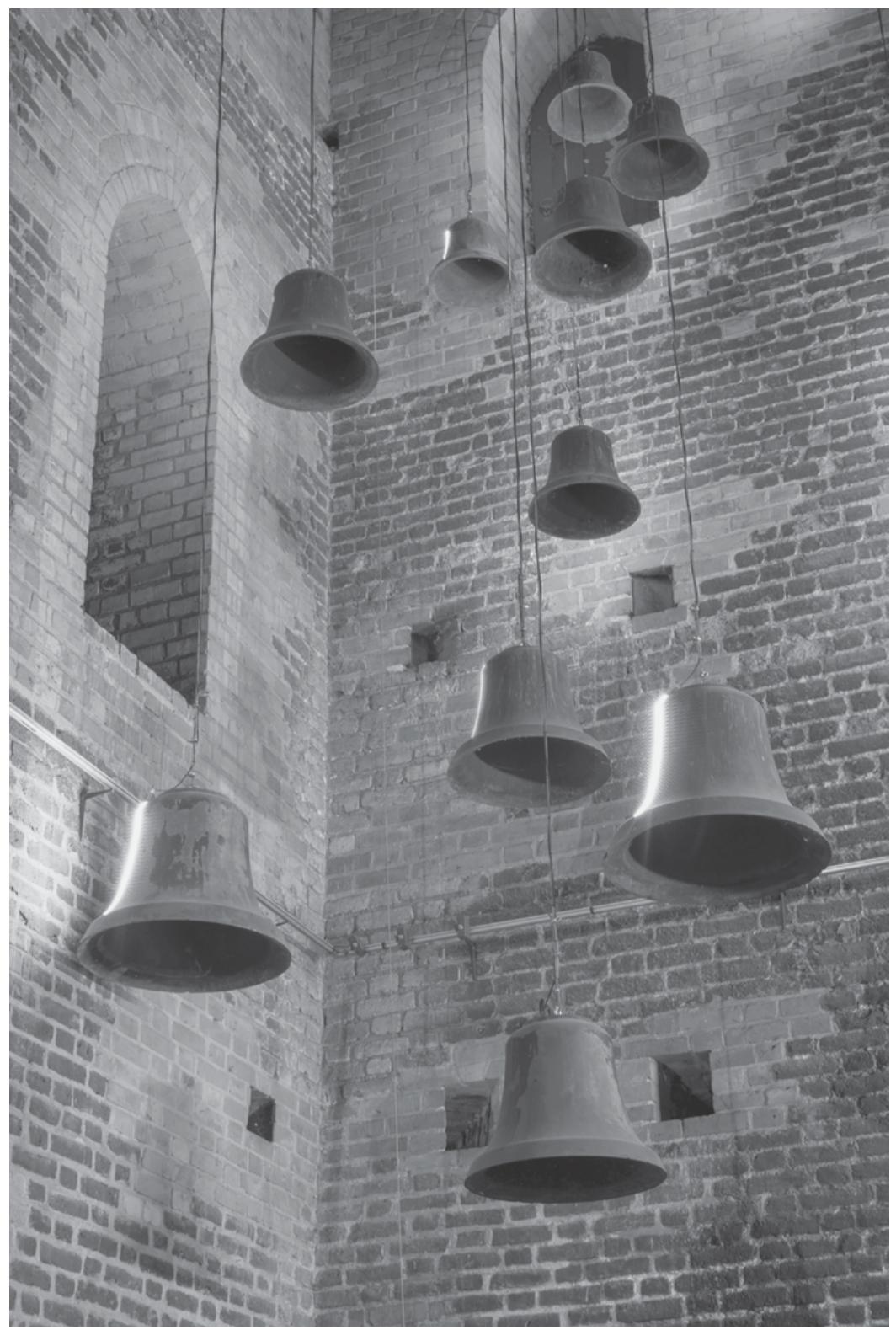

Fig. 59: Carillon bells on Bishop Hill. Gdańsk Science Museum, photo by M. Popinigis 
The sequence of automated play, concert play, and the repertoire have not been established. Wartime press reported on the Bishop Hill carillon playing older and newer popular songs as well as Hitlerjugend tunes. ${ }^{785}$

The Bishop Hill bells were partly or totally destroyed in March 1945. More than a decade later, sixteen bells were moved to the rebuilt Main Town Hall tower, with one of the three surviving Jan Moer bells added to them. A seventeen-bell carillon was thus created, scaled as follows: A\#4, B4, C5, C\#5, D5, D\#5, E5, F5, F\#5, G5, G\#5, A5, A\#5, B5, C6, D\#6, G6, completed by the clock chime of the church of St John. The whole was inaugurated in $1970 .{ }^{786}$ This new carillon of the Main Town Hall continued to play through the early 1990s when due to the poor technical conditions of the bells and mechanism, the decision was made to dismantle it. An acoustic assessment of the bells was undertaken, with spectral analysis of the partials, harmonic and nonharmonic relations between them, and frequencies of those partials determined by beats. An assessment of the inner tuning but also outer tuning, i.e., harmonic relations between bells, was made. It was not positive. From a musical point of view, outer tuning is particularly important, but the new Main Town carillon was mostly out of tune, a fact confirmed by subjective listening. This was partly due to the bells' heterogeneous origin as well as wartime damage to the waists: the bells did survive the war but had fissures and bullet holes. ${ }^{787}$

785 DNN 1940 no. 107 (8 May); DVoPo 1940 no. 212 (4 August).

786 There is conflicting information in the literature on the post-war Main Town Hall carillon, installed in 1970, as well as press articles. Some sources, notably FiebigDrzewiecka, Grabowski, and Szychliński, 'Notacja kołkowa bębna carillonu', 8, and Januszajtis, Gdańskie zegary, dzwony i karyliony, 130, indicate that all seventeen bells originated from Biskupia Górka. Other authors list only sixteen bells; see Sankiewicz, Budzyński, and Kaczmarek, 'Acoustic Investigation of the Carillons in Poland', 335.

787 Budzyński, Gudel, and Sankiewicz, 'Timbre of the Gdańsk Historical Bells', 73-89; Sankiewicz, Budzyński, and Kaczmarek, 'Acoustic Investigation of the Carillons in Poland', 337-52. 

Part Two Musical repertoire 



\section{Overview and description of sources for the Main Town Hall automated carillon repertoire}

Only a few sources inform our knowledge of the repertoire for Gdańsk's Main Town Hall carillon until the mid-eighteenth century. These include three books by eighteenth-century historians, an account of a direct witness of the 11 February 1646 events, and notes in Main Town cashbooks. Sources from the latter half of the eighteenth century and from subsequent centuries are considerably richer. They offer a solid overview of the Town Hall carillon repertoire, its evolution from the 1760s to 1928 , and based on musical manuscripts from the years 1796-1861, we can also characterise compositions for the carillon. Sources from that period include:

1. Four carillon tablatures from the years 1769-1812 (three by Theodor Friedrich Gülich and one by Paul Friedrich Knaack)

2. A manuscript by Carl Anton Kaschlinsky from 1861

3. Eighteenth-century song directories

4. Announcements in the Danziger Zeitung from the years 1907-28, indicating titles of songs programmed for the subsequent weeks of the year

\section{Seventeenth-century historical mentions}

The Gdańsk City Council cashbooks from the sixteenth and early seventeenth century only list the remuneration for bell setters. But from the 1630s, the circumstances of carillon play sometimes also indicate the type of programmed music. On the Council election day, the beginning and end of the St Dominic's Fair, religious ("geistliche," "christliche") songs were played, also names "usual songs" ("gewöhnliche Lieder"); during Gdańsk burghers' funeral, funeral songs ("Trauerlieder"), and on triumph days, thanksgiving songs ("Danklieder.")

Both witnesses and historians confirm the religious repertoire of the Main Town bells. A generic account of the music of the "singing clock mechanism" is given by Reinhold Curicke. He states the carillon played various religious songs every hour:

Uber sich hat dieses Rahthauß einen zierlichen vierkantigen Thurm auf welchem ein schlagendes und lieblich singendes Uhrwerck daß man eben wie andere Musicalische Wercke stimmen kan und allerley Geistliche Gesänge stündlich spielet. ${ }^{78}$

788 Curicke, Der Stadt Danzig, 53. 
Elsewhere, Curicke lists a specific composition. He mentions that on 1 July 1623 , on the occasion of the ceremonial arrival to Gdańsk of King Sigismund III Vasa, the hymn Te Deum laudamus was played. In his account of the royal visit, Curicke mentions that the carillon played "fast täglich andere angenehme Gesänge."789

What were those "pleasant songs" ("angenehme Gesänge"), played almost daily during the King's stay in the city? And how to interpret another expression to be found in a cashbook, of "merry songs" ("freudige Lieder"), for the playing of which on the visit of King Ladislaus IV a bell setter was paid on 18 March $1634 ?^{790}$ Did the bell setter of the time, Hans Neunaber, programmed some secular songs during both royal visits to the city? This is a highly risky theory, as other accounts of the Town Hall carillon only mention religious tunes. I shall thus consider these "pleasant" and "merry" tunes also to be religious in nature.

Information on specific Protestant songs as programmed on the Main Town carillon is listed by Adam Jacob Martini, who directly witnessed another event in Gdańsk. Martini was a city clerk, book binder, and author of circumstantial writings on Polish kings and various Gdańsk personalities. ${ }^{791} \mathrm{He}$ described the stay in Gdańsk of Ladislaus IV's spouse, Marie Louise Gonzaga, who arrived in the city on 11 February $1646 .{ }^{792}$ In his account of her ceremonial entry to the city, he mentions the clock as noticed by the pageant approaching the Town Hall. The "köstliche Cymbel" ("delicious cymbal"), Martini says, played the song Nun lob mein' Seel' den Herren:

Nach dem kam algemach neher zum Rahthauß, vnd fing darauff an das köstliche Cymbel. Vhrwerck den herlichen frewden Psalm, Nu lob mein Seele den Herren, mit hellen schal, hoch in der Lufft zu intoniren, welches gar deutlich für allen andern gethöne zu vernemen war. ${ }^{793}$

The information about the "singing clock mechanism" playing Nun lob mein' Seel" den Herren during the arrival of Marie Louise Gonzaga is also quoted (probably after Martini) by Reinhold Curicke:

... und die Heerpaucken und Trompeten auf dem Thurm des Rahthauses sich stets hören lassen worunter das singende Uhrwerck das Dancklied Nun lob mein Seel den Herren u[nd] auf vier Stimmen mit untergestimmet. ${ }^{794}$

789 Curicke, 73.

790 APG 300,12/67, p. 59.

791 Nowak, 'Martini Adam Jakub', 165.

792 The proxy marriage took place at Versailles on 5 November 1645.

793 Martini, Kurtze Beschreibung und Entwurff, fol. 43v.

794 Curicke, Der Stadt Danzig, 355. 
The thanksgiving tune Nun lob mein' Seel' den Herren was only programmed on special occasions; in any case, it did not feature in the eighteenth- and nineteenthcentury repertoire for successive weeks and holidays.

The first information on what songs were programmed on the carillon drum not occasionally but regularly, in one-hour intervals, is given by Stephanus Grau in his chronicle from the late seventeenth century. As already quotes, that historical described an event from the night of the 23/24 September 1596. The clock (likely because of a spontaneous defect) chimed midnight twice. After the incident, the bell setter programmed two tunes: Ach Vater unser der du bist and Verleih uns Frieden gnädiglich. The former, he writes, was programmed in its entirety, while the latter in an abridged version..$^{795}$ Why did the bell setter do so? He had probably underestimated the length of Verleih uns Frieden gnädiglich, and it turned out both songs could not be programmed in full. ${ }^{796}$ The later bell setter, Theodor Friedrich Gülich, never programmed those two chorales together, since based on the number of slats required to programme them, they would not fit on the carillon's drum. To programme Verleih uns Frieden gnädiglich, Gülich required no fewer than fiftyfour slats, ${ }^{797}$ and for Ach Vater unser der du bist, thirty-one or thirty-three slats. ${ }^{798}$

New information on the carillon repertoire is provided by Christoph Hartknoch's account of 1686, in which he mentions Calvinist songs played form the Main Town Hall. Hartknoch was a professor and connector of the Academic Gymnasium in Toruń, author of many books on history, religion, government, ethnography, and linguistics. In his last work, he focused on the history of Christiandom and Luteranims in Prussia, widely discussing the religious debates in Gdańsk at the end of the sixteenth century. ${ }^{799}$ Referring to the year 1592, he mentions the theologist of Gdańsk's Academic Gymnasium, Michael Coletus. As an adversary of the Calvinist, Coletus in his fiery speeches fumed at the carillon playing Calvinist songs to words by Antonius Lobwasser and required them to be deleted. ${ }^{800}$ This was not easy, however, as permission for programming French psalms on the Town Hall carillon was given by the City Council, which was

795 PAN BG Ms 53, fol. 516v.

796 The strophe of Verleih uns Frieden gnädiglich is composeed of five verse: "Verleih uns Frieden gnädiglich,/Herr Gott zu unsern Zeiten,/es ist doch ja kein ander nicht,/der für uns könnte streiten,/denn du unser Gott alleine."

797 APG 300,R/Pp,q9, pp. 144-45.

798 APG 300,R/Pp,q9, pp. 36, 75.

799 Serczyk, 'Hartknoch Krzysztof Jan', 164-65.

800 Hartknoch, Preussische Kirchen-Historia, 760. For more on religious debates in Gdańsk between Lutherans and Calvinists, see Cieślak, Między Rzymem, Wittenberga a Genewa, 141-52. 
sympathetic to Calvin: in 1587, ten out of its eighteen members were Calvinists. Later, the proportions were reversed, by as late as 1605 , reformists still prevailed. ${ }^{801}$

French tunes might have been introduced on the carillon by its first programmer, Franciscus de Rivulo. Originating from the Netherlands, it is probable that he belonged to the Reformed Church. Calvinist psalms were played by the carillon as early as 1693, as mentioned by Eduard David Schnaase in his history of the Evangelical Church in Gdańsk - but unlike Hartknoch, who saw them as part of a confession controversy, Schnaase lists them as an example of peaceful coexistence of both confessions. ${ }^{802}$ After an official agreement was reached in 1655, a change in relations between Lutherans and Calvinists in Gdańsk became obvious. ${ }^{803}$ Schnaase quotes from talks about psalms between Mayor Johann Ernst Schmieden and the pastor of St Mary, Constantin Schütz. Schmieden remarked that for the previous six or seven years during the first week of Advent, the carillon played Psalm 24, Dem Herrn der Erdkreis zusteht to Lobwasser's text. He considered it inappropriate to begin the liturgical year with melodies of Claude Goudimel, and suggested programming songs such as Nun freut euch lieben Christen gemein or Nun komm der Heiden Heiland, moving Lobwasser's psalms (in order to minimise the changes) to the Septuagesima Sunday, Reminiscere Sunday, and the sixth, twelfth, and eighteenth Sunday after Trinity. ${ }^{804}$ These remarks indicate that for many years, at least a few French melodies were included in the yearly programme of the Town Hall carillon. With time, the number of Calvinists in Gdańsk diminished, but as the tablature of Paul Friedrich Knaack suggests, Geneva psalms remained in the carillon repertoire through the nineteenth century. ${ }^{805}$

\section{Manuscripts of works for the Main Town Hall carillon}

Five manuscripts have survived with music for the Main Town Hall carillon: four tablatures and one manuscript with compositions written on a single staff in generic music notation. Three tablatures were authored by the Town Hall bell setter, Theodor Friedrich Gülich (1733-76), while the fourth comes from the city's watchmaker and bell setter Paul Friedrich Knaack. These tablatures include

801 Cieślak, Między Rzymem, Wittenberga a Genewa, 143-44.

802 Schnaase, Geschichte der evangelischen Kirche Danzigs, 594-5. French melodies in the carillon repertoire are also mentioned in Hirsch, Die Ober-Pfarrkirche von St. Marien, 2:237.

803 Cieślak, Między Rzymem, Wittenberga a Genewa, 210-11.

804 Schnaase, Geschichte der evangelischen Kirche Danzigs, 595.

805 APG 300,R/Uu,q9, pp. 36, 43, 80, 90, 100, 114. 
a total of 652 settings of Protestant songs. The fifth manuscript, which features only seven compositions (also Protestant songs), was the city watchmaker and Town Hall bell setter, Carl Anton Kaschlinsky (1822-82). The scholarly literature mentions yet another manuscript with compositions for the carillon, titled Choralbüsch von 1861, which might have also been a tablature and was kept in the interwar period at the Staatsarchiv für Freie Stadt Danzig. Unfortunately, it went missing during the Second World War. ${ }^{806}$

Tab. 17: Manuscripts with works for the Main Town Hall carillon

No. Title

Dating No. of No. of Catalogue

vols works no.

Tablatures by Theodor Friedrich Gülich

1 Auf hohe Verordnung Ihro Magnificens des Hochädelgebohrn[en] Vest[en] u[nd] Gestrengen Herrn H[e]r[r]n Carl Groddek gegenwärtig Praesidirendem Aeltesten $\mathrm{H}[\mathrm{e}]$ $1769-754$ $220^{807}$ APG $300, \mathrm{R} /$ Pp,q9 r[r]n Bürgermeistern, Protoscholarch u[nd] Administr[ators]: des Stübl[auschen] Werders. zum Gebrauch des Rechtst[ädtischen] Glokkenspiels ausgefertigte Thurm-Bücher nebst Vermehrung derer Sterbe-Lieder von Theodor Fridr[ich] Gülich. Raths-Uhr Glokst[e]ll[e]r. Anno 1769.

2 Choral Buch. Nach denen Evangelisch $\begin{array}{lll}1775-761 & 176 & \text { APG } \\ & & 300, R / \\ & & \text { Pp,q10 }\end{array}$ Lutherschen Kirchengesängen in Dantzig zum Gebrauch des Rechtst[ädtischen] Glokkenspiels ausgefertiget von Theodor Fridr[ich] Gülich E[ines] Hochedl[en] Hochweis[en] Raths: Uhr Glokkensteller. 1775.

3 Choral Buch Nach denen Evangelisch Reformirten Kirchengesängen in Dantzig zum Gebrauch des Rechtst[ädtischen] Glokkenspiels ausgefertiget von Theodor Fridr[ich] Gülich E[ines] Hochedl[en] Hochweis[en] Raths Uhr Glokkensteller. 1775.

$\begin{array}{lll}1775-761 & 136 & \text { APG } \\ & 300, R / \\ & \text { Pp,q10a } \\ & \\ & \end{array}$

(continued on next page)

806 Catalogue no. 300,RR 5719; see Pawlowski, 'Das Glockenspiel des Rechtstädtischen Rathause zu Danzig', 478.

807 In The Music Collections from Gdańsk, vol. 3, the tablature is quoted as containing 221 works, as the setting of Ecce Domine/Gottes Sohn ist kommen is erroneously split into two independent compositions. See Woźniak et al., Music Collections from Gdańsk 3, 150-51 and nos. 416, 488. 
Tab. 17: Continued

\begin{tabular}{|c|c|c|c|c|c|}
\hline No. & Title & Dating & $\begin{array}{l}\text { No. of } \\
\text { vols }\end{array}$ & $\begin{array}{l}\text { No. of } \\
\text { works }\end{array}$ & $\begin{array}{l}\text { Catalogue } \\
\text { no. }\end{array}$ \\
\hline$a b$ & lature by Paul Friedrich Knaack & & & & \\
\hline 4 & $\begin{array}{l}\text { Choral-Buch vom rechstädschen Glockenspiel. } \\
\text { der Stadt Danzig }\end{array}$ & $1808-12$ & 1 & 120 & $\begin{array}{l}\text { APG 300,R/ } \\
\text { Uu,q9 }\end{array}$ \\
\hline Man & nuscript by Carl Anton Kaschlinsky & & & & \\
\hline 5 & $\begin{array}{l}\text { Beschreibung des Glockenspiels auf dem Turme } \\
\text { des Rathauses zu Danzig nebst Verzeichnis der } \\
\text { Melodien, welches dasselbe spielt. } \\
\text { Verfaßt von Carl Anton Kaschlinsky, geboren } \\
\text { 28. Januar 1822, gestorben 24. Juli 1882 } \\
\text { Ratsturmuhrmacher und Glockenist 1847-1882 } \\
\text { Nebst einem Anhange, beiliegend, die Noten, } \\
\text { nach denen die Melodien gesetzt werden können. }\end{array}$ & 1861 & 1 & 7 & $\begin{array}{l}\text { PAN BG } \\
1093 \mathrm{IV}\end{array}$ \\
\hline & $\begin{array}{l}\text { Aus den Notennachlass des am 4. Dezember } \\
1884 \text { verstorbenen Musikdirektors Julius } \\
\text { Wilhelm Frühling, I. Organisten an St. } \\
\text { Johann, eines Freundes von Kaschlinsky, zur } \\
\text { dauernden Aufbewahrung überwiesen von Otto } \\
\text { Krieschen, I. Organist an St. Marien; Städtischer } \\
\text { Gesanglehrer, Danzig, den 19. Juli 1918. }\end{array}$ & & & & \\
\hline
\end{tabular}

Of the carillon tablatures from Gdańsk, one is in four volumes, dated at the period between 1769 and 775, and two in single volumes, both from 1775-76. They are currently held at the State Archive in Gdańsk. Stamp of the "Archiv der Stadt Danzig" and related catalogue numbers confirm these sources used to belong to the City of Gdańsk Archive. ${ }^{808}$

808 The State Archive in Gdańsk is the successor of the City of Gdańsk Archive (Archiv der Stadt Danzig). After the establishment in 1901 of the Königliches Staatsarchiv für Westpreußen in Danzig (Royal State Archive for West Prussia), the collections of the City of Gdańsk Archive were moved to a new location in 1902. In 1921, the name Königliches Staatsarchiv für Westpreußen in Danzig was changed to Staatsarchiv für Freie Stadt Danzig (State Archive of the Free City of Gdańsk), and in 1940, to Reichsarchiv Danzig. In 1945, the State Archive in Gdańsk was established after the city became part of Poland. That institution was named Wojewódzkie Archiwum Państwowe w Gdańsku (Voivodeship State Archive in Gdańsk) between 1951 and 1983, after which the first post-war name was reestablished. 
Tab. 18: Former catalogue numbers in the tablatures of Theodor Friedrich Gülich

\begin{tabular}{lll}
\hline No. & Olim & Current no. \\
\hline 1 & $\begin{array}{l}\text { Subsequent volumes: } \\
\text { "oct P. p,9,1.; “oct. Pp,9,2.; “oct Pp,9,3"; “oct, Pp,9,4.” }\end{array}$ & APG 300,R/Pp,q9 \\
& $\begin{array}{l}\text { On the spine of the box in which the volumes are placed: } \\
\text { "B. A. II Pp. 9." }\end{array}$ \\
& "oct, Pp,10". & APG 300,R/Pp,q10 \\
3 & "oct P. p,10". & APG 300,R/Pp,q10a \\
\hline
\end{tabular}

The old catalogue numbers suggest that the manuscripts belonged to an archive body named "Bibliotheca Archivi." ${ }^{009}$ That body became separated at the end of the sixteenth century and subsequently expanded by including various manuscripts. In the nineteenth century, it was subdivided into forty-six departments for various disciplines, marked by letters and a running number. ${ }^{810}$ When did Gülich's manuscripts join the Archive? An entry in the City Council cashbook indicates he received payment on 25 February 1774 for supplying four books with chorale for the carillon:

T. F. Gülich 4 Choral Bücher zum Glockenspiel verfertigt ins Archiv geliefert. ${ }^{811}$

This would indicate that in 1774, a four-volume tablature was donated to the Archive. Yet I believe Gülich and his two successors, Rudolph Liebegott Liebendey and Johann Gottlieb Borowski, continued to use it; otherwise they would have needed to programme music from memory. When Paul Friedrich Knaack edited a new tablature in 1808-12, ${ }^{812}$ the four-volume Gülich version and the two other tablatures were made obsolete and likely only then deposited in the Archive.

Paul Friedrich Knaak's tablature lacks the "Archiv der Stadt Danzig" stamp. Glued to its spine is a small paper note with the catalogue number " $300, \mathrm{H}$ quart Uu 9" written in black ink. The letter components of this number indicate that this tablature, like the previous ones, was assigned to the Bibliotheca Archivi library body. However, the number " 300 " before the letters and the running

809 This is unambiguously indicated by the catalogue number on the box: "B[ibliotheca] A[rchivi] II Pp. 9."

810 Sławoszewska, 'Zarys dziejów Archiwum Miasta Gdańska', 116-22; WęsierskaBiernatowa, Czaplicka, and Sławoszewska, Archiwum miasta Gdańska, 80-83.

811 APG 300,12/185, p. 115.

812 APG 300,R/Uu,q9. 
number were only added when the City of Gdańsk Archive was incorporated into the Königliches Staatsarchiv für Westpreußen in Danzig in 1901. The tablature was edited and referenced by Paul Friedrich Knaack, but was mostly used his successor, Carl Anton Kaschlinsky. I suppose Kaschlinsky continued to use it until 1861, the dating of the Choralbüsch von 1861, a source now lost which I mentioned above, and which probably replaced Knaack's tablature. I have been unable to determine when the latter joined the archive: whether in 1861, after Kaschlinsky's death in 1882, or later.

The manuscript of Carl Anton Kaschlinsky, city watchmaker and helper of Paul Friedrich Knaack and from 1847, standalone setter of the Main Town Hall bells, is kept today at the Polish Academy of Sciences Gdańsk Library. It was deposited in its predecessor, the Danziger Stadtbibliothek (Danzig City Library), in 1918, as indicated by its inventory number "D[anzig] 1918. 834" 813 and a day date, 19 July 1918, written at the end of the notes on the title page. These notes indicate that after Kaschlinsky's death, the manuscript was owned by Julius Wilhelm Frühling, organist at St John's in Gdańsk and Kaschlinsky's friend. ${ }^{814}$ Probably after Frühling's death in 1884, the manuscript passed to Otto Krieschen, first organist at St Mary's and singing teacher, who donated it to the city library. ${ }^{815} \mathrm{I}$ believe the title and content of the comments were entered by the Danziger Stadtbibliothek director, Otto Günther, when he received the donation. ${ }^{816} \mathrm{He}$ also noted the manuscript's author on the first page:

(von C[arl] A[nton] Kaschlinsky, Rathsuhrmacher u[nd] Glockenist v[on] 1847-1882.)

The manuscript was edited in 1861, as suggested by the notes on page seven, where Kaschlinsky lists the tunes he programmed for 23 September that year. ${ }^{817}$

\subsection{The tablatures of Theodor Friedrich Gülich}

\section{Tower books}

The oldest musical source with notation of works for the Main Town Hall carillon in Gdańsk is a tablature in four volumes by Theodor Friedrich Gülich, dated

813 This number is written in pencil at the top of the title page.

814 Michalak, 'Organista i dyrygent chórów Julius Wilhelm Frühling', 236-67.

815 Michalak, 261.

816 This highly probably supposition is based on an analysis of other documents written by Günther, kept notably in a folder of his correspondence related to expanding the Library's collections; see PAN BG Akta Kat. Nr 114.

817 I quote and comment on this note in Part One of the present book, discussing the origin and history of the Main Town Hall carillon; see page XXX. 
$1769-75 .{ }^{818}$ On the title page of its first volume, it is tagged as “Turm-Bücher," tower books. The name was mentioned for the first time by Andrzej Januszajtis in 1988, ${ }^{819}$ who extended it to the next two tablatures by Gülich from $1775-76,{ }^{820}$ though the latter are not termed as such on their title pages. Instead, the term used in them is "Choral-Buch," consistent with many manuscripts containing organ settings of Protestant chorale. "Tower books," on the other hand, is the term of choice of many authors writing about the Gdańsk carillons. ${ }^{821}$ I believe this is an appropriate term to use: it is historical and emphasises the special character of the Gdańsk sources, which are based on a unique notation system. ${ }^{822}$ The term should thus be extended to the manuscript of 1808-12, i.e., the fourth carillon tablature from Gdańsk. ${ }^{823}$

The title of the first volume of Gülich's four-volume tablature is very extensive. It suggests the manuscript was edited on the request of mayor Karl Groddeck. ${ }^{824}$ After elections to the City Council, which took place on 14 March 1769, Groddeck was replaced as lord mayor by Heinrich Zernecke, suggesting the tablature was begun in the first two months of 1769. The manuscript's last volume includes several notes, with the last dated 23 January $1775,{ }^{825}$ indicating work on the collection lasted no fewer than six years, from 1769 through 1775.

818 APG 300,R/Pp,q9.

819 Januszajtis, 'Muzyka gdańskich dzwonów', 13.

820 APG 300,R/Pp,q10; APG 300,R/Pp,q10a.

821 See notably Kaźmierczak, 'What the Gdańsk Carillons Played and Play', 71; Deleu, 'Johann Ephraim Eggert Choral Lieder'.

822 Dutch sources with music for automated carillon are termed in the literature "versteekboeken," "pin books." The English language literature uses the terms "re-pinning books" or "barrel-pegging book," while German scholars use "Steckbuch," referring to the action of programming the drum. The term used for Gdańsk carillon tablatures, "Turm-Bücher," does not refer to the action of programming tunes on the automaton's drum, but to the location where the books were used: the church tower. See Haspels, Automatic Musical Instruments, 169; Lehr, Truyen, and Huybens, The Art of the Carillon in the Low Countries, 110, 166; Rombouts, 'Carillon', 133.

823 APG 300,R/Uu,q9.

824 In the years 1458-1792, the Gdańsk Main City Council was composed of four mayors, who rotationally served as first mayor (lord mayor), and fourteen councillors. Karl Groddeck (1699-1774) became fourth mayor in 1758 and served as lord mayor in the years 1759, 1765, 1768, and 1772. See Zdrenka, Rats- und Gerichtspatriziat der Rechten Stadt Danzig, 2:126-39, 208-9. On the organisation of Gdańsk's City Council, see also Zdrenka, 'Ratusz Głównego Miasta w Gdańsku'.

825 APG 300,R/Pp,q9, p. 291. 


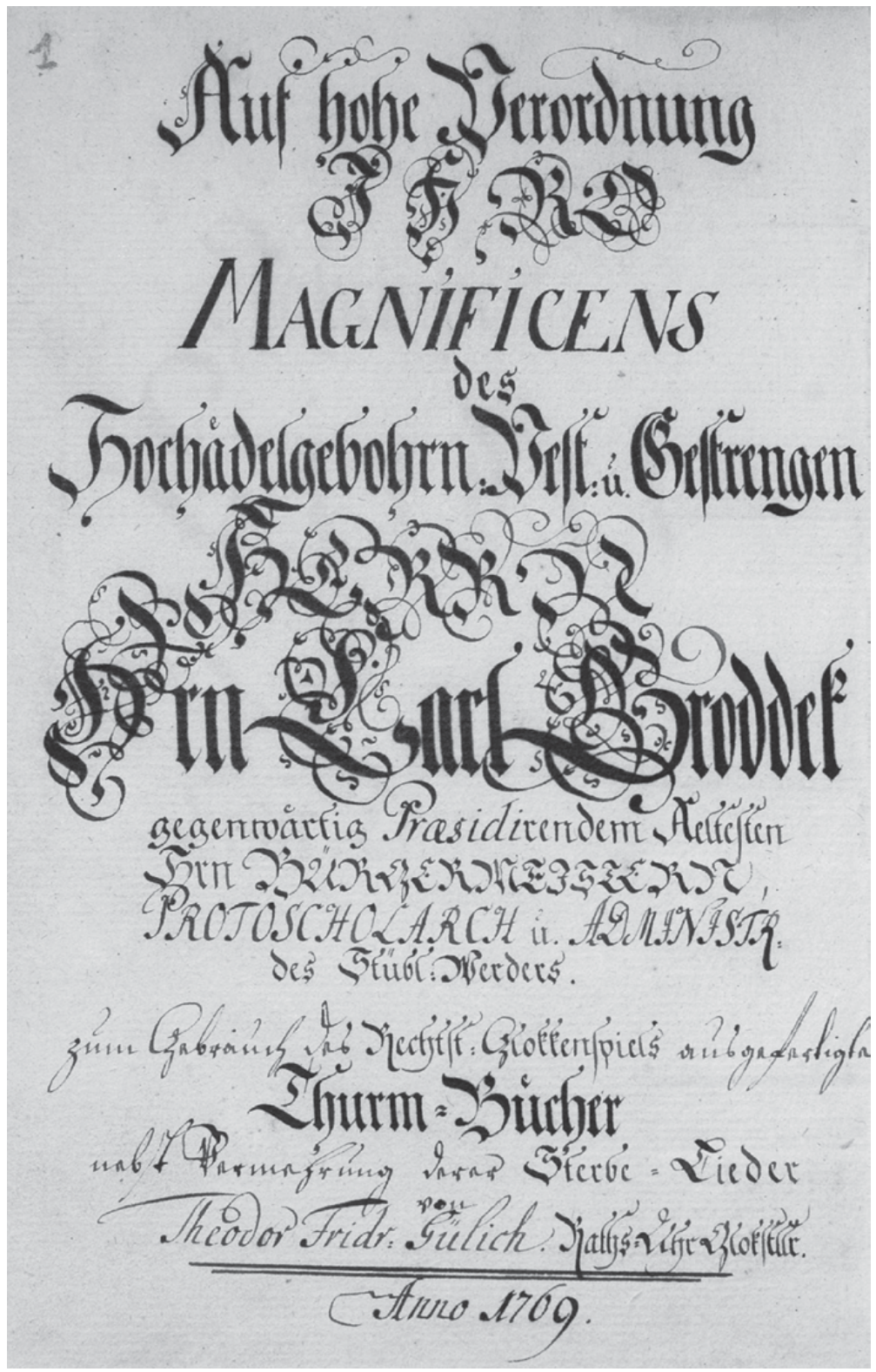

Fig. 60: Tablature of Th. F. Gülich, Turm-Bücher. APG 300,R/Pp,q9, title page 


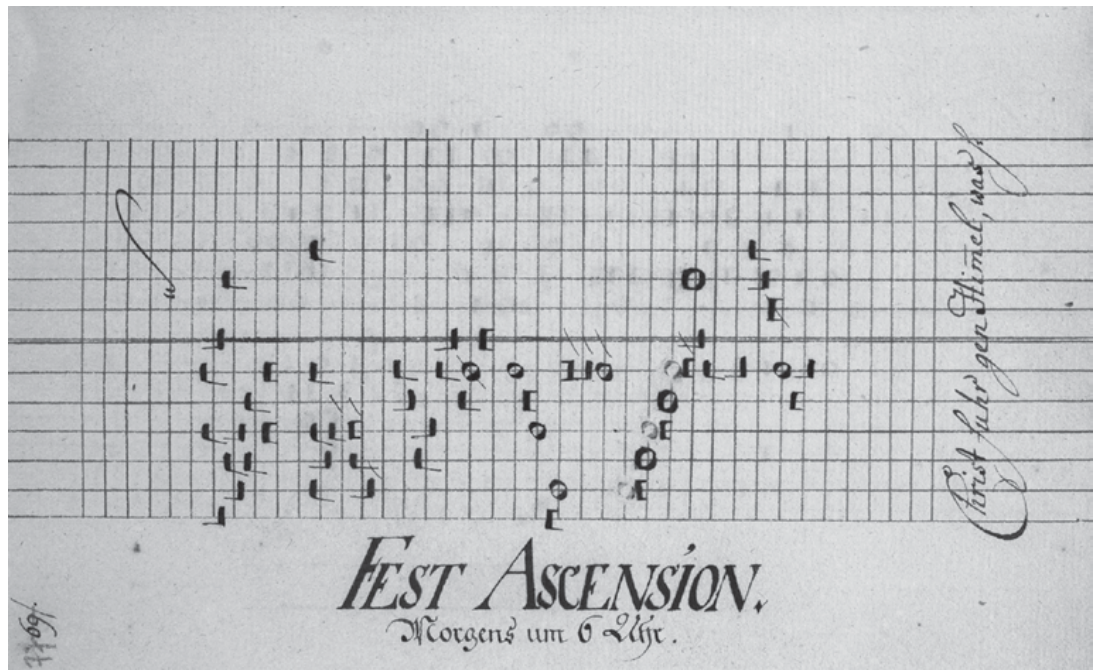

Fig. 61: Tablature of Th. F. Gülich, Turm-Bücher. APG 300,R/Pp,q9, p. 77

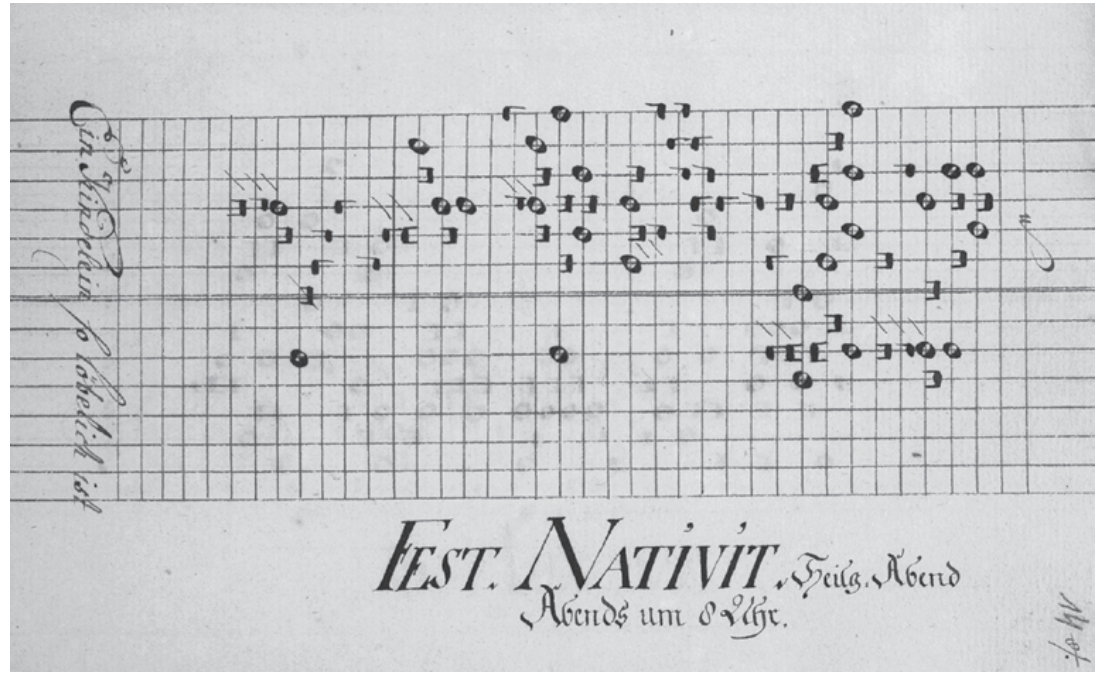

Fig. 62: Tablature of Th. F. Gülich, Turm-Bücher. APG 300,R/Pp,q9, p. 14 
Each volume is bound in the same brown leather. Covers are ornamented with a double or triple frame and a simple motif. The order is indicated by golden embossed roman numerals, "I," "II," "III," and "IV," placed at the top of back covers. In total, the manuscript includes 368 pages, numbered in pencil throughout. The pages also show an original numbering in Arabic digits, written in black ink. The cardboard box containing all four volumes measures $17 \mathrm{x}$ $13,5 \mathrm{~cm}$. On the spine, the following information about its content is embossed:

I, u[nd] IIter Theil, Jährliche Lieder.

IIIter Th[eil] Sterbe-

IVter Th[eil] Begräbniß

nebst Verordnungen.

1769.

In total, the four volumes include 220 song settings. They were authored - as well as, presumably, notated - by Theodor Friedrich Gülich, who was the setter of the Town Hall carillon between 1764 and 1776.

The volumes' content is varying. In the first two, Gülich wrote 128 settings of songs to be programmed on subsequent weeks and holidays. Their order is consistent with the liturgical calendar. We know that for each week and holiday, two different songs were programmed. Usually, a longer song was set on even hours and a shorter song on odd ones. Yet there are quite a few exceptions from that general rule. On a dozen weeks throughout the year, Gülich set a shorter song on the even hour, or songs of equal length on either hour. More importantly, the total length of two songs is always consistent: each pair fits the carillon drum.

Gülich labelled the first of two songs for each week with the name of that week or its related holiday, but there are exceptions to that rule, too. Occasionally, two or three variants of the same song appear in succession, while on Epiphany and the subsequent Sunday, only one song each is set. The reason for this inconsistency was simple. On Epiphany and the subsequent Sunday, the carol Puer natus in Bethlehem (Ein Kind geborn zu Bethlehem) was repeated after the New Year, so the lack of coherence is merely apparent. The key to a correct setting of songs on the carillon drum was not the succession of compositions in the manuscript but a directory placed at the end of the manuscript's second volume, which precisely indicates the order of songs for each week and holiday, divided into even and odd hours:

Register der jährl[ichen] Lieder. Mit der Cantzeley-Schrifft wird die gerade, und mit der Lateinischen die Ungerade Stunde angedeutt. ${ }^{826}$

826 The number of slats is listed consistently with the musical notation; two or three numbers listed indicated two or three variants of the same song. 


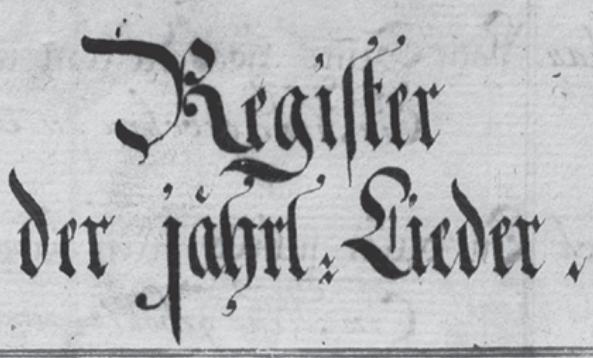

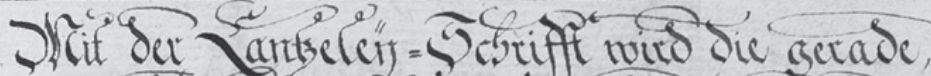

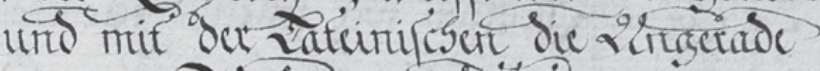
Sturde argeduift?

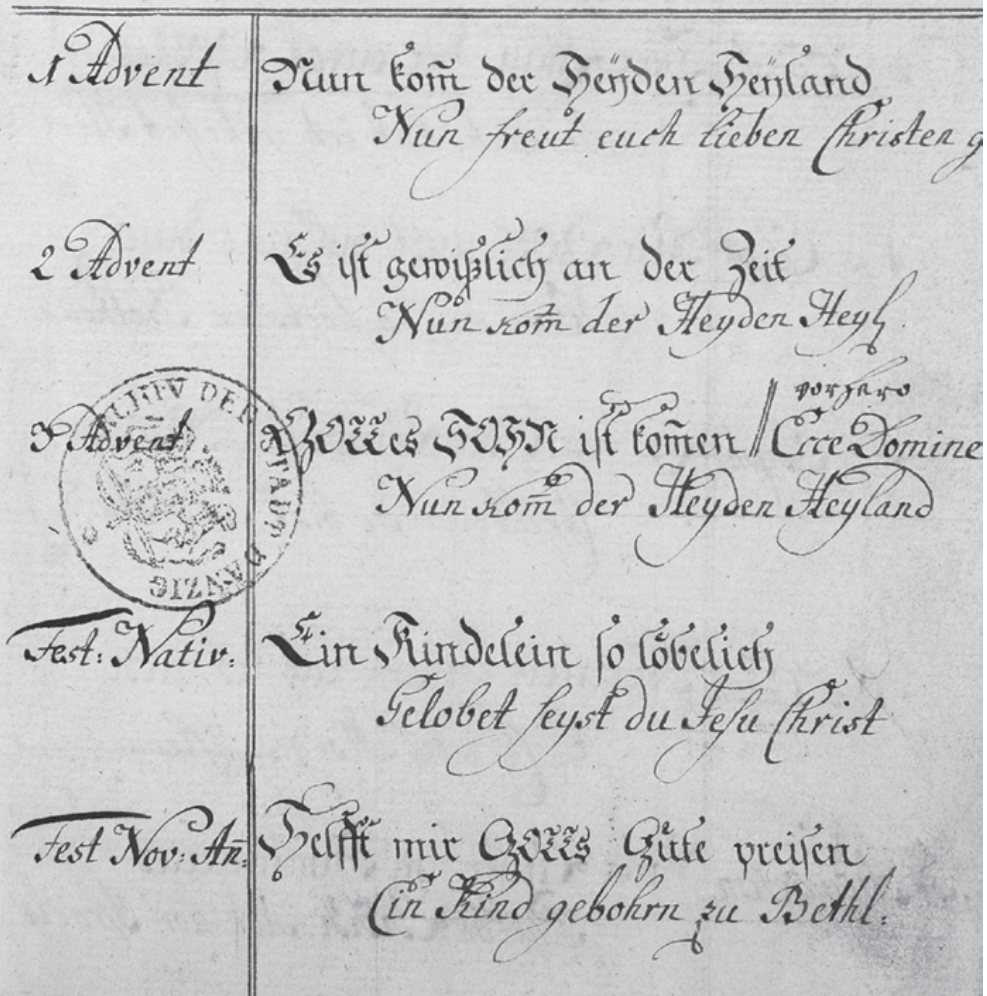

Fig. 63: Tablature of Th. F. Gülich, Turm-Bücher. APG 300,R/Pp,q9, p. 184 


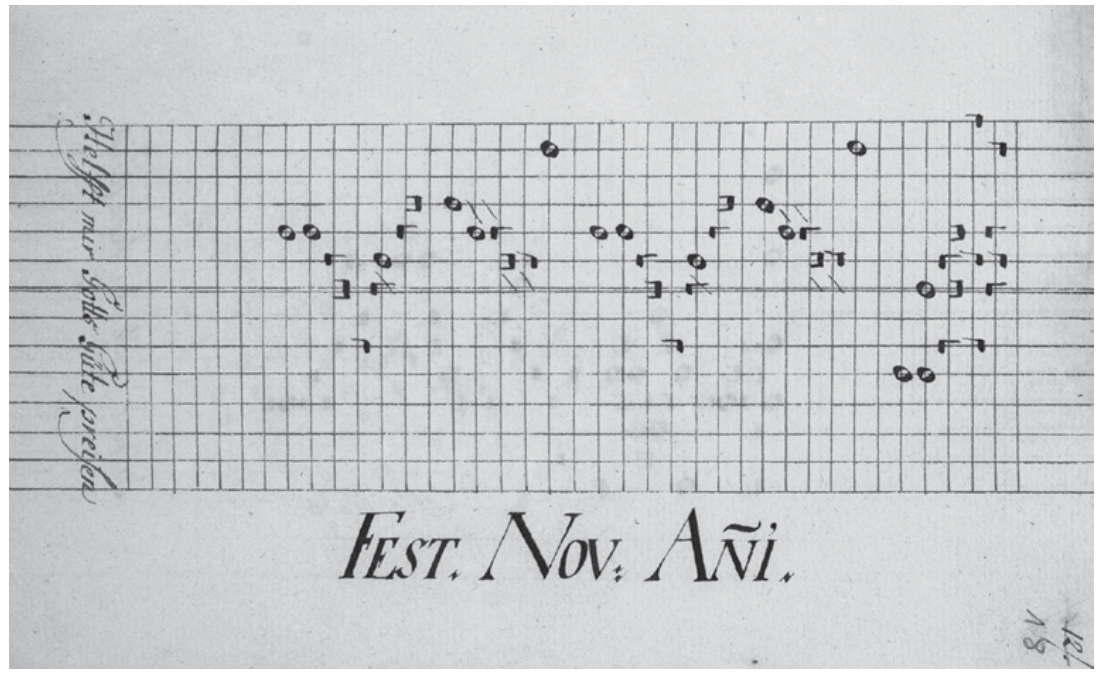

Fig. 64: Tablature of Th. F. Gülich, Turm-Bücher. APG 300,R/Pp,q9, p. 18

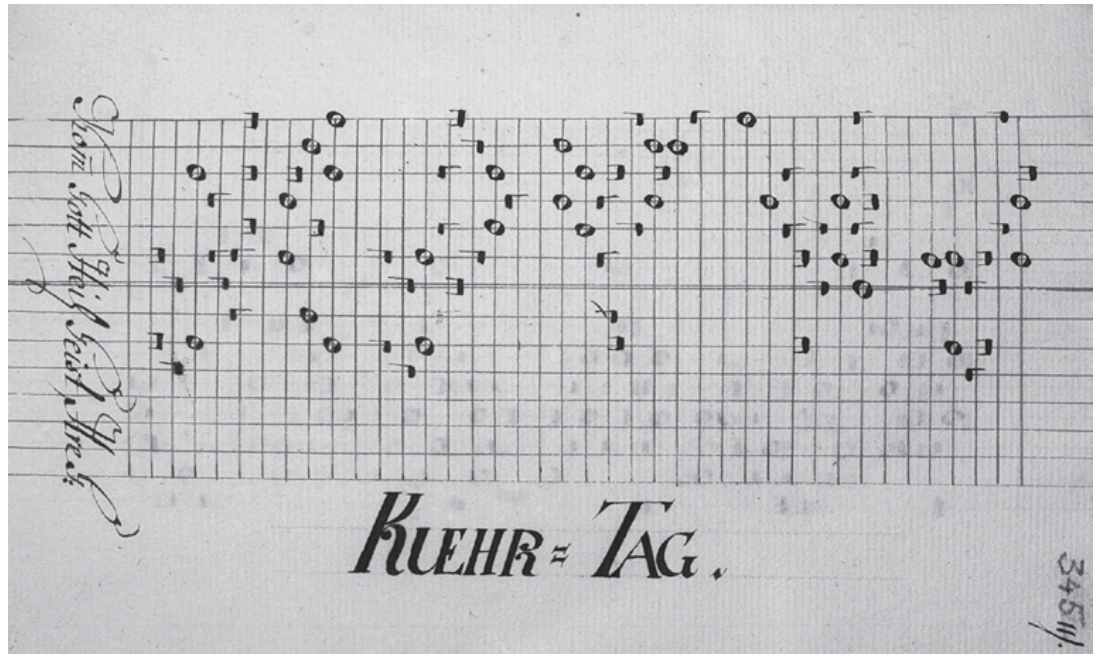

Fig. 65: Tablature of Th. F. Gülich, Turm-Bücher. APG 300,R/Pp,q9, p. 345 


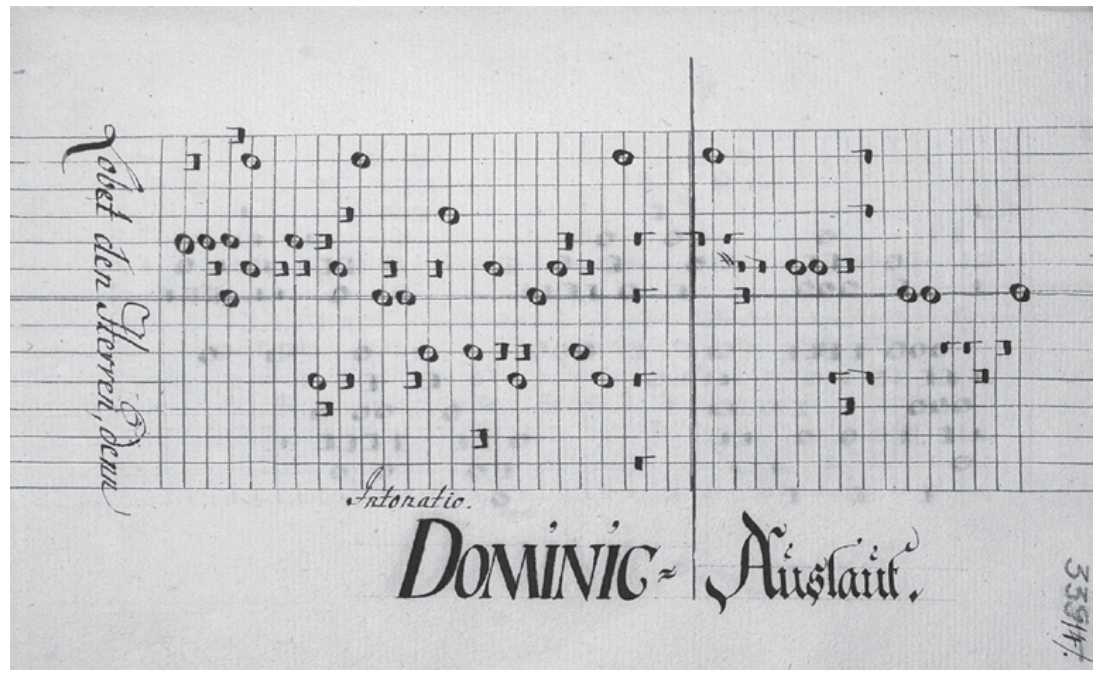

Fig. 66: Tablature of Th. F. Gülich, Turm-Bücher. APG 300,R/Pp,q9, p. 339

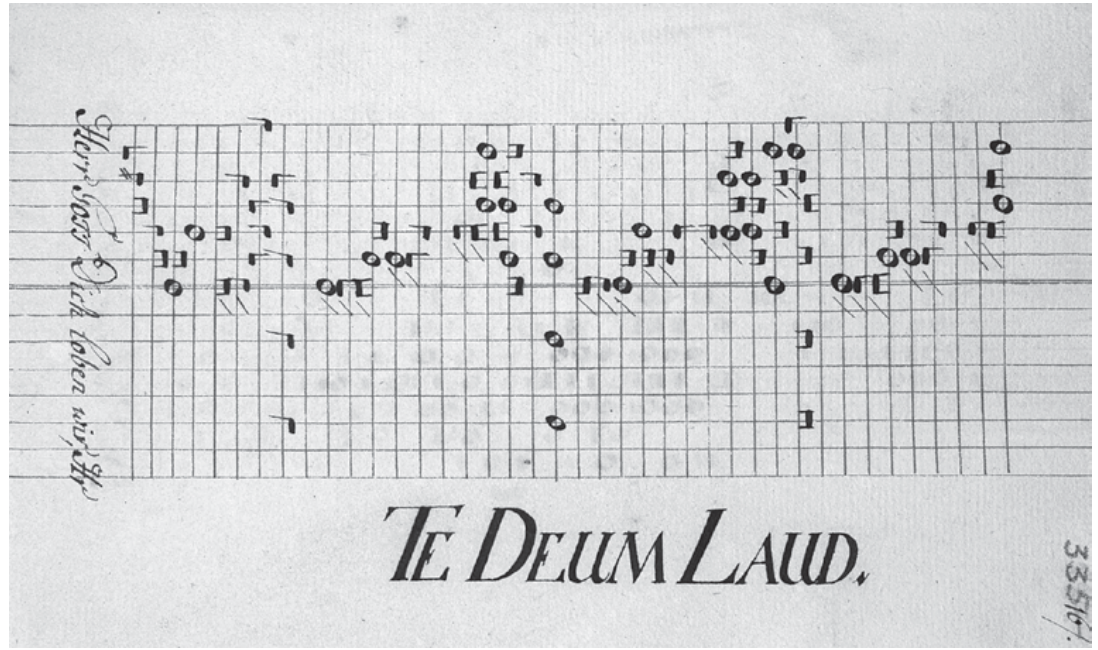

Fig. 67: Tablature of Th. F. Gülich, Turm-Bücher. APG 300,R/Pp,q9, p. 335 
Tab. 19: Yearly order of songs for the Main Town Hall carillon, after the directory in Gülich's four-volume tablature

\begin{tabular}{|c|c|c|}
\hline $\begin{array}{l}\text { Weeks and holidays of the } \\
\text { liturgical year }\end{array}$ & Song for the even and odd hour & $\begin{array}{l}\text { No. of } \\
\text { slats }^{837}\end{array}$ \\
\hline $\begin{array}{l}\text { Adventus, } \\
\text { Dominica } 1\end{array}$ & $\begin{array}{l}\text { Nun komm der Heiden Heiland } \\
\text { Nun freut euch lieben Christen gemein }\end{array}$ & $\begin{array}{l}21 \\
38 / 53\end{array}$ \\
\hline $\begin{array}{l}\text { Adventus, } \\
\text { Dominica } 2\end{array}$ & $\begin{array}{l}\text { Es ist gewißlich an der Zeit } \\
{ }^{\star} \text { Nun komm der Heiden Heiland }{ }^{838}\end{array}$ & $\begin{array}{l}37 / 52 \\
21\end{array}$ \\
\hline $\begin{array}{l}\text { Adventus, } \\
\text { Dominica } 3\end{array}$ & $\begin{array}{l}\text { Ecce Domine [Gottes Sohn ist kommen] } \\
{ }^{*} \text { Nun komm der Heiden Heiland }\end{array}$ & $\begin{array}{l}54 \\
21\end{array}$ \\
\hline Nativitas Domini & $\begin{array}{l}\text { Ein Kindelein so löbelich } \\
\text { Gelobet seist du Jesu Christ }\end{array}$ & $\begin{array}{l}53 \\
23 / 23\end{array}$ \\
\hline Novi Anni & $\begin{array}{l}\text { Helft mir Gottes Güte preisen } \\
\text { Ein Kind geborn zu Bethlehem [Puer natus in } \\
\text { Bethlehem] }\end{array}$ & $\begin{array}{l}53 \\
23 / 21\end{array}$ \\
\hline Epiphania Domini & $\begin{array}{l}\text { Vom Himmel hoch da komm' ich her } \\
{ }^{*} \text { Ein Kind geborn zu Bethlehem [Puer natus in } \\
\text { Bethlehem] }\end{array}$ & $\begin{array}{l}47 \\
23 / 21\end{array}$ \\
\hline $\begin{array}{l}\text { Epiphania Domini, } \\
\text { Dominica } 1\end{array}$ & $\begin{array}{l}\text { In dulci jubilo } \\
{ }^{\star} \text { Ein Kind geborn } z \text { uethlehem }[\text { Puer natus in } \\
\text { Bethlehem] }\end{array}$ & $\begin{array}{l}50 \\
23 / 21\end{array}$ \\
\hline $\begin{array}{l}\text { Epiphania Domini, } \\
\text { Dominica } 2\end{array}$ & $\begin{array}{l}\text { Christum wir sollen loben schon } \\
\text { Lobt Gott ihr Christen allzugleich }\end{array}$ & $\begin{array}{l}46 \\
31\end{array}$ \\
\hline $\begin{array}{l}\text { Epiphania Domini, } \\
\text { Dominica } 3\end{array}$ & $\begin{array}{l}\text { Herr Christ der ein'ge Gottes Sohn } \\
\text { In dich hab' ich gehoffet Herr }\end{array}$ & $\begin{array}{l}36 \\
34\end{array}$ \\
\hline $\begin{array}{l}\text { Epiphania Domini, } \\
\text { Dominica } 4\end{array}$ & $\begin{array}{l}\text { Wär' Gott nicht mit uns diese Zeit } \\
\text { Wenn wir in höchsten Nöten sein }\end{array}$ & $\begin{array}{l}37 \\
27\end{array}$ \\
\hline $\begin{array}{l}\text { Epiphania Domini, } \\
\text { Dominica } 5\end{array}$ & $\begin{array}{l}\text { Es spricht der Unweisen Mund } \\
\text { Christ der du bist der helle Tag }\end{array}$ & $\begin{array}{l}37 \\
30\end{array}$ \\
\hline $\begin{array}{l}\text { Epiphania Domini, } \\
\text { Dominica } 6\end{array}$ & $\begin{array}{l}\text { Meinen Jesum la } \beta^{\prime} \text { ich nicht } \\
\text { O Christe Morgensterne }\end{array}$ & $\begin{array}{l}39 \\
30\end{array}$ \\
\hline Septuagesima & $\begin{array}{l}\text { Vater unser im Himmelreich } \\
\text { Psalm } 80 \text { Ach hör Israels Hirt der wehrte }\end{array}$ & $\begin{array}{l}31 \\
31 / 45\end{array}$ \\
\hline Sexagesima & $\begin{array}{l}\text { O Herre Gott dein göttlich' Wort } \\
\text { Zwei Ding' o Herr bitt' ich von dir }\end{array}$ & $\begin{array}{l}46 / 44 \\
27\end{array}$ \\
\hline $\begin{array}{l}\text { Dominica } \\
\text { Esto mihi }\end{array}$ & $\begin{array}{l}\text { Kommt her zu mir spricht Gottes Sohn } \\
\text { Christe der du bist Tag und Licht }\end{array}$ & $\begin{array}{l}41 \\
28\end{array}$ \\
\hline
\end{tabular}

827 Asterisk at song title indicates a repeated setting.

828 APG 300,R/Pp,q9, pp. 177-84. 
Tab. 19: Continued

\begin{tabular}{|c|c|c|}
\hline $\begin{array}{l}\text { Weeks and holidays of the } \\
\text { liturgical year }\end{array}$ & Song for the even and odd hour & $\begin{array}{l}\text { No. of } \\
\text { slats }^{837}\end{array}$ \\
\hline Dominica Invocavit & $\begin{array}{l}\text { Ein' feste Burg ist unser Gott } \\
\text { Wenn wir in höchsten Nöten sein }\end{array}$ & $\begin{array}{l}47 \\
22 / 28\end{array}$ \\
\hline Dominica Reminiscere & $\begin{array}{l}\text { Psalm } 22 \text { Mein Gott ach wie verstößt du } \\
\text { Ach Gott und Herr }\end{array}$ & $\begin{array}{l}52 \\
22\end{array}$ \\
\hline Dominica Oculi & $\begin{array}{l}\text { Jesu meines Lebens Leben } \\
\text { Herzliebster Jesu was hast du verbrochen }\end{array}$ & $\begin{array}{l}54 \\
23\end{array}$ \\
\hline Dominica Laetare & $\begin{array}{l}\text { O Lamm Gottes unschuldig } \\
\text { Wenn meine Sünd' mich kränken }\end{array}$ & $\begin{array}{l}38 \\
38\end{array}$ \\
\hline Dominica Judica & $\begin{array}{l}\text { Christus der uns selig macht } \\
\text { O Jesu Christ mein's Lebens Licht }\end{array}$ & $\begin{array}{l}51 \\
22\end{array}$ \\
\hline Dominica in Palmis & $\begin{array}{l}\text { O Traurigkeit o Herzeleid } \\
\text { Da Jesus an dem Kreuze stand }\end{array}$ & $\begin{array}{l}46 \\
27\end{array}$ \\
\hline Feria 6 in Parasceve & Herr Jesu Christ wahr' Mensch und Gott & 28 \\
\hline Pascha & $\begin{array}{l}\text { Christ ist erstanden } \\
\text { Jesus Christus unser Heiland der den Tod } \\
\text { überwand }\end{array}$ & $\begin{array}{l}54 \\
22\end{array}$ \\
\hline Dominica Quasimodogeniti & $\begin{array}{l}\text { Christ lag in Todes Banden } \\
\text { Erstanden ist der heilige Christ }\end{array}$ & $\begin{array}{l}41 \\
27 / 27\end{array}$ \\
\hline $\begin{array}{l}\text { Dominica Misericordias } \\
\text { Domini }\end{array}$ & $\begin{array}{l}\text { Der Herr ist mein getreuer Hirt' } \\
\text { Surrexit Christus hodie }\end{array}$ & $\begin{array}{l}37 \\
27 / 27(30)\end{array}$ \\
\hline Dominica Jubilate & $\begin{array}{l}\text { Mag ich Unglück nicht widerstahn } \\
\text { Wenn wir in höchsten Nöten sein }\end{array}$ & $\begin{array}{l}46 \\
28\end{array}$ \\
\hline Dominica Cantate & $\begin{array}{l}\text { Vater unser im Himmelreich } \\
\text { Nun freut euch lieben Christen gemein }\end{array}$ & $\begin{array}{l}34 \\
38\end{array}$ \\
\hline Ascensio Domini & $\begin{array}{l}\text { Christ fuhr gen Himmel } \\
\text { Nun freut euch Gottes Kinder all }\end{array}$ & $\begin{array}{l}54 \\
23\end{array}$ \\
\hline Pentacostes & $\begin{array}{l}\text { Komm heiliger Geist Herre Gott } \\
\text { Komm Gott Schöpfer heiliger Geist }\end{array}$ & $\begin{array}{l}54 \\
22\end{array}$ \\
\hline Trinitas & $\begin{array}{l}\text { Allein Gott in der Höh' sei Ehr' } \\
\text { Nun bitten wir den heiligen Geist }\end{array}$ & $\begin{array}{l}38 / 39 \\
31\end{array}$ \\
\hline $\begin{array}{l}\text { Trinitas, } \\
\text { Dominica } 1\end{array}$ & $\begin{array}{l}\text { Es woll' uns Gott genädig sein } \\
\text { Ich glaub' an Gott der geschaffen hat }\end{array}$ & $\begin{array}{l}46(47) \\
30\end{array}$ \\
\hline $\begin{array}{l}\text { Trinitas, } \\
\text { Dominica } 2\end{array}$ & $\begin{array}{l}\text { Ach Gott vom Himmel sieh darein } \\
\text { Weltlich' Ehr' und zeitlich' Gut }\end{array}$ & $\begin{array}{l}39 \\
31\end{array}$ \\
\hline $\begin{array}{l}\text { Trinitas, } \\
\text { Dominica } 3\end{array}$ & $\begin{array}{l}\text { Aus tiefer Not schrei' ich zu dir } \\
\text { Psalm } 121 \text { Mein'Augen ich zu den Bergen }\end{array}$ & $\begin{array}{l}41 \\
29\end{array}$ \\
\hline $\begin{array}{l}\text { Trinitas, } \\
\text { Dominica } 4\end{array}$ & $\begin{array}{l}\text { Ich ruf' zu dir Herr Jesu Christ } \\
\text { Mensch willst du leben seliglich }\end{array}$ & $\begin{array}{l}45 \\
31\end{array}$ \\
\hline
\end{tabular}


Tab. 19: Continued

\begin{tabular}{|c|c|c|}
\hline $\begin{array}{l}\text { Weeks and holidays of the } \\
\text { liturgical year }\end{array}$ & Song for the even and odd hour & $\begin{array}{l}\text { No. of } \\
\text { slats }^{837}\end{array}$ \\
\hline $\begin{array}{l}\text { Trinitas, } \\
\text { Dominica } 5\end{array}$ & $\begin{array}{l}\text { Wo Gott zum Haus nicht gibt sein' Gunst } \\
\text { Zwei Ding' o Herr bitt' ich von dir }\end{array}$ & $\begin{array}{l}46 \\
27\end{array}$ \\
\hline $\begin{array}{l}\text { Trinitas, } \\
\text { Dominica } 6\end{array}$ & $\begin{array}{l}\text { Herr Christ der ein'ge Gottes Sohn } \\
\text { Es spricht der Unweisen Mund }\end{array}$ & $\begin{array}{l}36 \\
37 / 38\end{array}$ \\
\hline $\begin{array}{l}\text { Trinitas, } \\
\text { Dominica } 7\end{array}$ & $\begin{array}{l}\text { Warum betrübst du dich mein Herz } \\
\text { Psalm } 128 \text { Selig ist der gepreiset }\end{array}$ & $\begin{array}{l}33 \\
38\end{array}$ \\
\hline $\begin{array}{l}\text { Trinitas, } \\
\text { Dominica } 8\end{array}$ & $\begin{array}{l}\text { Dies sind die heil'gen zehn Gebot' } \\
\text { Ach Gott vom Himmel sieh darein }\end{array}$ & $\begin{array}{l}35 \\
39\end{array}$ \\
\hline $\begin{array}{l}\text { Trinitas, } \\
\text { Dominica } 9\end{array}$ & $\begin{array}{l}\text { Weltlich'Ehr' und zeitlich' Gut } \\
\text { Mensch willst du leben seliglich }\end{array}$ & $\begin{array}{l}35 \\
35\end{array}$ \\
\hline $\begin{array}{l}\text { Trinitas, } \\
\text { Dominica } 10\end{array}$ & $\begin{array}{l}\text { An Wasserflüssen Babylon } \\
\text { Wenn wir in höchsten Nöten sein }\end{array}$ & $\begin{array}{l}55 \\
22 / 22\end{array}$ \\
\hline $\begin{array}{l}\text { Trinitas, } \\
\text { Dominica } 11\end{array}$ & $\begin{array}{l}\text { Aus tiefer Not schrei' ich zu dir } \\
\text { Ach Gott und Herr }\end{array}$ & $\begin{array}{l}41 \\
22 / 22 / 31\end{array}$ \\
\hline $\begin{array}{l}\text { Trinitas, } \\
\text { Dominica } 12\end{array}$ & $\begin{array}{l}\text { Was mein Gott will das gescheh' allzeit } \\
\text { Psalm } 125 \text { Alle die auf Gott dem Herren }\end{array}$ & $\begin{array}{l}43 \\
31\end{array}$ \\
\hline $\begin{array}{l}\text { Trinitas, } \\
\text { Dominica } 13\end{array}$ & $\begin{array}{l}\text { Ich ruf' zu dir Herr Jesu Christ } \\
\text { Mensch willst du leben seliglich }\end{array}$ & $\begin{array}{l}46 \\
31\end{array}$ \\
\hline $\begin{array}{l}\text { Trinitas, } \\
\text { Dominica } 14\end{array}$ & $\begin{array}{l}\text { Herr Christ der ein'ge Gottes Sohn } \\
\text { Nun freut euch lieben Christen gemein }\end{array}$ & $\begin{array}{l}35 \\
38\end{array}$ \\
\hline $\begin{array}{l}\text { Trinitas, } \\
\text { Dominica } 15\end{array}$ & $\begin{array}{l}\text { Zwei Ding' o Herr bitt' ich von dir } \\
\text { Wenn wir in höchsten Nöten sein }\end{array}$ & $\begin{array}{l}54 \\
21\end{array}$ \\
\hline $\begin{array}{l}\text { Trinitas, } \\
\text { Dominica } 16\end{array}$ & $\begin{array}{l}\text { Mag ich Unglück nicht widerstahn } \\
\text { Auf meinen lieben Gott }\end{array}$ & $\begin{array}{l}46 \\
28\end{array}$ \\
\hline $\begin{array}{l}\text { Trinitas, } \\
\text { Dominica } 17\end{array}$ & $\begin{array}{l}\text { Wär' Gott nicht mit uns diese Zeit } \\
\text { In dich hab' ich gehoffet Herr }\end{array}$ & $\begin{array}{l}37 \\
35\end{array}$ \\
\hline $\begin{array}{l}\text { Trinitas, } \\
\text { Dominica } 18\end{array}$ & $\begin{array}{l}\text { Dies sind die heil'gen zehn Gebot' } \\
\text { Psalm } 110 \text { Der Herr zu meinem Herren hat } \\
\text { gesprochen }\end{array}$ & $\begin{array}{l}36 \\
38\end{array}$ \\
\hline $\begin{array}{l}\text { Trinitas, } \\
\text { Dominica } 19\end{array}$ & $\begin{array}{l}\text { Ich ruf' zu dir Herr Jesu Christ } \\
\text { Christe der du bist Tag und Licht }\end{array}$ & $\begin{array}{l}46 \\
28\end{array}$ \\
\hline $\begin{array}{l}\text { Trinitas, } \\
\text { Dominica } 20\end{array}$ & $\begin{array}{l}\text { Wie schön leuchtet der Morgenstern } \\
\text { Wohl dem der in Gottesfurcht steht [Wo Gott } \\
\text { zum Haus nicht gibt sein' Gunst] }\end{array}$ & $\begin{array}{l}53 \\
22\end{array}$ \\
\hline $\begin{array}{l}\text { Trinitas, } \\
\text { Dominica } 21\end{array}$ & $\begin{array}{l}\text { O Herr dein Ohren neig zu mir } \\
\text { Aus tiefer Not schrei' ich zu dir }\end{array}$ & $\begin{array}{l}35 \\
38\end{array}$ \\
\hline $\begin{array}{l}\text { Trinitas, } \\
\text { Dominica } 22\end{array}$ & $\begin{array}{l}\text { Erbarm dich mein o Herre Gott } \\
\text { Ach Gott und Herr }\end{array}$ & $\begin{array}{l}46 \\
29\end{array}$ \\
\hline
\end{tabular}


Tab. 19: Continued

\begin{tabular}{lll}
\hline $\begin{array}{l}\text { Weeks and holidays of the } \\
\text { liturgical year }\end{array}$ & Song for the even and odd hour & $\begin{array}{l}\text { No. of } \\
\text { slats }^{\mathbf{3 7}}\end{array}$ \\
\hline Trinitas, & Verleih uns Frieden gnädiglich & 54 \\
Dominica 23 & Wend ab deinen Zorn lieber Herre mit Gnaden & 23 \\
Trinitas, & Allein zu dir Herr Jesu Christ & 54 \\
Dominica 24 & Wenn wir in höchsten Nöten sein & 21 \\
Trinitas, & Freu dich sehr o meine Seele & 54 \\
Dominica 25 & Ihr lieben Christen freut euch nun & 21 \\
Trinitas, & Es ist gewißlich an der Zeit & 37 \\
Dominica 26 & Gott hat das Evangelium & 37 \\
Trinitas, & Wachet auf ruft uns die Stimme & 54 \\
Dominica 27 & Ach Gott wie manches Herzeleid & 22 \\
\hline
\end{tabular}

After the yearly songs, Gülich added four extra holiday songs ("Fest-Lieder") and an additional setting of the Ein' feste Burg in the tablature's second volume.

Tab. 20: Holiday songs added to the yearly order and the Ein' feste Burg song (with no indication of when it should be set)

\begin{tabular}{llll}
\hline Holiday & Song title & Note & No. of lats \\
\hline $\begin{array}{l}\text { Mariae (B. V.) } \\
\begin{array}{l}\text { Purificatio } \\
\text { Joannis }\end{array}\end{array}$ & Mit Fried' und Freud' & 39 \\
$\begin{array}{l}\text { Baptistae } \\
\text { Mariae (B. V.) Visitatio }\end{array}$ & $\begin{array}{l}\text { Christ unser Herr zum Jordan } \\
\text { Michaelis Archangeli }\end{array}$ & Morgens um 8 Uhr & 46 \\
& $\begin{array}{l}\text { Wer in dem Schutz des Höchsten } \\
\text { ist }\end{array}$ & Morgens um 7 Uhr & 39 \\
& Ein'feste Burg & 37 \\
& & 50 \\
\hline
\end{tabular}

Next, Gülich added the following instruction: "Die Veränderung derer Lieder auf der Waltze...," referring to the way of switching a tune on the carillon drum. ${ }^{829}$ I have already discussed that instruction in the chapter on time measurement (see Fig. 8). 
The tablature's second volume ends with three directories: ordered chronologically, ${ }^{830}$ alphabetically ("Zweytes Register derer jährl[ichen] Lieder nach dem Alphabeth"), ${ }^{831}$ and by holiday ("Fest-Lieder"). ${ }^{832}$

The tablature's third volume, titled "B[egräbnis-] Sterbe-Lieder," includes funeral songs and psalms, as indicated by the directory included on its last pages: "Register derer Sterbe-Lieder u[nd] Psalm[en]," ${ }^{833}$ as well as a note referring to the setting and selection of songs in agreement with the deceased person's family ("Sterbe-Hau $\beta$ "):

Diese Sterbe Lieder werden Tag um Tag aufgesetzt, einmahl die gerade, das andere mahl die ungerade Stunde, und zwar dasjenige welches von einem Hochedl[en] Sterbe-Hauß verlangt wird. ${ }^{834}$

This volume includes seventy-four funeral song settings, thirteen variants, and four psalms. The tablature's fourth volume is titled "Begräbniß-L[ieder] nebst Verordnung" and includes eleven settings of seven funeral songs:

Welt ich muß dich lassen (four settings)

Mit Fried' und Freud' (two settings)

Mitten wir im Leben sind

Gott der Vater wohn' uns bei

Durch Adams Fall ist ganz verderbt

Nun laßt uns den Leib begraben

Hört auf mit Trauern und Klagen

as well as seven settings of songs for: City Council elections: Komm heiliger Geist Herre Gott (two settings); the beginning and end of the St Dominic's Fair: Es woll' uns Gott genädig sein, Zwei Ding' o Herr bitt' ich, Lobet den Herren, Nun laßt uns Gott den Herrn; special occasions: Te Deum laudamus with the German title Herr Gott dich loben wir.

An extensive fragment of the tablature's fourth volume is the above-mentioned instruction ("Verordnung"). ${ }^{835}$ As we know, it includes recommendations on the occasions for each song programmed on the Town Hall carillon (notably king's coronation, king's death, mayor's death, mayor's wife death, elections to the City

830 APG 300,R/Pp,q9, pp. 177-84.

831 APG 300,R/Pp,q9, pp. 172-74.

832 APG 300,R/Pp,q9, p. 176.

833 APG 300,R/Pp,q9, pp. 185-89.

834 APG 300,R/Pp,q9, p. 189.

835 APG 300,R/Pp,q9, pp. 277-91. See my notes on signalling special events in this book's Part 1. 
Council, beginning and end of the St Dominic's Fair). Moreover, that fourth volume includes a slip note titled "Fortsezzung derer Sterbe. Lieder," which lists the titles of funeral songs and psalms, assigned to successive days from 30 January to 5 February, but unfortunately without the year. The handwriting on the slip is similar to that on other pages of the manuscript.

Graphically speaking, the tablature's four volumes do not differ between each other. They are very meticulously edited, though some song settings include corrections (deletions, scrapes, signs written in red ink). I believe that it was Theodor Friedrich Gülich who wrote the entire tablature.

\section{Evangelical-Lutheran songbook}

Apart from tower books, Theodor Friedrich Gülich is also the author of two single-volume tablatures. One, titled Choral Buch Nach denen Evangelisch Lutherschen Kirchengesängen, ${ }^{836}$ includes settings of Lutheran songs, while Choral Buch Nach denen Evangelisch Reformirten Kirchengesängen ${ }^{837}$ has settings of songs from the Reformed church. The two should be considered as a whole. They are bound identically in brown leather, with vegetal motifs on a golden background on the spince. The upper part of the spince has parchment slips, matching the ornaments, with the book's abridged titles: "Luthersches Choral Buch" and "Reformirtes Choral Buch," respectively.

I have assumed the four-volume tablature was edited entirely by Theodor Friedrich Gülich. On the other hand, I believe the Lutheran and Reformed Church songs were actually edited by two different people. Gülich wrote the music, titled the various settings, while someone else, perhaps a professional copyist (the handwriting is extremely precise), wrote the title pages, song directories, carillon drum programming indications, as well as the dedication letter and eleven pages of City Council members' names in the Evangelical-Lutheran volume.

On both books, the unknown copyist wrote the year 1775. Analysing the content of title pages, we can attempt a more precise dating of either tablature. The first pages of both manuscripts are graphically identical, including an ornamental frame with a vegetal ornament. Into each of the frame's arms, black-and-white coat of arms have been embedded: that of Gdańsk in the lower part, Conradi family in the upper part, Wolff family to the right, and Weickhmann family to the left. ${ }^{838}$ The coat of arms represents the highest authorities in Gdańsk in that

836 APG 300,R/Pp,q10.

837 APG 300,R/Pp,q10a.

838 Gizowski, Herby patrycjatu gdańskiego, 124-33, 656-59, 694-95. 
period: current mayor Eduard Friedrich Conradi and two mayors, Samuel Wolff and Gottlieb Gabriel Weickhmann. ${ }^{839}$

Interestingly enough, the coat of arms of the fourth mayor does not appear on the title page; instead, the city's coat of arms is featured. In fact, Heinrich Zernecke, the fourth mayor acting in 1775, had died on 30 July that year, and the position was left vacant until the next election. ${ }^{840}$ The lack of Zernecke's coat of arms on the title page indicates that both tablatures were edited after his death, possibly at the beginning of the following year, since a letter to the Council included in the Evangelical-Lutheran volume and signed by Gülich is dated 1 January $1776 .{ }^{841} \mathrm{Had}$ this indeed been the case, the editing time of either book would have been very short, as Theodor Friedrich was dead by May 1776. Of course, the letter might have been postdated, lengthening the time of editing the manuscripts by several months. Two borderline datings are unambiguous: editing started no earlier than 30 July 1775, the death of Heinrich Zernecke, and ended no later than 2 May 1776, when Gülich died.

As mentioned before, the tablature containing the Evangelical-Lutheran repertoire, Choral Buch Nach denen Evangelisch Lutherschen Kirchengesängen, includes elements absent from the Evangelical-Reformed book. One is pages with the names of all members of the Gdańsk City Council with the positions they held. ${ }^{842}$ The list opens with the name of royal burgrave Johann Bentzmann, followed by current mayor, Eduard Friedrich Conradi, mayor Samuel Wollf, and second mayor Gottlieb Gabriel Weickhmann. The fourth mayor, the late Heinrich Zernecke, is of course not mentioned. On the following pages, the following councillors are mentioned: Johann Friedrich Schumann, Christian Friese, Johann Caspar Tessin, Johann Georg Döring, Johann Nicolas Oehmchen, Gottfried Schwartz, Johann Gottlieb Pelegau, Johann Gottfried Reyger, Johann Anthon von Waesberghe, Paul Gottfried Aycke, Johann Hieronymus Broen, Friedrich Gottlieb Remmerson, Heinrich Martens, and town clerk Salomon Jantzen. ${ }^{843}$

The other element included exclusively in this book is a letter from the editor to the City Council. ${ }^{844}$ In it, Theodor Friedrich Gülich communicated a number of remarks and comments directly related to his work. He described the tasks

839 Zdrenka, Rats- und Gerichtspatriziat der Rechten Stadt Danzig, 2:140.

840 Ibid.

841 APG 300,R/Pp,q10, pp. 17-21.

842 APG 300,R/Pp,q10, pp. 7-17.

843 Zdrenka, Rats- und Gerichtspatriziat der Rechten Stadt Danzig, 2:140.

844 APG 300,R/Pp,q10, pp. 17-21. 


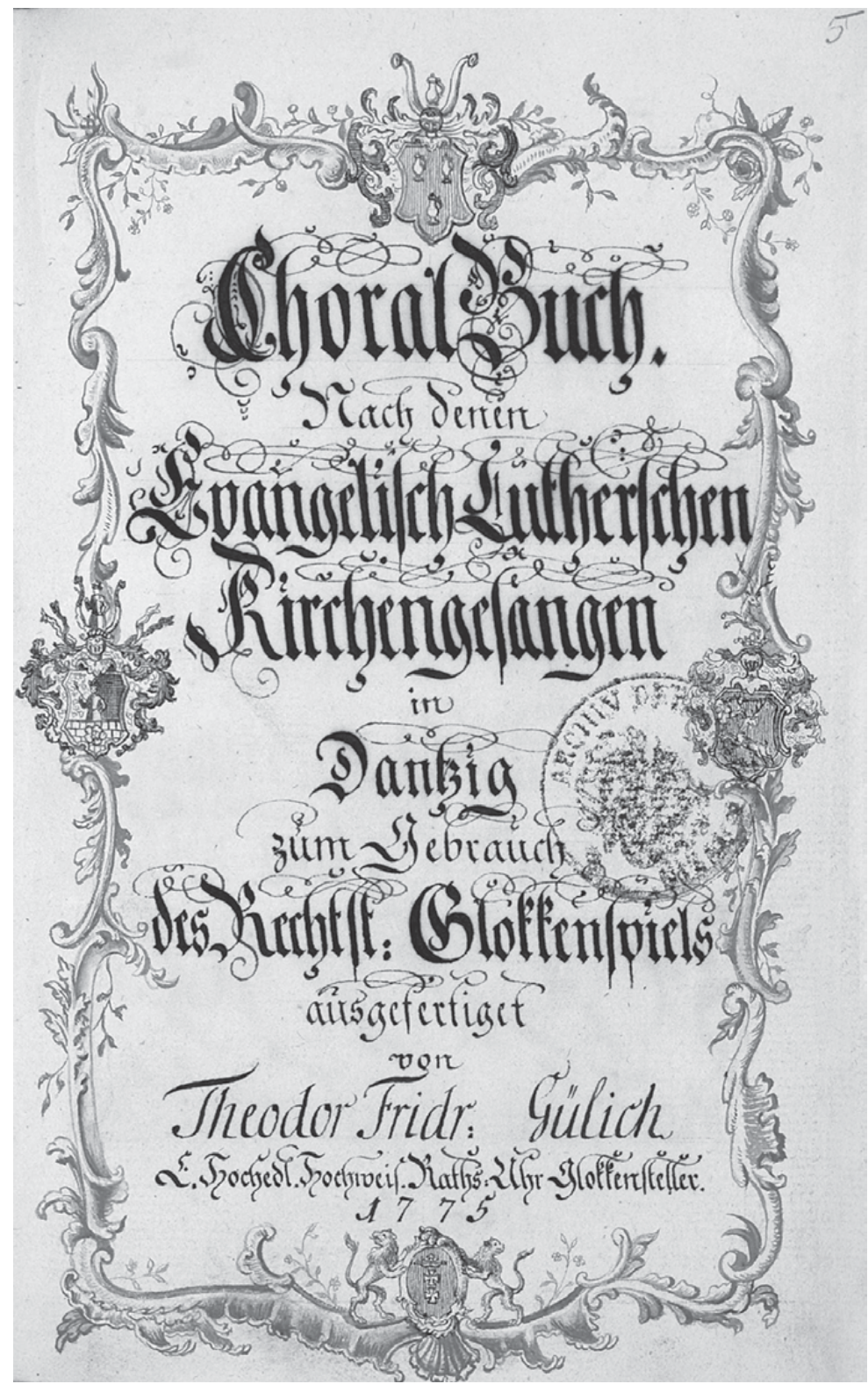

Fig. 68: Tablature of Th. F. Gülich, Choral Buch Nach denen Evangelisch Lutherschen Kirchengesängen. APG 300,R/Pp,q10, title page 
232

Main Town Hall automated carillon repertoire

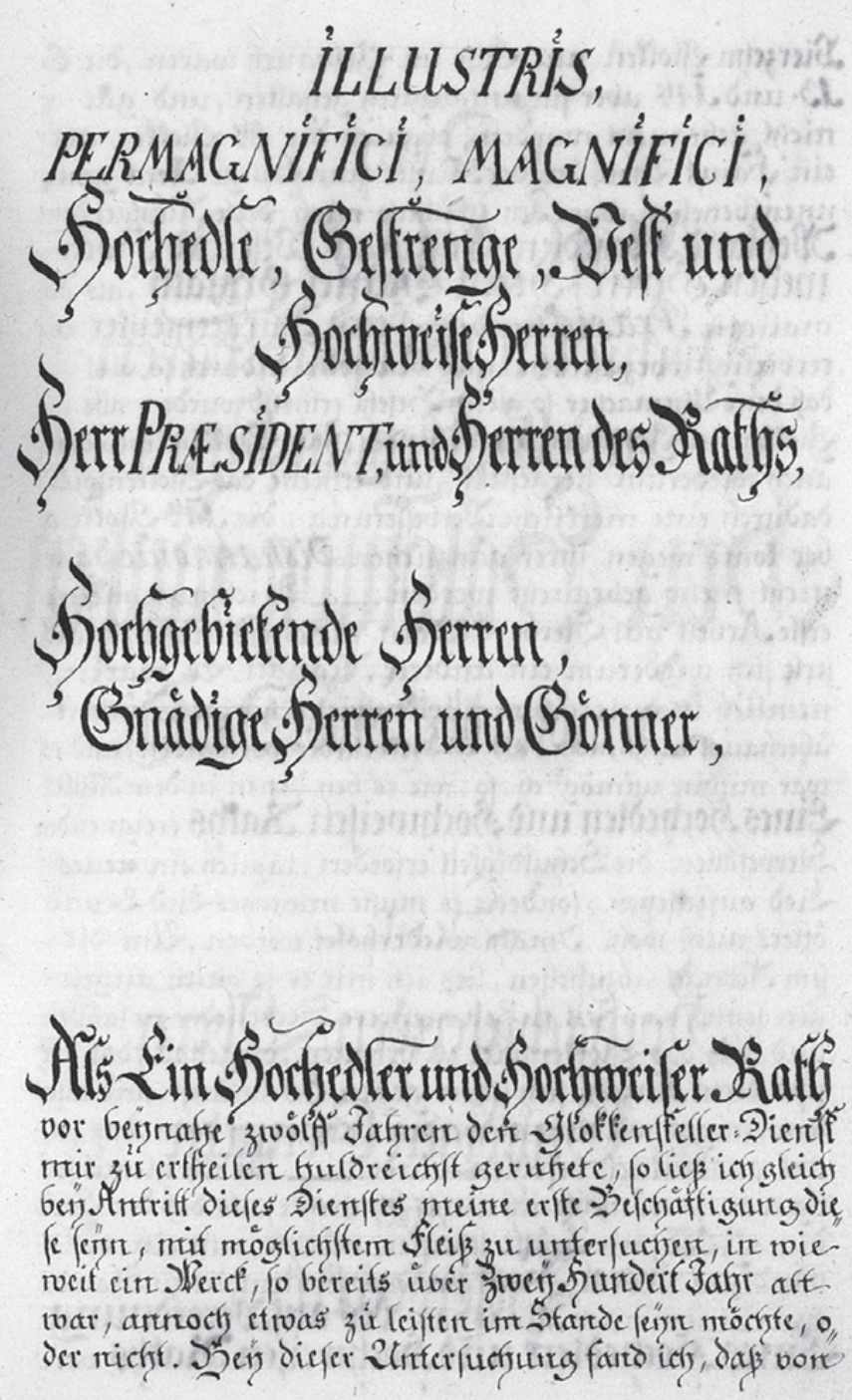

Fig. 69: Tablature of Th. F. Gülich, Choral Buch Nach denen Evangelisch Lutherschen Kirchengesängen. APG 300,R/Pp,q10, p. 17 


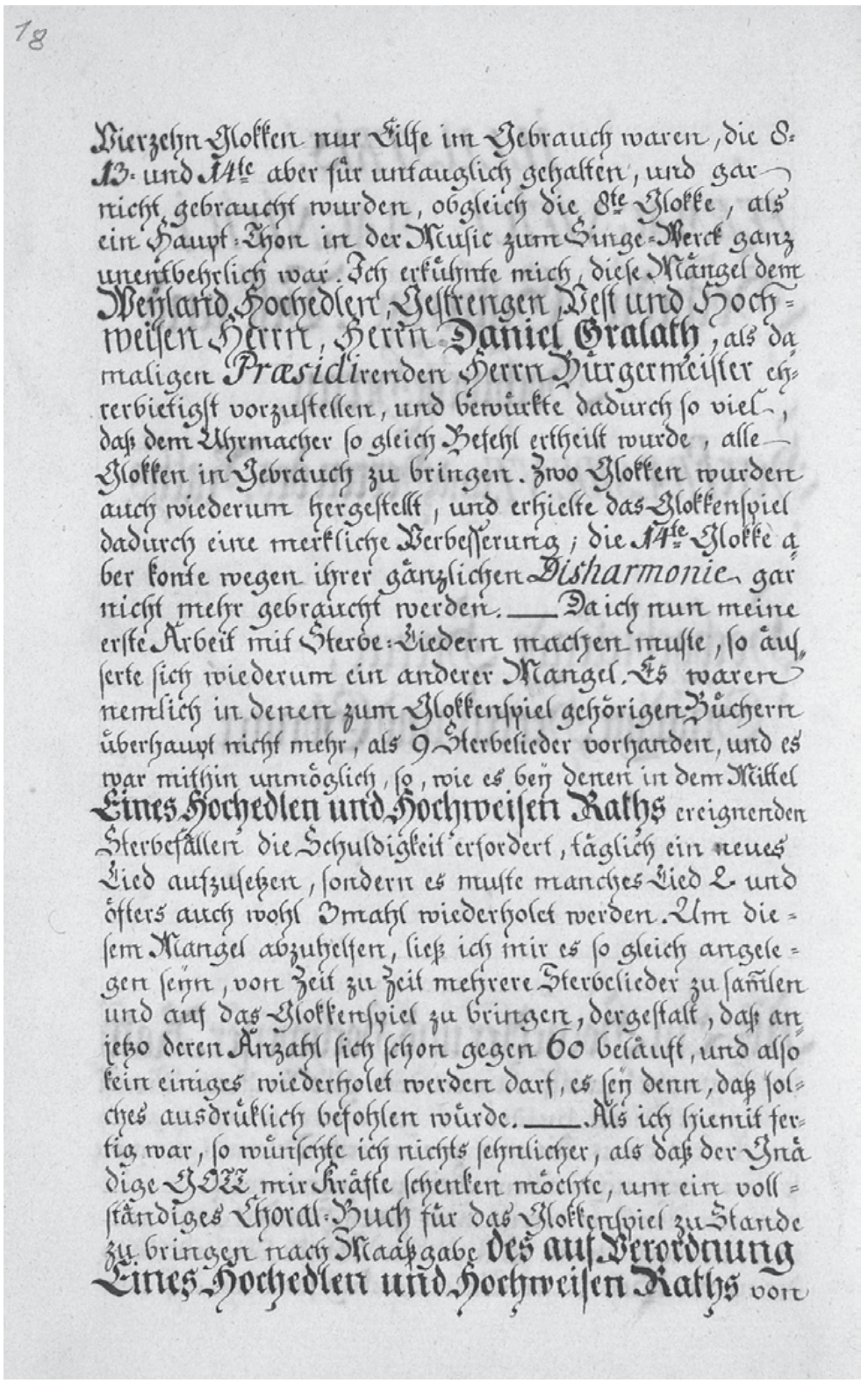

Fig. 70: Tablature of Th. F. Gülich, Choral Buch Nach denen Evangelisch Lutherschen Kirchengesängen. APG 300,R/Pp,q10, p. 18 


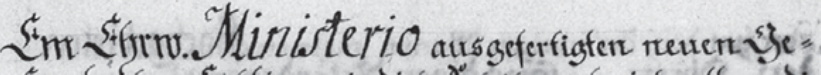

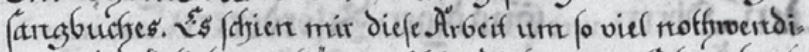

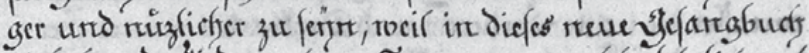

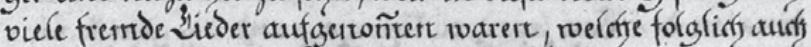

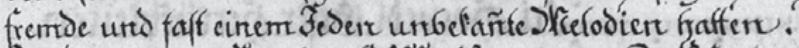

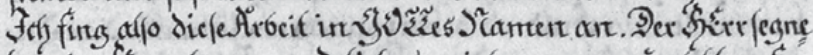

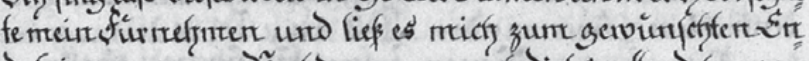

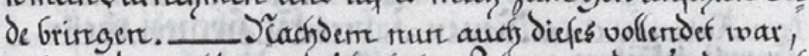

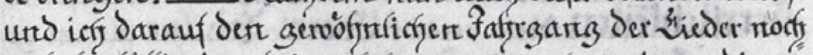
intals forgfatfig durefrging, fo fiefere mir unter anocrn die SBorfe Pauti it die Hugert. Sicdef unter circander vore

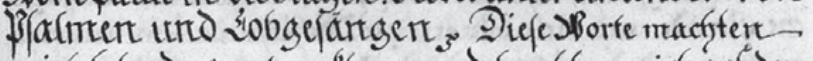
micry befortders aufmerffan, und Gradffert micy auf Dert

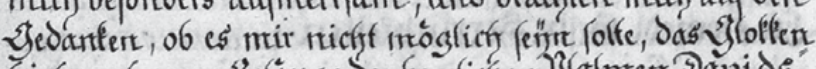

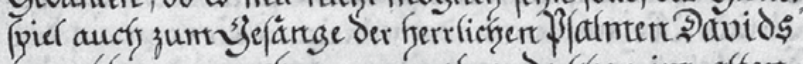
braucifbar zu ntacfyer, zuinatert, ba letyort int after

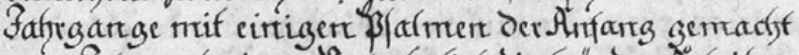

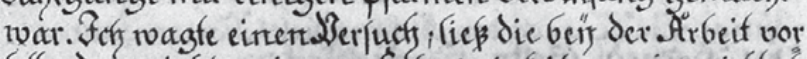

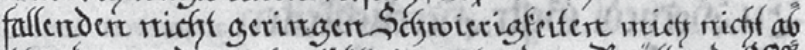

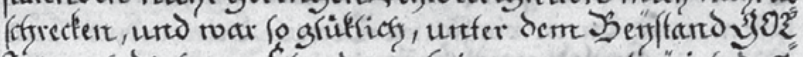

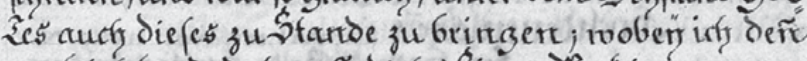

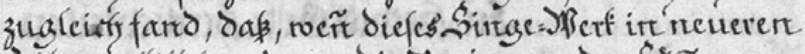

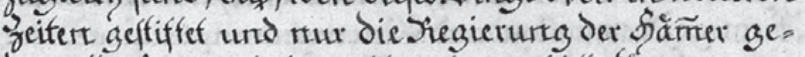

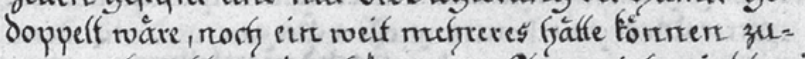

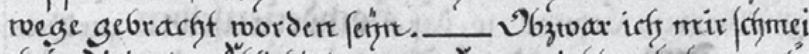

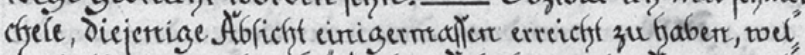

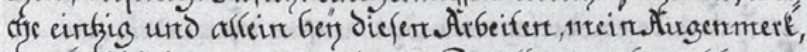
remfiefr diefe roar, in meirent Piertfe gerne fo nutbax

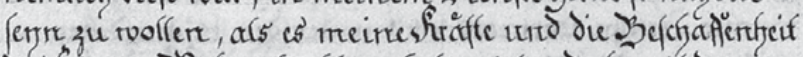

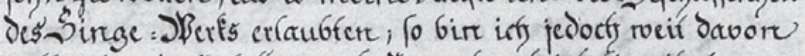

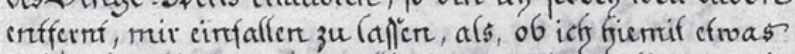
cuiferordentfieffes, oder volffententes geliecert fätfe, unde

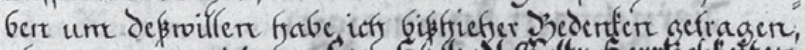

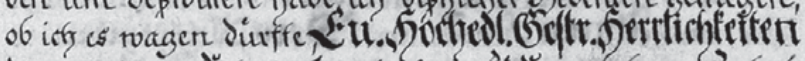

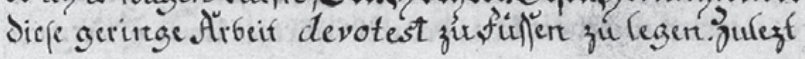

Fig. 71: Tablature of Th. F. Gülich, Choral Buch Nach denen Evangelisch Lutherschen Kirchengesängen. APG 300,R/Pp,q10, p. 19 
he undertook during his twelve years of service as bell setter. Most importantly, he audited the technical condition of the carillon immediately after starting his employment. He noticed that three out of fourteen bells could not be used: the eighth (E5), thirteenth (C6), and fourteenth (D6). He referred the matter to the current mayor, Daniel Gralath. ${ }^{845}$ The effect was that the Town Hall clockmaker, David Zoll, ${ }^{846}$ was ordered to repair the carillon. He did repair two bells, significantly improving the carillon's timbre, but the highest D6 bell remained unrepaired and could not be used: ${ }^{847}$

... die 14te Glocke aber konte wegen ihrer gänzlichen Disharmonie gar nicht mehr gebraucht warden. ${ }^{848}$

The second task undertaken by Gülich was the transcription of around sixty funeral songs ("Sterbe-Lieder"). As he indicated in his letter, existing songbooks included only nine songs of that time, forcing the bell setter to programme repeatedly the same pieces:

Um diese Mangel abzuhelfen, lie $\beta$ ich mir es so gleich angelegen seyn, von Zeit zu Zeit mehrere Sterbelieder zu sam[m]len und auf das Glokkenspiel zu bringen, dargestalt, da $\beta$ anjetzo deren Anzahl sich schon gegen 60 beläuft, und also kein einiges wiederholet werden darf, es sey denn, da $\beta$ solches ausdrüklich befohlen würde. ${ }^{849}$

Gülich then announced the performance of two tasks. One was the editing of a carillon book with songs for the Evangelical-Lutheran Church, and the other, of a similar book for the Reformed Church. He then proceeded to inform of minor issues that bothered him: the impossibility of faithfully recording a melody on the carillon drum due to the lack of some pitches on the automaton's scale and the imperfect action. Hence, he remarks, if it is ever decided to construct a new "singing mechanism," it would be necessary to double the number of hammers for each bell, which would substantially improve the mechanism's quality.

In the last section of his letter, Gülich humbly asks his employers to accept his books as a sign of gratitude for their tutelage. ${ }^{850}$ Dedications added to musical

845 Daniel Gralath (1708-67) acted as one of four mayors between 1763 and 1767, and became the first mayor in 1764 . See Zdrenka, Rats- und Gerichtspatriziat der Rechten Stadt Danzig, 2:134-36, 206.

846 Prószyńska, 'Słownik gdańskich zegarmistrzów i gnomoników’, 164-65.

847 Nontheless, the fourtheenth bell (D6) was used by Gülich in two song settings: Ich ruf' zu dir Herr Jesu Christ and Ach Gott und Herr; see APG 300,R/Pp,q9, pp. 99, 117.

848 APG 300,R/Pp,q10, p. 18.

849 APG 300,R/Pp,q10, p. 18.

850 APG 300,R/Pp,q10, pp. 19-21. 
works rarely contain as much exhaustive information on their authors and genesis as in the case of Gülich's letter to the Gdańsk City Coucil. He comprehensively discussed the intention of his work on the two hymnals. He was mostly motivated by practical reasons, wishing to supply bell setters with a wide repertoire for their various needs.

The Choral Buch Nach denen Evangelisch Lutherschen Kirchengesängen was supposed to be a full hymnal for the carillon ("vollständiges Choral-Buch für das Glockenspiel"). ${ }^{851}$ Gülich remarked that he edited it after the Gdańsk hymnal Danziger Gesangbuch, published in $1764 .{ }^{852}$ He believed that was the right thing to do because the Danziger Gesangbuch included many foreign songs with unknown melodies:

Es schien mir diese Arbeit um so viel nothwendiger und nüzlicher zu seyn, weil in dieses neue Gesangbuch viele fremde Lieder aufgenom[m]en waren, welche folglich auch fremde und fast einem Jeden unbekan[n]te Melodien hatten. Ich fing also diese Arbeit in Gottes Namen an. ${ }^{853}$

In his book, Gülich included 176 song settings, followed by a directory of all songs included in the current Danziger Gesangbuch - no fewer than 1126 titles. He cross-referenced these titles with the settings in the tablature, writing the following remark on the directory:

Register der Lieder auf die Zahl der Nummern gerichtet. Die mit rother Schrifft, sind aus dem gewöhnl[ichen] Jahrgange. ${ }^{854}$

Consequently, the following songs are written in red ink:

Ecce Domine

Erstanden ist der heilige Christ

Gott hat das Evangelium

Surrexit Christus hodie

Weltlich' Ehr' und zeitlich' Gut

851 APG 300,R/Pp,q10, p. 18.

852 Danziger Gesangbuch, welches auf E. Hochedlen Raths Verordnung zum allgemeinen Gebrauch der Kirchen und Haus Andachten von Em. Ehrwürdigen Ministerio der ungeänderten Augsp. Conf. allhier aufs Neue vermehrt und nebst einem Anhange von Gebeten herausgegeben worden ist (Danzig: gedruckt und verlegt von Thom. Joh. Schreibern, 1764).

853 APG 300,R/Pp,q10, p. 19.

854 APG 300,R/Pp,q10, p. 215. 
These songs, apart from Ecce Domine, were absent from the 1764 hymnal, ${ }^{855}$ but they are included in the first Gdańsk hymnal, published in 1719. ${ }^{856}$ Though not included in the current Danziger Gesangbuch, they did not disappear from local musical practice. In any case the four-volume tablature confirms that Gülich continued to set them on the Town Hall carillon and, ignoring the current version of the hymnal, he included their settings in this songbook, annexing two more songs deleted in the current Danziger Gesangbuch: Die Sonn' hat sich mit ihrem Glanz gewendet and O Mensch bewein dein' Sünde groß.

The intention of creating a carillon hymnal was performed quite meticulously in that Gülich generally copied the order of his tablature settings from the subsequent chapters of the Danziger Gesangbuch of $1764 .{ }^{857}$

Tab. 21: Songs set by Theodor Friedrich Gülich in Choral Buch Nach denen Evangelisch Lutherschen Kirchengesängen, cross-referenced to the chapters of the Danziger Gesangbuch of 1764

\begin{tabular}{lcl}
\hline Chapter number and title & No. $^{868}$ & Song title \\
\hline I. Sonntagsgesänge & 1 & Herr Jesu Christ dich zu uns wend \\
& 2 & Liebster Jesu wir sind hier \\
II. Adventsgesänge & 59 & Der Herr ist mein getreuer Hirt' \\
& 6 & Es ist gewißlich an der Zeit \\
& 3 & Gottes Sohn ist kommen \\
& 5 & Jesu du mein liebstes Leben \\
III. Weihnachtsgesänge & 4 & Nun komm der Heiden Heiland \\
& 7 & Wachet auf ruft uns die Stimme \\
& 8 & Christum wir sollen loben schon \\
& 9 & Den die Engel droben \\
& 11 & Der Tag der ist so freudenreich \\
\hline
\end{tabular}

(continued on next page)

855 In the Danziger Gesangbuch of 1764, the song Ecce Domine is set to a German text, Gottes Sohn ist kommen.

856 Dantziger Gesang-Buch, Welches auff E. Hoch-Edlen Raths daselbst Verordnung zur Beförderung der Kirchen- und Hauß Andacht aus Lutheri und anderer bewehrten Autorum geistreichen Liedern zusammen getragen und eingeführet worden (Dantzig: Auff Verlag der Frey-Schulen gedruckt, A. 1719).

857 About Evangelical hymnals from Gdańsk, see Kessler, Danziger Gesangbücher 15861793; Kessler, 'Christliche Religionsgesänge’; and Woźniak, 'Gdańskie kancjonały ewangelickie z XIX wieku'.

858 Ordering number in the tablature. 
Tab. 21: Continued

\begin{tabular}{|c|c|c|}
\hline Chapter number and title & No. ${ }^{868}$ & Song title \\
\hline & 10 & Ein Kind geborn zu Bethlehem \\
\hline & 12 & Ermuntre dich mein schwacher Geist \\
\hline & 13 & Gelobet seist du Jesu Christ \\
\hline & 14 & In dulci jubilo \\
\hline & 15 & Kommst du nun Jesu vom Himmel \\
\hline & 16 & herunter \\
\hline & 17 & Lobt Gott ihr Christen allzugleich \\
\hline & 19 & Vom Himmel hoch da komm' ich her \\
\hline & & Wir Christenleut' hab'n \\
\hline IV. Neujahrsgesänge & 18 & Freuet euch ihr Christen alle \\
\hline \multicolumn{3}{|l|}{$\begin{array}{l}\text { V. Gesänge auf das Fest der Erscheinung } \\
\text { Christi }\end{array}$} \\
\hline $\begin{array}{l}\text { VI. Gesänge auf das Fest der Reinigung } \\
\text { Mariä }\end{array}$ & 20 & Mit Fried' und Freud' \\
\hline $\begin{array}{l}\text { VII. Gesänge auf das Fest der } \\
\text { Verkündigung Mariä }\end{array}$ & 21 & Dies ist der Tag der Fröhlichkeit \\
\hline \multirow[t]{10}{*}{ VIII. Passionsgesänge } & $\begin{array}{l}34 \\
27\end{array}$ & $\begin{array}{l}\text { Ach stirbt denn so mein allerliebstes } \\
\text { Ach wir armen Sünder }\end{array}$ \\
\hline & 23 & Christus der uns selig macht \\
\hline & 31 & Da Jesus an dem Kreuze stund \\
\hline & 22 & $\begin{array}{l}\text { Ein Lämmlein geht und trägt die } \\
\text { Schuld }\end{array}$ \\
\hline & 26 & $\begin{array}{l}\text { Herzliebster Jesu was hast du } \\
\text { verbrochen }\end{array}$ \\
\hline & 24 & Jesu meines Lebens Leben \\
\hline & 32 & O Jesu Christ mein's Lebens Licht \\
\hline & 28 & O Lamm Gottes unschuldig \\
\hline & 30 & O Traurigkeit o Herzeleid \\
\hline & 33 & Wenn meine Sünd' mich kränken \\
\hline \multirow[t]{9}{*}{ IX. Ostergesänge } & 35 & Also heilig ist der Tag \\
\hline & 37 & Auf auf mein Herz mit Freuden \\
\hline & 38 & Christ ist erstanden \\
\hline & 36 & Christ lag in Todes Banden \\
\hline & 39 & Christus ist erstanden \\
\hline & 40 & Erschienen ist der herrlich' Tag. \\
\hline & 42 & Heut triumphieret Gottes Sohn \\
\hline & 41 & $\begin{array}{l}\text { Jesus Christus unser Heiland der den } \\
\text { Tod überwand }\end{array}$ \\
\hline & 175 & Lasset uns den Herren preisen \\
\hline
\end{tabular}


Tab. 21: Continued

\begin{tabular}{|c|c|c|}
\hline Chapter number and title & No. ${ }^{868}$ & Song title \\
\hline \multicolumn{3}{|l|}{ X. Himmelfahrtsgesänge } \\
\hline \multirow[t]{4}{*}{ XI. Pfingstgesänge } & 43 & Brunnquell aller Güter \\
\hline & 44 & Komm Gott Schöpfer heiliger Geist \\
\hline & 45 & Komm heiliger Geist Herre Gott \\
\hline & 46 & Nun bitten wir den heiligen Geist \\
\hline \multirow{2}{*}{$\begin{array}{l}\text { XII. Gesänge auf das Fest der heiligen } \\
\text { Dreieinigkeit }\end{array}$} & 47 & Allein Gott in der Höh' sei Ehr' \\
\hline & 48 & Kyrie Gott Vater in Ewigkeit \\
\hline $\begin{array}{l}\text { XIII. Gesänge am Tage Johannis des } \\
\text { Täufers }\end{array}$ & 49 & Gelobet sei der Herr der Gott Israel \\
\hline $\begin{array}{l}\text { XIV. Gesänge am Tage der Heimsuchung } \\
\text { Mariä }\end{array}$ & 50 & Meine Seele erhebet den Herrn \\
\hline \multicolumn{3}{|l|}{ XV. Gesänge auf das Michaelisfest } \\
\hline \multicolumn{3}{|l|}{ XVI. Von Gott und seinen Eigenschaften } \\
\hline \multirow{3}{*}{$\begin{array}{l}\text { XVII. Von Gottes Werken und Wohltaten } \\
\text { nach dem ersten Artikel }\end{array}$} & 51 & Befiehl du deine Wege \\
\hline & 52 & In allen meinen Taten \\
\hline & 53 & Wer nur den lieben Gott läßt walten \\
\hline $\begin{array}{l}\text { XVIII. Von dem göttlichen } \\
\text { Erlösungswerke nach dem }\end{array}$ & 163 & Dein Mittler kommt auf blöde Seele \\
\hline \multirow[t]{2}{*}{ anderen Artikel } & 25 & Die Propheten habn geprophezeit \\
\hline & 167 & Sei willkommen Davids Sohn \\
\hline $\begin{array}{l}\text { XIX. Von den Gnadenwirkungen und } \\
\text { Wohlthaten nach dem }\end{array}$ & 162 & Beschränkt ihr Weisen dieser Welt \\
\hline \multirow[t]{4}{*}{ dritten Artikel } & 55 & Durch Adams Fall ist ganz verderbt \\
\hline & 56 & Es ist das Heil uns kommen her \\
\hline & 60 & Herr Christ der ein'ge Gottes Sohn \\
\hline & 58 & Wie schön leuchtet der Morgenstern \\
\hline \multirow[t]{9}{*}{ XX. Von der christlichen Kirche } & 108 & Ach bleib bei uns Herr Jesu Christ \\
\hline & 61 & Ach Gott vom Himmel sieh darein \\
\hline & 62 & Ein' feste Burg ist unser Gott \\
\hline & 66 & Erhalt uns Herr bei deinem Wort \\
\hline & 64 & Es spricht der Unweisen Mund \\
\hline & 63 & Es woll' uns Gott genädig sein \\
\hline & 57 & O Herre Gott dein göttlich' Wort \\
\hline & $66 \mathrm{a}$ & Verleih uns Frieden gnädiglich \\
\hline & 65 & Wär' Gott nicht mit uns diese Zeit \\
\hline
\end{tabular}


Tab. 21: Continued

\begin{tabular}{|c|c|c|}
\hline Chapter number and title & No. ${ }^{868}$ & Song title \\
\hline $\begin{array}{l}\text { XXI. Von den Gnadenmitteln besonders } \\
\text { von dem Worte }\end{array}$ & 67 & Dies sind die heil' gen zehn Gebot' \\
\hline Gottes & 169 & Mensch willst du leben seliglich \\
\hline $\begin{array}{l}\text { XXII. Von den Gnadenmitteln besonders } \\
\text { von der heiligen Taufe }\end{array}$ & 68 & Christ unser Herr zum Jordan kam \\
\hline \multirow{11}{*}{$\begin{array}{l}\text { XXIII. Von den Gnadenmitteln und zwar } \\
\text { von der Busse }\end{array}$} & 74 & Ach Gott und Herr \\
\hline & 69 & Allein zu dir Herr Jesu Christ \\
\hline & 72 & Aus tiefer Not schrei' ich zu dir \\
\hline & 70 & Erbarm dich mein o Herre Gott \\
\hline & 73 & Herr ich habe mißgehandelt \\
\hline & 76 & Herr Jesu Christ du höchstes Gut \\
\hline & 71 & Herr nicht schicke deine Rache \\
\hline & 75 & Herr straf mich nicht in deinem Zorn \\
\hline & 77 & Jesu der du meine Seele \\
\hline & 78 & Straf mich nicht in deinem Zorn \\
\hline & 79 & Wo soll ich fliehen hin \\
\hline \multirow{9}{*}{$\begin{array}{l}\text { XXIV. Von den Gnadenmitteln und zwar } \\
\text { von dem Glauben }\end{array}$} & 81 & Ich glaub' an Gott der geschaffen hat \\
\hline & 84 & Ich lass' dich nicht \\
\hline & 86 & Jesu meine Freude \\
\hline & 165 & Mein Jesu dem die Seraphinen \\
\hline & 83 & Mein Jesus ist mein \\
\hline & 85 & Meinen Jesum laß’ ich nicht \\
\hline & 82 & Nun freut euch lieben Christen gemein \\
\hline & 88 & Warum sollt' ich mich denn grämen \\
\hline & 80 & Wir glauben all' an einen Gott \\
\hline \multirow{5}{*}{$\begin{array}{l}\text { XXV. Von den Gnadenmitteln und zwar } \\
\text { von dem heiligen Abendmahl }\end{array}$} & 90 & Gott sei gelobet und gebenedeiet \\
\hline & 87 & $\begin{array}{l}\text { Jesus Christus unser Heiland der von } \\
\text { uns }\end{array}$ \\
\hline & 166 & Mein Jesu der du vor dem Scheiden \\
\hline & 89 & Schmücke dich o liebe Seele \\
\hline & 113 & Werde munter mein Gemüte \\
\hline \multirow{2}{*}{$\begin{array}{l}\text { XXVI. Von den Gnadenmitteln und zwar } \\
\text { vom Gebet }\end{array}$} & 116 & Dir Jehova will ich singen. \\
\hline & 91 & Vater unser im Himmelreich \\
\hline
\end{tabular}


Tab. 21: Continued

\begin{tabular}{|c|c|c|}
\hline Chapter number and title & No. ${ }^{868}$ & Song title \\
\hline \multirow[t]{7}{*}{ XXVII. Lob- und Dankgesänge } & 98 & Als mich die große Not \\
\hline & 93 & Herr Gott dich loben wir \\
\hline & 92 & Lobet den Herren \\
\hline & 168 & Mein Gott ich preise deine Güte \\
\hline & 95 & Nun danket alle Gott \\
\hline & 96 & Nun laßt uns Gott dem Herren \\
\hline & 94 & Nun lob mein' Seel' den Herren \\
\hline \multirow[t]{7}{*}{ XXVIII. Morgengesänge } & 97 & Aus meines Herzens Grunde \\
\hline & 104 & Danket dem Herren denn er ist sehr \\
\hline & 100 & Der Tag vertreibt die finstre Nacht \\
\hline & 101 & Gott des Himmels und der Erden \\
\hline & 99 & Ich dank' dir lieber Herre \\
\hline & 102 & Ich dank' dir schon durch deinen Sohn \\
\hline & 103 & $\begin{array}{l}\text { Ich danke dir Herr Gott für deinem } \\
\text { Throne }\end{array}$ \\
\hline \multirow[t]{2}{*}{ XXIX. Tischgesänge } & 105 & Den Vater dort oben \\
\hline & 106 & Singen wir aus Herzensgrund \\
\hline \multirow[t]{5}{*}{ XXX. Abendgesänge } & 107 & Abend heller als der Morgen \\
\hline & 109 & Christe der du bist Tag und Licht \\
\hline & 110 & Der lieben Sonnen Licht und Pracht \\
\hline & 111 & Mein' Augen schließ' ich jetzt \\
\hline & 114 & Nun sich der Tag geendet hat \\
\hline \multirow{9}{*}{$\begin{array}{l}\text { XXXI. Vom christlichen Tugendwandel } \\
\text { überhaupt }\end{array}$} & 164 & Eins ist Not ach Herr dies Eine \\
\hline & 54 & Hab Geduld o liebes Herz \\
\hline & 118 & Herzlich lieb hab' ich dich o Herr \\
\hline & 117 & Ich ruf' zu dir Herr Jesu Christ \\
\hline & 120 & In dich hab' ich gehoffet Herr \\
\hline & 122 & Kommt her zu mir spricht Gottes Sohn \\
\hline & 115 & O Gott du frommer Gott \\
\hline & 121 & Sollt' es gleich bisweilen scheinen \\
\hline & 119 & Von Gott will ich nicht lassen \\
\hline \multirow{3}{*}{$\begin{array}{l}\text { XXXII. Vom christlichen Tugendwandel } \\
\text { nach eines jeden Stand und Beruf }\end{array}$} & 123 & O großer Gott der du sehr wohl \\
\hline & 124 & $\begin{array}{l}\text { Wo Gott zum Haus nicht gibt sein' } \\
\text { Gunst }\end{array}$ \\
\hline & 125 & Zwei Ding' o Herr bitt' ich von dir \\
\hline
\end{tabular}


Tab. 21: Continued

\begin{tabular}{|c|c|c|}
\hline Chapter number and title & No. ${ }^{868}$ & Song title \\
\hline \multirow[t]{17}{*}{ XXXIII. Kreutz- und Trostgesänge } & 134 & Ach Gott tu dich erbarmen \\
\hline & 139 & Ach lieben Christen seid getrost \\
\hline & 133 & Ach was soll ich Sünder machen \\
\hline & 126 & Ach wie flüchtig ach wie nichtig \\
\hline & 136 & Du Friedensfürst Herr Jesu Christ \\
\hline & 131 & Gott der Vater wohn' uns bei \\
\hline & 127 & Ist denn der Herr der Herrlichkeit \\
\hline & 138 & Mag ich Unglück nicht widerstahn \\
\hline & 141 & Nicht so traurig nicht so sehr \\
\hline & 135 & O Christe Morgensterne \\
\hline & 137 & O großer Gott von Macht \\
\hline & 140 & O Herr dein Ohren neig zu mir \\
\hline & 142 & Warum betrübst du dich mein Herz \\
\hline & 128 & Was Gott tut das ist wohlgetan \\
\hline & 129 & Was mein Gott will gescheh' allzeit \\
\hline & 132 & Wenn wir in höchsten Nöten sein \\
\hline & 130 & $\begin{array}{l}\text { Will mir Gott wohl so gehts mir } \\
\text { wohl }\end{array}$ \\
\hline \multirow[t]{15}{*}{ XXXIV. Sterbegesänge } & 146 & Alle Menschen müssen sterben \\
\hline & 147 & Christus der ist mein Leben \\
\hline & 149 & Freu dich sehr o meine Seele \\
\hline & 145 & Herr ich denk' an jene Zeit \\
\hline & 143 & $\begin{array}{l}\text { Herr Jesu Christ wahr' Mensch und } \\
\text { Gott }\end{array}$ \\
\hline & 156 & Hört auf mit Trauern und Klagen \\
\hline & 150 & Ich bin ja Herr in deiner Macht \\
\hline & 144 & $\begin{array}{l}\text { Ich hab' mein' Sach' Gott } \\
\text { heimgestellt }\end{array}$ \\
\hline & 153 & Machs mit mir Gott nach deiner Güt' \\
\hline & 148 & Mitten wir im Leben sind \\
\hline & 155 & Nun laßt uns den Leib begraben \\
\hline & 157 & O wie selig seid ihr doch ihr Frommen \\
\hline & 154 & So wünsch' ich nun ein' gute Nacht \\
\hline & 151 & Valet will ich dir geben \\
\hline & 152 & Welt ade ich bin dein müde \\
\hline
\end{tabular}


Tab. 21: Continued

\begin{tabular}{lll}
\hline Chapter number and title & No. ${ }^{868}$ & Song title \\
\hline XXXV. Von der Auferstehung & & \\
XXXVI. Vom jüngsten Gerichte & 158 & Jesus meine Zuversicht \\
& 159 & Wacht auf ihr Christen alle \\
XXXVII. Von der Ewigkeit & 160 & Du o schönes Weltgebäude \\
& 161 & O Ewigkeit du Donnerwort \\
& 174 & Es ist noch eine Ruh' vorhanden \\
\hline
\end{tabular}

Gülich did not supply setting for five chapters of the hymnal: those for Epiphany (V. Gesänge auf das Fest der Erscheinung Christi), Ascension (X. Himmelfahrtsgesänge), and St Michael's (XV. Gesänge auf das Michaelisfest) as well as chapters with reflections on God (XVI. Von Gott und seinen Eigenschaften) and Resurrection (XXV. Von der Auferstehung). However, this is a minor remark, as songs from those chapters can be located through the directory Gülich included at the end of his book.

In notating his chorales, Gülich made sure the users of his tablature would understand if two selected settings, one for the even and one for the odd hour, would fit on the carillon's drum: next to the songs' titles, he wrote the digit 1 or 2 in black or red ink or 0 in red ink. The drum could only be programmed with a pair of songs tagged 1 and 2, while 0 indicated long chorales that could not be paired with any other. No numerical indication was added to those songs that could be freely combined with each other. Gülich explained the meaning of those digits in his foreword ("Vorbericht"):

Da die Walze des Singe-Werks also beschaffen ist, daß das Maaß derselben nach Beschaffenheit des Liedes eingerichtet werden muß, wenn zwey Lieder Wechselsweise spielen sollen; als habe durch Ziffern es angedeutet, welche Lieder zusammen gesetzet werden können. Als:

Eine rothe Ziffer 1 und eine schwarze 1.

Eine rothe Ziffer 2 und eine schwarze 2.

Wo aber eine runde Ziffer 0 vorhanden, selbiges Lied nim[m]t die ganze Walze alleine ein.

Wo keine Ziffer beysteht - da kön[n]en ohne Unterscheid zwey davon auf der Walze gesezt werden. ${ }^{859}$ 


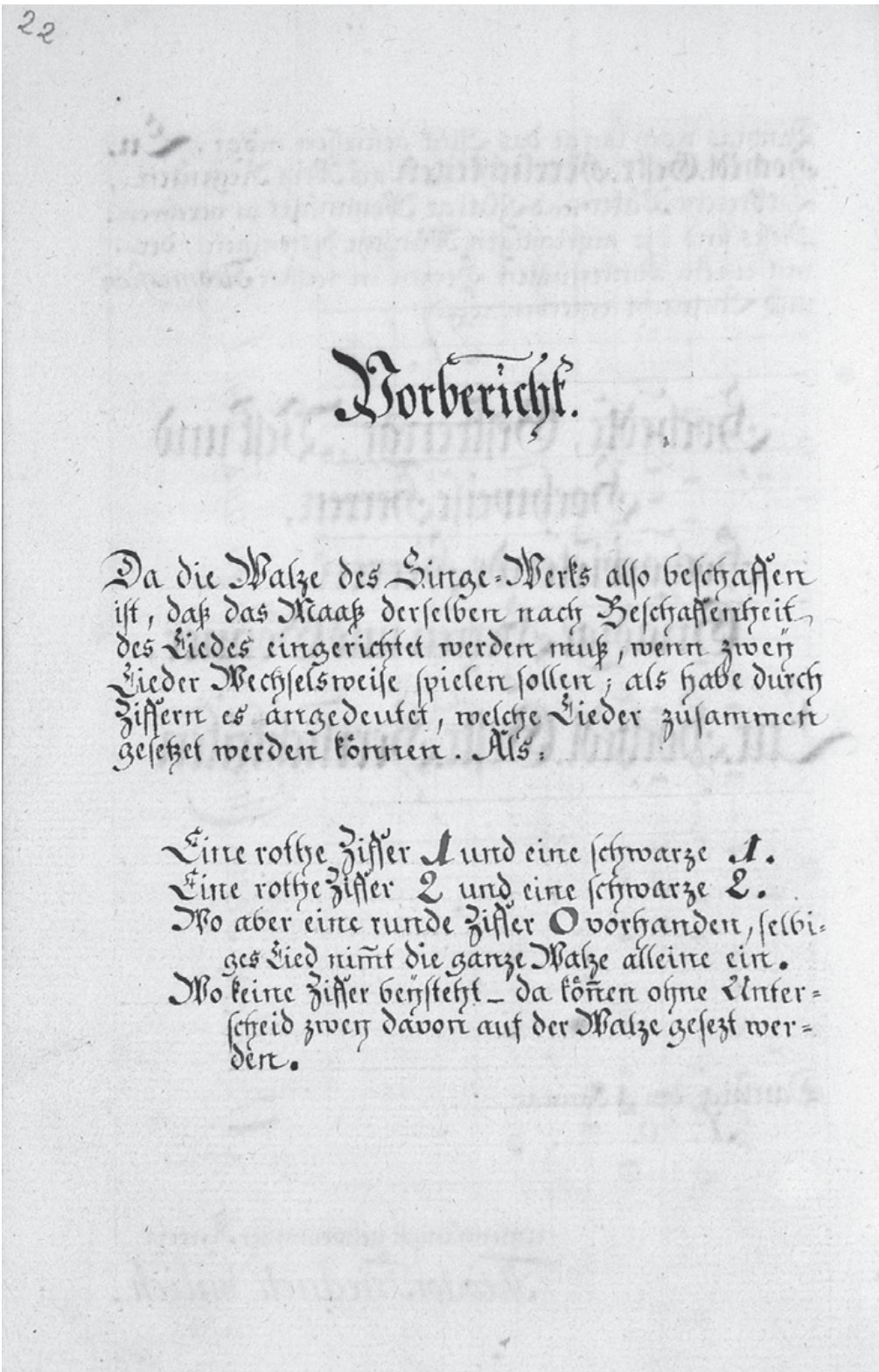

Fig. 72: Tablature of Th. F. Gülich, Choral Buch Nach denen Evangelisch Lutherschen Kirchengesängen. APG 300,R/Pp,q10, p. 22 


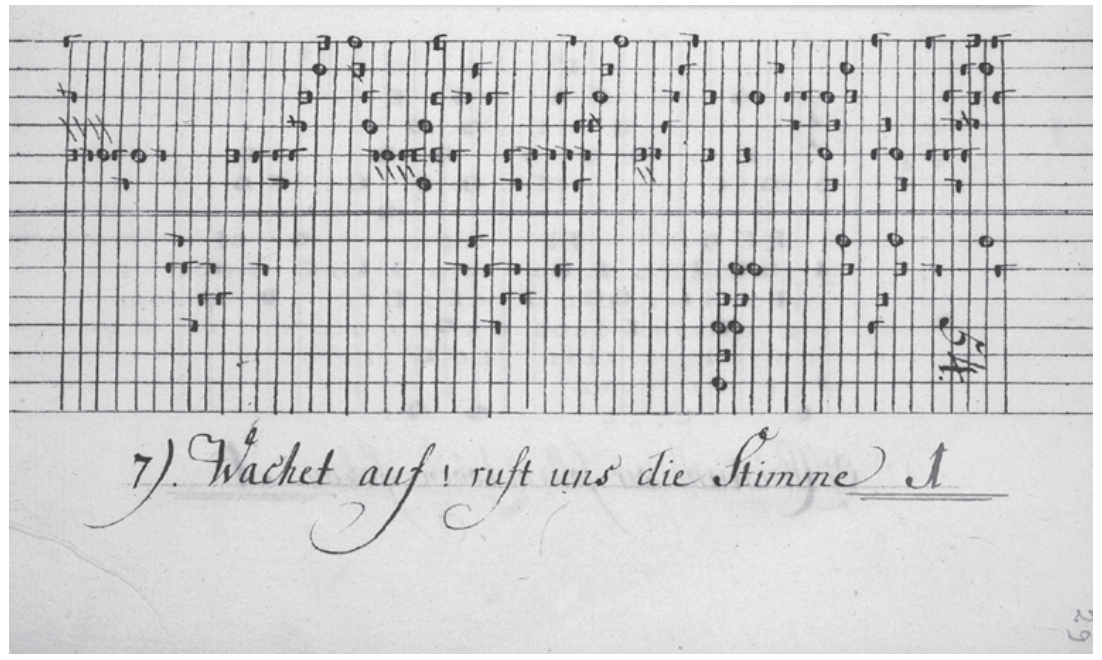

Fig. 73: Tablature of Th. F. Gülich, Choral Buch Nach denen Evangelisch Lutherschen Kirchengesängen. APG 300,R/Pp,q10, p. 29

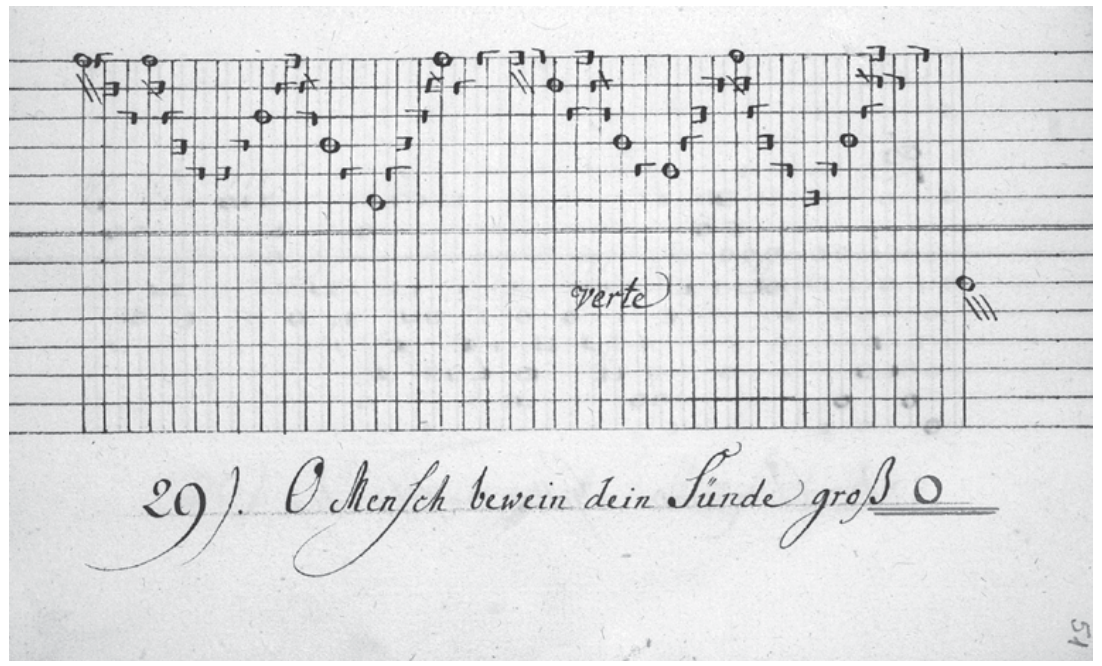

Fig. 74: Tablature of Th. F. Gülich, Choral Buch Nach denen Evangelisch Lutherschen Kirchengesängen. APG 300,R/Pp,q10, p. 51 


\section{Evangelical-Reformed songbook}

Gülich's second single-volume tablature is titled Choral Buch Nach denen Evangelisch Reformirten Kirchengesängen and consistently with its title, includes songs of the Reformed Church. Gülich based this volume on the first official hymnal of the Gdańsk Reformed parish, published in 1744. That hymnal was composed of two parts: the first included the texts of 150 psalms with melodies for $125,{ }^{860}$ and the second, texts for 300 songs ${ }^{861}$ In his tablature, Gülich included 125 psalm melody settings and 11 song settings. There was no need to set all the psalms and songs, since the same melody could be used with various texts; an indication how to match tunes with psalm or song titles was featured at the end of the book:

Wo eine schwarze Ziffer steht, da zeigt sie Paginam in diesem Buche; wo aber eine rothe Ziffer befindlich, dieselbe zeiget die Num[m]er der Melodie im andern Buche an. ${ }^{862}$

If the page number is written in black ink, the song setting is included in the volume in question, meaning a psalm melody or one of the eleven notated songs. Red ink indicates a different volume: the Evangelical-Lutheran tablature.

Gülich also added 1, 2, or 0 digits to musical notations of psalms and songs, again in black or red ink. Those digits (or lack thereof), according to the abovequoted note from the Evangelical-Lutheran foreword, indicate how to combine settings to fit on the carillon drum.

While it is obvious why Gülich edited a hymnal for Lutherans, who were the dominating confession in Gdańsk, it is intriguing why he would do likewise for

860 Kirchen Gesang-Buch Der Evangelisch-Reformirten Gemeinde in Dantzig: Worinn, nebst denen CL. Psalmen Davids, in deutsche Reimen gebracht, befindlich CCC. auserlesene, geistreich- und erbauliche Lieder, über allerley, beym öffentlichen Gottesdienst vorkommende Materien in eine bequeme Ordnung zusammen getragen. Ephes. V. v. 19. Redet untereinander, von Psalmen und Lobgesängen und geistlichen Liedern, singet und spielet dem Herrn in eurem Hertzen (Dantzig: Gedruckt bey Th. Joh. Schreiber, E. Hochedl. Raths Buchdrucker, 1744).

861 Des Kirchen-Gesang-Buchs Anderer Theil: Worinn, mit denen geistreichen Liedern Hrn. Doct. Martin Luthers und anderer Gottesgelehrten Männer, vorkommen, Viele auserlesene und erweckliche Lieder, als ein zulänglicher Vorrath über allerley bey öffentlichen Gottesdienst vorkommende Materien: nebst dem Catechismo (Dantzig: Gedruckt bey Thomas Johann Schreiber, eines Hochedlen. Hochweisen Raths und des löblichen Gymnasii Buchdrucker, 1744).

862 APG 300,R/Pp,q10a, p. 161. 


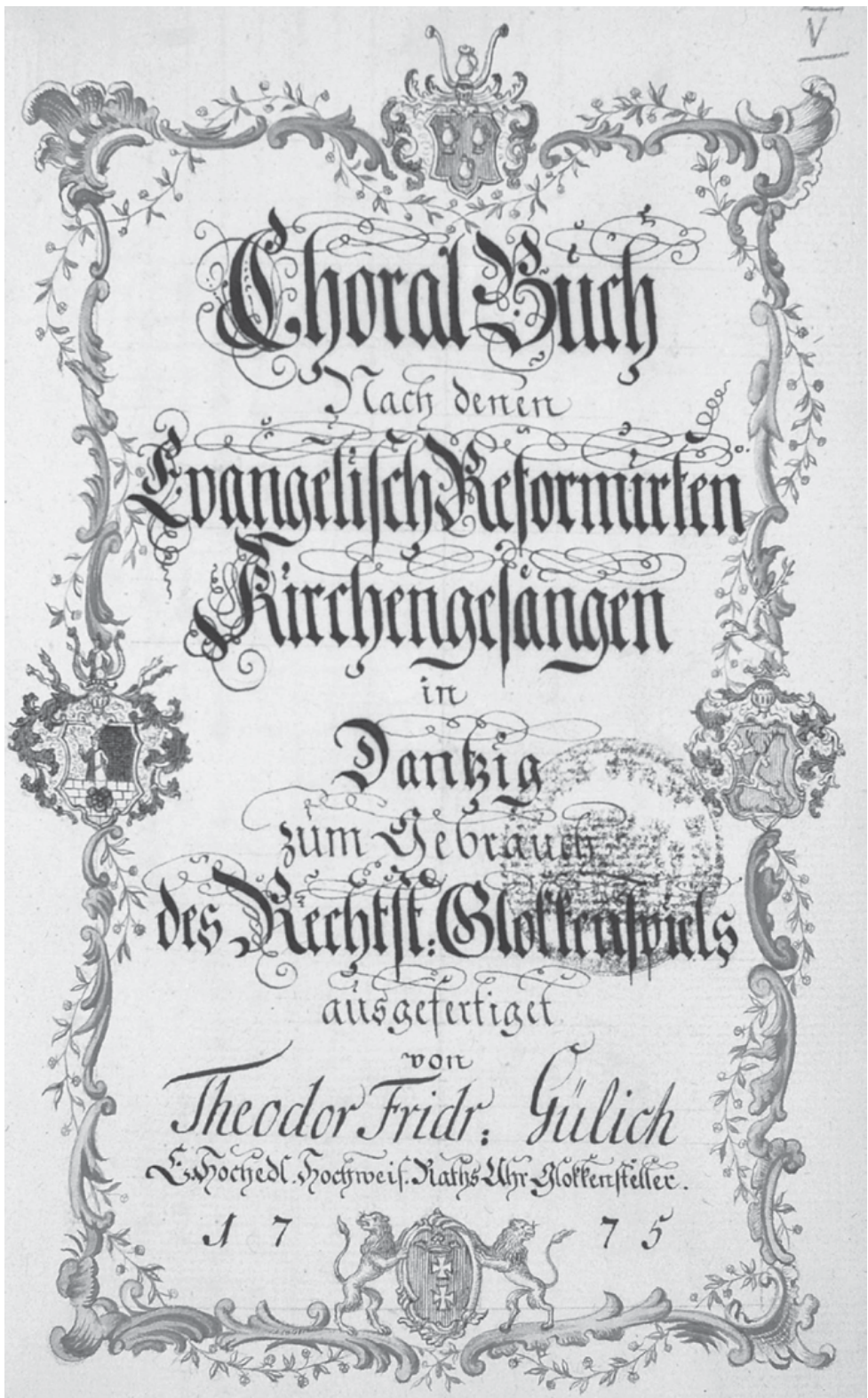

Fig. 75: Tablature of Th. F. Gülich, Choral Buch Nach denen Evangelisch Reformirten Kirchengesängen. APG 300,R/Pp,q10a, title page 


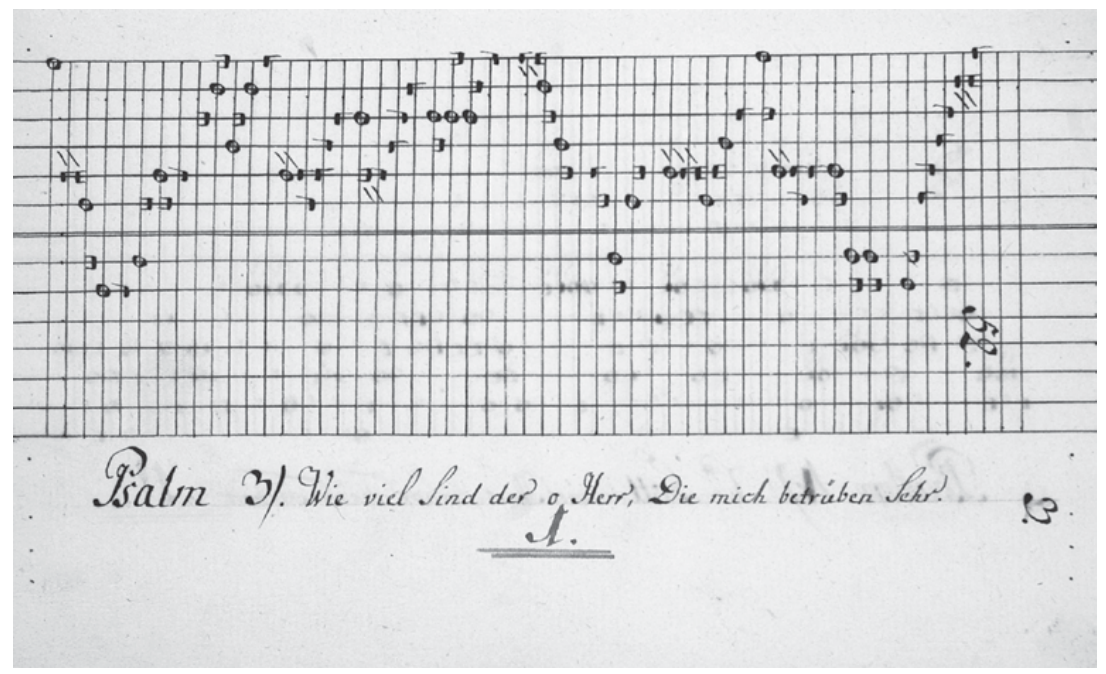

Fig. 76: Tablature of Th. F. Gülich, Choral Buch Nach denen Evangelisch Reformirten Kirchengesängen. APG 300,R/Pp,q10a, p. 3

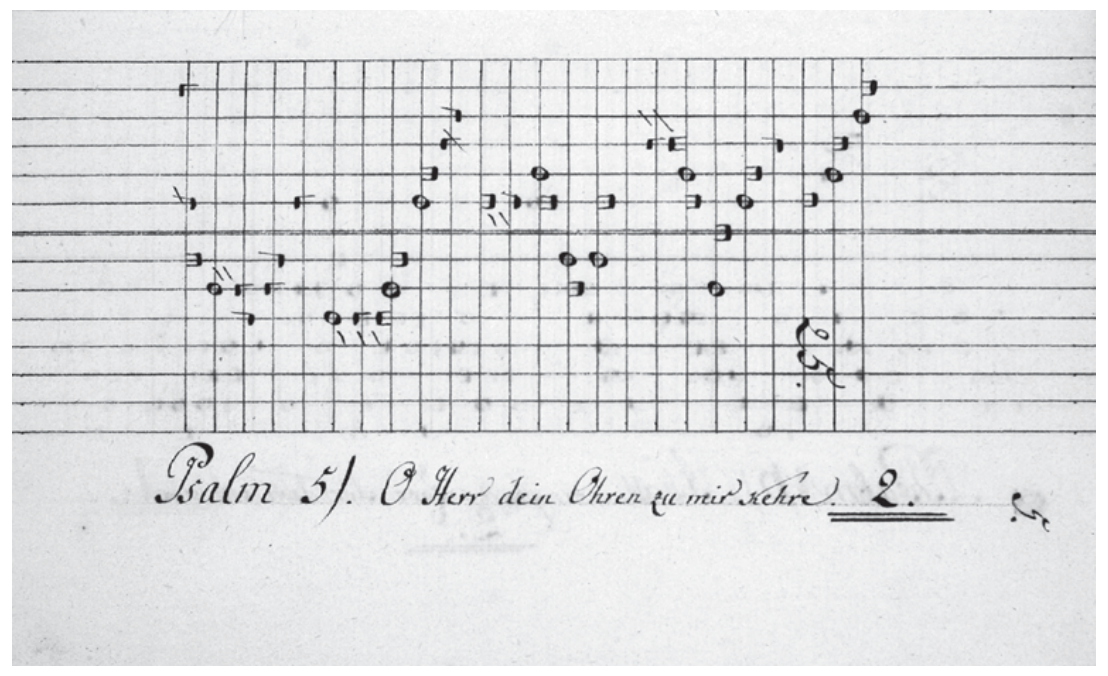

Fig. 77: Tablature of Th. F. Gülich, Choral Buch Nach denen Evangelisch Reformirten Kirchengesängen. APG 300,R/Pp,q10a, p. 5 
Calvinists, as in the 1770 s, that confession only made up $2.1 \%$ of the city population. ${ }^{863}$ So why would Gülich edit a carillon tablature with tunes of the Reformed Church? I believe he might have been encouraged to do so by Mayor Eduard Friedrich Conradi, who was a Calvinist. ${ }^{864}$

\subsection{The tablature of Paul Friedrich Knaack}

The last of the remaining tablatures was edited in 1808-12 by Paul Friedrich Knaak, city watchmaker and Main Town bell setter. ${ }^{865}$ The dating and authorship of the manuscript are confirmed by a note on the book's second page, introduced the manuscript's user, Carl Anton Kaschlinsky, Knaack's apprentice, who in the years 1847-82 became the sole bell setter:

Diese Kopie ist von dem Raths-Uhrmacher Knaack, in den Jahren 1808-12, nach dem

Original genommen. C[arl] A[nton] Kaschlinsky. Raths-Uhrmacher.

This handy-dimensioned $(24 \times 10 \mathrm{~cm})$ tablature, bound in an ordinary cover of the blue paper, is accurately titled: Choral-Buch vom rechstädschen Glockenspiel der Stadt Danzig. It includes chorale settings, ordered chronologically for the subsequent weeks and holidays of the liturgical year. In total, it includes 120 settings of 83 melodies, including two untitled ones. Knaack first prepared diagrams composed of intersecting horizontal and vertical lines, which schematically represent a fragment of the carillon's drum, assigning them (somewhat mechanically) to the names of subsequent week and holidays, together with the hours songs' settings (even or odd), for example, "Am heiligen Christ-Tage auf der geraden Stunde." Only after preparing those schemes did he encode the songs settings on the drum. He did not fill in those weeks in which a previous song was traditionally repeated, instead adding the remark "Bleib stehen" or "Wird nicht geändert." ${ }^{866} \mathrm{He}$ added a note also when a setting was due to be programmed for an atypical hour, for example "Ein Kindelein so löbelich. Am heiligen Christ-Tage auf der geraden Stunde. um 8 Uhr des Abends vorhero." ${ }^{867}$

863 Baszanowski, Przemiany demograficzne w Gdańsku, 171.

864 Eduard Friedrich Conradi was baptised on 16 November 1713 at St Peter and St Paul's, the main Calvinist church of Danzig; see Zdrenka, Rats- und Gerichtspatriziat der Rechten Stadt Danzig, 2:232. In 1748, Jean Jeremias Du Grain, organist of St Elisabeth's, mentioned Conradi amongst the dedicatees of his organ hymnal edited for the Reformed Church; see Muttray, 'Der Komponist Jean du Grain in Danzig', 35.

865 APG 300,R/Uu,q9.

866 APG 300,R/Uu,q9, pp. 10, 12, 17, 18, 20, 22, 65, 66, 69, 70.

867 APG 300,R/Uu,q9, p. 11. 


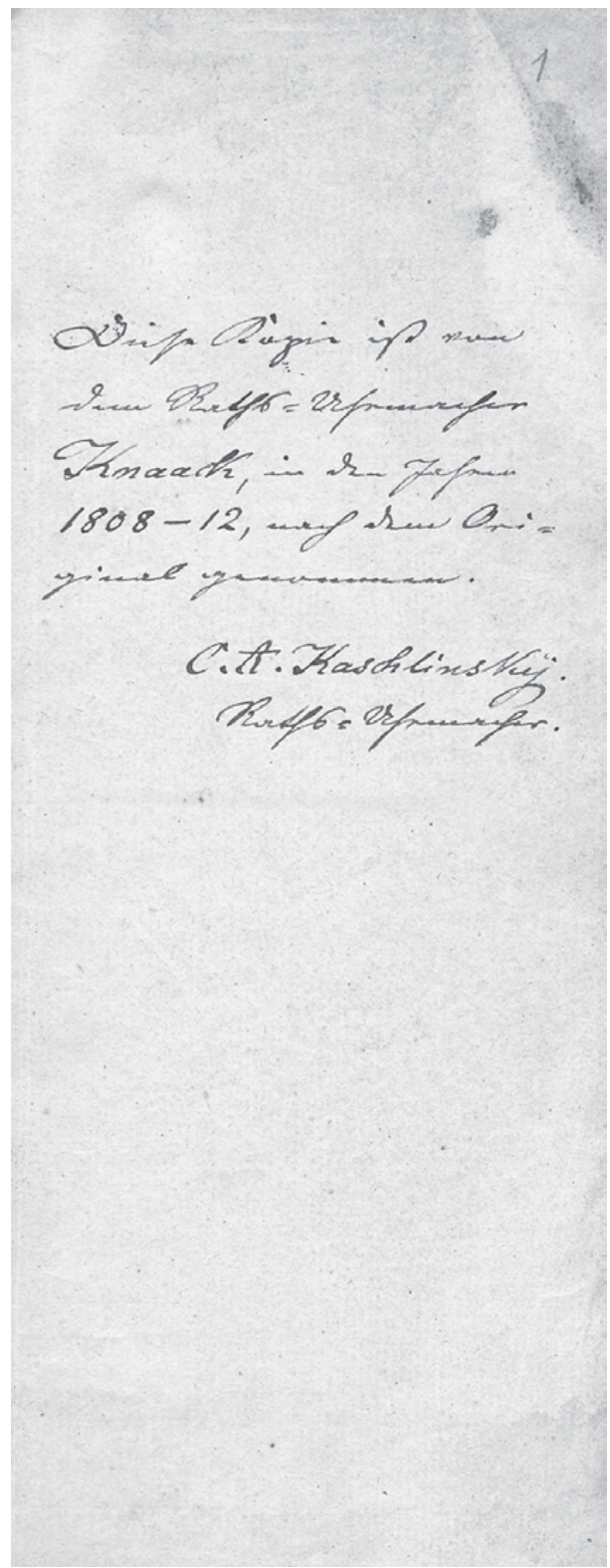

Fig. 78: Tablature of P. F. Knaack. APG 300,R/Uu,q9, p. 1 


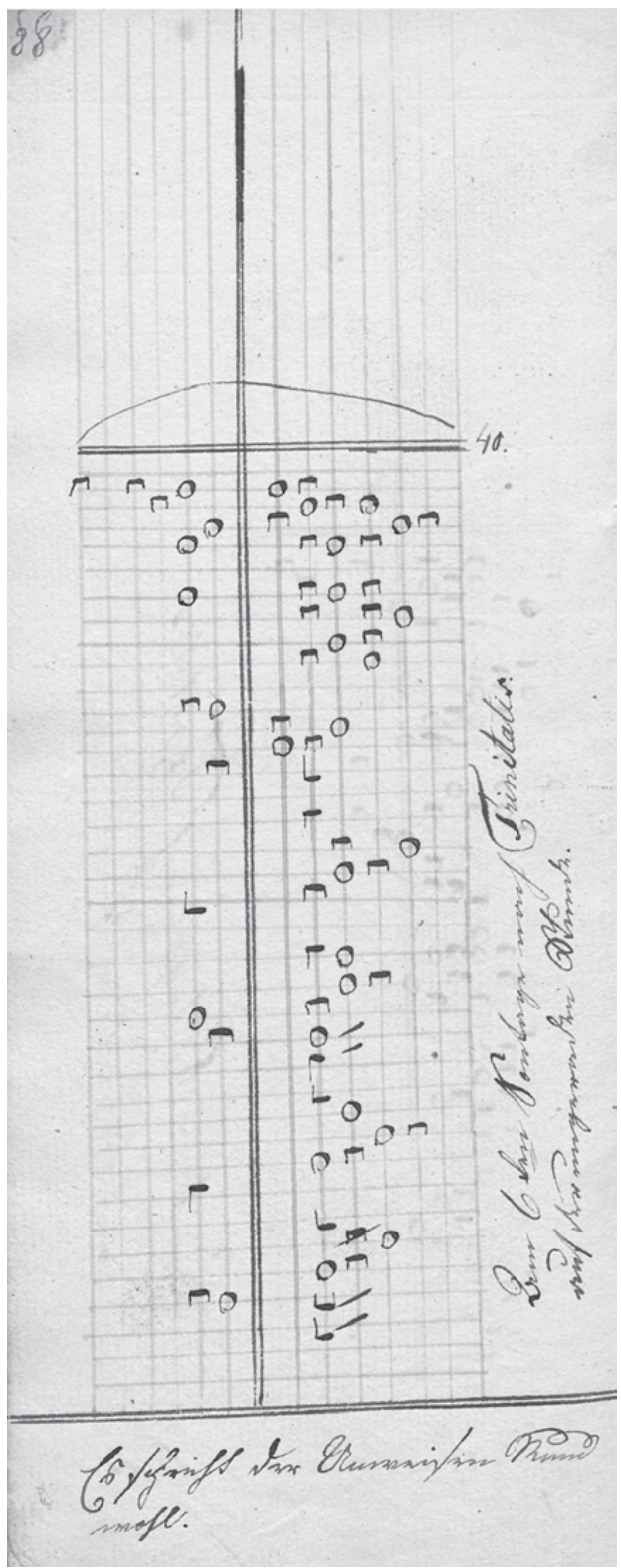

Fig. 79: Tablature of P. F. Knaack. APG 300,R/Uu,q9, p. 88 
Knaack worked on the manuscript very methodically, although he did not avoid some inconsistencies. For example, instead of leaving a blank diagram for the odd hours of the second week of Advent, when traditionally the chorale Nun komm der Heiden Heiland from the previous week was played, he wrote the transposition of the chorale Es ist gewißlich an der Zeit. Other examples of Knaack's inaccuracies include two songs with no titles (unfortunately, I have been unable to identify them $)^{868}$ and the index at the end of the manuscripts, which is incomplete. ${ }^{869}$

According to the note written by Kaschlinsky on the second page of the manuscripts, the tablature does not include Paul Friedrich Knaack's own setting, but is instead a copy of an original. That original could have only been the four-volume tablature by Theodor Friedrich Gülich, ${ }^{870}$ and more specifically its two first volumes, in which Knaack's predecessor notes song settings for the subsequent weeks and holidays of the liturgical years. The vast majority of these settings appear to be identical in both sources. The differences observed in Knaack's copies usually consist of omitted chord elements, minor modifications of the rhythm, or result from the transposition of Gülich's settings. ${ }^{871}$ A comparison of compositions from both sources clearly confirms that Knaack's tablature of 1808-12 is a copy of Theodor Friedrich Gülich's settings. ${ }^{872}$

In 1808, Paul Friedrich Knaack was promoted to a master by the Gdańsk watchmakers' guild, ${ }^{873}$ and it probably at that time that he was offered the position of city watchmakers, including the duty of overseeing the city clock and carillon. Those were difficult times, as living conditions deteriorated in the Free City during Napoleon's occupation. The consequences of Gdańsk's dramatic siege of 1807 and the impoverishment of its citizens had a major impact on living conditions as well as certain traditions. From Gülich's four-volume tablature, Knaack selected and copied only the yearly order of chorales, as it was necessary for the everyday operation of the carillon. The extensive instruction related to carillon settings for the King's arrival to the city, the King's convalescence, the death of a mayor's or councillor's wife, became obsolete in the current political situation of Gdańsk.

868 See APG 300,R/Uu,q9, pp. 9, 112. These are melody settings for even hours of the fourth week of Advent and the odd hours of the feast of St Michael's.

869 APG 300,R/Uu,q9, pp. 133-36.

870 APG 300,R/Pp,q9.

871 I shall discuss the differences between the original and copy later in this book.

872 Woźniak et al., Music Collections from Gdańsk 3, nos. 839-958 and pp. 145-46. Only after transcribing all the compositions of Gülich and Knaack have I concluded that ascribing the authorship of chorale settings in the APG 300,R/Uu,q9 tablature was a mistake. Knaack can at best be considered an arranger of Gülich's settings.

873 Prószyńska, 'Słownik gdańskich zegarmistrzów i gnomoników’, 148. 


\subsection{The notation of Gdańsk carillon tablatures}

Gdańsk carillon tablatures used a unique notation, to be found in no other European musical sources, where works for automated bells were notated on a standard single or double stave. This practice was also followed in the oldest extant manuscripts for automated carillon: those of Hendrick Claes of 1616-33, Theodorus de Sana of 1648, Philippus Wyckaert of 1681, and Joannes de Gruytters' brochure from the mid-eighteenth century which discusses the rules of programming music for the carillon. ${ }^{874} \mathrm{~A}$ similar notation to that used in Gdańsk's carillon tablatures is included in The Artificial Clock-Maker. A Treatise of Watch and Clock-Work..., a treatise by William Derham, first published in 1697. Derham mostly discusses clock mechanisms, but dedicates a short fragment to the programming of the drum of a small "chime." $\mathrm{He}$ illustrates his remarks with Psalm 100 in two variants: traditional and tablature notation. However, that Psalm's melody only includes two rhythmic values, making Derham's notation very simple in comparison to that used in Gdańsk sources. ${ }^{875}$

The existence of a Gdańsk notation is confirmed by a job application by Franz Tetius, who mentioned that he owned all his father's books and notes, and boasted he knew "das rechte fundament, welches mein Vater erfunden." ${ }^{876}$ I believe this remark refers to the original (tablature) musical notation used by Town Hall bell setters also in subsequent centuries. Yet Franz Tetius' claim that the notation was invented by his father Jacobus does not sound plausible. It seems more likely that the notation was proposed by Franciscus de Rivulo, who taught to Schönberg, who in turn transmitted it to bell setter Michael Colrep and the latter to Jacobus Tetius.

Discussing the Gdańsk “Turm-Bücher," Andrzej Januszajtis partly interpreted the notation featured in those sources. ${ }^{877}$ He remarked that

signs used in tower books refer to different pins - sadly we do not know which ones. The only solution is to adopt subsequent working hypotheses and compare the results with standard musical notation of the melodies. Determining the pitches is straightforward.

874 Haspels, Automatic Musical Instruments, 169-71, 247; Gruytters, Rules for Programming All Carillon Playing Drums; Van Eyndhoven, 'In Playing Those Bells'.

875 W[illiam] D[erham], The Artificial Clock-Maker. A Treatise of Watch and Clock-Work ..., London ... MDCCXXXIV, 50-51. I thank Carl Van Eyndhoven for drawing my attention to that manuscript.

876 APG 300,R/Vv,217, pp. 29-32.

877 Januszajtis, 'Muzyka gdańskich dzwonów', 13-14. 
The signs are placed on a grid made up of perpendicular lines. There are fourteen horizontal lines, equivalent to bells, so each line represents a pitch. The vertical lines represent the holes, i.e., musical bars. ${ }^{878}$

Januszajtis thus observed the rules of notating pitch but did not address the aspect of rhythm..$^{879}$

In 2000, Małgorzata Fiebig-Drzewiecka, Janusz Grabowski, and Grzegorz Szychliński published a consistent system for transcribing the Gdańsk sources ${ }^{880}$ They coined the term "pin notation," referring to the pins (sprigs) used for programming tunes on the carillon drum. According to the authors, the pin notation was based on the following premises:

1. Compositions are notated in tablatures as diagrams of intersecting horizontal and vertical lines, schematically representing a fragment of the carillon drum and the work that is programmed on it.

2. Each diagram is composed of 14 horizontal lines, representing the pitches of the 14 bells composing the carillon (the pitch axis), ordered according to the scale: F4-G4-A4-B,4-C5-D5-E5-E, 5-F5-G5-A5-B,5-C6-D6. The uncertainty about which outer line represents the highest pitch and which the lowest is easily clarified by deciphering the direction of the work's melody and comparing it with the universally known chorale. Moreover, the diagrams include hints as to in which direction they should be read. The end of a composition is always marked with the number of slats needed to programme it. That number was written into the diagram or below it, by the last vertical line next to the outer horizontal line. That horizontal line indicates the highest bell's pitch.

3. The vertical lines represent the slats on the carillon drum, i.e., the axis of time. Additional marks are added to these on the right and left. However, they are not, as in other systems of musical notation, rhythmic values, but signs (or graphs, as they are called by the method's authors) for the pins used to programme compositions. Those graphs schematically render the way of fixing pins. To decipher's a work's rhythmic shape, it is necessary to imagine the way a carillon drum works. The hammer striking the bells is connected by a pull rod with a lever, placed by the revolving drum. On the drum are placed slats to which the programmist fixes the pins. When the drum revolves, the pin lifts the lever, and the pulling rod pulls the hammer from the bell. After releasing the lever,

878 Januszajtis, 14.

879 Januszajtis, 20-22.

880 Fiebig-Drzewiecka, Grabowski, and Szychliński, 'Notacja kołkowa bębna carillonu', 5-25. 
the hammer hits the bell, generating a tone. The sign of a pin on the vertical line of the diagram indicates the beginning of a bell's tone and not its duration, which can be determined only when the next bell is struck. This observation is the key to understanding the notational system of Gdańsk carillon tablatures.

Fiebig-Drzewiecka, Grabowski, and Szychliński observed that five signs (graphs) were used in Gdańsk notation, which they assigned to the five pins used for programming tunes on the drum: ${ }^{881}$

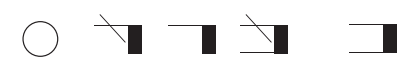

Fig. 80: Basic types of signs used in Gdańsk carillon tablatures

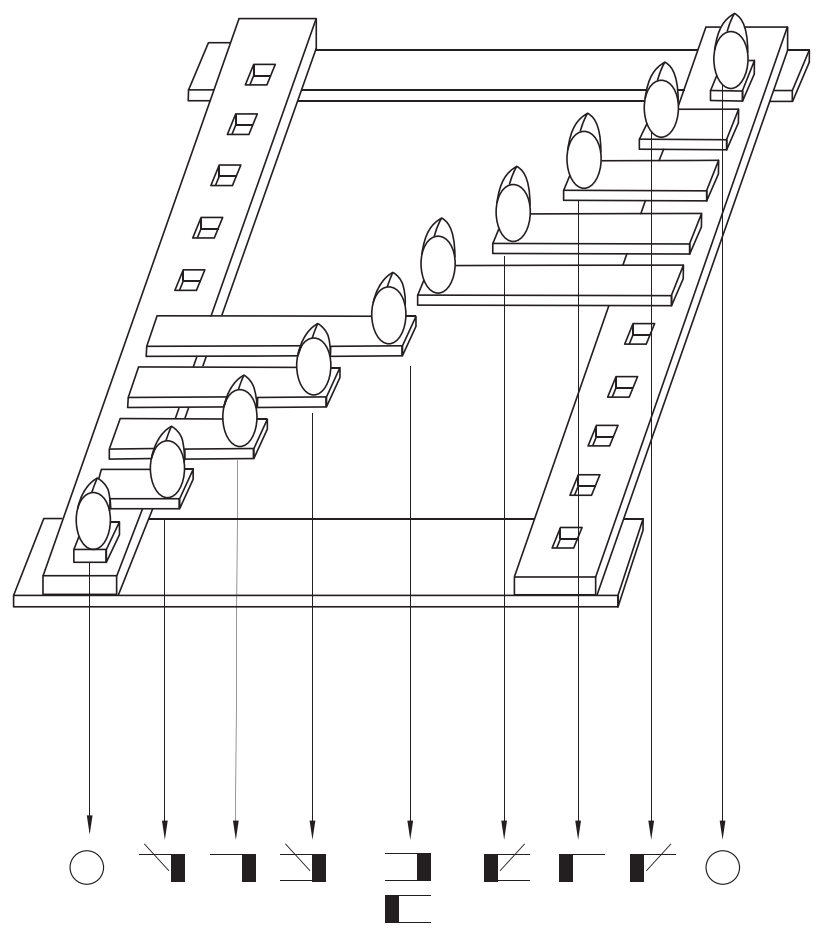

Fig. 81: Pattern of fixing pins to slats of the carillon drum

881 Five different types of pins ("Stiften") for the programming of the carillon drums are mentioned by the last Town Hall bell setters, Georg Edel. See Edel, 'Aus Danzigs Eigenart', 180. The Town Hall carillon's pins have not survived to our day. 
A circle is enscribed at each intersection of horizontal and vertical lines. The remaining four signs were notated to the left of right of the vertical lines (Fig. 81).

Fiebig-Drzewiecka, Grabowski, and Szychliński reached the following conclusions:

1. A circle indicates a straight pin introduced into a hole in the slat.

2. The remaining four signs indicate four bent pins of varying length, fixed to the slats in two opposite directions.

Consistently with the graphic diagram, the longest bent pin divides the distance between slats into the half. The three remaining pins are placed at equal intervals on that distance. Altogether, the distance between slats is divided into eight sections. The unity of sound duration is thus the multiplicity of $1 / 8$ of the distance between two adjacent pins. If the distance between slats is equal to a semibreve, the smallest rhythmic value is a quaver (Fig. 82 and Example 1).

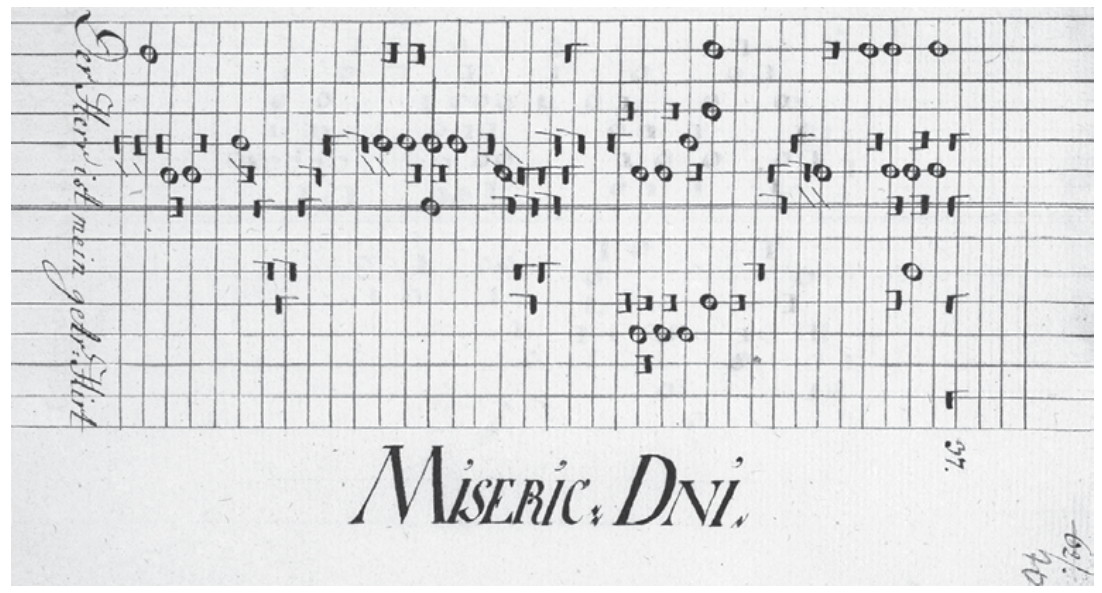

Fig. 82: Th. F. Gülich, Der Herr ist mein getreuer Hirt'. APG 300,R/Pp,q9, p. 70

The system described by Fiebig-Drzewiecka, Grabowski, and Szychliński is logical, though the authors failed to discuss all the signs used in Gdańsk carillon tablatures. They have briefly mentioned diagonal lines, often placed by other signs where a not is repeated, and have suggested that they might be related to the way pins were fixed. ${ }^{882}$ However, they do not mention several other signs: single- and

882 Fiebig-Drzewiecka, Grabowski, and Szychliński, 'Notacja kołkowa bębna carillonu', 23-24. 


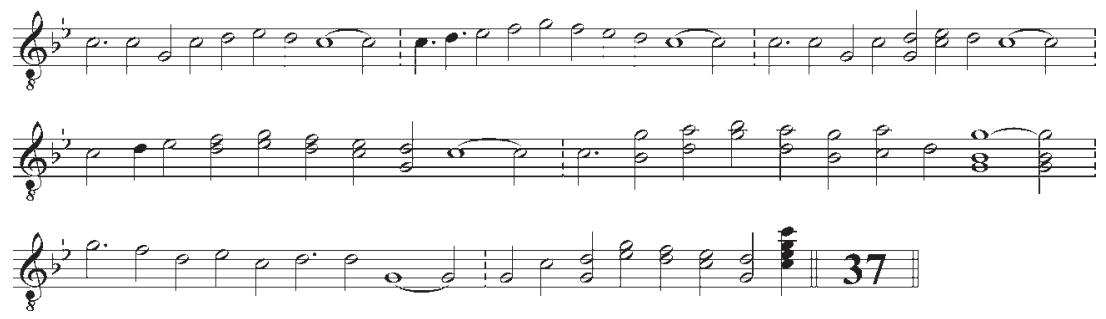

Example 1: Th. F. Gülich, Der Herr ist mein getreuer Hirt', APG 300,R/Pp,q9, p. 70

double-crossed circles and double crossed-out bent pin symbols. Although there have been numerous attempts at interpreting these signs, we still do not know their meaning; only in a few instances can they be considered to be copyist's errors.

A shortcoming of this transcription is that rhythm could not be synced with musical measure, so that the transcription must remain ametrical. ${ }^{883}$ The aural experience of music so notated is acceptable, although the graphic shape of transcribed compositions is objectionable. Assigning signs to pins in a different way would, of course, create a different transcription. Nonetheless, numerous attempts at proposing an alternative deciphering of the tablatures have not yielded satisfactory results; consequently, the transcription of 2000, discussed above, must be deemed satisfactory.

In that transcription's defense, we need to remember that the Gdańsk tablatures originate from the second half of the eighteenth century, and so were destined for a drum that at over 200 years old, was certainly not a perfect mechanism. The uneven rhythm was probably due to deformations of that drum. It is possible that undeciphered notational signs referred to technical corrections when programming pins.

The imperfect timbre of bells was commented upon in 1928 by Herbert Pawlowski:

Mittlerweile ist wiederum eine Stunde verflossen, und wir haben nun einmal Gelegenheit, das Spiel aus nächster Nähe vernehmen zu können. Aber nur schwer läßt sich die Melodie heraushören, denn in Glockenschlag übertönt den anderen. ${ }^{84}$

883 Although Fiebig-Drzewiecka, Grabowski, and Szychliński have proposed a coherent transcription method, they have departed from it in their musical edition, opting for a "smoothened" version adapted to chorales as set by Johann Sebastian Bach; see 'Notacja kołkowa bębna carillonu', 21-22.

884 Pawlowski, 'Das Glockenspiel des Rechtstädtischen Rathause zu Danzig', 482. 
The sounds of the carillon had to cover a long distance between the Main Town Hall tower and the listener's ears. The musical communication, disturbed as it was by wind and other weather factors, was far from the idea; nonetheless, listeners could quickly identify the tunes.

\subsection{The manuscript of Carl Anton Kaschlinsky}

The manuscript of Carl Anton Kaschlinsky is a quite roughly edited notebook. The manuscript includes eight pages, measuring $34 \times 21,5 \mathrm{~cm}$, sewn and bound in a simple cardboard cover of beige colour. In the manuscript, the author included:

1. A description of the Main Town Hall carillon

2. An index of song titles programmed on the carillon on the subsequent weeks of the year

3. Titles of songs (with short comments) for Harvest Thanksgiving, Reformation Day, and Day of the Dead, as well as those set for the beginning and end of the St Dominic's Fair, the title of a thanksgiving song and several titles of funeral songs

4. Settings of seven songs notated on staves in universal notation

Kaschlinsky titles his remarks about the Main Town Hall carillon as follows:

Beschreibung des Glockenspiels auf dem Rathhausthurme zu Danzig, und Verzeichniss der Melodien, welches dasselbe spielt. ${ }^{885}$

He begins his description stating that the carillon is composed of fourteen bells, and listing their tuning. He notates the bells' pitches not in real scale, but schematically starting with $\mathrm{C} 2$ :

Das Glockenspiel besteht aus 14. Glocken, welche folgende Töne haben:

C. D. E. F. G. A. B. H. c. d. e. f. g. a. Es ist zu bemercken, daß das $\underline{C}$ der Glocke nicht der $\mathrm{Kam}[\mathrm{m}]$ erton C, sondern der Kam[m]erton F. ist.

He continues by indicating the dimensions of the bells: diameter in feet and inches according to the Rhine standard ("Rheinländisch Maaß") ${ }^{886}$ as well as the weight of the first (lowest) bell and the bell an octave higher, in hundredweights (approximate weight, as the bells were not dismounted for measuring), and finally the weight of the clappers for ten bells (as he says, he was unable to estimate all of them). Further remarks are dedicated to carillon playing:

Dieses Glockenspiel, spielt spielt vor jedem Stundenschlage eine Choralmelodie und zwar jede woche zwei andere Melodien, welche Sonnabends oder bei einigen Festwochen (wie

885 PAN BG Ms 1093 IV, p. 1.

8861 Rhine inch = 26 mm; see Zernecke, Cały Gdańsk za dwadzieścia srebrnych groszy, 234 . 
Weihnachten und Neujahr) am heiligen Abend vorher gesetzt werden (d[as] h[eist]: die Hebestifte, welche mittels Schraubenmuttern im Innern der Walze befestigt sind, werden herausgenom[m]en und in die betreffenden Löcher der neuen Melodien gesteckt und befestigt.) Die Walze mit den Hebestiften dreht sich nicht bei jedesmaligem Spiele ganz herum, sondern nur theilweise, je nachdem die Melodien länger oder kürzer sind, so dass erst bei zweimaligem Spiele die Walze herum ist. Es ist hier Gebrauch, dass auf der g[e] raden Stunde (2, 4, 6, 8 etc.) die längere, auf der ungeraden Stunde (1, 3, 5, 7 etc.) die kürzere Melodie gesetzt wird. nur einige Melodien sind auf den geraden und ungraden Stunden gleich lang. Die Melodien werden nicht nach dem bürgerlichen, sondern nach dem Kirchenjahre gesetzt, und nehmen Rücksicht auf das Son[n]- oder Festtagsevangelium oder die Epistel. In dem nun folgenden Verzeichniss ist die erste Melodie diejenige welche auf die gerade, und die zweite welche auf die ungerade Stunde kom[m]t. Ferner kom[m]en nicht in jedem Jahre alle Epiphaniens- und Trinitatis-Son[n]tage vor, sondern es bleiben dan[n] die begänglichen Melodien fort. (Es ist dies in Folge der Beweglichkeit des Kirchenjahres).

From Kaschlinsky's remarks, we gather there were no changes in the everyday work of the Town Hall carillon and its repertoire since at least 1769, or the extant manuscripts of Theodor Friedrich Gülich.

The carillon was played every hour. For the subsequent weeks of the year, two Protestant songs were programmed. They were changed on Saturdays or on the eve of holidays, of which Kaschlinsky only mentioned Christmas and the New Year. He also comments on technical aspects of changing tunes: movable pins placed on the drum and screws used to fix them; he also mentions the drum does not make a full resolution at once, but only a partial one, before one of the two programmed tunes does not finish. Traditionally, a longer tune was programmed on even hours, and a shorter one on odd hours, but tunes in some pairs were of equal lengths. The author's final remarks relate to the carillon repertoire; he observed that the melodies were programmed not according to the secular but sacred calendar, including Sunday and holiday gospels and lessons. $\mathrm{He}$ also comments on the movable feasts of the liturgical calendar.

Kaschlinsky's completes his account of the Gdańsk carillon with a note above a quoted text. In it, he emphasises that 55 slats are used to programme even hours on the carillon, while 24 slats for odd hours:

NB. Für das größere Lied in der geraden St[unde] 55 Latten

Für das kleinere Lied in der ung[e]r[aden] St[unde] 24 ditto.

After describing the carillon and its functions, Kaschlinsky presents a list of song titles for the subsequent weeks and holidays of the liturgical year, as well as notes the titles of songs for three holidays: Harvest Thanksgiving, Reformation Day, and Day of the Dead, with notes on when these were celebrated. ${ }^{887}$ 
Tab. 22: Tunes listed by Carl Anton Kaschlinsky, programmed for Harvest Thanksgiving, Reformation Day, and Day of the Dead

\begin{tabular}{lll}
\hline Tune title & Holiday & Time \\
\hline $\begin{array}{l}\text { Nun danket alle Gott } \\
\text { Lobet den Herren den mächtigen König }\end{array}$ & $\begin{array}{l}\text { Harvest } \\
\text { Thanksgiving }\end{array}$ & first Sunday in October \\
$\begin{array}{l}\text { Ein' feste Burg ist unser Gott } \\
\text { Erhalt uns Herr bei deinem Wort }\end{array}$ & Reformation Day & first Sunday in November \\
$\begin{array}{l}\text { Ich bin ja Herr in deiner Macht } \\
\text { O wie selig seid ihr doch ihr Frommen }\end{array}$ & Day of the Dead & $\begin{array}{l}\text { last Sunday of the liturgical } \\
\text { or }\end{array}$ \\
Nun laßt uns den Leib begraben & & \\
\hline
\end{tabular}

Subsequently, Kaschlinsky included a comment on the coupling of tunes on the carillon bell according to their length. He then notated five settings to illustrate those rules:

Es folgen hier einige Notenbeispiele wie diese Melodien gesetzt werden. Bei $\mathrm{N}^{\circ} 1$. hat die Melodie ... auf der g[e]raden Stunde das längste, die auf der ungeraden Stunde das kürzeste Maaß. Bei № 2. ist die erste Mel[odie] kürzer, die zweite dagegen, etwas länger. Bei $\mathrm{N}^{\circ} 3$ sind beide Melodien gleich lang. ${ }^{888}$

Kaschlinsky illustrates the first principle correctly: in his examples of songs for the New Year, the longer one is assigned to the even hour. The second rule, according to which a shorter chorale should be played on even hours, is not illustrated by Trinity Sunday: the setting for the even hour is again longer than for the odd one. The next musical example used by Kaschlinsky is supposed to illustrate the third rule: that of setting melodies of equal length, but I was unable to interpret how the chorale Befiehl du deine Wege, listed with no comment, illustrates that rule.

Kaschlinsky later discusses the order of songs to be played for the beginning and end of St Dominic's Fair, with remarks on the technique of play, and follows with the thanksgiving song Nun lob mein' Seel' den Herren and titles of funeral songs, with notes on the circumstances in which they should be programmed. ${ }^{889}$ 
Tab. 23: Song titles listed by Carl Anton Kaschlinsky, illustrating the rules of coupled songs according to their length

\begin{tabular}{llll}
\hline Song title & Holiday & Setting & Duration \\
\hline $\begin{array}{l}\text { Es woll' Gott uns genädig sein } \\
\text { Wach auf mein Herz und singe }\end{array}$ & New Year & $\begin{array}{l}\text { even hour } \\
\text { odd hour }\end{array}$ & $\begin{array}{l}\text { longer } \\
\text { shorter }\end{array}$ \\
$\begin{array}{l}\text { Allein Gott in der Höh' sei Ehr' } \\
\text { [setting with no title] }\end{array}$ & Trinity Sunday & $\begin{array}{l}\text { even hour } \\
\text { odd hour }\end{array}$ & $\begin{array}{l}\text { longer } \\
\text { shorter }\end{array}$ \\
Befiehl du deine Wege & & & \\
\hline
\end{tabular}

Tab. 24: Order of songs programmed for St Dominic's Fair as listed by Carl Anton Kaschlinsky

\begin{tabular}{|c|c|c|}
\hline Function & Title/hour of play & Remarks \\
\hline $\begin{array}{l}5 \text { August, } \\
\text { beginning of } \\
\text { St Dominic's } \\
\text { Fair }\end{array}$ & $\begin{array}{l}\text { Präludium and Es woll' Gott } \\
\text { uns genädig sein } \\
\text { 11am, 11:30am, noon } \\
\text { Gott ist mein Lied } \\
\text { 1pm }\end{array}$ & $\begin{array}{l}\text { "5 Minuten vor 11. Uhr dan[n] } \\
\text { Stundenschlag, nach demselben Präludium } \\
\text { \& Es wolle Gott ... dan[n] folgt von dem } \\
\text { St[unde] Marienkirchthurm das Einläuten. } \\
11 \text { 1/2 Uhr u[nd] } 12 \text {. Uhr in gleicher Weise } \\
\text { dan[n] Präludium fort und auf die ung[e] } \\
\text { rade Stunde Gott ist mein Lied." }\end{array}$ \\
\hline $\begin{array}{l}10 \text { August, } \\
\text { ending of } \\
\text { St Dominic's } \\
\text { Fair }\end{array}$ & $\begin{array}{l}\text { Präludium and Lobet } \\
\text { den Herren } \\
\text { 11am, 11:30am, noon } \\
\text { Wach auf mein Herz } \\
\text { und singe } \\
\text { 1pm }\end{array}$ & $\begin{array}{l}\text { "11 Uhr vormittags: Präludium und } \\
\text { Lobet den Herrn } 11 \frac{1}{2} \text { Uhr und } 12 \text {. wie } \\
\text { früher: dan[n] Präludium fort und auf die } \\
\text { ung[e]rade Stunde »wach auf mein Herz } \\
\text { und singe«." }\end{array}$ \\
\hline
\end{tabular}

Tab. 25: Funeral songs listed by Carl Anton Kaschlinsky with remarks on their programming

\begin{tabular}{ll}
\hline Song title & Remarks \\
\hline Ich bin ja Herr in deiner Macht & "Bei einer Leiche von Magistrats- oder hohen- \\
O wie selig seid ihr doch ihr Frommen & $\begin{array}{l}\text { Standes-personen: während die Leiche über der } \\
\text { Erde steht" } \\
\text { Was Gott tut das ist wohlgetan }\end{array}$ \\
$\begin{array}{l}\text { Mache dich mein Geist bereit } \\
\text { Was Gott tut das ist wohlgetan }\end{array}$ & "Nach dem Begräbniß" \\
\hline
\end{tabular}

The manuscript ends with the musical notation of two songs. The first one, Christ unser Christ zum Jordan kam, is for the feat of St John. Kaschlinsky notes that it should be programmed on an even hour, while on the odd hour, the ordinary song for that week should be left. 


\section{1918.834}

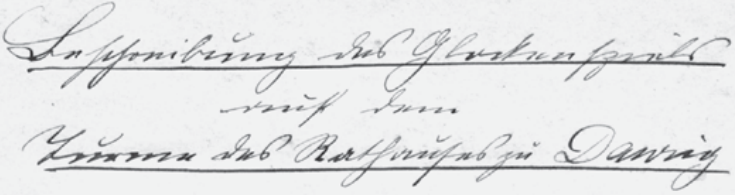

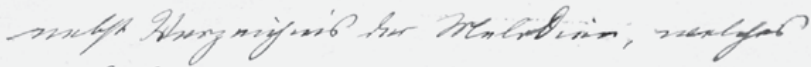

shorfockn forier.

Qlingmeat aro

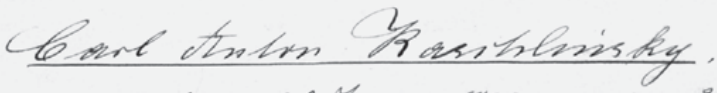

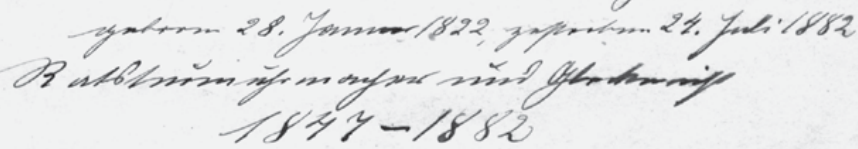

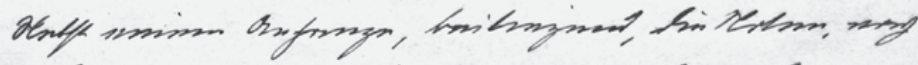

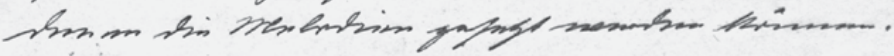

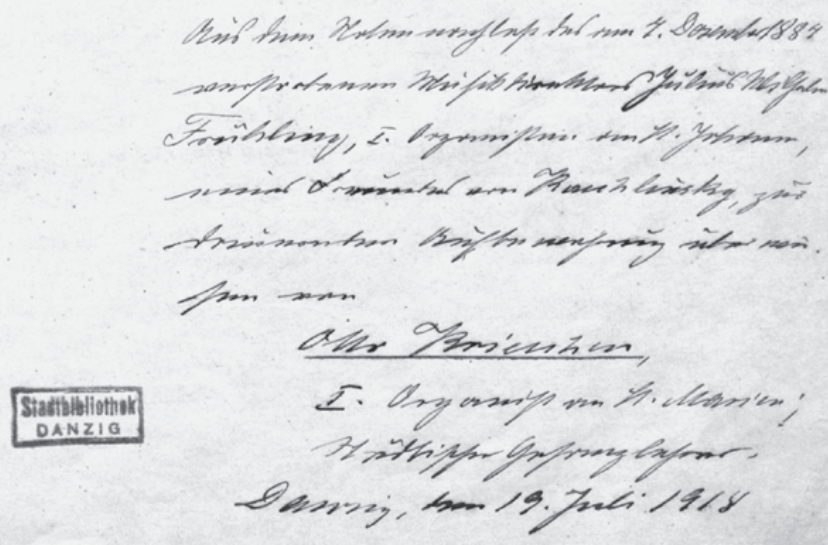

Fig. 83: Manuscript of C. A. Kaschlinsky. PAN BG Ms 1093 IV, title page 


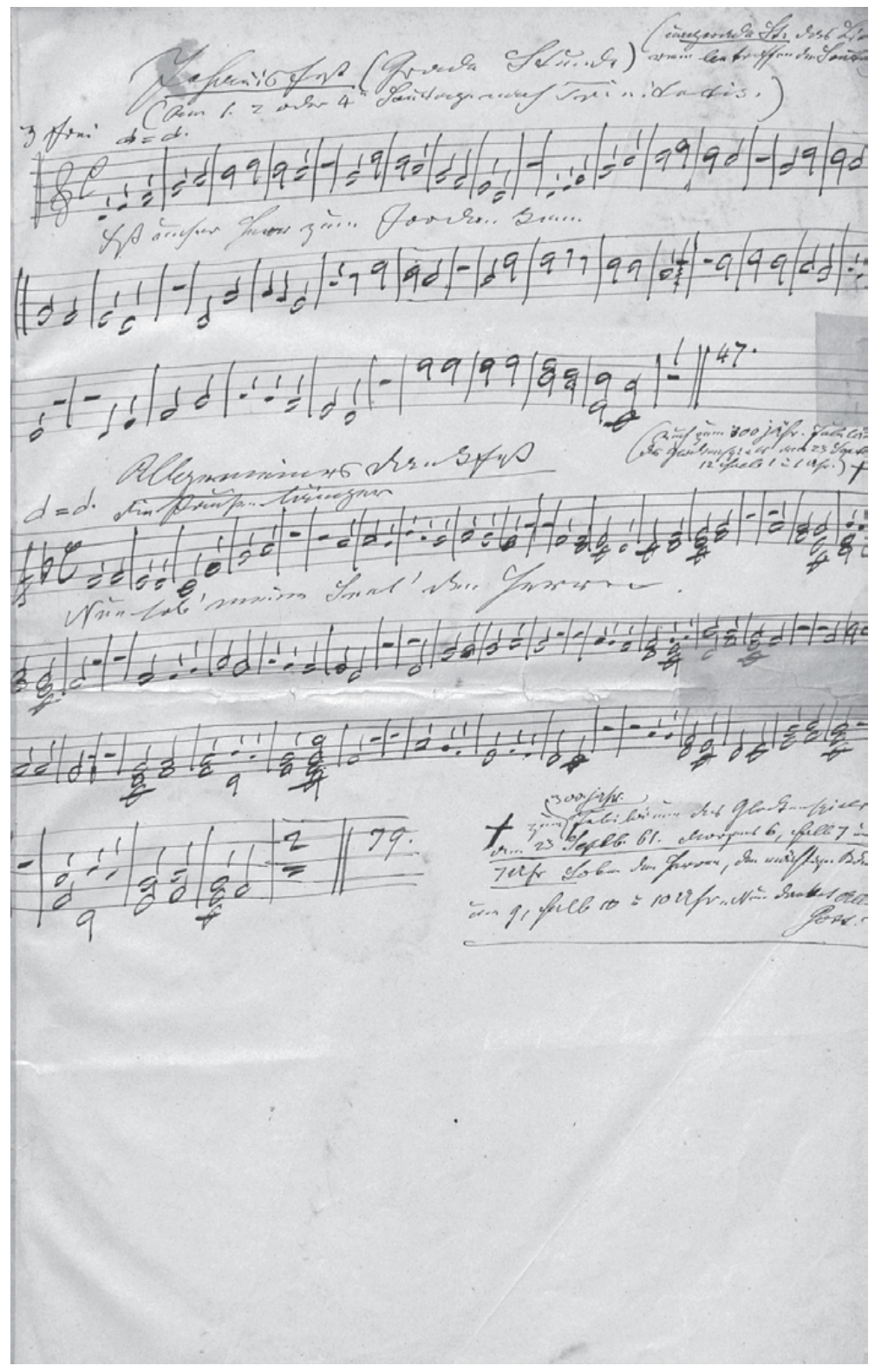

Fig. 84: Manuscript of C. A. Kaschlinsky. PAN BG Ms 1093 IV, p. 7 
The second notation includes the thanksgiving chorale Nun lob mein' Seel' den Herren. It was not programmed within the normal yearly order but on special occasions ${ }^{890}$ Kaschlinsky binds it with two other songs: Lobet den Herren den mächtigen König and Nun danket alle Gott for 23 September 1861, the 300th anniversary of the Main Town Hall carillon, as documented by notes placed above and below the song's notation. ${ }^{891}$

The manuscripts of Carl Anton Kaschlinsky, which includes detailed remarks on the Town Hall automaton and an index of its yearly order of play as well as occasional songs, is a remarkable example not only of the author's professional care for the instrument, but also his passion for documenting the history of Gdańsk and its current life. It should be noted Kaschlinsky left several other manuscripts. ${ }^{892}$

\section{Eighteenth-century song registers}

Eighteenth-century sources with information on the repertoire of the Main Town Hall carillon also include four manuscript registers of song titles programmed for the subsequent weeks and holidays of the liturgical year. These manuscripts are now held at the Polish Academy of Sciences Gdańsk Library. Before the Second World War, the Gdańsk City Library (Danziger Stastbibliothek) owned another register, dated 1723.

Tab. 26: Yearly song registers

\begin{tabular}{llll}
\hline 1. Extant & & \\
\hline No. & Title & Dating & Cat. no. \\
\hline 1 & Die rechtstädtsche Sing-Uhr fängt an zu spielen & before & PAN BG \\
2 & Jahr-Lieder des Rechtst[ädtischen] Glokkenspiels 1771 & 1764 ? & Ms 697/29 \\
& $\begin{array}{l}\text { Der Jahr-Gang der Lieder der Sing-Uhr auf dem rechtstädtischen } \\
\text { Rath-Hause an Seine geliebte Großmama von Henrich Gottfried }\end{array}$ & & PAN BG \\
& $\begin{array}{l}\text { Meyer. Anno 1782 } \\
\text { Verzeichniß derer Lieder welche durch gantze Jahr mit dem } \\
\text { Glocken-Spiel auf dem Rechtstädtschen Raths-Thurm gespielt } \\
\text { werden. Anno 1788 }\end{array}$ & PAN BG \\
& 1788 & PAN BG \\
& & Ms 1073 I \\
\hline
\end{tabular}

890 Remember that Nun lob mein' Seel' den Herren was programmed on the town hall carillon by Andreas Neunaber on 11 February 1646 to celebrate the visit of Maria Louise Gonzaga.

891 I quote and discuss these notes in Part 1 of the present book, in my account of the town hall carillon's origin and history.

892 See my remarks on bell setters in Part 1 of the present book. 
Tab. 26: Continued

\begin{tabular}{llll}
\hline 2. Lost & & \\
\hline No. & Title & Year Place & Cat. no. \\
\hline 1 & $\begin{array}{l}\text { Lieder-Ordnung auf dem Glockenspiel des Recht- } \\
\text { Städtischen Rahthauses } 1723\end{array}$ & 1723 PAN BG & Ms 642 \\
\hline
\end{tabular}

The oldest register, I believe, is an undated index written on a sheet included in the collective manuscript belonging to Johann Benjamin Schmidt, ${ }^{894} \mathrm{a}$ Gdańsk burgher known to have represented the Koggenquartier district in the Third Order from 1765, and in March 1774 became city juror. ${ }^{895}$ The manuscript mostly includes copies of various types of documents, originating from the seventeenth and eighteenth century. ${ }^{896}$ If we assume that the book was compiled before the Schmidt's death (on 9 April $1774^{897}$ ), then the chorale register it includes must have been created during the life of Theodor Friedrich Gülich, who was then the setter of the Town Hall carillon. Yet it was not Gülich who edited the register, as the handwriting is quite unlike the meticulous characters of his own tablatures. Given the dating of many documents included in Schmidt's manuscripts, which originate from before 1764, I have assumed that the song register was edited before Gülich became carillon setter in 1764: it thus might have been edited by his predecessor, David Krüger.

The register consists of a single sheet. In the manuscript's table of contents, it is tagged as "Lieder der Rechtstadt Singuhr." The register proper is preceded by a headline:

Die rechtstädtsche Sing-Uhr fängt an zu spielen.

The next extant manuscript originates from $1771 .^{898}$ It is small $(20 \mathrm{x} 13 \mathrm{~cm})$ and consists of seven pages. The copyist included a simple title:

Jahr-Lieder des Rechtst[ädtischen] Glokkenspiels. 1771.

At the end of the register, the copyist added song titles for four holidays: Purification of the Blessed Virgin Mary, St John, Visitation, and St Michael.

893 Bertling, Katalog der Danziger Stadtbibliothek, 1:364.

894 PAN BG Ms 697/29, fol. 302a-b.

895 Zdrenka, Rats- und Gerichtspatriziat der Rechten Stadt Danzig, 2:139, 283.

896 See Bertling, Katalog der Danziger Stadtbibliothek, 1:448-552.

897 Zdrenka, Rats- und Gerichtspatriziat der Rechten Stadt Danzig, 2:139, 283.

898 PAN BG Ms 863. 
On occasions requiring a different setting than the customary one, on the feat's eve, the register's author indicates the time a given song should be set for.

The register was edited when Theodor Friedrich Gülich was the Town Hall carillon setter. Several elements in the register are consistent with the fourvolume tablature by Gülich: his characteristically meticulous handwriting, the ordering of song titles, and a remark that titles written in chancery hand should be programmed for even hours, while those in Latin script, on odd hours. These elements confirm that Gülich was the actual author of this register.

The third extant register of the carillon's yearly order of play originates from $1782 .{ }^{899}$ It shares a similar format with the 1771 manuscript, though it is a little smaller $(16 \times 10 \mathrm{~cm})$. Its owner, and likely also the copyist, was Heinrich Gottfried Meyer, city juror, councillor and judge of the City Council in the years 1781-92. ${ }^{900}$ Meyer prepared that index for his beloved grandmother, as indicated on the manuscript's title page:

Der Jahr-Gang der Lieder der Sing-Uhr auf dem rechtstädtischen Rath-Hause an Seine geliebte Großmama von Henrich Gottfried Meyer. Anno 1782.

The manuscript was incorporated in the collection of the Gdańsk City Library in 1898. This is indicated by the inventory number placed at the top of the title page, as well as a provenance note on the inner cover, probably edited by the then head of the Library, Otto Günther. The manuscript was formerly in the estate of pastor Hoch of Lewin Brzeski (Löwen):

1898 aus der Nachlasse des Pastor prim. Hoch in Löwen (Kr. Brieg) erworben.

The last extant register was edited in $1788^{901}$ when Johann Gottlieb Borowski was the carillon setter. It is bound in its original blue paper cover, and its dimensions are similar to the registers of 1771 and $1782(18,5 \times 11,5 \mathrm{~cm})$. On the cover, written in fading ink, is the title:

Verzeichni $\beta$ derer Lieder welche durch gantze Jahr mit dem Glocken-Spiel auf dem Rechtstädtschen Raths-Thurm gespielt werden. Anno 1788.

The index of chorales (pages 3-16) is preceded by a headline title:

Anno. 1788. Der Jahrgang des Glokenspiels auf dem Rechtstädtschen Rath-Hauße.

The order of the chorales in this source remained valid for several years, as shown by a note written in different handwriting on the register's first page, dated 1792 .

900 Zdrenka, Rats- und Gerichtspatriziat der Rechten Stadt Danzig, 2:143-49, 249.

901 PAN BG Ms 1073 I. 
The owner of the manuscript is unknown, but it cannot be excluded that it was edited by Johann Gottlieb Borowski. The manuscript was in the collections of the Gdańsk City Library from 1911. It went missing during the Second World War but was recovered from Moscow in 1958..$^{902}$

The dedication included by Heinrich Gottfried Meyer in the 1782 register ("To my beloved Grandmother") and the inclusion of the oldest (undated) register in the manuscript owned by Johann Benjamin Schmidt, indicate that both documents were made for unofficial use. Could it be that the remaining two registers were also owned by private individuals?

The 1771 register was probably edited by Theodor Friedrich Gülich, while the latest one, by Johann Gottlieb Borowski. Knowing how the everyday life of eighteenth-century Gdańsk citizens was regulated by the restrictive legislation issued by the City Council, it can be assumed that the repertoire of the Town Hall carillon must have been officially regulated as well. In this context, the title of the lost register is telling: Lieder-Ordnung. ${ }^{903}$ Bell setters were probably obliged to file their yearly orders of play to the City Council. It is in this character of documents filed with the city authorities that the second and latest extant registers (by Gülich and Borowski) should be interpreted. This hypothesis (sadly unconfirmed) would also explain why the remaining two registers (of 1782 and the oldest, undated, probably pre-1764) ended up in private collections. Their owners were civil servants: Johann Benjamin Schmidt (representative for the Third Order and juror) and Heinrich Gottfried Meyer (juror, councillor, and judge), so they could have access to registers officially filed by bell setters and copied them for their own use.

\section{Press announcements of 1907-28}

Between 1907 and 1928, information on the repertoire of the Town Hall carillon was spread by the Danziger Zeitung. Announcements with the programme for the following week were published on Saturdays, usually in the evening edition, more occasionally in the morning one, or exceptionally on Fridays. The first announcement was published on 6 July 1907, while the last one on 14 January 1928. It belonged in the local news, but had no fixed place: initially, it was tied to church news ("Kirchliche Nachrichten"), which listed the services in Gdańsk's various churches, but was later moved amongst other miscellanea such as weather forecasts, news on hot air balloon flights, announcements

902 Szafran, Katalog Rękopisów Biblioteki Gdańskiej Polskiej Akademii Nauk, 10.

903 PAN BG Ms 642, see Bertling, Katalog der Danziger Stadtbibliothek, 1:364. 
on the dates of exams for teachers, news on local murders, and often livestock market news. The note mentioning two songs (with an indication of even and odd hour) was usually preceded by the headline "Glockenspiel des Rathauses" and the name of the liturgical calendar week. Liturgical announcements were discontinued in the early 1920s. On rare occasions, the Saturday edition of Danziger Zeitung lacked the announcement on forthcoming tunes: likely it was sent to late to the newspaper or simply did not fit in the edition. A missing announcement could also result from an interruption in the carillon service due to renovation or repairs.

An announcement of 6 July 1907 mentions the initiative of listing a weekly repertoire of the carillon and names Paul William Krieschen as the setter of the Town Hall automaton:

Wird von Herrn Organist Paul Krieschen bedient und es werden fortan die Lieder für jede Woche bekannt gegeben werden .....94

The name of Krieschen was often quoted in later announcements. Apart from song titles, he often included information on the tune to which the text was set. In the announcement of 14 January 1928 (the last to be published) no explanation is given on why that practice was discontinued.

\section{Evolution of the Main Town Hall automated carillon repertoire}

The first extant source for learning the yearly repertoire of the Main Town Hall carillon originates probably from the 1760s (the undated register included in the Johann Benjamin Schmidt's manuscript), while the last one is from 17 January 1928 (announcement in Danziger Zeitung). A comparison of these sources indicates that until 1861, the programme of the Town Hall automaton was based on a stable canon, repeated each year with almost no change. In 1861 that canon was modified, and starting with 1907, it was changed every year. The register of 1723, mentioned by August Bertling, is now lost. ${ }^{905}$ This is unfortunate, as access to that source would have afforded us an extra fifty years of comparison of the Town Hall carillon repertoire, as well as clarifying whether Theodor Friedrich Gülich continued to set tunes according to the standard of his time or following the tradition of his predecessors.

904 DZ 1907, no. 311 (6 July).

905 Bertling, 364. 
In the programme played until 1861, I have observed only a few changes. One was the introduction in the tablature of Paul Friedrich Knaack (dated 180812) of the song Ich glaub' an Gott der geschaffen hat for the even hour of the Annunciation (25 March). ${ }^{906}$ To explain while earlier sources lacked a song for that holiday, we need to go back to 1644, when city authorities ordered the holiday to be move to Palm Sunday. The Council's decree thus not only reduced the cult of the Virgin Mary, which Protestants opposed, but also cancelled a bank holiday, which might have been an even stronger motivation for Gdańsk burghers. ${ }^{907}$

Another type of change in registers until 1861 concern song titles. For the same weeks of the liturgical calendar, different titles were used in different years. This happens twelve times in the preserved sources, with regard to the third Sunday of Advent, the second and fourth Sunday after Epiphany, the even and odd hour of the sixth Sunday after Epiphany, Shrove Sunday, Misericordia Sunday, and the sixteenth, seventeenth, twentieth, twenty-fifth, and twenty-sixth Sunday after Trinity. The titles in later registers differed from the earlier extant one. In nine cases, a different chorale incipit did not mean a different tune, as both texts were set to the same melody.

The singing of different texts to the same tune was characteristic not only for Protestant religious repertoire. It is well illustrated by the register included in Johann Benjamin Schmidt's manuscript, where two song titles are entered for the even hour of the twenty-sixth Sunday after Trinity, ${ }^{908}$ as well as the four-volume tablature by Gülich of 1769. For the twentieth Sunday after Trinity, Gülich noted the title Wohl dem in der Gottesfurcht steht, but his musical notation has the incipit Wo Gott zum Haus nicht gibt sein' Gunst. ${ }^{909}$ Alternative song titles are further supported by a remark at the end of that register, which observes that tunes for the twenty-seventh Sunday after Trinity: Wachet auf ruft uns die Stimme (even hour) and Ach Gott wie manches Herzeleid (odd hour), can also be programmed for the sixth Sunday after Epiphany. ${ }^{910}$

906 APG 300,R/Uu,q9, p. 51.

907 Kizik, 'Gute Policey', 82.

908 Wachet auf ruft uns die Stimme/Es ist gewißlich an der Zeit.

909 The alternate character of both titles is confirmed by the chorale book of Johann David König, see PAN BG Ms Mar. Q. 183 (Popinigis et al., Music Collections from Gdańsk 1, no. 1257).

910 APG 300,R/Pp,q9, p. 177. 
Tab. 27: Identification of alternative titles: comparison of the first extant yearly song register with later sources (until 1861)

\begin{tabular}{|c|c|c|c|}
\hline Holiday & $\begin{array}{l}\text { Song title in the first } \\
\text { extant register }\end{array}$ & $\begin{array}{l}\text { Alternative song } \\
\text { title in later } \\
\text { sources (until } \\
1861)^{922}\end{array}$ & Identification \\
\hline $\begin{array}{l}\text { Adventus, } \\
\text { Dominica } 3\end{array}$ & $\begin{array}{l}\text { Menschen Kind wird } \\
\text { erben }\end{array}$ & $\begin{array}{l}\text { Gottes Sohn ist } \\
\text { kommen }\end{array}$ & $\begin{array}{l}\text { Danziger Gesangbuch, Danzig } \\
1764\end{array}$ \\
\hline $\begin{array}{l}\text { Epiphania Domini, } \\
\text { Dominica } 2\end{array}$ & $\begin{array}{l}\text { Was fürchtest du Feind } \\
\text { Herodes sehr }\end{array}$ & $\begin{array}{l}\text { Christum wir sollen } \\
\text { loben schon }\end{array}$ & $\begin{array}{l}\text { PAN BG Ms Mar. Q. 183, PAN } \\
\text { BG Ms 4019a }\end{array}$ \\
\hline $\begin{array}{l}\text { Epiphania Domini, } \\
\text { Dominica 6, even hour }\end{array}$ & $\begin{array}{l}\text { Wachet auf ruft uns die } \\
\text { Stimme }\end{array}$ & $\begin{array}{l}\text { Meinen Jesum laß' } \\
\text { ich nicht; } \\
\text { Ach Gott tu dich } \\
\text { erbarmen }\end{array}$ & APG $300, \mathrm{R} / \mathrm{Uu}, \mathrm{q} 9$ \\
\hline $\begin{array}{l}\text { Epiphania Domini, } \\
\text { Dominica 6, odd } \\
\text { hour }\end{array}$ & $\begin{array}{l}\text { Ach Gott wie manches } \\
\text { Herzeleid }\end{array}$ & $\begin{array}{l}\text { O Christe } \\
\text { Morgensterne; } \\
\text { Gott hat das } \\
\text { Evangelium }\end{array}$ & APG $300, \mathrm{R} / \mathrm{Uu}, \mathrm{q} 9$ \\
\hline $\begin{array}{l}\text { Dominica } \\
\text { Misericordias Domini, } \\
\text { even hour }\end{array}$ & $\begin{array}{l}\text { Gelobet sei Gott im } \\
\text { höchsten Thron }\end{array}$ & $\begin{array}{l}\text { Surrexit Christus } \\
\text { hodie }\end{array}$ & Zahn, Bd. I, s. $77^{923}$ \\
\hline $\begin{array}{l}\text { Trinitas, } \\
\text { Dominica 16, odd hour }\end{array}$ & Auf meinen lieben Gott & $\begin{array}{l}\text { Wo soll ich fliehen } \\
\text { hin }\end{array}$ & $\begin{array}{l}\text { PAN BG Ms Mar. Q. 183, PAN } \\
\text { BG Ms Mar. Q. 184, PAN BG } \\
\text { Ms Mar. Q. 185, PAN BG Ms } \\
4018\end{array}$ \\
\hline $\begin{array}{l}\text { Trinitas, } \\
\text { Dominica 20, odd hour }\end{array}$ & $\begin{array}{l}\text { Wo Gott zum Haus } \\
\text { nicht gibt sein' Gunst }\end{array}$ & $\begin{array}{l}\text { Wohl dem der in } \\
\text { Gottesfurcht steht }\end{array}$ & $\begin{array}{l}\text { PAN BG Mar. Q. 183, } \\
\text { APG 300,R/Pp,q9 }\end{array}$ \\
\hline $\begin{array}{l}\text { Trinitas, } \\
\text { Dominica 25, even } \\
\text { hour }\end{array}$ & $\begin{array}{l}\text { Zion klagt mit Angst } \\
\text { und Schmerzen }\end{array}$ & $\begin{array}{l}\text { Freu dich sehro } \\
\text { meine Seele }\end{array}$ & PAN BG Ms Mar. Q. 183 \\
\hline $\begin{array}{l}\text { Trinitas, } \\
\text { Dominica 26, even } \\
\text { hour }\end{array}$ & $\begin{array}{l}\text { Wachet auf ruft uns die } \\
\text { Stimme/Es ist gewißlich } \\
\text { an der Zeit }\end{array}$ & $\begin{array}{l}\text { Es ist gewißlich an } \\
\text { der Zeit }\end{array}$ & \\
\hline
\end{tabular}

911 PAN BG Ms 697/29, fol. 302a-b.

912 APG 300,R/Pp,q9; PAN BG Ms 863; PAN BG Ms 863a; PAN BG Ms 1073 I; APG $300, \mathrm{R} / \mathrm{Uu}, \mathrm{q} 9$.

913 Zahn, Die Melodien der Kirchenlieder, 1:77. 
In three cases, I have been unable to establish if a title appearing in later registers is alternative to that noted in the earliest extant source. As mentioned in the Danziger Gesangbuch of 1764, those songs were sung to well-known melodies ("In bekannter Melodie"), so it cannot be excluded they were identical.

Tab. 28: Song titles in the first extant yearly song register and later sources (until 1861), not identified as alternative

\begin{tabular}{lll}
\hline Holiday & Song title in the first extant register & $\begin{array}{l}\text { Alternative song title in } \\
\text { later sources (until 1861) }\end{array}$ \\
\hline $\begin{array}{l}\text { Epiphania Domini, } \\
\text { Dominica 4 }\end{array}$ & Ach Gott vom Himmel sieh darein & $\begin{array}{l}\text { Wär' Gott nicht mit uns } \\
\text { diese Zeit }\end{array}$ \\
Dominica Esto mihi & Da der Herr Christ zu Tisch sa $\beta$ & $\begin{array}{l}\text { Kommt her zu mir spricht } \\
\text { Gottes Sohn } \\
\text { Trinitas, Dominica 17 }\end{array}$ \\
& O Herr dein Ohren neig zu mir & $\begin{array}{l}\text { Wär' Gott nicht mit uns } \\
\text { diese Zeit }\end{array}$ \\
\hline
\end{tabular}

These remarks on the differences observed between the extant song registers not only do not modify my earlier position on the song canon, which was programmed almost unchanged from the 1760s to 1861, but they actually reinforce that conviction. That normative repertoire showed two characteristics. First, it incorporated (with two exceptions) songs that followed a model set by the first Gdańsk hymnal, in vigour from 1719. ${ }^{914}$

The only exception was the sixteenth-century anonymous song O Christe Morgensterne, which was included in the new canon, published in $1764,{ }^{915}$ as well as Ihr lieben Christen freut euch nun, an Advent song by Erasmus Alber (1500-53), long known in Gdańsk after it was published in 1626 by Georg Rhete in one of the first Gdańsk songbooks. ${ }^{916}$ Second, as confirmed by an analysis of text authors, songs programmed on the Main Town Hall carillon until 1861 originated (with a few exceptions) from the oldest, sixteenth-century collection of Protestant songs.

914 Dantziger Gesang-Buch (Danzig, 1719).

915 Danziger Gesangbuch (Danzig, 1764).

916 Geistliche Lieder und Psalmen D. Martini Lutheri auch anderer Gottsehligen Lehrer und Männer. Nach Ordnung der Jahrzeit mit zweyen richtigen Registern. Itzo auffs new übersehen und mit fleisse Corrigiret. Zu Dantzig Gedruckt und Verleg durch Georg Rheten. Im Jahre Christi 1626. 
Tab. 29: Songs titles of the yearly repertoire programmed until 1861, with text authors ${ }^{927}$

\begin{tabular}{ll}
\hline Song title & Text author \\
\hline Ach Gott tu dich erbarmen & unknown \\
Ach Gott und Herr & M. Rutilius, 1550-1618 \\
Ach Gott vom Himmel sieh darein & M. Luther, 1483-1546 \\
Ach Gott wie manches Herzeleid & M. Möller, 1547-1606 \\
Psalm 80 Ach hör Israels Hirt der wehrte & A. Lobwasser, 1515-85 \\
Psalm 125 Alle die auf Gott dem Herren & A. Lobwasser, 1515-85 \\
Allein Gott in der Höh' sei Ehr' & N. Decius, ca. 1485-after \\
& 1546 \\
An Wasserflüssen Babylon & W. Dachstein, ca. \\
& 1487-1553 \\
Auf meinen lieben Gott & unknown \\
Aus tiefer Not schre' ich zu dir & M. Luther, 1483-1546 \\
Christ der du bist der helle Tag & E. Alber, ca. 1500-53 \\
Christe der du bist Tag und Licht & M. Weiße, ca. 1488-1534 \\
Christ fuhr gen Himmel & pre-Reformation \\
Christ ist erstanden & pre-Reformation \\
Christ lag in Todes Banden & M. Luther, 1483-1546 \\
Christ unser Herr zum Jordan kam & M. Luther, 1483-1546 \\
Christum wir sollen loben schon & M. Luther, 1483-1546 \\
Christus der uns selig macht & M. Weiße, ca. 1488-1534 \\
Da der Herr Christ zu Tisch saß & unknown \\
Da Jesus an dem Kreuze stand & J. Böschenstein, 1472-1539 \\
Der Herr ist mein getreuer Hirt' & W. Meuslin, 1497-1553 \\
Psalm 110 Der Herr zu meinem Herren hat gesprochen & A. Lobwasser, 1515-85 \\
Dies sind die heil'gen zehn Gebot' & M. Luther, 1483-1546 \\
Ecce Domine - Gottes Sohn ist kommen & Czech Brethren, 1544 \\
Ein' feste Burg ist unser Gott & M. Luther, 1483-1546 \\
Ein Kind geborn zu Bethlehem & pre-Reformation \\
Ein Kindelein so löbelich & pre-Reformation \\
Erbarm dich mein o Herre Gott & E. Hegenwalt, early 1500s \\
Erstanden ist der heilige Christ & Czech Brethren, 1544 \\
Es ist gewißlich an der Zeit & B. Ringwaldt, 1530-99 \\
& M. Luther, 1483-1546 \\
&
\end{tabular}

917 Texts identified after: Hymnary.org: a comprehensive index of hymns and hymnals, accessed 27 August 2018, http://www.hymnary.org; Die christliche Liederbank, accessed 27 August 2018, http://www.liederdatenbank.de. 
Tab. 29: Continued

\begin{tabular}{|c|c|}
\hline Song title & Text author \\
\hline Es spricht der Unweisen Mund & M. Luther, 1483-1546 \\
\hline Es woll' uns Gott genädig sein & Ch. Demantius, 1567-1643 \\
\hline Freu dich sehr o meine Seele & M. Weiße, ca. 1488-1534 \\
\hline Gelobet sei Gott im höchsten Thron & M. Luther, 1483-1546 \\
\hline Gelobet seist du Jesu Christ & E. Alber, $1500-53$ \\
\hline Gott hat das Evangelium & P. Eber, 1511-69 \\
\hline Helft mir Gottes Güte preisen & E. Kreutziger, ca. 1504-35 \\
\hline Herr Christ der ein'ge Gottes Sohn & P. Eber, 1511-69 \\
\hline Herr Jesu Christ wahr' Mensch und Gott & J. Heermann, 1585-1657 \\
\hline Herzliebster Jesu was hast du verbrochen & unknown \\
\hline Ich glaub' an Gott der geschaffen hat & J. Agricola, $1492-1530$ \\
\hline Ich ruf' zu dir Herr Jesu Christ & E. Alber, $1500-53$ \\
\hline Ihr lieben Christen freut euch nun & A. Reissner, 1496-ca. 1575 \\
\hline In dich hab' ich gehoffet Herr & pre-Reformation \\
\hline In dulci jubilo & E. C. Homburg, 1605-81 \\
\hline Jesu meines Lebens Leben & M. Luther, 1483-1546 \\
\hline Jesus Christus unser Heiland der den Tod überwand & M. Luther, 1483-1546 \\
\hline Komm Gott Schöpfer heiliger Geist & M. Luther, 1483-1546 \\
\hline Komm heiliger Geist Herre Gott & G. Grünwald, ca. $1490-1530$ \\
\hline Kommt her zu mir spricht Gottes Sohn & N. Herman, $1500-61$ \\
\hline Lobt Gott ihr Christen allzugleich & A. Lobwasser, $1515-85$ \\
\hline Psalm 121 Mein' Augen ich zu den Bergen & Ph. Nocolai, 1556-1608 \\
\hline Mag ich Unglück nicht widerstahn & A. Lobwasser, 1515-85 \\
\hline Psalm 22 Mein Gott ach wie verstößt du & Lk 1:46 \\
\hline Meine Seele erhebet der Herren & unknown \\
\hline Meinen Jesum la $\beta^{\prime}$ ich nicht & M. Weiße, ca. 1488-1534 \\
\hline Menschenkind wird eben & M. Luther, 1483-1546 \\
\hline Mensch willst du leben seliglich & M. Luther, 1483-1546 \\
\hline Mit Fried' und Freud' & M. Luther, 1483-1546 \\
\hline Nun bitten wir den heiligen Geist & E. Alber, ca. $1500-53$ \\
\hline Nun freut euch Gottes Kinder all & M. Luther, 1483-1546 \\
\hline Nun freut euch lieben Christen gemein & M. Luther, 1483-1546 \\
\hline Nun komm der Heiden Heiland & unknown \\
\hline O Christe Morgensterne & B. Ringwaldt, 1530-99 \\
\hline O Herr dein Ohren neig zu mir & $\begin{array}{l}\text { A. von Wildenfels, ca. } \\
1490-1539\end{array}$ \\
\hline
\end{tabular}


Tab. 29: Continued

\begin{tabular}{ll}
\hline Song title & Text author \\
\hline O Herre Gott dein göttlich' Wort & M. Behm, 1557-1622 \\
O Jesu Christ mein's Lebens Licht & N. Decius, ca. 1485-after \\
& 1546 \\
O Lamm Gottes unschuldig & J. Rist, 1607-77 \\
O Traurigkeit o Herzeleid & A. Lobwasser, 1515-85 \\
Psalm 128 Selig ist der gepreiset & Czech Brethren \\
Surrexit Christus hodie & M. Luther, 1483-1546 \\
Vater unser im Himmelreich & M. Luther, 1483-1546 \\
Verleih uns Frieden gnädiglich & M. Luther, 1483-1546 \\
Vom Himmel hoch da komm' ich her & Ph. Nicolai, 1556-1608 \\
Wachet auf ruft uns die Stimme & M. Luther, 1483-1546 \\
Wär' Gott nicht mit uns diese Zeit & H. Sachs, 1494-1576 \\
Warum betrübst du dich mein Herz & M. Luther, 1483-1546 \\
Was fürchtest du Fein Herodes sehr & Duke Albrecht of Prussia, \\
& 1490-1568 \\
Was mein Gott will das gescheh' allzeit & M. Weiße, ca. 1488-1534 \\
Weltlich' Ehr' und zeitlich' Gut & B. Gesius, ca. 1560-1613 \\
Wend ab deinen Zorn lieber Herre mit Gnaden & J. Gesenius, 1601-73 \\
Wenn meine Sünd' mich kränken & P. Eber, 1511-69 \\
Wenn wir in höchsten Nöten sein & S. Heyden, 1494-1561 \\
Wer in dem Schutz des Höchsten ist & Ph. Nicolai, 1556-1608 \\
Wie schön leuchtet der Morgenstern & J. Kolrose, ca. 1487-1585 \\
Wo Gott zum Haus nicht gibt sein' Gunst & J. Heermann, 1585-1657 \\
Wo sol lich fliehen hin & M. Luther, 1483-1546 \\
Wohl dem der in Gottesfurcht steht & J. Heermann, 1585-1657 \\
Zion klagt mit angst und Schmerzen & P. Eber, 1511-69 \\
Zwei Ding' o Herr bitt' ich von dir & \\
\hline
\end{tabular}

The above index suggests that the Town Hall carillon repertoire from the second half of the eighteenth century to 1861 included some pre-Reformation songs as well as others from the Reformation and Counter-Reformation era. A large group was made up of songs by Martin Luther (twenty-four). The repertoire did not include pietist songs, though the 1719 hymnal did include several works by Paul Gerhardt (1607-76), one of the precursors of that movement. It is also evident that the yearly repertoire included six psalms to texts by Ambrosius Lobwasser, suggesting that the tradition of playing Calvinist tunes by the Town Hall carillon, so criticised in the late 1500s, endured through the following centuries. 
Tab. 30: Psalms to texts by Ambrosius Lobwasser included into the yearly register of songs played by the Gdańsk Town Hall carillon

\begin{tabular}{ll}
\hline Psalm 22 & Mein Gott ach wie verstößt du \\
Psalm 80 & Ach hör Israels Hirt der wehrte \\
Psalm 110 & Der Herr zu meinem Herren hat gesprochen \\
Psalm 121 & Mein' Augen ich zu den Bergen \\
Psalm 125 & Alle die auf Gott dem Herren \\
Psalm 128 & Selig ist der gepreiset \\
\hline
\end{tabular}

These remarks on texts and authors suggest that the grid of songs that continued to be used from the 1860s through 1861 might have been set up based on Protestant tradition earlier than 1719 codification.

The repertoire of the Town Hall carillon was significantly modified only by Carl Anton Kaschlinsky. His manuscript of 1861 presents a fairly different yearly repertoire than the earlier sources. ${ }^{918}$ What was the basis for that new grid? Was it based by the hymnal currently in vigour in Gdańsk, published in $1856,{ }^{919}$ or any other rules?

The order of play presented in 1861 by Carl Anton Kaschlinsky comprises 94 songs (of which one listed as alternative ${ }^{920}$ ), of which 85 are to be found in the Danziger Gesangbuch of 1856, including two songs from the appendix to that collection (Mein erst Gefühl sei Preis und Dank and Wie groß ist des Allmächtigen Güte). The remaining nine songs are absent from that hymnal but were known in Gdańsk for a long time, as confirmed by organ chorale collections and the booklet of Theodor Friedrich Kniewel. ${ }^{921}$

918 PAN BG Ms 1093 IV, pp. 1-4.

919 Danziger Gesangbuch für Kirchen- und Haus-Andachten. Mit Genehmigung Eines Königlichen Hochwürdigen Consistorii der Provinz Preussen nach der Ausgabe von 1764 neu aufgelegt und mit einem Anhange erbauliche Lieder vermehrt. Danzig. 1856. Verlegt und zu haben bei C. G. Gensch. Druck von A. W. Kafemann.

920 Nun ruhen all Wälder listed as alternative to In allen meinen Taten.

921 Melodie zum Gesangbuch für den evangelischen Gottesdienst. Für Kirche, Schule und Haus, Danzig 1841, Verlag von Fr. Sam. Gerhard. For more on Kniewel's songbook, see Woźniak, 'Melodien zum Gesangbuch', 171-75. For more on Kniewel himself, see Babnis, 'Kniewel Teodor Friedrich', 149-50; Woźniak, 'Gran Sonata per il cembalo', 123-31. 
Tab. 31: Songs in Carl Anton Kaschlinsky's register not included in the Danziger Gesangbuch canon of 1856

\begin{tabular}{lcl}
\hline Song title & $\begin{array}{l}\text { No. in the Kniewel } \\
\text { collection }\end{array}$ & Gdańsk organ hymnals \\
\hline Auf schicke dich & 36 & PAN BG Ms Mr. Q. 186, \\
& & PAN BG Ms 4255 I, \\
Die Himmel rühmen Gottes Ehre & 16 & PAN BG Ms. Danzig 4254 \\
& & PAN BG Ms Joh. 462, \\
& PAN BG Ms Mar. Q. 184, \\
& PAN BG Ms Mar. Q. 186, \\
& PAN BG Ms 4255 I, \\
Gott ist mein Lied & PAN BG Ms. Danzig 4254 \\
& PAN BG Ms Joh. 462, \\
& PAN BG Ms Mar. Q. 184, \\
& PAN BG Ms Mar. Q. 185, \\
& PAN BG Ms Mar. Q. 186, \\
& PAN BG Ms 4255 I, \\
& PAN BG Ms. Danzig 4254, \\
& & PAN BG Ms. Danzig 4020, \\
Morgenglanz der Ewigkeit & & PAN BG Ms. Danzig 4252 \\
& & PAN BG Ms Mr. Q. 185, \\
O du Liebe meiner Liebe & & PAN BG Ms. Danzig 4254 \\
& & PAN BG Ms Joh. 462, \\
Ringe recht wenn Gottes Gnade & & PAN BG Ms Mr. Q. 185 \\
& & PAN BG Ms Joh. 462, \\
Seelenbräutigam & & PAN BG Ms Mar. Q. 185 \\
Seele sinne doch nicht mehr & 95 & PAN BG Ms. Danzig 4254 \\
Wird das nicht Freude sein & & PAN BG Ms Joh. 462, \\
& & PAN BG Ms. Danzig 4254 \\
& & PAN BG Ms. Danzig 4254 \\
\hline & 98 &
\end{tabular}

Compared to the pre-1861 canon, Kaschlinsky's index includes over $50 \%$ more new song titles. However, it lacks any Calvinist psalms, as well as ten songs by Luther. The group of new songs does not appear to be linked by any specific characteristics. Several are relatively late, mostly dating from the seventeenth century. Authors are represented by one or two titles, with only the extremely popular output of Paul Gerhardt (1607-76) featured with seven compositions. The eighteenth-century repertoire is reflected by a dozen or so songs, including five by Christian Fürchtegott Gellert (1715-69). There appears not to be a general criterion of their selection. Given the authors of texts, the song index compiled by Kaschlinsky seems fairly random. 
Tab. 32: Alphabetical index of the yearly song repertoire as listed by Carl Anton Kaschlinsky

\begin{tabular}{ll}
\hline Song title ${ }^{932}$ & Text author ${ }^{933}$ \\
\hline Ach Gott und Herr & M. Rutilius \\
Ach Gott vom Himmel sieh darein & M. Luther \\
${ }^{*}$ Ach was soll ich Sünder machen & J. Flittner, 1618-78 \\
Allein Gott in der Höh' sei Ehr' & N. Decius \\
${ }^{*}$ Allein $z$ zu dir Herr Jesu Christ & K. Huber, 1507-77 \\
Auf meinen lieben Gott & unknown \\
${ }^{*}$ Auf schicke dich & Ch. F. Gellert, 1715-69 \\
Aus tiefer Not schre' ich zu dir & M. Luther \\
${ }^{*}$ Befiehl du deine Wege & P. Gerhardt, 1607-76 \\
Christ fuhr gen Himmel & pre-Reformation \\
Christ ist erstanden & pre-Reformation \\
Christ lag in Todes Banden & M. Luther \\
Christ unser Herr zum Jordan kam & M. Luther \\
${ }^{*}$ Christus der ist mein Leben & unknown \\
Christus der uns selig macht & M. Weiße \\
Der Herr ist mein getreuer Hirt & W. Meuslin \\
${ }^{*}$ Die Himmel rühmen Gottes Ehre & Ch. F. Gellert, 1715-69 \\
${ }^{*}$ Dir Jehova will ich singen & B. Crasselius, 1667-1724 \\
${ }^{*}$ Durch Adams Fall ist ganz verderbt & L. Spengler, 1479-1534 \\
Ein' feste Burg ist unser Gott & M. Luther \\
Ein Kindelein so löbelich & pre-Reformation \\
${ }^{*}$ Ein Lämmlein geht und trägt die Schuld & P. Gerhardt, 1607-76 \\
Erbarm dich mein o Herre Gott & E. Hegenwalt \\
${ }^{*}$ Ermuntre dich mein schwacher Geist & J. Rist, 1607-77 \\
${ }^{*}$ Erquicke mich du Heil der Sünder & L. A. Gotter, 1661-1735 \\
${ }^{*}$ Erschienen ist der herrlich' Tag & N. Herman, 1500-61 \\
Es ist gewißlich an der Zeit & B. Ringwaldt \\
Es woll' uns Gott genädig sein & M. Luther \\
Freu dich sehr o meine Seele & Ch. Demantius \\
Gelobet seist du Jesu Christ & M. Luther \\
${ }^{*}$ Gott des Himmels und der Erden & H. Albert, 1604-51 \\
${ }^{*}$ Gott ist mein Lied & Ch. F. Gellert, 1715-69 \\
${ }^{*}$ Gott sei Dank durch alle Welt & H. Held, 1620-59 \\
Gottes Sohn ist kommen & Czech Brethren \\
Herr Christ der einge Gottes Sohn & E. Kreutziger \\
${ }^{*}$ Herr ich habe mißgehandelt & J. Frank, 1618-77 \\
\hline & \\
\hline
\end{tabular}


Tab. 32: Continued

\begin{tabular}{ll}
\hline Song title $^{932}$ & Text author $^{933}$ \\
\hline${ }^{\star}$ Herr Jesu Christ dich zu uns wend & Wilhelm, Duke of Saxe- \\
& Weimar, 1598-1662 \\
Herr Jesu Christ wahr' Mensch und Gott & P. Eber \\
Herzliebster Jesu was hast du verbrochen & J. Heermann \\
${ }^{\star}$ Ich armer Mensch ich armer Sünder & C. Titius, 1641-1703 \\
Ich glaub' an Gott der geschaffen hat & unknown
\end{tabular}

*Ich habe nun den Grund gefunden

J. A. Rothe, 1688-1758

Ich ruf' zu dir Herr Jesu Christ

J. Agricola

*In allen meinen Taten

P. Fleming, 1609-40

In dich hab' ich gehoffet Herr
A. Reissner
F. C. Homburg
M. Luther

Jesu meines Lebens Leben

Jesus Christus unser Heiland der den Tod überwand

* Jesus meine Zuversicht

J. Crüger, 1598-1662

Komm Gott Schöpfer heiliger Geist

M. Luther

Komm heiliger Geist Herre Gott

M. Luther

Kommt her zu mir spricht Gottes Sohn

G. Grünwald

${ }^{*}$ Liebster Jesu wir sind her

T. Clausnitzer, 1618-84

Lobt Gott ihr Christen allzugleich

N. Herman

${ }^{*}$ Mache dich mein Geist bereit

J. B. Freystein, 1671-1718

${ }^{*}$ Mein erst Gefühl sei Preis und Dank

Ch. F. Gellert, 1715-69

${ }^{*}$ Mein Gott das Herze bring' ich dir

J. K. Schade, 1666-98

${ }^{*}$ Mein Jesu dem die Seraphinen

W. Ch. Dressler,

1660-1722

Meinen Jesum la $\beta^{\prime}$ ich nicht

unknown

${ }^{*}$ Mir nach spricht Christus unser Held

J. Scheffler, 1624-77

${ }^{*}$ Morgenglanz der Ewigkeit

Ch. Knorr von

Nun bitten wir den heiligen Geist

Rosenroth, 1636-89

Nun freut euch lieben Christen gemein

M. Luther

${ }^{*}$ Nun ruhen all Wälder

M. Luther

${ }^{*} O$ Ewigkeit do Donnerwort

P. Gerhardt, 1607-76

${ }^{*} O$ du Liebe meiner Liebe

J. Rist, 1607-77

${ }^{*} \mathrm{O}$ großer Gott von Macht

J. Scheffler, 1624-77

J. M. Meyfahrt, 1590-1642

O Jesu Christ mein's Lebens Licht

M. Behm

O Lamm Gottes unschuldig

N. Decius

O Traurigkeit o Herzeleid

J. Rist 
Tab. 32: Continued

\begin{tabular}{|c|c|}
\hline Song title ${ }^{932}$ & Text author ${ }^{933}$ \\
\hline${ }^{*}$ Ringe recht wenn Gottes Gnade & J. J. Winckler, 1670-1722 \\
\hline${ }^{\star}$ Schmücke dich o liebe Seele & J. Frank, 1618-77 \\
\hline${ }^{\star}$ Schwing dich auf zu deinem Gott & P. Gerhardt, 1607-76 \\
\hline${ }^{*}$ Seele sinne doch nicht mehr & unknown \\
\hline *Seelenbräutigam & A. Drese, $1620-1701$ \\
\hline${ }^{\star}$ Sei Lob und Her' dem höchsten Gut & J. J. Schütz, 1640-90 \\
\hline${ }^{*}$ Sollt' es gleich bisweilen scheinen & C. Titius, $1641-1703$ \\
\hline${ }^{*}$ Valet will ich dir geben & V. Herberger, 1562-1627 \\
\hline Vater unser im Himmelreich & M. Luther \\
\hline Vom Himmel hoch da komm' ich her & M. Luther \\
\hline${ }^{*}$ Von Gott will ich nicht lassen & L. Helmbold, 1532-98 \\
\hline${ }^{*}$ Wach auf mein Herz und singe & P. Gerhardt, 1607-76 \\
\hline Wachet auf ruft uns die Stimme & Ph. Nicolai \\
\hline${ }^{\star}$ Was Gott tut das ist wohlgetan & S. Rodigast, 1649-1708 \\
\hline *Was mein Gott will das gescheh' allzeit & $\begin{array}{l}\text { Duke Albrecht of Prussia, } \\
1490-1568\end{array}$ \\
\hline Wenn meine Sünd' mich kränken & J. Gesenius \\
\hline Wenn wir in höchsten Nöten sein & P. Eber \\
\hline${ }^{*}$ Wer nur den lieben Gott läßt walten & G. Neumark, 1621-81 \\
\hline${ }^{*}$ Wie groß ist des Allmächtigen Güte & Ch. F. Gellert, 1715-69 \\
\hline Wie schön leuchtet der Morgenstern & Ph. Nicolai \\
\hline${ }^{*}$ Wie soll ich dich empfangen & P. Gerhardt, 1607-76 \\
\hline${ }^{*}$ Wir Christenleut' hab’n & C. Füger, 1561-1617 \\
\hline${ }^{\star}$ Wird das nicht Freude sein & $\begin{array}{l}\text { H. C. von Schweinitz, } \\
\text { 1645-1722 }\end{array}$ \\
\hline Wo Gott zum Haus nicht gibt sein' Gunst & J. Kolrose \\
\hline${ }^{*}$ Zeuch ein zu deinen Toren & P. Gerhardt, 1607-76 \\
\hline
\end{tabular}

I assume that the yearly carillon repertoire presented by Carl Anton Kaschlinsky remained valid from the year 1861. Due to a lack of documentation, however, I am unable to state precisely for how long it remained operational. Another dubious issue is the musical notation of songs in Kaschlinsky's register.

922 Asterisks indicate songs introduced by Carl Anton Kaschlinsky.

923 Birth and death dates are only indicated for authors of songs introduced by Carl Anton Kaschlinsky. 
Apart from seven settings in his manuscript, no later collection of works for the Town Hall carillon has survived. From the text on the title page of Kaschlinsky's manuscript, it transpires that it included a musical appendix that allowed for programming tunes on the carillon. Sadly, there is no further information on that appendix. Another manuscript, now lost but kept until 1928 in the State Archive of the Free City of Danzig, is mentioned by Herbert Pawlowski. ${ }^{924} \mathrm{He}$ writes about a Choralbüsch that included information on the weekly order of songs. We do not know, however, whether it was a yearly register or merely a musical notation of songs. Given the manuscript's dating as cited by Pawlowski, 1861, it is highly likely that it included musical settings of the chorales from Kaschlinsky's register. Pawlowski's remarks about this manuscript (tablature?) which is now lost implies the following question: if the 1861 Choralbüsch was kept in Danzig's Archive in 1928, what was the basis used by Georg Edel for programming the Town Hall carillon from 1923? Did he not need musical notation of the songs?

The last period with confirmed information about the Main Town Hall carillon is 1907-28. Based on announcements in the Danziger Zeitung, we observe two significant changes in the yearly programme of carillon play compared to earlier periods. The first change is the introduction of nonreligious songs, while the second the relinquishing of a stable yearly repertoire: the programme now changed from year to year.

The introduction of nonreligious songs was the most important modification of the early twentieth century. Reasons for this fact included social change and political events in which Gdańsk residents participated, passively or actively, at the turn of the nineteenth and twentieth century. Music also participated to some extent in social change, as exemplified notably by singing societies, the emergence of numerous choirs and music lovers' societies. This movement endeavoured to renovate religious song, but in a course of time it also became highly involved in patriotic songs, variously tagged as "Volkslieder" (folksongs) or "Heimatlieder" (fatherland songs), understood as national and patriotic. Some of these songs became universally acclaimed, so that carillon programmers such as Paul William Krieschen and Georg Edel decided to break with the nearly 350-years-long tradition and introduce a few of those secular songs into the carillon repertoire. These songs included notably: $:^{925}$

924 Pawlowski, 'Das Glockenspiel des Rechtstädtischen Rathause zu Danzig', 478.

925 Data based on an analysis of announcements in the Danziger Zeitung from 1907-11, 1914-15, 1919-20, 1924-25, and 1926-28. 


\author{
Wir treten zum Beten \\ Traute Heimat meiner Lieben \\ Goldne Abendsonne \\ Abend wird es wieder \\ Aus dem Himmel ferne \\ Kennt ihr das Land \\ Glocke du singst fröhlich
}

These songs belong to the current of romantic German lyric poetry and can be classified as "Volkslieder" or "Heimatlieder" as mentioned above, with Abend wird es wieder and Aus dem Himmel ferne belonging to the group of "Kinderlieder" (children's songs).

The song with the longest history is Wir treten zum Beten, which is a nineteenth-century translation of the Dutch song Wilt heden nu treden, likely composed after the victory of the Low Countries against Spain at the battle of Turnhout in 1597. It was included in Andriaen Valerius' collection Nederlandtsche gedenck-clanck of $1626 .{ }^{926}$ In 1877, the text was translated into German by Joseph Weyl. Wir treten zum Beten quickly gained popularity: it was eagerly sung by soldiers not only of William II but also later German armies.

Lied eines Landmanns in der Fremde, which begins with the verse Traute Heimat meiner Liebe, also belongs to the early romantic heritage. The song was composed by German sentimentalist poet Johann Gaudenz von Salis-Seewis (1762-1834), who in his nostalgic output, just as the quoted poem, eagerly connected with the topos of longing for nature and fatherland. His poetry was set to music by Franz Schubert and Vincenzo Righini (1756-1812). ${ }^{927}$

The song Goldne Abendsonne originates from the same period. It was set to music by Hans Georg Nägeli (1773-1836), renowned Swiss music publisher, teacher, composer, and founder of the Zürcherische Singinstitut, Sängerverein der Stadt Zürich, and Musikalischer Frauenverein. His numerous songs were composed for the members of these institutions ${ }^{228}$ and so was likely also Goldne Abendsonne.

The song Abend wird es wieder is a lullaby to a text by Hoffmann von Fallersleben (1798-1874), collector and researcher of German folksong. It was printed for the first time in the collection Fünfzig neue Kinderlieder in 1845. ${ }^{929}$

926 Rasch, 'Valerius, Adriaen', col. 1292.

927 Henzel, 'Righini, Vincenzo', col. 109.

928 Burchard, 'Nägeli Hans Georg', 3.

929 Volksliederarchiv, accessed 27 August 2018, http://www.volksliederarchiv.de. 
Another children's song is Aus dem Himmel ferne, to a text by Johann Wilhelm Hey (1789-1854), pastor, author of numerous tales and popular works for children..$^{930}$

Still, the song Kennt ihr das Land is difficult to date and impossible to identify, as several texts functioned in nineteenth-century German literature that open with an identical verse. Nonetheless, there is no doubt a song with such an incipit belongs to the patriotic repertoire, perfectly fitting the notion of "Heimatlied." The song Glocke du singst fröhlich, whose title refers to the chiming of bells, proved equally difficult to identify.

These songs, gathered from announcements in the Danziger Zeitung, transcend the previously homogeneous, purely religious character of the Gdańsk Town Hall carillon repertoire - making their appearance all the more relevant. The first nonreligious song, notes the newspaper, was Wir treten zum Beten, programmed in 1908 by Paul William Krieschen and presented on the even hour in the third week after Epiphany.

The breakthrough achieved by Krieschen and continued by Georg Edel notwithstanding, Protestant song remained dominant in the carillon repertoire in the interwar period. Bell setters who planned the weekly order of play predominantly used Evangelisches Gesangbuch, the official songbook for Gdańsk and the two Prussian provinces (of East and West Prussia) published in 1888 after it was authorised by the Provincial Council of $1884 .{ }^{931}$ That hymnal listed 607 songs, grouped into chapters of songs for the subsequent periods and holidays of the liturgical year, as well as chapters dedicated to different areas of the Christian faith. The sixth and last chapter of the hymnal is titled "Geistliche Volkslieder" (religious folksongs) and was a novelty. According to Arleta Nawrocka-Wysocka, that category encompassed

mainly a religious repertoire that functioned within a given community of the faithful, but was not used during masses because of its content or form. The category of "geistlische Volkslieder" was included in songbooks, featuring songs to be used outside the church: children's and young people's songs or those used during religious gatherings. The primary characteristic of this genre was the function, closely linked to its style and formal features. ${ }^{932}$

930 Volksliederarchiv, accessed 27 August 2018, http://www.volksliederarchiv.de.

931 Evangelisches Gesangbuch für Ost-und Westpreussen. Unter Zustimmung der ProvinzialSynode vom Jahre 1884 und mit Genehmigung des Evangelischen Ober-Kirchenrats herausgegeben vom Königlichen Konsistorium der Provinzen Ost- und Westpreussen. Danzig. Verlag und Druck von A. W. Kafemann. 1888.

932 Nawrocka-Wysocka, Śpiewy protestanckie na Mazurach, 10-11. 
In Gdańsk hymnals, the "religious folksongs" chapter first appeared in 1888. Songs from that chapter met with approval from the Town Hall bell setters. Works from that group were composed predominantly in the nineteenth century. They include a text by Gdańsk-born Johannes Daniel Falk (1768-1826), author of satirical and seaman's poetry, son of a poor wigmaker from Lastadia. Falk even befriended Goethe and Schiller, but failed to succeed as a poet. His only work to achieve any popularity was a short Christmas poem $O d u$ fröhliche $o$ du selige, set to a Sicilian folk melody, which was also set on the Town Hall carillon. ${ }^{933}$

Tab. 33: Religious folksongs ("Geistliche Volkslieder") from the hymnal Evangelisches Gesangbuch (1888), programmed on the Main Town Hall carillon between 1907 and 1928

\begin{tabular}{ll}
\hline Song title & Text author \\
\hline Das Feld ist wei $\beta$ & W. O. Gortzitza, 1811-89 \\
Es ist ein Ros entsprungen & unknown \\
Ich bete an die Macht der Liebe & G. Tersteegen, 1697-1769 \\
Immer mu $\beta$ ich wieder lesen & L. Hensel, 1798-1876 \\
In die Ferne möcht ich ziehen & M. von Schenkendorf, 1783-1817 \\
Näher mein Gott zu dir näher zu dir & S. Adams, 1805-48 \\
O du fröhliche o du selige & J. D. Falk, 1768-1826 \\
O selig Haus wo man dich aufgenommen & K. J. Ph. Spitta, 1801-59 \\
Schönster Herr Jesu & A. H. Hoffmann, 1798-1874 \\
So nimm denn meine Hände & J. von Hausmann, 1826-1901 \\
Stille Nacht & J. Mohr, 1792-1848 \\
Wenn ich ihn nur habe & F. L. von Hardenberg, 1772-1801 \\
\hline
\end{tabular}

The "Geistliche Volkslieder" were introduced into the Town Hall carillon repertoire gradually. In 1915, the songs Ich bete an die Macht der Liebe, Wenn ich ihn nur habe, and Stille Nacht were programmed. The introduction of the latter, a popular Christmas carol, was noted by Danziger Zeitung as early as the first year of its running announcements about the carillon (1907), although we do not know the exact year when that tune started to be played. In subsequent years, Stille Nacht was often featured in the programmes, but not every year.

933 Loew, Das literarische Danzig, 28. 
Apart from songs featured in the hymnal officially functioning in Gdańsk from 1888, as well as the songbook edited especially for the Free City of Danzig, ${ }^{934}$ bell setters Paul William Krieschen and Georg Edel also programmed chorales absent from those collections, as well as religious songs not mentioned at all in Gdańsk hymnals.

Press announcements running in the Danziger Zeitung from 1907 to 1928 confirm that the carillon repertoire was still primarily based on Protestant song, both of the oldest and newer traditions. Additionally, it featured religious folk songs and nonreligious songs. The emergence of the latter was a highly significant change in the carillon tradition. Another was the yearly modification of the order of play, which went against the practice consistent from the 1760 s to 1861 . Of course, it was still possible for the Town Hall carillon to play identical songs in successive years, but the yearly order of chorales was not replicated, as was the practice before.

934 Evangelisches Gesangbuch. Ausgabe für die Evangelische Kirche in der Freie Stadt Danzig (undated). 


\section{The specificity of the musical repertoire for the Main Town Hall automated carillon}

\section{The settings of Theodor Friedrich Gülich}

There are 532 compositions in the tablatures signed by Theodor Friedrich Gülich; all, as mentioned before, are settings of Protestant songs. Due to that large number of works, I suggest to analyse then by category as classified by the bell setter, namely:

1. Songs of the yearly cycle and holiday songs, to be programmed for subsequent weeks and holidays of the liturgical year ${ }^{935}$

2. Death songs and funeral songs ${ }^{936}$

3. Songs for City Council elections, for the beginning and end of the St Dominic's Fair, and the Te Deum laudamus hymn ${ }^{937}$

4. Songs for the Evangelical-Lutheran Church $^{938}$

5. Songs for the Evangelical-Reformed Church ${ }^{939}$

\subsection{Yearly cycle and holiday songs}

This category includes 128 settings of 83 chorales. The settings of songs under the same titles were left unmodified or just slightly changed by Gülich. When he noted two versions in close succession, he usually added the remark Alio modo to the variant. Repetitions of the same titles happen two or three times, more rarely four times, but the chorale Wenn wir in höchsten Noten sein is repeated no fewer than eight times.

The modifications within the settings of the same song titles are very limited. They are usually related to the rhythm, melody, and voice structure of the original work. Rhythmic modification usually consists of a slight lengthening or shortening of note values (one or two). Melodic variants typically consist of an occasional, momentary modification of the pitch succession. Changes to the voice structure are usually limited to dropping more complex chords in favour of two-note vertical structures or adding a third note to such structures. The narrow scope, relative rarity, and almost random occurrence of modifications do not alter the deep structure of songs.

935 APG 300,R/Pp,q9, vol. 1-2.

936 APG 300,R/Pp,q9, vol. 3-4.

937 APG 300,R/Pp,q9, vol. 4.

938 APG 300,R/Pp,q10.

939 APG 300,R/Pp,q10a. 
Another variant to be found in that the source is a transposition. Gülich used it over a dozen times. Move a chorale by a fifth upwards allowed for embellishing the melody with a counterpointing voice, while transposing is down by a fifth forced the carillonist to drop some chords. The second notation of the Gelobet seist du Jesu Christ song was transposed down by a major second.

A representative example of the changes introduced by Gülich in setting the same title is the song Ach Gott und Herr. He set it no fewer than five times: twice identically (Example 2), once with minor changes (Example 3), as well as a transposed monody (Example 4) and a transposition with a more elaborate counterpoint (Example 5).

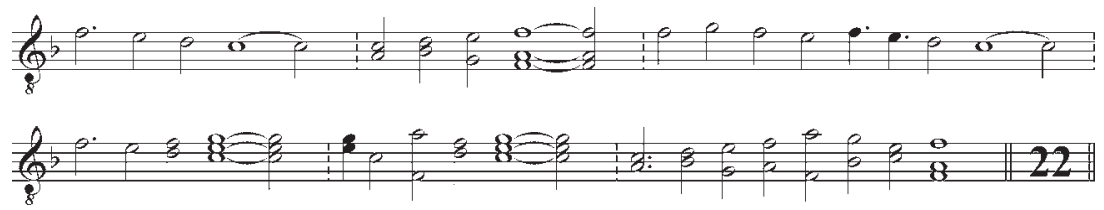

Example 2: T. F. Gülich, Ach Gott und Herr, APG 300,R/Pp,q9, pp. 52 and 116

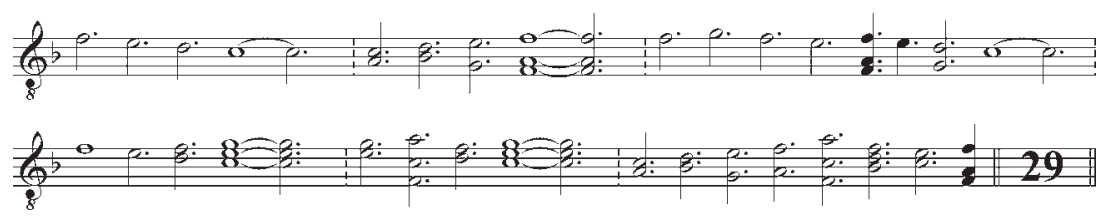

Example 3: T. F. Gülich, Ach Gott und Herr, APG 300,R/Pp,q9, p. 143

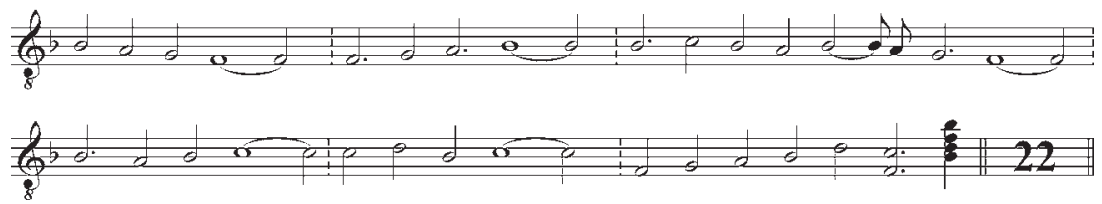

Example 4: T. F. Gülich, Ach Gott und Herr, APG 300,R/Pp,q9, p. 116

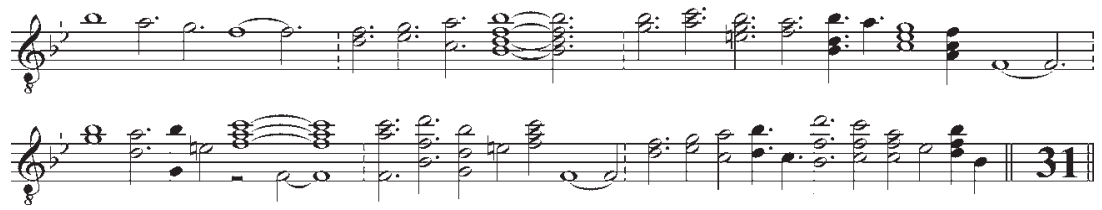

Example 5: T. F. Gülich, Ach Gott und Herr, APG 300,R/Pp,q9, p. 117 
When entering the same song again into the manuscript, Gülich often used a different number of slats to programme them. This is less confusing when that number differed but slightly: it was sufficient to introduce minor changes to the rhythm or add ornamental passing notes to a couple of phrasings to influence the setting's length. This happened notably to two chorales: Aus tiefer Not schrei' ich zu dir (number of slats: 41 and 38), Puer natus in Bethlehem/Ein Kind geborn $z u$ Bethlehem (23 and 21), Ein' feste Burg ist unser Gott (47 and 50), O Herre Gott dein göttlich' Wort (46 and 44), Mensch willst du leben seliglich (31 and 35), Vater unser im Himmelreich (31 and 34), and Weltlich' Ehr' und zeitlich' Gut (31 and 35). More complex are those cases where settings of the same songs differ by a larger number of slats: by seven in the case of Wenn wir in höchsten Nöten sein; by nine in Ach Gott und Herr; by a dozen in Es ist gewißlich an der Zeit, Nun freut euch lieben Christen gemein, and Ach hör Israels Hirt der (Psalm 80); and even by over twenty in Wo Gott zum Haus nicht gibt sein' Gunst and Zwei Ding'o Herr bitt' ich von dir. The difference in the number of slats in various settings of the same songs triggers the question of whether Gülich set the chorales in full or abridged them? This is a legitimate doubt given the limited time available to the carillon programmer and the fact he needed to mind the capacity of the carillon drum and encode two songs so that they would fit.

Analysing the issue of completeness of song settings, I have concluded that the best research method will be to compare the versions of Gülich with earlier sources from Gdańsk that transmit Protestant song melodies. I have analysed only more extensive collections: the manuscript from the church of St John, dated to the mid-seventeenth century and including anonymous song settings for four vocal voices, ${ }^{940}$ and two eighteenth-century organ chorale books: an anonymous one from 1762 of unknown provenance ${ }^{941}$ and another from 1763 , edited by one Johann David König (we know little about him) and used in the church of St Mary. ${ }^{942}$

A comparison of songs featured in Theodor Friedrich Gülich's tablature with melodies notated in other Gdańsk sources shows that Gülich set all songs anew in their entirety. Why, therefore, did he use a (sometimes widely) different

940 PAN BG Ms Joh. 456-59.

941 PAN BG Ms 4017.

942 PAN BG Ms Mar. Q. 183. The manuscript of Johann David König proved to be particularly useful for researching carillon version of Protestant chorale. This is due to the fact it is the most extensive source of all extant Gdańsk chorale books, featuring 280 song settings. Its title page includes the date 1763 and a note stating that the manuscript was 
number of slats to programme two chorales of the same title? This can be explained as follows. Gülich used two approaches here. The first was linked to a change in rhythmic values. As mentioned before, the occasional lengthening of a few notes implied the use of one or two more slats, while the consistent extension of rhythmic values throughout the setting called for the use of many more slats compared to the original. This is notably the case of the following titles: Es ist gewißlich an der Zeit (number of slats: 38 and 52, see examples 6 and 7); Wenn wir in höchsten Nöten sein (22 and 28), and Ach hör Israels Hirt $\operatorname{der}(31$ and 45).
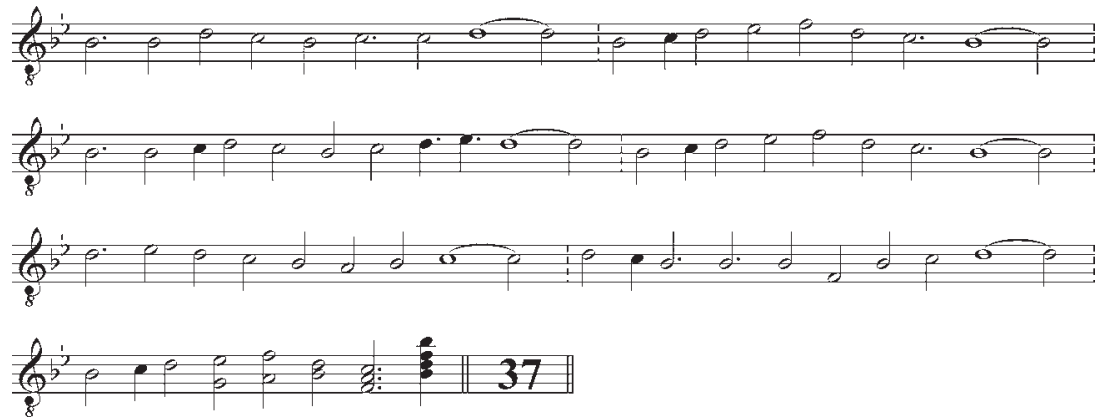

Example 6: T. F. Gülich, Es ist gewißlich an der Zeit, APG 300,R/Pp,q9, p. 7

edited after a Gdańsk songbook ("eingerichtet nach dem Dantziger Kirchen Gesang Buch"). We can thus conclude that it was likely edited after the first Gdańsk hymnal of 1719, although it cannot be excluded that König had access to the second edition of that hymnal, then in preparation, which was eventually published in 1764 . The song index placed at the manuscript's end features more titles than the canon in the Danziger Gesangbuch of 1764, as it includes notably titles of "unofficial" songs from the private collection Das Sing- und Bethende Kind Gottes..., published in 1743 by city and school printer, Thomas Johann Schreiber, as well as other songs that could not be identified with any songbook published in Gdańsk. The script in many titles featured in the index is different from the main body of the text, suggesting it was updated with more songs desired in the religious practice of Gdańsk Lutherans. For this reason, the König manuscript is an invaluable source for researching the local chorale practice. As noted in its catalogue number, the manuscript belonged to the church of St Mary, and so was edited for the use of its organist. Sadly, we have no more specific information about Johann David König, the manuscript's copyist and likely also the author of the chorale settings for organ; we do not know if he was linked to St Mary or was an organist working somewhere else. 


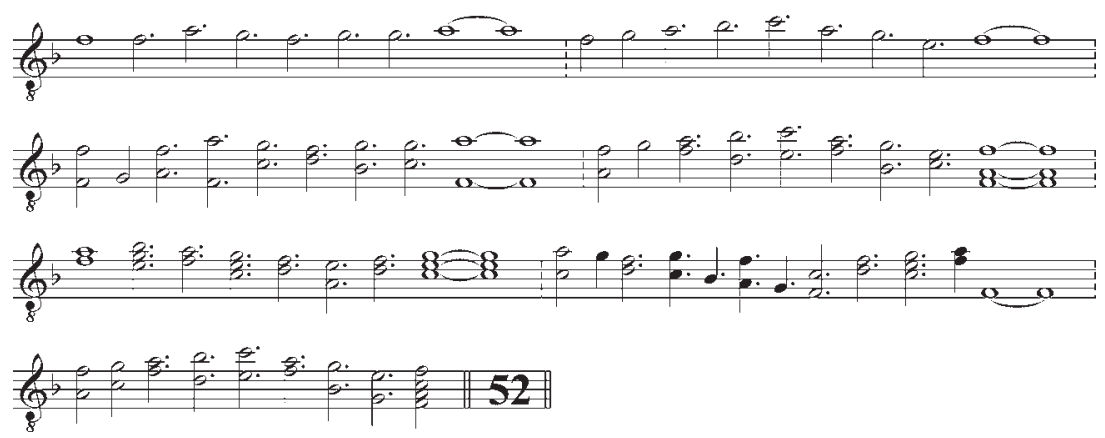

Example 7: T. F. Gülich, Es ist gewißlich an der Zeit, APG 300,R/Pp,q9, pp. 10-11

Another approach that resulted in a doubled number of slats in the new setting was the repetition of the entire song. Gülich followed that approach in two short songs (of four and five verses, respectively): Wo Gott zum Haus nicht gibt sein' Gunst (number of slats: 22 and 46) and Zwei Ding' o Herr bitt' ich von dir (27 and 54).

Tab. 34: Repeated songs programmed to a different number of slats ${ }^{953}$

\begin{tabular}{lll}
\hline Song title & Number of slats & Order in the liturgical year \\
\hline Ach Gott und Herr & 22 & Dominica Reminiscere \\
Ach Gott und Herr & $22,22,31$ & Trinitas, Dominica 11 \\
Ach Gott und Herr & 29 & Trinitas, Dominica 22 \\
Aus tiefer Not schrei' ich zu dir & 41 & Trinitas, Dominica 3 \\
Aus tiefer Not schrei' ich zu dir & 41 & Trinitas, Dominica 11 \\
Aus tiefer Not schrei' ich zu dir & 38 & Trinitas, Dominica 21 \\
Puer natus in Bethlehem & 23,21 & Novi Anni \\
Ein' feste Burg ist unser Gott & 47 & Dominica Invocavit \\
Ein' feste Burg ist unser Gott & 50 & no ordering \\
Es ist gewißlich an der Zeit & 38,52 & Adventus, Dominica 2 \\
Es ist gewißlich an der Zeit & 37 & Trinitas, Dominica 26 \\
Nun freut euch lieben Christen gemein & 38,53 & Adventus, Dominica 1 \\
Nun freut euch lieben Christen gemein & 38 & Trinitas, Dominica 14 \\
Nun freut euch lieben Christen gemein & 38 & Dominica Cantate \\
\hline
\end{tabular}

(continued on next page)

943 The table does not include repetitions of songs that differ by one slat only. 
Tab. 34: Continued

\begin{tabular}{lll}
\hline Song title & Number of slats & Order in the liturgical year \\
\hline Mensch willst du leben seliglich & 31 & Trinitas, Dominica 4 \\
Mensch willst du leben seliglich & 35 & Trinitas, Dominica 9 \\
Mensch willst du leben seliglich & 31 & Trinitas, Dominica 13 \\
O Herre Gott dein göttlich' Wort & 46,44 & Sexagesima \\
Psalm 80 Ach hör Israels Hirt der & 31,45 & Septuagesima \\
Surrexit Christus hodie & $27,27(30)$ & Dominica Misericordias \\
& & Domini \\
Vater unser im Himmelreich & 31 & Septuagesima \\
Vater unser im Himmelreich & 34 & Dominica Cantate \\
Weltlich' Ehr' und zeitlich' Gut & 31 & Trinitas, Dominica 2 \\
Weltlich' Ehr' und zeitlich' Gut & 35 & Trinitas, Dominica 9 \\
Wenn wir in höchsten Nöten sein & 27 & Epiphania Domini, \\
Wenn wir in höchsten Nöten sein & 22,28 & Dominica 4 \\
Wenn wir in höchsten Nöten sein & 28 & Dominica Invocavit \\
Wenn wir in höchsten Nöten sein & 22,22 & Dominica Jubilate \\
Wenn wir in höchsten Nöten sein & 21 & Trinitas, Dominica 10 \\
Wenn wir in höchsten Nöten sein & 21 & Trinitas, Dominica 15 \\
& & Trinitas, Dominica 24 \\
Wo Gott zum Haus nicht gibt sein' Gunst & 47 & Trinitas, Dominica 5 \\
Wo Gott zum Haus nicht gibt sein' Gunst & 22 & Trinitas, Dominica 20 \\
Zwei Ding' o Herr bitt' ich von dir & 27 & Sexagesima \\
Zwei Ding' o Herr bitt' ich von dir & 27 & Trinitas, Dominica 5 \\
Zwei Ding' o Herr bitt' ich von dir & 54 & Trinitas, Dominica 15 \\
\hline & &
\end{tabular}

When setting songs for the Town Hall carillon, Theodor Friedrich Gülich could use fourteen pitches: F4, G4, A4, B, 4 , C5, D5, Eb5, E5, F5, G5, A5, Bb5, C6, and D6. The scale of the bells limited the availability of keys and modes. Preferred keys included B flat major (used in ca. $37 \%$ of settings) and F major (17\%). In other works, Gülich used transposed modes that are sometimes difficult to identify: D aeolian, $\mathrm{G}$ aeolian, $\mathrm{C}$ dorian, and less frequently represented, $\mathrm{G}$ dorian and $\mathrm{C}$ mixolydian.

The carillon's scale not only limited the choice of keys or modes but also hindered Gülich's compositional imagination. He set songs in one of two ways: monodically or embellished with chords. In his yearly repertoire of songs, we thus have only two groups of settings: simple (one voice) and embellished (with chords).

The former group includes around a quarter of all settings. While of these settings do include chords, they are few and far between and do not contradict 
the overall monadic character of the setting. A one-voice form is also used for four out of seven psalms:

Psalm 22 Mein Gott ach wie verstößt du

Psalm 80 Ach hör Israels Hirt der wehrte (two versions)

Psalm 110 Der Herr zu meinem Herrn hat gesprochen

Psalm 128 Selig ist der gepreiset

Psalms belong to the Calvinist tradition, as shown by their titles, referring to translations by Ambrosius Lobwasser, and the melodies of Claude Goudimel. The first official Gdańsk hymnal of the Reformed Church, Kirchen Gesang-Buch der Evangelisch-Reformirten Gemeinde, was published in $1744 .{ }^{944}$ This source shows just slight modifications from the psalm melodies in Gülich's tablature (Examples 8 and 9), which happen when the automaton's scale made it impossible to render the melody faithfully. In those cases, Gülich compromised by replacing minor seconds with major seconds or introducing pitches proper to the local harmony.

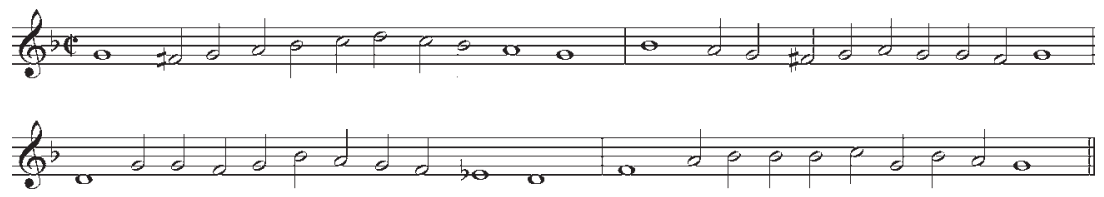

Example 8: Psalm 110 Der Herr zu meinem Herrn hat gesprochen, in Kirchen GesangBuch, Dantzig 1744, 177

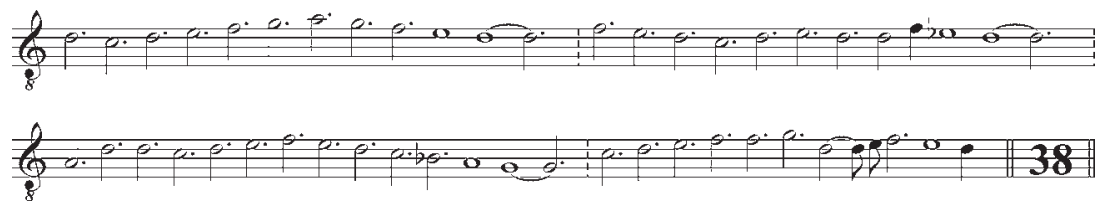

Example 9: T. F. Gülich, Psalm 110 Der Herr zu meinem Herrn hat gesprochen, APG 300,R/Pp,q9, p. 133

In the embellished settings group, the cantus firmus melody is enriched with dyads and chords. The resulting two-note structures are led in a simple counterpoint, often using parallel thirds or sixth. Gülich used this technique to ornament

944 Kirchen Gesang-Buch DerEvangelisch-Reformirten Gemeinde in Dantzig(Danzig, 1744). 


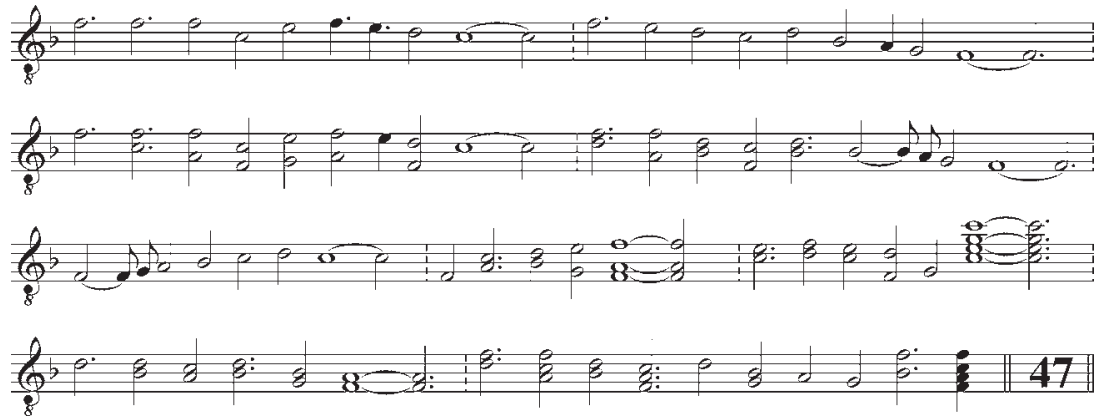

Example 10: T. F. Gülich, Ein’ feste Burg, APG 300,R/Pp,q9, pp. 46-47

the two remaining psalms: Psalm 121 Meine Augen ich zu den Bergen and Psalm 125 Alle die auf Gott den Herren.

Amongst embellished settings, we observe a clear scheme: the first verse, and sometimes the successive one, is monodic (Example 10).

In some settings, however, two-voice structures appear in the second part of the initial phase - though only three songs display a two-voice and chordal structure from the very beginning: Nun komm der Heiden Heiland, a song set for the beginning of the liturgical year; Wenn wir in höchsten Nöten sein, for the odd hour of the fourth week after Epiphany; and Komm heiliger Geist Herre Gott, played on the even hour on Pentecost and on the occasion of elections to the City Council (see Example 21).

The counterpoint appearing after monodic verses (first verse or subsequent ones) is led in a nota contra notam technique. Sometimes, the two-voice structure is interrupted by a single passing tone. The segmentation of songs is strongly emphasised. Each verse ends with a lengthened rhythmic value tone or chord. Chords also occasionally fall within verses. There are some extended cadences, ending with three- or four-note chords.

The rule of beginning a song setting with a monodic verse or verses helps the aural identification and recognisability of songs, showing an unambiguous communication value. Sounds from the tall tower of the Main Town Hall are, depending on weather conditions, not always sufficiently vivid to easily identify a tune, as demonstrated by the aural experience of the modern carillon (which is technically much superior to its sixteenth-century predecessor). Theodor Friedrich Gülich understood this very well, and it was his task to ensure that citizens could recognise the tunes he played. Monodic beginnings of songs served precisely that purpose. 
A few settings display a thorough if ultimately simple structure based on repeating the entire cantus firmus melody. The first presentation of the tune is monodic while the second is polyphonic, based on nota contra notam. The melodies of these songs are short, which is why Gülich programmed them twice each. I have pointed out this setting type with relation to the repetitions of the same titles ${ }^{945}$ but it is also present in those songs Gülich did not set repeatedly, such as Vom Himmel hoch da komm' ich her, played on Epiphany, Christum wir sollen loben schon for the second Sunday after Epiphany, and O Traurigkeit o Herzeleid for Palm Sunday (Example 11).
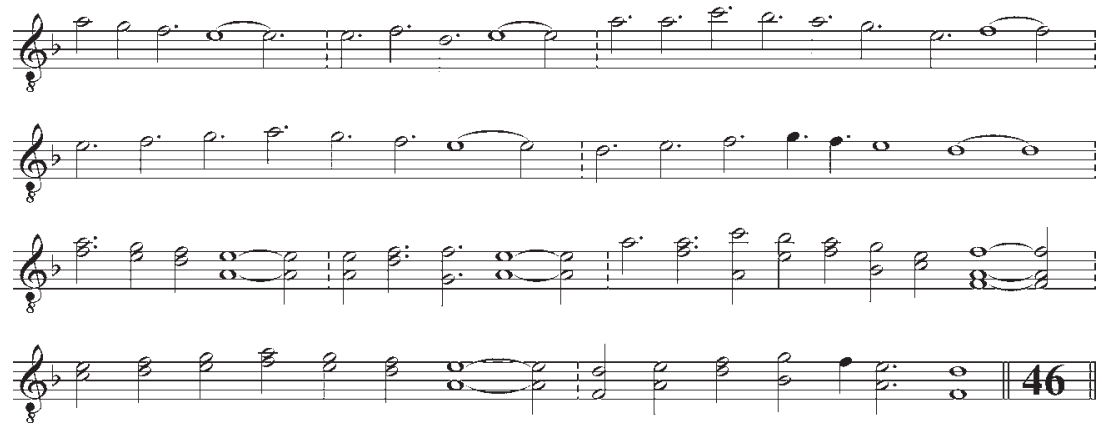

Example 11: T. F. Gülich, O Traurigkeit o Herzeleid, APG 300,R/Pp,q9, p. 61

Leading the counterpoint to the cantus firmus melody, Gülich predominantly used thirds and sixths. Sometimes, he would set the entire verse to these parallel intervals, and when looking to diversify the progression, he would use parallel tenths in two or three successive chords. In his harmonisations, he of course used fifths, fourths, and octaves as well, in those cases using counterpoint in contrary motion.

The settings of Theodor Friedrich Gülich follow an unrefined musical narrative and recurrent patterns. Consequently, those sections that are unlike others deserve to be emphasised. One of such examples is a variational ending on split dominant seventh and tonic chords, proposed by Gülich in the second version of the song Surrexit Christus hodie for the Misericordia Sunday (Example 12).

945 Wo Gott zum Haus nicht gibt sein' Gunst (Trinitas, Dominica 5), Zwei Ding' o Herr bitt' ich von dir (Trinitas, Dominica 15). 

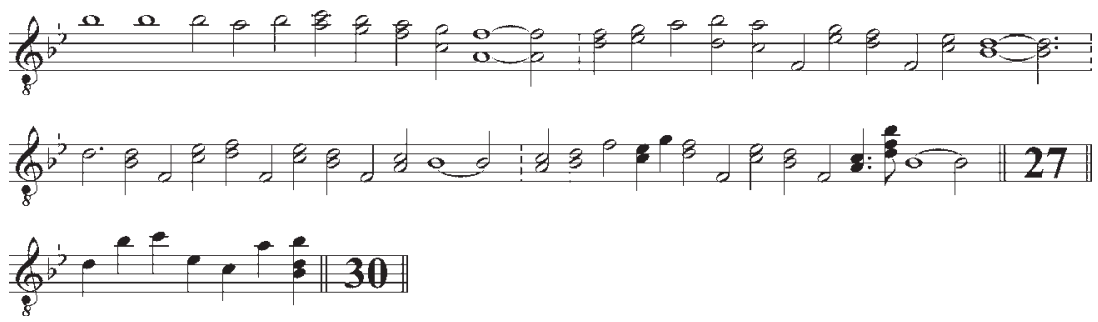

Example 12: T. F. Gülich, Surrexit Christus hodie, APG 300,R/Pp,q9, p. 72

In two other instances, the songs Es woll' uns Gott genädig sein and An Wasserflüssen Babylon, Gülich noted variants of the cadences, marking them Alio modo. Despite expectations of significant divergences, after transcribing the fragments, they turned out to be only mildly different (Example 13).
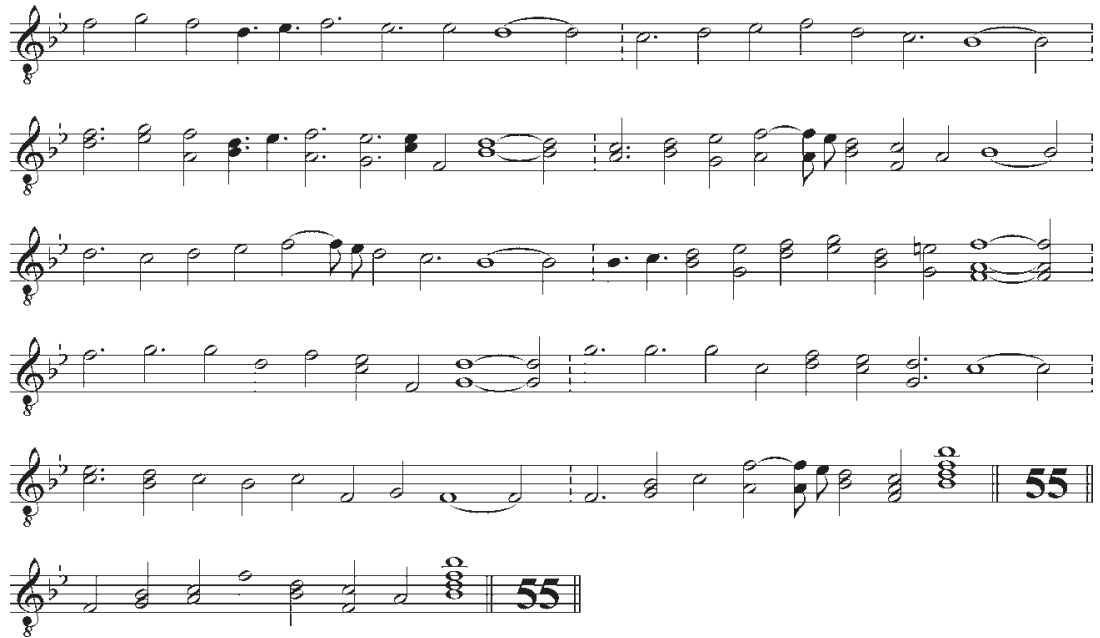

Example 13: T. F. Gülich, An Wasserflüssen Babylon, APG 300,R/Pp,q9, pp. 112-13

An atypical solution is used in the setting of the Advent song Gottes Sohn ist kommen. Gülich added three verses of introduction, based on the cantus firmus (Example 14).

In the Christmas carol In dulci jubilio, short progressions within a fifth are used in the conclusion of the two last verses: a simple compositional device but rare enough with Gülich to merit a mention, the more so that the ascending or descending scales in minor rhythmic values are very characteristic of the carillon texture (Example 15). 


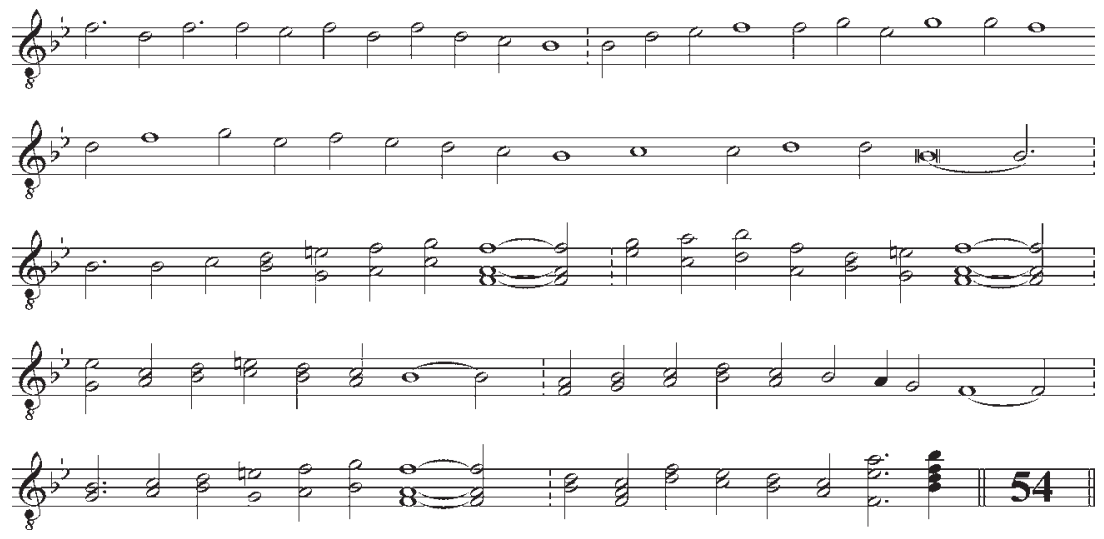

Example 14: T. F. Gülich, Gottes Sohn ist kommen, APG 300,R/Pp,q9, pp. 12-13
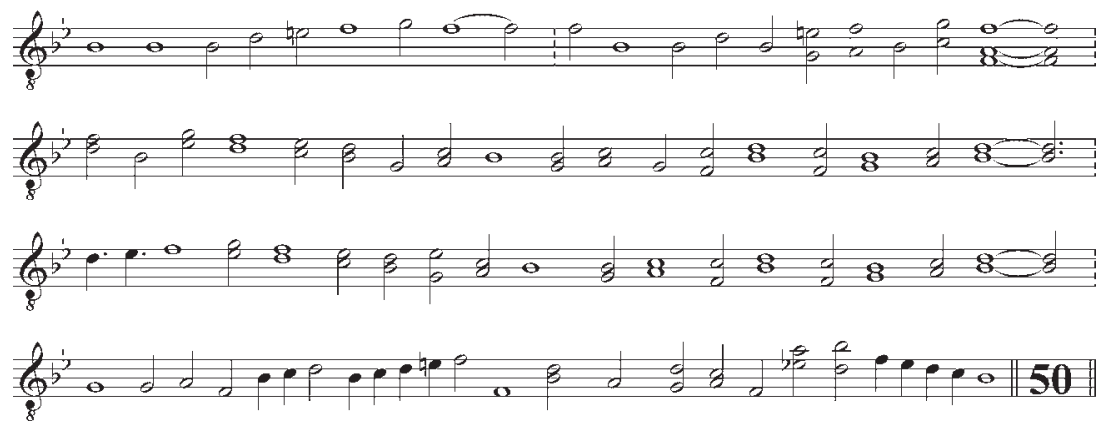

Example 15: T. F. Gülich, In dulci jubilio, APG 300,R/Pp,q9, pp. 24-25

Gülich's settings lack finesse or refinement; they are exceedingly simple. At best, Gülich uses the nota contra notam technique. On the other hand, he keeps ensuring good communication with his listeners so that melodies remain easy to recognise. This is made possible by monodic initial verses and clear-cut song segmentation. It is best to look at those pedestrian settings from the viewpoint of Protestant faith and social behaviour. Indeed, nothing else was expected from a bell setter than to convey the message of the songs clearly. Prayer books and hymnals spread an austere ideal of life that should following the teachings of the Church, with no room for refined melodies coming from the Town Hall tower. 


\subsection{Death songs and funeral songs}

Following custom, Theodor Friedrich Gülich's duties included programming songs on the carillon that communicated the death and funerals of members of the Gdańsk City Council as well as the wives of mayors and councillors, the death of the King and members of the royal family. In total, Gülich programmed 85 such settings (included in the third and fourth volume of his tablature). Death songs were programmed after the tune Mitten wir in Leben sind was removed from the carillon drum, which announced the death of City Council members, mayors' wives, councillors, the King and members of the royal family; funeral songs were programmed on the day of the funerary ceremony.

Eschatological songs were an essential part of Protestant song repertoire. The two oldest such songs, Martin Luther's Mitten wir in Leben sind and Mit Fried' und Freud', had a permanent place in tradition. The former is an adaptation of the antiphon Media vita in mortus sumus while the latter paraphrases the Song of Simeon, Nunc dimittis. The hymnals published in the seventeenth and eighteenth century featured an increasing number of death-related songs. ${ }^{946}$ This was linked with the developing movement of religious spirituality and deepening piety, in which much attention was dedicated to the end of human life. Political and social events also contributed to that growing interest, such as wars and plagues that haunted Europe, emphasising the miserable human condition and frailty of human life.

The number of death songs also increased in eighteenth-century Gdańsk hymnals. In the first official Danziger Gesangbuch of 1719, 36 death songs were included, while there were already 53 in the 1764 edition of the same book. Yet this was not the entire funeral repertoire of the time: songs from other chapters of the hymnal should also be included here, such as Kreuz- und Trostgesänge (Songs of the Cross and comfort), Von Auferstehung (On resurrection), Vom jüngsten Gerichte (On the Last Judgment), Von der Ewigkeit (On eternity), which, according to practice, were also used to express sadness and regret after a man's death. It should also be remembered that consolation in pain and the inevitable was found in Psalms. Thus, the number of what was understood as death songs was much greater than what is included in hymnals as "Sterbe-Lieder."

946 The research of Eberhard Schmidt on the rise of the funeral repertoire, based on the content of hymnals at the Dresden court, is quoted by Cwalińska, 'Mitten wir im Leben sind', 169. 
For this group, Gülich selected titles from various hymnal categories. The most represented group is death songs and funeral songs, but together, they constitute less than half his settings. To these, Gülich added other eschatological-related tunes from other groups in the collections, as well as those that while belonging to the categories Auf das Fest der Reinigung Mariä (On the Feast of the Purification of the Virgin), Vom christlichen Tugendwandel (On zealous Christian life), and Adventsgesänge (Advent songs) according to the 1764 hymnal, did address topics related to man's destiny, transience, death, and hope laid in faith in a righteous God. With relation to the issue of song classification, the chorale Mit Fried' und Freud' should be mentioned: in the 1719 hymnal, it was included in the SterbeLieder group, but was moved in the 1764 version to Feast of the Purification of the Virgin songs. This case illustrates how informative should the entire hymnal classification be treated, as it rarely reflected the practice of singing the same songs on various occasions. Changes in the order of chorales in hymnals merely reflected tendencies typical of Lutheran spirituality of the seventeenth and eighteenth century. Although assigned to the Purification chapter in the 1764 hymnal, Mit Fried' und Freud' was for every Lutheran primarily a funeral song.

From amongst the songs set by Gülich, six are absent from official Gdańsk songbooks of 1719 and $1764 .{ }^{947}$ Yet Gdańsk organ chorale books confirm their local fame. I have found the missing title in a register of songs annexed to the extensive collection of Johann David König ${ }^{948}$ as well as in other Gdańsk chorale books.

Death songs generally are based on the same structures as yearly cycle songs. Gülich usually set their initial verses in monodic fashion, with the counterpoint - usually maintained in nota contra notam technique - entered in the second or third verse. Yet there were exceptions to that rule. For example, in one of the versions of the chorale $O$ Tod was willt du schrecken, Gülich introduced counterpoint as soon as the first verse. On the other hand, several death songs are kept entirely monodic. Some alternative settings are also for one voice only. Variants (Alio modo) are transposed by a fifth or second. Their melody is sometimes slightly modified, and they usually differ in programming time. Gülich noted the following songs in two monodic versions: Es ist genug so nim Herr meinen Geist, Du siehest Mensch wie fort und fort, and Ich bin müde mehr zu leben, only changing their rhythm so that one version is longer than the other. Typical characteristics of death songs are displayed by the three versions of the chorale $O$ Tod was willt du schrecken (Examples 16, 17, and 18).

947 Es ist genug mein matter Sinn, Groß' Freud in meinem Herzen, Ich hab' Gottlob das Mein, Kurz ist die Zeit, O Ewigkeit o Himmels, and Wie lieblich sind dort oben.

948 PAN BG Ms Mar.Q.183. 

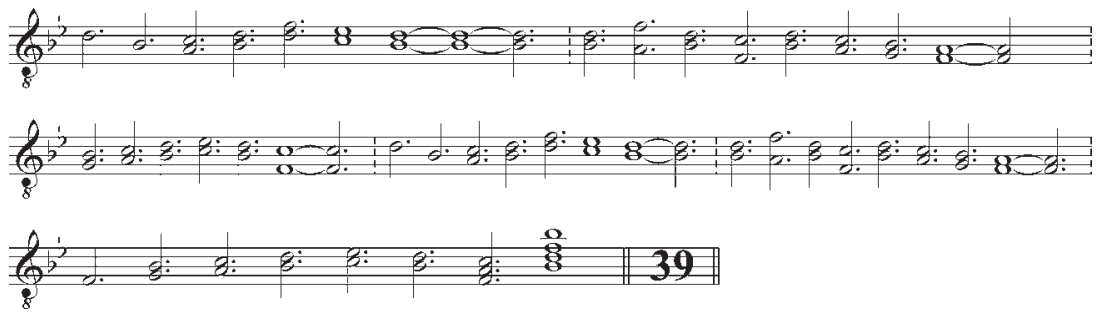

Example 16: T. F. Gülich, O Tod was willt du schrecken, APG 300,R/Pp,q9, p. 239
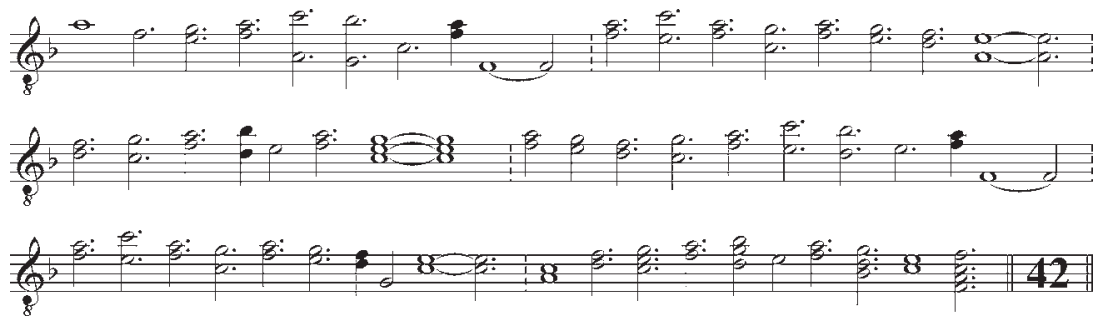

Example 17: T. F. Gülich, O Tod was willt du schrecken, APG 300,R/Pp,q9, p. 238

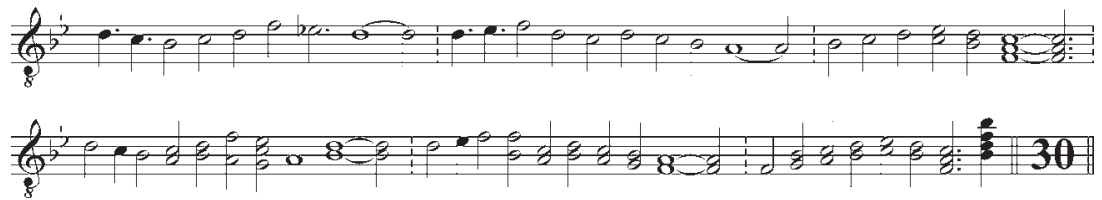

Example 18: T. F. Gülich, O Tod was willt du schrecken, APG 300,R/Pp,q9, p. 237

The second version of that song is particularly striking. Apart from chords in thirds and sixths, compound tenth chords also make an appearance. The final cadence, as well as verse endings, are economical. Single notes closing the first and third verse are worthy of particular note, apparently used to soften the musical narrative. Note also the difference in register between the second-last chord and last note in those verses. These sounds, scattered through space, distant from one another, clearly selective, surely encourage a reflection on death and transience.

The rare dissonances appearing in death songs, such as in Es ist gewi $\beta$ ein' große Gnad', can be interpreted in terms of musical rhetorics rather than compositional mistakes (Example 19). 


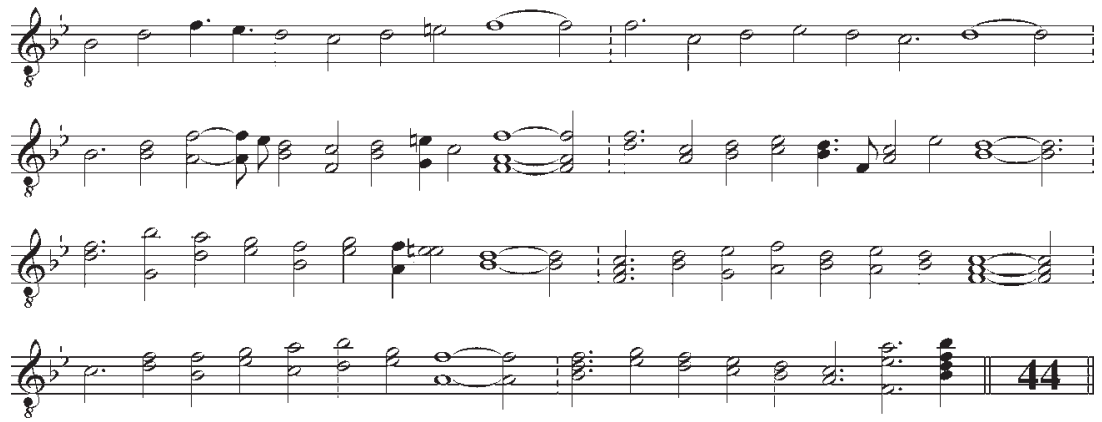

Example 19: T. F. Gülich, Es ist gewi $\beta$ ein' große Gnad', APG 300,R/Pp,q9, 254-55

Death songs include four settings dedicated to Calvinists: Bewahr mich Herr mein Trost (Psalm 16), Ich war bei mir entschloßen (Psalm 39), Du bist der auf den wir (Psalm 90), and Da Zion durch (Psalm 126). Gülich kept them monodic, applying only minor corrections to the melodic line, as the automated carillon's register made it impossible to simple transcribe the melody, or filling leaps of thirds with passing notes.

Gülich classified eleven settings as funeral songs. This includes the oldest songs such as Mitten wir im Leben sind or Mit Fried' und Freud' to texts by Luther, as well as later texts such as Nun laßt uns gehn und treten by Paul Gerhardt. These settings are different from those of death songs. They are primarily distinguished by their duration. All required a full resolution of the carillon drum ( 76 to 78 slats). ${ }^{949}$ Two, Mitten wir im Leben sind and Gott der Vater wohn' uns bei, were so long (composed of over a dozen verses) that they required no other actions to fill the carillon drum. Other melodies were too short and had to be extended. Gülich use two solutions here: he either programmed a tune in very slow tempo, as in the case of Durch Adams Fall ist ganz verderbt, or he repeated the chorale: Mit Fried' und Freud' was repeated twice, while Hört auf mit Trauern und Klagen, three times.

Gülich sets the majority of funeral songs, just as many death songs, in monodic fashion. In the relatively rare two-voice sections, progressions of parallel thirds dominate, occasionally interspersed with sixth or single notes.

The greatly popular song Mitten wir im Leben sind gained, for its carillon version, a four-note introduction based on an arpeggiated A minor chord.

949 From amongst the death songs notated by Gülich in the third volume of his work, only Herzlich lieb hab' ich o Herr was to be programmed on 75 slats. The other death songs could form pairs that filled the entire carillon drum. 
Johann Ephraim Eggert used a similar device when he set the same song for the carillon of St Catherine's. That introduction can thus be considered a characteristic element linked with the performance of that song for Gdańsk bells. An additional embellishment used by Gülich in the melody Mitten wir im Leben sind was a small figure in the last verse, consisting of a progression by seconds of four notes of shorter rhythmic (Example 20).

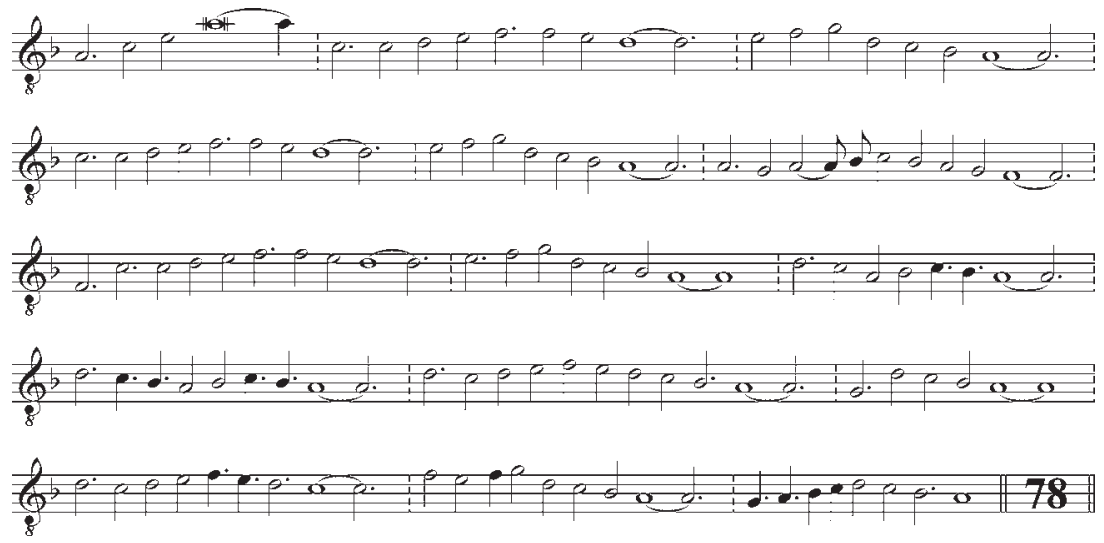

Example 20: T. F. Gülich, Mitten wir im Leben sind, APG 300,R/Pp,q9, pp. 364-65

\subsection{Songs for the City Council election, beginning and end of the St Dominic's Fair, and the hymn Te Deum laudamus}

On the occasion of elections to the City Council, the song Komm heiliger Geist Herre Gott was programmed, which was assigned mainly to Pentecost. Gülich set this tune twice, each time for a full resolution of the carillon drum (78 slats). ${ }^{950}$ His first setting is marked "Kuehr-Tag." Since both settings are almost identical, the note Alio modo that accompanies the second seems redundant, unless the explanation is an error in the tune's title: the first setting is titled erroneously Kom [m] Gott Heil[iger] Geist, H[er]re G[ott], with only the second being correctly tagged Kom [m] Heiliger Geist, H[er]re (Example 21).

950 The version for Pentecost, as well as the notation of this song in the book of the Evangelical-Lutheran Church, require only 54 slats. See APG 300,R/Pp,q9, p. 80; APG 300,R/Pp,q10, p. 68. 


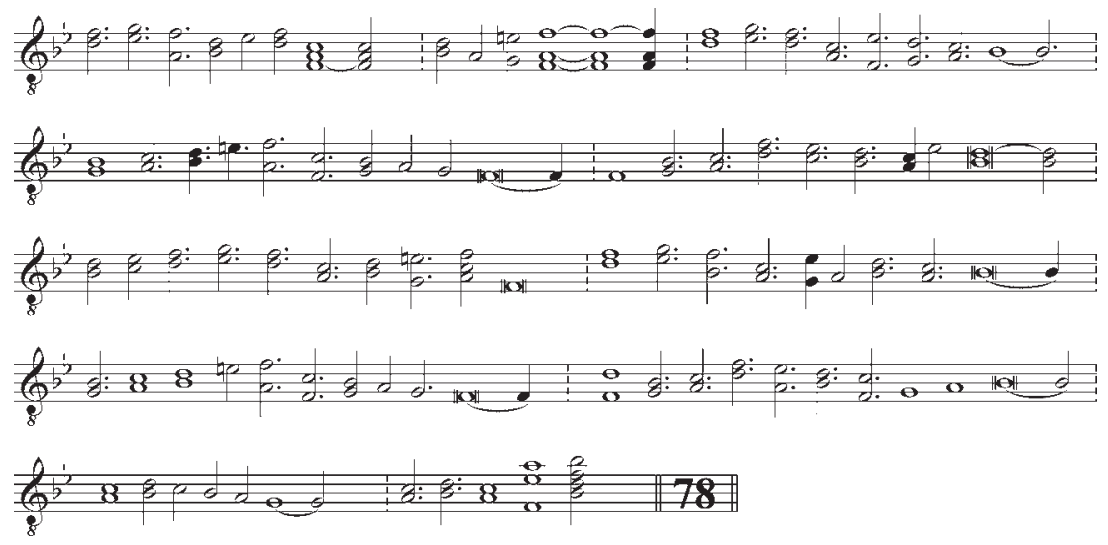

Example 21: T. F. Gülich, Komm heiliger Geist Herre Gott, APG 300,R/Pp,q9, pp. $342-43$

Here, the melody is treated differently than in most other songs. The difference is in the narrative. Usually, the first verses of songs were presented monodically, with the counterpoint only entering at a later stage. In Komm heiliger Geist Herre Gott, a two-voice structure appears from the beginning, based on a nota contra notam technique. Nonetheless, the counterpoint structure is based, as usual, on thirds.

On the occasion of St Dominic's Fair, four songs were programmed: Es woll' uns Gott genädig sein, Lobet den Herren, Zwei Ding' o Herr bitt' ich, and Nun laßt uns Gott den Herrn. Superficially, these settings seem undistinguished, yet two, Es woll' uns Gott genädig sein and Lobet den Herren, the former programmed for the Fair's beginning and the latter for the end, reveal a specific structure.

Both songs require a full resolution of the carillon drum. As indicated in the announcement, they were played three times, before 11 a.m., 11:30 a.m., and noon, and were followed by a second song at one o' clock: Zwei Ding' o Herr bitt' ich for the Fair's beginning and Nun laßt uns Gott den Herrn at the end, respectively. Those added songs only required 23 and 21 slats, but would not fit the carillon drum anyway, since Es woll' uns Gott genädig sein and Lobet den Herren occupied 77 slats. What was the solution? The bell setter removed part of the morning song and only then programmed the entire one o' clock song. 
The correctness of this procedure is suggested by annotations such as "Intonatio. Dominic-Einlaut" and "Intonatio. Dominic-Auslaut," placed above the musical notation; it is further confirmed by the formal structure of the songs. The latter is atypical compared to other compositions. Both tunes (Es woll' uns Gott genädig sein and Lobet den Herren) have an introduction based on the song's first verses, only followed by the setting of the entire melody. That introduction is clearly separated from the subsequent narrative by a cadence, ending with a particularly long rhythmical value. Thus, the remark "Intonatio" above the musical notation refers to verses that should be removed from the drum to make room for programming the songs recommended for one o' clock (Example 22).

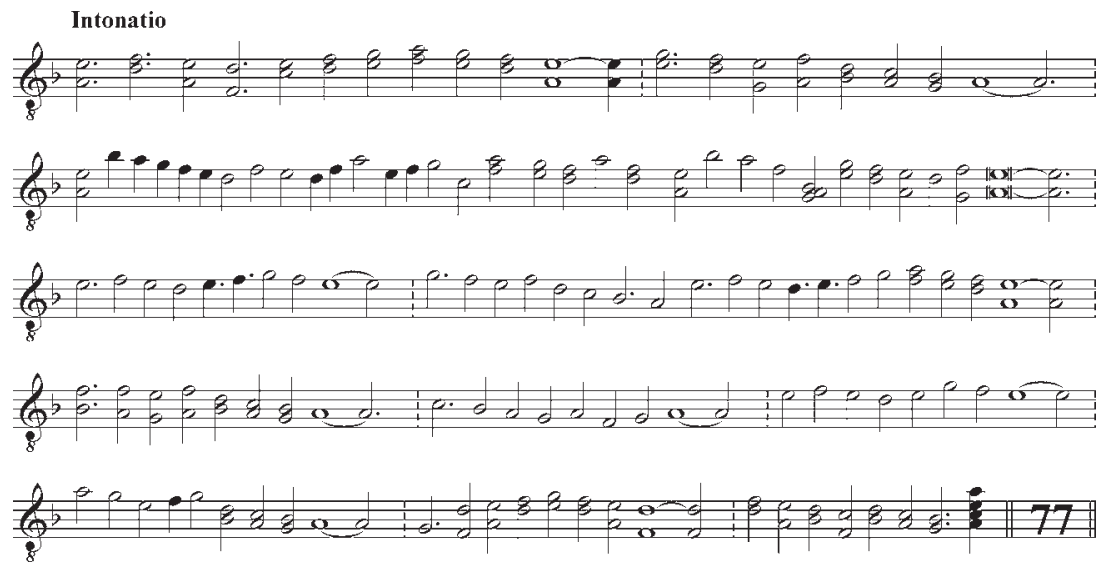

Example 22: T. F. Gülich, Es woll' uns Gott genädig sein, APG 300,R/Pp,q9, pp. 340-41

The last setting notated by Gülich in the fourth volume of this tablature is the hymn Te Deum laudamus (Luther's German text: Herr Gott dich loben wir), which was played during particularly solemn occasion (Example 23). This song was encoded using the full resolution of the mechanism (78 slats), though the drum would not fit the entire song in any case. Consequently, Gülich only programmed the melody's first thirteen verses. The setting follows a specific structure called alternatim, which befits a hymn's text. Successive verses, from the first to the last, are presented first in monodic form and then in two-voice counterpoint. 


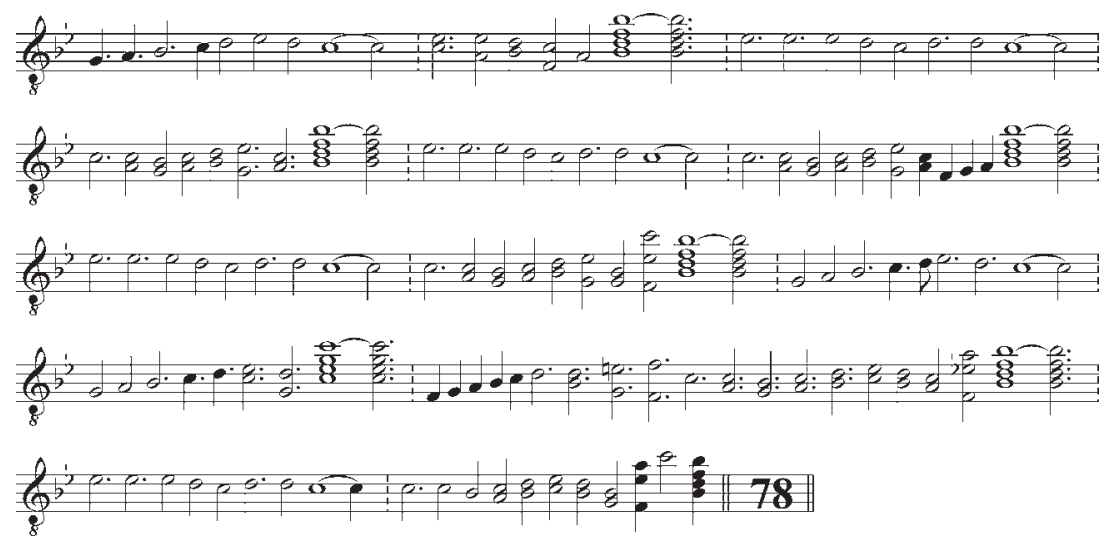

Example 23: T. F. Gülich, Te Deum laudamus, APG 300,R/Pp,q9, pp. 334-35

\subsection{Evangelical-Lutheran songs}

As mentioned, in the Choral Buch Nach denen Evangelisch Lutherschen Kirchengesängen, Theodor Friedrich Gülich notated 176 song settings. As the book was designed to be used independently from the earlier four-volume tablature, it includes many of the same chorales. For example, the song Es ist gewißlich an der Zeit is set three times throughout the yearly cycle but has a separate version in the book in question as well, subtly differing from the earlier notated versions. The solemn invocation to the Holy Spirit Komm heiliger Geist Herre Gott, noted in the four-volume tablature, is set here to a somewhat simpler version. Gülich relinquishes the two-voice structure in the first verse, making the song's narrative similar to other songs. Nonetheless, many settings in this Evangelical-Lutheran collection are simply faithful copies of the tower book versions.

Counterpoint throughout the song is only used in a few instances, notably in Nun komm der Heiden Heiland, which is notated in a nearly identical way to the yearly cycle version. A two-voice structure is also used in the setting of Herr Jesu Christ dich zu uns wend, which has no precedent in earlier volumes. Gülich sets other songs with his most typical technique, with the first verse(s) of the cantus firmus melody in a monodic version and counterpoint entering at a later stage. An example is the chorale Aus tiefer Not schrei' ich zu dir (no. 72), which also has three versions in the yearly cycle tablature. The Evangelical-Lutheran version is transposed downwards by a fifth, which in context of its text, can be considered a conscious rhetorical device (Example 24). 

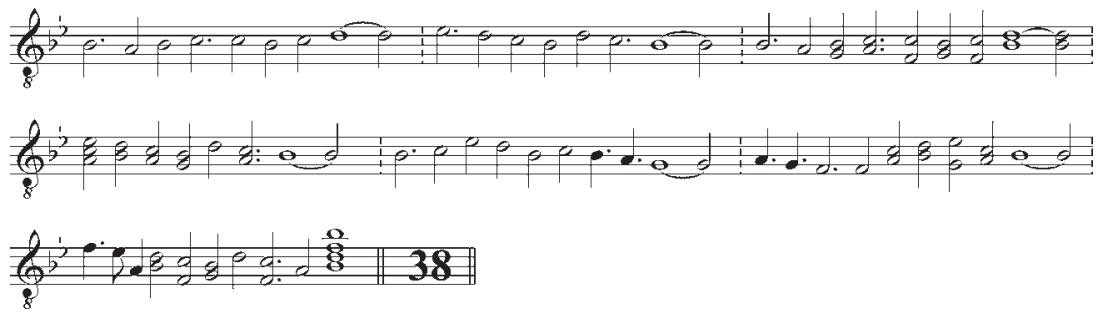

Example 24: T. F. Gülich, Aus tiefer Not schrei' ich zu dir, APG 300,R/Pp,q10, 97

Idiosyncrasies in the Evangelical-Lutheran book settings are so insignificant compared to earlier versions in the four-volume tablature that it seems redundant to discuss them here in detail. One fact is noteworthy: Gülich introduced or copied from earlier volumes many monodic versions. Over 40 per cent of settings follow that form. Some are merely closed by a three- or four-note chord, while others have a two- or three-chord cadence. What was the reason behind this choice? Did Gülich lose patience to embellish melodies with a counterpoint? Was he bored with the limited sound combinations available to him? Or was he in a hurry to complete the notation as quickly as possible? Each possibility seems plausible.

\subsection{Evangelical-Reformed songs}

Calvinists preferred singing psalms, but by the end of the sixteenth century, their liturgy started including other songs as well. That practice is confirmed by the earliest published psalters, to which other songs were added. ${ }^{951}$ Andreas Schiemmel and Andreas Hünefeld, who published Calvinist psalters in Gdańsk, included the following titles: Erheb dein Herz tu auf dein Ohren, Lass deinen Knecht nunmehr, Was Gottes Wort uns tut verkünden, and O Gott du unser Vater bist. ${ }^{952}$ Also in later years, Calvinists continued to use such songs, especially in the context of religious practices at schools and for home use. A collection of psalms was often combined with another set, with its own title page, which included songs essentially belonging to the Lutheran tradition. This was notably the case of the first official songbook published for the Gdańsk EvangelicalReformed community in 1744 , as discussed before. ${ }^{953}$ The edition of psalms in

951 Marti and Luth, 'Calvinistische Musik', cols 333-38.

952 Kessler, Danziger Gesangbücher 1586-1793, 14-16, 20-37; Przywecka-Samecka, Drukarstwo muzyczne w Polsce, 119-22, 185-87; Nowak, 'Hünefeld Andrzej', 2:24243; Nowak, 'Gdańska drukarnia Guillemota-Hünefelda', 165-90.

953 Kirchen Gesang-Buch Der Evangelisch-Reformirten Gemeinde in Dantzig (Dantzig, 1744). 
this book was slightly modified compared to the seventeenth-century versions by Ambrosius Lobwasser. Franz Kessler states that texts were adapted to the current language, which triggered rhythmic modifications in the psalm melodies. ${ }^{954}$

In the carillon book for the Evangelical-Reformed church, Theodor Friedrich Gülich notates the melodies of Goudimel, transmitted by the Gdańsk hymnal published in 1744. Yet only a single psalm, Singt mit freier Stimm' (Psalm 81), is reproduced unchanged. The most significant modifications were applied to the melody Danket und lobt den Herren (Psalm 107, see Example 25 and 26), while in other psalms, the departures from the hymnal versions are minor.
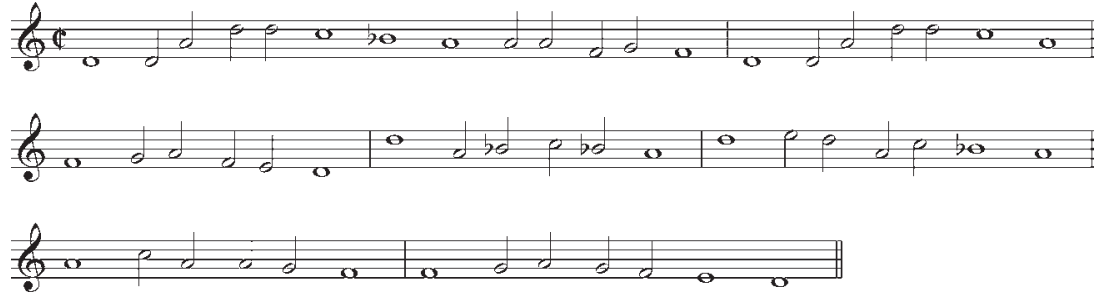

Example 25: Psalm 107 Danket und lobt den Herren, in Kirchen Gesang-Buch, Dantzig 1744,171
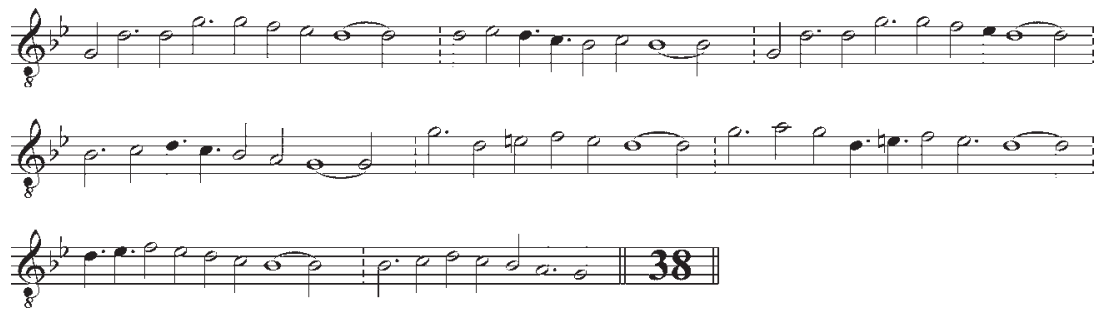

Example 26: T. F. Gülich, Psalm 107 Danket und lobt den Herren, APG 300,R/Pp,q10a, p. 93

Gülich could often not copy the psalm melodies faithfully, as the carillon lacks bells with chromatic pitches. Their lack limited the options, especially when composing cadences, both internal and final. Gülich circumvented the issue by omitting the unavailable, leading tone and reached the tonic either through a descending second or an ascending third or fourth (Examples 27 and 28).

954 Kessler, Danziger Gesangbücher 1586-1793, 68. 


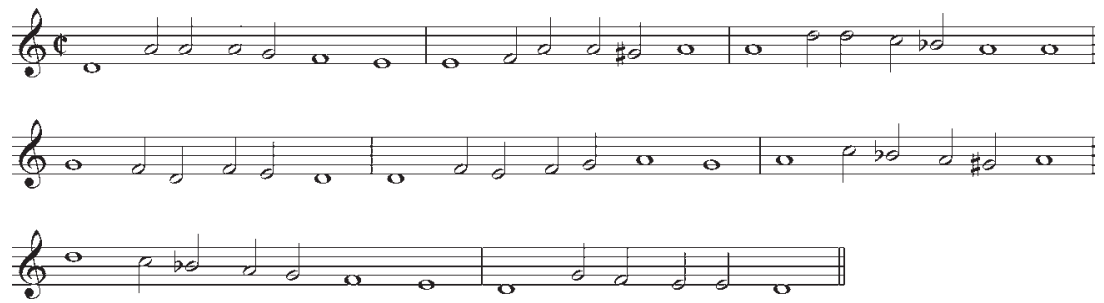

Example 27: Psalm 128 Selig ist der gepreiset der Gott, in Kirchen Gesang-Buch, Dantzig 1744, p. 205

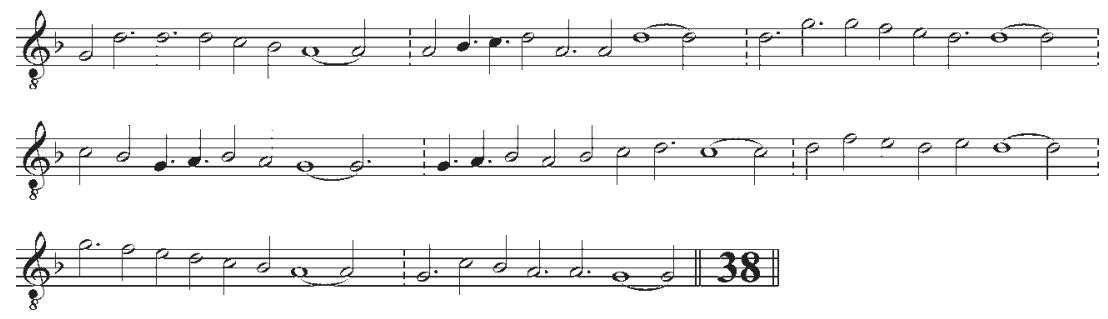

Example 28: T. F. Gülich, Psalm 128 Selig ist der gepreiset der Gott, APG 300,R/ Pp,q10a, p. 108

The lack of chromatic tones on the carillon also forced Gülich to modify the melody. The unavailable minor third was replaced by a major third, while the minor second was replaced by other intervals, for example, a fourth. This technique was used repeatedly, including in the Psalm's first verse, so crucial for the melody's recognisability (Examples 29 and 30).

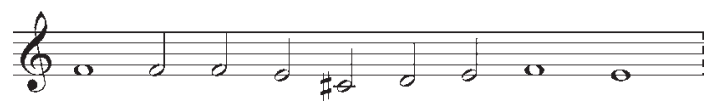

Example 29: Psalm 4 O Gott mein Hort erhör mein Flehen, in Kirchen Gesang-Buch, Dantzig 1744, p. 4

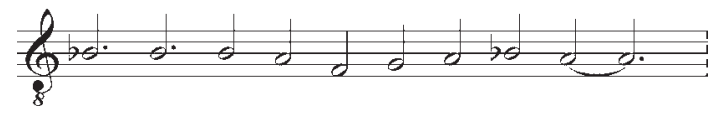

Example 30: T. F. Gülich, Psalm 4 O Gott mein Hort erhör mein Flehen, APG 300,R/ Pp,q10a, p. 4 
Gülich own innovation in psalm setting was the introduction of a passing tone to fill a third in the original melody. This characteristic modification can be observed in nearly every setting. It is a way of embellishing a melody, however blunt and mannered. It does appear, however, as Gülich's original (compositional?) contribution. Passing tones are also introduced occasionally in broken chords.

Gülich departs from the one-voice standard psalm narrative in a few instances, adding chords and dyads to the final cadences. Such more elaborate finales are to be found in three psalms: Ich hab mir vorgesetzt vor allen Dingen (Psalm 101), Mein' Augen ich zu den Bergen (Psalm 121), and Schau wie so fein und lublich ist (Psalm 133). In five other cases: Wie nach einer Wasserquelle (Psalm 42), Herr Gott es haben uns're Ohre (Psalm 44), Nun ihr Völker all frohlocket (Psalm 47), Alle die auf Gott den Herren (Psalm 125), and Ihr Knecht' des Herren allzugleich (Psalm 134), a counterpoint is added to the melody. As simple as it is, this is Gülich's most creative contribution in his settings of Calvinist psalms. The counterpoint follows the nota contra notam pattern of the yearly cycle songs, dominated by thirds or sixth. The beginning of the psalm is each time monodic, with the counterpoint voice appearing in the melody's later phase, with the exception of Psalm 42, where it enters as soon as the text's third verse.

Apart from the musical notation for 125 psalms, the tablature for the Reformed Church includes eleven other songs:

Tab. 35: Songs set by T. F. Gülich in his Choral Buch Nach denen Evangelisch Reformirten Kirchengesängen

\section{Song title}

1. O Gott du unser Vater bist

2. Sieh hie bin ich Ehren-König

3. Eitelkeit was wir hier sehen

4. Willst du wahre Probe sehn

5. Ich trau auf Gott

6. Der Mensch der Gott gelassen bleibt

7. Wohl dem Menschen der von Herzen

8. Jammer hat mich ganz umgeben

9. Mein' Wallfahrt ich vollendet hab

10. Einen guten Kampf hab' ich

11. Es wird schier der letzte Tag herkommen
Number and title of chapter in 1744 hymnal

I. Bei dem öffentlichen Gottesdienst vor und nach der Predigt

XXIX. Von der Verleugnung alles andern und Nachfolge Christi

XXX. Vom Gesetz und guten Wercken

XXXI. Vom Vertrauen

XXXII. Von der Zufriedenheit und Gelassenheit

XXXV. In allerlei Leiden

XLIII. In Kranckheit und Todes-Noth

XLIV. Begräbniß-Lieder

XLV. Von der Auferstehung und dem jüngsten Tage 
Amongst the songs set by Gülich, the oldest was $O$ Gott du unser Vater bist, usually sung before the sermon. It is set to music by earlier Gdańsk songbooks, but the 1744 hymnal only includes the text, similarly to ten other songs. Likely for this reason Gülich thought it relevant to notate them for the carillon.

These songs are set in a similar fashion to psalms, although with far fewer passing tones that fill the thirds in psalm melodies. Sevens songs are set monodically, as preferred in the Reformed Church. In Ich trau auf Gott and Wohl dem Menschen der von Herzen, the final cadences are enhanced by chords, while in Eitelkeit was wir hier sehen and Willst du wahre Probe sehn, some verses are set to a two-voice counterpoint.

\section{Settings of Theodor Friedrich Gülich copied by Paul Friedrich Knaack}

The last of the extant carillon tablatures, edited in 1808-12 by Paul Friedrich Knaack, includes 120 works ordered according to the successive weeks and holidays of the liturgical year. These are not Knaack's original settings but copies from the two first volumes of the four-volume tablature by Theodor Friedrich Gülich. Most settings are copied unchanged, and some are just slightly modified. While the differences between Gülich's and Knaack's versions are minor, they are relatively frequent.

Paul Friedrich Knaack modified chords and dyads. In more elaborate chords, he omitted one of the components, while he often added notes to dyads. When copying settings, he used alternative pins. In many cases, this did not alter Gülich's settings but sometimes engendered minor modifications to the rhythm. In Knaack's versions, there are also corrections to the melodies compared to the four-volume tablature. He would occasionally colour the melodic contour by introducing passing notes where Gülich failed to do so. He corrected dissonant chords and dyads, modified cadences, and omitted notes erroneously notated by his predecessor.

Knaack also transposed two of Gülich's settings. In the case of the song Aus tiefer Not schrei' ich zu dir, set on the third Sunday after Trinity, this triggered minor changes: Knaack omits a component in several chords and dyads as the carillon lacked notes to fill the harmony after the song was transposed downward by a fifth. The other transposed song was Wer in dem Schutz das Höchsten ist for the day of St Michael. Here, there are more differences. Knaack moved the setting upward by a fifth, led the counterpoint in a different way, and extended the composition from Gülich's 37 slats to 47 (see Examples 31 and 32). 


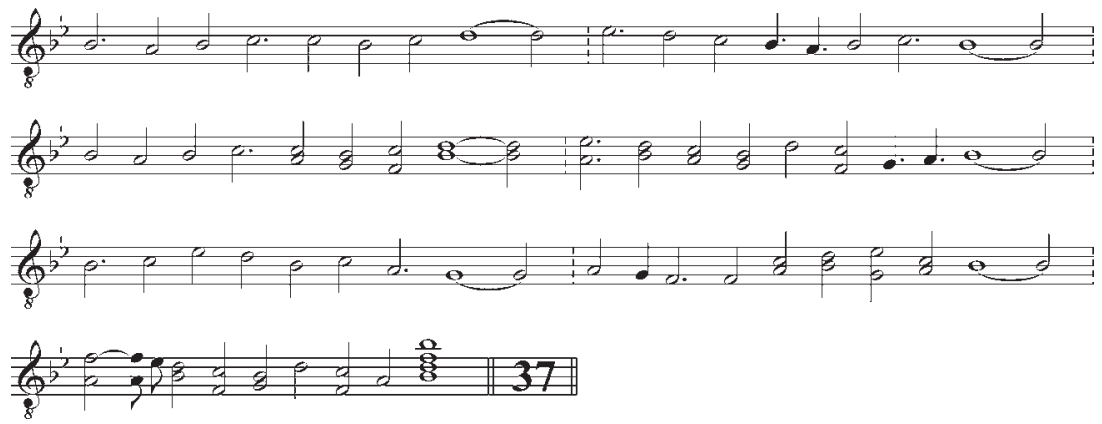

Example 31: T. F. Gülich, Wer in dem Schutz das Höchsten ist, APG 300,R/Pp,q9, p. 162
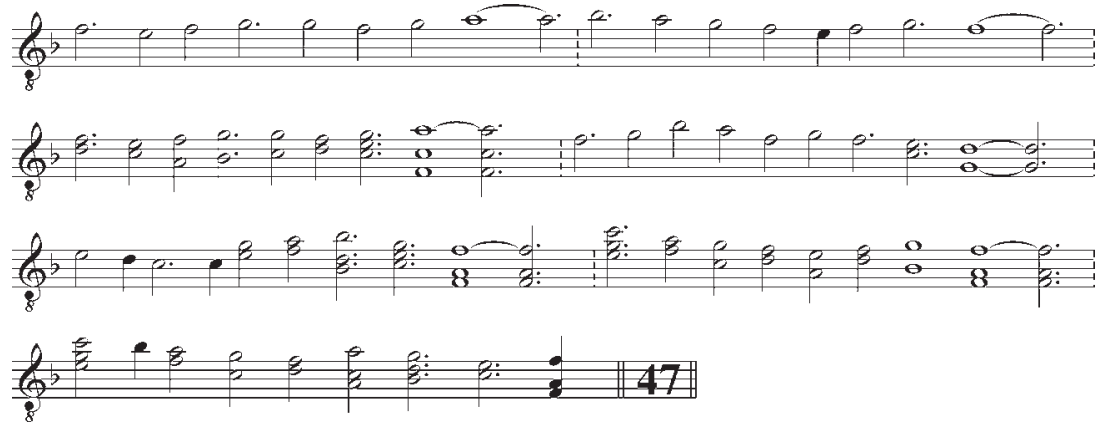

Example 32: P. F. Knaack, Wer in dem Schutz das Höchsten ist, APG 300,R/Uu,q9, p. 111

The settings of the song Es spricht der Unweisen Mund, programmed for odd hours of the sixth Sunday after Trinity, differ quite significantly in both tablatures. Knaack could choose between two versions by Gülich, of which the second, harmonically more elaborate, was a transposition upward by a fifth of the first. Knaack opted for that version but simplified it to a nearly one-voice melody (Examples 33 and 34).

The yearly order of play in Knaack's tablature differs by one title from Gülich's patterns. The melody Auf meinen lieben Gott, played on even hours in the sixteenth week after Trinity, is set to an alternative text, Wo soll ich fliehen hin. ${ }^{955}$ However, Knaack did not copy Gülich's setting for that week, but chose one of the variants included in Gülich amongst the "Sterbe-Lieder." 

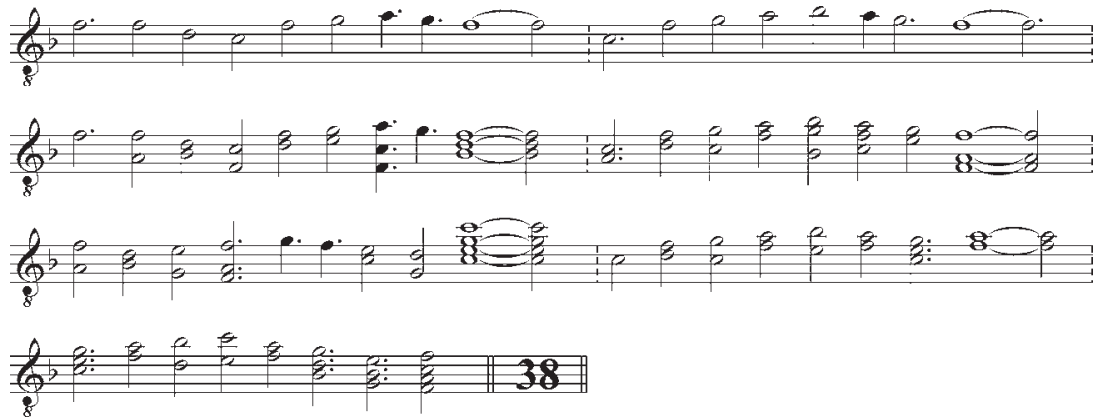

Example 33: T. F. Gülich, Es spricht der Unweisen Mund, APG 300,R/Pp,q9, p. 105
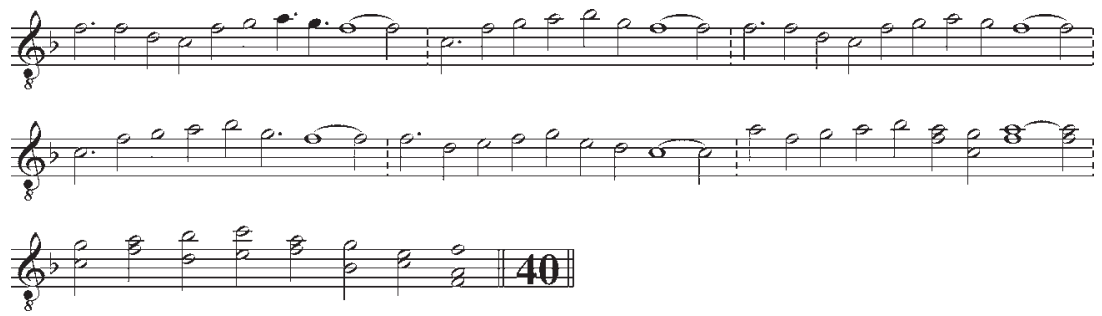

Example 34: P. F. Knaack, Es spricht der Unweisen Mund, APG 300,R/Uu,q9, p. 88

Another departure from Gülich's practice is the introduction by Knaack of a setting for Annunciation, which lacked in all other extant song registers for the entire year. Knaack used the song Ich glaub' an Gott der geschaffen hat, usually set on odd hours of the first week after Trinity, but modified it slightly and transposed downwards by a fourth (Examples 35 and 36).
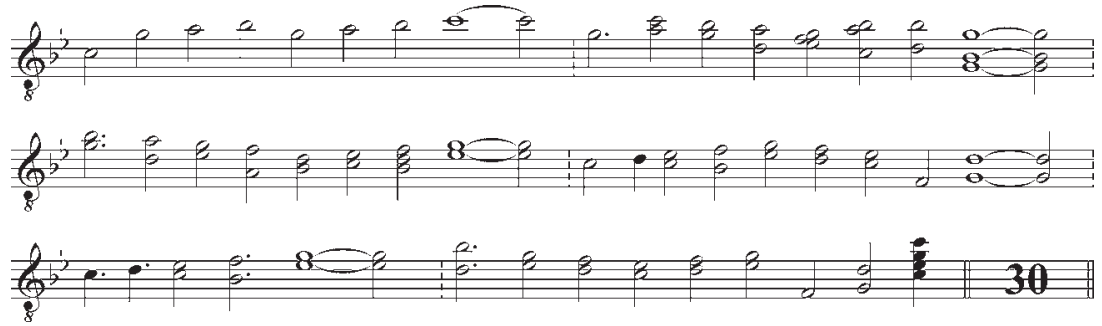

Example 35: T. F. Gülich, Ich glaub' an Gott der geschaffen hat, APG 300,R/Pp,q9, p. 88 


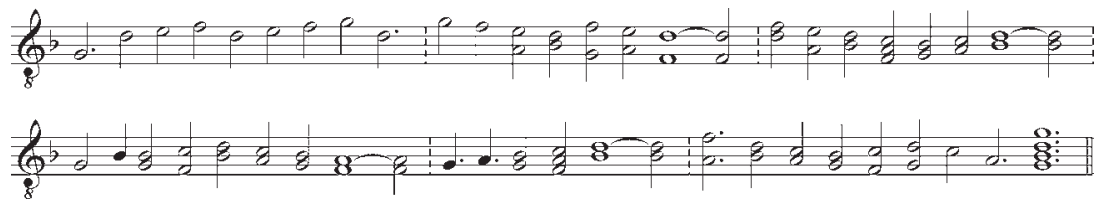

Example 36: P. F. Knaack, Ich glaub' an Gott der geschaffen hat, APG 300,R/Uu,q9, p. 51

Paul Friedrich Knaack's tablature includes two musical settings that I am unable to identify. They are the song Nun komm der Heiden Heiland for the third week of Advent, but with a different melody than that used for the first week of the Liturgical year, and an untitled chorale notated for the fourth week of Advent.

\section{The settings of Carl Anton Kaschlinsky}

In his 1861 manuscript, Carl Anton Kaschlinsky notated seven songs. In alphabetical order, they are:

\section{Allein Gott in der Höh' sei Ehr' \\ Befiehl du deine Wege \\ Christ unser Herr zum Jordan kam \\ Es woll' Gott uns genädig sein \\ Nun lob mein' Seel' den Herren \\ Wach auf mein Herz und singe \\ an unidentified song with no title}

Kaschlinsky wrote all these songs on staves, using traditional notation. They are also notated rhythmically in duple metre, unlike the ametrical tablature notation. Kaschlinsky set the chorales in a technique similar to Gülich's, although the melodies for the same songs sometimes differ slightly (see Examples 37 and 38). ${ }^{956}$

Kaschlinsky, as mentioned before, included a new yearly register of songs in his manuscript. Apart from well-established chorales, he also featured tunes that entered the Gdańsk canon in 1810,1841 , or as late as 1856 . No fewer than ten songs are included that had no previous versions for the carillon. Surprisingly, however, Kaschlinsky did not propose any musical settings. Thus, there must have existed a manuscript with the musical notation of these songs, as it seems unlikely that Kaschlinsky would programme songs on the carillon drum from

956 Kaschlinsky notates the chorales by transposing the melody downwards by a fourth compared to the bells' tuning. 

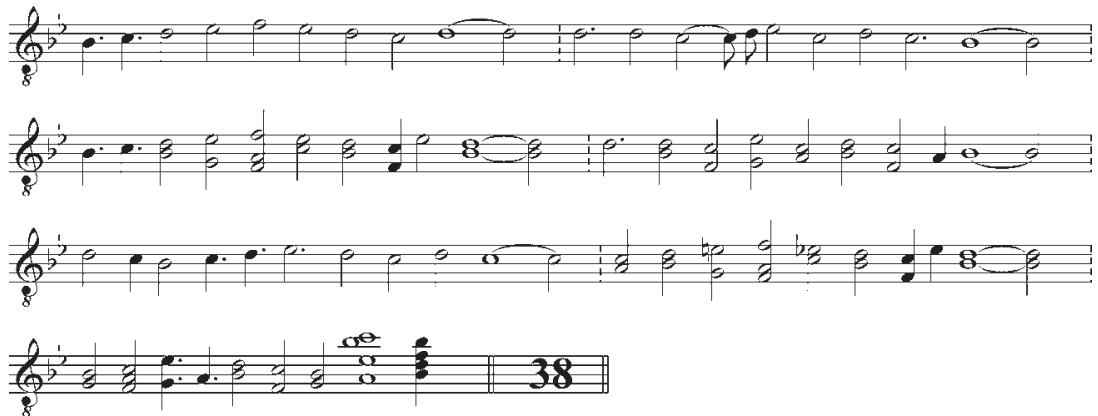

Example 37: T. F. Gülich, Allein Gott in der Höh’ sei Ehr', APG 300,R/Pp,q9, p. 83

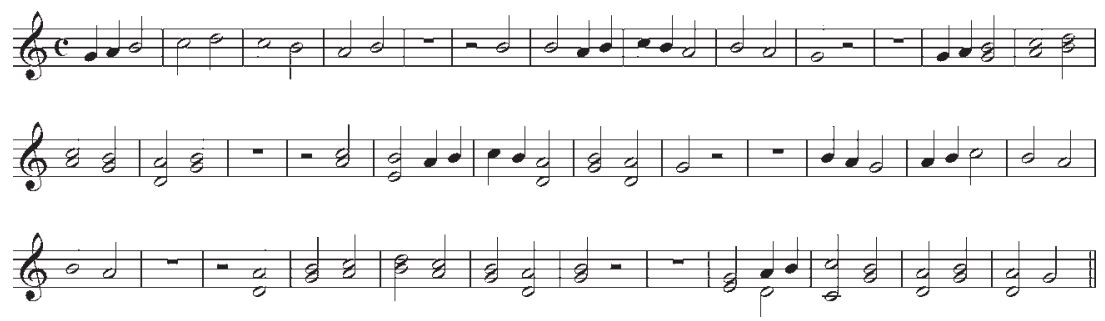

Example 38: C. A. Kaschlinsky, Allein Gott in der Höh' sei Ehr', PAN BG Ms 1093 IV, p. 5

memory. As suggested before, it was likely the collection Choralbüsch, which is mentioned by Herbert Pawlowski in $1928,{ }^{957}$ or alternatively, the musical appendix mentioned on the title page of Kaschlinsky's manuscript in the following remark: "Nebst einem Anhange, beiliegend, die Noten, nach denen die Melodien gesetzt werden können."

957 Pawlowski, 'Das Glockenspiel des Rechtstädtischen Rathause zu Danzig’, 478. 


\section{Overview and description of sources for the carillon repertoire of the church of St Catherine}

\section{Musical manuscripts}

We have no information whatsoever on the music or signals played by "striking mechanisms" hung in the tower of St Catherine in 1575 and 1634. We can define and assess only the music for the instrument built in 1738. The manuscript used by the first carillonist, Eltjen Wolthers, is lost, but the compositions it included are mentioned in 1926 by Bruno Meyer. ${ }^{958}$ The only preserved source is the manuscript of Johann Ephraim Eggert, dated 1784. It includes 260 Protestant songs with a double purpose: both for automated and concert carillon play. Sadly, there are no later sources with music for the Old Town carillon. Since the carillon bells installed in 1910 were tuned differently from those cast by Jan Nicolaas Derck, the carillonist in charge in that time, Paul William Krieschen, decided to copy the chorales from an old manuscript (possible that of Eggert), given the timbre of the new instrument. He informed the management of the church of St Catherine of his work on these arrangements in a letter of 15 May $1912 .{ }^{959}$ His collection was likely used also by his successor, Georg Edel, the last carillonist of St Catherine. Sadly, I have been unable to trace the manuscript of Paul William Krieschen.

958 Meyer, 'Die Glockenspiele auf St. Katharinen in Danzig', 7-9.

959 APG 351/231, pp. 165-67. 
Tab. 36: Musical manuscripts with works for the St Catherine carillon

\begin{tabular}{ll}
\hline 1. Extant & \\
\hline Title & Library, cat. no. \\
\hline $\begin{array}{l}\text { Choral-Lieder zu dem Glocken-Spiel der Altstädtschen } \\
\text { Ober-Pfarr-Kirche zu St: Catharinen ausgesetzt mit }\end{array}$ & APG 300,R/Pp,45 \\
$\begin{array}{l}\text { Variationes von Johann Ephraim Eggert Glockenist } \\
\text { des Altstädtschen Glockenspiels, und Organist zum }\end{array}$ & \\
$\begin{array}{l}\text { Heil[igen] Leichnam Danzig A[nn]o MDCCLXXXIV. } \\
\text { 2. Lost }\end{array}$ & \\
\hline Title & Library, cat. no. \\
\hline Collection of Eltjen Wolthers & Until 1926 in the Staatsarchiv für \\
& Freie Stadt Danzig: 300 Abt. 35 Nr \\
& 843 \\
Collection of Paul William Krieschen & Information about this \\
& collection: APG 353/231, p. 165-67 \\
\hline
\end{tabular}

The manuscript of Johann Ephraim Eggert is now held at the State Archives in Gdańsk. Its history can only be traced hypothetically. Describing the manuscript, Frank Deleu questioned it was ever used in practice, arguing that the state of conservation is too good. The Choral-Lieder book, dedicated to the Old Town Council, was a gift for that institution and for this reason, Deleu argues, was never used for programming the carillon. ${ }^{961}$ Were he right, after 1784 Eggert's manuscript should have gone to the Old Town Archives. However, establishing that archive's detailed history, especially the ways is was supplied with many manuscripts, is very difficult as no appropriate register was kept for the collections.

The Old Town Archives were located in the district's town hall on a low storey above the representative first floor, the piano nobile. ${ }^{962}$ After the Second Partition of Poland in 1793, when Gdańsk was incorporated into Prussia, new administrative structures were imposed. To emphasise the city's political allegiance, patterns from Berlin and Königsberg. The Old Town Council was liquidated, and the city, divided into three districts (Main Town, Old Town, and Suburbs), was governed by a single institution, the Magistrate. ${ }^{963}$ In the once-ceremonial Grand Hall of the Old Town Hall, a public lottery was held, while the lower floors were rented out to clerks and court ushers. Soon, the town hall became the seat of the

960 Meyer, 'Die Glockenspiele auf St. Katharinen in Danzig', 7-9.

961 Deleu, 'Johann Ephraim Eggert Choral Lieder'.

962 Habela, 'Ratusz Staromiejski w Gdańsku', 141-42.

963 Biernat, ‘Organizacja nowych władz miejskich’, 26-30. 
City and Land Court. ${ }^{964}$ From 1794, the archives of the Old Town Council were migrated to the Jurors' House, where it joined the collections of the Gdańsk City Archives (Archiv der Stadt Danzig). In 1797, a specification of these archives was made for the Magistrate, but the Eggert manuscript is not mentioned in that document. ${ }^{965}$ This fact calls into question the assumption of Frank Deleu about the lack of practical use for the manuscript. It seems more correct to assume that it was used at least by its author, who lived until 1803.

On the book's cover, there are two stickers: one at the bottom, with the catalogue number Stadt Danzig $300 \mathrm{Abt}$. H fol Pp Nr. 45, and another at the top, with the institution's name: Staatsarchiv Danzig. The latter name was used with reference to the Königliches Staatsarchiv für Westpreußen in Danzig, the successor of the Archiv der Stadt Danzig from 1901. The words Stadt Danzig belonging to the catalogue number and the letters $P p$ indicate the assignment of the manuscript to the historical collection Bibliotheca Archivi, but the number 300 before the letters and the current number were given to documents from that collection only after $1901 .{ }^{966}$ Of course, this is not synonymous with the fact the manuscript was in use from that year. One of Eggert's successors might have given up its use and donate it to the Archive, though some other collection of compositions for the Old Town carillon must have existed at that time. We know of no such source, so I believe the Eggert manuscript remained in use until the tragic fire of 1905 . When it turned out it could no longer be used due to a different tuning of the carillon, Paul William Krieschen edited a new version of the chorales in 1912.

The above-mentioned specification of archives moved from the Old Town Hall to the Jurors' House sheds some light on the history of the manuscript of Eltjen Wolthers, now lost. His collection was registered in that specification with the following note:

Noten des altstädtischen Glockenspiels von Wolters. ${ }^{967}$

This suggests that the Eggert manuscript replaced the Wolthers manuscript, and the latter, made obsolete, was moved to the Old Town Archives, eventually sharing the destiny of other documents from those archives. ${ }^{968}$ It ended up in the

964 Habela, 'Ratusz Staromiejski w Gdańsku', 142-43.

965 This specification is cited by Josef Kaufmann in 'Studien zur Geschichte der Altstadt Danzig', 105-9.

966 Sławoszewska, 'Zarys dziejów Archiwum Miasta Gdańska', 118-22.

967 Quoted after Kaufmann, 'Studien zur Geschichte der Altstadt Danzig', 109.

968 It is worth adding that the register also included writings about the construction of the St Catherine carillon and invoices related to the carillon; see Kaufmann. 
Königliches Staatsarchiv für Westpreußen in Danzig, which was again renamed as the Staatsarchiv für Freie Stadt Danzig in 1921. The Wolthers manuscript remained available in the interwar period. It was mentioned in 1926 by Bruno Meyer, who cited its original catalogue number as " 300 , Abt. $35 \mathrm{Nr} 843$." do not know the circumstances in which it went missing, but after the Second World War, that document was no more in the Gdańsk Archives.

\subsection{The lost manuscript of Eltjen Wolthers}

Information on the Eltjen Wolthers collection can be gathered from the description of Bruno Meyer, in the context of a discussion of the technical properties and carillon play possibilities at the church of St Catherine. Though Meyer's remarks are by no means exhaustive enough to assess the manuscript itself and its contents, it enables us to estimate its dating, purpose, and generic features of the music it included.

The remark "in seinem Notenheft von 1744 " ${ }^{\prime 90}$ in Meyer's description suggests that the Wolthers manuscript was edited after the automatic mechanism was installed in 1741. The words quoted by Meyer, "auf die Walze gesteckt warden," a fragment of the manuscript's title or commentary. Indeed, Meyer's later remarks indicate that the Wolthers manuscript included an instruction in Dutch language of how to programme tunes on the carillon drum. This suggests that compositions for automated play were also included in the Wolthers manuscript.

Meyer noted that the manuscript was composed of 67 sheets and featured 171 notated chorales. We only learn about those chorale settings that on even hours, songs in simple and figurative-variational forms were played, and that the rhythm in Wolthers' settings was very lively ("sehr bewegt"). ${ }^{972}$ This remark undoubtedly referred to the counterpoint, which was based on quavers.

Sadly, Bruno Meyer failed to leave more information about the manuscript and the music it featured. We do not know the provenance of Wolthers' chorales: whether it followed his original Dutch tradition or he set tunes known and sung in Gdańsk.

Concerning the manuscript's dating from 1744, one has to ask whether Wolthers use some other scores before that date, or he played and programmed chorales from memory. Wolthers came to Gdańsk and was hired as carillonist as early as 1738 , while the first certain mention of his salary comes from

969 Meyer, 'Die Glockenspiele auf St. Katharinen in Danzig', 7-9.

970 Meyer, 7.

971 Meyer, 7.

972 Meyer, 9. 
14 May $1739 .{ }^{973}$ The carillon of the church of St Catherine, after some confusion related to the bells having to be cast again, was operational in early December 1739. Wolthers, who concertised on that instrument each day, might have used some musical scores or, which is highly likely, simply improvised. The notation of repertoire became a necessity only later, in 1741, when the carillon was equipped with a mechanism for automated play. The programming of the drum requires special care and was made easier if the carillonist had a musical notation at hand.

\subsection{The manuscript of Johann Ephraim Eggert}

Written in 1784, the manuscript of Johann Ephraim Eggert was edited with great care and has survived in excellent condition. It is a book of 226 pages measuring $37,2 \times 23,5 \mathrm{~cm}$, bound in black, slightly faded leather. ${ }^{974}$ On the front and back cover along the edges, there are two gilded frames, and inside the inner frame, a rhomboid with matching flower and vegetal ornaments. The cover's spince is also ornamented in gold. At the top, the inscription Choral Buch zum Glocken Spiel is embossed.

The manuscript is richly decorated with black-and-white drawing and a single colour illustration. On the title page (page i) is the coat of arms of Gdańsk; on the dedication page (iii), framed by vegetal ornaments with embedded coat of arms of five consuls to the Old Town Council, is a drawing of the church of St Catherine and a musical scene with puttos. On the first page of the manuscript proper (ix), titled "Lieder zur ganzen Stunde," is a cupid chiming bells, while on the first page of the collection's second part "Lieder zur halben Stunde" (121), a cupid playing the trumpet. The last page of the index (213) features a drawing with musical instrument: a cornett, two trumpets, and two timpani. On page vii, a colour drawing shows the position of the carillon bells on the tower of St Catherine; this illustration is captioned:

Rangirung derer Glocken bey dem neuen Glocken Spiel auf St. Catharinen Thurm Anno 1738.

The illustrations were made by an artist identifying himself as Cappun ("Cappun fecit."). Dariusz Kaczor theorises that this could refer to Gdańsk painter Carl August Cappuhn, meaning he would have made the drawings a dozen years before 1784, the date of publication, as Cappuhn died in 1772. Thus, another suggestion by Dariusz Kaczor seems more likely: that it was a possible son of Carl August Cappuhn or (which cannot be excluded) another painter of the same surname. ${ }^{975}$

973 APG 300,41/7, p. 56.

974 A detailed description of the manuscript is quoted in Kaczor, 'Wstęp', 26-27.

975 Kaczor, 26. 
Johann Ephraim Eggert dedicated his collection to the Old Town Council, which was elected on 16 March $1784 .{ }^{976}$ It was made up of five "consules," including one with the position of a spokesman ("Wortführender Herr"), as well as twelve jurors. On the dedication page of the manuscript (page iii), the names were written of the Christian Wilhelm Fichtel, the current spokesman of the Council, and the remaining four consuls: Johann Ernst Schmidt, Gabriel Lorentz Braemer, Benjamin Krey, and Abraham Wolters. After the dedication page, a letter was reproduced (pages v-vi) dated 22 April 1784, which could suggest that Eggert waited to donate his edition for the Council to inaugurate its office.

The letter follows a style widespread in that era. Eggert first refers to nature and religion, two fundamental values in the life of each person. To obey them, oblivious of his frail health, he takes the challenge and prepares an edition of contemporary songs for his successors, hoping for the benevolence of his patrons, to whom the collection is dedicated.

Sadly, this fairly conventional text lacks any information about the origin of the manuscript and the process of its creation. The letter only mentions the intentions of Eggert himself:

Natur mit Religion, beyde verpflichten schon vor der zartesten Jugend an den Menschen, seine ihm von dem weisesten Schöpfer verliehene Kentniß und Fähigkeiten, zur Verfertigung der Ehre Gottes und zum Nutzen der Nebenmenschen anzuwenden. Und dies war der Weg, den ich in diesem mühseeligen Leben von jeher mich zu wandeln bemühete, den ich immer mit der grösten Sorgfalt betrat, ob ich gleich auch hiezu meine Kräffte oft zu schwach fühlte. Aus dieser Absicht übernahm ich die Ausfertigung gegenwärtiger Lieder, die zum Gebrauch des Glockenspiels an der Altstädtschen Oberpfarr-Kirche zu St. Catharinen bestimmt sind, welche ich zwar mit der grösten Sorgfalt ausgearbeitet habe, aber dennoch sehr zweifle, dass ich dem Endzweck eines solchen Wercks völlig Genüge geleistet hätte. Nun der Nutzen davon bewog mich diese Arbeit zu übernehmen, weil ich glaube, dass sie in meinem künftigen Nachfolgern höchst dienstlich sein könte, denn Ihro Hochseelige Vorfahren erkanten schon den Nutzen eines solchen Glockenspiels, daher Sie die Errichtung desselben mit vieler Beschwerde, Hindernißen und großen Unkosten übernahmen. ${ }^{977}$

Although the composition in the Eggert manuscript are numbered with Arabic digits from 1 through 257, two compositions: Der 74te, 116te Psalm and Ach wir armen Sünder, share the same number 244, while two other ones are unnumbered: they are marked with the 3/4 fraction. Thus, in reality, the Eggert manuscript contains 260 compositions.

976 Kaczor, 22; Zdrenka, Rats- und Gerichtspatriziat der Rechten Stadt Danzig, 2:233.

977 Eggert, Choral-Lieder zu dem Glocken-Spiel, v. 
The manuscript consists of two parts. The first, titled "Lieder zur ganzen Stunde," includes works to be performed on full hours (pages 1-120), while the second, "Lieder zur halben Stunde," includes tunes to be performed on halfhours (pages 121-200).

In total, 130 compositions are notated for full hours, including 116 in the chapter "Lieder zur ganzen Stunde" and fourteen at the end of the "Lieder zur halben Stunde" chapter, starting with page 187. Compositions to be performed on half-hours are 128, all in the relevant chapter. In the group "Lieder zur ganzen Stunde" on pages 104 and 112, under the compositions no. 100 and 108, two very short pieces (essentially musical examples) are notated, which are only marked with the $3 / 4$ fraction. They are single-verse tunes to be performed on the first and third quarter of an hour.

The manuscript ends with an index of composition titles in alphabetical order (pages 201-13), preceded by a remark on how it is organised:

Register über dieses Choral-Buch. Die Zahlen, welche vor dem Liede stehen, zeigen das Pagna an, nehm[lich]: die Erste Abtheilung die gantze; die zweyte die halbe Stunde. Die

Zahlen aber nach dem Liede, zeigen die N[ummer]o des Liedes; nehml[ich]: die erste Abtheilung die gantze, die zweyte die halbe Studen an. ${ }^{978}$

The compositions included in the Eggert manuscript are based on Protestant song, as was the case with the Gülich settings. While the collection contains 260 song settings, most of them are pairs, with each title featured with a variant for the full hour and the half-hour; two songs are also present as quarter-hour tunes, and one composition is notated twice. ${ }^{979}$ Thus, the actual number of song settings is 173; additionally, Eggert notated three psalm settings.

In his dedication letter, Eggert mentioned that he endeavoured to set the most current songs for the carillon. Compiling them, he used the latest official Gdańsk hymnal, Danziger Gesangbuch, published in $1764 .{ }^{980}$ Eggert then set songs from twenty-eight chapters of that songbook. Characteristically, he omitted those songs that served a daily prayer function: morning and evening songs as well as those sung before meals (“Morgengesänge," "Abendgesänge," and “Tischgesänge”). Moreover, he also did not feature songs relative to the Communion ("Von den Gnadenmitteln und zwar von dem heiligen Abendmahl"), baptism ("Von den Gnadenmitteln besonders von der heiligen Taufe"), and Epiphany ("Gesänge

\footnotetext{
978 Eggert, 201.

979 The composition Mit Fried und Freud ad Intermedio, Was sorgst du ängstlich für dein Leben, Bachs Mel[odie], is notated twice as no. 13 and 101.

980 Danziger Gesangbuch (Danzig, 1764).
} 


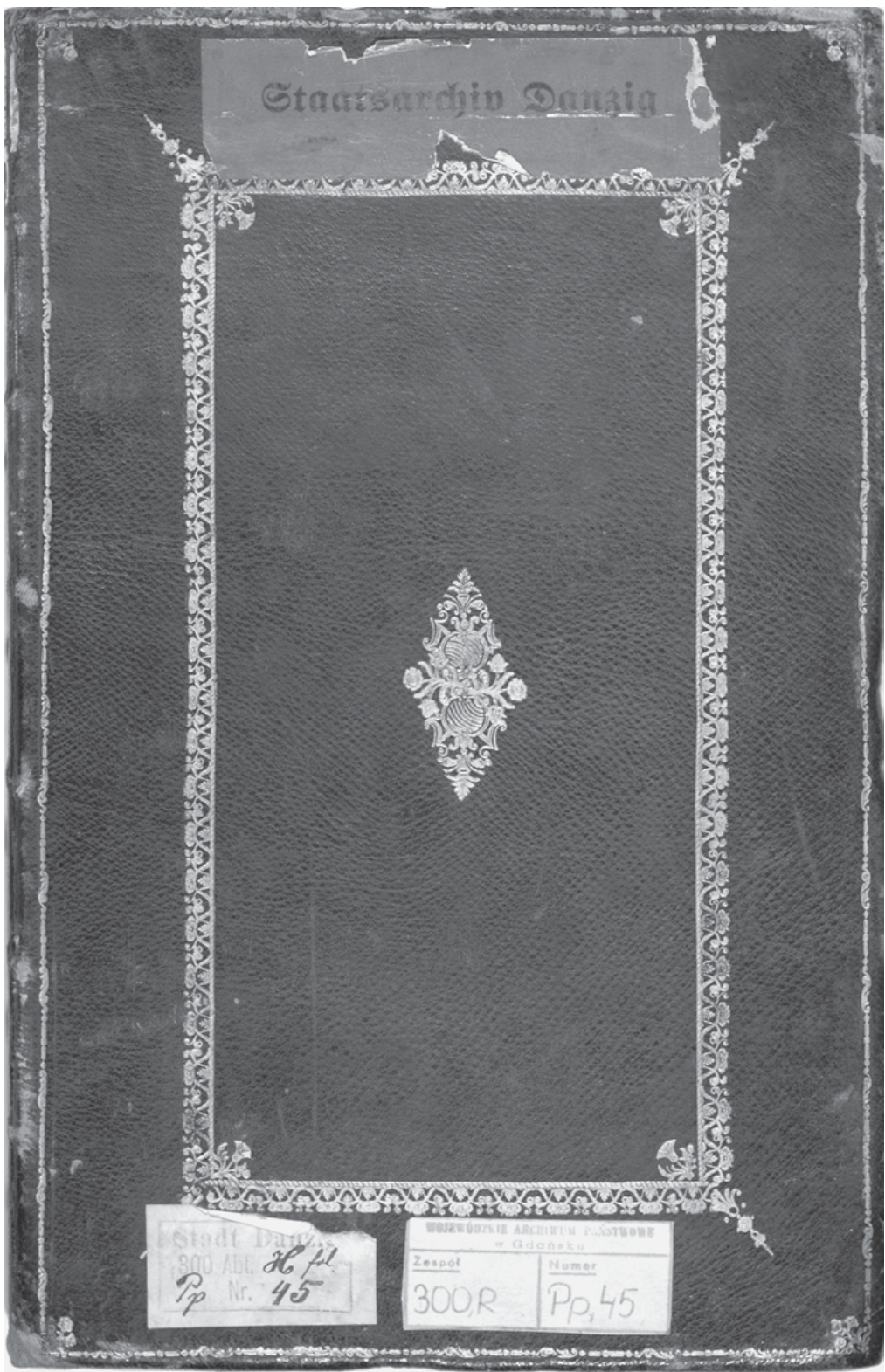

Fig. 85: Manuscript of J. E. Eggert. APG 300,R/Pp,45, cover 


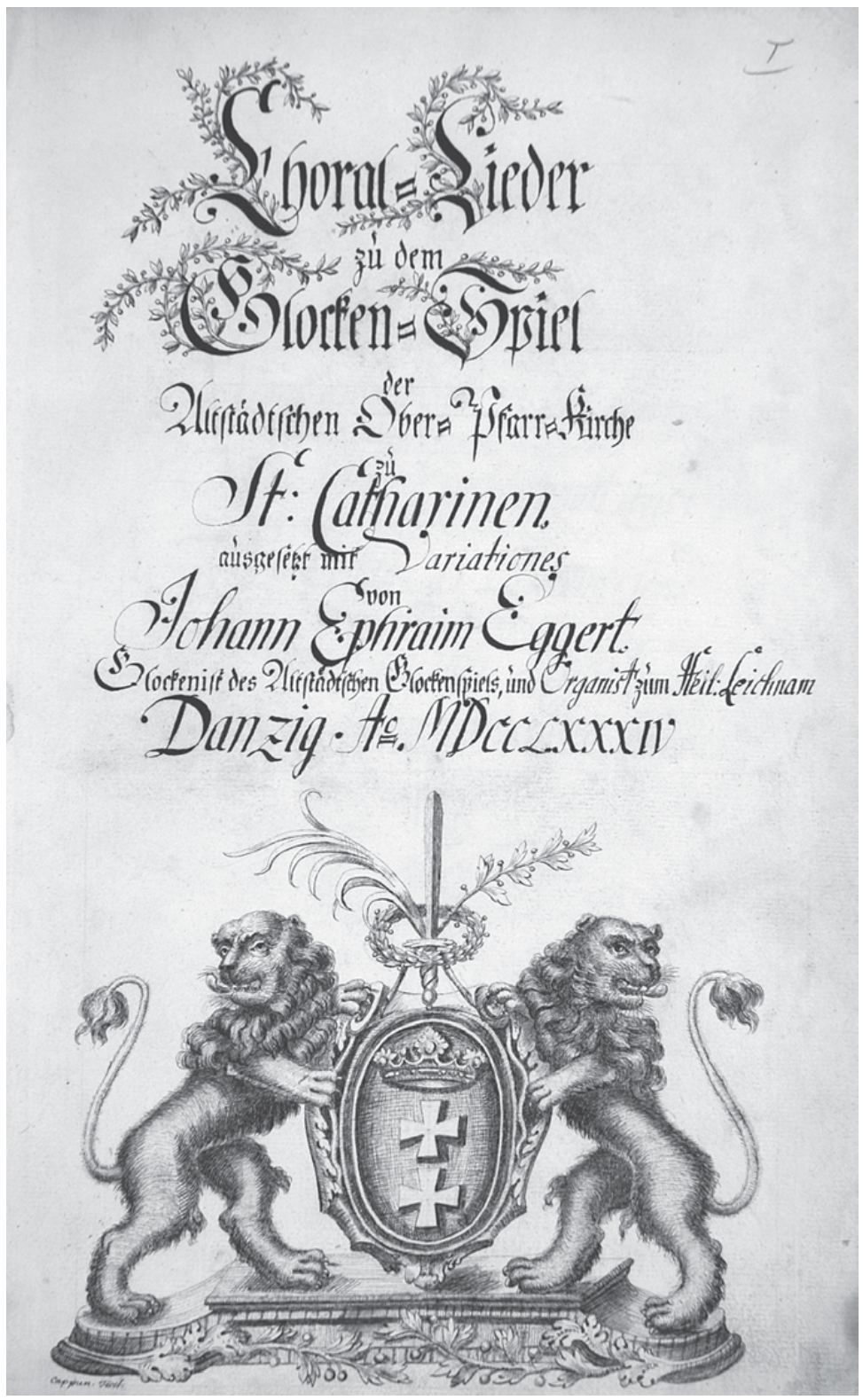

Fig. 86: Manuscript of J. E. Eggert. APG 300,R/Pp,45, title page 


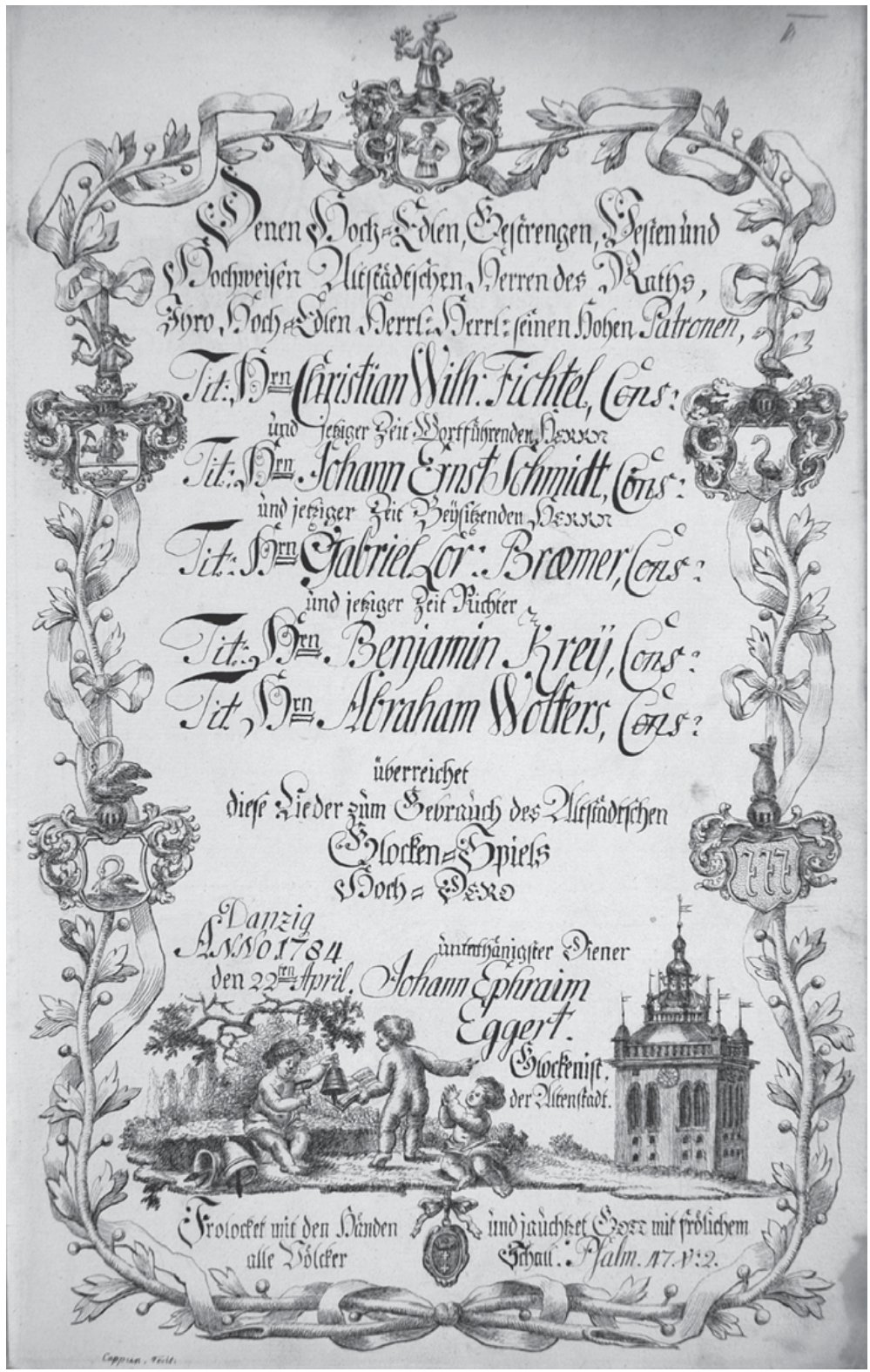

Fig. 87: Manuscript of J. E. Eggert. APG 300,R/Pp,45, p. iii 


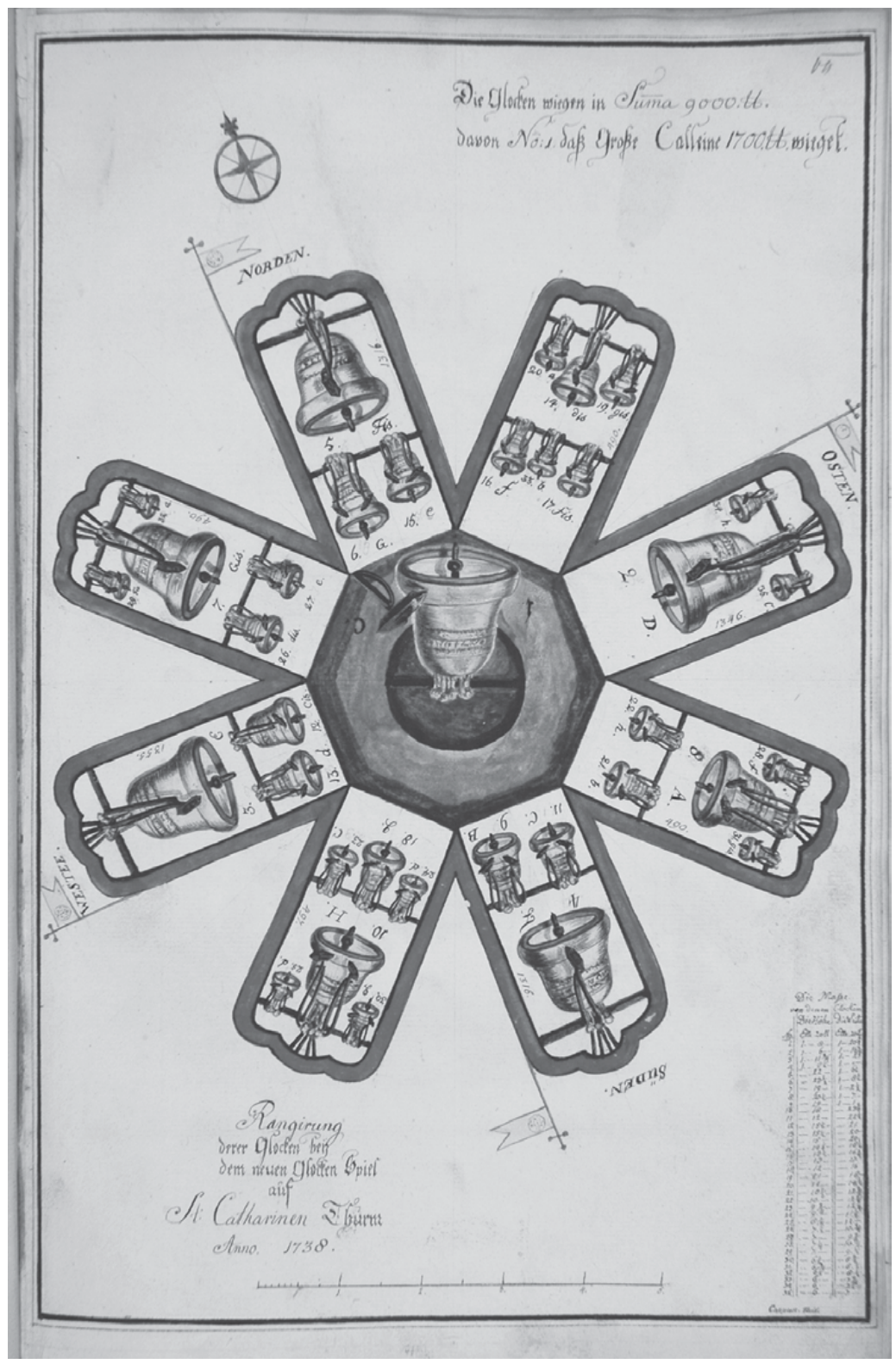

Fig. 88: Manuscript of J. E. Eggert. APG 300,R/Pp,45, p. vii 


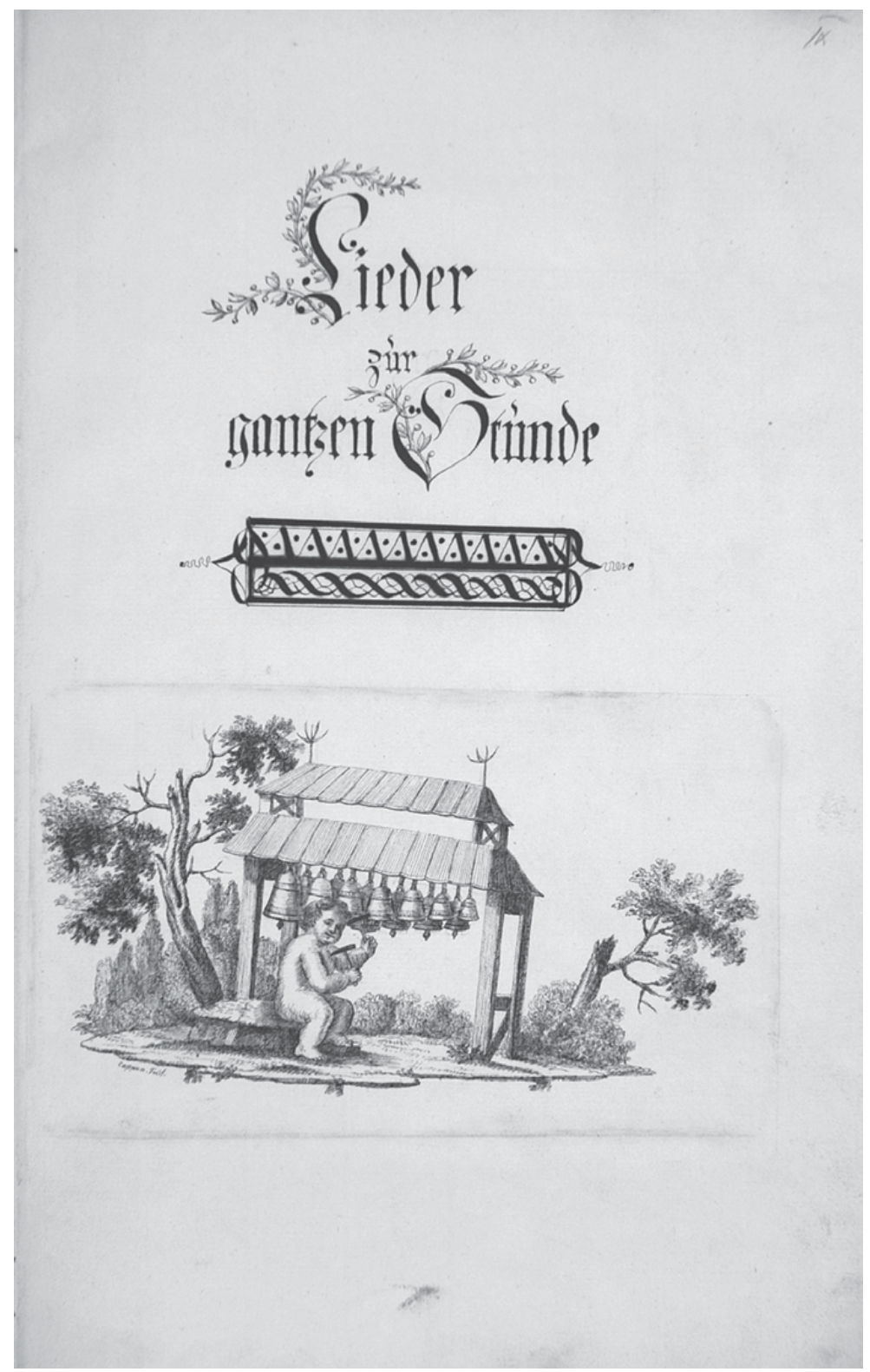

Fig. 89: Manuscript of J. E. Eggert. APG 300,R/Pp,45, p. ix 
$\int \frac{2}{0}: 1$

7 (imfonmer er

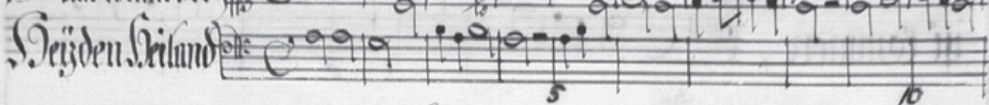

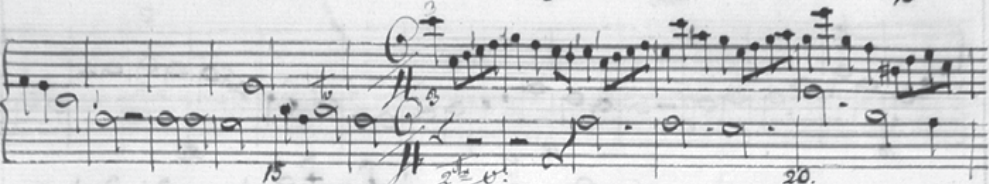

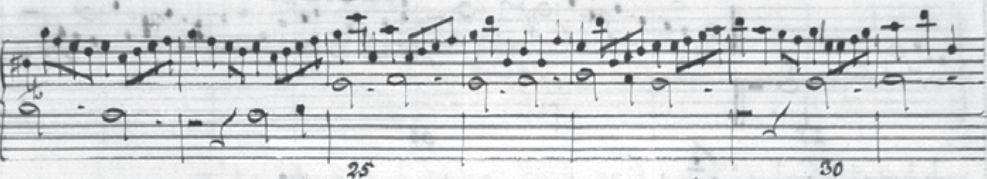

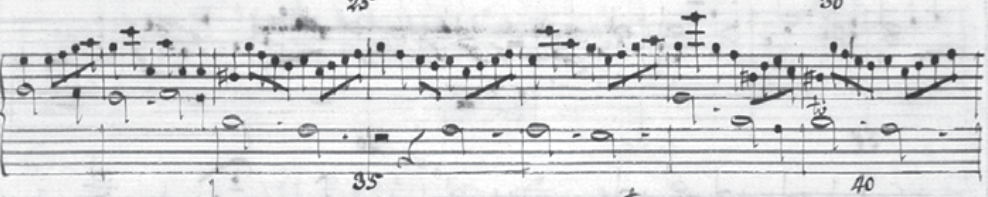

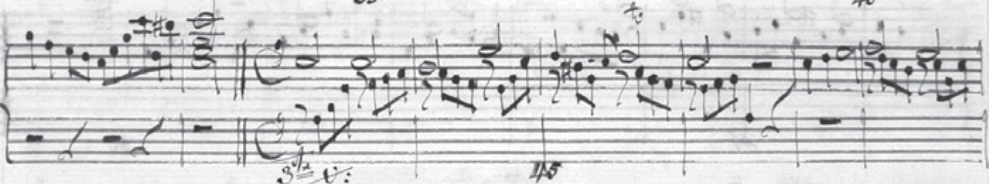

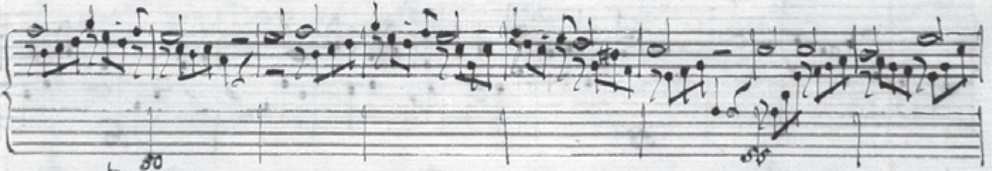

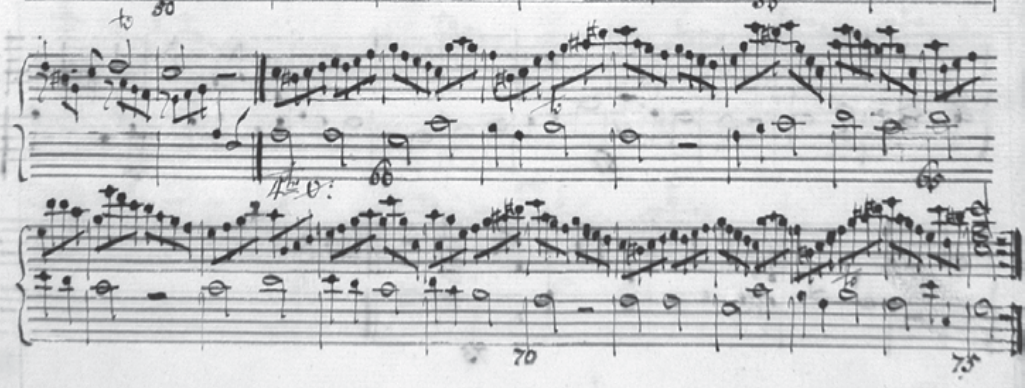

Fig. 90: Manuscript of J. E. Eggert. APG 300,R/Pp,45, p. 1 
auf das Fest der Erscheinung Christi"), which is quite surprising, as the latter was a so-called great or full feat, lasting the entire day. ${ }^{981}$ In trying to explain this lack in the Eggert manuscript, we can recall the practice of programming the carillon the Gdańsk's Main Town Hall. There, two Christmas songs were set for Epiphany: Vom Himmel hoch da komm' ich her and Ein Kind geborn zu Bethlehem. It can be presumed the same practice was followed in the Old Town, and since the same two songs are included in the Eggert collection, the composer might have consciously left out other songs proper to the Epiphany feat. He also did not set any songs for Annunciation ("Gesänge auf das Fest der Verkündigung Mariä"). This means the St Catherine carillon did not signal that feat, as in the case of the "singing automaton" of the Main Town Hall. ${ }^{982}$

In the Eggert collection, the numerical dominance of some song groups is noteworthy. The most abundant group is passion songs (twenty compositions) and Christmas songs (sixteen). There are also many confession and dogmatic songs, dedicated to religious reflection, faith-deepening, and strengthening of man's moral condition. There are songs on means of grace such as penitence ("Von den Gnadenmitteln und zwar von der Busse," fifteen compositions); cross and solace ("Kreutz- und Trostgesänge," fourteen); pious Christian life ("Vom christlichen Tugendwandel überhaupt," ten); the Christian Church ("Von der Christlichen Kirche," ten). Of note is also a large group of twelve death songs ("Sterbegesänge"), an obvious presence given that the carillon of St Catherine, just as the "singing automaton" of the Main Town Hall, was used during the funerals of esteemed citizens of the Old Town.

In the group of songs for Pentecost ("Pfingstgesänge") is the chorale setting Komm heiliger Geist Herre Gott. According to a resolution of the Old Town Council of 7 April 1785, thus the year after the Eggert manuscript was finished, the carillonist was supposed to play that song also during election to the Old Town Council.

It should be added that Johann Ephraim Eggert marked several psalm settings in his collection, including of Psalm 8 (no. 242 in the collection), Psalm 22 (no. 243), and Psalm 74/116 (no. 244), as well as added seven songs absent from the 1764 canon. Five of these:

Was sorgst du ängstlich für dein Leben (no. 13, 65, 101)

Du bist's dem Ruhm und Ehre (no. 43) ) $^{983}$

Gott ist mein Lied (no. 42)

981 Kizik, 'Gute Policey’, 81-84.

982 The song for Annunciation is only included in the tablature of Paul Friedrich Knaack.

983 Title in the hymnal: Du bist dem Ehr und Ruhm. 
Erforsche mich erfahr mein Herz (no. 18)

Wie groß ist des Allmächtigen Güte (no. 114)

were included in the next official Gdańsk hymnal, published in 1810, ${ }^{984}$ confirming their popularity. Two songs, O Herr mein Gott durch den ich bin und lebe (no. 257) and Herr lehr mich wenn ich der Tugend diene (no. 241), are absent from all Gdańsk songbooks and chorale books. It should be assumed that Eggert's own preferenced determined the fact they were set and included in his collection.

Tab. 37: Chapter order in the Danziger Gesangbuch (Danzig 1764) and number of songs sert by J. E. Eggert for each chapter

\begin{tabular}{llc}
\hline No. & Chapter & Number of songs ${ }^{95}$ \\
\hline I & Sonntagsgesänge & 1 \\
II & Adventsgesänge & 7 \\
III & Weihnachtsgesänge & 16 \\
IV & Neujahrsgesänge & 2 \\
V & Gesänge auf das Fest der Erscheinung Christi & \\
VI & Gesänge auf das Fest der Reinigung Mariä & 1 \\
VII & Gesänge auf das Fest der Verkündigung Mariä & - \\
VIII & Passionsgesänge & 20 \\
IX & Ostergesänge & 8 \\
X & Himmelfahrtsgesänge & 3 \\
XI & Pfingstgesänge & 6 \\
XII & Gesänge auf das Fest der heiligen Dreieinigkeit & 2 \\
XIII & Gesänge am Tage Johannis des Täufers & 1 \\
XIV & Gesänge am Tage der Heimsuchung Mariä & 1 \\
XV & Gesänge auf das Michaelisfest & 1 \\
XVI & Von Gott und seinen Eigenschaften & 1 \\
XVII & Von Gottes Werken und Wohlthaten nach dem ersten & 5 \\
& Artikel & \\
XVIII & Von dem göttlichen Erlösungswerke nach dem anderen & 3 \\
& Artikel & \\
XIX & Von den Gnadenwirkungen und Wohlthaten nach dem & 3 \\
& dritten Artikel & 10 \\
XX & Von der Christlichen Kirche & \\
\hline & &
\end{tabular}

(continuedon next page)

984 Christliche Religions-Gesänge, für die öffentliche und häusliche Gottesverehrung; gesammelt von dem geistlichen Ministerio des Danziger Freistaates Mit Obrigkeitlicher Genehmigung. Danzig, gedruckt und zu bekommen in der Müllerischen Buchdruckerei. 1810.

985 The number of chorales listed here omits double settings. 
Tab. 37: Continued

\begin{tabular}{llc}
\hline No. & Chapter & Number of songs \\
\hline XXI & Von den Gnadenmitteln besonders von dem Worte Gottes & 3 \\
XXII & Von den Gnadenmitteln besonders von der heiligen Taufe & - \\
XXIII & Von den Gnadenmitteln und zwar von der Busse & 15 \\
XXIV & Von den Gnadenmitteln und zwar von dem Glauben & 8 \\
XXV & Von den Gnadenmitteln und zwar von dem heiligen & - \\
& Abendmahl & 1 \\
XXVI & Von den Gnadenmitteln und zwar vom Gebet & 5 \\
XXVII & Lob- und Dankgesänge & - \\
XXVIII & Morgengesänge & - \\
XXIX & Tischgesänge & - \\
XXX & Abendgesänge & 10 \\
XXXI & Vom christlichen Tugendwandel überhaupt & 2 \\
XXXII & Vom christlichen Tugendwandel nach eines jeden Stand & \\
& und Beruf & 14 \\
XXXIII & Kreutz- und Trostgesänge & 11 \\
XXXIV & Sterbegesänge & 1 \\
XXXV & Von der Auferstehung & 1 \\
XXXVI & Vom jüngsten Gerichte & 4 \\
XXXVII & Von der Ewigkeit & 166 \\
Total & & \\
\hline & & 4
\end{tabular}

The compositions in Eggert's collection are essentially consistent with the order of chapters in the Danziger Gesangbuch of 1764. The group "Lieder zur ganzen Stunde" opens with five advent songs, followed by Christmas songs, settings of the melody Mit Fred' und Freud' for Candlemas ("Auf das Fest der Reinigung Mariä"), and Passion songs ("Pasionsgesänge"), but also by the song Freut euch ihr Christen alle (no. 112), which according to order, should fall after the Christmas songs. Inconsistencies in the order can also be observed in the group of thematic songs. A similar situation happens in the chapter "Lieder zur halben Stunde."

A lack of correlation can also be observed with regard to works for full and half-hours. From five Advent songs, only three are set for both options. The remaining songs have unique appearances, with half-hours featuring new titles. A dramatic disproportion exists within the Christmas songs group, where Eggert set seven pieces for full hours and no fewer than thirteen for half-hours. In other groups, the divergences are less important, and for several holidays and thematic groups, Eggert consistently set pairs of songs. 
Tab. 38: Advent songs ("Adventsgesänge") set by J. E. Eggert

\begin{tabular}{llll}
\hline "Lieder zur ganzen Stunde" & \multicolumn{3}{c}{ "Lieder zur halben Stunde" } \\
\hline Title & No. & Title & No. \\
\hline Nun komm der Heiden Heiland & 1 & - & \\
Gottes Sohn ist kommen & 2 & Gottes Sohn ist kommen & 119 \\
Wie soll ich dich empfangen & 3 & Wie soll ich dich empfangen & 120 \\
Warum willst du draußen stehen & 4 & Warum willst du draußen stehen & 121 \\
Wacht auf ruft uns die Stimme & 5 & - & \\
- & & Auf ihr Reichsgenossen & 117 \\
- & & Gott sei Dank durch alle Welt & 118 \\
\hline
\end{tabular}

Tab. 39: Christmas songs ("Weihnachtsgesänge") set by J. E. Eggert

\begin{tabular}{lclc}
\hline "Lieder zur ganzen Stunde" & \multicolumn{2}{l}{ "Lieder zur halben Stunde" } & No. \\
\hline Title & No. & Title & \\
\hline Adam hat im Paradies & 6 & - & 124 \\
Den die Engel droben & 7 & Den die Engel droben & 126 \\
Ein Kindelein so löbelich & 8 & Ein Kindelein so löbelich & 129 \\
Gelobet seist du Jesu Christ & 9 & Gelobet seist du Jesu Christ & 131 \\
Lobt Gott ihr Christen allzugleich & 10 & Lobt Gott ihr Christen allzugleich & \\
In dulci jubilo & 11 & - & \\
Vom Himmel hoch da komm' ich her & 12 & - & 122 \\
- & & Christum wir sollen loben schon & 123 \\
- & & Da Christus geboren war & 125 \\
- & & Ein Kind geborn zu Bethlehem & 127 \\
- & & Ermuntre dich mein schwacher Geist & 127 \\
- & & Fröhlich soll mein Herze springen & 128 \\
- & & Kommst du nun Jesu vom Himmel & 130 \\
- & & herunter & \\
& & Wir Christenleut' habn & 132 \\
- & & Wir singen dir Immanuel & 133 \\
- & & Zartes Kind doch großer Gott & 134 \\
\hline
\end{tabular}


Tab. 40: Songs on pious Christian life ("Vom christlichen Tugendwandel überhaupt") set by J. E. Eggert

\begin{tabular}{|c|c|c|c|}
\hline \multicolumn{2}{|l|}{ "Lieder zur ganzen Stunde" } & \multicolumn{2}{|l|}{ "Lieder zur halben Stunde" } \\
\hline Title & No. & Title & No. \\
\hline Ach höchster Gott verleihe mir & 84 & Ach höchster Gott verleihe mir & 204 \\
\hline Ich ruf' zu dir Herr Jesu Christ & 85 & Ich ruf'zu dir Herr Jesu Christ & 205 \\
\hline O Gott du frommer Gott & 86 & O Gott du frommer Gott & 207 \\
\hline Mein Gott das Herze bring' ich dir & 87 & Mein Gott das Herze bring' ich dir & 206 \\
\hline Herzlich lieb hab' ich dich o Herr & 88 & - & \\
\hline Von Gott will ich nicht lassen & 89 & - & \\
\hline Kommt her zu mir spricht Gottes Sohn & 90 & Kommt her zu mir spricht Gottes Sohn & 208 \\
\hline Eins ist Not ach Herr dies Eine & 91 & Eins ist Not ach Herr dies Eine & 232 \\
\hline- & & Mir nach spricht Christus unser Held & 209 \\
\hline- & & Sollt' es gleich bisweilen scheinen & 230 \\
\hline
\end{tabular}

An analysis of song titles in the "Lieder zur ganzen Stunde" and "Lieder zur halben Stunde" groups, as well as their order in the Eggert manuscript, suggest the following conclusions.

First, it must be considered that the Eggert collection was, according to the author's intention, a universal chorale book for the St Catherine carillon, as was the older Choral Buch Nach denen Evangelisch Lutherschen Kirchengesaengen of Theodor Friedrich Gülich for the "singing automaton" of the Main Town Hall. Eggert selected songs based on the Danziger Gesangbuch of 1764 (with seven exceptions), and the order of compositions in his manuscript, especially in the "Lieder zur ganzen Stunde" group, is essentially consistent with the chapters of the Danziger Gesangbuch.

Second, we should assume that Johann Ephraim Eggert planned his manuscript for creative use, as there is no direct correlation of his paired settings, with a different number of compositions in the various song groups. It is only evident which tunes should be set on full hours and which on half-hours. Although the collection lacks a precise assignment of songs to the successive Sundays of the liturgical year, it can be assumed that for an experienced carillonist, this made no difference in programming the automated bells or selecting works for everyday concerts. The Eggert manuscript, as confirmed by the unique characteristics of its notation, played a double role: it was a collection used for programming works on the carillon bell and also for everyday concert play. 


\subsection{Notation of works in the manuscript of Johann Ephraim Eggert}

Johann Ephraim Eggert notated musical compositions using the traditional notation: on two staves with an $\mathrm{F}$ bass clef or $\mathrm{C}$ soprano clef.

A characteristic of the notation in the "Lieder zur ganzen Stunde" chapter is that works are numbered from 5 through 10,15 and so forth to 75 , while in "Lieder zur halben Stunde," from 5 to 35, written under each composition under the lower stave. In the case of works in $4 / 4$ metre, the numbering fits the number of measures, while in ternary metre, there is no correlation.

Bruno Meyer, who discussed the carillon's instrument and technical features in 1926, stated that the pins used for programming works divided the distance between slats into eight even parts. This observation is confirmed by Meyer's remark on the compositions of Eltjen Wolthers, which he knew personally. In those works, the counterpoint to the cantus firmus was composed mainly of quavers. ${ }^{986}$ This the distance between two slats can be identified with a four-beat measure, internally subdivided into eight units, equivalent to eight quavers.

Between five slats, forty units (quavers) could be fitted. When he notated a composition, Eggert computed the fivefold multiple of eight units (forty quavers), notating the number of the slat under the lower stave. This fitted the number of the bar in duple metre works, but not in triple metre works or fragments. ${ }^{987}$

It should be remembered that the drum of the St Catherine carillon was fitted with 120 slats. Works to be performed on full hours were programmed to a maximum of 75 slats, and they were notated in the manuscript on 75 measures in a $4 / 4$ metre. Songs performed at half-hours were programmed to a maximum of 35 slats, while those at quarter-hours, to a maximum of 5 slats. Based on modern performances of Eggert's settings, we can believe that a full resolution of the carillon drum lasted no more than around five minutes. Thus, compositions played on the full hour lasted around three minutes, those on the half-hour, one minute and a half, and quarter-hour tunes around fifteen seconds only. ${ }^{988}$

If the work was shorter than 75 or 35 slats, its setting was started not on the drum's first slat but on a subsequent one, which had the effect of giving an "empty" (silent) run of the drum. The number of the slat to begin the work from was indicated in the notation.

986 Meyer, 'Die Glockenspiele auf St. Katharinen in Danzig', 7-8.

987 I thank Monika Kaźmierczak, Frank Deleu, and the late Jacques Maassen for drawing my attention to the solution to the issue of lat numbering in triple metre works, as well as for discussing other issues related to the mechanism of the St Catherine's carillon.

988 See the duration of compositions featured on the CD included in the facsimile edition of the Eggert manuscript. 
In the Eggert manuscript, there are also many compositions - around 80 where the first five slats are assigned more rhythmic values than 40 quavers (20 crotchets) planned for that section. Such cases are marked:

1. With a small circle with a dot in the middle, placed at the upper stave, always at the first barline

2. With a small circle with a dot in the middle, placed at the lower stave at the first barline

3. A series of numbers from 1 through 8 , written above successive notes

These indications are only used at the beginning of a work and are written either in isolation or in a combination of numbers above notes and dotted circle at the upper stave. How should these indications be understood?

It has been remarked that a circle with a dot in the middle, placed at the upper stave, happens in compositions with an upbeat. That upbeat was simply programmed before the first slat. Since the last bar of the composition (last slat) was half-filled (the final chord or chords totalled a minim), the setting of such an upbeat was technically possible. The dotted circle happens both in works programmed for full hours and half-hours.

The series of numbers, the dotted circle at the lower stave, or the simultaneous use of numbers and dotted circle at the upper stave can only be found in works for full hours: compositions that were too long to programme on the carillon drum without a modification of rhythm. These indications suggest that the carillonist should shorten rhythmic values of initial sounds in such a way to fit the entire composition into a given number of slats.

Through this practice of shortening rhythmic values, not only overly long compositions could be fitted on the drum, but it was also possible to make room for very short tunes signalling durations of a half-quarter-hour: indeed, we know from historical testimonies that in some periods, the St Catherine carillon played in sequences of seven and a half minutes.

The numbers $1,2,3,4,5,6,7$, and 8 appearing in some works are an important information: they demonstrate that pins divided the distance between slats in eight sections only. Thus, the smallest rhythmic value that could be programmed on the St Catherine carillon drum, was a (contractual) quaver. On the one hand, this is consistent with information given by Bruno Meyer, ${ }^{989}$ and on the other, with our knowledge of the practice of eighteenth-century carillon construction. ${ }^{990}$

989 Meyer, 'Die Glockenspiele auf St. Katharinen in Danzig', 7-8.

990 Lehr et al., 'Glocken und Glockenspiele', cols 1469-72; Haspels, Automatic Musical Instruments, 61-64, 169-77. 
These remarks unambiguously suggest that the compositions of Johann Ephraim Eggert were written with automated play in mind. Yet in his notation, apart from rhythmic values of minims, crotchets, dotted crotchets, and quavers, we also sporadically observe dotted quavers, semiquavers, and even demisemiquavers. Yet it transpires from our earlier analysis that semiquavers and demisemiquavers could not technically be programmed on the St Catherine carillon drum. Analysing this notation, we also notice several other elements of notations that increase the dubious possibility of setting Eggert's compositions on the Old Town carillon mechanism. Eggert followed the spirit of his time by embellishing his works with many ornaments. They are particularly concentrated in works such as Teures Wort aus Gottes Munde (no. 186) and Warum sollt' ich mich denn grämen (no. 77). Eggert uses appoggiaturas in three variants: simple, double, and triple. Other ornaments include turns, mordents, and trills. These appear in several graphic forms, indicating various ways of performing ornaments.

Simple ornaments could be programmed on the drums of eighteenthcentury carillons; more complex ones depended on the number of hammers. ${ }^{991}$ Trills were possible when bells were equipped with three hammers; since the bells of St Catherine had two hammers at most, it was not possible to feature trills. Eggert also supplied performance indications for many of his composition. The components of some chords in cadences are slurred, indicating they should be arpeggiated. There are also numerous legato slurs between notes.

An automated carillon could not play arpeggiated chords or legato notes. Therefore, one may ask for what type of carillon did Johann Ephraim Eggert compose his works: a musical automaton or an instrument. On the one hand, his notation includes indications that undoubtedly refer to automated play (number of slats, regulation of the rhythmic value duration); on the other hand, it includes semiquavers ordered into rhythmic patterns and passagework, demisemiquavers, a wide array of ornaments, and performance indication that can only refer to manual play.

These characteristics of notation support a double use for the Eggert manuscript: the compositions it features could be programmed on an automated carillon, but also played at the keyboard. The carillonist who set pins on the carillon drum operated a reduction of the notation, simplifying the musical narrative. $\mathrm{He}$ eliminated those rhythms and ornaments that could not be achieved, leaving the musician to perform trills, arpeggios, and legato notes.

991 Lehr et al., 'Glocken und Glockenspiele', cols. 1469-72. 


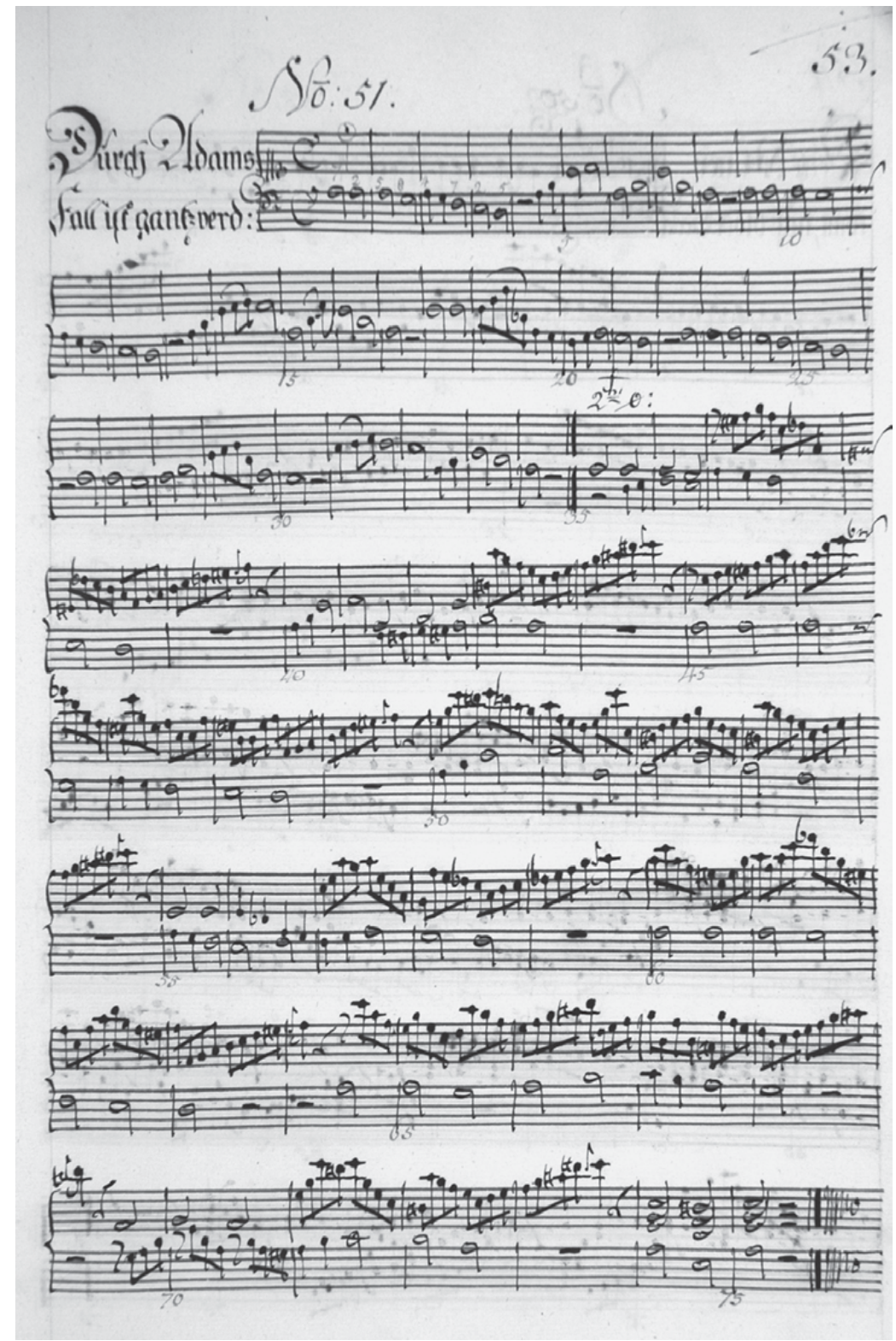

Fig. 91: Manuscript of J. E. Eggert. APG 300,R/Pp,45, p. 53 


$$
\int_{\overline{0}:}: 82
$$

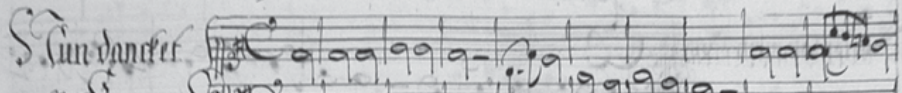

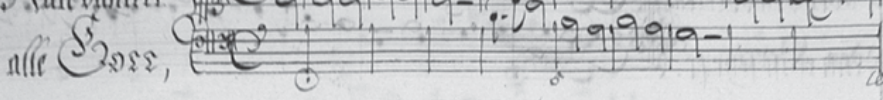

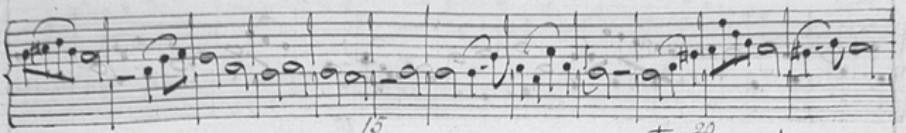

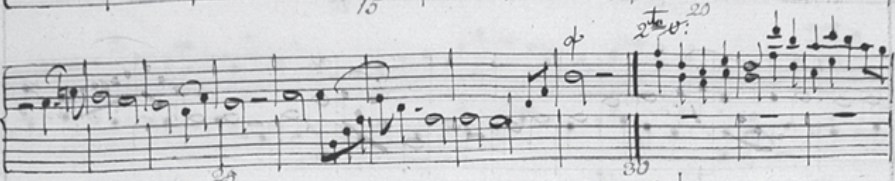

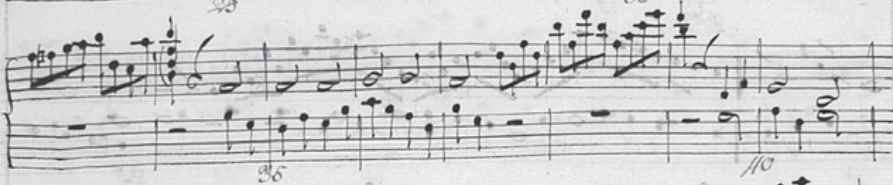

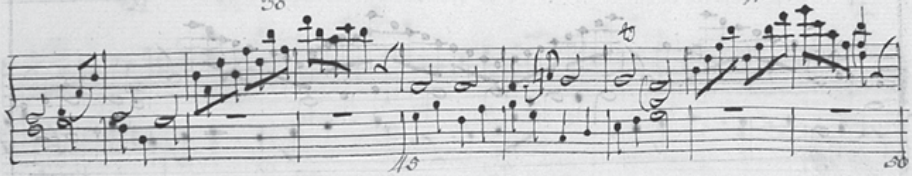

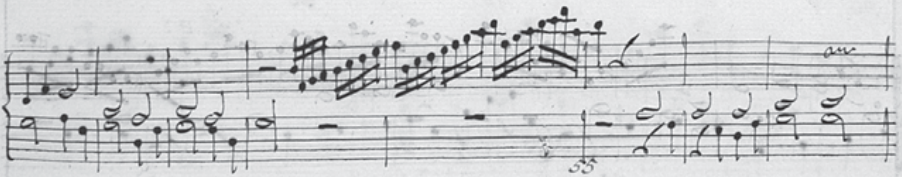

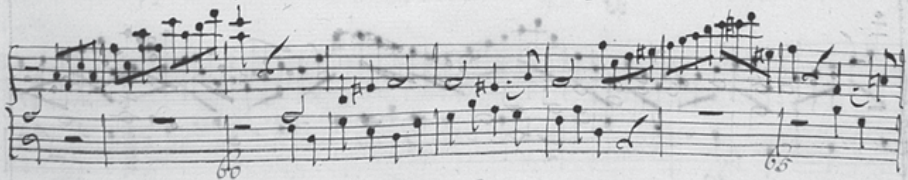

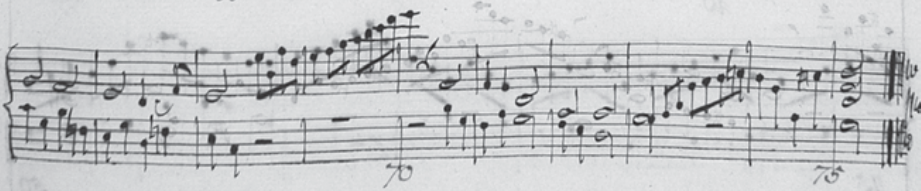

Fig. 92: Manuscript of J. E. Eggert. APG 300,R/Pp,45, p. 85 


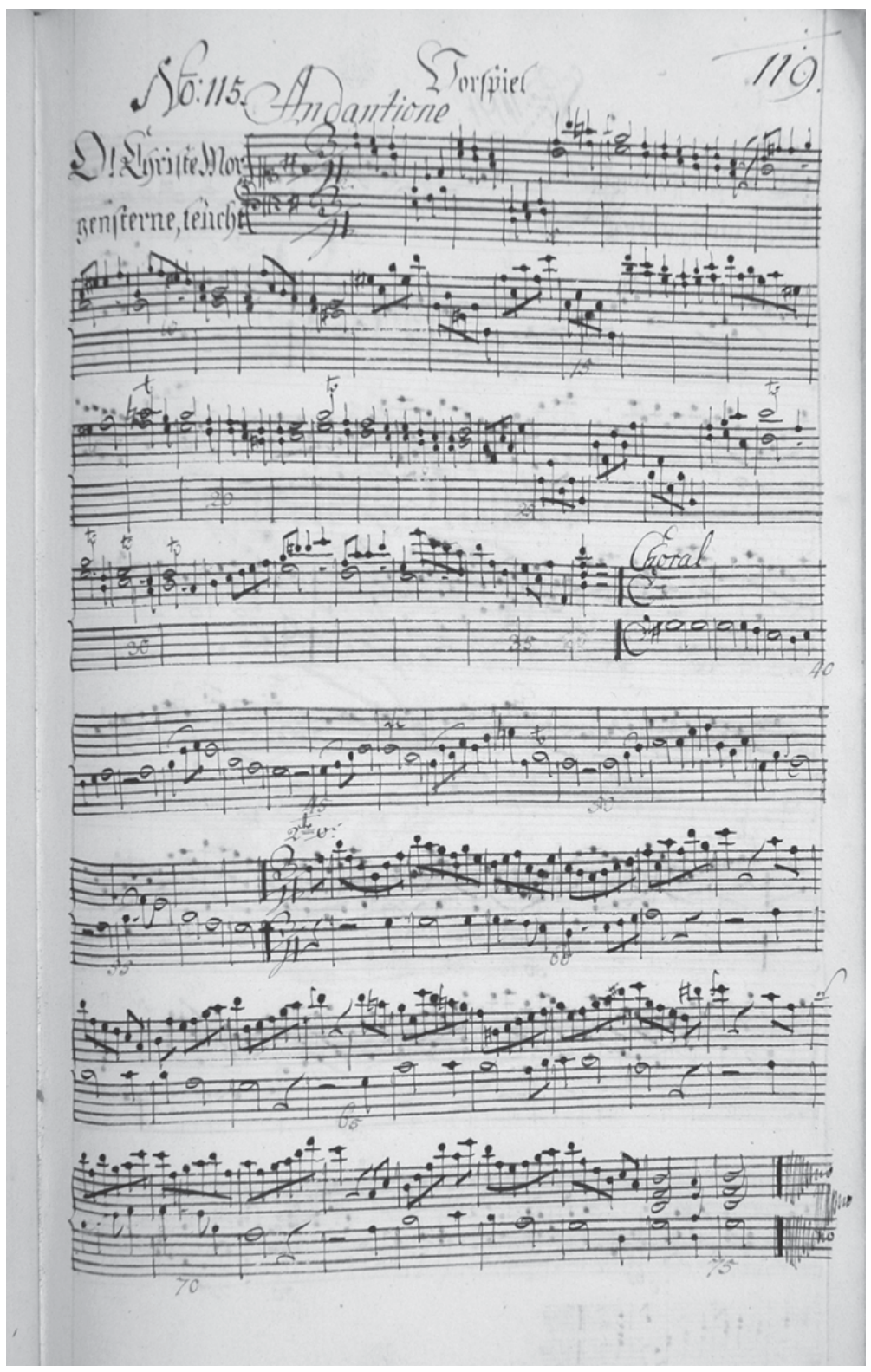

Fig. 93: Manuscript of J. E. Eggert. APG 300,R/Pp,45, p. 119 


\section{Press announcements from 1910-27}

The new automated carillon of 1910 resumed play on 3 September, although as early as 25 August the Danziger Zeitung wrote that due to the visit of Emperor Wilhelm II and his wife to the city, two songs were scheduled to be performed on 27 August: Großer Gott wir loben Dich (on full hours) and $O$ dass ich tausend Zungen hätte (on half-hours). ${ }^{992}$ Announcements with the programme of automated play on the St Catherine carillon were published jointly with those on the Main Town Hall automaton. Sometimes, the latter announcements were omitted, occasionally for several weeks. It could also happen that a given edition of the Danziger Zeitung could not fit a full announcement about both Gdańsk carillons, so the note about the St Catherine one was dropped.

The last announcement about the Old Town carillon was published in the Danziger Zeitung on 10 December 1927; as mentioned before, less than a month later, announcements about the Main Town Hall carillon were also discontinued. ${ }^{993}$

\section{Evolution of the repertoire of the St Catherine carillon}

Research on the evolution of the repertoire of the St Catherine carillon is based on information given by Bruno Meyer about the contents of the lost manuscript of the first carillonist, Elthen Wolthers; the musical works included in the Johann Ephraim Eggert's manuscript; and the content of press announcements in the Danziger Zeitung from the years 1910-27, which listed the programme of Old Town automaton.

We should remember that according to Meyer, the lost manuscript of Eltjen Wolthers included 171 Protestant chorales. We do not know which tradition they represented: Wolthers' original Dutch tradition or the local Gdańsk custom. Given that the manuscript was edited when Wolthers was already resident in Gdańsk for three years, we can assume he was sufficiently familiar with the local practice and requirements of Old Town citizens to set melodies that were familiar to that audience. Wolthers probably also used songs from the first official Danziger Gesangbuch, published in 1719.

The settings of Johann Ephraim Eggert were based upon the second edition of the Gdańsk hymnal, published in 1764. Moreover, Eggert included seven songs

992 DZ 1910, no. 396 (25 August).

993 The last announcement with the programme for the Main Town Hall carillon was published in Danziger Zeitung on 14 January 1928. 
from outside that canon. Since historical sources do not confirm the existence in the nineteenth century of another collection of chorales for the St Catherine carillon, we can assume that Eggert's settings continued to be used until the tragic fire of the church in 1905. This would mean that the order of play of the Old Town automated carillon was based on the same repertoire between 1784 and 1905. Nonetheless, we have no register that would assign songs to the successive weeks of the liturgical year, similarly to the ones that survive for the Main Town Hall carillon.

The reconstruction of the yearly order of play for the St Catherine carillon is only possible after 1910 when the Danziger Zeitung daily started publishing announcements with the titles of two songs set for each successive week on full hours and half-hours. These announcements allow us to state that the repertoire of the Old Town carillon followed a similar evolution to that of the Main Town Hall.

The most significant change was the extension of the repertoire with nonreligious songs. This is notably confirmed by the programming of the popular soldier's song Wir treten zum Beten, which was also featured on the Main Town Hall carillon. No mention of other nonreligious songs could be found in the Danziger Zeitung announcements, ${ }^{994}$ but Wir treten zum Beten, though not programmed too often, did endure in the repertoire of the carillon.

Analysing the religious repertoire programmed from 1910 on the St Catherine carillon, we can see it was combined fairly freely, unlike in previous periods, when the programmes both for the Old Town carillon (as per the Eggert manuscript) and the Main Town Hall (as shown by the Gülich collection and Kaschlinsky register) were strongly linked to official songbooks, published with local practice in mind. In the twentieth-century repertoire of both carillons, songs were included not only absent from the official Evangelical songbook, published in Gdańsk in $1888,{ }^{995}$ but also absent from a later edition edited specially for the Free City of Danzig. ${ }^{996}$ It should be mentioned, however, that from 1910, songs were featured in the programme of the St Catherine carillon from the "Geistliche Volkslieder" (religious folksongs) category, introduced into the Gdańsk hymnal in 1888. In the case of the Old Town carillon, these songs were:

994 Data based on an analysis of announcements in the Danziger Zeitung of 1910-11, 1914-15, 1919-20, 1924-25, and 1926-28.

995 Evangelisches Gesangbuch (Danzig, 1888).

996 Evangelisches Gesangbuch. Ausgabe für... (undated). 
Der beste Freud ist in der Himmel

Ich bete an die Macht der Liebe

Harre meine Seele

Laßt mich gehen

Näher mein Gott zu dir häher zu dir

Nun singet und seid froh

O du fröhliche o du selige

O selig Haus da man dich aufgenommen

Schönster Herr Jesu

So nimm denn meine Hände

Stille Nacht

Wenn ich ihn nur habe

Wie könnt ich ruhig schlafen

From the programmes of both carillons published in the Danziger Zeitung, it is clear that their repertoire differed. The Main Town Hall automaton featured many more songs than that of St Catherine, and while it happened that the same songs were played on both carillons in some weeks, the rule of thumb was a different repertoire for either instrument.

\section{Concert repertoire}

We do not have detailed information about the programmes of the daily or occasional concerts played by the carillonists of St Catherine. With the exception of a single testimony, we do not have other documents supporting the claim that some music other than religious (Protestant) songs were played during such concerts.

According to Friedrich Wilhelm Pfahl's contract of 1840, he was expected to play every day a "Vorspiel" (prelude) followed by two pious songs consistent with the liturgical period. ${ }^{997}$ Also in the contract of Georg Edel, edited on 18 September 1924, there is mention of concert programmes. The carillonist was expected "as a rule" ("im Regel") to present chorales and religious folksongs ("Geistliche Volkslieder"). ${ }^{998}$ These contracts thus indicate that the repertoire of daily concerts throughout the operation of the Old Town carillon was identical to the programmes of automated play. During Advent concerts on the last Saturday of the liturgical year, chorales were also played.

Those daily concerts, scheduled between the half-hourly cycles of automated play, lasted probably around twenty minutes. During that time, the carillonists could perform several chorale settings by Johann Ephraim Eggert (for example 
five compositions from the "Lieder zur ganzen Stunde" group or more from the "Lieder zur halben Stunde" chapter). They could also opt against the Eggert settings, choosing instead to improvise on the theme of one or more chorale melodies. Each carillonist of St Catherine (except Walter Krieschen) was a trained musician: all played the organ and clearly had the ability to freely improvise on bells as well.

It is worth remembering that Georg Edel's composition for the carillon, Thema mit Variationen, Improvisationen über Choräle, was also based on chorale. The monolithic repertoire of concert play was disrupted only once. During a concert in late October 1938 within the Ostdeutsche Kirchenmusiktagung programme, Edel performed the Glockensonate, an arrangement of a sonata by Handel. It is the only information I have found about the performance on the Old Town carillon of music not based on Protestant melodies. 


\section{Structure of the works of Johann Ephraim Eggert}

The title of Johann Ephraim Eggert's collection: Choral-Lieder zu dem GlockenSpiel der Altstädtschen Ober-Pfarr-Kirche zu St: Catharinen ausgesetzt mit Variationes, suggest unambiguously that the works it contains should be variations. Indeed, from amongst the 130 works to be played on full hours, no fewer than 124 are in variation forms. Six follow different forms: five are chorale preludes and one is a simple monophonic chorale setting. In the group of 128 compositions to be played on half-hours, most are also variations or chorale preludes, but the proportions between the two groups are different compared to full-hour compositions: variations make up less than $25 \%$ of this subset. This ratio is due to the technical parameters of the automated carillon: for the "Lieder zur halben Stunde," about half the duration on the carillon drum was available compared to the full-hour compositions. On 35 slats (equivalent to 35 bars in duple metre), only relatively short compositions could be programmed, lasting around ninety seconds. Given this, Eggert could only set short songs in variation forms, while longer ones could only be composed as chorale preludes.

The strict duration limit of compositions, set by the space available for their programming on 75 or 35 slats of the drum, was a significant limitation to the composer. The chorale selected for setting could not be freely transformed, and the duration of the melody determined the choice of musical form. In the case of six longer songs of a dozen or more verses each, Eggert deemed a variation setting could not fit within the 75 slats of the carillon drum, and set them for full hours only, dropping the variation form and opting in five cases (Ich grüße dich am Kreuzesstamm, no. 21; Herr Gott dich loben wir, no. 80; Herzlich lieb hab' ich o Herr, no. 88; Gott der Vater wohn' uns bei, no. 99; and Verleih uns Frieden gnädiglich, no. 250) for the chorale prelude form, and in one (Mitten wir im Leben sind, no. 100) for the monodic song form.

The duration of the chorale's cantus firmus also determined the number of variations that followed. Over 70 works for full hours only have one section; the remaining number, based on short chorales of four or five verses, have three or four variations. On the other hand, in almost all compositions to be played on half-hours, the theme is only varied once. The various units of variation form are separated graphically with the abbreviations "2te V," “3te V," “4te V," (second, third, fourth variation) or a double barline, though some notations lack the appropriate sign. 
Johann Ephraim Eggert carefully planned the narrative of both his variations and preludes. The technical characteristics of the automated carillon forced him to limit the duration of his works. He compressed them, using metre as a tool. Instead of duple metre, he used triple metre, decreasing the basic pulsation value of the chorale melody from a minim to a dotted crotchet. In this way, he modified the theme in three works for full hours: Was soll ich liebster Jesu du (no. 17), Mein Heiland nimmt die Sünder an (no. 96), and Wacht aufruft uns die Stimme (no. 5) as well as many settings for half-hours. A large number of variation units for full hours and half-hours are also written in triple metre, as are several preludes for half-hours such as Ein Kindelein so löbelich (no. 126) and Ein Lämmlein geht und trägt die Schuld (no. 136). ${ }^{999}$ Amongst works for half-hours, there are examples where Eggert used the narrative-shortening triple metre only in the first part of the chorale. There are also counterexamples, such as the variations on Es spricht der Unweisen Mund (no. 58), where Eggert extended the pulsation value of the melody from a minim to a dotted minim to adapt the work's duration to 75 slats.

\section{Variations for full hours}

The compositions of Eggert belong to the cantus firmus variation type, where the themes are borrowed from the melodies of Protestant songs. The theme is almost always presented monodically, usually in the lower register, thus beginning in the small octave. Following the spirit of this time, Eggert often ornamented the main melody with appoggiaturas, turns, or trills. He added passagework between phrases, and embellished final cadences with three- or four-note chords, preceding them with ascending quaver progressions or broken tonic chords (Example 39).

There were exceptions from the above rule. A two-voice structure appears in the presentation of the song Warum sollt' ich mich denn grämen (no. 77) when the melodic phrases start to repeat. Eggert introduces a counterpoint based on his signature figure: a rest followed by three quavers (Example 40).

Another departure from the rule of beginning variations with a monodic presentation of the chorale is the practice of placing an elaborate introduction ("Vorspiel") before the theme, as happens in O Christe Morgensterne (no. 115). This introduction lasts no less than half the total duration of the composition and is written in a contrasting metre to the successive variation theme. It begins with motifs in opposed registers. This way of building a narrative, often employed in compositions for the carillon, was adopted by Eggert also in the later phases of the introduction (Example 41).

999 Both chorales for full hours (no. 8 and no. 14) are notated in duple metre. 

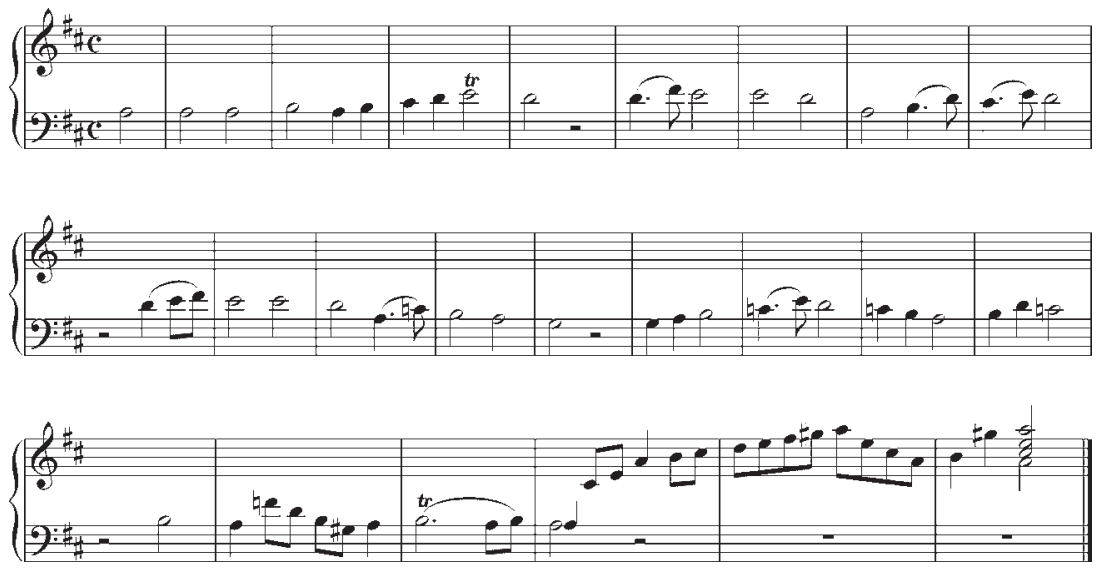

Example 39: J. E. Eggert, Dies sind die heil'gen zehn Gebot', no. 61, bars 1-24
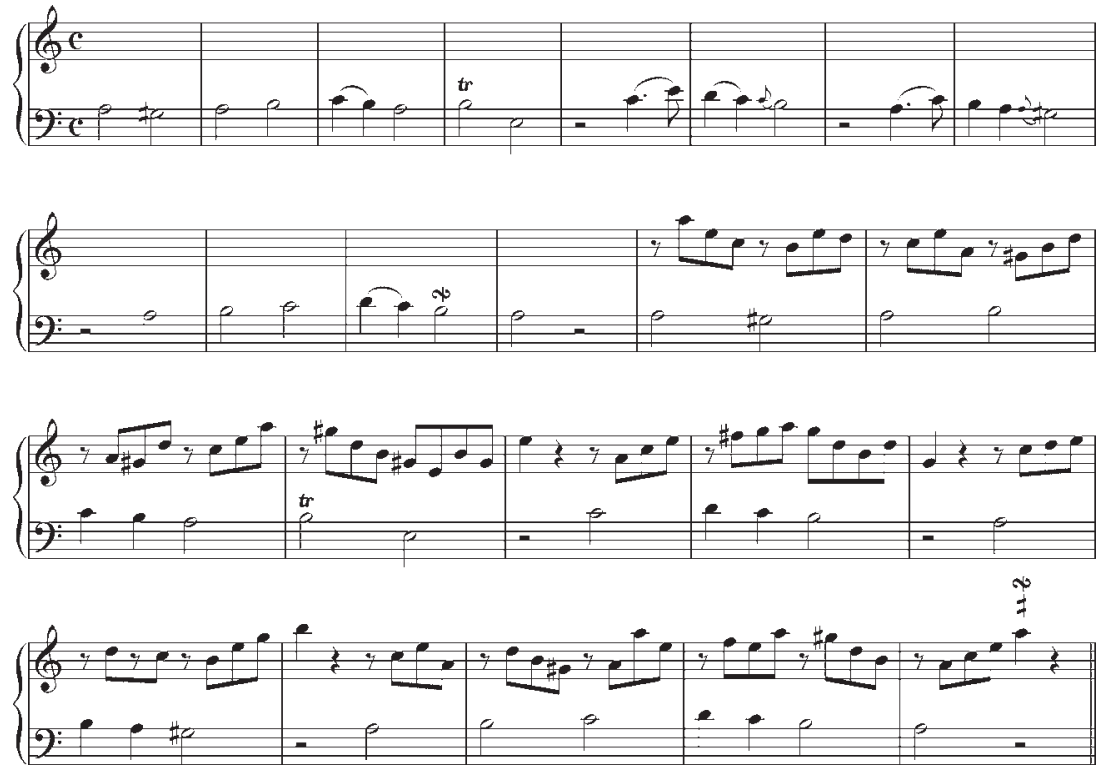

Example 40: J. E. Eggert, Warum sollt' ich mich denn grämen, no. 77, bars 1-24 


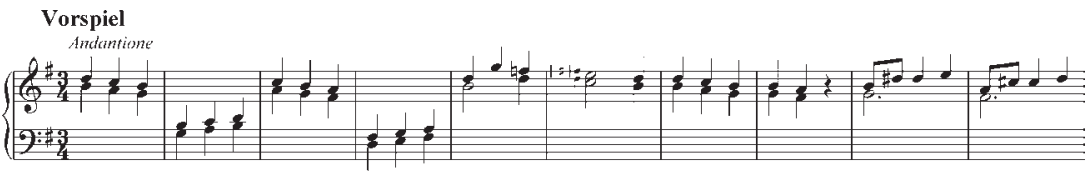

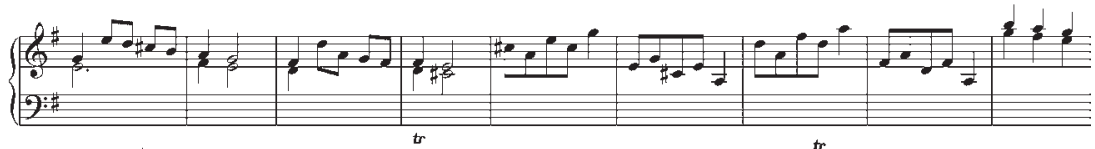

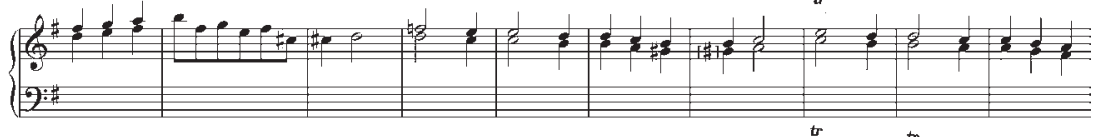

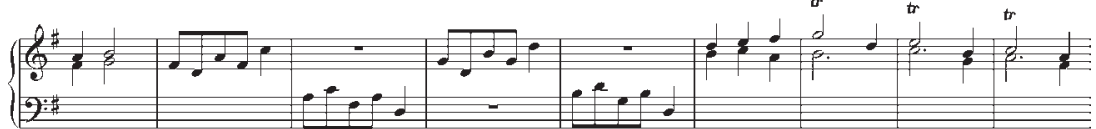

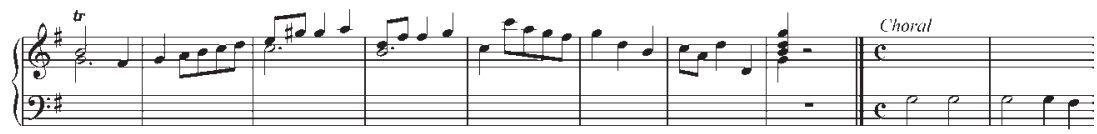
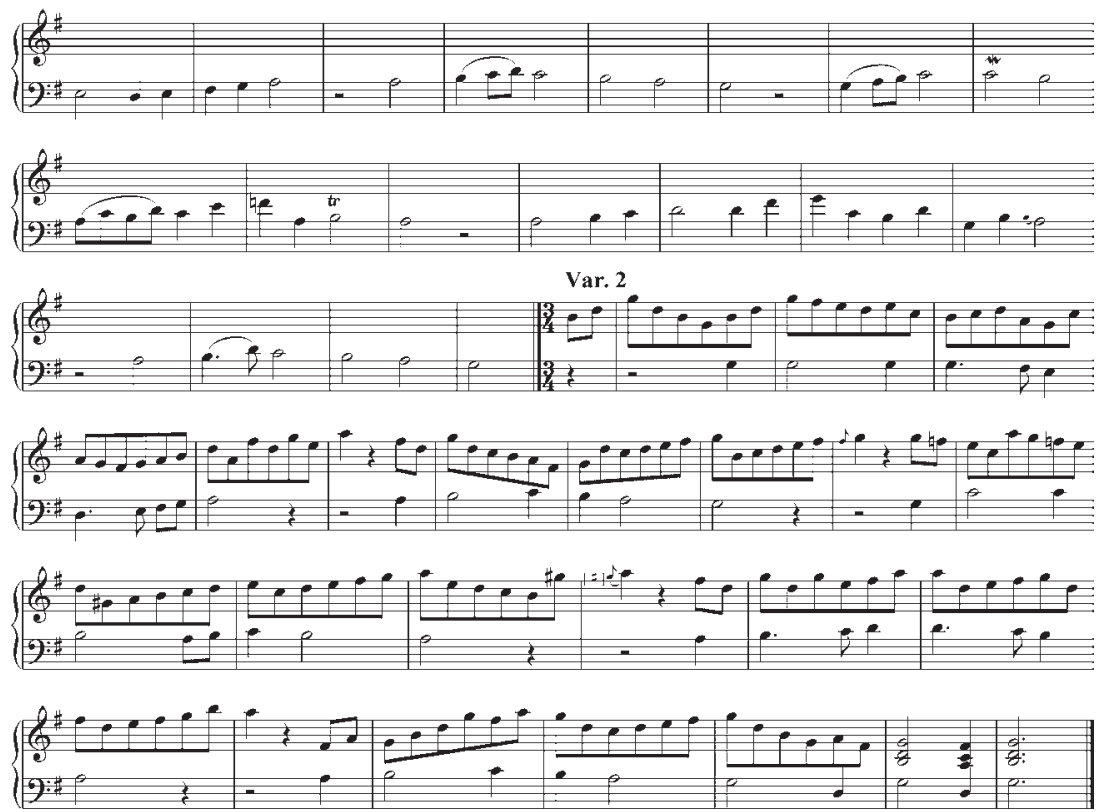

Example 41: J. E. Eggert, O Christe Morgensterne, no. 115 
Eggert's variations are written predominantly in a two-voice texture. Only in one composition did he adopt a three-voice counterpoint consistently: the variations on Es ist gewißlich an der Zeit (no. 109). In that piece, the upper voices (played on the manual keyboard in concert play) move in dyads, while the lower voice, played on the pedal keyboard, leads the cantus firmus melody. Eggert preferred a wide rather than narrow disposition of voices, as was natural given the instrument's specificity, though he also recurrently used progressions of parallel thirds and sixths. Building his forms, he endeavoured to maintain selective timbre, emphasising it with frequent register changes and emphasising with rhythmic contrasts between the variation units. He placed the chorale melody most often in the lower voice.

The primary means of variations technique as used by Eggert were changes of the texture: from monodic to two-voice and from figurative to nonfigurative.

The change of the texture from monodic to two-voice follows the theme's presentation. The first variation (or a successive variation where the first one is also monodic) most often displays a two-voice texture. This device ensures a significant timbral contrast and clearly differentiates the work's narrative. The same function of textural contrast is played by monodic phrases, which Eggert called interludes (intermezzos), embedded into three variation sets: Was soll ich liebster Jesu du, ad Interludium, Auf Seele, nimm die Glaubens Flügel (no. 17), So wahr ich lebe spricht dein Gott ad Interludium, Ach was soll ich Sünder machen (no. 66), and Auf, auf mein Hertz mit Freuden, Interm[edio] Jesus lebt, mit ihm auch ich (no. 245).

The change of the texture from figurative to nonfigurative is used either in successive variation units or within a single unit in the successive phrases or sections.

The two-voice texture dominating in the variations of Johann Ephraim Eggert encourages their analysis with the use of Johann Joseph Fux's manual of counterpoint, which codified the principles of late baroque musical composition. Despite the harmonic and tonal changes that happened especially in secular music throughout the eighteenth century, religious works often remained written in a more traditional sacred style, closely related to historical rules of voice leading. ${ }^{1000}$ According to the rules set in Fux's manual Gradus ad Parnassum, the phrases, sections, and units of Eggert's variation forms written in figurative textures are none else than the second or third genre of

1000 Chomiński, Historia harmonii i kontrapunktu, 3:91. 
counterpoint, while nonfigurative phrases, sections, or units follow the first, second, or fifth genre. ${ }^{1001}$

Other means of variation technique adopted by Eggert include changes of the register of the cantus firmus, melodic, rhythmic, and metrical modifications of the theme, additions such as linking phrases, contrasting metres between the cycle's phrases or units, or disruptions to the homogeneity of the sound material through the addition of interludes. Eggert often chose one of those means and based the concept of successive variational units on it. This allows us to identify the following variation types within his output:

1. Variations based on repetitions of the theme

2. Figurative variations

3. Nonfigurative variatioons

4. Variations with a mixed texture

5. Variations with interludes

\subsection{Variations based on repetitions of the theme}

A simple variation-building device is a repetition of the theme an octave higher. Eggert construed only the first unit in two- or three-unit cycles in this way. $\mathrm{He}$ did use this unrefined device no fewer than nineteen times. He embellished the transposed theme slightly, adding trills, mordents, and turns, filling the diminution with intervallic leaps and dividing minims, which in his compositions constitutes the basic pulsation value of the chorale melody, into rhythmic figures of a dotted crotchet and quaver. Eggert used this dotted rhythm so often that it can be considered the most characteristic element of his compositional technique (Example 42). Sometimes, as in Herzliebster Jesu was hast du verbrochen (no. 20), he introduced a short connecting phrase between the phrases of a transposed cantus firmus. He also ornamented endings of one-voice variations with quaver progressions or chords. In the variations Heut triumphieret Gottes Sohn (no. 30) and Herr Christ der einig' Gottes Sohn (no. 53), alongside a change of register, he changed the melody's metre after its first appearance.

\subsection{Figurative variations}

Figurations are the dominant means of variation technique in Eggert's compositions but are confined to the counterpoint. It is either melodic or

1001 Fux, The Study of Counterpoint. 

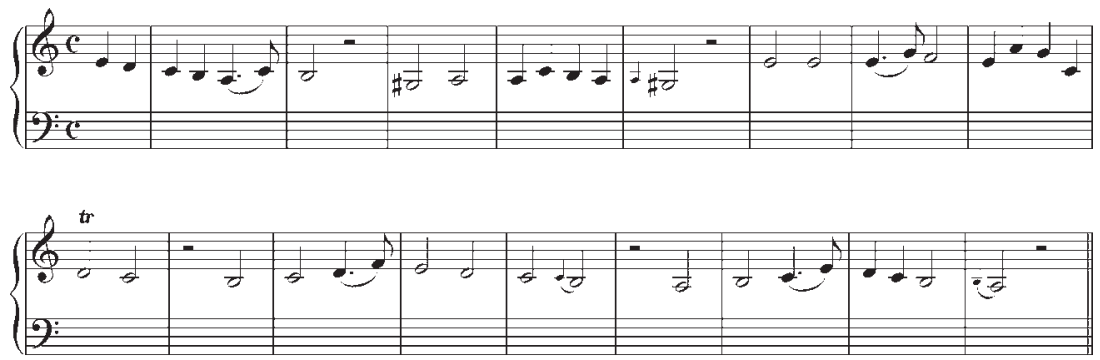

Var. 2
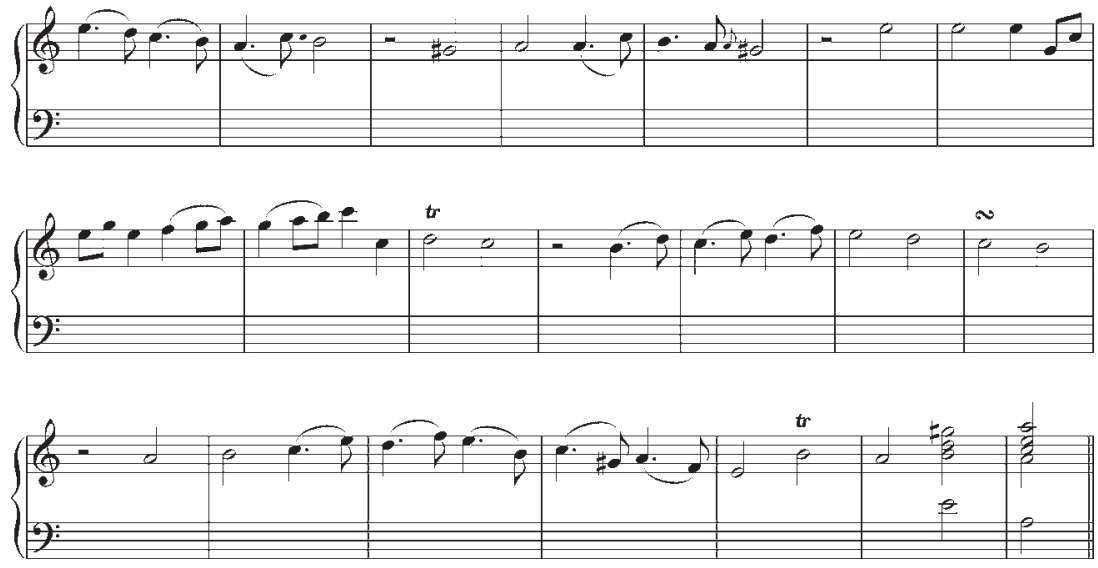

Example 42: J. E. Eggert, O Traurigkeit o Herzeleid, no. 27

harmonic - it is difficult to estimate which of these options Eggert used more often. In figurative variations, the cantus firmus is repeated in the lower voice, in principle in its original form. The theme remains recognisable even when it is modified through small diminutions, ornaments, changes of register or metre.

The most distinctive form of figurative variation consists of a repetition of the theme, accompanied by a counterpoint in the upper voice, based on continuous quaver motion or with a rest at the beginning of each pulsation unit: a quaver rest before a group of three quavers. Such counterpoints can be found in several compositions with a single variation, for example in O Herre Gott dein göttlich' Wort (no. 55) and Mein Jesu dem die Seraphinen (no. 78). In multiunit variations, figurative counterpoint is used within single units (Example 43). 

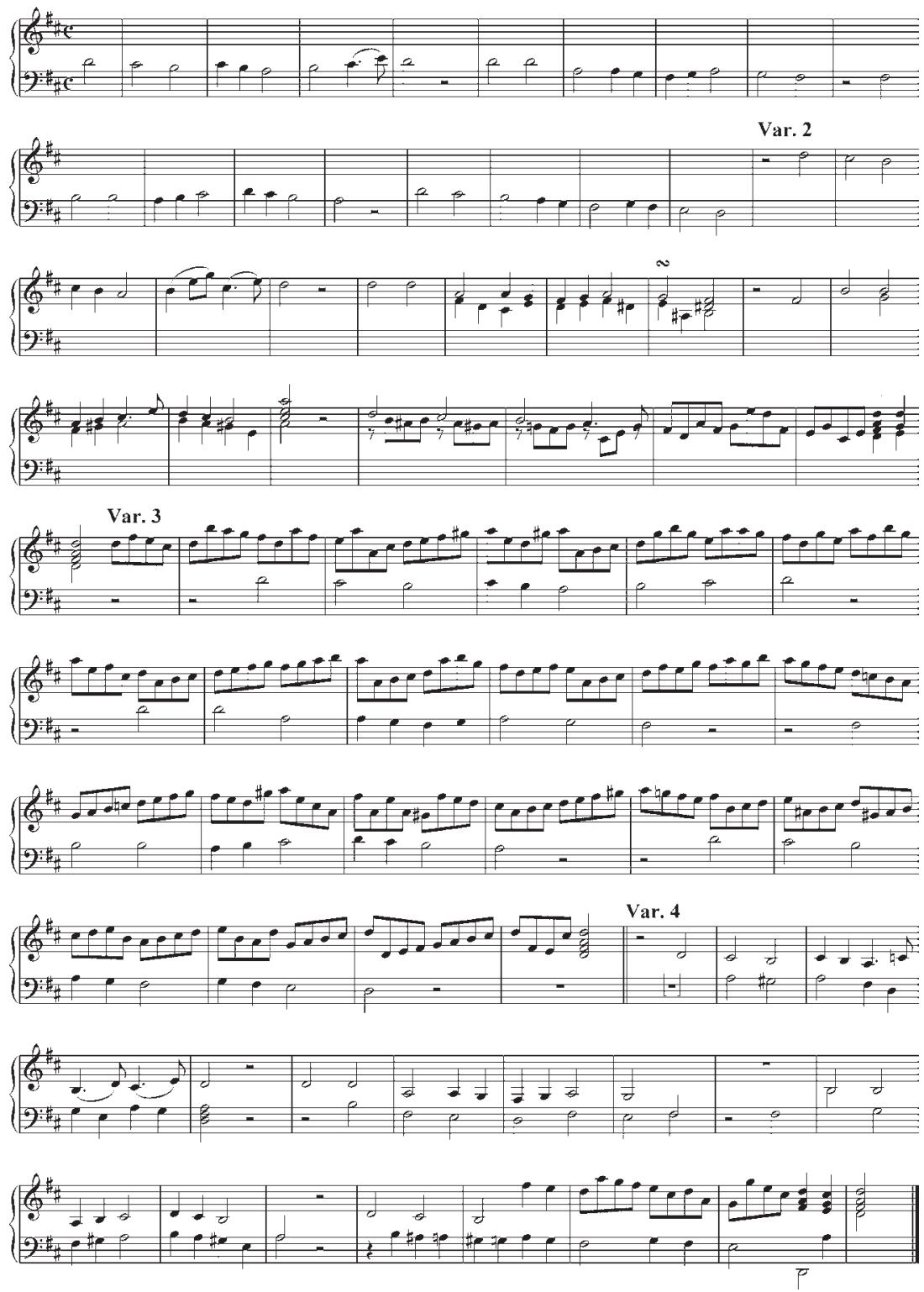

Example 43: J. E. Eggert, Vom Himmel hoch da komm' ich her, no. 12 


\subsection{Nonfigurative variations}

A nonfigurative texture is less typical of Eggert's variations. Phrases are developed according to the first or second counterpoint genre, but more often they assume the form of free homorhythmic structures. We also find progressions of parallel thirds and sixths. The cantus firmus in nonfigurative variations, contrarily to figurative ones, is usually placed in the upper voice. Examples of singleunit variation with nonfigurative counterpoint exclusively include Dein Mittler kommt aufblöde Seel' (no. 50) and In dulci jubilo (no. 11). The latter composition is especially noteworthy, as Eggert employs a device characteristic of his compositional style and, more generally, carillon technique, based on a succession of register-contrasting phrases (Example 44).

Timbral contrast, reinforced by metric and rhythmic oppositions, lies at the basis of the variations on Valet will ich dir geben (no. 107). The chorale's successive phrases are set in a simple, homorhythmic way, first in triple metre in the higher octave, then an octave lower in duple metre. In nonfigurative variations, Eggert sometimes used imitations, often supported by diminution, as in Herr ich denk' an jene Zeit (no. 102, Example 45).

\subsection{Variations with a mixed texture}

Many of Eggert's variations have a mixed texture. The composer would choose one type of texture (figurative or nonfigurative) and depending on his concept, would use it to set a phrase or linking phrase. In such works, the cantus firmus often moves freely, migrating from the upper to the lower voice or vice versa (Example 46). A mixed texture can be found within a single variation, for example in Es ist das Heil uns kommen her (no. 52) and Wo Gott der Herr nicht bei uns hält (no. 59).

Some units of mixed-texture variations are additionally virtuosic in style, which precluded their automated play. In the compositions Nun danket alle Gott (no. 82) and Ach höchster Gott verleihe mir (no. 84), such features include scale passages in semiquaver motion.

\subsection{Variations with interludes}

Amongst the myriad variations included in the Eggert collection, a particularly relevant group consists of eleven works with characteristic titles, indicating the use of interludes. 

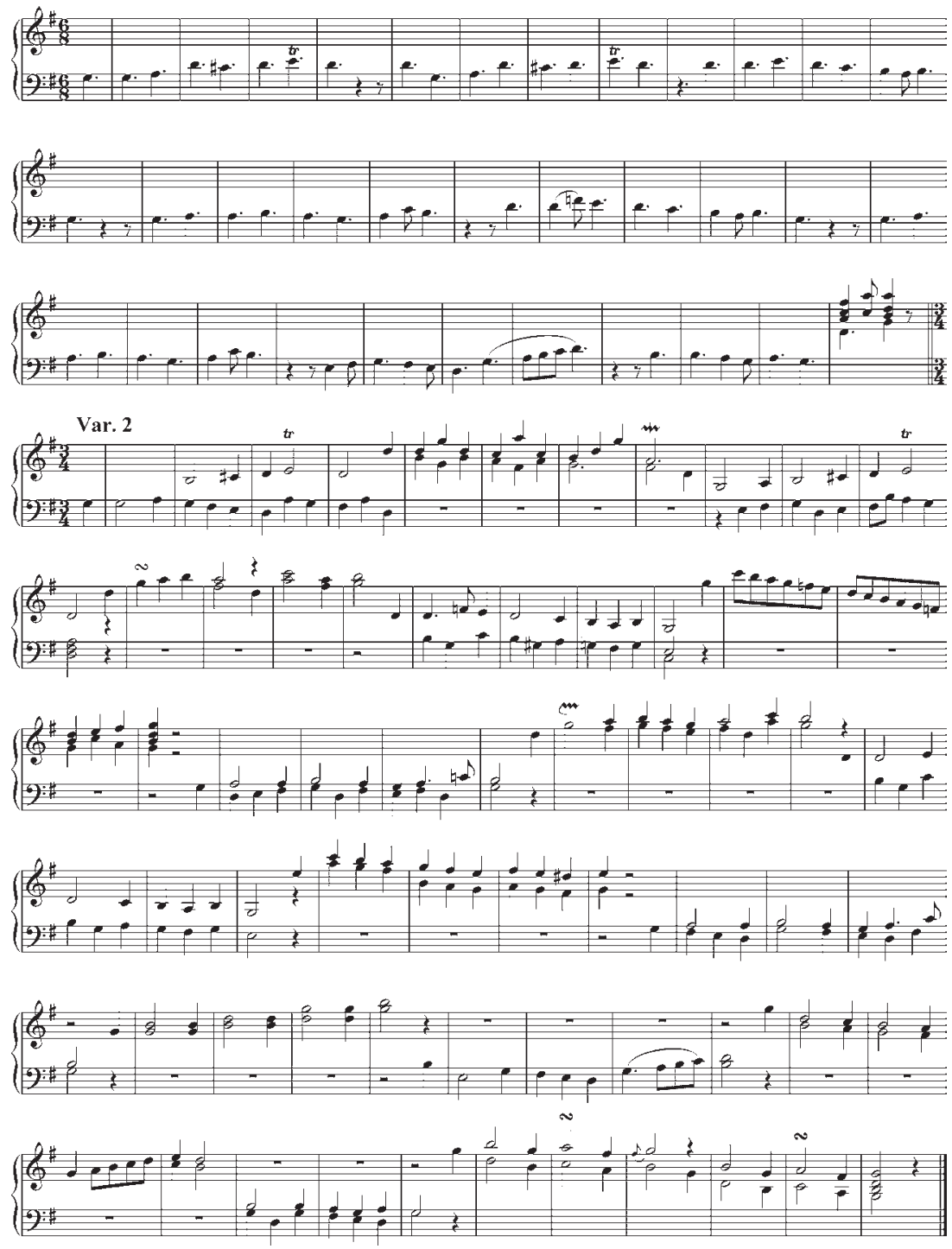

Example 44: J. E. Eggert, In dulci jubilo, no. 11 

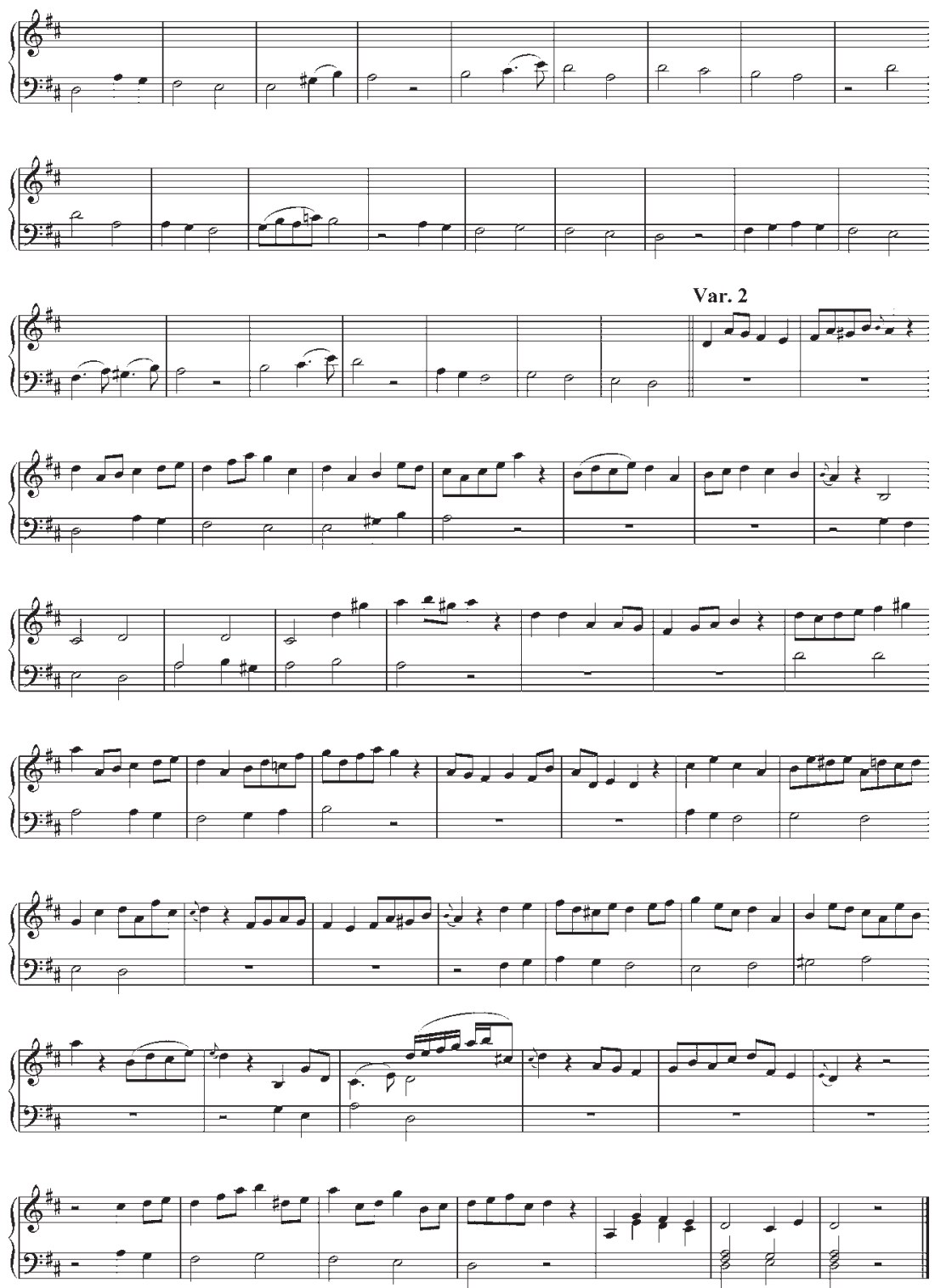

Example 45: J. E. Eggert, Herr ich denk' an jene Zeit, no. 102 

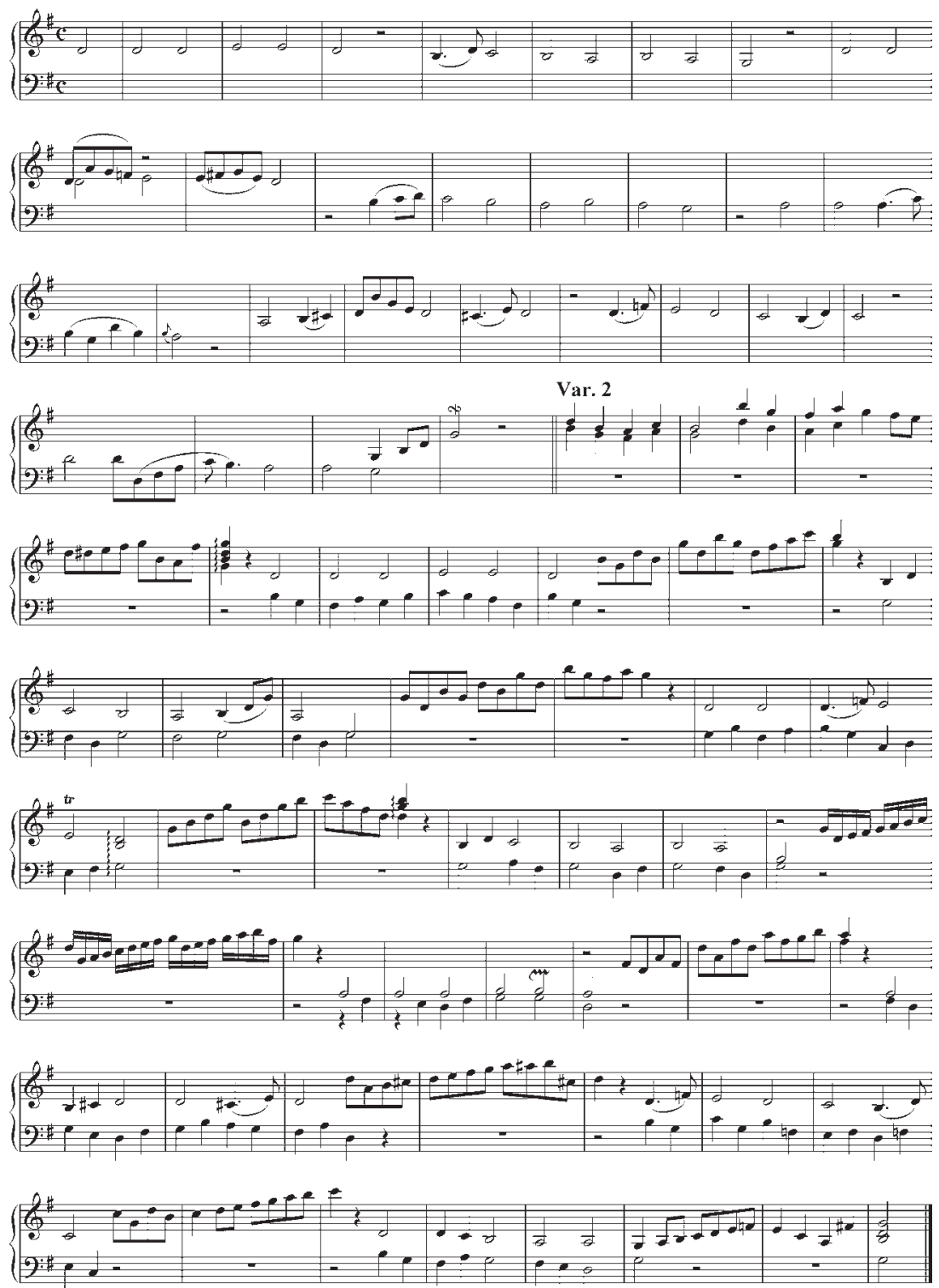

Example 46: J. E. Eggert, Nun danket alle Gott, no. 82 
Tab. 41: Works by J. E. Eggert that include interludes

\begin{tabular}{|c|c|c|}
\hline No. & $\begin{array}{l}\text { Work no. in } \\
\text { manuscript }\end{array}$ & Work title in manuscript \\
\hline 1 & 13 & $\begin{array}{l}\text { Mit Fried und Freud ad Intermedio Was sorgst du ängstlich für dein } \\
\text { Leben, Bachs Mel[odie] }\end{array}$ \\
\hline 2 & 17 & $\begin{array}{l}\text { Was soll ich liebster Jesu du, ad Interludium, Auf Seele, nimm die } \\
\text { Glaubens Flügel }\end{array}$ \\
\hline 3 & 18 & $\begin{array}{l}\text { Weg Welt mit deinen Freuden, ad Interludium Erforsche mich, erfahr } \\
\text { mein Herz, Bachs Mel[odie] }\end{array}$ \\
\hline 4 & 32 & Jesus lebt, mit ihm auch ich: ad Interludium Bachs Mel[odie] \\
\hline 5 & 45 & $\begin{array}{l}\text { Der Herr der aller Enden, ad Interlud[ium] O Herr meine Gott durch } \\
\text { den ich bin und lebe, Bachs Mel[odie] }\end{array}$ \\
\hline 6 & 46 & Herr dein Allmacht reicht so weit, als: \& Interludium. \\
\hline 7 & 65 & $\begin{array}{l}\text { O! wie mögen wir doch unser Leben, ad Interl[udium]: Was sorgst du } \\
\text { ängstlich für den Leben? Bachs Mel[odie] }\end{array}$ \\
\hline 8 & 66 & $\begin{array}{l}\text { So wahr ich lebe spricht dein Gott ad Interludium, Ach was soll ich } \\
\text { Sünder machen, }\end{array}$ \\
\hline 9 & 92 & $\begin{array}{l}\text { Was Gott thut, das ist wohlgeth[an] ad Interl[udium] O! Herr mein } \\
\text { Gott, durch den ich bin und lebe, }\end{array}$ \\
\hline 10 & 101 & $\begin{array}{l}\text { Mit Fried und Freud, ad Interm[edio] Was sorgst du ängstlich für } \\
\text { dein Leben }\end{array}$ \\
\hline 11 & 245 & $\begin{array}{l}\text { Auf, auf mein Hertz mit Freuden, Interm[edio] Jesus lebt, mit ihm } \\
\text { auch ich }\end{array}$ \\
\hline
\end{tabular}

The interludes in five compositions (nos. 13, 18, 32, 45, and 65) are, consistently with their titles, Bach melodies. They do not, however, originate from the most famous Bach: Johann Sebastian, but from the family representative who enjoyed the greatest fame in the eighteenth century: Carl Philipp Emanuel Bach. They are borrowed from the song collection titled Herrn Prof. Gellerts geistliche Oden und Lieder, first published in Berlin in 1758 by Georg Ludwig Winter. ${ }^{1002}$ This was the first and likely the most renowned edition of Carl Philipp Emanuel Bach's songs. It was reprinted three times, in 1759,1764 , and 1771 , while in 1784, it was also published by the Leipzig publishing house of Johann Gottlob Immanuel Breitkopf. ${ }^{1003}$

1002 RISM A/I/1 B-122; Wq 194.

1003 RISM A/I/1 B-123, 124, 125, 126. A copy of this collection held at the PAN BG (cat. no. Ee $16794^{\circ}$ ) which I consulted lacks the original title page. The title was written by hand in black ink "Herrn Prof. Gellerts Geistliche Oden ünd Lieder mit Melodien von Carl Philipp Emanuel Bach. [4. Aufl.?] Berlin: G. L. Winter [1771?].” 
The texts set by Carl Philipp Emanuel Bach were authored by the highly esteemed poet and religious moralist, Christian Fürchtegott Gellert. His verses, due to their high spirituality and moral message, quickly won recognition amongst Protestant audiences. In his introduction to the volume, Gellert emphasised the importance of music in human life, pointing its power and capacity to reinforce the meaning of words; he thus encouraged composers to set his poetry to music. Carl Philipp Emanuel Bach became interested in texts from the Geistliche Oden und Lieder collection and composed music to them within a year of publication. ${ }^{1004}$

The structure of all Eggert's variations that include Bach interlude is similar. After a monodic presentation of the chorale indicated in the composition's title, the first verse of Carl Philipp Emanuel Bach's song is quoted. Subsequently, the first verse of the main chorale appears as a variation, followed by the second verse of the Bach song. The successive narrative follows this pattern, alternating variations on the chorale and quotes from the Bach songs (see examples 47 and 48).

In the course of the variations, the fragments borrowed from Carl Philipp Emanuel Bach are sharply distinguished, as their texture differs from Eggert's straightforward chorale variations. This was clearly the purpose of these compositions: he endeavoured to showcase and not hide Bach's music.

The composition number 32 invites an explanation. In its title, Jesus lebt, mit ihm auch ich: ad Interludium Bachs Mel[odie], the incipit is given of only one song. The structure of these variations is as follows: the composition opens with a monodic presentation of the melody Jesus meine Zuversicht, which in the eighteenthcentury Gdańsk canon of Protestant song (Danziger Gesangbuch, Danzig 1764) is indicated as appropriate for the text of Christian Fürchtegott Gellert, Jesus lebt mit ihm auch ich. ${ }^{1005}$ Successive fragments are built similarly to works no. 13, 18, 45, and 65 , but in this case, the variations on the Jesus meine Zuversicht chorale alternate with verses from Bach's song Jesus lebt mit ihm auch ich.

Quotations from Carl Philipp Emanuel Bach's collection Herrn Prof. Gellerts geistliche Oden und Lieder, embedded as interludes into the variationally set chorales, can also be found in two other compositions by Eggert whose titles do not refer to Bach: Mit Fried und Freud, ad Interm[edio] Was sorgst du ängstlich

1004 Hryszczyńska, 'Gellert Christian Fürchtegott', 258-59.

1005 Danziger Gesangbuch (Danzig, 1764), 830. See also Popinigis et al., Music Collections from Gdańsk 1. 


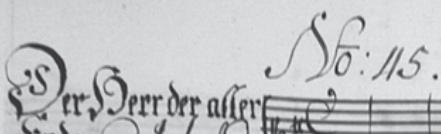

S.nden ad Anlerud.

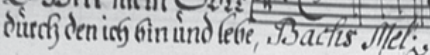

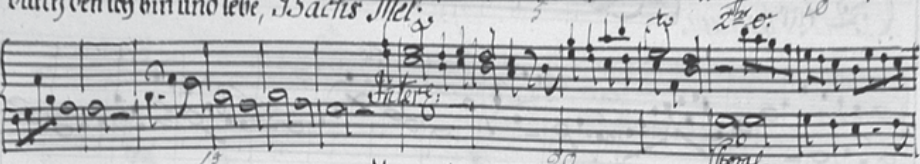
$\frac{x^{3}}{20}$

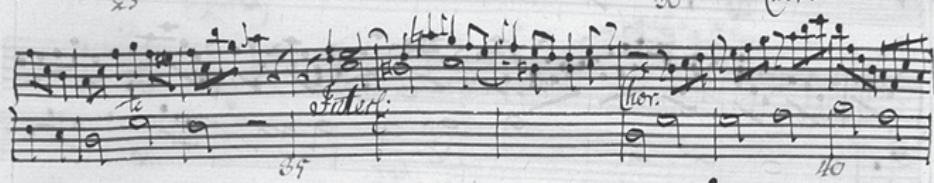

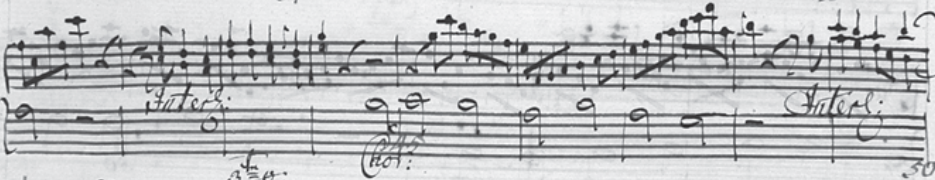
(1)

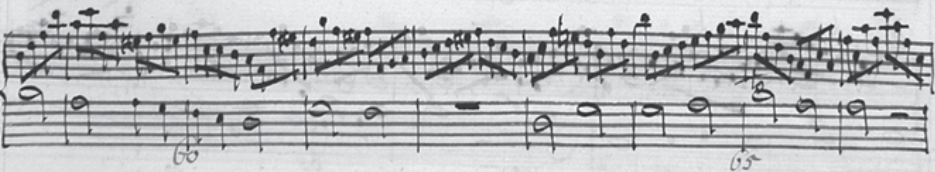

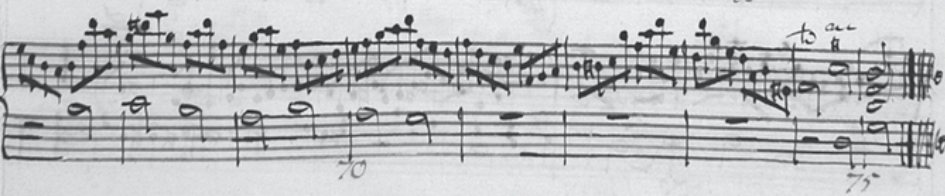

Fig. 94: Manuscript of J. E. Eggert. APG 300,R/Pp,45, p. 47 

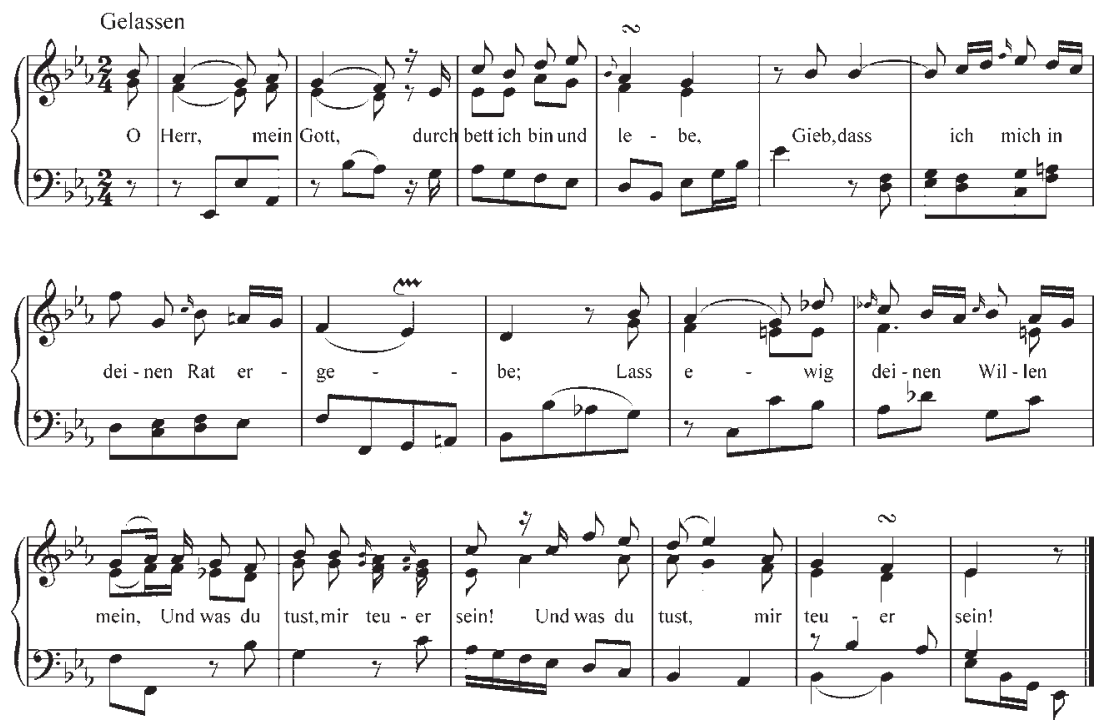

Example 47: C. Ph. E. Bach, O Herr meine Gott durch den ich bin und lebe

für dein Leben (no. 101) and Was Gott thut, das ist wohlgeth[an] ad Interl[udium] O! Herr mein Gott, durch den ich bin und lebe (no. 92); the former is actually a copy of another composition, no. 13.

Bach's songs are essentially composed in a three-voice texture. Eggert quotes consistently only the two upper voices. There were three reasons for such a choice. First, many notes of Bach's bass lines fell beyond the scope of Gdańsk's Old Town carillon. Second, quoting only the two upper voices made Carl Philipp Emanuel Bach's song more recognisable. Third, it cannot be excluded that Eggert planned the variations with interludes to be performed in concert, so the reduced texture of the Bach quotes made their performance easier.

The reduction of voices is not the only changed introduced by Eggert into his Bach quotations. He also uniformised their metres and keys, adapting both elements to the chorale that formed the basis for the variations. He renounced many ornaments that abounded in Carl Philipp Emanuel Bach's songs, although at times, he introduced his own embellishments where Bach had none. Still, a question arises concering Eggert's variations with quotations from Carl Philipp Emanuel Bach's songs to texts by Christian Fürchtegott Gellert: Whose popularity did these compositions illustrate, Bach's or Gellert's?

Bach enjoyed quite some recognition in Gdańsk, which comes as no surprise knowing the vivid reception of his output generally throughout northern and 

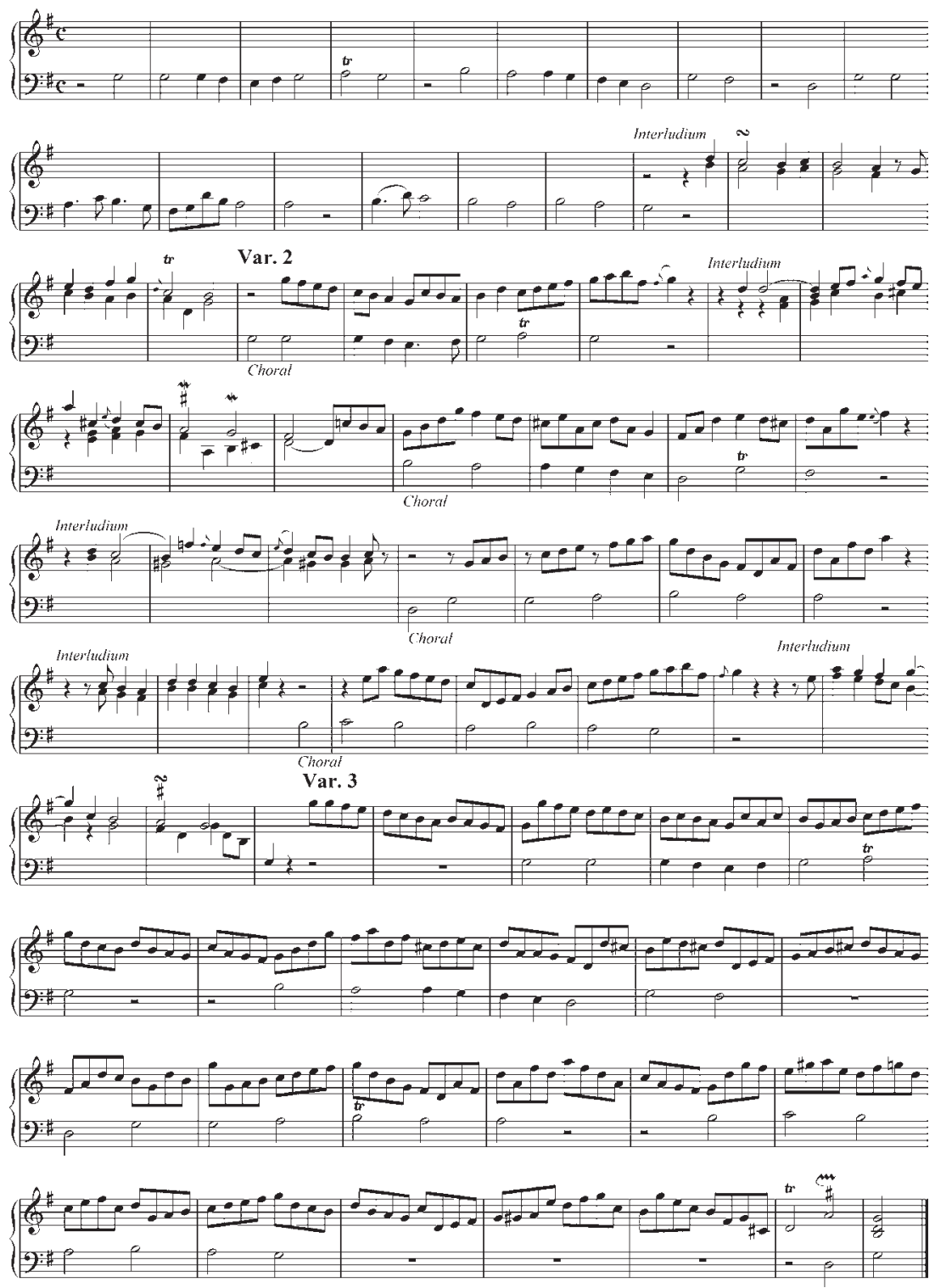

Example 48: J. E. Eggert, Der Herr der aller Enden, ad Interlud[ium]: O Herr meine Gott durch den ich bin und lebe, Bachs Mel[odie], no. 45 
central Europe. His music was performed in Gdańsk at numerous concerts and people even subscribed to scores of his compositions. ${ }^{1006}$

One of the most useful sources on the concert life of Gdańsk in the latter half of the eighteenth century is a brochure by Johann Daniel Glummert (1734-88), Briefwechsel über Danziger Musik und Musiker, published in Berlin in 1785. The author, a writer, poet, composer, and conductor, ${ }^{1007}$ quotes concert programmes from the 1781/82 winter season, which ran in Gdańsk from 12 November to 15 April, together with names of performers. ${ }^{1008}$ Amongst the twenty-one concerts that took place in that period, the works of Carl Philipp Emanuel Bach were presented no fewer than twelve times. Mostly his piano concertos were played in Gdańsk, but on 3 December 1781, also his oratorio Die Israeliten in der Wüste was presented, one of several occasions: it was performed in the days preceding Christmas in 1776, 1777, 1778, and 1784. The work was presented at the Gdańsk Academic Gymnasium, with the musical ensemble formed by that school's students, directed by the local cantor, Carl Friedrich Bartholdi. ${ }^{1009}$ It should be emphasised that Die Israeliten in der Wüste was not Carl Philipp Emanuel Bach's only oratorio to be performed in Gdańsk: another was Auferstehung und Himmelfahrt Jesu. ${ }^{1010}$

Further data on the presence of Carl Philipp Emanuel Bach's works in Gdańsk concert programmes is supplied by announcements in the local press and advertisements for the subscription of his works. ${ }^{1011}$ Subscriptions were notably offered by Friedrich August Klügling, a pianist well known in Gdańsk, concert organiser and organist at St Peter and Paul's. ${ }^{1012}$ We even know the individual purchasers of the different collections, as a list of subscribers was habitually added to printed musical editions. For example, two parts of another popular collection of Bach songs, Geistliche Gesänge mit Melodien of 1781 to texts by Christoph Christian Sturm, were ordered by the following people: Baronofski, Brömer (pastor), Johann Gottfried Ewert (organist at St John's), Kliewer, Lüdecke

1006 About the reception of Carl Philipp Emanuel Bach's music in Gdańsk, see Popinigis, 'Die Rezeption des Schaffens C. P. E. Bachs', 57-58; Kostka, 'Die Musik Carl Philipp Emanuel Bachs', 342-53.

1007 Chojnacki, 'Glummert, Jan Daniel', 84.

1008 Concert programmes for the $1781 / 82$ season are quoted after Glummert also by Rauschning, Geschichte der Musik und Musikpflege in Danzig, 392-95.

1009 Popinigis, 'Gimnazjum Gdańskie i muzyka', 290.

1010 Kostka, 'Die Musik Carl Philipp Emanuel Bachs', 353.

1011 For example, DaNa 1787, Nr. 11 (17 March), 102; DaNa 1787, Nr. 12 (24 March), 112.

1012 Rauschning, Geschichte der Musik und Musikpflege in Danzig, 390-91, 404, 422. 
(organist), Rorz, Siehl, Thiel, Wagner, and one miss Z. ${ }^{1013}$ Compared to the list of subscribers in Hamburg, which included over 200 names, ten music lovers in Gdańsk are of course a small number, but they testify again to the vivid reception of Carl Philipp Emanuel Bach's music in the Baltic city. The collection Herrn Prof. Gellerts geistliche Oden und Lieder, from which the quotations in Eggert's compositions originate, belonged to Theodor Friedrich Kniewel (1783-1859), a theologist well-known in Gdańsk, professor of the local Gymnasium, musician, and composer. ${ }^{1014}$

The strong influence of Carl Philipp Emanuel Bach's music on the output of Eggert finds further confirmation in the fact that he used the melodies from Herrn Prof. Gellerts geistliche Oden und Lieder in several other compositions:

Gott ist mein Lied! er ist der Gott (no. 42, 165)

Du bist's dem Ruhm und Ehre (no. 43, 166)

Herr lehr mich wenn ich der Tugend diene (no. 241)

O Herr mein Gott durch den ich bin und lebe (no. 257)

In these works (except for Herr lehr mich wenn ich der Tugend diene, no. 241), Bach's melodies serve as the constructive base of variations. They are initially presented in monodic version, with Eggert even keeping Bach's original ornaments. In the first unit, Eggert cites more or less directly the two upper voices of Bach's original, while subsequently setting the song's melody with the use of standard variational means (Examples 49 and 50).
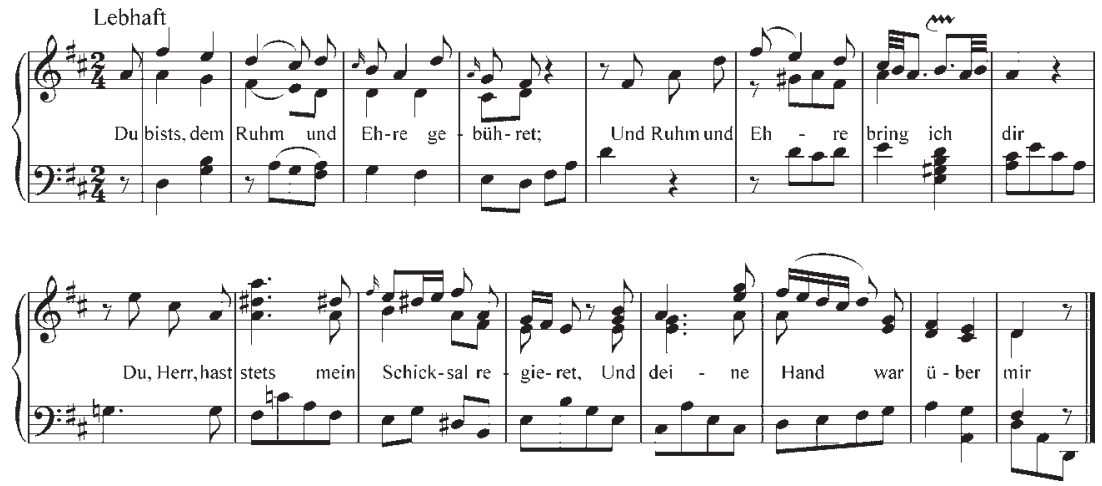

Example 49: C. Ph. E. Bach, Du bist's dem Ruhm und Ehre

1013 RISM A/I/1 B-132, 136; PAN BG Ee 1677 4.

1014 The older cover lining of the copy held at the PAN BG (cat. no. Ee $16794^{\circ}$ ) features a signature of the collection's owner: "Dr. Kniewel Ged." and a catalogue number on 


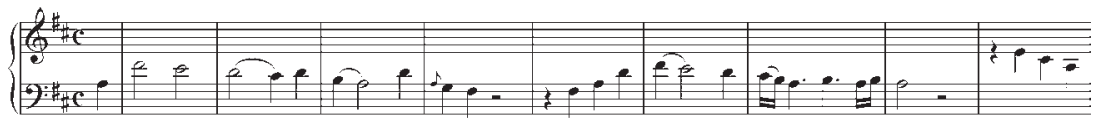
Var. 2

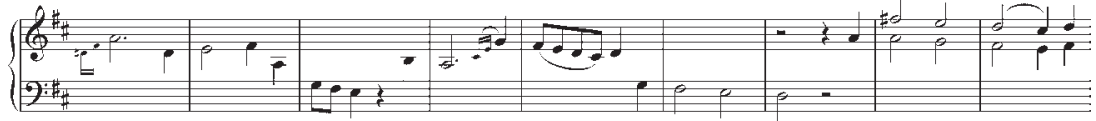

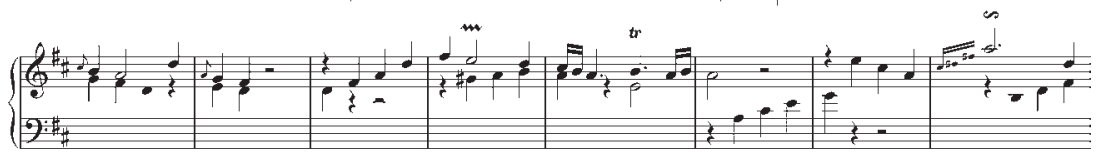

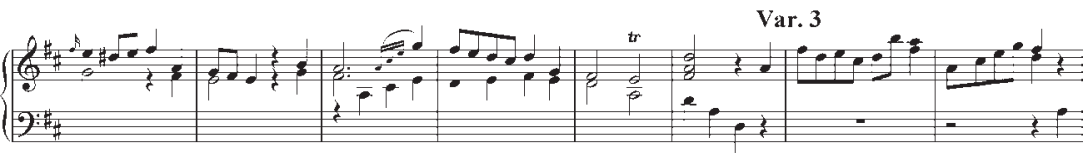

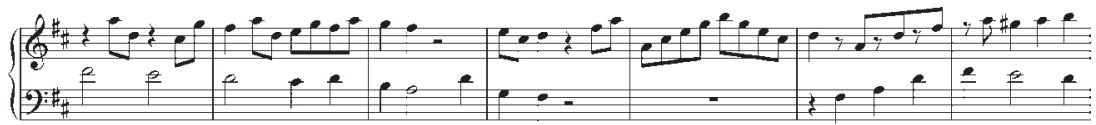

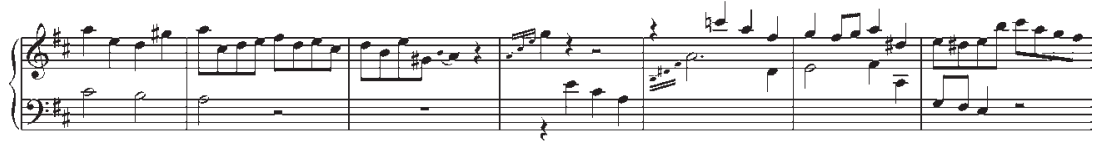

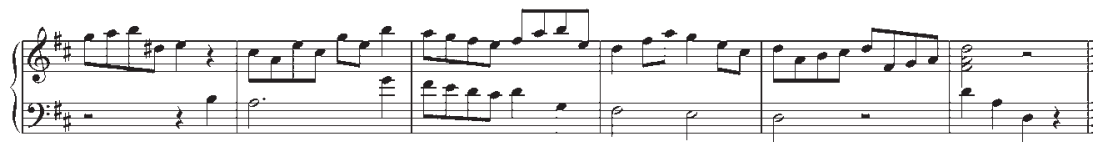

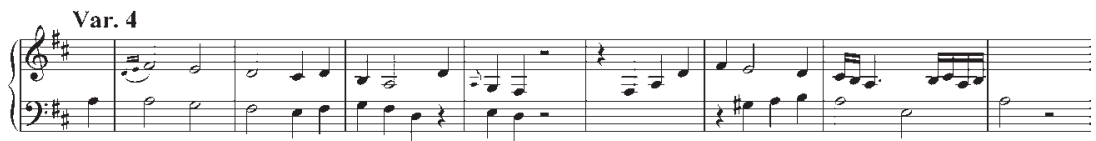

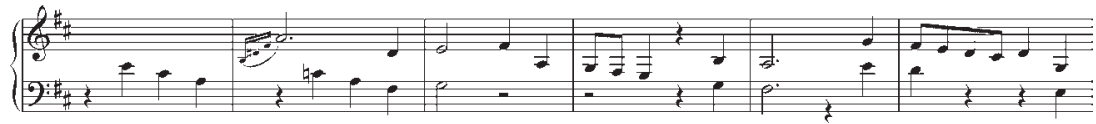

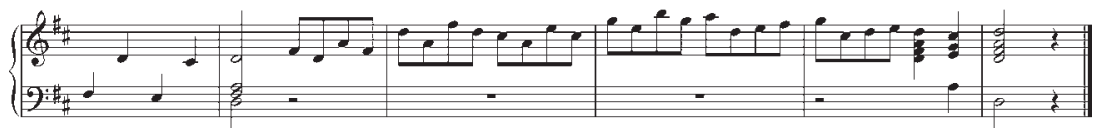

Example 50: J. E. Eggert, Du bist's dem Ruhm und Ehre, no. 43 
The composition Herr lehr mich wenn ich der Tugend diene (no. 241) that we have indicated as an exception was programmed to be played on half-hours. It is not in variation form but is a chorale prelude - an arrangement of Bach's song.

Carl Philipp Emanuel Bach was undoubtedly a composer not only renowned by popular in Gdańsk, with his admirers and propagators. What was the resonance in the city of the work and thought of Christian Fürchtegott Gellert? Was it equally vivid and deep as the reception of Carl Philipp Emanuel Bach's music?

In 1752, several young residents of Gdańsk, students of the Academic Gymnasium, founded the Deutsche Gesellschaft der Wissenschaften zu Danzig (German Society of Sciences). Their goal was to perfect and cultivate the German language. They translated French texts into German but also wrote literature. They also studied the works of ancient and modern authors, and Christian Fürchtegott Gellert was indeed their particular focus. ${ }^{1015}$

The popularity of Gellert's output is confirmed by the entries in the albums of the young Gdańsk elite, recruited mainly from amongst the Academic Gymnasium. Their diaries filled especially when they intended to leave Gdańsk for further studies, and friends, patrons, and protectors noted appropriate poems or sentences by distinguished philosophers and writers, including Christian Fürchtegott Gellert. ${ }^{1016}$

The output of that German moralist also attracted professors of the Gdańsk Gymnasium. Johann Gottfried Guzowiusz, a teacher of Polish language, grammar, and orthography, used Gellert's writings, which were primarily published in Breslau but also Warsaw. ${ }^{1017}$

Johanna Schopenhauer mentions that her mother's readings also included the works of Christian Fürchtegott Gellert, and lists his epistolary novel, Leben der Schwedischen Gräfinn von $G^{* * *} .{ }^{1018}$

However, Gellert did not meet with the same approval from all Gdańsk burghers. The local Spiritual Ministry (Geistliches Ministerium) voiced objections; its members included only two songs by Gellert in the Gdańsk hymnal, published in 1764. ${ }^{1019}$ This reserve was due to the fact that Gellert also wrote comedies, which, within the austere social canon of Protestant Gdańsk,

the title page: "Musicalien f. 7," indicating that the volume belonged to the library collection of Theodor Friedrich Kniewel.

1015 Kotarski, Gdańsk literacki, 26.

1016 Kotarski, 126, 131.

1017 Kotarski, 34.

1018 Quoted after Kotarski, Gdańska poezja okolicznościowa, 226.

1019 Jesus lebt mit ihm auch ich and Wenn ich o Schöpfer deine Macht. 
was viewed in a very negative light. ${ }^{1020}$ One of Gellert's comedies was even staged in the city for the Carnival of 1775 (on 23 January): the singspiel Das Orakel with music by C. Laube. ${ }^{1021}$

How then to assess the decision of Johann Ephraim Eggert to incorporate interludes, derived from fragments of Bach's songs to texts by Gellert, into his variations for the carillon? Whose popularity was he seeking to illustrate? As a musician, he undoubtedly felt a closer affinity to Carl Philipp Emanuel Bach. By including Bach's compositions into his works, he increased the outreach of his local admirers to students, pianists, musicians, music lovers, booksellers, and musical life organisers.

Returning to our variations whose titles indicate the interludes they contain (with no Bach references), we should now comment on the hitherto omitted compositions numbered $17,46,66$, and 245 . In three of these (nos. 17, 66, and 245 ), the interludes are monodic chorale melodies. Eggert incorporated the subsequent phrases of those melodies amongst the variationally reworked verses of the chorale listed in the composition's title (Example 51).

Unfortunately, I have been unable to identify the origin of the interlude in Herr dein Allmacht reicht so weit, als: \& Interludium (no. 46). The majority of phrases in that interlude are not monodic but two-voiced and ornamented, similar to the structure of Carl Philipp Emanuel Bach's songs.

\section{Variations for half-hours}

Variational reworkings of chorales to be played on half-hours share a simple architecture: they are composed of a monodic chorale presentation and a single variation. The only exceptions to that rule are the compositions Gelobet sei der Herr der Gott Israel (no. 167) and Meine Seele erhebet den Herren (no. 168), which include three and two variations, respectivelty.

The above-mentioned technical limitations of the carillon drum repeatedly forced Eggert to shorten themes or successive variations. To achieve this, Eggert used a triple metre, in which the pulsation unit of the melody (a minim) is reduced to a dotted crotchet. It should be emphasised that in variations for half-hours, Johann Ephraim Eggert used triple metre particularly frequently (see Example 52).

1020 Kotarski, Gdańska poezja okolicznościowa, 29.

1021 Kotarski, Gdańska poezja okolicznościowa, 17, 317. The music for the singspiel Das Orkel was composed not by C. Laube, as indicated on the title page of the printed libretto, but by Anton Laube (1718-84); see Kapsa, 'Laube, Anton', col. 1322. 

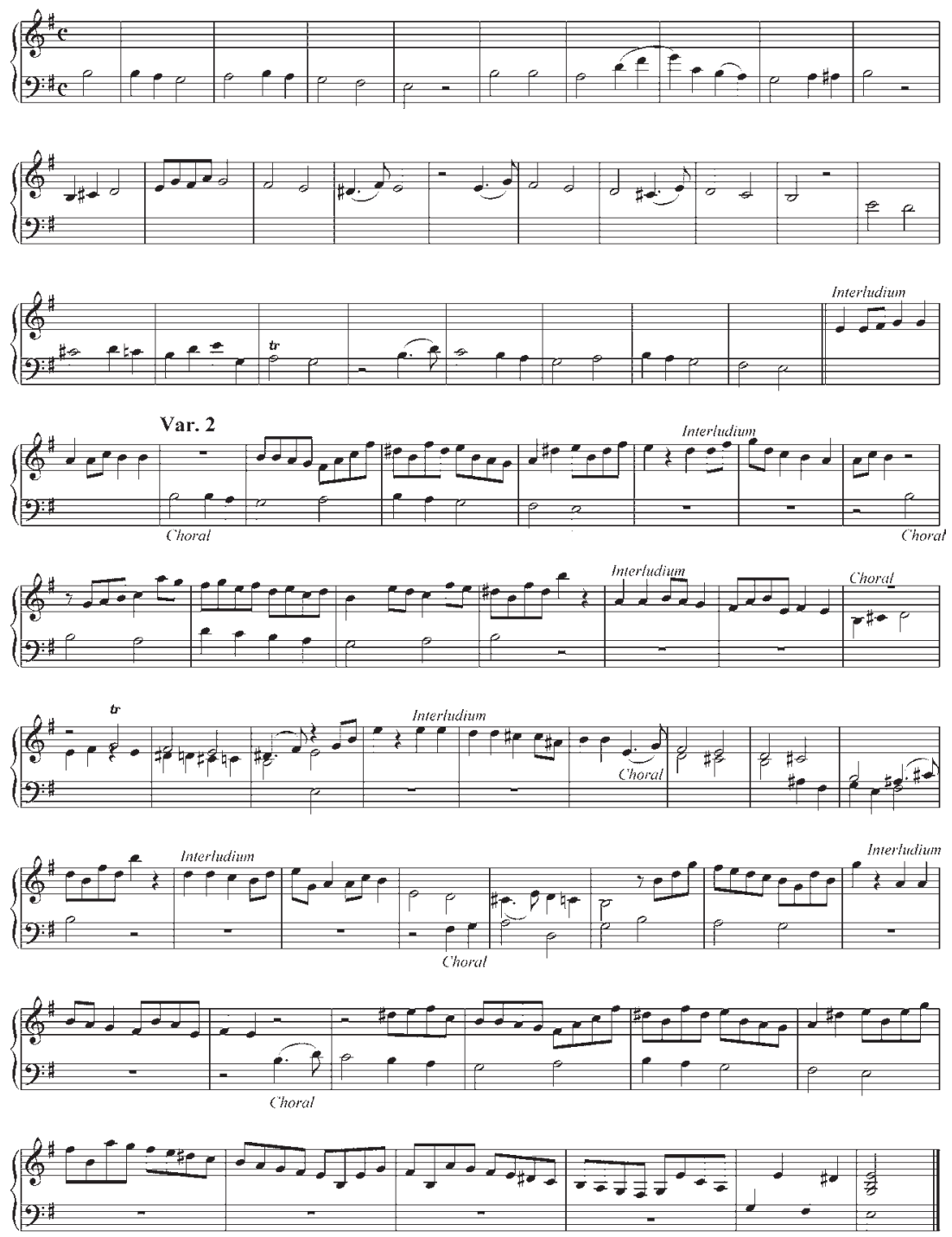

Example 51: J. E. Eggert, So wahr ich lebe spricht dein Gott ad Interludium, Ach was soll ich Sünder machen, no. 66 

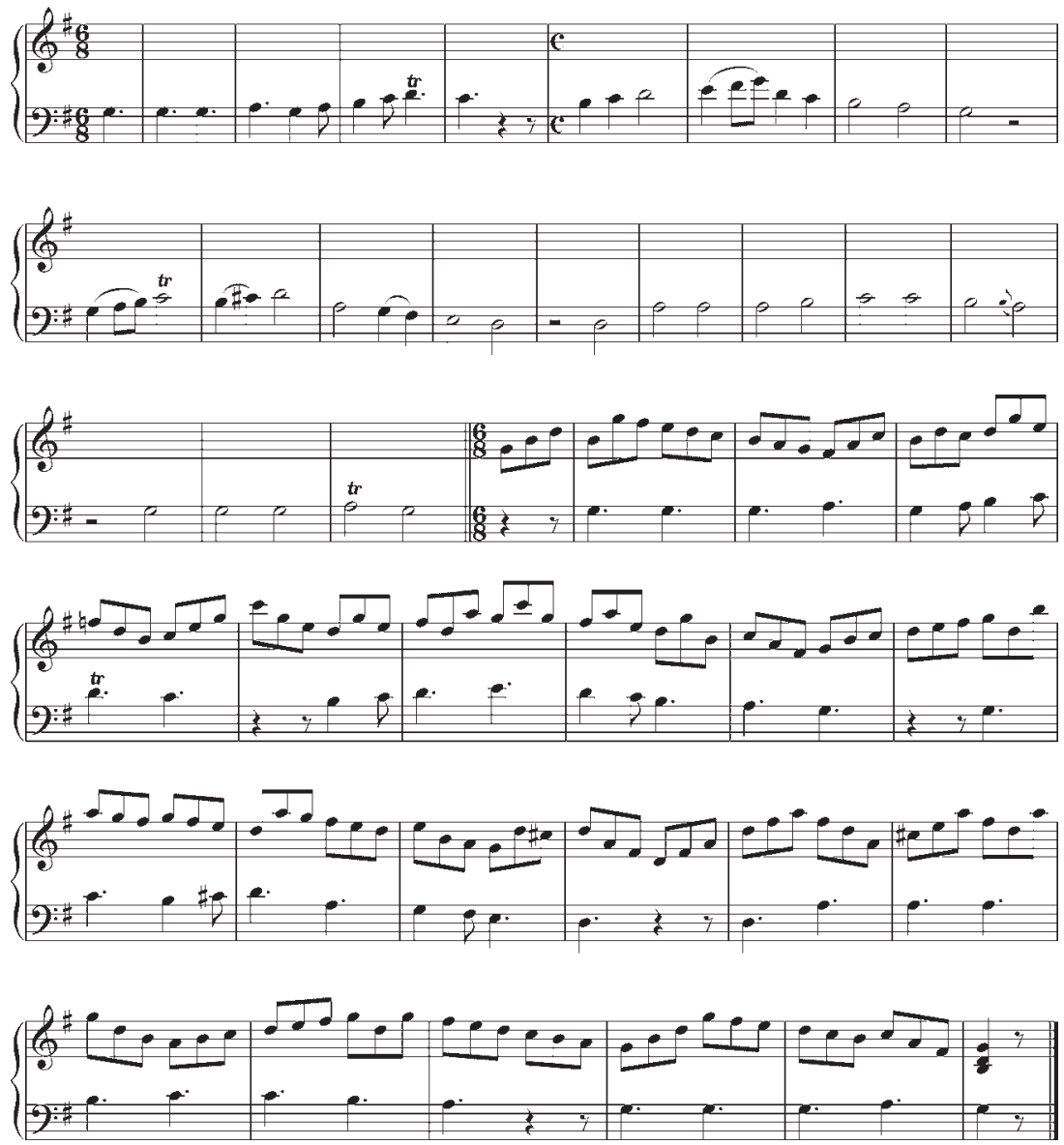

Example 52: J. E. Eggert, Gelobet seist du Jesu Christ, no. 129

Amongst Eggert's variations for half-hours, three categories can be distinguished:

1. Figurative variations

2. Nonfigurative variations

3. Variations with a mixed texture

Figurative variations are to be found in very many compositions for halfhours. The figuration, just as in the group of variations for full hours, regards 
the counterpoint voice. It is usually a figuration in continuous quaver motion, though in the settings of the chorales Herr Jesu Christ war' Mensch und Gott (no. 215) and Ich hab' mein Sach' Gott heimgestellt (no. 225) there appears a figure typical for the carillon texture: four (or three in triple metre) quavers, of which the first is replaced by a rest.

The approach to structuring nonfigurative variations for half-hours is analogous to the same genre as adopted for full hours.

I would assign merely a single composition, Ein Kind geborn zu Bethlehem (no. 125), to the mixed texture type (Example 53).
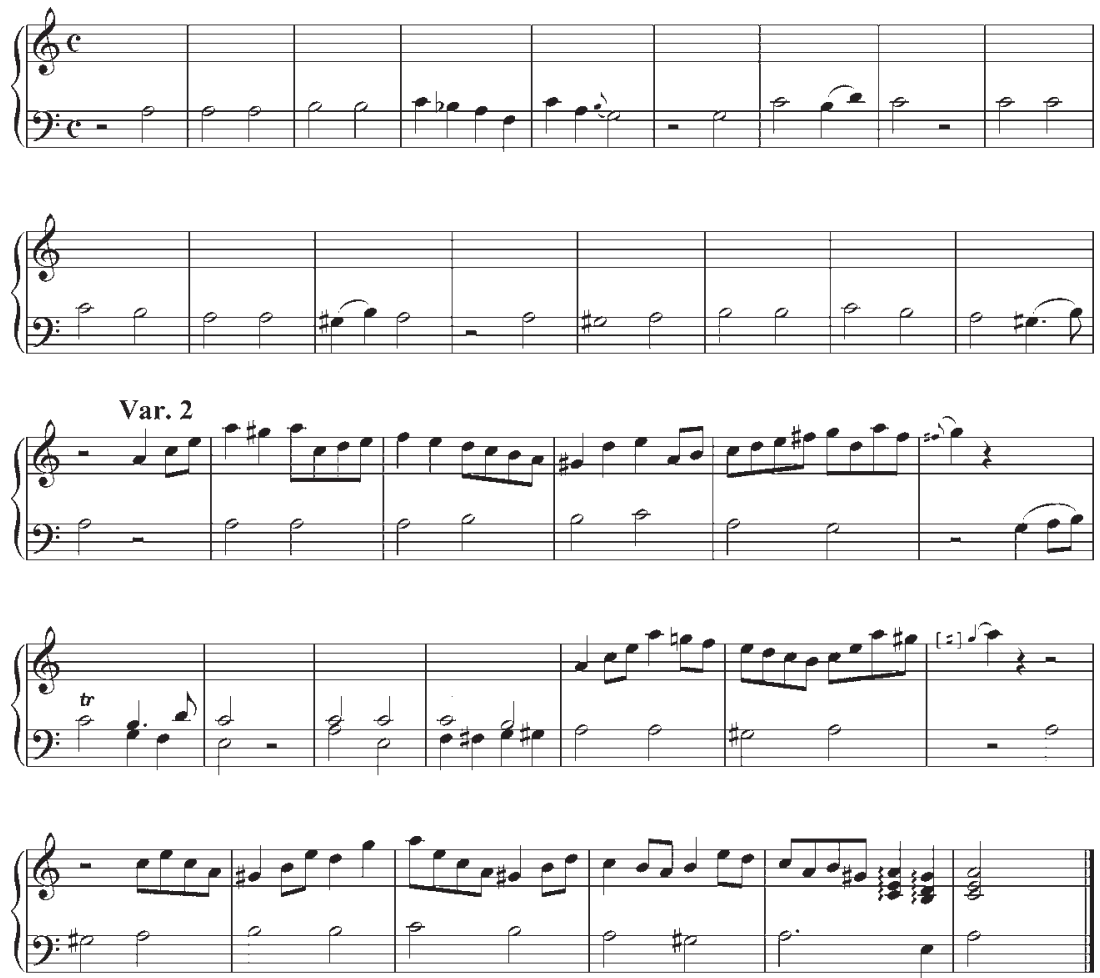

Example 53: J. E. Eggert, Ein Kind geborn zu Bethlehem, no. 125

For a dozen or so songs, Eggert included two variation versions: one for the full hour and the other for the half-hour. Yet not in all half-hour compositions did he show enough invention to find original solutions. For example, in the variations on Ach Jammer Not und Herzeleid (no. 145), Komm Gott Schöpfer 
heiliger Geist (161), or Christus der ist mein Leben (no. 217) he simply repeated the cycle's last unit on a full hour (no. 25, 247, and 254, respectively). The variation of the chorale Du bist's dem Ruhm und Ehre (no. 43 and 166) is also a repetition, though not of the cycle's first unit. Another similar setting, though in two different keys ( $G$ major and $\mathrm{D}$ major), is the first variation on the songs Den die Engel droben for the full hour (no. 7) and the variation on that song for the half-hour (no. 124).

\section{Choral preludes for full hours}

When setting chorales, Johann Ephraim Eggert acknowledged that variations could not be added to long melodies of a dozen or so verses, due to the a lack of space on the carillon drum. Consequently, these chorales became set as preludes. This category includes five compositions: Ich grüße dich am Kreuzesstamm (no. 21), Herr Gott dich loben wir (no. 80), Herzlich lieb hab' ich o Herr (no. 88), Gott der Vater wohn' uns bei (no. 99), and Verleih uns Frieden gnädiglich (no. 250). In these preludes, only the initial verses of the chorale appear in monodic version, while the subsequent ones are usually accompanied by a figurative counterpoint. Only in Herzlich lieb hab' ich o Herr (no. 88) do homorhythmic structures dominate over figurative ones (Example 54).

In those songs where the melody does not sufficiently fill the space for a fullhour composition, Eggert extended the linking phrases, thereby lengthening the entire form. In the prelude Ich grüße dich am Kreuzesstamm (no. 21), he achieved this goal through a different device: after the first four phrases in duple metre, he changes the metre to triple, in which he extends the pulsation unit of the chorale melody by half, from a minim to a dotted minim.

\section{Choral preludes for half-hours}

The way Eggert composed chorale preludes for half-hours is similar to those for full hours. All works open with a monodic presentation of the first or successive verse of the chorale melody, followed by a counterpoint with a consistent figuration in quaver motion. Examples include Was soll ich liebster Jesu du (no. 147) and Wacht auf ihr Christen alle (no. 224). A more distinctive technique is the diversification of chorale setting, with figurative phrases juxtaposed with homorhythmic ones (Example 55).

In his preludes for half-hours, due to their limited duration, Eggert used fewer technical means than in compositions for full hours. Nonetheless, there are preludes such as Auf mein Herz mit Freuden (no. 152) in which he links the verses with an ascending passage, finishing the narrative with an arpeggiated 


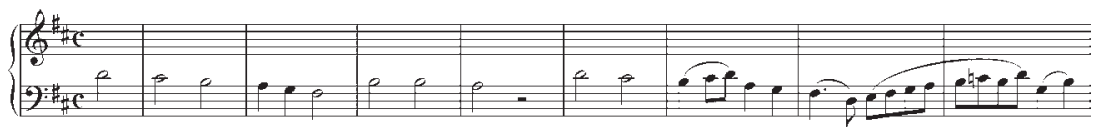

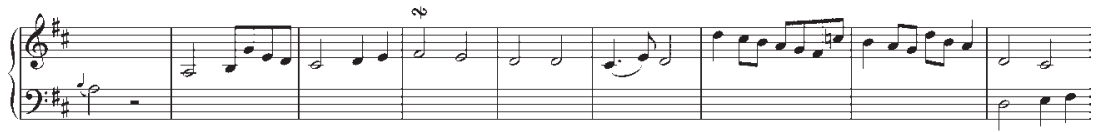

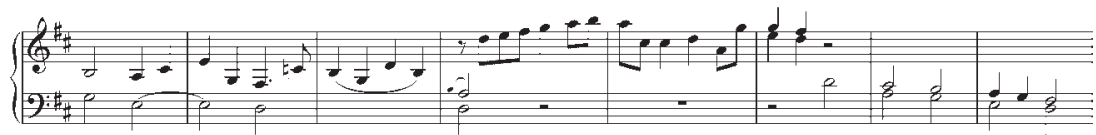

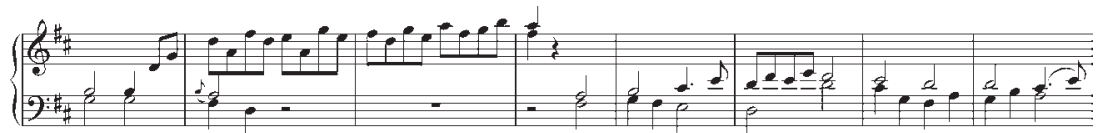

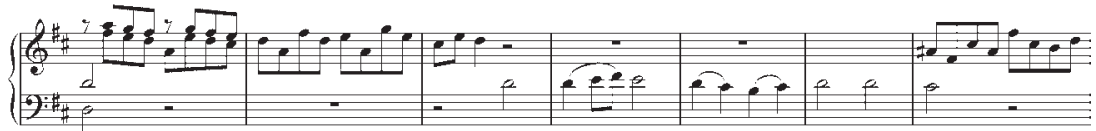

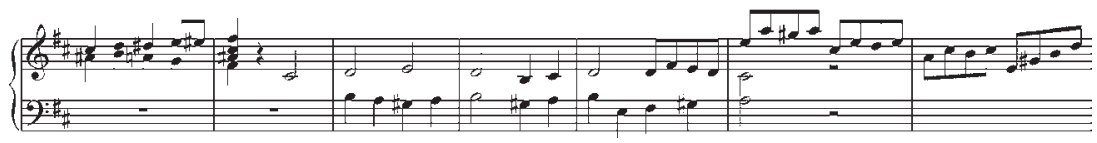

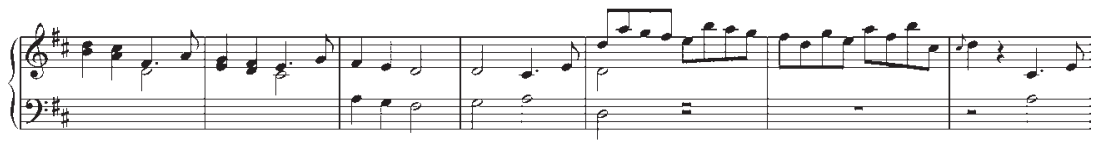

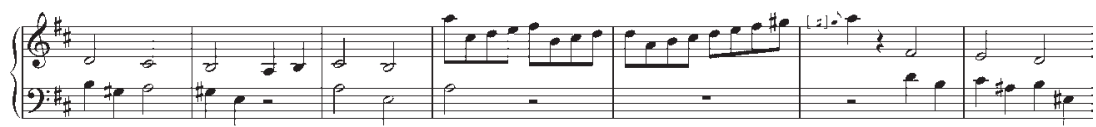
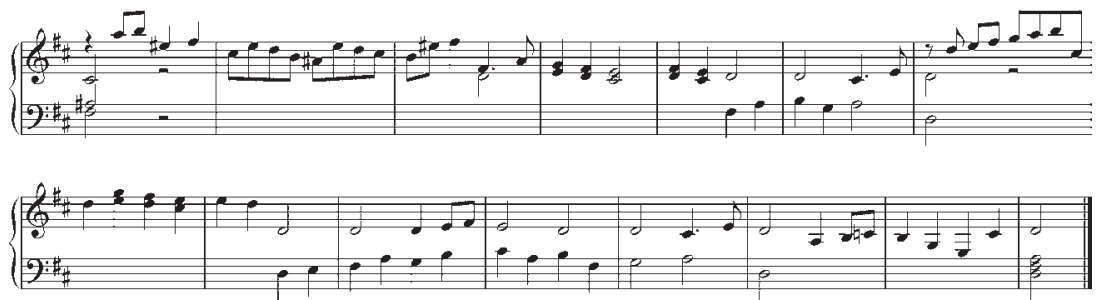

Example 54: J. E. Eggert, Herzlich lieb hab' ich o Herr, no. 88 


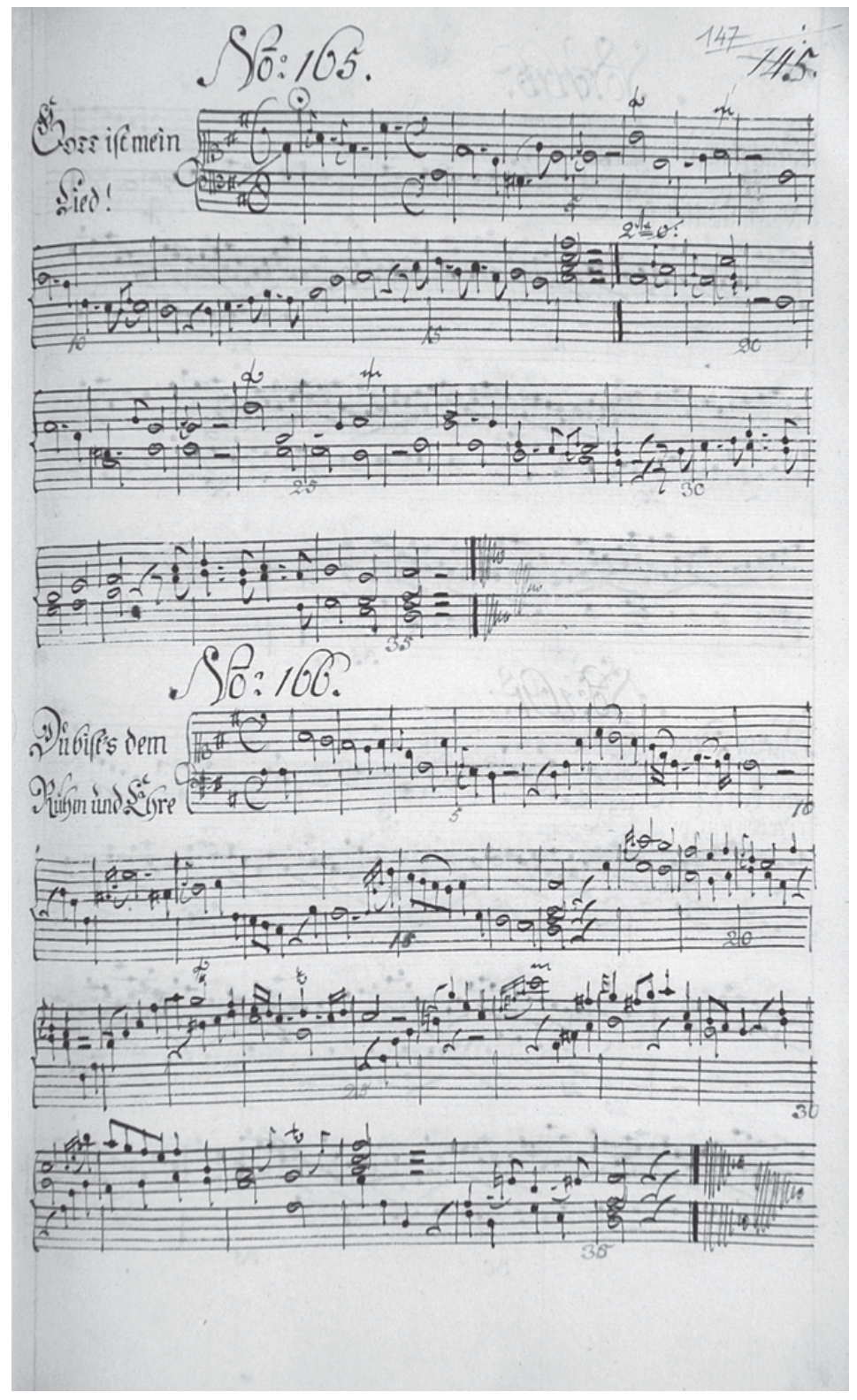

Fig. 95: Manuscript of J. E. Eggert. APG 300,R/Pp,45, p. 147 


$$
\text { . 50:129. }
$$
dit iferfingriter
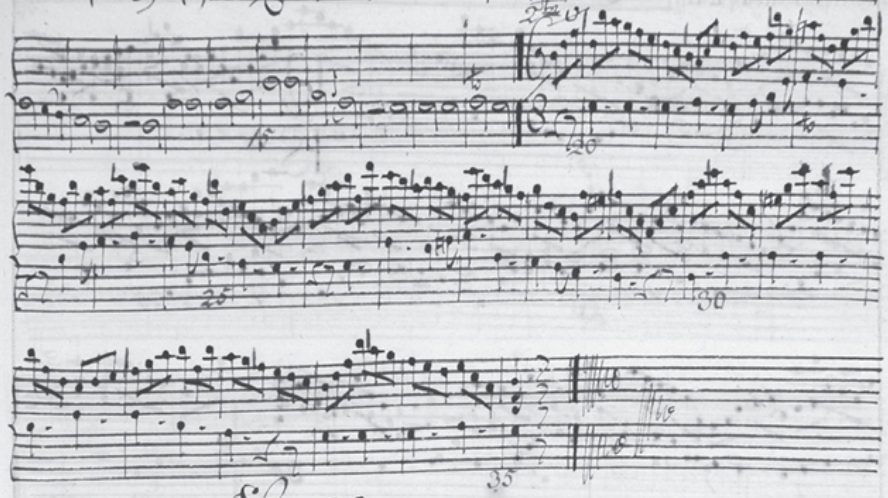

$$
50: 180 \text {. }
$$
Gromplouninin Itruvombine

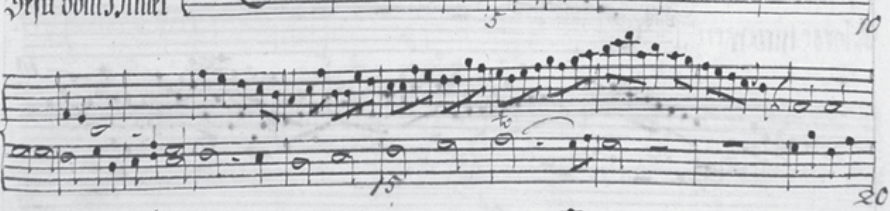
Fofg:

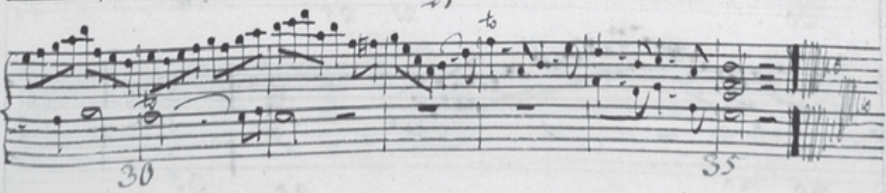

Fig. 96: Manuscript of J. E. Eggert. APG 300,R/Pp,45, p. 129 

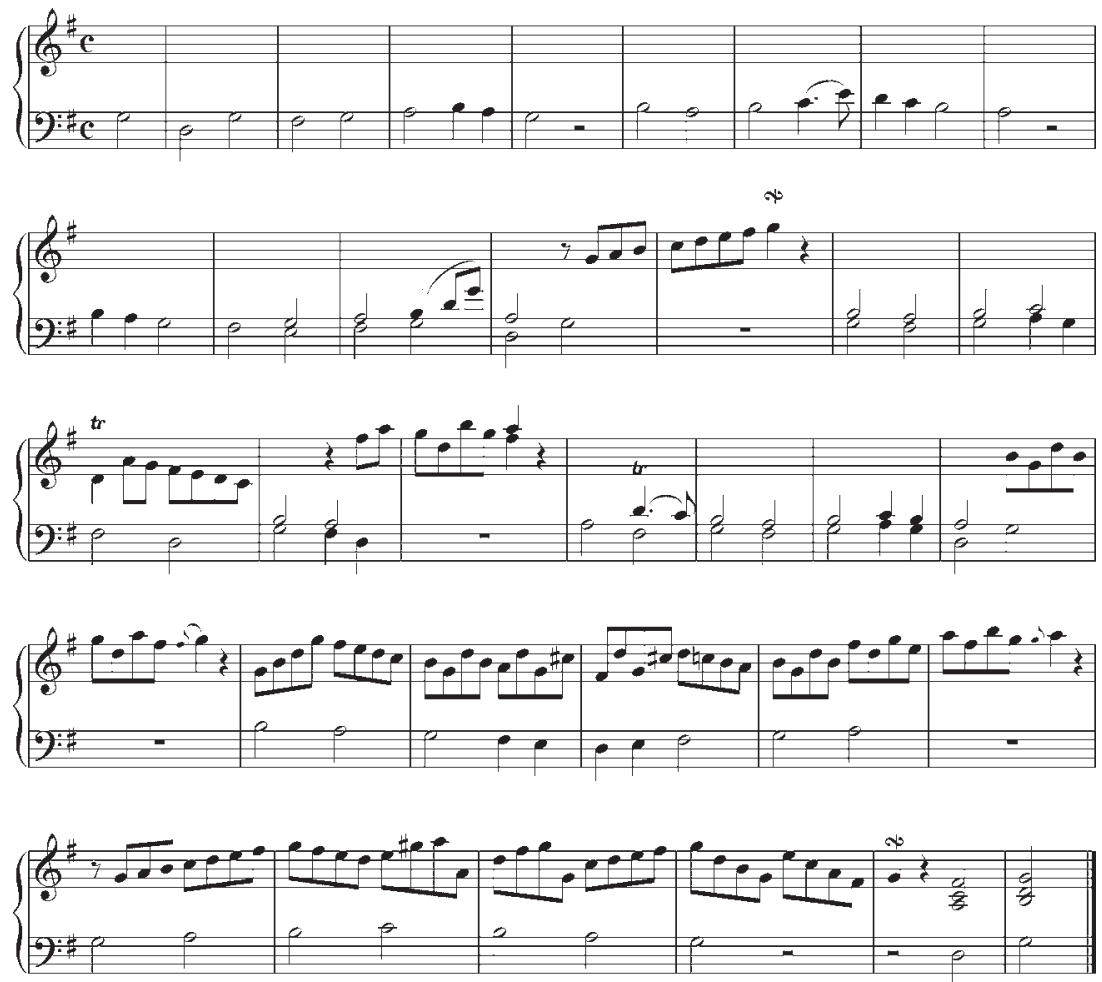

Example 55: J. E. Eggert, Herr Jesu Christ du höchstes Gut, no. 195

chors, and also obtains a diversification of timbre as in many other preludes for half-hours: through a quick reduction of the two-voice texture. Relatively long chorale melodies such as Ein' feste Burg ist unser Gott (no. 234), Ein Kindlein so löbelich (no. 126), and Jesu deine tiefe Wunden (no. 141), are shortened in the same way as used by Eggert in other compositions, by reducing the pulsation value of the melody from a minim to a dotted crotchet, or applying a triple metre to the whole prelude or its fragments.

\section{Choral preludes for quarter-hours}

Quarter-hour preludes lasted around fifteen seconds. Five slats were reserved to programme them on the carillon drum. The purpose of these very short and simple interjections was to signal the first and third quarter of each hour. Eggert 
only notated two such preludes in his manuscript: Mitten wir im Leben sind (no. 100a) and Hört auf mit Trauren und Klagen (no. 108a), suggesting that all similar compositions were structured in the same way and the composer saw no need to notate them. The programming of quarter-hour preludes was left to the carillonist, who as a practitioner was expected to deal with their structure and correct positioning on the drum.

The quarter-hour preludes notated by Eggert consisted but of the first verse of the song set for full hours. In both cases, Eggert placed the melody in the lower voice, while the upper voice performs a counterpoint in quavers (Example 56). The question arises why Eggert notates those two preludes? The answer can be surprisingly simple: he might have wanted to use up the free space left on those pages after noting his chorale settings.

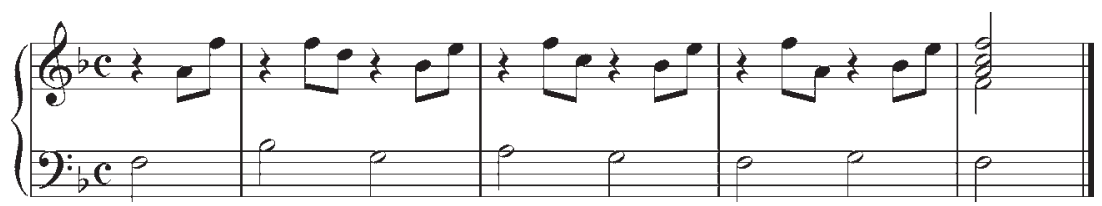

Example 56: J. E. Eggert, Hört auf mit Trauren und Klagen, no. 108a

\section{Monodic chorale settings for full hours}

The song Mitten wir im Leben sind (no. 100) is notated by Eggert in the manuscript on a simple monodic setting and is the only title to be so treated by the composer. This solution was influenced by two factors: the length of the chorale and its character - the latter was apparently decisive (Example 57).
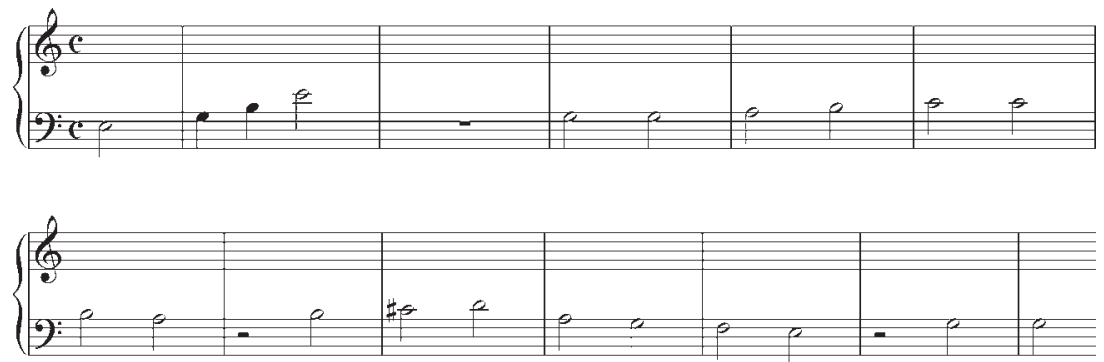

Example 57: J. E. Eggert, Mitten wir im Leben sind, no. 100, beginning 
This song belongs to the "Sterbe-Lieder" (death songs) category, and while it is not the only song from that group in Eggert's collection, it is the only one to be left fully monodic. This happened likely because it was the most popular funeral song amongst European Protestants. It was also programmed on the Main Town Hall carillon, notably announcing the death of the King and distinguished residents of the city.

The melody Mitten wir im Leben sind is composed of fourteen verses in a calm, steady rhythm. The original pulsation values are modified by Eggert but slightly in a few phrases, where they are sectioned by dotted rhythms and in one case, a turn. The melody is programmed on 55 slats, with a four-note intonation (a broken $\mathrm{E}$ minor chord) added at the beginning, followed by a one-bar rest, which sounds like a fanfare or a call to appear before God - a distinctive memento mori. 


\section{Conclusion}

\section{Gdańsk carillons in the city's soundscape}

The soundscape of a city is composed of many phonic phenomena. If we looked at city agglomerations from a selected geographical area in any given time, we would certainly be able to discern recurrent elements of their sound fabric. Yet those recurrent elements would not mean the same in each of those places. They would likely have a similar meaning but would also show individual characteristics, making a given place - the city - a unique, unrepeatable soundscape.

A Gdańsk citizen of the mid-sixteenth century, with a hectic lifestyle throughout the day, hurrying to reach his home, work, or temple, or peacefully strolling through the streets, was surrounded by noise characteristic for this dynamic port city and commercial centre. Traffic on the piers, the main streets and squares must have been considerable, given Gdańsk was the largest city of the Polish-Lithuanian Commonwealth in that time. On top of the population of around 40,000, there were also many travellers from throughout the Commonwealth and foreign countries, which came to the city to trade or simply visit. Many languages were heard on the streets: German, Polish, English, Kashubian, and Dutch. Merchants advertised their wares by shouting:

Hier frischen Retick volck hier

dröge spöne frawe

hier frischen Krabben hier... ${ }^{1022}$

The city's soundscape also included musical signals from the towers of St Mary, St John, and St Catherine's, played by tower officers. Pipers gave the time but also warned of fires or enemies approaching the city gates. This type of musical information was used not only in Gdańsk but numerous other cities in medieval and early modern Europe.

A prinicpal ingredient of Gdańsk's soundscape, generally characteristic of human gatherings that emphasised their religious identity through sacred architecture, was the timbre of church bells, calling the community to prayer and cult. These attracted the attention of people to spiritual matters essential to their existence but also contributed to the secular life of the community.

1022 Such shouts by street merchants were recalled by Franciscus de Rivulo, the first setter of the town hall's carillon, who reworked them in a four-voice song form. See PAN BG Ms 4003 (Popinigis et al., Music Collections from Gdańsk 1, 339). 
In 1561, the city's rich soundscape was enriched by the sounds of a fourteenbell automated carillon, the "singing mechanism" hung on the tower of the Main Town Hall. Soon after, signals of the "striking mechanism" could also be heard in Gdańsk's Old Town after it was installed on the tower of the church of St Catherine, although this was mechanically imperfect and needed to be modernised. Eventually, a 35-bell carillon was built at St Catherine's in 1738, which after necessary adjustments, could be played from 1739 onwards, with automated play available from 1741 .

The sounds of the Gdańsk carillons were noticed by visitors to the city. Some such as Alexander Gwagnin (1534-1614), a Polish historian of Italian descent were enthralled by these sounds:

On the town hall by the clock, which is made by strange, miraculous hands, bells are so intricately set that for each full hour, they sing various tunes and songs, throwing passers-by who gather there into great awe. ${ }^{1023}$

Others, such as Jadwiga Łuszczewska (Deotyma), were less impressed with the Town Hall carillon:

Every hour, an unexpected tremble permeates the city, the air filling with a procession of numerous, solemn sounds.

That is bell music played on the towers of churches and the Town Hall.

Those pieces of music are greatly loud and somewhat painful, as their scale lacks semitones and even some whole tones. One can discern some melodic outline, but it is so vague and pained that is has an agonising effect on newcomers. Yet your soul not only gets used to it but it cherishes this lament of bronze, so travellers who leave Gdańsk will inexorably miss it. ${ }^{1024}$

Both Gdańsk carillons - that of the Main Town and the Old Town - measured the passage of time, complementing each other and rhythmically filling the city soundscape with sounds. The Old Town automaton, similarly to that of the Main Town, was triggered every hour, but with additional signals on the half-hour and for many decades, also on the quarter-hour, as well as in seven-and-a-halfminute intervals during certain periods.

Thanks to the St Catherine carillon, which from its very beginnings featured a keyboard that enabled carillon play, the Old Town soundscape was enriched in comparison with the Main Town with another solid component: concert play. Initially, the carillonist played twice daily, and generally once daily in

1023 Gwagnin, Z kroniki Sarmacyi europejskiej, 267.

1024 Jadwiga Łuszczewska, 'Wycieczka do Gdańska', Tygodnik Ilustrowany 4 (1861), 133232, quoted after Fabiani-Madeyska, Odwiedziny Gdańska w XIX wieku, 198-99, 322. 
later periods. Composing programmes, playing tunes and interpreting them, carillonists built a special emotional relationship with audiences, which was an invaluable contribution.

Apart from signalling the passage of time and featuring regular concert play on the St Catherine instrument, both Gdańsk carillons also emitted sounds to mark social events in the city (such as elections to the Main Town and Old Town councils, the St Dominic's Fair, arrival of the King or royal court) and other locations in the Commonwealth (election of the King, royal marriage, birth of royal children, death of the King or Queen, won battles). The sounds of carillons intervened into the everyday soundscape with information on the deaths of city council representatives and their family members, as well as later accompanying and enhancing their elaborate funerals so typical of early modern European cities.

The first sets of bells playable from a keyboard originated in Europe over 500 years ago, followed somewhat later by automatons with programmable drums, which first appeared in the 1530s. The cradle of both carillon types and the region where this instrument was most widely produced were the Low Countries. The appearance of a fourteen-bell carillon in Gdańsk as early as 1561 puts the city amongst the earlier adopters of bell music outside the Netherlands.

Thanks to foreign bell founders, sounds characteristic of Dutch cities were introduced to the Gdańsk soundscape. Bells, the most essential component of any carillon, were indeed commissioned in the Netherlands. Those for the Main Town Hall tower were ordered from Jan Moer, a member of a famous bellcasting family operating since the mid-fifteenth century in 's-Hertogenbosch in Brabant. The bells for the St Catherine tower were commissioned from Jan Nicolaas Derck, a bell founder from Hoorn, who had distinguished himself by manufacturing a 41-bell carillon for the royal palace in Copenhagen.

As for the other constructive elements of Gdańsk carillons, it is assumed that the drum of the "singing clock" was produced in a local craftsman's workshop, likely to the instructions of Franciscus de Rivulo, a musician summoned to Gdańsk who set the Town Hall bells and had been cantor at the St Mary parish church since 1560. It is certified that both the Old Town carillon's drum for automated play and keyboard for manual play were manufactured locally: the former by watchmaker Daniel Böttcher and the latter by Andreas Hildebrandt, a renowned organ master operating in Gdańsk and surrounding towns.

The frequent change of programme of automated play was an individual solution for Gdańsk, differing from Dutch practice. In Brabant and Frisia, drums were reprogrammed a few times a year, while in Gdańsk, every Saturday for both carillons. 
Another characteristic of the Gdańsk carillons was the repertoire, limited to one type of music: religious song - exclusively Protestant. While in Dutch cities, carillon programmes included many religious songs, they also featured settings of popular tunes of various types as well as compositions written especially for the carillon, as documented by extant manuscripts with pieces for both carillon types. ${ }^{1025}$ In Gdańsk, it was only in the early twentieth century that nonreligious songs were introduced in the automated carillon programmes. Yet their appearance was so sporadic that the essential structure of those programmes hardly changed.

The Dutch collections of extant historical sources contain relatively little music for either automated or concert carillon play. In this context, the number of works included in Gdańsk musical manuscript is truly impressive (over 900 compositions) and constitutes a stiff competition for European collections. Let us recall that works for the Main Town Hall automaton were written down in unique tablature notation.

The settings of Protestant songs in Gdańsk manuscripts display a more or less extensive musical structure, directly dependent on the technical capacities of the carillon: modest in the case of the Main Town Hall's fourteen-bell automaton and much more elaborate for St Catherine's thirty-five-bell instrument.

Through the Main Town automaton and Old Town instrument, Protestant song was introduced into the Gdańsk soundscape. Between 1561 and 1945, it was a consistent component of that soundscape and at the same time, a recognisable signature of the city's confessional identity. It should be remembered that Gdańsk was an early adopter of Martin Luther's theses. From the mid-sixteenth century to 1945 , the denominational structure of the city's population did evolve, but the religious preferences remained unchanged: Lutheranism was the dominant confession. ${ }^{1026}$ Scholars who researched the consolidation of Protestantism in Gdańsk have linked it to various social and cultural processes. Yet to date, they have not discussed the music of Gdańsk carillons, which were a distinctive characteristic of the city's soundscape from 1561 to March 1945. As long as the two carillons of the Main Town Hall and the church of St Catherine existed, their play confirmed the confessional identity of the majority of Gdańsk residents.

1025 Halsted, 'Beÿaert 1728'; Huybens, 'De Liederen Uit Beÿaert 1728', 71; Rombouts and Van Eyndhoven, 'Back to the Future'.

1026 On the confession structure of Gdańsk's community, see Baszanowski, Przemiany demograficzne $w$ Gdańsku, 171; Romanow, 'Rozwój przestrzenny i demograficzny', $1: 21,281,2: 29$. 
As in past centuries, the sound of the carillons today permeates the soundscape of Gdańsk. Brilliant new instruments play again at St Catherine's, the Main Town Hall, and Gdańsk's Mobile Carillon. The Main Town and Old Town bells again measure the passing time. Automata are triggered every full hour, with the exception of night hours, in order not to disturb the residents' sleep. Their repertoire is less homogeneous than in the past. The programmes appear to be somewhat random, likely to accommodate the musical expectations and taste of most residents and tourists. Thus, one can hear dances from the tablature of Jan of Lublin, Catholic religious songs, Protestant chorale set by Johann Ephraim Eggert, Feliks Nowowiejski's patriotic Rota, or the French song Plaisir d'amour. During weekly and occasional concerts, carillonists perform the music of Fryderyk Chopin, Johann Sebastian Bach, Ludwig van Beethoven, Karol Szymanowski, traditional Polish folk melodies, and jazz standards. Modernity blends with tradition; in rainy or sunny weather, on weekdays and holidays, the brass sounds of the carillon enrich, as in the past, Gdańsk's multicoloured soundscape. 



\section{Appendix: Summary of the repertoire of the automatic carillon of the Main Town Hall and church of St Catherine}

1. Sources:

a. Mid-18th century to 1861: PAN BG Ms 697/29; Ms 302a-b; Ms 863; Ms 863 a; Ms 1073 I; APG 300,R/Pp q9; 300,R/Uu q9.

b. 1861: PAN BG Ms 1093 IV.

c. 1910-11: Danziger Zeitung, empty cases indicate a missing press announcement.

2. Titles:

a. Main Town Hall: the first title denotes a song for the even hour, the second song for an odd hour.

b. Church of St Catherine: the first title denotes a song for the full hour, the second one for a half-hour.

c. Titles in brackets indicate the correct (alternative) song tune quoted in the press announcement.

d. A title quoted after the slash indicates it is listed in the sources as alternative.

e. A title quoted after a double slash indicates it is not listed as alternative in the sources. 
Appendix

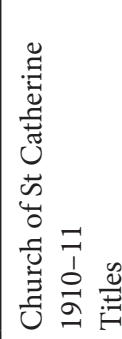

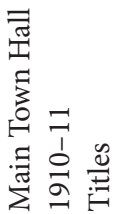

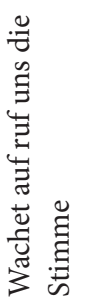

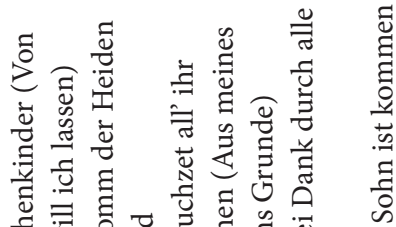

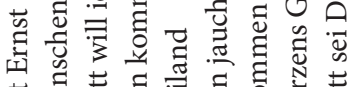

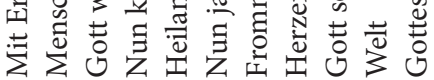

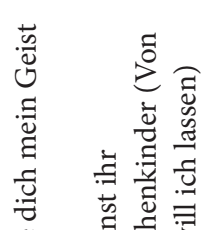

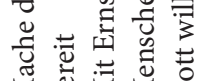

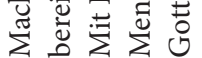

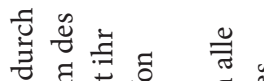

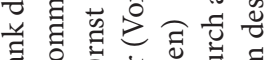

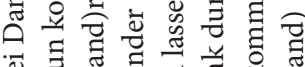

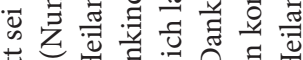

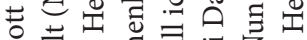

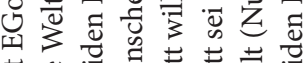

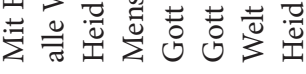

莒

:

章营

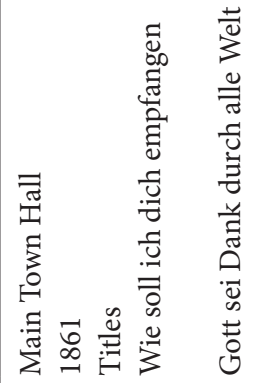

एँ

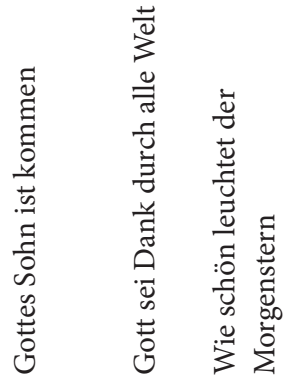

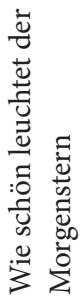

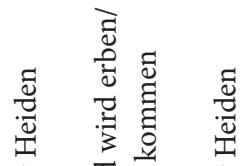

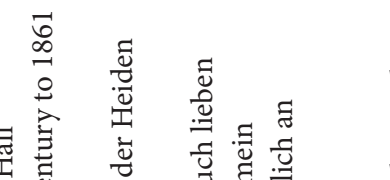

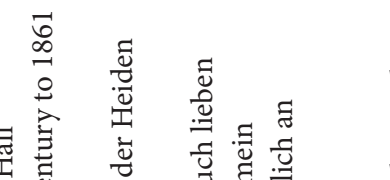

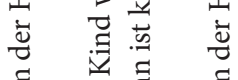

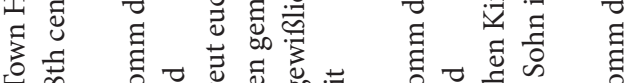

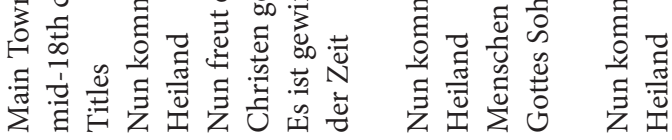

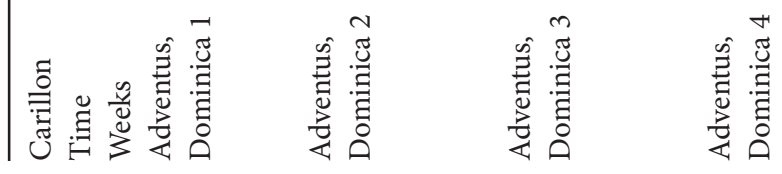



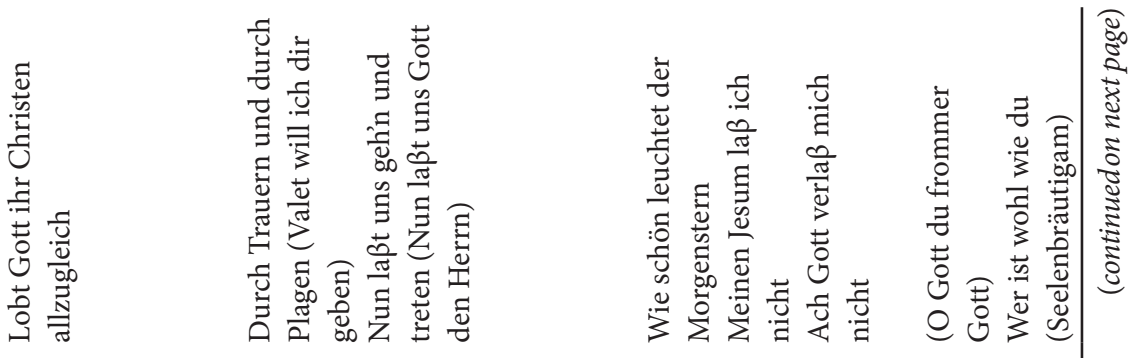

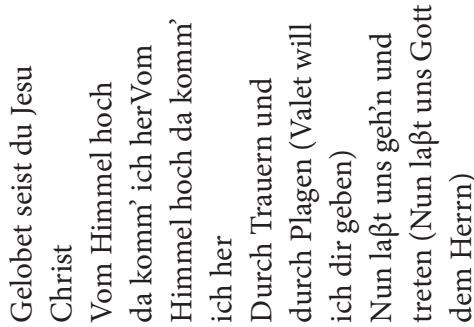

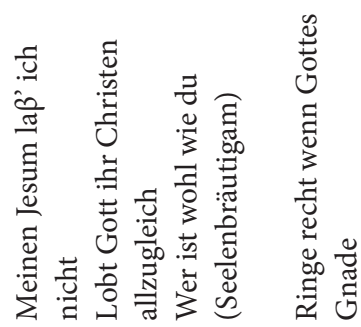

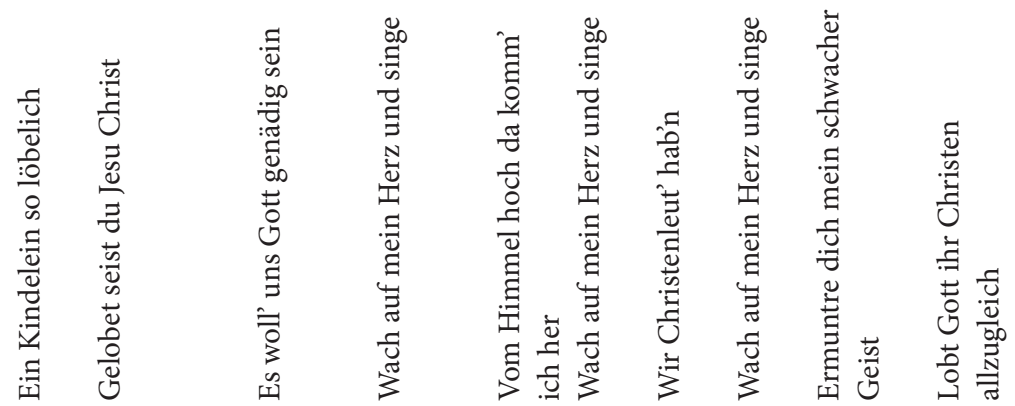

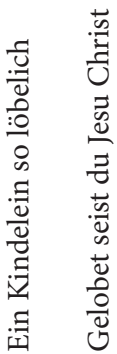

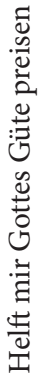

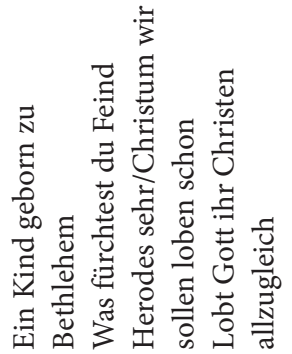

营

芩
它
خ

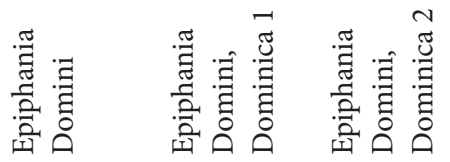




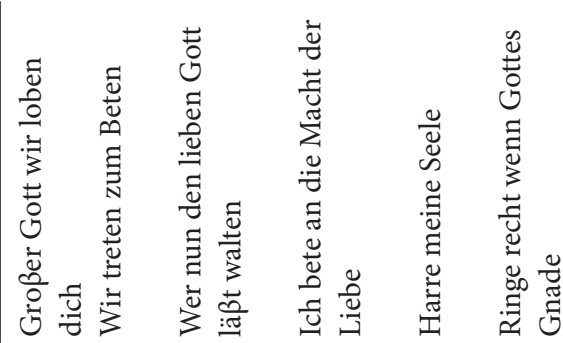

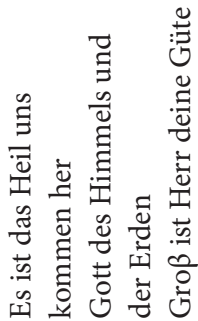

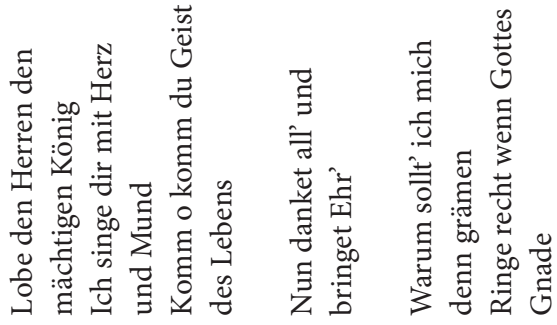

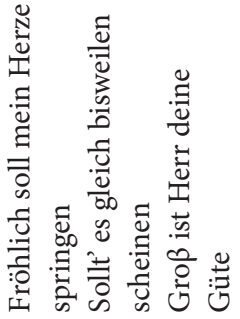

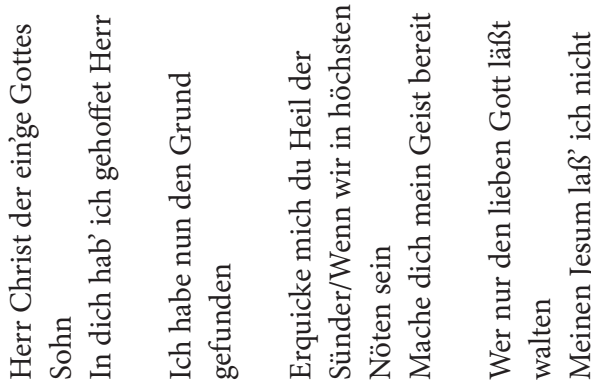

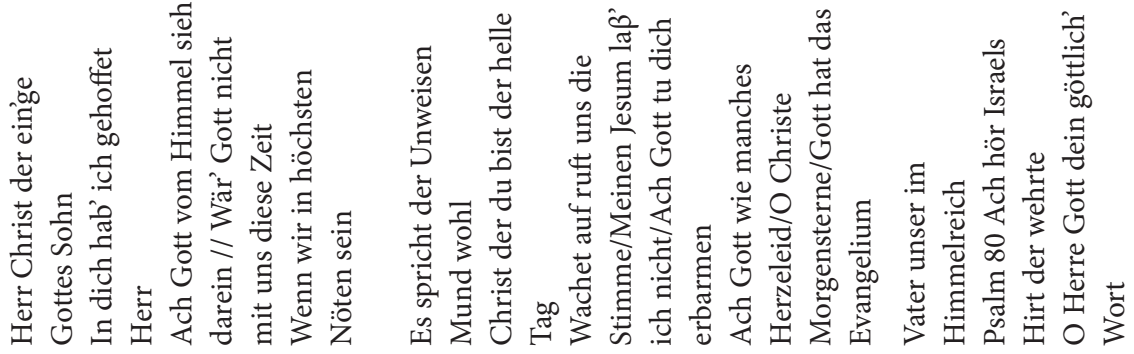

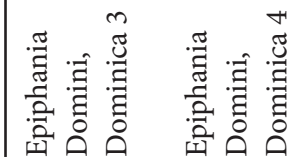
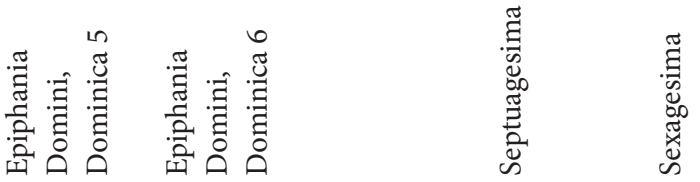


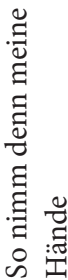

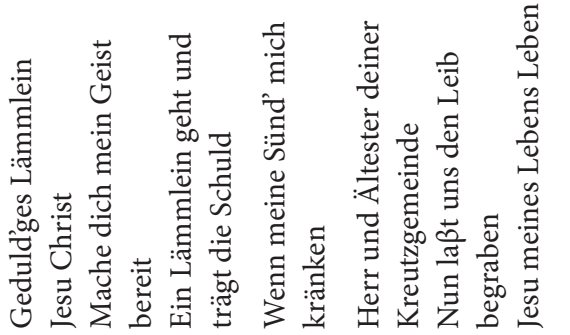

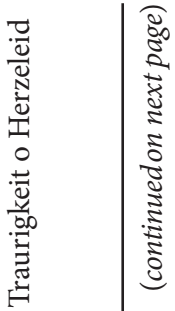

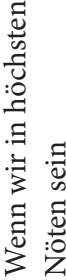

.ํㅛㅁ

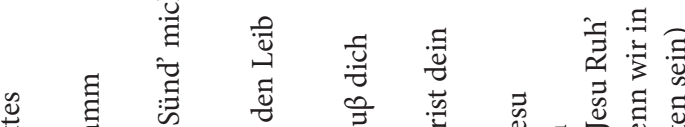

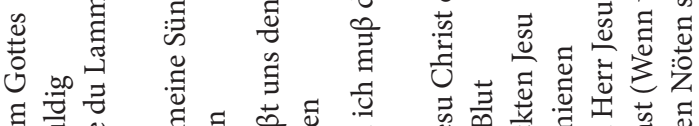

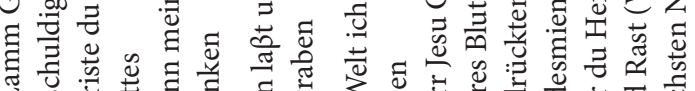
प्ड

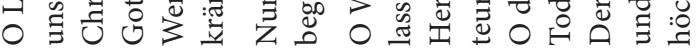

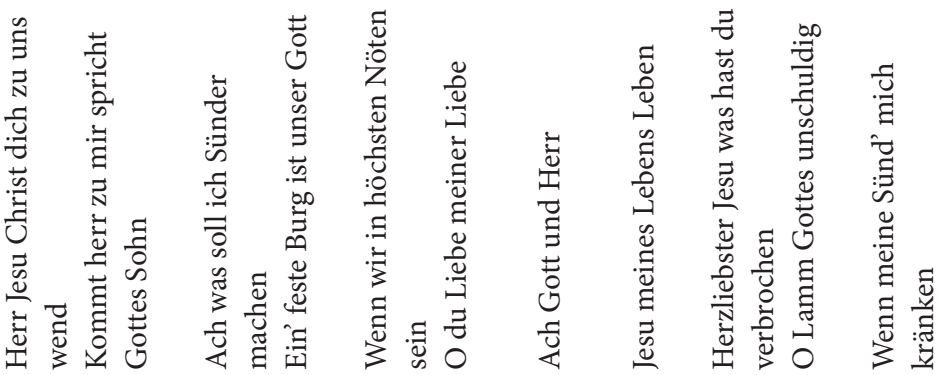

耐

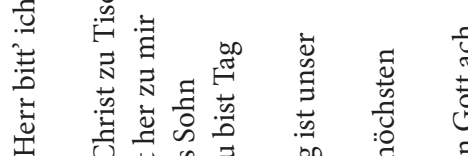

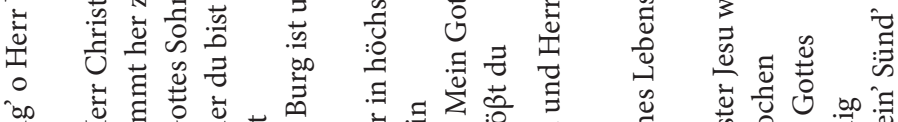

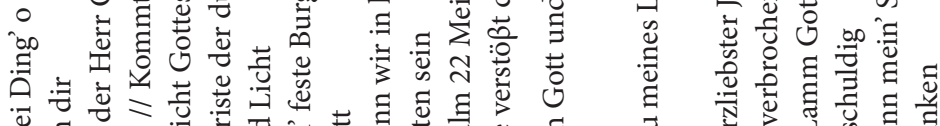

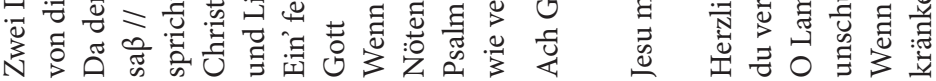
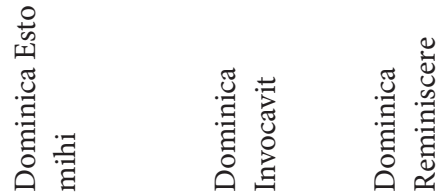

竞:

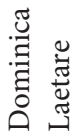


Appendix

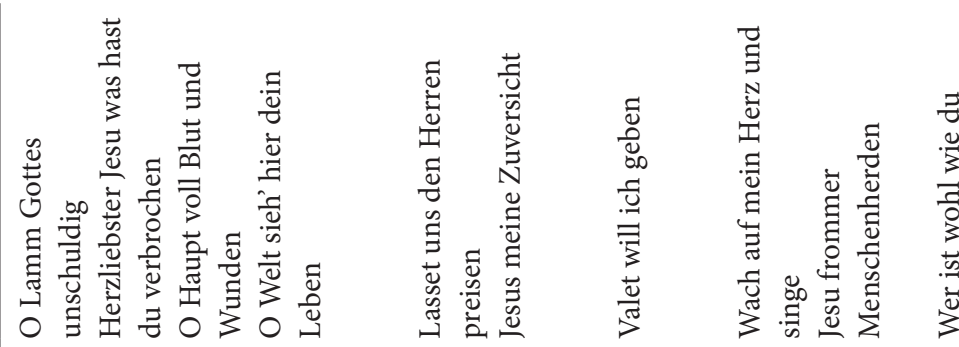

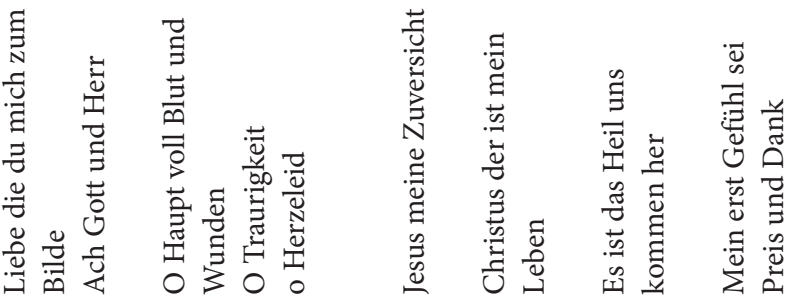

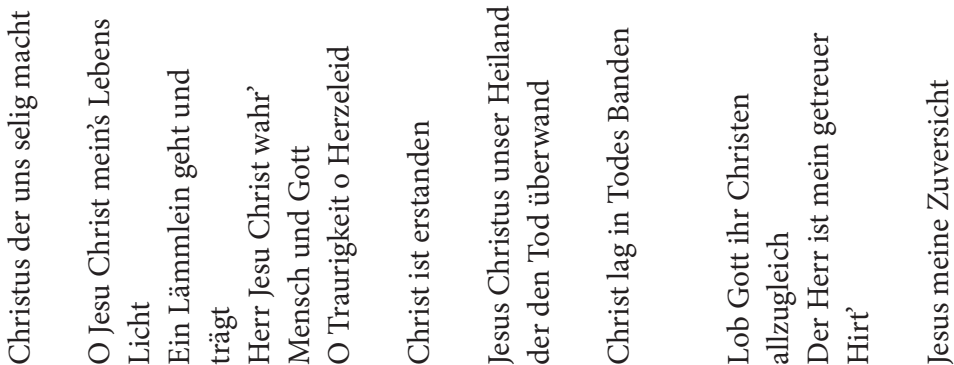

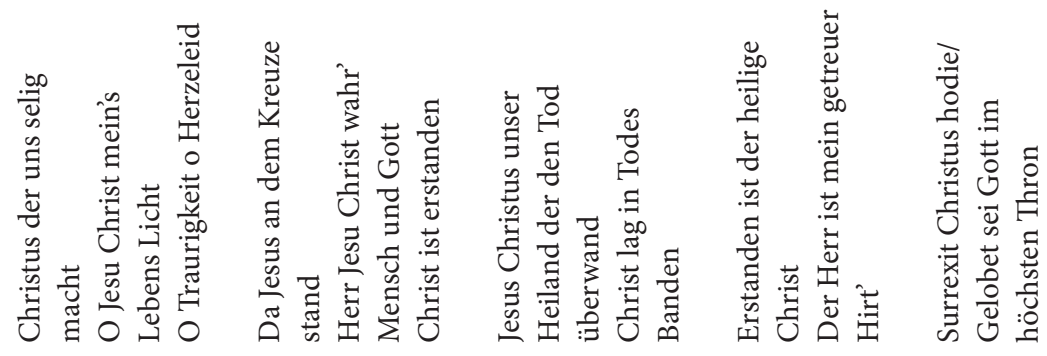

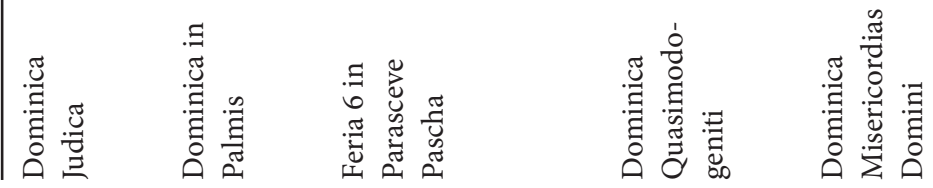




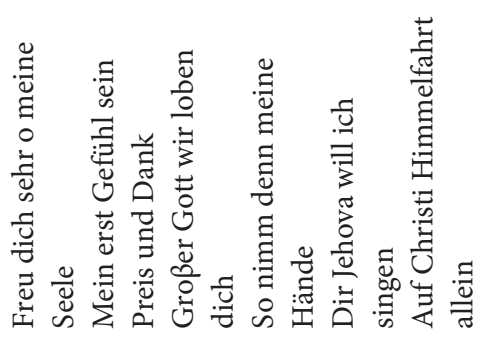

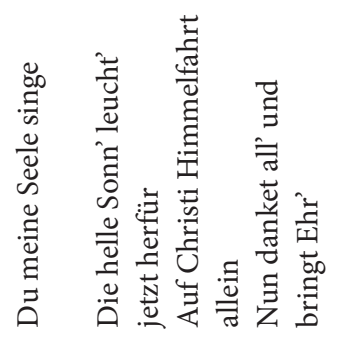

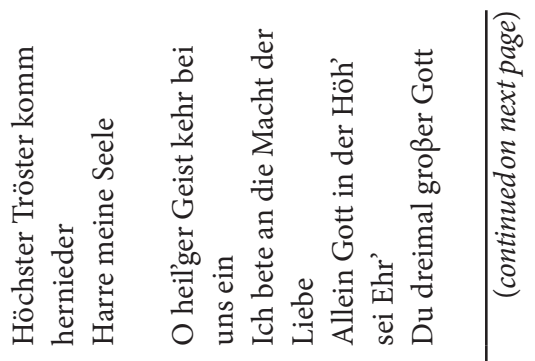

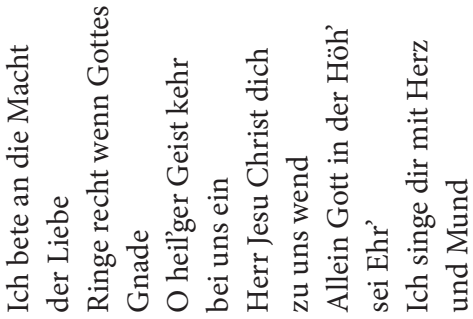

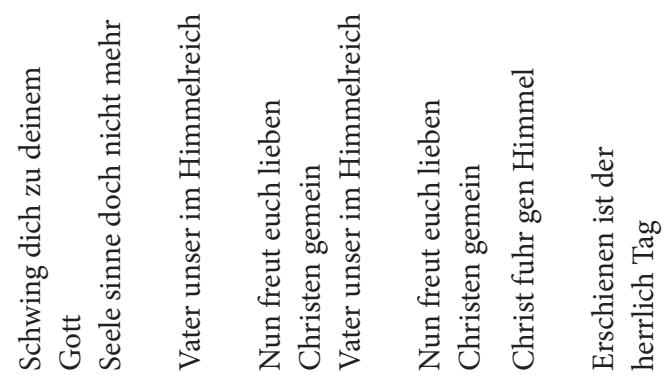

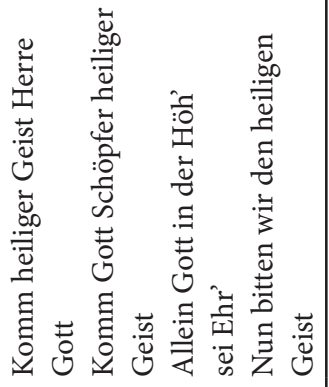

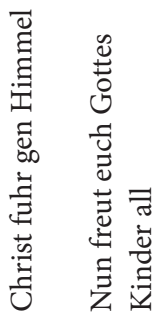

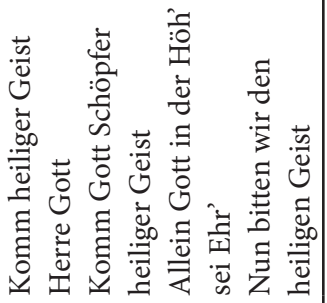

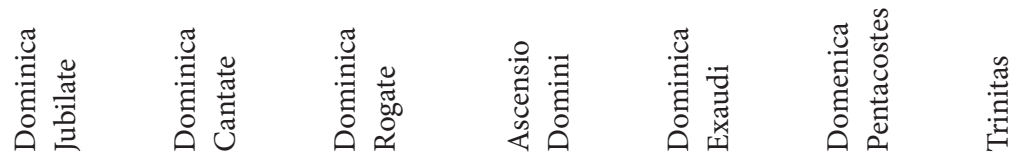




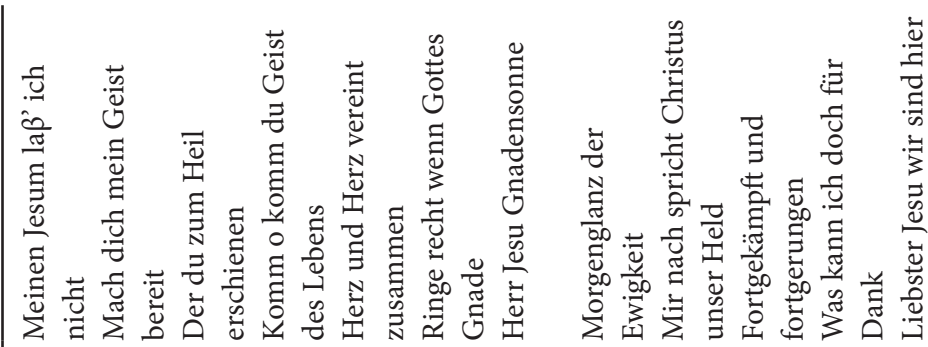

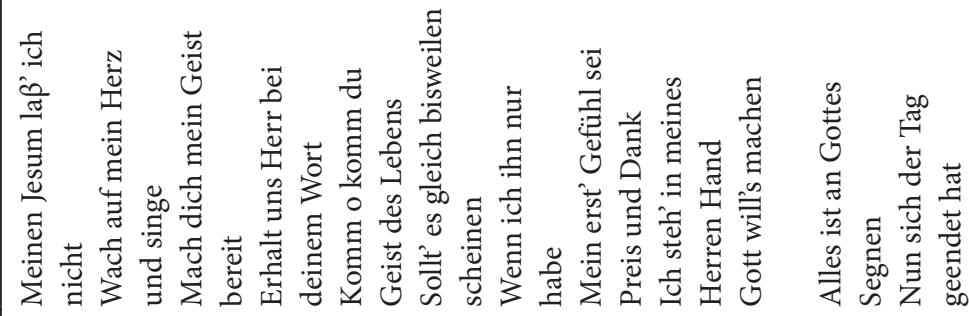

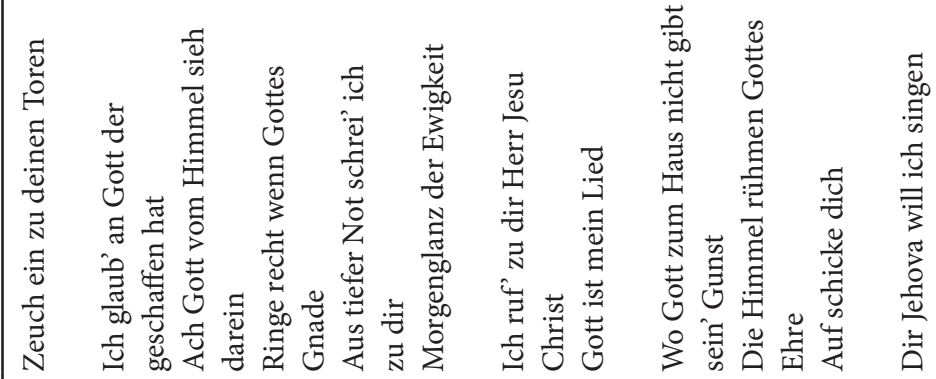

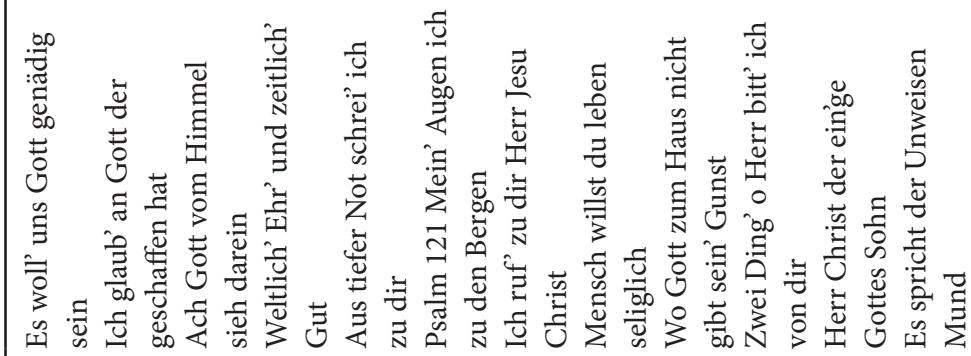

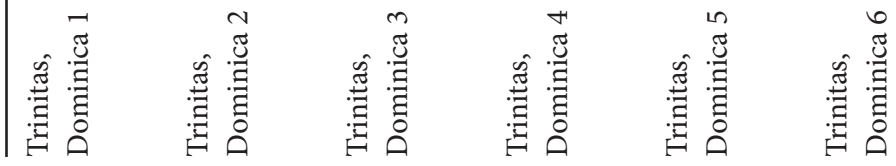




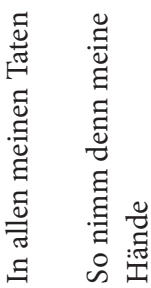

:

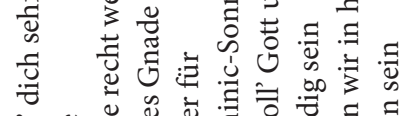

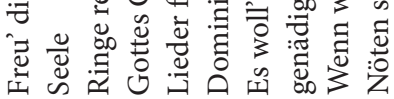

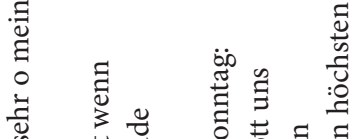

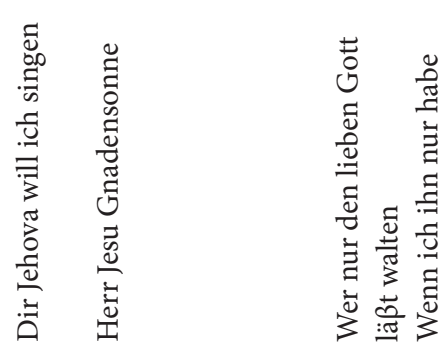

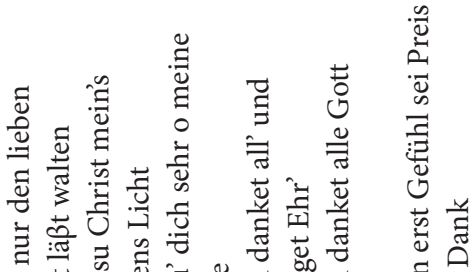

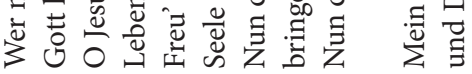

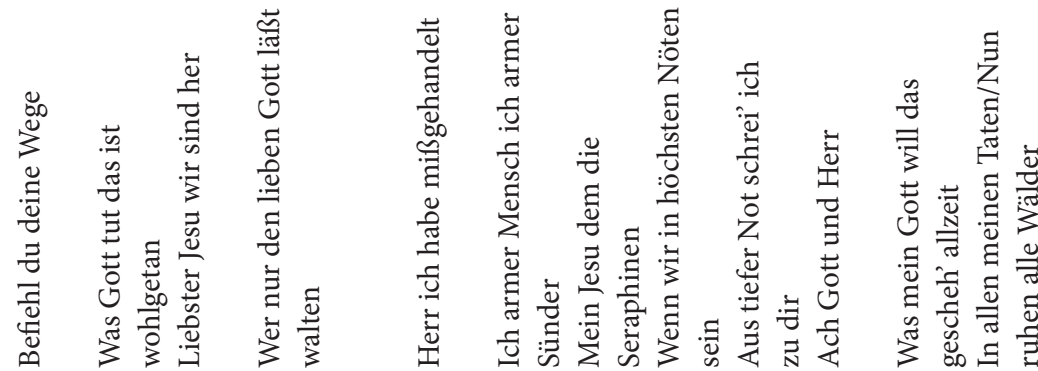

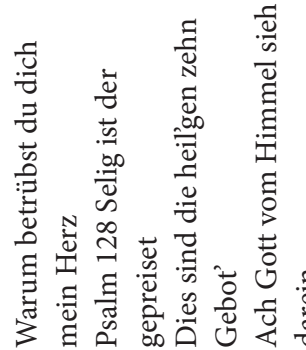

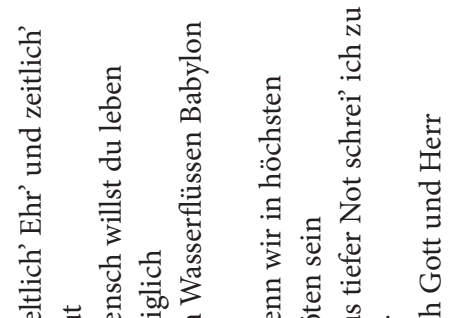

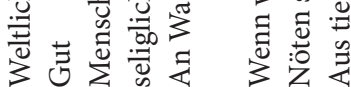

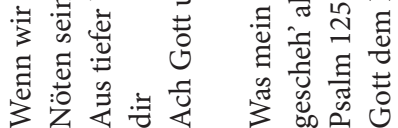

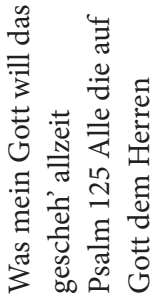

苞节

重
气 
Appendix

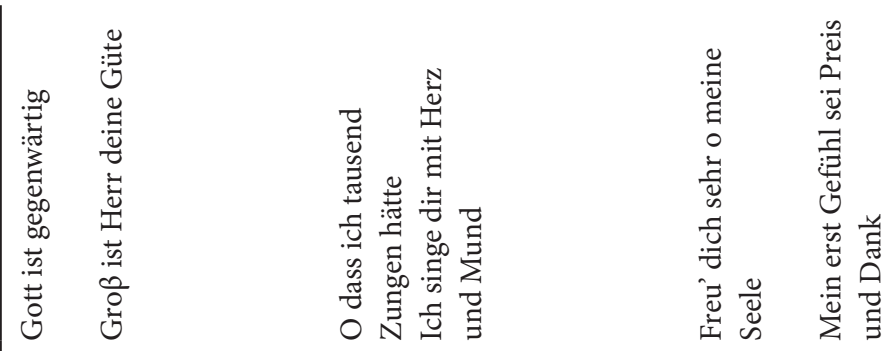

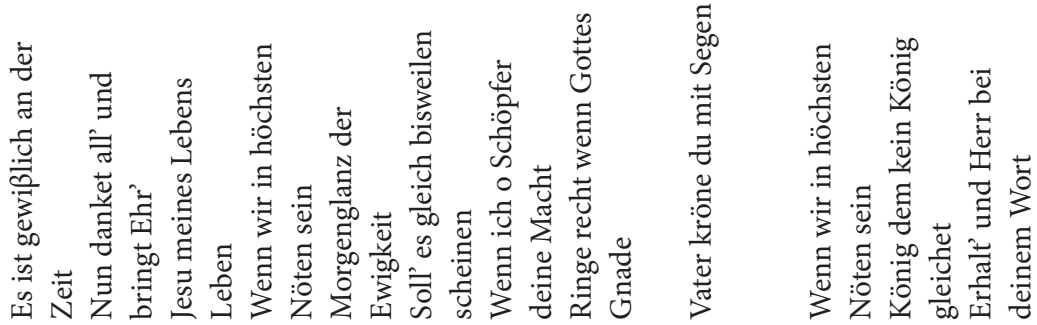

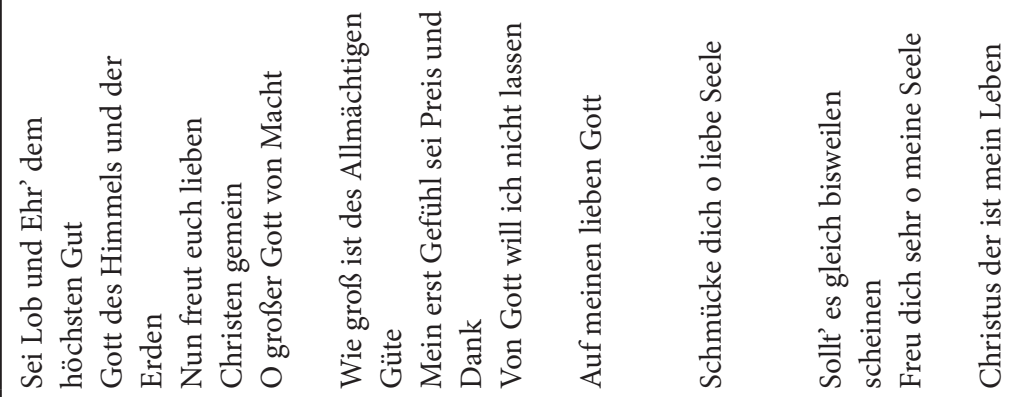

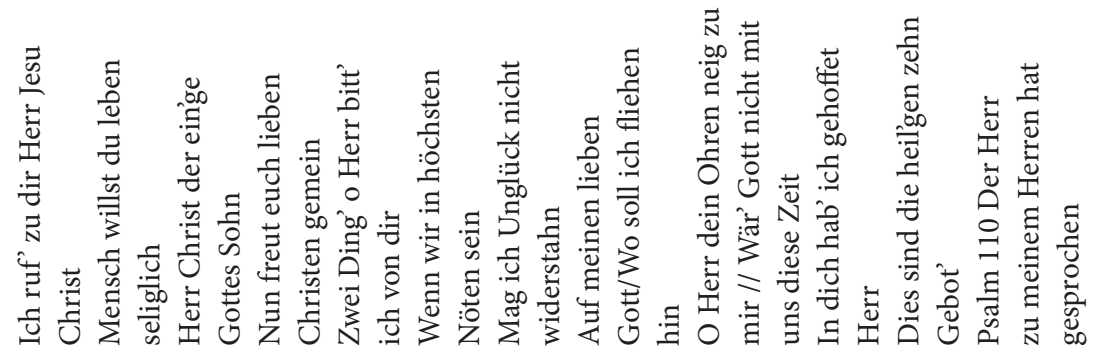

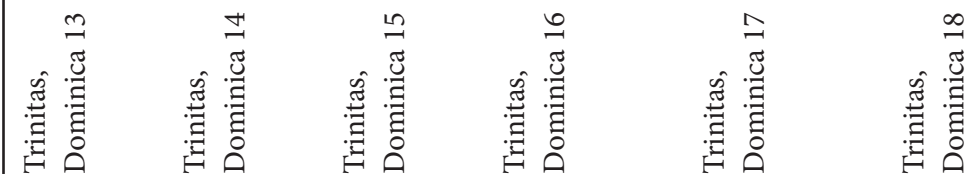



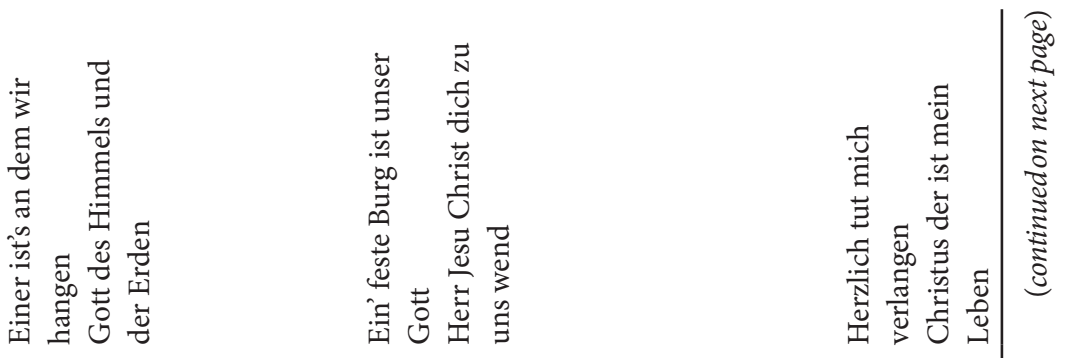

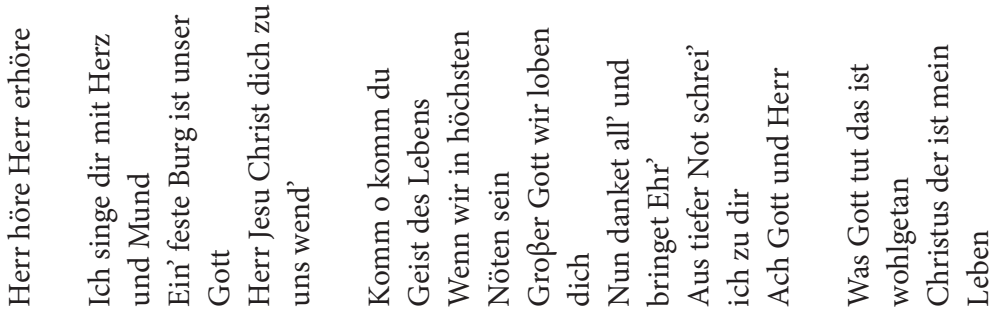

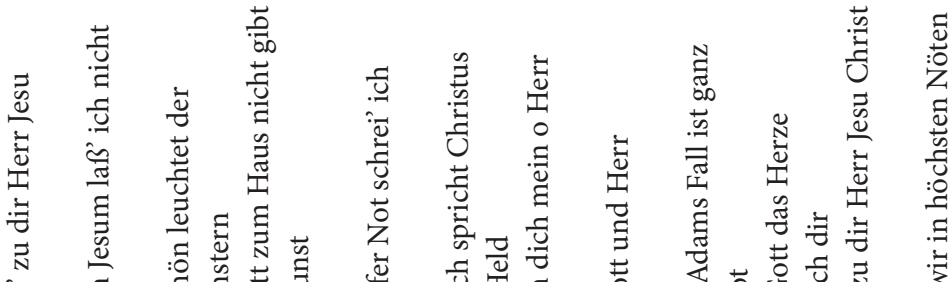

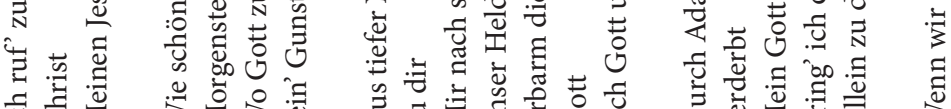

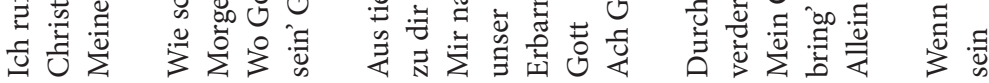

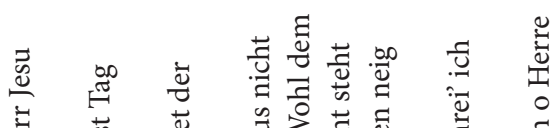

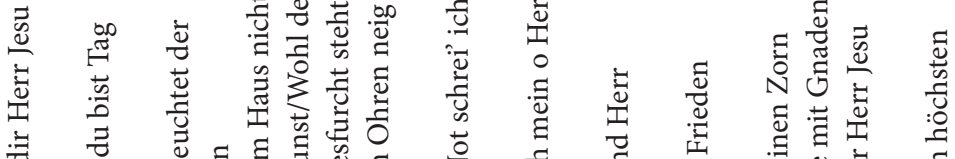

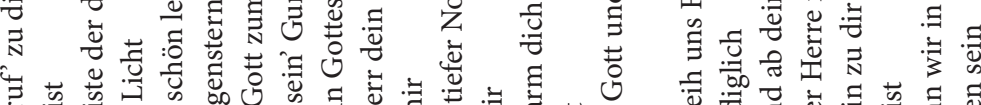

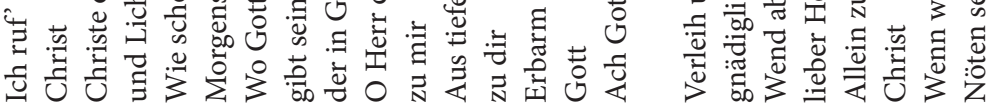

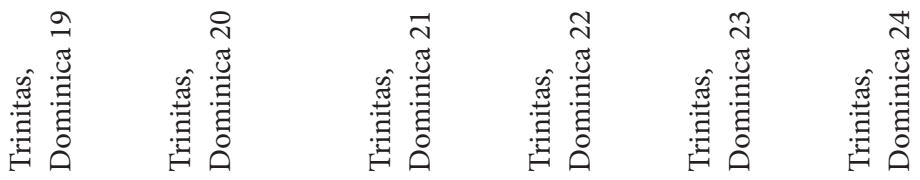




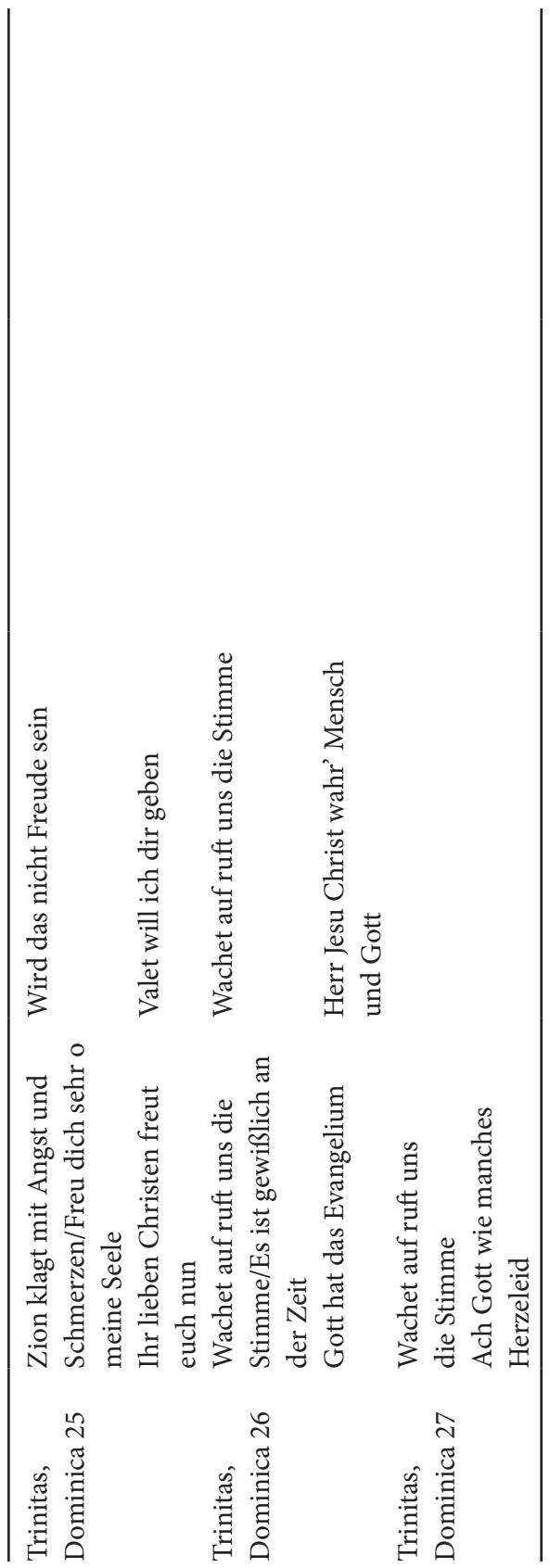




\section{List of illustrations}

Fig. 1: The Main City Town Hall in Gdańsk. Curicke, Der Stadt Danzig, 52 37

Fig. 2: The Main City Town Hall in Gdańsk. PAN BG AL/IV/23/15. ...... 38

Fig. 3: The bells of Jan Moer in the tower of the Main Town Hall. Photo by P. Czarnecki, from the collection of J. W. Wołodźko ... 49

Fig. 4: The bells of Jan Moer in the tower of the Main Town Hall. Photo by P. Czarnecki, from the collection of J. W. Wołodźko ... 51

Fig. 5: $\quad$ Contract for the bells of Jan Moer. GAHt, R 1377, fol. 305 ........ 55

Fig. 6: A bell by Jan Moer. Museum of Gdańsk, photo by M. Popinigis 56

Fig. 7: The mechanism of the Main Town Hall automated carillon. PAN BG AL/III/91/8

Fig. 8: Instruction for reprogramming tunes on the Main Town Hall automated carillon drum. APG 300,R/Pp,q9, p. 171 70

Fig. 9: Instruction for programming occasional tunes on the Main Town Hall automated carillon drum. APG 300,R/Pp,q9, p. 277 ..... 75

Fig. 10: Instruction for programming occasional tunes on the Main Town Hall automated carillon drum. APG 300,R/Pp,q9, p. 281 76

Fig. 11: Instruction for programming occasional tunes on the Main Town Hall automated carillon drum. APG 300,R/Pp,q9, p. 286

Fig. 12: Instruction for programming occasional tunes on the Main Town Hall automated carillon drum. APG 300,R/Pp,q9, p. 287

Fig. 13: F. de Rivulo, Laudamus Dominum. PAN BG Ms 4003, Altus book, fol. 75v-76r

Fig. 14: F. de Rivulo, Ach Mutter liebste Mutter mein. PAN BG Ms 4003, Altus book, fol. 101v-102r

Fig. 15: Das jetzlebende Danzig, 1772, title page .................................... 97

Fig. 16: Das jetzlebende Danzig, 1772, register of musicians, 78 ............ 97

Fig. 17: Entry informing of the death of P. Bewersdorff and the instruments he bequeathed to the church of St John. APG 352/22, p. 128

Fig. 18: Notes by C. A. Kaschlinsky. PAN BG Ms 1089 II, pp. 68-69 ..... 102 
Fig. 19: Advertisement of C. A. Kaschlinsky. Gdańsk Science Museum, desposit of the National Museum in Gdańsk, photo by M. Popinigis 104

Fig. 20: Employment of P. Bewersdorff as bell setter. APG 300,1/140, p. 248 107

Fig. 21: Employment of D. Krüger as bell setter. APG 300,1/144, p. 46 ...... 108

Fig. 22: Quarterly salary of J. Eichstedt. APG 300,12/338, p. 27 .............. 112

Fig. 23: Quarterly salary of J. G. Borowski, PG 300,12/465, p. 279 ......... 113

Fig. 24: $\quad$ Motion of Ph. Schönberg. APG 300,R/Vv,217, p. 1 .................... 115

Fig. 25: $\quad$ Motion of Ph. Schönberg. APG 300,R/Vv,217, p. 2 .................... 116

Fig. 26: Salary for A. Neunaber for occasional programming of the carillon. APG 300,12/69, p. 211

Fig. 27: Salary for J. Neunachber for occasional programming of the carillon. APG 300,12/100, p. 37

Fig. 28: Salary for G. Wernick for occasional programming of the carillon. APG 300,12/121, p. 198

Fig. 29: $\quad$ Church of St Catherine. Curicke, Der Stadt Danzig, 327 ........... 127

Fig. 30: Church of St Catherine. PAN BG Al./IV/3/6 128

Fig. 31: Contract for the bells of J. N. Derck, GA Amsterdam, Notariële Archieven, no. 9939, akte nr. 139, [p. 1]

Fig. 32: Contract for the bells of J. N. Derck, GA Amsterdam, Notariële Archieven, no. 9939, akte nr. 139, [p. 2]

Fig. 33: Letter of E. Wolthers to G. Havingha. Spruijt, Beschrijving van Klokken,

Fig. 34: Letter of E. Wolthers to G. Havingha. Spruijt, Beschrijving van Klokken,

Fig. 35: Acceptance report of bells refurbished by J. N. Derck. Spruijt, Beschrijving van Klokken, 139

Fig. 36: Acceptance report of bells refurbished by J. N. Derck. Spruijt, Beschrijving van Klokken, 140 140

Fig. 37: Acceptance report of bells refurbished by J. N. Derck. Spruijt, Beschrijving van Klokken, 141 141

Fig. 38 Church of St Catherine in Gdańsk. PAN BG P/1 144

Fig. 39: Church of St Catherine in Gdańsk. PAN BG P/1 144

Fig. 40: Church of St Mary in Lübeck: the carillon bells of Gdańsk' St Catherine. Photo by D. Popinigis

Fig. 41: Church of St Mary in Lübeck: the carillon bells of Gdańsk' St Catherine. Photo by D. Popinigis

Fig. 42: Church of St Mary in Lübeck: the carillon bells of Gdańsk' St Catherine. Photo by D. Popinigis 
Fig. 43: Church of St Mary in Lübeck: the carillon bells of Gdańsk' St Catherine. Photo by D. Popinigis 152

Fig. 44: Hoorn, house of J. N. Derck. Photo by D. Popinigis ..................... 154

Fig. 45: Hoorn, house of J. N. Derck, detail. Photo by D. Popinigis ........ 155

Fig. 46: Entry with information about the marriage of J. N. Derck and Maria Oker. WA DTB, Hoorn 68, fol. 229

Fig. 47: $\quad$ Entry with information about the marriage of J. N. Derck and Sara Elisabeth Mom. WA DTB, Hoorn 69, fol. 107 156

Fig. 48: Entry with information about the death of J. N. Derck. WA DTB, Hoorn 109, fol. 51

Fig. 49: Entry with information about the baptism of J. E. Eggert. APG 349/208, p. 342 181

Fig. 50: Entry with information about the employment of C. H. Dircksen as trumpeter at the church of St Catherine, replacing J. E. Eggert. APG 300,41/7, p. 519

Fig. 51: Testimony of J. E. Eggert. APG 353/231, p. 3 183

Fig. 52: J. E. Eggert, Orgeln in Danzig. PAN BG Ms 926, title page 187

Fig. 53: J. E. Eggert, Orgeln in Danzig. PAN BG Ms 926, fol. 8v-9r 187

Fig. 54: Quarterly salary of C. G. Busch and J. E. Eggert. APG $300,41 / 74$, p. 56

Fig. 55: Quarterly salary of C. G. Busch and J. E. Eggert. APG $300,41 / 74$, p. 63

Fig. 56: Contract with P. W. Krieschen. APG 351/231, p. 93 .................... 198

Fig. 57: $\quad$ Contract with P. W. Krieschen. APG 351/231, p. 94 ................... 199

Fig. 58: Youth hostel on Bishop Hill. Photo from the collection of K. Grynder 203

Fig. 59: Carillon bells on Bishop Hill. Gdańsk Science Museum, photo by M. Popinigis 204

Fig. 60: Tablature of Th. F. Gülich, Turm-Bücher. APG 300,R/Pp,q9, title page

Fig. 61: Tablature of Th. F. Gülich, Turm-Bücher. APG 300,R/Pp,q9, p. 77

Fig. 62: Tablature of Th. F. Gülich, Turm-Bücher. APG 300,R/Pp,q9, p. 14

Fig. 63: Tablature of Th. F. Gülich, Turm-Bücher. APG 300,R/Pp,q9, p. 184

Fig. 64: Tablature of Th. F. Gülich, Turm-Bücher. APG 300,R/Pp,q9, p. 18

Fig. 65: Tablature of Th. F. Gülich, Turm-Bücher. APG 300,R/Pp,q9, p. 345 
Fig. 66: Tablature of Th. F. Gülich, Turm-Bücher. APG 300,R/Pp,q9, p. 339

Fig. 67: Tablature of Th. F. Gülich, Turm-Bücher. APG 300,R/Pp,q9, p. 335

Fig. 68: Tablature of Th. F. Gülich, Choral Buch Nach denen Evangelisch Lutherschen Kirchengesängen. APG 300,R/ Pp,q10, title page 231

Fig. 69: Tablature of Th. F. Gülich, Choral Buch Nach denen Evangelisch Lutherschen Kirchengesängen. APG 300,R/ Pp,q10, p. 17

Fig. 70: Tablature of Th. F. Gülich, Choral Buch Nach denen Evangelisch Lutherschen Kirchengesängen. APG 300,R/ Pp,q10, p. 18

Fig. 71: Tablature of Th. F. Gülich, Choral Buch Nach denen Evangelisch Lutherschen Kirchengesängen. APG 300,R/ Pp,q10, p. 19

Fig. 72: Tablature of Th. F. Gülich, Choral Buch Nach denen Evangelisch Lutherschen Kirchengesängen. APG 300,R/ Pp,q10, p. 22 244

Fig. 73: Tablature of Th. F. Gülich, Choral Buch Nach denen Evangelisch Lutherschen Kirchengesängen. APG 300,R/ Pp,q10, p. 29 245

Fig. 74: Tablature of Th. F. Gülich, Choral Buch Nach denen Evangelisch Lutherschen Kirchengesängen. APG 300,R/ Pp,q10, p. 51

Fig. 75: $\quad$ Tablature of Th. F. Gülich, Choral Buch Nach denen Evangelisch Reformirten Kirchengesängen. APG 300,R/ Pp,q10a, title page

Fig. 76: Tablature of Th. F. Gülich, Choral Buch Nach denen Evangelisch Reformirten Kirchengesängen. APG 300,R/ Pp,q10a, p. 3

Fig. 77: Tablature of Th. F. Gülich, Choral Buch Nach denen Evangelisch Reformirten Kirchengesängen. APG 300,R/

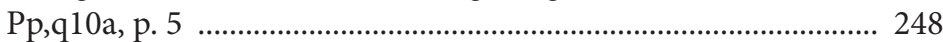

Fig. 78: Tablature of P. F. Knaack. APG 300,R/Uu,q9, p. 1 ....................... 250

Fig. 79: Tablature of P. F. Knaack. APG 300,R/Uu,q9, p. 88 ...................... 251

Fig. 80: Basic types of signs used in Gdańsk carillon tablatures .............. 255

Fig. 81: Pattern of fixing pins to slats of the carillon drum ...................... 255

Fig. 82: Th. F. Gülich, Der Herr ist mein getreuer Hirt'. APG 300,R/ Pp,q9, p. 70 
Fig. 83: $\quad$ Manuscript of C. A. Kaschlinsky. PAN BG Ms 1093 IV, title

Fig. 84: $\quad$ Manuscript of C. A. Kaschlinsky. PAN BG Ms 1093 IV, p. 7 ....... 263

Fig. 85: Manuscript of J. E. Eggert. APG 300,R/Pp,45, cover ................... 320

Fig. 86: Manuscript of J. E. Eggert. APG 300,R/Pp,45, title page ............. 321

Fig. 87: Manuscript of J. E. Eggert. APG 300,R/Pp,45, p. iii ..................... 322

Fig. 88: $\quad$ Manuscript of J. E. Eggert. APG 300,R/Pp,45, p. vii .................... 323

Fig. 89: Manuscript of J. E. Eggert. APG 300,R/Pp,45, p. ix .................... 324

Fig. 90: $\quad$ Manuscript of J. E. Eggert. APG 300,R/Pp,45, p. 1 ...................... 325

Fig. 91: $\quad$ Manuscript of J. E. Eggert. APG 300,R/Pp,45, p. 53 .................... 334

Fig. 92: Manuscript of J. E. Eggert. APG 300,R/Pp,45, p. 85 _................... 335

Fig. 93: $\quad$ Manuscript of J. E. Eggert. APG 300,R/Pp,45, p. 119 .................. 336

Fig. 94: $\quad$ Manuscript of J. E. Eggert. APG 300,R/Pp,45, p. 47 ................... 355

Fig. 95: Manuscript of J. E. Eggert. APG 300,R/Pp,45, p. 147 .................. 368

Fig. 96: Manuscript of J. E. Eggert. APG 300,R/Pp,45, p. 129 _................. 369 



\section{List of tables}

Tab. 1: $\quad$ Genealogy of the Moer (Moor) family ........................................... 54

Tab. 2: Diameter, height, and weight of surviving Jan Moer bells .......... 57

Tab. 3: Diameters of Jan Moer bells after C. A. Kaschlinsky ................... 58

Tab. 4: Weight of the lowest Jan Moer bell and the octave higher after C. A. Kaschlinsky ..................................................................... 58

Tab. 5: Weight of clappers in ten Jan Moer bells after

Tab. 6: Programme of Gdańsk Town Hall carillon during St Dominic's Fair (after Gülich's manual) ...................................... $\quad 74$

Tab. 7: Town Hall carillon setters who were also organists in Gdańsk churches ......................................................................... 94

Tab. 8: List of carillon setters at the Main Town Hall in Gdańsk ............ 105

Tab. 9: Comparison of hypothetical fees as quoted by Gülich with actual payments documented in cashbooks ................................. 118

Tab. 10: Genealogy of the Derck family ....................................................... 158

Tab. 11: Summary of 1738 Gdańsk carillon bell weights, after the notebook of Spruijt (in pounds) ..................................................... 161

Tab. 12: Carillonists of the church of St Catherine ................................... 173

Tab. 13: Occupations and activities of St Catherine's carillonists ............. 175

Tab. 14: Carillonists of the Martinitoren in Groningen in the years

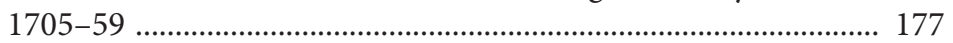

Tab. 15: Siblings of J. E. Eggert ..................................................................... 179

Tab. 16: Remuneration summary of C. F. Eggert for the year 1825 .......... 196

Tab. 17: Manuscripts with works for the Main Town Hall carillon .......... 213

Tab. 18: Former catalogue numbers in the tablatures of Theodor Friedrich Gülich

Tab. 19: Yearly order of songs for the Main Town Hall carillon, after the directory in Gülich's four-volume tablature ........................... 224

Tab. 20: Holiday songs added to the yearly order and the Ein' feste Burg song (with no indication of when it should be set) ............ 227

Tab. 21: Songs set by Theodor Friedrich Gülich in Choral Buch Nach denen Evangelisch Lutherschen Kirchengesängen, crossreferenced to the chapters of the Danziger Gesangbuch of 1764

Tab. 22: Tunes listed by Carl Anton Kaschlinsky, programmed for Harvest Thanksgiving, Reformation Day, and Day of the Dead 
Tab. 23: Song titles listed by Carl Anton Kaschlinsky, illustrating the rules of coupled songs according to their length 261

Tab. 24: Order of songs programmed for St Dominic's Fair as listed by Carl Anton Kaschlinsky 261

Tab. 25: Funeral songs listed by Carl Anton Kaschlinsky with remarks on their programming 261

Tab. 26: Yearly song registers 264

Tab. 27: Identification of alternative titles: comparison of the first extant yearly song register with later sources (until 1861) 270

Tab. 28: Song titles in the first extant yearly song register and later sources (until 1861), not identified as alternative 271

Tab. 29: Songs titles of the yearly repertoire programmed until 1861, with text authors 272

Tab. 30: Psalms to texts by Ambrosius Lobwasser included into the yearly register of songs played by the Gdańsk Town Hall carillon 275

Tab. 31: Songs in Carl Anton Kaschlinsky's register not included in the Danziger Gesangbuch canon of 1856 276

Tab. 32: Alphabetical index of the yearly song repertoire as listed by Carl Anton Kaschlinsky 277

Tab. 33: Religious folksongs ("Geistliche Volkslieder") from the hymnal Evangelisches Gesangbuch (1888), programmed on the Main Town Hall carillon between 1907 and 1928 283

Tab. 34: Repeated songs programmed to a different number of slats ...... 289

Tab. 35: Songs set by T. F. Gülich in his Choral Buch Nach denen Evangelisch Reformirten Kirchengesängen 307

Tab. 36: Musical manuscripts with works for the St Catherine carillon 314

Tab. 37: Chapter order in the Danziger Gesangbuch (Danzig 1764) and number of songs sert by J. E. Eggert for each chapter 327

Tab. 38: Advent songs ("Adventsgesänge") set by J. E. Eggert .................... 329

Tab. 39: Christmas songs ("Weihnachtsgesänge") set by J. E. Eggert ....... 329

Tab. 40: Songs on pious Christian life ("Vom christlichen Tugendwandel überhaupt") set by J. E. Eggert

Tab. 41: Works by J. E. Eggert that include interludes 353 


\section{List of musical examples}

Example 1: Th. F. Gülich, Der Herr ist mein getreuer Hirt', APG $300, \mathrm{R} / \mathrm{Pp}, \mathrm{q} 9$, p. 70

Example 2: T. F. Gülich, Ach Gott und Herr, APG 300,R/Pp,q9, pp. 52 and 116

Example 3: T. F. Gülich, Ach Gott und Herr, APG 300,R/Pp,q9, p. 143 286

Example 4: T. F. Gülich, Ach Gott und Herr, APG 300,R/Pp,q9, p. 116 286

Example 5: T. F. Gülich, Ach Gott und Herr, APG 300,R/Pp,q9, p. 117 286

Example 6: T. F. Gülich, Es ist gewißlich an der Zeit, APG 300,R/ Pp,q9, p. 7 288

Example 7: T. F. Gülich, Es ist gewißlich an der Zeit, APG 300,R/ Pp,q9, pp. 10-11 289

Example 8: Psalm 110 Der Herr zu meinem Herrn hat gesprochen, in Kirchen Gesang-Buch, Dantzig 1744, 177

Example 9: T. F. Gülich, Psalm 110 Der Herr zu meinem Herrn hat gesprochen, APG 300,R/Pp,q9, p. 133

Example 10: T. F. Gülich, Ein' feste Burg, APG 300,R/Pp,q9, pp. $46-47$ 292

Example 11: T. F. Gülich, O Traurigkeit o Herzeleid, APG 300,R/ Pp,q9, p. 61 293

Example 12: T. F. Gülich, Surrexit Christus hodie, APG 300,R/Pp,q9, p. 72 294

Example 13: T. F. Gülich, An Wasserflüssen Babylon, APG 300,R/ Pp,q9, pp. 112-13 294

Example 14: T. F. Gülich, Gottes Sohn ist kommen, APG 300,R/Pp,q9, pp. $12-13$ 295

Example 15: T. F. Gülich, In dulci jubilio, APG 300,R/Pp,q9, pp. $24-25$ 295

Example 16: T. F. Gülich, O Tod was willt du schrecken, APG 300,R/ Pp,q9, p. 239 298

Example 17: T. F. Gülich, O Tod was willt du schrecken, APG 300,R/ Pp,q9, p. 238 298

Example 18: T. F. Gülich, O Tod was willt du schrecken, APG 300,R/ Pp,q9, p. 237 
Example 19: T. F. Gülich, Es ist gewi $\beta$ ein' große Gnad', APG 300,R/ Pp, q9, 254-55 299

Example 20: T. F. Gülich, Mitten wir im Leben sind, APG 300,R/ Pp,q9, pp. 364-65 300

Example 21: T. F. Gülich, Komm heiliger Geist Herre Gott, APG 300,R/Pp,q9, pp. 342-43 301

Example 22: T. F. Gülich, Es woll' uns Gott genädig sein, APG 300,R/ Pp,q9, pp. 340-41 302

Example 23: T. F. Gülich, Te Deum laudamus, APG 300,R/Pp,q9, pp. 334-35

Example 24: T. F. Gülich, Aus tiefer Not schrei' ich zu dir, APG 300,R/ Pp,q10, 97 304

Example 25: Psalm 107 Danket und lobt den Herren, in Kirchen Gesang-Buch, Dantzig 1744, 171 305

Example 26: T. F. Gülich, Psalm 107 Danket und lobt den Herren, APG 300,R/Pp,q10a, p. 93 305

Example 27: Psalm 128 Selig ist der gepreiset der Gott, in Kirchen Gesang-Buch, Dantzig 1744, p. 205 306

Example 28: T. F. Gülich, Psalm 128 Selig ist der gepreiset der Gott, APG 300,R/Pp,q10a, p. 108 306

Example 29: Psalm 4 O Gott mein Hort erhör mein Flehen, in Kirchen Gesang-Buch, Dantzig 1744, p. 4 306

Example 30: T. F. Gülich, Psalm 4 O Gott mein Hort erhör mein Flehen, APG 300,R/Pp,q10a, p. 4 306

Example 31: T. F. Gülich, Wer in dem Schutz das Höchsten ist, APG 300,R/Pp,q9, p. 162 309

Example 32: P. F. Knaack, Wer in dem Schutz das Höchsten ist, APG 300,R/Uu,q9, p. 111 309

Example 33: T. F. Gülich, Es spricht der Unweisen Mund, APG 300,R/ Pp,q9, p. 105

Example 34: P. F. Knaack, Es spricht der Unweisen Mund, APG 300,R/Uu,q9, p. 88

Example 35: T. F. Gülich, Ich glaub' an Gott der geschaffen hat, APG 300,R/Pp,q9, p. 88

Example 36: P. F. Knaack, Ich glaub' an Gott der geschaffen hat, APG 300,R/Uu,q9, p. 51

Example 37: T. F. Gülich, Allein Gott in der Höh' sei Ehr', APG 300,R/ Pp,q9, p. 83

Example 38: C. A. Kaschlinsky, Allein Gott in der Höh' sei Ehr', PAN BG Ms 1093 IV, p. 5 
Example 39: J. E. Eggert, Dies sind die heil'gen zehn Gebot', no. 61, bars $1-24$

Example 40: J. E. Eggert, Warum sollt' ich mich denn grämen, no. 77,

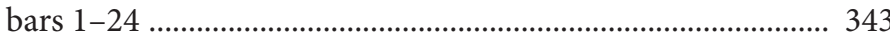

Example 41: J. E. Eggert, O Christe Morgensterne, no. 115 ........................ 344

Example 42: J. E. Eggert, O Traurigkeit o Herzeleid, no. 27 ........................ 347

Example 43: J. E. Eggert, Vom Himmel hoch da komm' ich her, no. 12 .... 348

Example 44: J. E. Eggert, In dulci jubilo, no. 11 ........................................ 350

Example 45: J. E. Eggert, Herr ich denk' an jene Zeit, no. 102 .................... 351

Example 46: J. E. Eggert, Nun danket alle Gott, no. 82 ……...................... 352

Example 47: C. Ph. E. Bach, O Herr meine Gott durch den ich bin

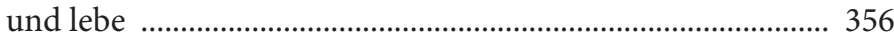

Example 48: J. E. Eggert, Der Herr der aller Enden, ad Interlud[ium]: O Herr meine Gott durch den ich bin und lebe, Bachs Mel[odie], no. 45 ................................................ 357

Example 49: C. Ph. E. Bach, Du bist's dem Ruhm und Ehre ....................... 359

Example 50: J. E. Eggert, Du bist's dem Ruhm und Ehre, no. 43 ............... 360

Example 51: J. E. Eggert, So wahr ich lebe spricht dein Gott ad Interludium, Ach was soll ich Sünder machen, no. 66 .......... 363

Example 52: J. E. Eggert, Gelobet seist du Jesu Christ, no. 129 ................... 364

Example 53: J. E. Eggert, Ein Kind geborn zu Bethlehem, no. 125 ............ 365

Example 54: J. E. Eggert, Herzlich lieb hab' ich o Herr, no. 88 ................... 367

Example 55: J. E. Eggert, Herr Jesu Christ du höchstes Gut, no. 195 ......... 370

Example 56: J. E. Eggert, Hört auf mit Trauren und Klagen, no. 108a ...... 371

Example 57: J. E. Eggert, Mitten wir im Leben sind, no. 100, beginning 



\section{Bibliography}

\section{Manuscript sources}

\section{Amsterdam, Stadsarchief Amsterdam}

Notariële Archieven, no. 9939, akte nr. 139.

Berlin, Staatsbibliothek zu Berlin - Preussischer Kulturbesitz, Musikabteilung mit Mendelssohn-Archiv

Ms. Danzig 4020

XXXI Choralmelodien. Eine Beilage zum alten Danziger Choralbuch. 1811.

Ms. Danzig 4252

Choralmelodien zum neuen Danziger Gesangbuch, 1810 von Benjamin Gotthold Siewert, Cappelmeister post 1810.

Ms. Danzig 4254

Choral-Buch zum neuen Gesangbuche, für den evangelischen Gottesdienst vom Jahre 1841. Geschrieben von C.A. Kaschlinsky, im Jahre 1846.

\section{Gdańsk, Archiwum Państwowe w Gdańsku (State Archive in Gdańsk)}

Biblioteca Archivi: 300,R

$300, \mathrm{R} / \mathrm{K}, 2 ; 300, \mathrm{R} / \mathrm{K}, 4$

"Solennia", 17th-18th century.

300,R/LI,96

Wutstrack Christian Friedrich, Historisch-topographisch-statistische Nachrichten von der Königlisch-West-Preussischen See- und Handels-Stadt Danzig ..., Danzig 1807.

$300, \mathrm{R} / \mathrm{Pp}, \mathrm{q} 9$

Auf hohe Verordnung Ihro Magnificens des Hochädelgebohrn: Vest: $u$.

Gestrengen Herrn Hrn Carl Groddek gegenwärtig Praesidirenden Aeltesten Hrn Bürgermeistern, Protoscholarch u. Administr: des Stübl: Werders. zum Gebrauch des Rechtst: Glokkenspiels ausgefertigte Thurm-Bücher nebst Vermehrung derer Sterbe-Lieder von Theodor Fridr: Gülich. Raths-Uhr Glokstllr. Anno 1769.

300,R/Pp,q10

Choral Buch. Nach denen Evangelisch Lutherschen Kirchengesängen in

Dantzig zum Gebrauch des Rechtst: Glokkenspiels ausgefertiget von Theodor

Fridr: Gülich E. Hochedl. Hochweis. Raths: Uhr Glokkensteller. 1775. 
Choral Buch Nach denen Evangelisch Reformirten Kirchengesängen in Dantzig zum Gebrauch des Rechtst: Glokkenspiels ausgefertiget von Theodor Fridr: Gülich E. Hochedl. Hochweis. Raths Uhr Glokkensteller. 1775. $300, \mathrm{R} / \mathrm{Pp}, 45$

Choral-Lieder zu dem Glocken-Spiel der Altstädtschen Ober-Pfarr-Kirche zu St: Catharinen ausgesetzt mit Variationes von Johann Ephraim Eggert Glockenist des Altstädtschen Glockenspiels, und Organist zum Heil: Leichnam Danzig $A^{\circ}$ MDCCLXXXIV.

$300, \mathrm{R} / \mathrm{Uu}, \mathrm{q} 9$

Choral-Buch vom rechtstädschen Glockenspiel. der Stadt Danzig. $300, \mathrm{R} / \mathrm{Vv}, 217$

Motions by watchmakers and bell setters.

Office of the Presiding Mayor: 300,1 $300,1 / 140 ; 300,1 / 144 ; 300,1 / 186$.

Registry Office: 1609 1609/77; 1609/159; 1609/509.

Magistrate Court: 300,43

$300,43 / 110$

Cashbooks: 300,12

$300,12 / 12 ; 300,12 / 21 ; 300,12 / 26 ; 300,12 / 28 ; 300,12 / 31 ; 300,12 / 41 ; 300,12 / 45$;

$300,12 / 59 ; 300,12 / 60 ; 300,12 / 61 ; 300,12 / 64 ; 300,12 / 67 ; 300,12 / 81 ; 300,12 / 84$;

$300,12 / 87 ; 300,12 / 97 ; 300,12 / 99 ; 300,12 / 100 ; 300,12 / 109 ; 300,12 / 112$;

$300,12 / 116 ; 300,12 / 118 ; 300,12 / 121 ; 300,12 / 123,300,12 / 129 ; 300,12 / 131$;

$300,12 / 140 ; 300,12 / 141 ; 300,12 / 142 ; 300,12 / 149 ; 300,12 / 169 ; 300,12 / 178$;

$300,12 / 181 ; 300,12 / 185 ; 300,12 / 199 ; 300,12 / 338 ; 300,12 / 465$.

Arts and science: 300,36

$300,36 / 74$.

Old Town: 300,41.

$300,41 / 7 ; 300,41 / 10 ; 300,41 / 71 ; 300,41 / 73 ; 300,41 / 74$.

Church of St Bartholemew: 348

348/586.

Church of Corpus Christi: 349

349/208.

Church of St John: 352

$352 / 22$.

Church of St Catherine: 353 
$353 / 51 ; 353 / 149 ; 353 / 150 ; 353 / 153 ; 353 / 154 ; 353 / 164 ; 353 / 231 ; 353 / 232$;

$353 / 237 ; 353 / 238 ; 353 / 239 ; 353 / 240$.

Church of St Mary: 354

$354 / 349 ; 354 / 351$.

$1461 / 136$.

Gdańsk, Polska Akademia Nauk Biblioteka Gdańska (Polish Academy of Science Gdańsk Library)

Akta Kat. Nr. 114

Ms 53

Stephanus Grau, Erster Theil Danziger Geschichte ..., [after 1676].

Ms 145, 146, 149

Rubach's Danziger monatliche Sammlung.

Ms 697/29

Die rechtstädtische Sing-Uhr fängt an zu spielen.

Ms 806

Genealogieen einiger Danziger Patricier-Familien, mit Anmerkungen von C. A. Kaschlinsky.

Ms 863

Jahr-Lieder des Rechtst. Glokkenspiels 1771.

Ms $863 \mathrm{a}$

Der Jahr-Gang der Lieder der Sing-Uhr auf dem rechtstädtischen Rath-Hause an Seine geliebte Großmama von Henrich Gottfried Meyer. Anno 1782.

Ms 926

Eggert Johann Ephraim, Orgeln in Danzig.

Ms 1073 I

Verzeichni $\beta$ derer Lieder welche durch gantze Jahr mit dem Glocken-Spiel auf dem Rechtstädtschen Raths-Thurm gespielt werden. Anno 1788.

Ms 1089 II

Notes by Carl Anton Kaschlinsky.

Ms 1093 IV

Beschreibung des Glockenspiels auf dem Turme des Rathauses zu Danzig nebst Verzeichnis der Melodien, welches dasselbe spielt. Verfasst von Carl Anton Kaschlinsky....

Ms 4003

4 part-books; 143 vocal compositions; late 16th century. 
Ms 4017

210 chorale settings for organ; 1762 .

Ms 4018

169 chorale settings for organ; 18th century.

Ms 4019a

Choral Buch. Johann Friedrich Wagner. Anna 1771.

Ms 4255 I

261 chorale settings for organ; 18 th century.

Ms 5750

Carl Anton Kaschlinsky, Gdańsk miscellanea.

Ms 5751

Carl Anton Kaschlinsky, Danziger Familien.

Ms Joh.19

Cantata an den hohen Geburts-Feste... von Johann Balthasar Christin Freislich.

Ms Joh.456-469

4 part-books; 110 religious song settings; mid-17th century.

Ms Joh.462

82 chorale settings for trumpet; late 19th century

Ms Mar.Q.183

Vollkomenes Musicalisches Choral-Buch. Welches mit allem Fleiss eingerichtet, nach dem Dantziger Kirchen Gesang Buch. Worine alle Witzgese Gänge auffs Sorgfältigste vermieden sind. und auch Etliche Melodeyen Transponiret sind, in andere Töne. und ist Verfertiget von Johan David König. Anno 1763. Dantzig.

Ms Mar.Q.184

212 chorale settings for organ; 18th/19th century.

Ms Mar.Q.185

295 chorale settings for organ; 18th century.

Ms Mar.Q.186

153 chorale settings for organ; early 19th century.

Groningen, Regionaal Historisch Centrum Groninger Archieven

Collectie DzB Inventarisnummer 149, 150, 175.

\section{Hoorn, Westfries Archief}

Nummer 134E69 
Beschrijving van Klokken en Klokken-Spelen door Juriaan Spruijt klokkenist en organist Stad Hoorn in West-Friesland.

DTB, Enkhuizen 38/2; 98/1.

DTB, Hoorn 49/4; 50/1; 50/2; 50/3; 68; 69; 109.

's-Hertogenbosch, Stadsarchief 's-Hertogenbosch (GAHt)

R 1377.

\section{Printed sources}

ABuch 1796

Adressbuch der Königl. West-Preussische See und Handelsstadt Danzig und der combinirten Städte Stolzenberg ..., Danzig, 1796.

ABuch 1797

Adressbuch der Königl. West-Preussischen See- und Handelsstadt Danzig und der combinirten Städte Stolzenberg fürs Jahr 1797 ..., Danzig, 1797.

ABuch 1800

Adressbuch der Königl. West-Preussischen See- und Handelsstadt Danzig und der combinirten Städte Stolzenberg ..., Danzig, 1800.

ABuch 1817

Adress-Buch für das Königliche Danziger Regierungs-Departement mit besonderer

Berücksichtigung der Stadt Danzig und ihres Polizei-Bezirks, Danzig 1817.

ABuch 1839

Adressbuch der Stadt Danzig und der dazu gehörigen Vorstädte, Danzig 1839.

ABuch 1854

Allgemeiner Wohnungs-Anzeiger für Danzig und dessen Vorstädte auf das Jahr 1854.

ABuch 1880

Neuer Wohnungs-Anzeiger nebst Allgemeinem Geschäfts-Anzeiger pro ... 1880 von Danzig und dessen Vorstädten.

ABuch 1902, 1920, 1922, 1924, 1925, 1939

Neues Adreßbuch für Danzig und Vororte.

Bach Carl Philipp Emanuel, Herrn Christoph Christian Sturms ... geistliche Gesänge mit ..., Leipzig 1780, 1781 (RISM A/I/1 B-132, 136).

Bach Carl Philipp Emanuel, Herrn Prof. Gellerts Geistliche Oden und Lieder ..., Berlin 1771 (RISM A/I/1 B-126). 
Buhse [Daniel], Plan von Danzig. Nach trigonometr. Aufnahme im Auftrage d. Magistrates in d. Jahren 1866 bis 1869 gefertigt, Danzig [1869].

Christliche Religions-Gesänge, für die öffentliche und häusliche Gottesverehrung; gesammelt von dem geistlichen Ministerio des Danziger Freistaates Mit Obrigkeitlicher Genehmigung. Danzig, gedruckt und zu bekommen in der Müllerischen Buchdruckerei. 1810.

Dantziger Gesang-Buch, Welches auff E. Hoch-Edlen Raths daselbst Verordnung zur Beförderung der Kirchen- und Hauss Andacht aus Lutheri und anderer bewehrten Autorum geistreichen Liedern zusammen getragen und eingeführet worden, Dantzig Auff Verlag der Frey-Schulen gedruckt 1719.

Danziger Gesangbuch für Kirchen- und Haus-Andachten. Mit Genehmigung Eines Königlichen Hochwürdigen Consistorii der Provinz Preussen nach der Ausgabe von 1764 neu aufgelegt und mit einem Anhange erbauliche Lieder vermehrt. Danzig 1856. Verlegt und zu haben bei C. G. Gensch. Druck von A. W. Kafemann.

Danziger Gesangbuch, welches auf E. Hochedlen Raths Verordnung zum allgemeinen Gebrauch der Kirchen und Haus Andachten von Em. Ehrwürdigen Ministerio der ungeänderten Augsp. Conf. allhier aufs Neue vermehrt und nebst einem Anhange von Gebeten herausgegeben worden ist, Danzig, gedruckt und verlegt von Thom. Joh. Schreibern. 1764.

D[erham], W[illiam] The Artificial Clock-Maker. A Treatise of Watch and ClockWork ..., London ... MDCCXXXIV.

Duisburg, Friedrich Karl Gottlieb von, Geschichte der Belagerungen und Blokaden Danzig's von der frühesten bis auf gegenwärtige Zeit. Ein historischer Versuch, Danzig 1808.

Eigendliche- und gewisse Nachricht Der Von Hr: Kön: Majestät zu Pohlen Wieder Den allgemeinen Erb-Feind der Christenheit Erhaltenen herrlichen Victori, Und Wie es bey dem neulich den 9. und 10. Octobris Anno 1683. blutigen Treffen gegen Gran über abgelauffen. Gedruckt im Jahr Christi An. 1683.

Evangelisches Gesangbuch. Ausgabe für die Evangelische Kirche in der Freie Stadt Danzig. [n.d.].

Evangelisches Gesangbuch für Ost- und Westpreussen. Unter Zustimmung der Provinzial-Synode vom Jahre 1884 und mit Genehmigung des Evangelischen Ober-Kirchenrats herausgegeben vom Königlichen Konsistorium der Provinzen Ost- und Westpreussen. Danzig. Verlag und Druck von A. W. Kafemann. 1888.

Geistliche Lieder und Psalmen D. Martini Lutheri auch anderer Gottsehligen Lehrer und Männer. Nach Ordnung der Jahrzeit mit zweyen richtigen Registern. Itzo auffs new übersehen und mit fleisse Corrigiret. Zu Dantzig Gedruckt und Verleg durch Georg Rheten. Im Jahre Christi 1626. 
Hartknoch, Christoph. Preussische Kirchen-Historia, darinnen von Einführung der Christlichen Religion in diese Lande, wie auch von der Conservation, Fortpflanzung, Reformations u dem heutigen Zustande derselben ausführlich gehandelt wird. Franckfurt am Mayn-Leipzig: Simon Beckenstein, 1686.

[Hingelberg, Johann Gottfried], Über Danziger Musik und Musiker, Elbing 1785.

Das jetztlebende Danzig, 1755-1810.

Kirchen Gesang-Buch Der Evangelisch-Reformirten Gemeinde in Dantzig: Worinn, nebst denen CL. Psalmen Davids, in deutsche Reimen gebracht, befindlich CCC. auserlesene, geistreich- und erbauliche Lieder, über allerley, beym öffentlichen Gottesdienst vorkommende Materien in eine bequeme Ordnung zusammen getragen. Ephes. V. v. 19. Redet untereinander, von Psalmen und Lobgesängen und geistlichen Liedern, singet und spielet dem Herrn in eurem Hertzen. Dantzig, Gedruckt bey Th. Joh. Schreiber, E. Hochedl. Raths Buchdrucker. 1744.

Des Kirchen-Gesang-Buchs Anderer Theil: Worinn, mit denen geistreichen Liedern Hrn. Doct. Martin Luthers und anderer Gottesgelehrten Männer, vorkomme, Viele auserlesene und erweckliche Lieder, als ein zulänglicher Vorrath über allerley bey öffentlichen Gottesdienst vorkommende Materien: nebst dem Catechismo. Dantzig, 1744. Gedruckt bey Thomas Johann Schreiber, eines Hochedlen. Hochweisen Raths und des löblichen Gymnasii Buchdrucker.

Kurtze Relation Des Erfrewliche Einzugs Welchen Ihr Königliche Majestet ... Joannes Casimirus König zu Pohlen ... Aus dem Polnischen Lager In Die Stadt Dantzig gehalten den 15. Novemb. Anno 1656.

Martini Adam Jacob, Kurtze Beschreibung und Entwurff alles dessen was bey der ... Ludovicae Mariae Gonzagae ... Einzuge in die Königl: Stadt Dantzig, sich denckwürdiges begeben, und zugertragen ... worden ... Gedruckt zu Dantzigk, bey Georg Rheten [1646].

Melodie zum Gesangbuch für den evangelischen Gottesdienst. Für Kirche, Schule und Haus, Danzig 1841, Verlag von Fr. Sam. Gerhard.

Sammlung einiger Nachrichten von berühmten Orgel-Wercken in Teutschland mit vieler Mühe aufgesetzt von einem Liebhaber der Musik, Bresslau, verlegts Carl Gottfried Meyer, 1757.

Das Sing- und Bethende Kind Gottes, Worinn 840. der besten und Geistreichesten Lieder, Sonderlich des Seel. Doct. Martini Lutheri, und anderer in Gott erleuchteten Männer, enthalten; Zur Übung in der Gottseligkeit, So wohl allhier, als anderer Orten in Kirchen und Häusern nützlich zu gebrauchen: Nebst angefügtem Gebeth-Büchlein, In diesem bequemen Format 
zum sechsten mahl ausgefertiget. Dantzig, 1743. Mit Thom. Johann Schreibers Verlag und Schriften.

Verzeichni $\beta$ der Grundstücke in der Stadt, und zwar innerhalb der Rachtstadt, Altstadt, Vorstadt, Niederstadt und Außenwerke, zusammengestellt nach den neuen und alten Servisi Nummern. Hinzugefügt sind die HypothekenbuchsNummern und Namen der Besitzer nach den Kämmerei-Heberegistern, Danzig 1854.

\section{References}

Adriaenssen, Leo F. W. 'De Bossche klokengietersfamilie Moer, 1540-1570'. Noordbrabants Historisch Jaarboek 6 (1989): 45-78.

Babnis, Maria. 'Kniewel Teodor Friedrich'. Edited by Zbigniew Nowak. Słownik Biograficzny Pomorza Nadwiślańskiego. Gdańsk: Gdańskie Towarzystwo Naukowe-Uniwersytet Gdański, 1998.

Baszanowski, Jan. Przemiany demograficzne w Gdańsku w latach 1601-1846 w świetle tabel ruchu naturalnego. Gdańsk: Uniwersytet Gdański, 1995.

Bertling, August. Katalog der Danziger Stadtbibliothek. Band I, Theil 1: Die Danzig betreffenden Handschriften. Vol. 1. Danzig: A. Schroth, 1892.

Biernat, Czesław. 'Organizacja nowych władz miejskich'. In Historia Gdańska, edited by Edmund Cieślak, 3/2 (1793-1815): 26-30. Gdańsk: Wydawnictwo Morskie, 1993.

Blech, Ernst. 'Das alte und das erneute Glockenspiel von St. Katharinen in Danzig. Mitteilungen des Westpreussischen Geschichtsvereins XVIII, no. 2 (1919): 13-21.

Blech, Ernst. 'Leidensjahre von St. Katharinen in Danzig'. Zeitschrift des Westpreussischen Geschichtsvereins 48 (1905): 159-92.

Bogucka, Maria. 'Funkcje społeczno-polityczne ratusza Głównego Miasta w Gdańsku do końca XVIII w. In Ratusz w miastach pótnocnej Europy. Materiały $z$ sesji: Ratusz w miastach nadbałtyckich, edited by Stanisław Latour, 79-89. Gdańsk: Marpress, 1997.

Bogucka, Maria. 'Gdańsk - największy port Bałtyku'. In Historia Gdańska, edited by Edmund Cieślak, 2:465-507. Gdańsk: Wydawnictwo Morskie, 1982.

Bogucka, Maria. 'Kultura materialna i obyczajowość. In Historia Gdańska, edited by Edmund Cieślak, 2:658-85. Gdańsk: Wydawnictwo Morskie, 1982.

Bogucka, Maria. 'Przemiany społeczne i walki społeczno-polityczne w XV i XVI w.' In Historia Gdańska, edited by Edmund Cieślak, 2:208-59.

Gdańsk: Wydawnictwo Morskie, 1982. 
Bogucka, Maria. 'Zmiany w handlu bałtyckim na przełomie XVI i XVII w.' In Historia Gdańska, edited by Edmund Cieślak, 2:445-64. Gdańsk: Wydawnictwo Morskie, 1982.

Boon, Piet. 'De Hoornse Klok- en Geschutgieterij van de familie Derck'. Westfried Museum Krant 2, no. 1 (1991): 10.

Budzyński, Gustaw, Joachim Gudel, and Marianna Sankiewicz. 'Timbre of the Gdańsk Historical Bells and Carillons'. In Preservation of the Industrial Heritage - Gdańsk Outlook. International Seminar - European Workshop Preservation of the Industrial Heritage, May 11-14, 1993, Gdańsk, Poland: International Seminar - European Workshop: Proceedings, 73-89. Technical University of Gdańsk - The Archaeological Museum in Gdańsk, 1993.

Burchard, Maria. 'Nägeli Hans Georg'. Edited by Elżbieta Dziębowska. Encyklopedia muzyczna PWM. Kraków: Polskie Wydawnictwo Muzyczne, 2002.

Chodkowski, Andrzej. Encyklopedia muzyki. Warszawa: Państwowe Wydawnictwo Naukowe, 1995.

Chojnacki, Władysław. 'Glummert, Jan Daniel'. Edited by Kazimierz Lepszy. Polski Słownik Biograficzny. Wrocław: Zakład Narodowy im. OssolińskichWydawnictwo Polskiej Akademii Nauk, 601959.

Chomiński, Józef Michał. Historia harmonii i kontrapunktu. Vol. 3. Kraków: Polskie Wydawnictwo Muzyczne, 1990.

Cieślak, Katarzyna. Między Rzymem, Wittenberga a Genewą. Sztuka Gdańska jako miasta podzielonego wyznaniowo. Monografie Fundacji na Rzecz Nauki Polskiej. Seria humanistyczna. Wrocław: Fundacja na rzecz Nauki Polskiej, 2000.

Curicke, Reinhold. Der Stadt Danzig historische Beschreibung, FaksimileDruck nach der Originalausgabe Amsterdam und Dantzigk 1687 und einer Einführung von Ernst Bahr. Hamburg: Siegfried Rosenberg, 1979.

Cwalińska, Paulina. "Mitten wir im Leben sind, mit dem Tod umfangen... Luterańska muzyka czasu śmierci (lata 20. XVI - lata 20. XVII w.)”. Barok 11, no. 2 (2004): 163-83.

Cyrson, Edward. 'Ustrój Gdańska w latach 1793-1807'. Czasopismo prawnohistoryczne 19, no. 1 (1967): 109-34.

Davies, Norman. God's Playground. A History of Poland: Volume 1: The Origins to 1795. Vol. 1. Oxford: Oxford University Press, 2005.

Deleu, Frank. 'Johann Ephraim Eggert Choral Lieder for the St.-Catharina Carillon in Gdansk'. In XV World Carillon Congress Gdańsk 16th-20th July 2006. [Gdańsk], 2007. 
Dollinger, Philippe. The German Hansa. Translated by D. S. Ault and Sigfrid Henry Steinberg. Macmillan: London-Basingstoke, 1970.

Domagała, Tadeusz. Gdańsk. Ratusz Głównego Miasta. Gdańsk: Krajowa Agencja Wydawnicza, 1981.

Döring, Heinrich. 'Glockenspiel'. Edited by Hermann Brockhaus. Allgemeine Encyklopädie der Wissenschaften und Künste. Erste Section A-G. Leipzig: Gleditsch, 1860.

Drobner, Mieczysław. Instrumentoznawstwo i akustyka. 4th ed. Kraków: Polskie Wydawnictwo Muzyczne, 1971.

Dzienis, Helena. Katalog rękopisów Biblioteki Gdańskiej Polskiej Akademii Nauk. Sygnatury Ms 5412 - Ms 5873. Gdańsk: Biblioteka Gdańska PAN, 1999.

Edel, Georg. 'Aus Danzigs Eigenart. Die wunderbaren Glockenspiele'.

Ostdeutsche Monatshefte 16, no. 3 (1935-36): 179-81.

Eggert, Johann Ephraim. 111 Danziger Choräle für Carillon 1784. Edited by Georg Köppl. München: printed by the editor, 1990.

Eggert, Johann Ephraim. 258 Choral-Variationen. Teil I-II. Edited by Georg Köppl. München: printed by the editor, 2006.

Eggert, Johann Ephraim. Choral-Lieder zu dem Glocken-Spiel der Altstädtschen Ober-Pfarr-Kirche zu St. Catharinen ausgesetzt mit Variationes Danzig 1784. Facsimile edition. Edited by Danuta Popinigis and Dariusz Kaczor. Gdańsk: Muzeum Historyczne Miasta Gdańska, 2006.

Fabiani-Madeyska, Irena. Gdzie rezydowali w Gdańsku królowie polscy? Wrocław-Warszawa-Kraków-Gdańsk: Zakład Narodowy im. Ossolińskich, 1976.

Fabiani-Madeyska, Irena. Odwiedziny Gdańska w XIX wieku. Gdańsk: Gdańskie Towarzystwo Naukowe, 1957.

Fiebig-Drzewiecka, Małgorzata, Janusz Grabowski, and Grzegorz Szychliński. 'Notacja kołkowa bębna carillonu Ratusza Głównego Miasta w Gdańsku'. d'Oriana. Awiza biblioteczne, no. 5 (2000): 5-25.

Foltz, Max. Geschichte des Danziger Stadthaushalts. Quellen und Darstellungen zur Geschichte Westpreussens 8. Danzig: A. W. Kafemann, 1912.

Furtak, Tadeusz. Ceny w Gdańsku w latach 1701-1815. Badania z Dziejów Społecznych i Gospodarczych 22. Lwów: Skład główny Kasa im. Rektora J. Mianowskiego-Instytut Popierania Polskiej Twórczości Naukowej, 1935.

Fux, Johann Joseph. The Study of Counterpoint from Johann Josepf Fux's 'Gradus Ad Parnassum'. Edited and translated by Alfred Mann. Revised. New YorkLondon: W. W. Norton, 1971.

Gancarczyk, Paweł. 'Origin, Repertory, and Context of "Lasso's Autograph" from Gdańsk'. In Die Münchner Hofkapelle Des 16. Jahrhunderts Im 
Europäischen Kontext, edited by Theodor Göllner and Bernhold Schmid, 297-309. München: Verlag der Bayerischen Akademie der Wissenschaften, 2006.

Gizowski, Mariusz. Herby patrycjatu gdańskiego. Wappenschilder des Danziger Patriziats. Translated by Hanna Maria Piechowicz. Gdańsk: Krajowa Agencja Wydawnicza, 1999.

Gliński, Mateusz. 'Gdańszczanie epoki napoleońskiej 1807-1814. Wybór biogramów'. In Napoleon i Gdańsk. Pierwsze Wolne Miasto Gdańsk 18071813/14. Materiaty z sympozjum i wystawy w 200. rocznice utworzenia Wolnego Miasta Gdańska, Gdańsk 20 lipca - 30 grudnia 2007, edited by Tadeusz Stegner, 121-43. Gdańsk: Muzeum Historyczne Miasta Gdańska, 2008.

Gloger, Zygmunt. Encyklopedia staropolska ilustrowana. Vol. 3. Warszawa: Wiedza Powszechna, 1958.

Groth, Andrzej. 'Anthony Jan Gotfryd'. Edited by Zbigniew Nowak. Słownik Biograficzny Pomorza Nadwiślańskiego. Gdańsk: Gdańskie Towarzystwo Naukowe-Uniwersytet Gdański, 1992.

Gruytters, Joannes de. Rules for Programming All Carillon Playing Drums. Regelement Ofte Maniere Om Alle Trommels Dienende Tot Bë̈aert Spelen Te Ver(Steken). Edited by Eddy Mariën and Margo Halsted. Carillon Music from the University of Michigan 16. Ann Arbor: University of Michigan, 2004.

Gwagnin, Alexander. Z kroniki Sarmacyi europejskiej ..., opisanie Polski, W. Ks. Litewskiego, Ziemie Ruskiej, Ziemie Pruskiej, Ziemie Inflantskiej, Ziemie Żmudzkiej. Edited by Kazimierz Józef Turowski. Kraków: Wydawnictwo Biblioteki Polskiej, 1860.

Habela, Jadwiga. 'Ratusz Staromiejski w Gdańsku'. In Ratusz w miastach północnej Europy. Materiały z sesji: Ratusz w miastach nadbaltyckich, edited by Stanisław Latour, 135-56. Gdańsk: Marpress, 1997.

Habela, Jerzy. Słowniczek muzyczny. 8th ed. Biblioteka słuchacza koncertowego. Kraków: Polskie Wydawnictwo Muzyczne, 1972.

Halsted, Margo. “"Beÿaert 1728”. A Historical and Bibliographical Approach'. Jaarboek van Het Vlaams Centrum Voor Oude Muziek 1 (1985): 9-20.

Hartmann, Karl-Günther. 'Musikgeschichtliches aus der ehemaligen Danziger Stadtbibliothek'. Die Musikforschung, no. 4 (1974): 387-411.

Haspels, Jan Jaap. Automatic Musical Instruments, Their Mechanics and Their Music 1580-1820. Utrecht: Nirota, 1987.

Heinemann, Michael. 'Siewert, Kniewel, Klügling. Zu Danziger Choralbüchern des frühen 19. Jahrhundert'. In Organy i muzyka organowa X, edited by 
Janusz Krassowski, 23-41. Prace Specjalne 54. Gdańsk: Akademia Muzyczna im. Stanisława Moniuszki, 1997.

Henzel, Christoph. 'Righini, Vincenzo (Maria)'. Musik in Geschichte und

Gegenwart. Personenteil. Kassel-Stuttgart: Bärenreiter, 2005.

Hirsch, Theodor. Die Ober-Pfarrkirche von St. Marien in Danzig in ihren

Denkmälern und in ihren Beziehungen zum kirchlichen Leben Danzigs überhaupt. Vol. 2. Danzig: S. Anhuth, 1843.

Hoburg, Karl. Geschichte und Beschreibung des Rathauses der Rechtstadt Danzig. Danzig: Bertling, 1857.

Hryszczyńska, Helena. 'Gellert Christian Fürchtegott'. Edited by Elżbieta

Dziębowska. Encyklopedia muzyczna PWM. Kraków: Polskie Wydawnictwo Muzyczne, 1987.

Huybens, Gilbert. 'De Liederen Uit “Beÿaert 1728”. Summary'. Jaarboek van Het Vlaams Centrum Voor Oude Muziek 1 (1985): 71.

Iwanoyko, Eugeniusz. Sala Czerwona ratusza gdańskiego. Wrocław-WarszawaKraków-Gdańsk-Łódź: Zakład Narodowy im. Ossolińskich, 1986.

Jakimowicz, Teresa. 'Ratusz jako miejsce kulturowe'. In Ratusz w miastach pótnocnej Europy. Materiały z sesji: Ratusz w miastach nadbaltyckich, edited by Stanisław Latour, 37-47. Gdańsk: Marpress, 1997.

Jakrzewska-Śnieżko, Zofia. Gdańsk w dawnych rycinach. Wrocław-WarszawaKraków-Gdańsk: Zakład Narodowy im. Ossolińskich, 1977.

Janca, Jan. 'Hildebrandt, Andreas'. Musik in Geschichte und Gegenwart.

Personenteil. Kassel-Stuttgart: Bärenreiter, 2002.

Januszajtis, Andrzej. 'Beiträge zur Musikgeschichte Danzigs'. In Musica Baltica. Interregionale musikkulturelle Beziehungen im Ostseeraum. Konferenzbericht Greifswald-Gdańsk, 28. Nov. bis 3. Dez. 1993, edited by Ekkehard Ochs, Nico Schüler, and Lutz Winkler, 315-19. Deutsche Musik im Osten 8. Sankt Augustin: Academia, 1996.

Januszajtis, Andrzej. 'Die vergessene Kunst des Glockenläutens'. In Musica Baltica. Danzig und die Musikkultur Europas, edited by Danuta Popinigis, 61-68. Prace Specjalne 57. Gdańsk: Akademia Muzyczna im. Stanisława Moniuszki w Gdańsku, 2000.

Januszajtis, Andrzej. 'Gdańskie gry dzwonów - rys historyczny. Bell-playing in Gdańsk - A Historical Outline’. In Gdańskie carillony. Przeszłość i teraźniejszość/The Gdańsk Carillons. The Past and the Present, edited by Joanna Zimińska, 41-53. Gdańsk: Muzeum Historyczne Miasta Gdańska, 2003.

Januszajtis, Andrzej. Gdańskie zegary, dzwony i karyliony.

Pelplin: Wydawnictwo Diecezji Pelplińskiej Bernardinum, 2003. 
Januszajtis, Andrzej. “Koroną herb twój ozdobiono...”. Gdańsk: Marpress, 1997. Januszajtis, Andrzej. 'Mowa i muzyka gdańskich dzwonów'. Universitas Gedanensis 11 (1999): 191-98.

Januszajtis, Andrzej. 'Muzyka gdańskich dzwonów. In Muzyka wczoraj i dziś I, edited by Janusz Krassowski, 7-24. Kultura Muzyczna Północnych Ziem Polski 3. Gdańsk: Akademia Muzyczna im. Stanisława Moniuszki w Gdańsku, n.d. Januszajtis, Andrzej. 'The Bells of Gdańsk and Their Music'. TASK Quarterly 3, no. 4 (1999): 498-508.

Kaczor, Dariusz. 'Gdańskie rzemiosło zegarmistrzowskie od XVI do XVIII wieku'. In Zegary gdańskie, edited by Zuzanna Prószyńska, Ewa Barylewska-Szymańska, Dariusz Kaczor, and Wojciech Szymański, 59-76. Gdańsk: Muzeum Historyczne Miasta Gdańska, 2005.

Kaczor, Dariusz. 'Podstawy prawne polityki fiskalnej Wolnego Miasta Gdańska w latach 1807-1813'. In Napoleon i Gdańsk. Pierwsze Wolne Miasto Gdańsk 1807-1813/14, edited by Tadeusz Stegner, 67-83. Gdańsk: Muzeum Historyczne Miasta Gdańska, 2008.

Kaczor, Dariusz. 'Wstęp'. In Choral-Lieder zu dem Glocken-Spiel der Altstädtschen Ober-Pfarr-Kirche zu St. Catharinen ausgesetzt mit Variationes Danzig 1784. Facsimile edition, by Johann Ephraim Eggert, 19-27. Edited by Danuta Popinigis and Dariusz Kaczor. Gdańsk: Muzeum Historyczne Miasta Gdańska, 2006.

Kałaj, Daniel. 'Klimakteryk heroiczny'. In Muza gdańska Janowi Sobieskiemu 1673-1696, by Edmund Kotarski, 99. Wrocław - Warszawa - Kraków Gdańsk - Łódź: Zakład Narodowy im. Ossolińskich-Wydawnictwo Polskiej Akademii Nauk, 1985.

Kapsa, Václaw. 'Laube, Anton, Antonín'. Musik in Geschichte und Gegenwart. Personenteil. Kassel-Stuttgart: Bärenreiter, 2003.

Karłowicz, Jan, Adam Kryński, and Władysław Niedźwiedzki, eds. Słownik języka polskiego. Vol. 2. Warszawa: Kasa im. Mianowskiego, 1902.

Kaufmann, Josef. 'Studien zur Geschichte der Altstadt Danzig. Zeitschrift des Westpreussischen Geschichtsvereins 55 (1913): 77-123.

Kaźmierczak, Monika. 'Co grały i grają gdańskie carillony. What the Gdańsk Carillons Played and Play'. In Gdańskie carillony. Przeszłość i teraźniejszośćl The Gdańsk Carillons. The Past and the Present, edited by Joanna Zimińska, 71-77. Gdańsk: Muzeum Historyczne Miasta Gdańska, 2003.

Kessler, Franz. 'Christliche Religionsgesänge. Ein Danziger Gesangbuch aus der Zeit Aufklärung. In Preussische Landesgeschichte. Festschrift für Bernhart Jähnig zum 60. Geburtstag, edited by Udo Arnold, Mario Glauert, and Jürgen Sarnowsky, 569-82. Marburg: N. G. Elwert, 2001. 
Kessler, Franz. Danziger Gesangbücher 1586-1793. Einzelschriften der Historischen Kommission für Ost- und Westpreussische Landesforschung 15. Lüneburg: Verlag Nordostdeutsches Kulturwerk, 1998.

Kizik, Edmund. 'Finanse Gdańska w latach napoleońskich Wolnego Miasta 1807-1813/14'. In Napoleon i Gdańsk. Pierwsze Wolne Miasta Gdańsk 18071813/14. Materiały z sympozjum i wystawy Muzeum Historycznego Miasta Gdańska w 200. Rocznicę utworzenia Wolnego Miasta Gdańska, Gdańsk 20 lipca - 30 grudnia 2007, edited by Tadeusz Stegner, 55-64. Gdańsk: Muzeum Historyczne Miasta Gdańska, 2008.

Kizik, Edmund. 'Gdańskie uroczystości żałobne po śmierci królów polskich i członków ich rodzin w XVII i XVIII wieku’. In Pamiętnik XV Powszechnego Zjazdu Historyków Polskich, edited by Jacek Staszewski, 1: 293-306. ToruńGdańsk: Adam Marszałek, 1995.

Kizik, Edmund. “'Gute Policey’. Dyscyplinowanie zachowań społecznych w ewangelickim Gdańsku w XVI i w pierwszej połowie XVII wieku”. In Panorama lojalności. Prusy Królewskie i Prusy Książęce w XVI wieku, edited by Anna Skolimowska, 73-91. Warszawa: Ośrodek Badań nad Tradycją Antyczną w Polsce i w Europie Środkowschodniej UW, 2001.

Kizik, Edmund. Wesele, kilka chrztów i pogrzebów. Uroczystości rodzinne w mieście hanzeatyckim od XVI do XVIII wieku. Gdańsk: Wydawnictwo Uniwersytetu Gdańskiego, 2001.

Köppl, Georg. 'Vorwort'. In 111 Danziger Choräle für Carillon 1784, by Johann Ephraim Eggert, edited by Georg Köppl. München: printed by the editor, 1990.

Kostka, Violetta. 'Die Musik Carl Philipp Emanuel Bachs in Danzig in der zweiten Hälfte des 18. Jahrhunderts. Bericht über das Internationale Symposium vom 12. bis 16. März 1998 in Frankfurt (Oder), Zagan und Zielona Gora'. In Die Verbreitung der Werke Carl Philipp Emanuel Bachs in Ostmitteleuropa im 18. und 19. Jahrhundert, edited by Ulrich Leisinger and Hans-Günter Ottenberg, 342-54. Carl Philipp Emanuel Bach Konzepte, Sonderband 3.2. Frankfurt am Oder: Konzerthalle 'Carl Philipp Emanuel Bach', 2002.

Kotarski, Edmund. Gdańsk literacki (Do końca XVIII wieku). Gdańsk: Mestwin, 1997.

Kotarski, Edmund. Gdańska poezja okolicznościowa XVIII wieku. Gdańsk: Wydawnictwo Uniwersytetu Gdańskiego, 1997.

Kotarski, Edmund. Muza gdańska Janowi Sobieskiemu 1673-1696.

Wrocław-Warszawa-Kraków-Gdańsk-Łódź: Zakład Narodowy im. Ossolińskich, 1985.

Kowalski, Krzysztof Maciej. Inskrypcje na dzwonach gotyckich w Prusach. Studium z epigrafiki kampanologicznej. Gdańsk: Wydawnictwo Uniwersytetu Gdańskiego, 2006. 
Krzemiński, Jan Michał. 'Emblematyczny wiersz Joachima Pastoriusa "In Horologium Gedanense”. Barok X, no. 2 (2003): 117-20.

Kubik, Kazimierz, and Lech Mokrzecki. Trzy wieki nauki gdańskiej. Szkice $z$ dziejów od XVI do XVIII wieku. Wrocław-Warszawa-KrakówGdańsk: Zakład Narodowy im. Ossolińskich, 1976.

Lam, Stanisław, ed. Encyklopedyczny słownik wyrazów obcych. Warszawa: Trzaska, Evert i Michalski, 1939.

Lehr, André. Campanology Textbook. The Musical and Technical Aspects of Swinging Bells and Carillons. Translated by Kimberly Schafer. Bulletin of the Guild of Carillonneurs in North America 54. California: Guild of Carillonneurs in North America, 2005.

Lehr, André. Van paardebel tot speelklok. De geschiedenis von de klokgietkunst in de Lage Landen. Europese Bibliotheek: Zaltbommel, 1981.

Lehr, André, Martin Gimm, Ellen Hickmann, and Gerhard Kubik. 'Glocken und Glockenspiele'. Musik in Geschichte und Gegenwart. Sachteil. Kassel-Stuttgart: Bärenreiter, 1995.

Lehr, André, Wim Truyen, and Gilbert Huybens. The Art of the Carillon in the Low Countries. Tielt: Lannoo, 1991.

Lengnich, Gottfried. Ius publicum civitatis Gedanensis oder der Stadt Danzig Verfassung und Rechte, 1769. Nach der Orginalhandschrift des Danziger Stadtarchivs. Edited by Otto Günther. Quellen und Darstellungen zur Geschichte Westpreußens 1. Danzig: Theodor Bertling, 1900

Leszczyńska, Agnieszka. 'Franciscus de Rivulo and the Manuscript Gdańsk, Biblioteka Gdańska Polskiej Akademii Nauk 4003'. In 'Uno Gentile et Subtile Ingenio': Studies in Renaissance Music in Honour of Bonnie J. Blackburn, edited by Bloxam M. Jaannifer, Filocamo Gioia, and Holford-Strevens Leofranc, 259-70. Turnhout: Brepols, 2009.

Leszczyńska, Agnieszka. 'Początki niemieckiej polifonii religijnej w Królewcu, Gdańsku i Rydze’. Muzyka, no. 4 (2007): 45-57.

Leszczyńska, Agnieszka. 'Późnorenesansowe fragmenty mszalne z dawnej biblioteki elbląskiego kościoła Mariackiego’. In Źródła muzyczne. Krytykaanaliza - interpretacja, edited by Ludwik Bielawski and Katarzyna DadakKozicka, 190-99. Warszawa: Związek Kompozytorów Polskich-Instytut Sztuki Polskiej Akademii Nauk, 1999.

Leszczyńska, Agnieszka. 'Technika parodii w twórczości renesansowych kompozytorów kręgu gdańskiego’. Polski Rocznik Muzykologiczny 4 (2005): 41-55.

Leszczyńska, Agnieszka. 'The Königsberg Manuscript from the Kugelmann Circle. Journal of the Alamire Foundation 2, no. 1 (2010): 52-66. 
Leszczyńska, Agnieszka. 'Tropem Franciscusa de Rivulo. Nowe wątki i hipotezy'. Polski Rocznik Muzykologiczny 5 (2006): 65-70.

Linde, M. Samuel Bogumił. Słownik języka polskiego. Vol. 1/2. Warszawa: printed by the author, 1808 .

Loew, Peter Oliver. Danzig und seine Vergangenheit 1793-1997: die Geschichtskultur einer Stadt zwischen Deutschland und Polen. Osnabrück: Fibre, 2003.

Loew, Peter Oliver. Das literarische Danzig 1793 bis 1945. Bausteine für eine lokale Kulturgeschichte. Danziger Beiträge zur Germanistik 25. Frankfurt am Main: Peter Lang, 2009.

Loew, Peter Oliver. 'Lexikon Danziger Komponisten (Mitte 19. bis Mitte 20. Jahrhundert). Ein Beitrag zur Geschichte der lokalen Musikkultur'. In Musikalische Beziehungen zwischen Mitteldeutschland und Danzig im 18. Jahrhundert. Konferenzbericht Gdańsk, edited by Danuta Popinigis and Klaus-Peter Koch, 227-312. Sinzig: Studio, 2002.

Löschin, Gotthilf. Danzig und seine Umgebungen. 3rd ed. Danzig: S. Anhuth, 1853.

Löschin, Gotthilf. Geschichte Danzigs von der ältesten bis zur neuesten Zeit. Mit beständiger Rücksicht auf Cultur der Sitten, Wissenschaften, Künste, Gewerbe und Handelszweige. Neue Ausgabe. 2 vols. Danzig: Ewer, 1828.

Mackenney, Richard. Sixteenth Century Europe: Expansion and Conflict. Palgrave History of Europe. New York: Palgrave, 1993.

Maliszewski, Kazimierz. 'Gdańsk jako ośrodek transferu i komunikacji społecznej w Rzeczypospolitej'. In Mieszczaństwo gdańskie. Sesja naukowa 21-23.11.1996, edited by Stanisław Salmonowicz, 223-238. Gdańsk: Nadbałtyckie Centrum Kultury - Gdańskie Towarzystwo Naukowe, 1997.

Marti, Andreas, and Jan R. Luth. 'Calvinistische Musik'. Musik in Geschichte und Gegenwart. Sachteil. Kassel-Stuttgart: Bärenreiter, 1995.

Meyer, Bruno. 'Die Glockenspiele auf St. Katharinen in Danzig. Heimatblätter des Deutschen Heimatbundes 3, no. 1 (1926): 3-17.

Michalak, Jerzy Marian. 'Krieschen (Kryszan) Anna Maria Hertha'. Edited by Błażej Śliwiński. Encyklopedia Gdańska. Gdańsk: Fundacja Gdańska, 2012.

Michalak, Jerzy Marian. 'Organista i dyrygent chórów Julius Wilhelm Frühling w życiu muzycznym Gdańska 1847-1884'. In Od Förstera do Frühlinga. Przyczynki do dziejów życia muzycznego i teatralnego dawnego Gdańska, edited by Janusz Krassowski. Kultura Muzyczna Północnych Ziem Polski 12. Gdańsk: Akademia Muzyczna im. Stanisława Moniuszki w Gdańsku, 2009. 
Mrongovius, C[hristoph] C[ölestin]. Dokładny Stownik Polsko-Niemiecki krytycznie wypracowany. Königsberg: Bornträger, 1835.

Muttray, Alfred. 'Der Komponist Jean du Grain in Danzig.' Mitteilungen des Westpreussischen Geschichtsvereins 20, no. 3 (1921): 35.

Nawrocka-Wysocka, Arleta. Śpiewy protestanckie na Mazurach. Warszawa: Instytut Sztuki Polskiej Akademii Nauk, 2002.

'Niderlandzcy artyści w Gdańsku w czasach Hansa Vredemana de Vriesa. Materiały z konferencji naukowej zorganizowanej przez Muzeum Historyczne Miasta Gdańska i Weserrenaissance-Museum Schloss Brake Lemgo, Ratusz Głównego Miasta, Gdańsk, 20-21 listopada 2003 r'. GdańskLemgo: Muzeum Historyczne Miasta Gdańska-Weserrenaissance-Museum Schloss Brake, 2006.

Nowak, Zbigniew. 'Gdańska drukarnia Guillemota-Hünefelda w służbie polskiej reformacji (1603-1652)'. In Po stara ksiegę sięgam ze wzruszeniem. Szkice z dziejów i kultury książki w Prusach Królewskich od XV do XVIII wieku, by Zbigniew Nowak, 165-90. Gdańsk: słowo/obraz terytoria, 2008.

Nowak, Zbigniew. 'Hünefeld Andrzej. Edited by Zbigniew Nowak. Słownik Biograficzny Pomorza Nadwiślańskiego. Gdańsk: Gdańskie Towarzystwo Naukowe-Uniwersytet Gdański, 1994.

Nowak, Zbigniew. 'Kultura, nauka i sztuka w Gdańsku na przełomie dwóch epok. In Historia Gdańska, edited by Edmund Cieślak, 2:352-402. Gdańsk: Wydawnictwo Morskie, 1982.

Nowak, Zbigniew. 'Lata rozkwitu kultury, nauki i sztuki'. In Historia Gdańska, edited by Edmund Cieślak, 2:686-753. Gdańsk: Wydawnictwo Morskie, 1982.

Nowak, Zbigniew. 'Martini Adam Jakub'. Edited by Zbigniew Nowak. Słownik Biograficzny Pomorza Nadwiślańskiego. Gdańsk: Gdańskie Towarzystwo Naukowe-Uniwersytet Gdański, 1997.

Ogier, Charles. Dziennik podróży do Polski 1635-1636. Edited by Zenon Gołaszewski. Gdańsk: Maszoperia Literacka, 2010.

Orgelbrand, Maurycy. Słownik języka polskiego. Vol. 1. Wilno: printed by the author, 1861.

Orgelbrand, Samuel. Encyklopedja powszechna z ilustracjami i mapami. Vol. 3. Warszawa: S. Orgelbranda Synowie, 1898.

Orgelbrand, Samuel. Encyklopedyja powszechna. Vol. 4. Warszawa: Orgelbrand, 1860.

Pawlowski, Herbert. 'Das Glockenspiel des Rechtstädtischen Rathause zu Danzig. Ostdeutsche Monatshefte 9, no. 6 (1928): 477-81. 
Popinigis, Danuta. 'Bachowskie interludia w wariacjach na carillon Johanna Ephraima Eggerta z roku 1784'. In Muzykolog wobec świadectw źródłowych $i$ dokumentów. The Musicologist and source Documentary Evidence. Księga pamiątkowa dedykowana Profesorowi Piotrowi Poźniakowi w 70. rocznice urodzin. A Book of Essays in Honour of Professor Piotr Poźniak on his 70th Birthday, edited by Zofia Fabiańska, Jakub Kubieniec, Andrzej Sitarz, and Piotr Wilk, 533-45. Kraków: Musica Iagellonica, 2009.

Popinigis, Danuta. 'Carillons and Carillon Music in Old Gdansk'. In XV World Carillon Congress Gdańsk 16th-20th July 2006. [Gdańsk], 2007.

Popinigis, Danuta. 'Choral-Lieder ... mit Variationes - kompozycja Johanna Ephraima Eggerta na carillon kościoła św. Katarzyny w Gdańsku'. Aspekty muzyki, no. 1 (2011): 157-79.

Popinigis, Danuta. 'Das Carillon Repertoire der Kirche St. Katharinen in Danzig für das Jahr 1784'. In Das geistliche Lied im Ostseeraum, edited by Ekkehard Ochs, Walter Werbeck, and Lutz Winkler, 155-70. Greifswalder Beiträge zur Musikwissenschaft 13. Frankfurt am Main: Peter Lang, 2004.

Popinigis, Danuta. 'Das singende Uhrwerk zu Füssen von König Zygmunt August - ein Beitrag zur Herkunft des automatischen Glockenspiels im Rechtstädtischen Rathaus von Danzig. In Das singende Uhrwerk, edited by Paweł Gancarczyk and Agnieszka Leszczyńska, 227-33. Warszawa: Instytut Sztuki PAN-Uniwersytet Warszawski-Biblioteka Narodowa, 2012.

Popinigis, Danuta. 'Die Danziger Glockenspiele als Komponente der städtischen Musiktradition. Forschungsprobleme und -perspektiven'. In Musik - Stadt. Traditionen und Perspektiven urbaner Musikkulturen. Bericht über den XIV. Internationalen Kongress der Gesellschaft für Musikforschung vom 28. September bis 3. Oktober 2008 am Institut für Musikwissenschaft der Universität Leipzig, edited by Helmut Loos, 1:110-16. Leipzig: Gudrun Schröder, 2011.

Popinigis, Danuta. 'Die Rezeption des Schaffens C. P. E. Bachs in Gdańsk in der zweiten Hälfte des 18. Jahrhunderts'. In Die Entwicklung des Doppelund Gruppenkonzertes im 18. Jh. bis zur "Sinfonia concertante". Fragen der Aufführungspraxis und Interpretation von Werken Carl Philipp Emanuel Bachs - ein Beitrag zum 200. Todestag, edited by Thomas Eitelfriedrich, 57-58. Studien zur Aufführungspraxis und Interpretation der Musik des 18. Jahrhunderts 39. Michaelstein-Blankenburg: Kultur- u. Forschungsstätte Michaelstein, 1989.

Popinigis, Danuta. 'Einige terminologische Bemerkungen über das Danziger Singwerk und das Glockenspiel, über Glockensteller und die Glockenisten'. In Musica Baltica. The Music Culture of Baltic Cities in Modern Times, 
edited by Jolanta Woźniak, 281-87. Prace Specjalne 80. Gdańsk: Akademia Muzyczna im. Stanisława Moniuszki w Gdańsku, 2010.

Popinigis, Danuta. 'Gdańsk Carillon Tablatures'. Interdisciplinary Studies in Musicology 11 (2012): 103-22.

Popinigis, Danuta. 'Gdańska afera carillonowa w świetle rękopisu Juriaana Spruijta’. Muzyka 58, no. 1 (2013): 59-76.

Popinigis, Danuta. 'Gimnazjum Gdańskie i muzyka’. In Gdańskie Gimnazjum Akademickie. Szkice $z$ dziejów, edited by Edmund Kotarski, 1:275-97.

Gdańsk: Wydawnictwo Uniwersytetu Gdańskiego, 2008.

Popinigis, Danuta. 'Rivulo Franziscus de’. Edited by Elżbieta Dziębowska. Encyklopedia muzyczna PWM. Kraków: Polskie Wydawnictwo Muzyczne, 2004.

Popinigis, Danuta. 'Sylwetka Pawła Sieferta w świetle źródeł'. In Muzyka w Gdańsku wczoraj i dziś, edited by Janusz Krassowski, 1:57-71. Kultura Muzyczna Północnych Ziem Polski 3. Gdańsk: Akademia Muzyczna im. Stanisława Moniuszki w Gdańsku, 1988.

Popinigis, Danuta. 'Ustawiacze automatycznego carillonu ratusza Głównego Miasta w Gdańsku - Franciscus de Rivulo i jego następcy'. Aspekty muzyki, no. 2 (2012): 67-79.

Popinigis, Danuta. 'W swoim stylu - melodie z wież Ratusza Głównego Miasta i kościoła św. Katarzyny w Gdańsku'. Forum Muzykologiczne, 2005, 122-131.

Popinigis, Danuta. 'Wstęp'. In Choral-Lieder zu dem Glocken-Spiel der Altstädtschen Ober-Pfarr-Kirche zu St. Catharinen ausgesetzt mit Variationes Danzig 1784. Facsimile edition, by Johann Ephraim Eggert, 27-32. Edited by Danuta Popinigis and Dariusz Kaczor. Gdańsk: Muzeum Historyczne Miasta Gdańska, 2006.

Popinigis, Danuta, Barbara Długońska, Danuta Szlagowska, and Jolanta Woźniak. Thematic Catalogue of Music in Manuscript at the Polish Academy of Sciences Gdańsk Library. Music Collections from Gdańsk 1. Kraków-Gdańsk: Musica Iagellonica-Akademia Muzyczna im. Stanisława Moniuszki, 2011.

Prószyńska, Zuzanna. 'Słownik gdańskich zegarmistrzów i gnomoników' In Zegary gdańskie, edited by Zuzanna Prószyńska, Ewa BarylewskaSzymańska, Dariusz Kaczor, and Wojciech Szymański, 129-201. Gdańsk: Muzeum Historyczne Miasta Gdańska, 2005.

Prószyński, Stanisław. Świat mechanizmów grających. Warszawa: Wiedza Powszechna, 1994.

Przybyszewska-Jarmińska, Barbara. Muzyczne dwory polskich Wazów. Warszawa: Semper, 2007. 
Przywecka-Samecka, Maria. Drukarstwo muzyczne w Polsce do końca XVIII wieku. Kraków: Polskie Wydawnictwo Muzyczne, 1969.

Rasch, Rudof. 'Valerius, Adriaen, Adrianus'. Musik in Geschichte und Gegenwart. Personenteil. Kassel-Stuttgart: Bärenreiter, 2006.

Rauschning, Hermann. Geschichte der Musik und Musikpflege in Danzig. Von den Anfängen bis zur Auflösung der Kirchenkapellen. Quellen und Darstellungen zur Geschichte Westpreussens 15. Danzig: Danziger Verlags-Gesellschaft, 1931.

Renkewitz, Werner, and Jan Janca. Geschichte der Orgelbaukunst in Ost- und Westpreussen von 1333 bis 1944. Vol. 1. Würzburg: Weidlich, 1984.

Rhode, Jacob. Chronica oder Handbüchlein Danziger Geschichte gedruckt durch Jacob Rhode Danzig 1594. Edited by F. Schwarz. Vol. 3-4. Heimatblätter des Deutschen Heimatbundes Danzig 3. Danzig: Kafemann, 1926.

Romanow, Andrzej. 'Rozwój przestrzenny i demograficzny'. In Historia Gdańska, edited by Edmund Cieślak, 4/2:7-32. Sopot: Lex, 1998.

Rombouts, Luc. 'Carillon'. Edited by Stanley Sadie and John Tyrrell. New Grove Dictionary of Music and Musicians. Oxford: Oxford University Press, 2001.

Rombouts, Luc. Singing Bronze. A History of Carillon Music.

Leuven: Lipsius, 2014.

Rombouts, Luc, and Carl Van Eyndhoven. " Back to the Future”. Artistic Research of Historical Carillon Music with the Purpose of Contemporary Interpretation Practice. In XV World Carillon Congress Gdanisk 16th-20th July 2006. [Gdańsk], 2007.

Roome, Karl Gerhard. 'Die Glöckner der Katharinen Kirche in Danzig. Unser Danzig 50, no. 10 (1998): 28-29.

Sachs, Curt. The History of Musical Instruments. New York: W. W. Norton, 1940. Samsonowicz, Henryk. 'Gdańsk w okresie wojny trzynastoletniej'. In Historia Gdańska, edited by Edmund Cieślak, 2:43-76. Gdańsk: Wydawnictwo Morskie, 1982.

Sankiewicz, Marianna, Gustaw Budzyński, and A. Kaczmarek. 'Acoustic Investigation of the Carillons in Poland'. Archives of Acoustics 19 (1994): 333-53.

Schilling, Margarete. Glocken und Glockenspiele.

Rudolfstadt: Greifenverlag, 1985.

Schnaase, Eduard David. Geschichte der evangelischen Kirche Danzigs. Danzig: Theodor Bertling, 1863.

Schopenhauer, Johanna. Gdańskie wspomnienia młodości. Edited and translated by Tadeusz Kruszyński. Gdańsk: słowo/obraz/terytoria, 2010. 
Seiffert, Max. 'Paul Siefert (1586-1666). Biographische Skizze'. Vierteljahrschrift für Musikwissenschaft, no. 7 (1891): 397-428.

Serczyk, Jerzy. 'Hartknoch Krzysztof Jan'. Edited by Zbigniew Nowak. Słownik Biograficzny Pomorza Nadwiślańskiego. Gdańsk: Gdańskie Towarzystwo Naukowe-Uniwersytet Gdański, 1994.

Siegler, Hans Georg. 'Im alten Danzig. Unser Danzig 30, no. 10 (1978): 13-15.

Sławoszewska, Maria. 'Zarys dziejów Archiwum Miasta Gdańska'. Rocznik Gdański XIV (1955): 92-128.

Śledziński, Stefan, ed. Mała encyklopedia muzyki. 3rd ed. Warszawa: Państwowe Wydawnictwo Naukowe, 1981.

Spierings, Megchelina Henriette Maria. Het Schepenprotocol van 'sHertogenbosch 1367-1400. Bijdragen Tot de Geschiedenis van Het Zuiden van Nederland 49. Tilburg: Stichting Zuidelijk Historisch Contact, 1984.

Spruijt, Juriaan. Beschrijving van Klokken en Klokken-Spelen (circa 1760). Edited by André Lehr. Asten: Nationaal Beiaard- en Natuurmuseum, 2008.

Szafran, Przemysław. Katalog Rękopisów Biblioteki Gdańskiej Polskiej Akademii Nauk. Uzupetnienie do tomów I-IV (Sygnatury 1-4258). Gdańsk: Polska Akademia Nauk Biblioteka Gdańska, 1988.

Szarszewski, Adam. Szpital i kościół św. Jakuba w Gdańsku. Zarys historyczny.

Toruń: Firma Wydawniczo-Handlowa Mado, 1999.

Szczuczko, Witold. 'Giese Jerzy’. Edited by Zbigniew Nowak. Słownik

Biograficzny Pomorza Nadwiślańskiego. Gdańsk: Gdańskie Towarzystwo Naukowe-Uniwersytet Gdański, 1994.

Szlagowska, Danuta. 'Gdańscy muzycy w darze królowi Janowi II Kazimierzowi'. Aspekty muzyki, no. 2 (2012): 81-98.

Szlagowska, Danuta, Barbara Długońska, Danuta Popinigis, and Jolanta Woźniak. Thematic Catalogue of Music in Manuscript from the Former Stadtbibliothek Danzig Kept at the Staatsbibliothek Zu Berlin - Preussischer Kulturbesitz, Musikabteilung Mit Mendelssohn-Archiv. Music Collections from Gdańsk 2. Kraków-Gdańsk: Musica Iagellonica-Akademia Muzyczna im. Stanisława Moniuszki, 2007.

Szychliński, Grzegorz. 'Zegar wieżowy Ratusza Głównego Miasta w Gdańsku’. In Zegary gdańskie, edited by Zuzanna Prószyńska, Ewa Barylewska-Szymańska, Dariusz Kaczor, and Wojciech Szymański, 223. Gdańsk: Muzeum Historyczne Miasta Gdańska, 2005.

'Über die weitere Vervollständigung des Glockenspiels'. St. Marien Jahrbuch 1961 des St.-Marien-Bauvereins, 1960.

Van Eyndhoven, Carl. “'In Playing Those Bells, His Amazing Dexterity Raised My Wonder Much Higher”: Performance Practice by Seventeenth- and 
Eighteenth-Century Carilloneurs'. In Interpreting Historical Keyboard Music: Sources, Contexts and Performance, edited by Andrew Wooley and John Kitchen, 141-55. Ashgate Historical Keyboard Series. Farnham-Burlington: Ashgate, 2013.

Vogel, Benjamin. 'Johann Werner Woge - gdański budowniczy klawesynów' In Muzyka fortepianowa XIV, edited by Janusz Krassowski, 541-55. Prace Specjalne 74. Gdańsk: Akademia Muzyczna im. Stanisława Moniuszki, 2007.

Volckmar, Nicolaus. Nicolausa Volckmara Viertzig Dialogi 1612. Źródto do badań nad życiem codziennym $w$ dawnym Gdańsku. Edited by Edmund Kizik and Radosław Grześkowiak. Gdańsk: Wydawnictwo Uniwersytetu Gdańskiego, 2005.

Walter, Karl. Glockenkunde. Regensburg-Rom: Friedrich Pustet, 1913.

Węsierska-Biernatowa, Teresa, Janina Czaplicka, and Maria Sławoszewska, eds. Archiwum miasta Gdańska. Przewodnik po zasobach 1253-1945. WarszawaŁódź: Państwowe Wydawnictwo Naukowe, 1970.

Wielka Encyklopedya Powszechna Ilustrowana. Vol. 11. Warszawa: S. Sikorski, 1893.

Włodarczyk, Edward. 'Miejsce Gdańska w państwie pruskim'. In Historia Gdańska, edited by Edmund Cieślak, 4/1:23-49. Sopot: Lex, 1998.

Wotquenne, Alfred. Thematisches Verzeichnis der Werke von C. Ph. E. Bach. 4th ed. Wiesbaden: Breitkopf \& Hartel, 1988.

Woźniak, Jolanta. 'Gdańskie kancjonały ewangelickie z XIX wieku'. In Europejski repertuar muzyczny na ziemiach Polski. Ogólnopolska Konferencja Muzykologiczna Związku Kompozytorów Polskich, edited by Elżbieta Wojnowska, Ludwik Bielawski, and Katarzyna Dadak-Kozicka, 147-58. Warszawa: Związek Kompozytorów Polskich-Biblioteka Narodowa, 2003.

Woźniak, Jolanta. 'Gran Sonata per il cembalo... gdańskiego pastora Theodora Friedricha Kniewela'. In Complexus effectuum musicologiae: Studia Miroslao Perz septuagenario dedicata, edited by Tomasz Jeż, 123-32. Studia et Dissertationes Instituti Musicologiae Universitatis Varsoviensis. Seria B. Kraków: RABID, 2003.

Woźniak, Jolanta."'Melodien zum Gesangbuch für den evangelischen Gottesdient. Für Kirche, Schule und Haus', Evangelische Lieder aus Danzig (1841)". In Das geistliche Lied im Ostseeraum, edited by Ekkehard Ochs, Walter Werbeck, and Lutz Winkler, 171-75. Greifswalder Beiträge zur Musikwissenschaft 13. Frankfurt am Main: Peter Lang, 2004.

Woźniak, Jolanta, Barbara Długońska, Danuta Popinigis, and Danuta Szlagowska. Thematic Catalogue of Music in Manuscript in the State Archive in Gdańsk. Music Collections from Gdańsk 3. Kraków-Gdańsk: Musica Iagellonica-Akademia Muzyczna im. Stanisława Moniuszki, 2008. 
Zahn, Johannes. Die Melodien der deutschen evangelischen Kirchenlieder. Vol. 1. Gütersloh: C. Bertelsmann, 1889.

Zarębska, Teresa. 'Budowle i urządzenia komunalne Gdańska w jego złotym wieku'. In Mieszczaństwo gdańskie. Sesja naukowa 21-23.11.1996, edited by Stanisław Salmonowicz, 343-76. Gdańsk: Gdańskie Towarzystwo NaukoweNadbałtyckie Centrum Kultury, 1997.

Zarębska, Teresa. 'Kontekst urbanistyczny ratusza Głównego Miasta w Gdańsku'. In Ratusz w miastach północnej Europy. Materiały z sesji: Ratusz w miastach nadbałtyckich, edited by Stanisław Latour, 53-77. Gdańsk: Marpress, 1997.

Zdrenka, Joachim. 'Rada Miejska'. Edited by Błażej Śliwiński. Encyklopedia Gdańska. Gdańsk: Fundacja Gdańska, 2012.

Zdrenka, Joachim. Rats- und Gerichtspatriziat der Altstadt (1377-1792) und der Jungstadt (1387-1454/1455) Danzig. Hamburg: Selbstverlag des Vereins, 1991.

Zdrenka, Joachim. Rats- und Gerichtspatriziat der Rechten Stadt Danzig. Vol. 2 (1526-1792). Hamburg: Selbstverlag des Vereins, 1989.

Zdrenka, Joachim. 'Ratusz Głównego Miasta w Gdańsku i jego użytkownicy w okresie od XIV do XIX wieku'. In Ratusz w miastach pótnocnej Europy, Materiały $z$ sesji: Ratusz w miastach nadbaltyckich, edited by Stanisław Latour, 91-100. Gdańsk: Marpress, 1997.

Zernecke, Wilhelm Ferdinand. Cały Gdańsk za dwadzieścia srebrnych groszy. Najnowszy przewodnik po Gdańsku i jego okolicy. Alfabetycznie ułożony opis wszystkiego, co w Gdańsku i jego okolicy jest godne uwagi lub w jakikolwiek sposób interesujące. Wraz z dodatkiem: Trzy dni w Gdańsku i okolicy 1843. Translated by Aleksander Masłowski and Roman Kowald. Gdańsk: Yellow Factory, 2010.

Zieliński, Marek Grzegorz. “'Vivos voco, mortuos plango, fulgura frango' - rzecz o dzwonach". In Tajemnice starych dzwonów Torunia i Chetmna w 500tna rocznice ulania wielkiego Tuba Dei, edited by Tomasz Jaworski, Marek Nasieniewski, and Krzysztof Przegiętka, 97-140. Toruń: Wydawnictwo TNOiK, 2001.

Zimińska, Joanna, ed. Gdańskie carillony. Przeszłość i teraźniejszość/The Gdańsk Carillons. The Past and the Present. Gdańsk: Muzeum Historyczne Miasta Gdańska, 2003.

Zlat, Mieczysław. 'Ratusz - zamek mieszczan: symbolika typu architektonicznego i jego form'. In Ratusz w miastach północnej Europy. Materiały $z$ sesji: Ratusz $w$ miastach nadbaltyckich, edited by Stanisław Latour, 13-36. Gdańsk: Marpress, 1997.

Żórawska-Witkowska, Alina. 'Status społeczny muzyka w baroku'. Barok VI, no. 1 (1999): 25-51. 



\section{Index of names}

Names mentioned in the bibliography, list of illustrations, tables, and musical examples are not indexed.

A

Adriaenssen, Leo F. W. 29, 42-44, $52,53,60,61,130$

Alber, Erasmus 271

Albrecht, Hohenzollern von

Brandenburg-Ansbach 90

Alexander IV, pope 73

Andersen, Hedwig 143

Anthony, Johann Gottfried 57

Augustus II the Strong, King of

Poland 122

Augustus III, King of Poland 81, 82

Aycke, Paul Gottfried 230

B

Babnis Maria 275

Bach Carl Philipp Emanuel 28, 353, 377

Bach Johann Sebastian 172, 257, 319, $353,354,356,358,359,361,362$

Bagge Jan Frederik 159

Baronofski 358

Bartholdi Carl Friedrich 100, 358

Baszanowski Jan 249, 376

Becker Johann Gottlieb 130, 137, 138

Beek Jacob van 138

Beethoven Ludwig van 377

Benda Georg 184

Beneke Paul 201, 202

Benning, family 160

Bentzmann Johann 230

Berger, engineer 202

Bertling August 138, 167, 265, 267, 268
Bewersdorff Peter 99, 106, 110, 111,114

Biehn (Bihn, Bühn) Christian 94

Biehn (Byhahn, Bichan, Bian)

Bartel 96, 97, 106, 109, 124

Biehn Ephraim 137

Biernat Czesław 314

Blech Ernst 26, 126, 142, 145, 147-149, 164, 169, 191-193

Blech-Trebnitz Ernst 149

Bleche Wilhelm 184

Bodeck Valentin von 109

Bogucka Maria 36, 39-41, 129

Bońkowski Wojciech 11

Boon Piet 11, 29, 153, 159

Borck Michael 122

Borkowski, pastor 142

Borowski Johann Gottlieb 24, 96, 97, 111, 114, 124, 215, 266, 267

Böttcher Daniel 101, 163, 164, 375

Brandes Elisabeth 42

Brandes Johann 42, 43

Braunitz Johann Carl 137

Breitenbach, councillor 48

Breitkopf Johann Gottlob

Immanuel 353

Broen Johann Hieronymus 230

Brömer Carl Gabriel 358

Buhse Daniel 193, 194

Busch Carl Gottfried 174, 180, 186, 193, 195

Bütner Crato 100

Budzyński Gustaw 205

Burchard Maria 281 
C

Cappuhn Carl August 317

Cappun 317

Casimir IV Jagiellon, King of Poland 125

Chodkowski Andrzej 20

Chojnacki Władysław 358

Chomiński Józef M. 345

Chopin Fryderyk 377

Cieślak Katarzyna 211, 212

Claes Hendrick 253

Clement Mary 145

Coletus Michael 211

Colrep (Kolrep, Kalrep) Michael 21, 94, 96, 110, 124, 253

Conradi Eduard Friedrich 229, 230, 249

Crans Jan 154, 160

Curicke Reinhold 21, 24, 36, 45, 46, $82,83,125,126,134,160,209,210$

Cwalińska Paulina 296

Cyrson Edward 191

Czaplicka Janina 126, 215

Czikorska Anna Rosina 184

Czirenberg Konstancja 72

D

Daniels Dirk 39, 44-46

Danielssen (see Moer) Anna Henrick 53

Davies Norman 40

Deleu Frank 11, 28, 217, 314, 315, 331

Derck Jan Nicolaas, also Derck Johann Nicolaus (father) 11, 26, 29-31, 130-134, 137, 138, 153-162, $178,313,375$

Derck Jan Nicolaas (son) 153

Derham William 253

Dijck Lucas van 11, 44

Dircksen Carl Henrich 180

Doedens (see Wolthers)

Reintjene 177
Döring Johann George 230

Döring Heinrich 25, 126

Dollinger Philippe 40

Domagała Tadeusz 36, 46

Drobner Mieczysław 16

Du Grain Jean Jeremias 249

Duisburg Friedrich Karl

Gottlieb von 84

Dumery Joris 164

Dzienis Helena 101

E

Edel Georg 26, 63, 94, 96, 149, 165-167, 171-173, 175, 190, 191, $255,280,282,284,313,339,340$

Eggebrecht Hans 9

Eggert Carl Friedrich 100, 174, 186, 188, 196, 197

Eggert Carl Simon 94, 95, 105, 170

Eggert Daniel 179

Eggert Dorothea 179

Eggert Georg Friedrich 100

Eggert Johann Daniel 186

Eggert Johann Ephraim 11, 27, 28, $30,32,100,161,162,166,169$, $170,174,175,179,180,184-186$, $188,191,193-195,217,300$, 313-315, 317-319, 326-333, $337-342,344-350,352,354,356$, $358-360,362,364-366,368$, 370-372, 377

Ehrhardt Albrecht 148

Eichstedt Johann 99, 111

Elert Joachim 110

Erben Balthasar 111

Evert Ludwik Józef 19

Ewert Johann Gottfried 358

Eyck Jacob van 35

F

Fabiani-Madeyska Irena 50, 82, 374 Falk Johannes Daniel 283 
Fehlhaber Karl 145, 148

Ferber (née Fischer, promo voto

Stendel) Dorothea Constantia 129

Ferber Johann Ernst 129

Ferber Konstantin 43

Fichtel Christian Wilhelm 318

Fiebig-Drzewiecka Małgorzata 30, $32,63,205,254-257$

Fischer, cellist 145

Fischer (see Stendel) Dorothea

Constantia 129

Förster Georg 101

Förster Kaspar Jr 101

Förster Kaspar Sr 101, 122

Foltz Max 65

Freislich Johann Balthasar

Christian 82, 100, 101, 137

Freislich Maximilian Dietrich 101

Freudenberg Wilhelm 148

Friese Christian 230

Frühling Julius Wilhelm 100, 176, $189,214,216$

Funk Gertrude 145

Furtak Tadeusz 65

Fux Johann Joseph 345, 346

G

Gancarczyk Paweł 42

Gellert Christian Fürchtegott 276, $353,354,356,359,361,362$

Genée Friedrich 101

Gensch C. G. 275

Gerhardt Paul 276, 299

Ghein, Van den, family 53

Giese Georg 43

Giese Tiedemann 43

Gizowski Mariusz 229

Glauert Mario 415

Gliński Mateusz 191

Gloger Zygmunt 18

Glummert Johann Daniel 358

Goethe Johann Wolfgang von 283
Göring Hermann 149

Goudimel Claude 212, 291, 305

Grabowski Janusz 30, 32, 63, 205, 254-257

Gralath Daniel 235

Grau Stephanus 21, 24, 45, 67, 68,211

Grobbema (see Wiardi) Aaltjen 177

Groddeck Carl (Karl) 88, 217

Gronau Daniel Magnus 137

Gronau Georg 145, 148

Groth Andrzej 57

Gruytters Joannes de 253

Gülich Christian 96

Gülich Johann Christian 96

Gülich Theodor Friedrich 25, 27, $32,65,68,69,71,72,74,79-83$, 85-88, 94, 96, 100, 105, 110, 117, $123,124,209,211-213,215-217$, 220, 224, 229, 230, 235-237, 243, 246, 249, 252, 259, 265-269, 285-297, 299-311, 319, 330, 338

Günther Otto 167, 216, 266

Gudel Joachim 205

Guillemot Wilhelm 304

Guzowiusz Johann

Gottfried 361

Gwagnin (Guagnini) Alexander

(Alessandro) 347

$\mathbf{H}$

Habela Jadwiga 126, 314, 315

Habela Jerzy 20

Hakenberger Andreas 101

Halsted Margo 376

Handel George Frideric 173, 340

Hartknoch Christoph 21, 24, 43, 211, 212

Hartmann Karl-Günther 42

Haspels Jan Jaap 217, 253, 332

Hauff Wilhelm 201

Haverkamp Leonardus 159 
Havingha Gerhardus 133, 134, 137, 138, 176, 178

Heinemann Michael 100

Hemony François 35

Hemony Pieter 35, 50

Henzel Christoph 281

Hey Johann Wilhelm 282

Heyking Friedrich 145, 164

Heyking Julius 145, 164

Hildebrandt Andreas 133, 137, 375

Hingelberg Johann

Gottfried 97, 184

Hirsch Hans 64

Hirsch Theodor 25, 212

Hitler Adolf 84

Hoburg Karl 23, 25, 45, 46

Hoch, pastor 266

Hoernken Jan 43

Hoernken Willem 43

Hoffman Jacobus 22

Hoffmann von Fallersleben August

Heinrich 281

Holbein Hans Jr 43

Holten Arnold von 122

Hryszczyńska Helena 354

Hünefeld Andreas 304

Huybens Gilbert 29, 35, 50, 52, 53, 217,376

I

Iwanoyko Eugeniusz 39, 44

J

Jakimowicz Teresa 36, 39

Jakrzewska-Śnieżko Zofia 22

Janca Jan 133, 185, 186

Jantzen (Janzen) Salomon 138, 170,230

Januszajtis Andrzej 11, 17-19, 27, $29,46,57,60-66,72,89,99,126$, $134,138,160,163,164,173,205$, $217,253,254$
Jaskulska Ewa 11

John II Casimir Vasa, King of Poland 22

John III Sobieski, King of

Poland 22, 83

K

Kaczmarek Andrzej 205

Kaczor Dariusz 11, 28, 61, 126, $129,133,163,165,167,168,174$, 177-179, 184, 191-193, 195, 196, 317,318

Kafemann August Wilhelm 275, 282

Kalckreuth Friedrich Adolf von 142

Kaless Eleonora 184

Kaless Philip 184

Kałaj Daniel 9, 22

Kapsa Václaw 362

Karłowicz Jan 18, 19

Kaschlinsky Carl Anton 25, 30, $46,47,49,57-59,68,69,71,79$, 89, 99-101, 209, 213, 216, 249, 252, 258-261, 264, 275-277, 280, 311,312

Kasprzycka Anna 11

Kaufmann Josef 315

Kaźmierczak Monika 11, 27, 217, 331

Kessler Franz 237, 304, 305

Kizik Edmund 67, 71, 80, 85-87, 196, 269, 326

Klawitter, family 163

Kleefeld Georg 43, 114

Kleinfeld Arndt 40, 41

Kleinfeld Heinrich 41

Kleinfeld Reinhold 41

Kliewer 358

Klügling Friedrich August 100, 358

Knaack Paul Friedrich 32, 68, 99, $100,105,209,212,215,216,249$, $252,269,308-311,326$ 
Kniewel Theodor Friedrich 100, 275, 359, 361

Kniprode Winrich von 87

Kohl Marten 133

König Gottfried 168, 170, 178

König Johann David 269, 287, 288, 297

Konopnicka Maria 9

Kopaliński Władysław 17

Köppl Georg 28

Korfhage Eduard 147, 149, 202

Körner Carl Wilhelm 172, 192, 193

Kostka Violetta 358

Kotarski Edmund 67, 361, 362

Kowalski Krzysztof Maciej 59, 60

Kraszewski Józef Ignacy 50

Krey Benjamin 318

Krieschen (Kryszan) Anna Maria Hertha 189

Krieschen (née Pfahl) Emma Wilhelmine 189

Krieschen Gustav 94, 96, 99, 105, 175, 190

Krieschen Julius Johann 94-96, 105, 171, 174, 188-190, 197

Krieschen Konrad 172, 188, 189

Krieschen Otto 142, 163, 166, 171, 216

Krieschen Paul William 94-96, 161, 162, 164, 166, 168, 169, 171, 174, $175,188-190,195,197,268,280$, 282, 284, 313-315

Krieschen Walter 175, 188, 189,340

Kroon Jaap 11

Krüger David 82, 101, 106, 110, 111, 265

Kryński Adam 18, 19

Krzemiński Jan Michał 22

Kubik Kazimierz 41

Kugelmann Paul 89-91
L

Läder Mathias 95

Lasso Orlando di 42

Laube C. [Anton] 362

Lehr André 15, 16, 29, 35, 50, 52, $53,63,130,133,153,159,163$, $214,217,332,333$

Lengnich Gottfried 167, 191

Leseman Hendrik 138

Leszczyńska Agnieszka 60,89-91, 94

Liebendey Rudolph Liebegott 94, $105,110,215$

Linde M. Samuel Bogumił 18

Lindus Carl 124

Lobwasser Ambrosius 25, 211, 212, 274, 291, 305

Loew Peter Oliver 11, 48, 95, 190, 202, 283

Löschin Gotthilf 23, 25, 126, 166

Lüdecke, organist 358

Luther Martin 246, 274, 276, 296, 299, 376

Luszczewska Jadwiga 374

M

Maassen Jacques 11, 331

Mackenney Richard 40

Maliszewski Kazimierz 67

Marie Louise Gonzaga, Queen of Poland 21, 82, 83, 210, 264

Martens Heinrich 230

Marti Andreas 304

Martini Adam Jacob 21, 24, 82, 125, 177,210

Memling Hans 201

Merula Tarquinio 95

Meurling P. J. 159

Meyer Bruno 26, 57, 126, 129, 130, $133,137,138,142,143,145,148$, $149,161,163-166,170,171,174$, $178,185,189,313,314,316,331$, 332,337 
Meyer Heinrich Gottfried 266, 267

Meyfahrt Johann Matthäus

Michał Korybut Wiśniowiecki, King of Poland 81, 122

Michalak Jerzy Marian 11, 28, 100, 176, 180, 189, 216

Michalski Jan 19

Moer (de Moor) Cornelis Jans 54

Moer Gobel 43, 44, 52

Moer (Moor) Jan 11, 29, 30, 42, 44-46, 49, 51-54, 57, 59-61, 90, 205, 375

Moer Jaspar 44, 52

Moer Willem 52

Mokrzecki Lech 41

Mom (see Derck) Sara

Elisabeth 158, 159

Montigni Rudolphus de 134

Moor Cornelis de 54

Moor Jan de 54

Mrongowiusz (Mrongovius)

Christoph Cölestin 18

Müller Carl Friedrich 188, 197

Müller, family 327

Müller-Landeck Erna 148

Muttray Alfred 249

$\mathbf{N}$

Nägeli Hans Georg 281

Napoleon Bonaparte, Emperor of the French 84, 170, 252

Nawrocka-Wysocka Arleta 282

Neumann 145

Neunaber Andreas 41, 94, 95, 99, $109,117,122,264$

Neunaber Hans 41, 65, 66, 72, 99, 106, 109-111, 114, 117, 122, 124,210

Neunachber (Neunaber) Jakob 81, $94,95,117,122$

Niedźwiecki Władysław 18

Nowak Zbigniew 40, 41, 210, 304
Nowowiejski Feliks 9, 377

O

Oehmchen Johann Nicolas 230

Ogier Charles 71, 72

Ohlsson [Martin Wilhelm] 146

Ohlsson [Olof] 146

Oker (see Derck) Maria 158

Oldenbeuving Gert 11

Olędzki Stanisław 16

Opitz Martin 48

Orgelbrand Maurycy 17

Orgelbrand Samuel 18, 19

$\mathbf{P}$

Pastorius Joachim 22

Pawlowski Herbert 25, 26, 47, 50, $57,62,63,213,257,280,312$

Pelegau Johann Gottlieb 230

Perz Anna 202

Petratz Christian 137

Pfahl (see Krieschen) Emma Wilhelmine 189

Pfahl Friedrich Wilhelm 167, 168, $170,171,174,188,189,193,195$, 197, 339

Poliński Aleksander 20

Popinigis Danuta 11, 20, 27-30, 36, $41,43,89,91,100,126,137,269$, $354,358,373$

Proite Johann 43, 114

Prószyńska Zofia 62, 64, 99, 101, 163, 235, 252

Prószyński Stanisław 16, 17, 28

Przybyszewska-Jarmińska Barbara 11, 95

Przywecka-Samecka Maria 304

$\mathbf{R}$

Rasch Rudolf 281

Rauschning Hermann 26, 41, 67, 89, 91, 94-96, 99, 137, 175, 180, 358

Remmerson Friedrich Gottlieb 230 
Renkewitz Werner 185, 186

Renner Karl 191

Reyger Johann Gottfried 230

Rhete Georg 271

Rhode Jacob 24, 125

Righini Vincenzo 281

Rivulo Franciscus de 27, 61, 72, 89-91, 93-97, 99, 101, 103, 105, $114,124,212,253,373,375$

Romanow Andrzej 376

Rombouts Luc 15, 16, 29, 35, 149, $163,217,376$

Roome Karl Gerhard 149

Rorz 359

Rothländer Daniel 174, 180

Ruzius-Brummans Monique 11

$S$

Sachs Curt 16

Salis-Seewis Johann Gaudenz von 281

Samsonowicz Henryk 125

Sankiewicz Marianna 205

Sausse, violist 145

Schaeft, abbot 52

Schaeft (see Moer) Sijcken Henricx van der 52

Scharasch Jorge, city watchmaker 62,64

Scharasch Michael 64, 66, 114

Schenck, brothers 40

Schiller Johann Christoph Friedrich von 283

Schilling Franz 146, 147, 149, 164

Schilling Margarete 28

Schiemmel Andreas 304

Schmidt, archdeacon 195

Schmidt, church clerk

Schmidt Eberhard 296

Schmidt Johann Benjamin 265, 267-269

Schmidt Johann Ernst 318

Schmidt Michael Gottfried 87
Schmieden Johann Ernst 212

Schmieden Nathanael 83

Schnaase Eduard David 212

Schönberg Philipp 21, 26, 89, 91, 96, $97,110,114,124,253$

Schopenhauer Johanna 73, 361

Schreiber Thomas Johann 236, 288

Schröder Johann (Andreas)

Gottlieb 101, 106, 114

Schubert Franz 281

Schultz Michael 66, 117, 118

Schultze, family 40

Schultze Claus 40

Schumann Johann Friedrich 230

Schumann Salomon Gabriel 23

Schütz Constantin 212

Schütz Heinrich 190

Schwartz Gottfried 230

Schwarzwald Hans 114

Seiffert Max 95

Seltenreich, violinist 145

Serczyk Jerzy 43, 211

Siefert Paul 41, 95

Siegler Hans Georg 149

Siehl 359

Sievert Christoph 23, 101, 105,118

Siewert Benjamin Gotthold 100

Sigismund III Vasa, King of

Poland 81-83, 210

Sikorski Saturnin 19, 20

Silcher Friedrich 201

Sinkenbring, keymaster 163

Sławoszewska Maria 126, 215, 315

Smit Johannes 130, 133, 162

Sonnenburg, violinist 149

Spierings Megchelina Henriette Maria 44

Sprengel Christian 130, 137, 138

Spruijt Juriaan 29, 31, 130, 133-136,

$138,153,159,161,162,176,178$

Stanislas Augustus Poniatowski,

King of Poland 169 
Stendel Andreas 101, 129, 133, 134, 192

Stendel (née Fischer, secondo voto Ferber) Dorothea Constantia 129

Sturm Christoph Christian 143, 358

Sweelinck Jan Pieterszoon 41

Szafran Przemysław 101, 267

Szarszewski Adam 186

Szlagowska Danuta 11, 82

Szychliński Grzegorz 11, 30, 32, 45, $54,57,63,205,254-257$

Szymanowski Karol 377

Śledziński Stefan 20

$\mathrm{T}$

Tessin Johann Caspar 230

Tetius Franz 94, 106, 109, 110, 253

Tetius Jacobus 65, 94, 106, 109, 110, $111,123,253$

Thiel 359

Truyen Wim 29, 35, 50, 52, 53, 217

Trzaska Władysław 19

U

Uphagen Peter 88

Urlich Carl Friedrich 146

V

Valerius Andriaen 281, 422

Van Eyndhoven Carl 11, 253, 376

Vogel Benjamin 184

Volckmar Nicolaus 86

Vorsing Michael 111

Voss Carl 146

Vries Hans Vredeman de 419

W

Waesberghe Johann Anthon von 166,230

Waga Raphael 137

Waghevens, family 52

Wagner Richard 201, 359
Walkusz Marta 11

Walter Karl 53, 59, 146

Wanning Johannes 97

Wehart (see Derck) Hester Alida 154

Weickhmann Gottlieb Gabriel 230

Weickhmann Joachim Heinrich von 191, 230

Wernick Gottfried 82, 101

Węsierska-Biernatowa

Teresa 126, 215

Weyl Joseph 281

Wiardi Rudolph 177

Wilhelm II, German Emperor 169, 337

Winter Georg Ludwig 148, 353

Wit Mighiel de 138

Włodarczyk Edward 191

Woge Johann Werner 184

Wolff Samuel 230

Wolthers (née Grobbema, primo voto Wiardri) Aaltjen 177

Wolters Abraham 318

Wolthers (Wolters) Eltjen 26, 133, $134,137,138,165,170,173-179$, $181,183,185,187,189,195,196$, 313-317, 331, 337

Wolthers Goosen 177

Wolthers Johanna 177

Wolthers Lucas, son of Eltjen 177

Wolthers Luckreesija 177

Wolthers Namijna 177

Wolthers (née Doedens)

Reintjen 177

Wolthers Wolther 177

Wołodźko Jerzy Wojciech 49

Wou Geert van 43, 52

Woźniak Jolanta 73, 213, 237, 252, 275

Wutstrack Christian Friedrich 24, $126,161,163,166,167,170$

Wyckaert Philippus 253 
Z

Zahn Johannes 270, 425

Zarębska Teresa 36, 44
Zdrenka Joachim 40-42, 71, 114, $126,129,130,166,167,217,230$, 235, 249, 265, 266

Zernecke Heinrich 25, 217, 230 



\section{Eastern European Studies in Musicology}

Edited by Maciej Gołąb

Vol. 1 Paweł Gancarczyk / Lenka Hlávková-Mráčková / Remigiusz Pośpiech (eds.): The Musical Culture of Silesia before 1742. New Contexts - New Perspectives. 2013.

Vol. 2 Laura Vasiliu/Florin Luchian/Loredana Iaţeşen/Diana-Beatrice Andron (eds.): Musical Romania and the Neighbouring Cultures. Traditions-Influences-Identities. Proceedings of the International Musicological Conference July 4-7, 2013, Iaşi (Romania). 2014.

Vol. 3 Barbara Przybyszewska-Jarmińska: Marcin Mielczewski and Music under the Patronage of the Polish Vasas. Translated by John Comber. 2014.

Vol. 4 Tomasz Jasiński: The Musical Rhetoric of the Polish Baroque. Translated by Wojciech Bońkowski. 2015.

Vol. 5 Bogusław Raba: Between Romanticism and Modernism. Ignacy Jan Paderewski's Compositional OEuvre. Translated by John Comber. 2015.

Vol. 6 Maciej Gołąb: Musical Modernism in the Twentieth Century. Translated by Wojciech Bońkowski. 2015.

Vol. 7 Wojciech Bońkowski: Editions of Chopin's Works in the Nineteenth Century. Aspects of Reception History. 2016.

Vol. 8 Ivana Perković / Franco Fabbri (eds.): Musical Identities and European Perspective. An Interdisciplinary Approach. 2017.

Vol. 9 Bożena Muszkalska (ed.): The Kolbergs of Eastern Europe. 2018.

Vol. 10 Renata Tańczuk / Sławomir Wieczorek (eds.): Sounds of War and Peace. Soundscapes of European Cities in 1945. 2018.

Vol. 11 Tomasz Jeż: The Musical Culture of the Jesuits in Silesia and the Kłodzko County (15811776). 2019.

Vol. 12 Magdalena Walter-Mazur: Musical Culture of Polish Benedictine Nuns in the 17th and 18th Centuries. 2018.

Vol. 13 Danuta Popinigis: Carillons and Carillon Music in Old Gdańsk. 2019.

www.peterlang.com 
